CAROLINA ALVES DE SOUZA FERREIRA

REMOÇÃO DE COMPOSTOS ORGÂNICOS CAUSADORES DE GOSTO E ODOR EM ÁGUAS DE ABASTECIMENTO EM SISTEMAS PÓS-FILTROS ADSORVEDORES DE CARVÃO ATIVADO GRANULAR

São Paulo, 
CAROLINA ALVES DE SOUZA FERREIRA

\title{
REMOÇÃO DE COMPOSTOS ORGÂNICOS CAUSADORES DE GOSTO E ODOR EM ÁGUAS DE ABASTECIMENTO EM SISTEMAS PÓS-FILTROS ADSORVEDORES DE CARVÃO ATIVADO GRANULAR
}

\author{
Tese apresentada à Escola \\ Politécnica da Universidade de São \\ Paulo para obtenção do título de \\ Doutor em Engenharia
}

São Paulo, 
FERREIRA, C. A. S. Remoção de compostos orgânicos causadores de gosto e odor em águas de abastecimento em sistemas pós-filtros adsorvedores de carvão ativado granular. Tese apresentada à Escola Politécnica da Universidade de São Paulo para obtenção do título de Doutor em Engenharia.

Aprovado em:

Banca Examinadora

Prof. Dr.:

Instituição:

Julgamento:

Assinatura:

Prof. Dr.:

Instituição:

Julgamento:

Assinatura:

Prof. Dr.:

Instituição:

Julgamento:

Assinatura:

Prof. Dr.:

Instituição:

Julgamento:

Assinatura:

Prof. Dr.:

Instituição:

Julgamento:

Assinatura: 
CAROLINA ALVES DE SOUZA FERREIRA

REMOÇÃO DE COMPOSTOS ORGÂNICOS CAUSADORES DE GOSTO E ODOR EM ÁGUAS DE ABASTECIMENTO EM SISTEMAS PÓS-FILTROS ADSORVEDORES DE CARVÃO ATIVADO GRANULAR

Tese apresentada à Escola

Politécnica da Universidade de São

Paulo para obtenção do título de

Doutor em Engenharia

Área de Concentração: Engenharia Hidráulica e Sanitária

Orientador: Prof. Dr. Sidney Seckler Ferreira Filho 
Autorizo a reprodução e divulgação total ou parcial deste trabalho, por qualquer meio convencional ou eletrônico, para fins de estudo e pesquisa, desde que citada a fonte.

\author{
Catalogação da Publicação \\ Serviço de Documentação de Engenharia \\ Escola Politécnica da Universidade de São Paulo
}

Este exemplar foi revisado e alterado em relação à versão original, sob

responsabilidade única do autor e com a anuência de seu orientador.

São Paulo, ........ de novembro de 2009.

Assinatura do autor

Assinatura do orientador

Ferreira, Carolina Alves de Souza.

Remoção de compostos orgânicos causadores de gosto e odor em águas de abastecimento em sistemas pós-filtros adsorvedores de carvão ativado granular / C.A.S. Ferreira. - ed. rev. - São Paulo, 2009.

$226 p$.

Tese (Doutorado) - Escola Politécnica da Universidade de São Paulo. Departamento de Engenharia Hidráulica e Sanitária.

1. Filtros biológicos 2. Ozônio 3. Carvão ativado I. Universidade de São Paulo. Escola Politécnica. Departamento de Engenharia Hidráulica e Sanitária II.t. 


\section{DEDICATÓRIA}

A Mau. 


\section{AGRADECIMENTOS}

Aos meus pais, meus melhores amigos e heróis, pelo eterno apoio e amor.

Ao meu adorado e querido esposo por acreditar em mim.

Ao Professor Sidney, pela orientação e cuidado durante todo o trabalho.

À Cláudia e ao Ricardo, por dividir comigo as vitórias e dificuldades do experimento.

Ao Fábio, Laerte e pessoal da SABESP, pela dedicada parceria na realização das análises. 


\section{RESUMO}

FERREIRA, C. A. S. Remoção de compostos orgânicos causadores de gosto e odor em águas de abastecimento em sistemas pós-filtros adsorvedores de carvão ativado granular. 2009. 226 f. Tese (Doutorado) - Escola Politécnica, Universidade de São Paulo, São Paulo, 2009.

O objetivo desta pesquisa foi 0 de estudar 0 desempenho de pós-filtros adsorvedores de carvão ativado granular de origem mineral e de origem vegetal, com relação a, principalmente, remoção de 2-metilisoborneol e trans-1,10-dimetiltrans-9-decalol. Os ensaios experimentais foram conduzidos na estação de tratamento de água Alto da Boa Vista, empregando-se quatro filtros piloto em acrílico com diâmetro interno de $14,2 \mathrm{~cm}$ e 1,5 m de profundidade de meio filtrante cada, sendo dois deles preenchidos com o carvão ativado granular Filtrasorb 300 da CALGON (filtros 1 e 3) e os outros dois, com o carvão ativado granular 119 12x25 da CARBOMAFRA (filtros 2 e 4). Os filtros operaram em paralelo, $24 \mathrm{~h}$ por dia, 7 dias por semana, sendo o 3 e 4 abastecidos com água filtrada da estação; e o 1 e 2, com água filtrada ozonizada. A taxa média de aplicação nos filtros durante os ensaios foi de $143 \mathrm{~m}^{3} / \mathrm{m}^{2}$.d, o que gerou um tempo de contato no leito vazio médio de $15 \mathrm{~min}$. O tempo médio total de detenção nas colunas de ozonização ficou em 21 min e a dosagem média total de ozônio aplicada na água filtrada da estação em $1,11 \mathrm{mg} / \mathrm{L}$. Os valores de 2-metilisoborneol na água filtrada da estação de tratamento foram superiores aos da água ozonizada, indicando que a ozonização contribuiu para a redução (média de 53,4\%) deste composto. O filtro que apresentou os menores valores de 2-metilisoborneol foi o do carvão betuminoso, alimentado com água ozonizada (filtro 1), com uma remoção média de 50,6 \%. Além disso, foi o único filtro que apresentou valores médios de 2-metilisoborneol abaixo da concentração limiar de odor (<9,0 ng/L). O filtro que apresentou os maiores valores de 2-metilisoborneol foi 04 (carvão vegetal alimentado com água filtrada da estação).

Palavras-chave: Filtros biológicos. Ozônio. Carvão ativado. 


\begin{abstract}
FERREIRA, C. A. S. Removal of taste and odor producing organic substances in water supply in post-filter granular activated carbon adsorber systems. 2009. 226 f. Tese (Doutorado) - Escola Politécnica, Universidade de São Paulo, São Paulo, 2009.

The main purpose of this research was to study the performance of granular activated carbon post filter adsorbers made of bituminous coal and vegetal coal (coconut), regarding, mainly, removal of 2-methylisoborneol and trans-1,10-dimethyltrans-9-decalol. The experimental researches were conducted in the water treatment plant Alto da Boa Vista, using four pilot filters, made in acrylic, with an internal diameter of $14.2 \mathrm{~cm}$ and a filter media depth of $1.5 \mathrm{~m}$, each. Two of them (named 1 and 3) were filled with the carbon Filtrasorb 300 (CALGON) and the other two (named 2 and 4), with the carbon 119 12x25 (CARBOMAFRA). The filters operated in parallel, $24 \mathrm{~h}$ per day, 7 days per week. The filters 3 and 4 were fed with filtered water from the plant and the filters 1 and 2, with filtered plus ozonated water. The average hydraulic loading rate in the filters was $143 \mathrm{~m}^{3} / \mathrm{m}^{2} . \mathrm{d}$ and the empty bed contact time, $15 \mathrm{~min}$. The average detention time in the ozone contact columns was $21 \mathrm{~min}$ and the average ozone dosage, $1.11 \mathrm{mg} / \mathrm{L}$. The 2-methylisoborneol values in the filtered water of the plant were higher than in the ozonated water, which indicates that the ozonation reduced (average of $53.4 \%$ ) this substance. The filter that showed the lower values of 2-methylisoborneol was the bituminous one, fed with ozonated water (filter 1 ), with an average removal of $50.6 \%$. Moreover, was the only one that presented average values of 2-methylisoborneol lower than the odor threshold concentration (<9,0 ng/L). The filter that presented the higher values of 2 methylisoborneol was the vegetal one, fed with filtered water (filter 4).
\end{abstract}

Keywords: Biological filters. Ozone. Activated carbon. 


\section{LISTA DE FIGURAS}

Figura 3.1.1 - Efeitos do tempo de contato do ozônio na remoção de MIB (KAWAMURA, 2000).

Figura 3.1.2 - Mudanças na intensidade do gosto e odor pela ozonização (KAWAMURA, 2000).

Figura 3.1.3 - Remoção de MIB pelo ozônio para diferentes águas de superfície (KAWAMURA, 2000).

Figura 3.1.4 - Remoção de odor pelo processo de adsorção por CAG (KAWAMURA, 2000) 16

Figura 3.1.5 - Escolha do CAP ou CAG para o controle de gosto e odor (KAWAMURA, 2000).

Figura 3.1.6 - Porcentagem de remoção de geosmina em filtros de CAG e antracito (ELHADI; HUCK; SLAWSON, 2006)

Figura 3.1.7 - Porcentagem de remoção de MIB em filtros de CAG e antracito (ELHADI; HUCK; SLAWSON, 2006)

Figura 3.2.1 - Curvas de traspasse de MIB para carvões ativados granulares disponíveis no mercado (MACKENZIE; TENNANT; MAZYCK, 2005).

Figura 3.2.2 - Taxas de contra lavagem versus taxas de expansão de leitos de CAG (adaptado do boletim da Calgon, 2006). 25

Figura 3.2.3 - Perdas de carga versus taxas de contra lavagem para leitos de CAG (adaptado do boletim da Calgon, 2006). .25

Figura 3.2.4 - Remoção de COT em filtros de CAG (EMELKO et al., 2006)...... 29

Figura 3.2.5 - Aumento dos THM ao longo do tempo (AWWA, 1987)...... 31 
Figura 3.3.1 - Redução do potencial total de trialometanos através de processos em escala piloto (KAWAMURA, 2000)

Figura 3.3.2 - Perfis de THMFP para ensaios de ozonização intermediária (CHAIKET et al., 2002).

Figura 3.3.3 - Remoção de THM em filtros alimentados por águas decantadas e/ou ozonizadas (AWWARF, 2005).

Figura 3.4.1 - Quatro componentes principais do sistema de ozonização: gás de alimentação, gerador de ozônio, tanque de contato e unidade destruidora de off-gas (RAKNESS, K. L., 2005).....

Figura 3.4.2 - Produção de ozônio versus consumo de energia (KAWAMURA, 2000) 40

Figura 3.4.3 - Mecanismos de decomposição do ozônio na água (LANGLAIS; HECKHOW; BRINK, 1991).

Figura 3.4.4 - Caminhos de reação do ozônio na água (LANGLAIS; HECKHOW; BRINK, 1991).

Figura 3.4.5 - Efeitos a longo prazo da introdução do ozônio nas concentrações de COA (ESCOBAR; RANDOM, 2001).

Figura 3.4.6 - Efeitos a longo prazo da introdução do ozônio nas concentrações de CPH (ESCOBAR; RANDOM, 2001)

Figura 3.4.7 - Remoção de MIB por ozonização e biofiltração em Estações de Tratamento de Água (AWWARF, 2005).

Figura 3.4.8 - Remoção de geosmina por ozonização e biofiltração em Estações de Tratamento de Água (AWWARF, 2005). .48

Figura 3.4.9 - Remoções de compostos e acúmulo de biomassa versus TCLV (CARLSON; AMY, 2001).

Figura 3.4.10 - Efeitos da fonte de MON e TCLV na remoção de COT em filtros (HOSALSKI; GOEL; BOUWER, 1995). 
Figura 3.5.1 - Fração das partículas no efluente dos filtros ao longo de suas carreiras de filtração para os materiais inorgânicos segundo condições de operação variáveis (a) ([metais] $=53$ ppm) e constantes (b) ([metais] $=42$ ppm) e para os orgânicos, segundo condições de operação variáveis (c) ([COT] $=2,98$ ppm) e constantes $(\mathrm{d})([\mathrm{COT}]=2,81 \mathrm{ppm})($ AwwaRF, 2007).

Figura 4.1.1 - ETA ABV, localização e principais acessos (Google Maps, 2008)....66

Figura 4.1.2 - Estrutura de chegada de água bruta .68

Figura 4.1.3 - Floculadores .68

Figura 4.1.4 - Decantadores 69

Figura 4.1.5 - Filtros 69

Figura 4.2.1 - ETA piloto ABV. 73

Figura 4.2.2 - Local dos filtros piloto de CAG. .73

Figura 4.2.3 - Base em aço dos filtros, tubulações de lavagem a ar (mangueira negra), água (mangueira transparente) e saída de água filtrada (PVC). .74

Figura 4.2.4 - Distribuidor de fundo de filtro para lavagem a ar e água (dispositivo em azul). .74

Figura 4.2.5 - Filtros de CAG, identificados da esquerda para direita de 1 a $4 \ldots \ldots . . .75$

Figura 4.2 .6 - Piezômetros para leitura da perda de carga..................................77

Figura 4.2.7 - Reservatório de equalização de água filtrada... .77

Figura 4.2.8 - Bombas centrífugas (KSB-HYDROBLOC P 500T), nomeadas da esquerda para direita de 1 a 4, com variação de freqüência, para a alimentação das colunas de ozonização. 78

Figura 4.2.9 - Colunas de ozonização 78

Figura 4.2.10 - Reservatório de equalização de água ozonizada. .79 
Figura 4.2.11 - Gerador de ozônio. . .80

Figura 4.2.12 - Analisador da concentração de ozônio gerado (AFX, modelo H1)...80 Figura 4.2.13 - Rotâmetros para leitura da vazão de ozônio nas colunas. .81

Figura 4.2.14 - Rotâmetro (KING, de 0 a $5 \mathrm{gpm}$ ) para a leitura da vazão de água na coluna de ozonização.

Figura 4.2.15 - Unidade catalítica destruidora de ozônio. .82

Figura 4.2.16 - Distribuição da água ozonizada para os Filtros 1 e 2 (esquerda) e distribuição da água filtrada para os Filtros 3 e 4 (direita). .83

Figura 4.2.17 - Rotâmetro (DIGIFLOW, de 0 a 500 L/h) para a leitura da vazão de alimentação do filtro .83

Figura 4.2.18 - Esquema geral simplificado da ETA piloto ABV. .84

Figura 4.2.19 - Turbidímetro empregado nas análises. 87

Figura 4.2.20 - Equipamento para análise de COT .88

Figura 4.2.21 - Equipamento para análise do UV $254 \mathrm{~nm}$ .88

Figura 4.2.22 - Contador de partículas. .89

Figura 4.2.23 - Cromatógrafo associado a espectrômetro de massas .90

Figura 4.2.24 - Aparelhagem para análise de cloro livre residual. 91

Figura 4.2.25 - DR/890 utilizado para a análise de ozônio residual. 91

Figura 5.1.1 - Lavagem dos carvões. .93

Figura 5.1.2 - Secagem dos carvões em estufa .94

Figura 5.1.3 - Agitador de peneiras para análise granulométrica dos carvões. .94

Figura 5.1.4 - Pesagem dos carvões, por peneira, para análise granulométrica......95

Figura 5.1.5 - Porcentagem de material retido nas peneiras. 96 
Figura 5.1.6 - Amostras de carvão em picnômetros com água destilada.

Figura 5.1.7 - Aplicação de vácuo nas amostras por $24 \mathrm{~h}$ para o preenchimento dos vazios internos das partículas

Figura 5.1.8 - Pesagem das amostras após a aplicação de vácuo, para a determinação da massa específica do material.

Figura 5.1.9 - Pesagem do carvão superficialmente seco. 100

Figura 5.1.10 - Saturação das amostras em vácuo por 24h. 101

Figura 5.1.11 - Manta de bidim como camada suporte dos carvões 101

Figura 5.1.12 - Preenchimento de $60 \%$ do volume do permeâmetro com água.....102

Figura 5.1.13 - Colocação do carvão no permeâmetro 102

Figura 5.1.14 - Expansão de 30\% do volume do carvão. 103

Figura 5.1.15 - Características dos índices físicos dos carvões. 105

Figura 5.1.16 - Características dos índices físicos em filtro dos carvões. 106

Figura 5.2.1 - Turbidez das águas efluentes dos filtros, ao longo do tempo 108

Figura 5.2.2 - Perda de carga dos filtros, ao longo do tempo. 108

Figura 5.2.3 - Perda de carga nos filtros versus turbidez da água tratada. 109

Figura 5.3.1 - Valores de COT para a água filtrada e ozonizada, ao longo do tempo. 112

Figura 5.3.2 - Valores de COT para as águas efluentes dos filtros, ao longo do tempo. 113

Figura 5.4.1 - Residual de ozônio versus dosagem de ozônio aplicada. 114

Figura 5.4.2 - Turbidez da água ozonizada versus dosagem de ozônio aplicada..115 
Figura 5.5.1 - Valores do número de partículas $\geq 2,0 \mu \mathrm{m}$ ao longo do tempo, para a água do REAF e REAO.

Figura 5.5.2 - Valores do número de partículas $\geq 2,0 \mu \mathrm{m}$ ao longo do tempo, para as águas efluentes dos filtros

Figura 5.5.3 - Valores do número de partículas entre 1,2 $\mu \mathrm{m}$ e 2,0 $\mu \mathrm{m}$ ao longo do tempo, para a água do REAF e REAO.

Figura 5.5.4 - Valores do número de partículas entre 1,2 $\mu \mathrm{m}$ e 2,0 $\mu \mathrm{m}$ ao longo do tempo, para as águas efluentes dos filtros.

Figura 5.5.5 - Valores de $\mathrm{CBH}$ ao longo do tempo, para as águas do REAF, REAO e efluentes dos filtros.

Figura 5.5.6 - Valores do número de partículas $\geq 2,0 \mu \mathrm{m}$ na água ozonizada versus dosagem de ozônio aplicada.

Figura 5.5.7 - Valores do número de partículas entre 1,2 $\mu \mathrm{m}$ e 2,0 $\mu \mathrm{m}$ na água ozonizada versus dosagem de ozônio aplicada.

Figura 5.5.8 - Relação entre o número de partículas $\geq 2,0 \mu \mathrm{m}$ versus a turbidez, para as águas efluentes dos filtros.

Figura 5.5.9 - Relação entre o número de partículas entre 1,2 $\mu \mathrm{m}$ e 2,0 $\mu \mathrm{m}$ versus a turbidez, para as águas efluentes dos filtros. 124

Figura 5.5.10 - Valores do número de partículas $\geq 2,0 \mu \mathrm{m}$ na entrada versus saída dos filtros. 125

Figura 5.5.11 - Valores do número de partículas entre 1,2 $\mu \mathrm{m}$ e 2,0 $\mu \mathrm{m}$ na entrada versus saída dos filtros. 125

Figura 5.5.12 - Valores do número de partículas entre 1,2 $\mu \mathrm{m}$ e 2,0 $\mu \mathrm{m}$ versus 0 número de partículas $\geq 2,0 \mu \mathrm{m}$, na água efluente aos filtros 126

Figura 5.5.13 - Valores de COT versus o número de partículas $\geq 2,0 \mu \mathrm{m}$, nas águas efluentes dos filtros. 
Figura 5.5.14 - Valores de COT versus o número de partículas entre 1,2 $\mu \mathrm{m}$ e 2,0 $\mu \mathrm{m}$, nas águas efluentes dos filtros

Figura 5.5.15 - Porcentagem de remoção nos filtros, do número de partículas $\geq 2,0$ $\mu \mathrm{m}$. 129

Figura 5.5.16 - Porcentagem de remoção nos filtros, do número de partículas entre $1,2 \mu \mathrm{m}$ e $2,0 \mu \mathrm{m}$ 129

Figura 5.5.17 - Perda de carga nos filtros versus número de partículas $\geq 2,0 \mu \mathrm{m} . .130$

Figura 5.5.18 - Perda de carga nos filtros versus número de partículas entre 1,2 $\mu \mathrm{m}$ e $2,0 \mu \mathrm{m}$ 130

Figura 5.6.1 - Valores de MIB ao longo do tempo 133

Figura 5.6.2 - Valores de geosmina ao longo do tempo. 134

Figura 5.6.3 - Porcentagem de remoção de MIB nos filtros. .134

Figura 5.6.4 - Porcentagem de remoção de geosmina nos filtros 135

Figura 5.6.5 - Remoção de MIB versus dosagem de ozônio aplicada. 136

Figura 5.6.6 - Remoção de geosmina versus dosagem de ozônio aplicada 136

Figura 5.6.7 - Valores de MIB nas águas efluentes dos filtros versus a razão volume de filtração/volume do meio filtrante.

Figura 5.6.8 - Valores de geosmina nas águas efluentes dos filtros versus a razão volume de filtração/volume do meio filtrante. 


\section{LISTA DE TABELAS}

Tabela 3.1.1 - Sensações correspondentes aos principais compostos causadores de

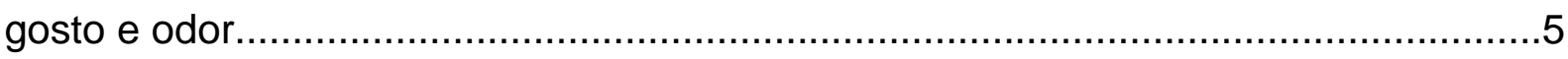

Tabela 3.1.2 - Características químicas e físicas do MIB e da geosmina..................6

Tabela 3.1.3 - Estruturas químicas dos compostos que produzem gosto e odor........7

Tabela 3.1.4 - Algas e organismos associadas a problemas de gosto e odor e dosagens de produtos químicos para seus controles.............................................

Tabela 3.1.5 - Resumo de estudos de ozonização para remoção de MIB................15

Tabela 3.1.6 - Resumo de estudos de biofiltração para remoção de MIB..................17

Tabela 3.1.7 - Exemplo de taxa de remoção de MIB e geosmina pelo CAP, $\mathrm{KmnO}_{4}$,

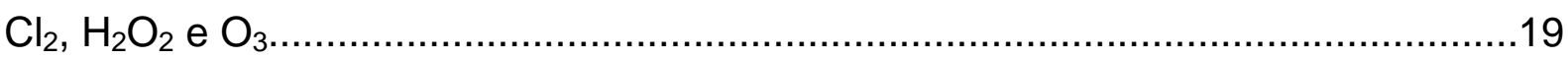

Tabela 3.4.1 - Características físicas do ozônio...................................................41

Tabela 3.4.2 - Remoções de MIB e geosmina obtidas em testes............................46

Tabela 3.4.3 - Parâmetros que influenciam a filtração biológica..............................53

Tabela 3.4.4 - Efeito do meio e do tempo de contato em biofiltros..........................54

Tabela 3.4.5 - Remoção de MIB e geosmina em biofiltros......................................55

Tabela 3.4.6 - Principais subprodutos conhecidos da ozonização...........................57

Tabela 4.1.1 - Parâmetros físicos, químicos, microbiológicos e hidrobiológicos da água bruta da ETA ABV............................................................................

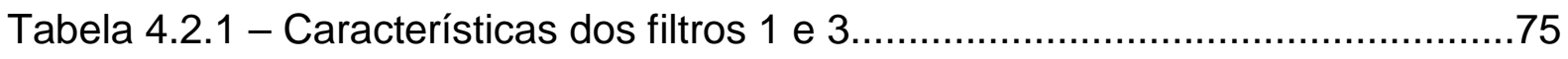

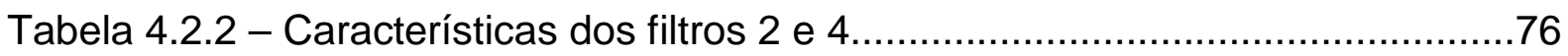


Tabela 4.2.3 - Valores mínimo, médio, máximo e desvio padrão da vazão, tempo de contato no leito vazio e taxa de aplicação empregados nos filtros

Tabela 4.2.4 - Valores mínimo, médio, máximo e desvio padrão da vazão, tempo de detenção e dosagem de ozônio empregados nas colunas de ozonização.

Tabela 4.2.5 - Análises realizadas para o estudo de desempenho dos filtros de CAG.

Tabela 5.1.1 - Distribuição granulométrica dos carvões. 96

Tabela 5.1.2 - Massa específica dos carvões. 99

Tabela 5.1.3 - Massa específica das partículas e porosidade interna dos carvões. 100

Tabela 5.1.4 - Características dos índices físicos em filtro dos carvões. 104

Tabela 5.2.1 - Valores mínimo, médio, máximo e desvio padrão da turbidez. 106

Tabela 5.2.2 - Valores mínimo, médio, máximo e desvio padrão da perda descarga. 107

Tabela 5.2.3 - Valores mínimo, médio, máximo e desvio padrão da porcentagem de remoção da turbidez. 107

Tabela 5.3.1 - Valores mínimo, médio, máximo e desvio padrão do COT. 110

Tabela 5.3.2 - Valores mínimo, médio, máximo e desvio padrão da absorção do UV no $254 \mathrm{~nm}$ 110

Tabela 5.3.3 - Valores mínimo, médio, máximo e desvio padrão da porcentagem de remoção do COT.

Tabela 5.3.4 - Valores mínimo, médio, máximo e desvio padrão da porcentagem de remoção da absorção do UV no 254 nm

Tabela 5.4.1 - Valores mínimo, médio, máximo e desvio padrão do cloro livre residual e ozônio residual. 
Tabela 5.5.1 - Valores mínimo, médio, máximo e desvio padrão do número de partículas $\geq 2,0 \mu \mathrm{m}$.

Tabela 5.5.2 - Valores mínimo, médio, máximo e desvio padrão do número de partículas entre $1,2 \mu \mathrm{m}$ e $2,0 \mu \mathrm{m}$.

Tabela 5.5.3 - Valores mínimo, médio, máximo e desvio padrão da contagem de bactérias heterotróficas.

Tabela 5.5.4 - Valores mínimo, médio, máximo e desvio padrão da porcentagem de remoção do número de partículas $\geq 2,0 \mu \mathrm{m}$.

Tabela 5.5.5 - Valores mínimo, médio, máximo e desvio padrão da porcentagem de remoção do número de partículas entre 1,2 $\mu \mathrm{m}$ e 2,0 $\mu \mathrm{m}$.

Tabela 5.6.1 - Valores mínimo, médio, máximo e desvio padrão de MIB.

Tabela 5.6.2 - Valores mínimo, médio, máximo e desvio padrão de geosmina

Tabela 5.6.3 - Valores mínimo, médio, máximo e desvio padrão da porcentagem de remoção de MIB.

Tabela 5.6.4 - Valores mínimo, médio, máximo e desvio padrão da porcentagem de remoção de geosmina. 132

Tabela 5.7.1 - Valores mínimo, médio, máximo e desvio padrão de THM instantâneos. 138

Tabela 5.7.2 - Valores mínimo, médio, máximo e desvio padrão de THM na rede de distribuição

Tabela 5.7.3 - Valores mínimo, médio, máximo e desvio padrão da porcentagem de remoção de THM instantâneos.

Tabela 5.7.4 - Valores mínimo, médio, máximo e desvio padrão da porcentagem de remoção de THM na rede de distribuição 
$\mathrm{AB}$

ABV

APHA

Ana EX

ASCE

AWWA

AWWARF

CAG

CAP

CAP

$\mathrm{CBH}$

CETESB Companhia de Tecnologia de Saneamento Ambiental

$\mathrm{Cl}_{2}$

COA

CODB

$\cos$

COT

COVS

$\mathrm{CO} 1$

Água Bruta

Alto da Boa Vista

American Public Health Association

Anabena sp.

American Society of Civil Engineers

American Water Works Association

American Water Works Research Foundation

Carvão Ativado Granular.

Carvão Ativado em Pó

Carvão Ativado em Pó

Contagem de Bactérias Heterotróficas

Cloro

Carbono Orgânico Assimilável

Carbono Orgânico Dissolvido Biodegradável

Compostos Orgânicos Sintéticos

Carbono Orgânico Total.

Compostos Orgânicos Voláteis Sintéticos

Coluna de Ozonização 1 


$\begin{array}{ll}\text { CO2 } & \text { Coluna de Ozonização 2 } \\ \text { CO3 } & \text { Coluna de Ozonização 3 } \\ \text { CO4 } & \text { Coluna de Ozonização 4 } \\ \text { CPH } & \text { Contagem de Placas Heterotróficas } \\ \text { CTH } & \text { Centro Tecnológico de Hidráulica da USP } \\ \text { DBP } & \text { Subprodutos da Desinfecção } \\ \text { DSW } & \text { Dismal Swamp Water } \\ \text { EPUSP } & \text { Escola Politécnica da Universidade de São Paulo } \\ \text { ETA } & \text { Estação de Tratamento de Água } \\ \text { EUA } & \text { Estados Unidos da América } \\ \text { F1 } & \text { Filtro 1 } \\ \text { F2 } & \text { Filtro 2 } \\ \text { F3 } & \text { Filtro 3 } \\ \text { F4 } & \text { Filtro 4 } \\ \text { FGW } & \text { Florida Groundwater } \\ \text { Meosmina } & \text { trans-1,10-dimetil-trans-9-decalol } \\ \text { HAA } & \text { Ácidos Haloacéticos } \\ \text { LOX } & \text { Oxigênio Líquido } \\ \text { MIB } & \text { Matéria Orgânica Biodegradável } \\ \text { MON } & \end{array}$




\begin{tabular}{|c|c|}
\hline NKT & Nitrogênio Kjeldahl Total \\
\hline NP & Número de Partículas \\
\hline OBP & Subprodutos da Ozonização \\
\hline OD & Oxigênio Dissolvido \\
\hline $\mathrm{O}_{3}$ & Ozônio \\
\hline REAF & Reservatório e Equalização de Água Filtrada \\
\hline REAO & Reservatório de Equalização de Água Ozonizada \\
\hline RMC & Reator de Mistura Completa \\
\hline RMCB & Reator de Mistura Completa em Batelada \\
\hline SABESP & Companhia de Saneamento Básico do Estado de São Paulo \\
\hline SDT & Sólidos Dissolvidos Totais \\
\hline SI & Sistema Internacional \\
\hline SPME & Micro extração em fase sólida \\
\hline SPO & Subprodutos da Ozonização \\
\hline SPW & State Project Water \\
\hline ST & Sólidos Totais \\
\hline TCLV & Tempo de Contato de Leito Vazio \\
\hline THMFP & Potencial de Formação de Trialometanos \\
\hline THM & Trialometanos \\
\hline THMT & Trialometanos Totais \\
\hline TPTHM & Potencial Total de Trialometanos \\
\hline
\end{tabular}


USP Universidade de São Paulo

UV 254 nm Absorção Específica da Radiação Ultravioleta no Comprimento de Onda Igual a $254 \mathrm{~nm}$

WEF Water Environmental Federation 


\section{LISTA DE SÍMBOLOS}
A Massa específica do material
B Material seco + água interna
C Material seco
D Massa específica das partículas
E Porosidade interna
F $\quad$ Volume aparente em filtro
G Material seco' 


\section{SUMÁRIO}

1. INTRODUÇÃO

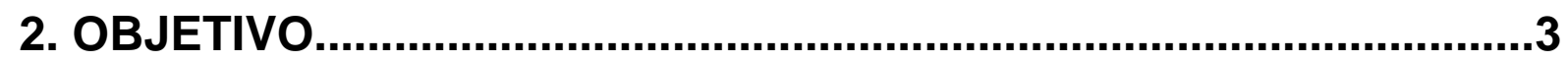

3. REVISÃO BIBLIOGRÁFICA..........................................................4

3.1. CONTROLE DE GOSTO E ODOR........................................................

3.1.1. PRINCIPAIS SUBSTÂNCIAS CAUSADORAS DE GOSTO E ODOR....4

3.1.2. MEDIDAS DE CONTROLE...........................................................

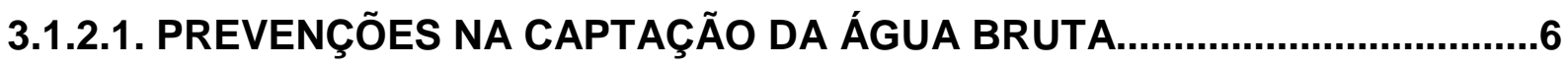

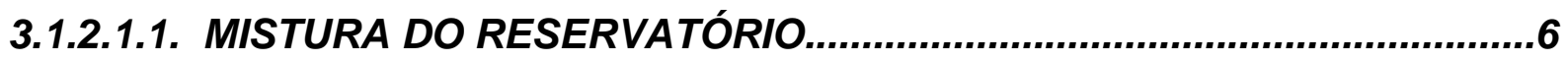

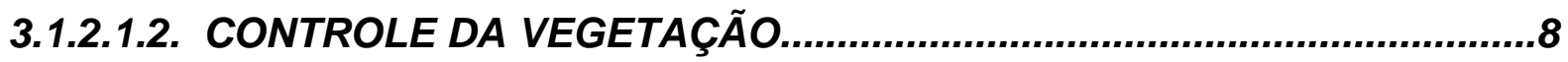

3.1.2.1.3. GERENCIAMENTO DO RESERVATÓRIO.........................................10

3.1.2.2. REMOÇÕES NA ESTAÇÃO DE TRATAMENTO.....................................10

3.1.2.2.1. AERAÇÃO

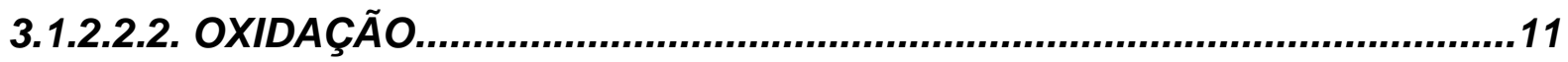

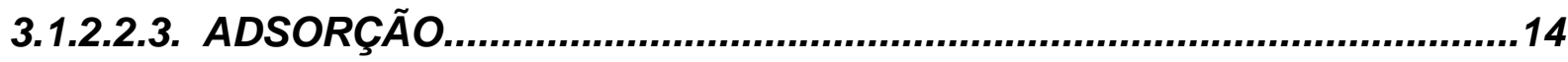

3.1.2.3. CONTROLE NO SISTEMA DE DISTRIBUIÇÃO.......................................20

3.2. ADSORÇÃO POR CARVÃO ATIVADO GRANULAR...........................22

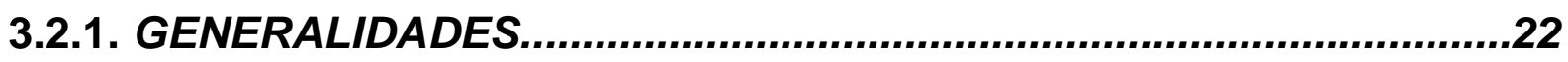

3.2.2. CARACTERÍSTICAS DO CAG....................................................22

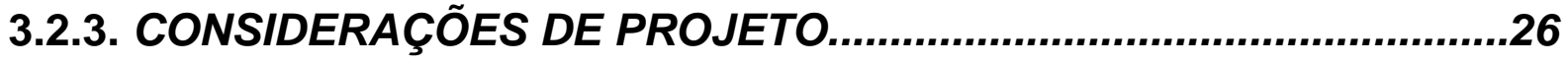


3.2.3.2. LEITOS DE CAG COMO PROCESSO DE FILTRAÇÃO E ADSORÇÃO....27

3.2.3.3. TAMANHO DO CAG. .30

3.2.3.4. TEMPO DE CONTATO DE LEITO VAZIO. .30

3.2.3.5. LOCALIZAÇÃO DOS LEITOS DE CAG NA CADEIA DO TRATAMENTO.31

3.3. CONTROLE DE SUBPRODUTOS DA DESINFECÇÃO. .32

3.3.1. TRIALOMETANOS. .32

3.3.1.1. PRECURSORES. 33

3.3.1.2. NÍVEL DE CLORO LIVRE RESIDUAL .33

3.3.1.3. TEMPERATURA E pH DA ÁGUA .33

3.3.1.4. TEMPO DE CONTATO DO CLORO. .34

3.3.2. MEDIDAS DE CONTROLE DOS THM. 34

3.4. OZONIZAÇÃO EM ÁGUAS DE ABASTECIMENTO. .38

3.4.1. PROPRIEDADES FÍSICAS E QUÍMICAS DO OZÔNIO. 38

3.4.2. ESTABILIDADE DO OZÔNIO NA ÁGUA. 40

3.4.3. OXIDAÇÃO DE MICROPOLUENTES ORGÂNICOS. 41

3.4.4. DESINFECÇÃO. .44

3.4.5. OXIDAÇÃO DO FERRO E MANGANÊS. 45

3.4.6. OXIDAÇÃO DE MIB E GEOSMINA. .45

3.4.7. CONTROLE DE PRECURSORES DOS SUBPRODUTOS DA DESINFECÇÃO.. 
3.4.8.2. DESEMPENHO DA BIOFILTRAÇÃO. .53

3.4.9. INATIVAÇÃO DE PATOGÊNICOS E EFICIÊNCIA DA DESINFECÇÃO. .56

3.4.10. SUBPRODUTOS DA OZONIZAÇÃO. .56

3.5. PARTÍCULAS NOS FILTROS. .59

3.5.1. CARACTERÍSTICAS GERAIS DOS AFLUENTES E EFLUENTES DOS FILTROS. .59

3.5.2. TRATAMENTO ANTERIOR AOS FILTROS. .60

3.5.3. FATORES OPERACIONAIS E DESEMPENHO DOS FILTROS. .61

3.5.4. REMOÇÃO MICROBIOLÓGICA. .64

4. MATERIAIS E MÉTODOS 66

4.1. A ESTAÇÃO DE TRATAMENTO DE ÁGUA ALTO DA BOA VISTA......66

4.2. ENSAIOS EXPERIMENTAIS. .72

4.2.1. ENSAIOS DE CARACTERIZAÇÃO DOS CARVÕES. .92

5. APRESENTAÇÃO E ANÁLISE DOS RESULTADOS EXPERIMENTAIS. .93

5.1. APRESENTAC̄̃̃ E ANÁLISE DOS RESULTADOS DOS ENSAIOS DE CARACTERIZAÇẪO DOS CARVÕES. .93

5.2. APRESENTAÇÃO E ANÁLISE DOS RESULTADOS DE TURBIDEZ E PERDA DE CARGA. 106

5.3. APRESENTAÇÃO E ANÁLISE DOS RESULTADOS DE CARBONO ORGÂNICO TOTAL E ABSORÇÃO ESPECÍFICA DA RADIAÇÃO ULTRAVIOLETA NO COMPRIMENTO DE ONDA IGUAL A 254 NM...........110

5.4. APRESENTAÇÃO E ANÁLISE DOS RESULTADOS DE OZÔNIO E CLORO LIVRE RESIDUAL 
5.5. APRESENTAÇÃO E ANÁLISE DOS RESULTADOS DE CONTAGEM DE PARTÍCULAS E CONTAGEM DE BACTÉRIAS HETEROTRÓFICAS..115 5.6. APRESENTAÇÃO E ANÁLISE dOS RESULTADOS DE MIB E GEOSMINA. 131

5.7. APRESENTAÇÃO E ANÁLISE DOS RESULTADOS DE THM INSTANTÂNEOS E NA REDE DE DISTRIBUIÇÃO. 138

6. CONCLUSÕES 141

7. REFERÊNCIAS BIBLIOGRÁFICAS. 144

APÊNDICE A - Vazões, Tempos de Detenção e Taxas de Aplicação dos Filtros 151

APÊNDICE B - Vazões, Tempos de Detenção e Dosagens de Ozônio nas Colunas de Ozonização. 163

APÊNDICE C - Valores de Turbidez, COT, UV 254 nm, Perda de Carga, $\mathrm{O}_{3}$ Residual e $\mathrm{Cl}_{2}$ Residual.

APÊNDICE D - Valores de CP $\geq 2,0 \mu \mathrm{m} ; 1,2 \mu \mathrm{m} \leq \mathrm{CP}<2,0 \mu \mathrm{m}$ e $\mathrm{CBH}$ 196

APÊNDICE E - Valores de MIB e Geosmina 217

APÊNDICE F - Valores de THM Instantâneos e na Rede de Distribuição.

ANEXO A - Boletim Técnico do Filtrasorb 300

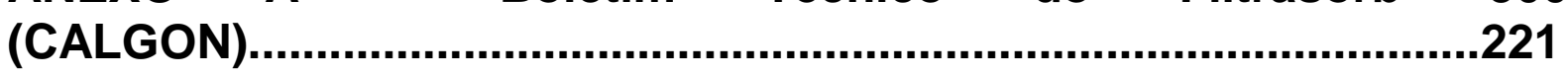

ANEXO B - Boletim Técnico do CAG $119 \quad 12$ x 25 (CARBOMAFRA) 


\section{INTRODUÇÃO}

O uso do ozônio para obtenção de água potável, especialmente nos EUA, tem crescido muito nos últimos anos devido aos avanços tecnológicos e preocupações com relação aos sub-produtos da desinfecção.

A ozonização tem muitos benefícios e sua localização na cadeia do tratamento deve ser escolhida considerando seu impacto sobre outras unidades de processo, como a filtração (AWWARF, 2007). O desempenho de um filtro, com relação à remoção de partículas e carreiras de filtração, por exemplo, depende dos processos de prétratamento e das características das partículas da água afluente do filtro. Uma melhor qualidade na água filtrada é verificada quando a ozonização ocorre imediatamente antes da filtração.

Geralmente, os impactos da ozonização dependem do tipo de coagulante empregado e da qualidade da água bruta. O ozônio converte a matéria orgânica natural (MON) em compostos menores mais oxigenados (ácido oxálico), que podem exercer uma demanda maior de coagulante, quando este é adicionado à água bruta. Além disso, pelo fato dos polímeros catiônicos reagirem com partículas e matérias orgânicas maiores, a dosagem de polímero após a ozonização, cresce; o que pode levar a uma sub ou sobre dosagem de coagulante, prejudicando o desempenho dos processos à jusante.

A adoção de padrões de qualidade mais rigorosos e o aumento do uso da ozonização no tratamento da água ao redor do mundo têm também aumentando a atenção sobre a filtração biológica, cujos benefícios incluem a redução do potencial de crescimento bacteriano, redução dos subprodutos da desinfecção formados durante a desinfecção secundária e redução do potencial de corrosão.

Adicionalmente, a biofiltração possui a capacidade de controlar micropoluentes de preocupações estéticas e de saúde, além de compostos causadores de gosto e odor. Gosto e odor de terra e mofo são muitas vezes causados pelos metabólitos microbianos geosmina (trans-1,10-dimetil-trans-9-decalol) e MIB (2-metilisoborneol), que são de grande preocupação para as companhias de abastecimento de água e 
conseqüentemente, para as estações de tratamento de água, como por exemplo, para a Estação de Tratamento de Água Alto da Boa Vista (ETA ABV) na cidade de São Paulo/SP, devido ao limiar extremamente baixo de suas concentrações de odor (4 ng/L para geosmina e $9 \mathrm{ng} / \mathrm{L}$ para MIB, conforme apresentado por McGuire et al., 1981) e suas resistências aos processos convencionais de tratamento de água. Como estes compostos são biodegradáveis, a ozonização, em conjunto com a biofiltração, tem o potencial de fornecer um meio eficiente de remoção. Diversos fatores podem influenciar significativamente a remoção de MIB e geosmina nos biofiltros, além de interagirem entre si: presença de MOB (matéria orgânica biodegradável), características e concentrações dos afluentes dos biofiltros, natureza transiente dos eventos de gosto e odor, variações na temperatura da água, tipo de meio filtrante (carvão ativado granular, antracito ou areia), tempo de contato no leito vazio (TCLV), taxa hidráulica de aplicação e contralavagem, especialmente se esta é realizada com água contendo algum desinfetante residual (ELHADI; HUCK; SLAWSON, 2006).

O uso de filtros biológicos para a produção de uma água estável vem também sendo reconhecido na Europa nas últimas duas décadas, mostrando que tanto em um único estágio como quando empregados em seqüência, são eficientes na produção de águas com baixa turbidez e alta remoção de partículas. Em filtros biologicamente ativos, as bactérias heterotróficas alojadas no meio filtrante, como biofilmes, oxidam a matéria orgânica biodegradável e a utilizam como energia e fonte de carbono (URFER et al., 1997).

Dos meios filtrantes possíveis de serem aplicados, o carvão ativado granular (CAG) torna-se o preferido em relação a outros materiais, uma vez que serve tanto como meio filtrante quanto meio adsorvedor (GRENS; WERTH, 2001). 


\section{OBJETIVO}

O objetivo desta pesquisa foi 0 de estudar 0 desempenho de pós-filtros adsorvedores de CAG de origem mineral (betuminoso) e vegetal (casca de coco), alimentados com água filtrada da ETA ABV, seguida ou não de ozonização, com relação a, principalmente:

- Remoção de MIB e geosmina;

- Remoção de partículas;

- Remoção de carbono orgânico total e;

- Avaliação das perdas de carga nos filtros. 


\section{REVISÃO BIBLIOGRÁFICA}

\subsection{CONTROLE DE GOSTO E ODOR}

No segmento do tratamento de água não é incomum que empresas de abastecimento recebam queixas de clientes relacionados a gosto e odor objetáveis na água potável, oriunda de fontes superficiais que muitas vezes são afetadas por microrganismos, substâncias orgânicas e resíduos industriais.

As causas mais freqüentes de gosto e odor em águas de abastecimento são as algas, os actinomicetos (durante certas estações do ano) e o apodrecimento de vegetações; além de, ocasionalmente, sulfeto de hidrogênio, vazamentos químicos industriais, descartes ilegais e poluição por esgoto.

Usualmente, torna-se difícil controlar problemas de gosto e odor uma vez que estes já tenham se desenvolvido. O projeto de uma estação deve, desta forma, permitir à operação um certo grau de flexibilidade, como o uso de produtos químicos alternativos e pontos/níveis de profundidade diferentes na tomada de captação, que possam variar de acordo com as mudanças na qualidade da água bruta.

\subsubsection{PRINCIPAIS SUBSTÂNCIAS CAUSADORAS DE GOSTO E ODOR}

A maioria dos problemas de odor é o resultado de algas ou actinomicetos. Na Tabela 3.1.1 encontram-se listados os principais compostos causadores de gosto e odor e suas correspondentes sensações. Entre estes compostos a geosmina e o MIB (Tabela 3.1.2) causam odores objetáveis em concentrações muito baixas (10 ng/L), levando a níveis de aceitação da ordem de $8 \mathrm{ng} / \mathrm{L}$.

$\mathrm{Na}$ Tabela 3.1.3 encontram-se apresentadas as estruturas dos compostos que produzem gosto e odor e na Tabela 3.1.4, os tipos de algas associados a esses 
problemas e as dosagens de cloro e sulfato de cobre recomendadas para seus controles.

Tabela 3.1.1 - Sensações correspondentes aos principais compostos causadores de gosto e odor.

\begin{tabular}{|c|c|c|c|c|c|}
\hline \multirow{2}{*}{ Gênero de alga } & \multirow{2}{*}{$\begin{array}{l}\text { Grupo de } \\
\text { alga }\end{array}$} & \multicolumn{2}{|c|}{$\begin{array}{c}\text { Odor quando a quantidade de } \\
\text { alga é: }\end{array}$} & \multirow{2}{*}{ Gosto } & \multirow{2}{*}{$\begin{array}{c}\text { Sensação na } \\
\text { língua }\end{array}$} \\
\hline & & Moderada & Abundante & & \\
\hline Anabaena & Verde azul & $\begin{array}{l}\text { Grama, mofo, } \\
\text { agrião }\end{array}$ & Séptico & - & - \\
\hline Anacystis & Verde azul & Grama & Séptico & Doce & - \\
\hline Aphanizomenon & Verde azul & $\begin{array}{l}\text { Grama, mofo, } \\
\text { agrião }\end{array}$ & Séptico & Doce & Secura \\
\hline Asterionella & Diatomácea & $\begin{array}{l}\text { Gerânio, } \\
\text { picante }\end{array}$ & Peixe & - & - \\
\hline Ceratium & Flagelada & Peixe & Séptico & Amargo & - \\
\hline Dinobryon & Flagelada & Violeta & Peixe & - & Oleosidade \\
\hline Oscillatoria & Verde azul & Grama & Mofo, picante & - & - \\
\hline Scenedesmus & Verde & - & Grama & - & - \\
\hline Spirogyra & Verde & - & Grama & - & - \\
\hline Synura & Flagelada & $\begin{array}{l}\text { Pepino, } \\
\text { melão, picante }\end{array}$ & Peixe & Amargo & $\begin{array}{l}\text { Secura, } \\
\text { metálica }\end{array}$ \\
\hline Tabellaria & Diatomácea & Gerânio & Peixe & - & - \\
\hline Ulothrix & Verde & - & Grama & - & - \\
\hline Volvox & Flagelada & Peixe & Peixe & - & - \\
\hline
\end{tabular}

Fonte: Adaptado de Palmer, 1962.

* As algas verdes azuis são atualmente classificadas como cianobactérias.

\subsubsection{MEDIDAS DE CONTROLE}

No tratamento da água para abastecimento três medidas básicas para controle de gosto e odor são empregadas: (1) prevenções na captação da água bruta; (2) remoções na estação de tratamento e (3) controle no sistema de distribuição. 
Tabela 3.1.2 - Características químicas e físicas do MIB e da geosmina.

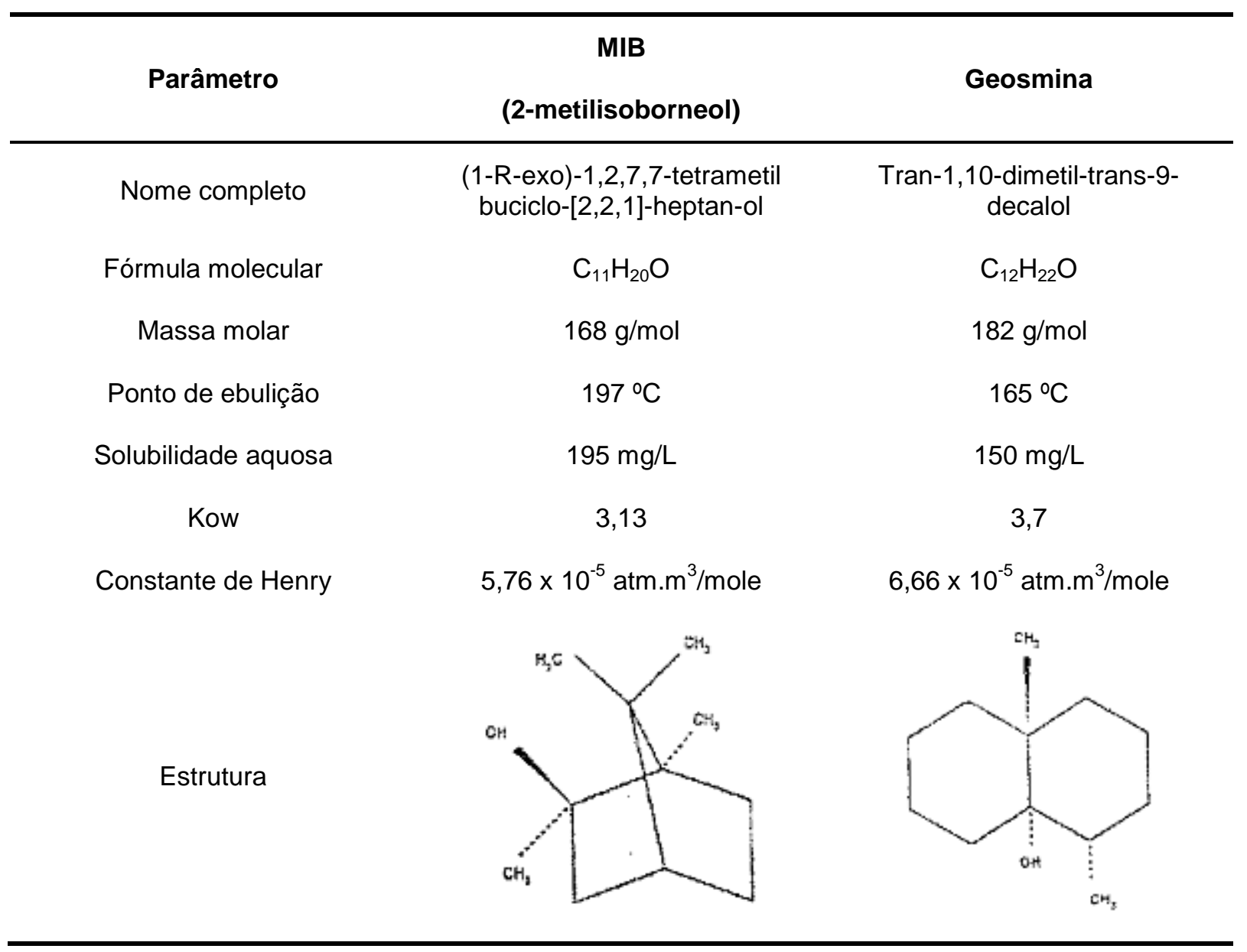

Fonte: AWWARF, 2005.

\subsubsection{PREVENÇÕES NA CAPTAÇÃO DA ÁGUA BRUTA}

\subsection{MISTURA DO RESERVATÓRIO}

A maioria dos lagos e reservatórios se estratificam durante as estações quentes, levando freqüentemente a uma deficiência de oxigenação da sua camada de fundo (hipolímnio). Nestas condições anaeróbicas, tanto o sulfeto de hidrogênio quanto a degradação de substâncias orgânicas resultam na emissão de odores objetáveis. As experiências adquiridas desde a última metade do século vinte têm demonstrado que a agitação de lagos através de misturadores mecânicos, bombas submersíveis ou bombas do tipo "air lift", melhoram significativamente a qualidade da água, 
diminuindo assim a carga sobre as estações de tratamento no controle dos problemas de gosto, odor, ferro e manganês.

Tabela 3.1.3 - Estruturas químicas dos compostos que produzem gosto e odor.

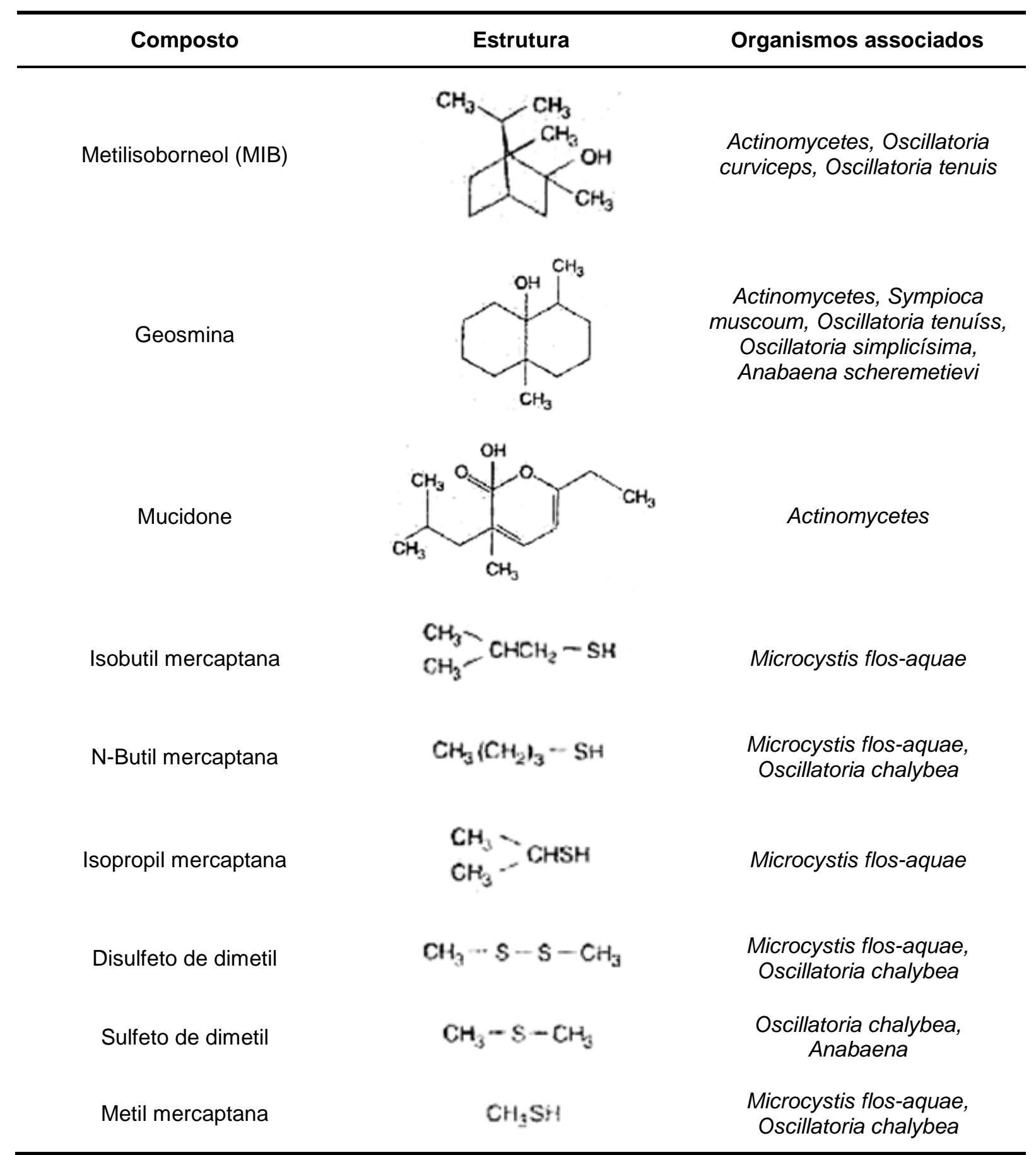

Fonte: Adaptado de MWH, 2005. 


\subsection{CONTROLE DA VEGETAÇÃO}

O controle da vegetação aquática de um reservatório é um método eficiente de preservação da qualidade da água, tornando-se mais complicado conforme maior o seu tamanho. O método mais comum de controle do crescimento algal é o uso do sulfato de cobre, cuja dosagem requerida varia entre 0,05 e $0,8 \mathrm{mg} / \mathrm{L}$, dependendo do tipo de alga.

Espécies algais sensíveis, como as verdes azuis, que freqüentemente causam intenso gosto e odor, podem ser tratadas com dosagens menores; já as verdes, requerem dosagens mais altas. No entanto, dosagens acima de $0,8 \mathrm{mg} / \mathrm{L}$ não são recomendadas uma vez que são letais para a maioria dos peixes.

Uma alternativa para o uso do sulfato de cobre é o permanganato de potássio, com uma dosagem eficiente variando entre 0,5 e $5,0 \mathrm{mg} / \mathrm{L}$. Todavia, fatores como sua baixa solubilidade $\left(5 \mathrm{~g} / 100 \mathrm{~mL}\right.$ a $\left.20{ }^{\circ} \mathrm{C}\right)$, maior custo e o desenvolvimento de uma coloração violeta, desencorajam seu uso.

Outros métodos que foram tentados no passado incluem o carvão ativado em pó (CAP) e a aplicação de compostos de cloro. O tratamento com carvão fica usualmente limitado a pequenos reservatórios e é uma medida temporária, pois este sedimenta rapidamente sem agitação.

Compostos de cloro, como o hipoclorito de cálcio e o hipoclorito de sódio, podem ser usados no controle de algas com 0,2 a 1,0 mg/L de cloro residual livre, entretanto sua eficiência é rapidamente perdida com a exposição aos raios solares e à matéria orgânica presente na água. 
Tabela 3.1.4 - Algas e organismos associados a problemas de gosto e odor e dosagens de produtos químicos para seus controles.

\begin{tabular}{|c|c|c|c|c|}
\hline Alga & Organismo & Problema & $\begin{array}{l}\text { Sulfato de } \\
\text { cobre }(\mathrm{mg} / \mathrm{L})\end{array}$ & Cloro (mg/L) \\
\hline \multirow{3}{*}{ Diatomácea } & $\begin{array}{c}\text { Asterionella, Synedra, } \\
\text { Tabellaria }\end{array}$ & Odor: aromático, peixe & $0,1-0,5$ & $0,5-1,0$ \\
\hline & Flagillaria, Navicula & Turbidez & $0,1-0,3$ & - \\
\hline & Melosira & Turbidez & 0,2 & 2,0 \\
\hline \multirow{5}{*}{ Verde-grama } & Eudorina $^{\mathrm{a}}$, Pandorina $^{\mathrm{a}}$ & Odor: peixe & $2-10$ & - \\
\hline & Volvox ${ }^{a}$ & Odor: peixe & 0,25 & $0,3-1,0$ \\
\hline & & & & \\
\hline & Chara, Cladophora & Turbidez, espuma & $0,1-0,5$ & - \\
\hline & Coelastrum, Spirogyra & Turbidez, espuma & $0,1-0,3$ & $1,0-1,5$ \\
\hline \multirow{3}{*}{ Verde-azul } & Anabaena, Aphanizomenon & Odor: mofo, grama, repulsivo & $0,1-0,5$ & $0,5-1,0$ \\
\hline & $\begin{array}{l}\text { Clathrocystis, } \\
\text { Coelosphaerium }\end{array}$ & Odor: grama, repulsivo & $0,1-0,3$ & $0,5-1,0$ \\
\hline & Oscillatoria & Turbidez & $0,2-0,5$ & 1,1 \\
\hline \multirow{5}{*}{ Amarelo-marrom } & Cryptomonas $^{\mathrm{b}}$ & Odor: aromático & $0,2-0,5$ & - \\
\hline & Dynobryon & Odor: aromático, peixe & 0,2 & $0,3-1,0$ \\
\hline & Mallomonas & Odor: aromático & $0,2-0,5$ & - \\
\hline & Synura & Gosto: pepino & $0,1-0,3$ & $0,3-1,0$ \\
\hline & Uroglenopsis & Odor: peixe. Gosto: oleoso & $0,1-0,2$ & $0,3-1,0$ \\
\hline \multirow{3}{*}{ Dinoflagelados } & Geratium & Odor: peixe, repulsivo & $0,2-0,3$ & $0,3-1,0$ \\
\hline & Glenodinium & Odor: peixe & $0,2-0,5$ & - \\
\hline & Peridinium & Odor: peixe & $0,5-2,0$ & - \\
\hline \multirow{2}{*}{$\begin{array}{c}\text { Bactéria } \\
\text { filamentosa }\end{array}$} & Beggiatoa (enxofre) & $\begin{array}{c}\text { Odor: podre. Crescimento em } \\
\text { tubulação }\end{array}$ & 5,0 & - \\
\hline & Crenothrix (ferro) & $\begin{array}{c}\text { Odor: podre. Crescimento em } \\
\text { tubulação }\end{array}$ & $0,3-0,5$ & 0,5 \\
\hline \multirow{2}{*}{ Crustácea } & Cyclops & c & - & $1,0-3,0$ \\
\hline & Daphnia & c & 2,0 & $1,0-3,0$ \\
\hline \multirow[t]{2}{*}{ Miscelânea } & Chironomus (pulga d'água) & c & - & $15-50$ \\
\hline & Craspedacusta (água-viva) & c & 0,3 & - \\
\hline
\end{tabular}

Fonte: Adaptado de MWH, 2005.

${ }^{a}$ Estes organismos são também classificados como protozoários flagelados. 
${ }^{\mathrm{b}}$ Classificação incerta.

${ }^{c}$ Estes organismos são individualmente visíveis e causam reclamações por parte dos consumidores.

\subsection{GERENCIAMENTO DO RESERVATÓRIO}

Durante as quatro estações do ano, a maioria dos lagos e reservatórios passam por uma estratificação térmica, formando-se uma zona de estagnação (hipolímnio) onde a água abaixo de 7,5 m fica quase estancada, tanto durante os meses quentes quanto os frios. Uma vez que a zona de estagnação apresenta pouco ou nenhum oxigênio dissolvido, os sulfatos e nitratos servem como fonte de oxigênio para a oxidação bioquímica pelas bactérias anaeróbicas e o íon sulfato é reduzido a íon sulfeto, formando sulfeto de hidrogênio, em níveis tão altos quanto de 5 a 6 mg/L.

Além disso, as mudanças de temperatura fazem com que a água represada revirese, arrastando o sulfeto de hidrogênio e outros compostos causadores de odor para a superfície. Um controle eficiente na formação do sulfeto de hidrogênio pode ser obtido com a mistura da água do reservatório, impedindo o desenvolvimento da zona de estagnação. A eficiência da mistura depende das dimensões do reservatório, do tipo de misturador e do seu posicionamento.

O gerenciamento do reservatório também engloba o controle de sua poluição, isto é, descartes ilegais, principalmente de ordem industrial.

\subsubsection{REMOÇÕES NA ESTAÇÃO DE TRATAMENTO}

Caso as medidas preventivas sejam ineficientes ou impraticáveis, o problema é controlado na estação de tratamento. As três medidas básicas são: aeração; oxidação e adsorção. 


\subsection{AERAÇÃO}

A aeração é uma solução prática no controle dos problemas de gosto e odor causado por compostos voláteis, como o sulfeto de hidrogênio. Todavia, não é o melhor método para controlar MIB e geosmina.

\subsection{OXIDAÇÃO}

Na maioria dos casos, a oxidação é o método mais prático e eficiente para controlar os problemas de gosto e odor, através do uso do permanganato de potássio, ozônio, ozônio conjuntamente com peróxido de hidrogênio, dióxido de cloro ou cloro. O oxidante mais usado é o permanganato de potássio.

A ozonização também é um método eficiente de oxidação, que na verdade muda as características de gosto e odor, além de reduzir os níveis dos compostos causadores. A dosagem do ozônio varia de 1 a $5 \mathrm{mg} / \mathrm{L}$, com uma média usualmente empregada de $2 \mathrm{mg} / \mathrm{L}$. Neste método, a chave de um controle bem sucedido de gosto e odor é a de fornecer pontos de aplicação diferentes além de um sistema de oxidação alternativo, caso necessário.

Diversos estudos pilotos conduzidos nos últimos anos mostram que o uso conjunto do ozônio com o peróxido de hidrogênio, pode ou não, ser superior ao uso do ozônio sozinho. Deste modo, testes de bancada e piloto são conduzidos para avaliar sua eficiência. O dióxido de cloro foi muito utilizado nos EUA no passado, atualmente porém, seu uso é desencorajado devido aos seus efeitos potencialmente prejudiciais à saúde humana. Similarmente, o cloro também se apresenta como um oxidante eficiente no controle de gosto e odor, mas seu emprego deve ser avaliado cuidadosamente devido à possível formação de subprodutos da desinfecção (DBP) e clorofenol.

Usualmente, se qualquer problema de gosto e odor é antecipado, a estação de tratamento de água costuma possuir um sistema de aplicação de permanganato de 
potássio e cloro, além de conduzir ensaios em escala piloto para ajudar na seleção da melhor dosagem.

$\mathrm{Na}$ Figura 3.1.1 tem-se ilustrado a relação entre a concentração de MIB e a dosagem de ozônio, para tempos de contato de 2,5; 5 e $10 \mathrm{~min}$; quanto maior o tempo de contato, menor a concentração de MIB. Na Figura 3.1.2 estão mostradas as mudanças na intensidade do gosto e odor para diferentes dosagens e tempos de contato; quanto maiores as dosagens, menores as intensidades de odor. E na Figura 3.1.3, encontra-se traçada uma relação entre dosagem de ozônio e a remoção de MIB; aumentando-se a dosagem, cresce a porcentagem de remoção.

Na Tabela 3.1.5 encontra-se um resumo de vários estudos realizados com o ozônio para a remoção de MIB. Aumentando-se a dosagem de ozônio aumentou-se a remoção de MIB, especialmente quando a ozonização foi seguida de uma filtração biológica (até $100 \%$ ), conforme documentado na Tabela 3.1.6.

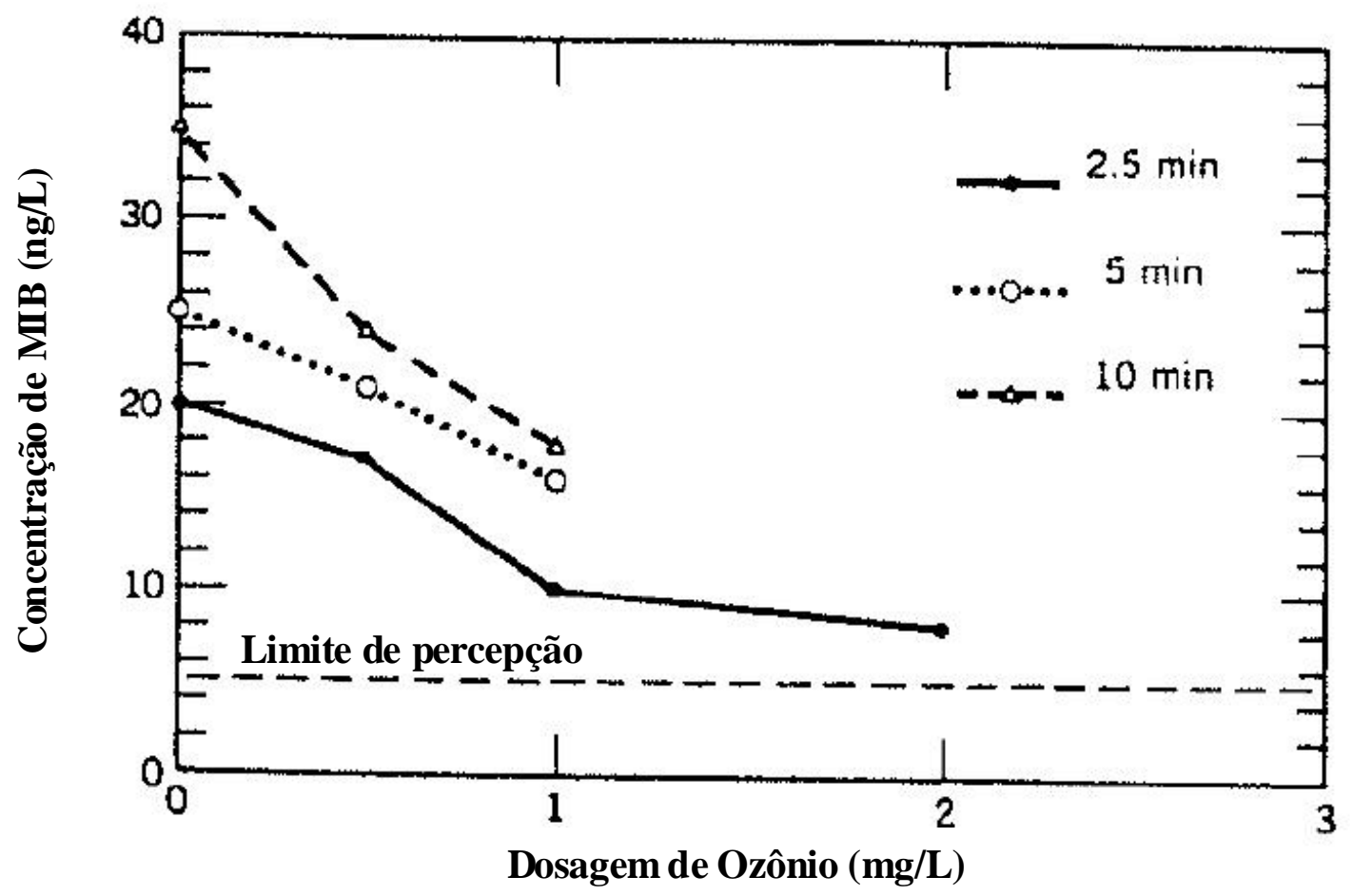

Figura 3.1.1 - Efeitos do tempo de contato do ozônio na remoção de MIB (KAWAMURA, 2000). 

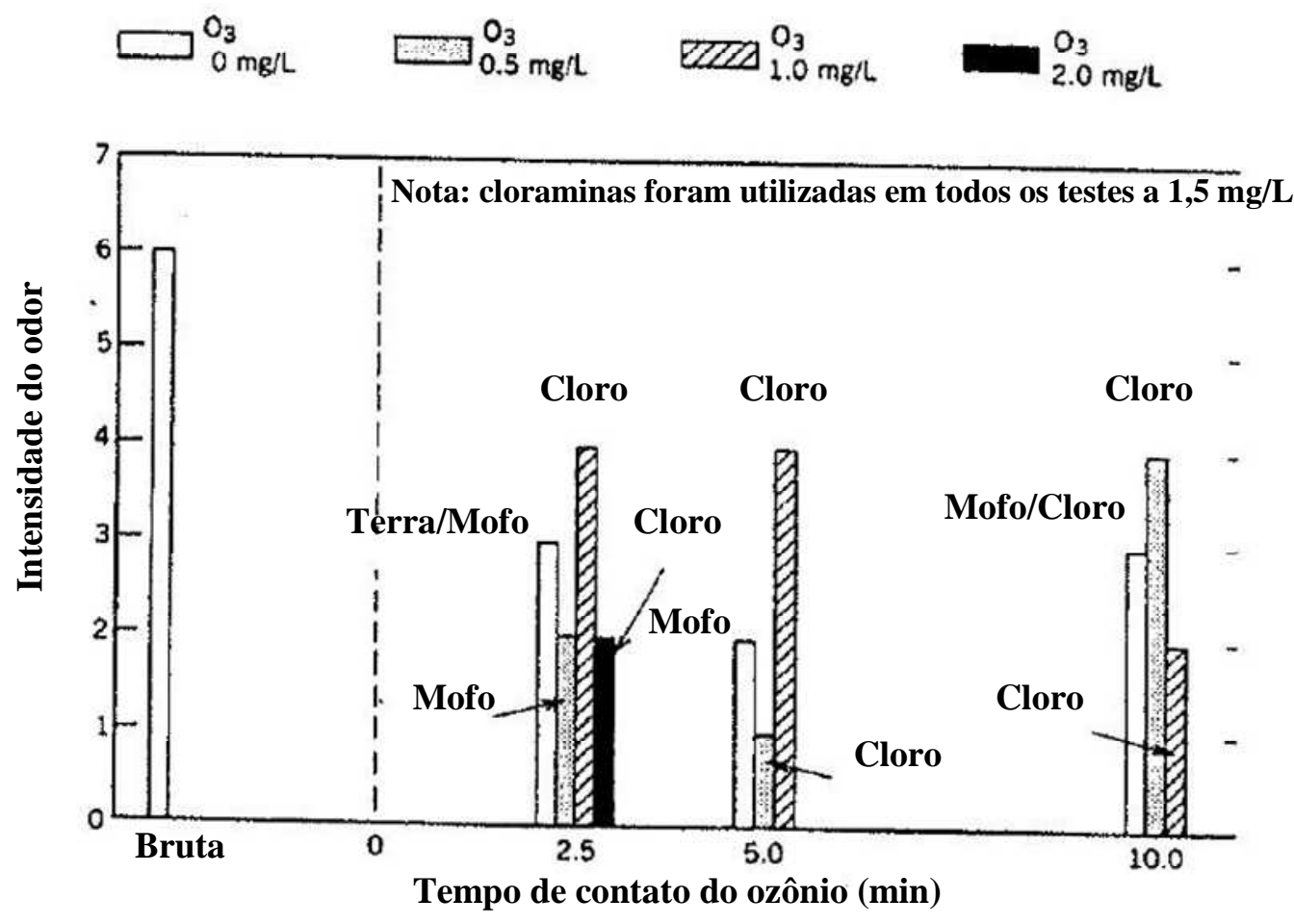

Figura 3.1.2 - Mudanças na intensidade do gosto e odor pela ozonização (KAWAMURA, 2000).

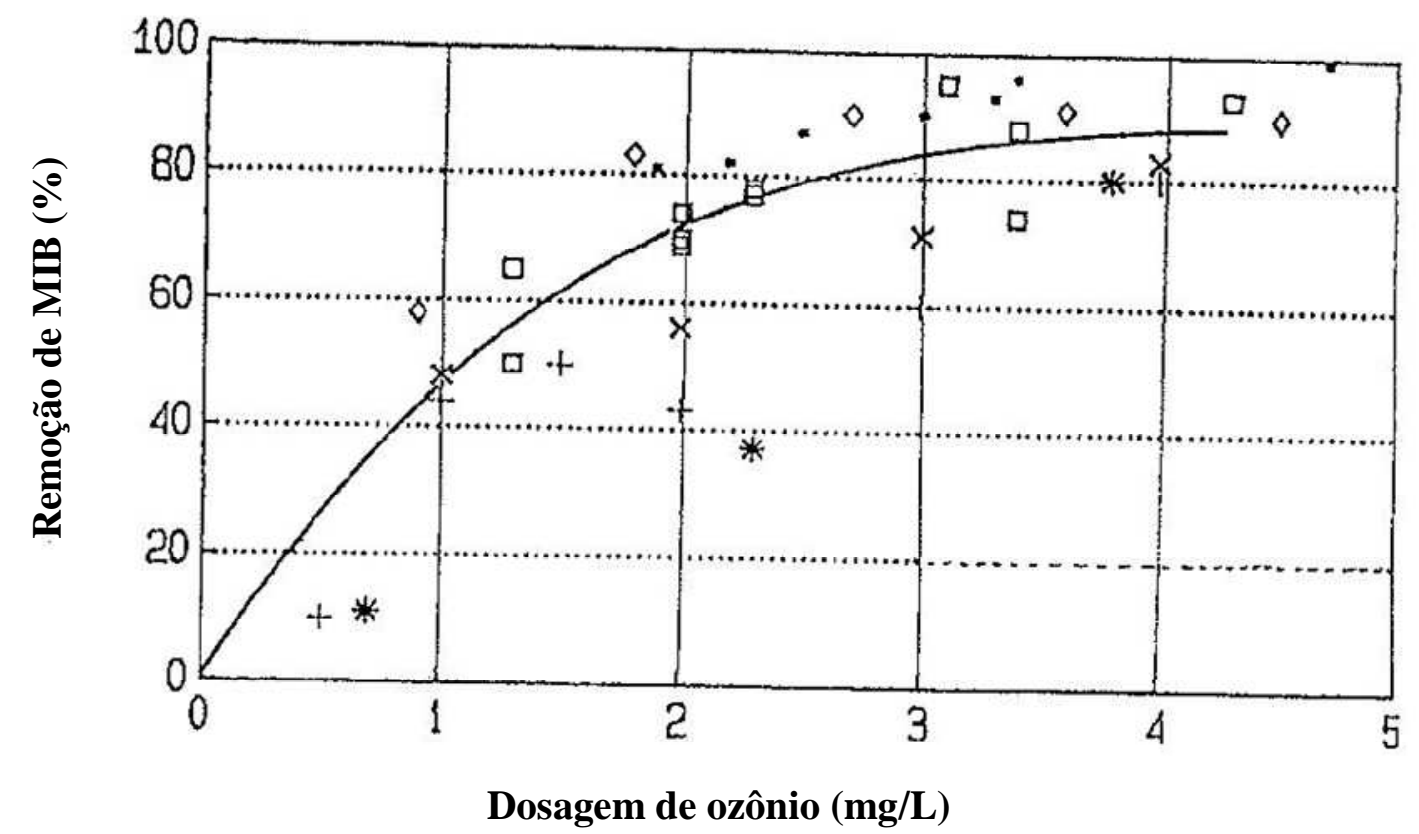

Figura 3.1.3 - Remoção de MIB pelo ozônio para diferentes águas de superfície (KAWAMURA, 2000). 


\subsubsection{ADSORÇÃO}

Os dois básicos e eficientes processos de adsorção na remoção de gosto e odor são a adição de CAP à água e o emprego de leitos de CAG para filtrar esta água. O uso da adsorção pelo CAP é mais apropriado em problemas infrequentes e moderados de gosto e odor (estações de pequeno e médio porte), com dosagens variando entre 1 e $50 \mathrm{mg} / \mathrm{L}$, sendo a média de $25 \mathrm{mg} / \mathrm{L}$ considerada comumente como a máxima dosagem admissível.

Sempre que um problema de gosto e odor, considerado de moderado à crônico, existir, avalia-se o emprego de leitos de adsorção de CAG, que são similares a filtros comuns, mas que levam em grande consideração o TCLV.

Valores típicos do TCLV variam de 3 a 10 min (principalmente $3 \mathrm{~min}$ ) para remoções de gosto e odor com a taxa de filtração entre 180 e $360 \mathrm{~m}^{3} / \mathrm{m}^{2}$. d. O tamanho padrão do meio filtrante é semelhante ao dos filtros rápidos de areia e a profundidade da camada, aproximadamente duas vezes maior.

Experiências operacionais de estações européias indicam que os leitos de CAG precisam ser regenerados a cada 4 ou 5 anos.

Na Figura 3.1.4 vê-se apontado o efeito do TCLV na remoção de alguns tipos de odores baseados em estudo piloto; aumentando-se o TCLV, reduz-se a intensidade do odor.

Estações de tratamento que freqüentemente requerem remoções de gosto e odor por carvão ativado, usualmente comparam o custo, facilidade operacional e manutenção do CAP versus CAG. Na Figura 3.1.5 encontra-se apresentada uma comparação de custo entre CAP e CAG, para o controle de gosto e odor; os custos do CAP sobem linearmente enquanto os do CAG são pontuais. E na Tabela 3.1.7, têm-se os resultados de testes de bancada para avaliar a eficiência da remoção de gosto e odor pelo CAP e outros quatro típicos oxidantes, adicionando-se $100 \mathrm{ng} / \mathrm{L}$ de MIB e geosmina à água filtrada; os produtos que apontaram remoções mais altas foram o ozônio e o peróxido de hidrogênio. 
Tabela 3.1.5 - Resumo de estudos de ozonização para remoção de MIB (continua).

\begin{tabular}{|c|c|c|c|c|c|c|c|}
\hline \multicolumn{3}{|c|}{ Qualidade da Água } & \multirow{2}{*}{$\begin{array}{c}\text { Dosagem } \\
\text { de } \\
\text { Ozônio } \\
\text { (mg/L) }\end{array}$} & \multirow{2}{*}{$\begin{array}{c}\text { Dosagem } \\
\text { de } \\
\text { Ozônio/COT }\end{array}$} & \multirow{2}{*}{$\begin{array}{c}\text { MIB } \\
\text { inicial } \\
\text { (ng/L) }\end{array}$} & \multirow{2}{*}{$\begin{array}{c}\text { Remoção } \\
\text { de MIB } \\
(\%)\end{array}$} & \multirow[b]{2}{*}{ Fonte } \\
\hline $\begin{array}{c}\text { COT } \\
(\mathrm{mg} / \mathrm{L})\end{array}$ & $\mathrm{pH}$ & $\begin{array}{c}\text { Alcalinidade } \\
\text { (mg/L) }\end{array}$ & & & & & \\
\hline \multirow[t]{3}{*}{9} & $x$ & $x$ & 1,5 & 0,17 & 50 & 75 & Ludgren et al. \\
\hline & & & 7 & 0,78 & 50 & $>95$ & \\
\hline & & & 20 & 2,22 & 50 & $>95$ & \\
\hline \multirow[t]{2}{*}{1,5} & 7,2 & $x$ & 1 & 1,67 & 165 & 27 & Hattori \\
\hline & & & 3 & 2,00 & 165 & 73 & \\
\hline \multirow[t]{2}{*}{$2,7-2,8$} & $8,3-8,4$ & $125-133$ & 2 & $0,74-0,71$ & 100 & 40 & Glaze et al. \\
\hline & & & 4 & $1,48-1,42$ & 100 & $73-83$ & \\
\hline \multirow[t]{2}{*}{$2,8-3,0$} & $8,1-8,3$ & $80-84$ & 2 & $0,71-0,66$ & 100 & 82 & \\
\hline & & & 4 & $1,42-1,33$ & 100 & 92 & \\
\hline \multirow[t]{3}{*}{$2,6-2,9$} & $8,3-8,4$ & $126-134$ & 1 & $0,38-0,34$ & 100 & 58 & Ferguson et al. \\
\hline & & & 2 & $0,76-0,68$ & 100 & 78 & \\
\hline & & & 4 & $1,53-1,37$ & 100 & 91 & \\
\hline \multirow[t]{3}{*}{$2,5-2,7$} & $7,8-8,1$ & $80-85$ & 1 & $0,4-0,37$ & 100 & 58 & \\
\hline & & & 2 & $0,8-0,74$ & 100 & 65 & \\
\hline & & & 4 & $1,6-1,48$ & 100 & 81 & \\
\hline \multirow[t]{3}{*}{$x$} & $7,8-8,2$ & $65-95$ & 1 & & 100 & 58 & Koch et al. \\
\hline & & & 2 & & 100 & 66 & \\
\hline & & & 4 & & 100 & 81 & \\
\hline$x$ & $7,9-8,5$ & $125-135$ & 1 & & 100 & 57 & \\
\hline
\end{tabular}


Tabela 3.1.5 - Resumo de estudos de ozonização para remoção de MIB (conclusão).

\begin{tabular}{|c|c|c|c|c|c|c|c|}
\hline \multicolumn{3}{|c|}{ Qualidade da Água } & \multirow{2}{*}{$\begin{array}{c}\text { Dosagem } \\
\text { de } \\
\text { Ozônio } \\
\text { (mg/L) }\end{array}$} & \multirow{2}{*}{$\begin{array}{c}\text { Dosagem } \\
\text { de } \\
\text { Ozônio/COT }\end{array}$} & \multirow{2}{*}{$\begin{array}{c}\text { MIB } \\
\text { inicial } \\
\text { (ng/L) }\end{array}$} & \multirow{2}{*}{$\begin{array}{c}\text { Remoção } \\
\text { de MIB } \\
(\%)\end{array}$} & \multirow[b]{2}{*}{ Fonte } \\
\hline $\begin{array}{c}\text { COT } \\
(\mathrm{mg} / \mathrm{L})\end{array}$ & pH & $\begin{array}{c}\text { Alcalinidade } \\
\text { (mg/L) }\end{array}$ & & & & & \\
\hline & & & 2 & & 100 & 76 & \\
\hline & & & 4 & & 100 & 90 & \\
\hline \multirow[t]{3}{*}{2,0 * } & 8,4 * & $111 *$ & 1,33 & 0,66 & 37 & 54 & Nerenberg; \\
\hline & & & 1,33 & 0,66 & 14 & 36 & Rittmann e \\
\hline & & & 1,62 & 0,81 & 43 & 65 & Soucie, 2000 \\
\hline
\end{tabular}

Fonte: Nerenberg; Rittmann; Soucie, 2000.

X: Sem dados.

*: Valor típico.
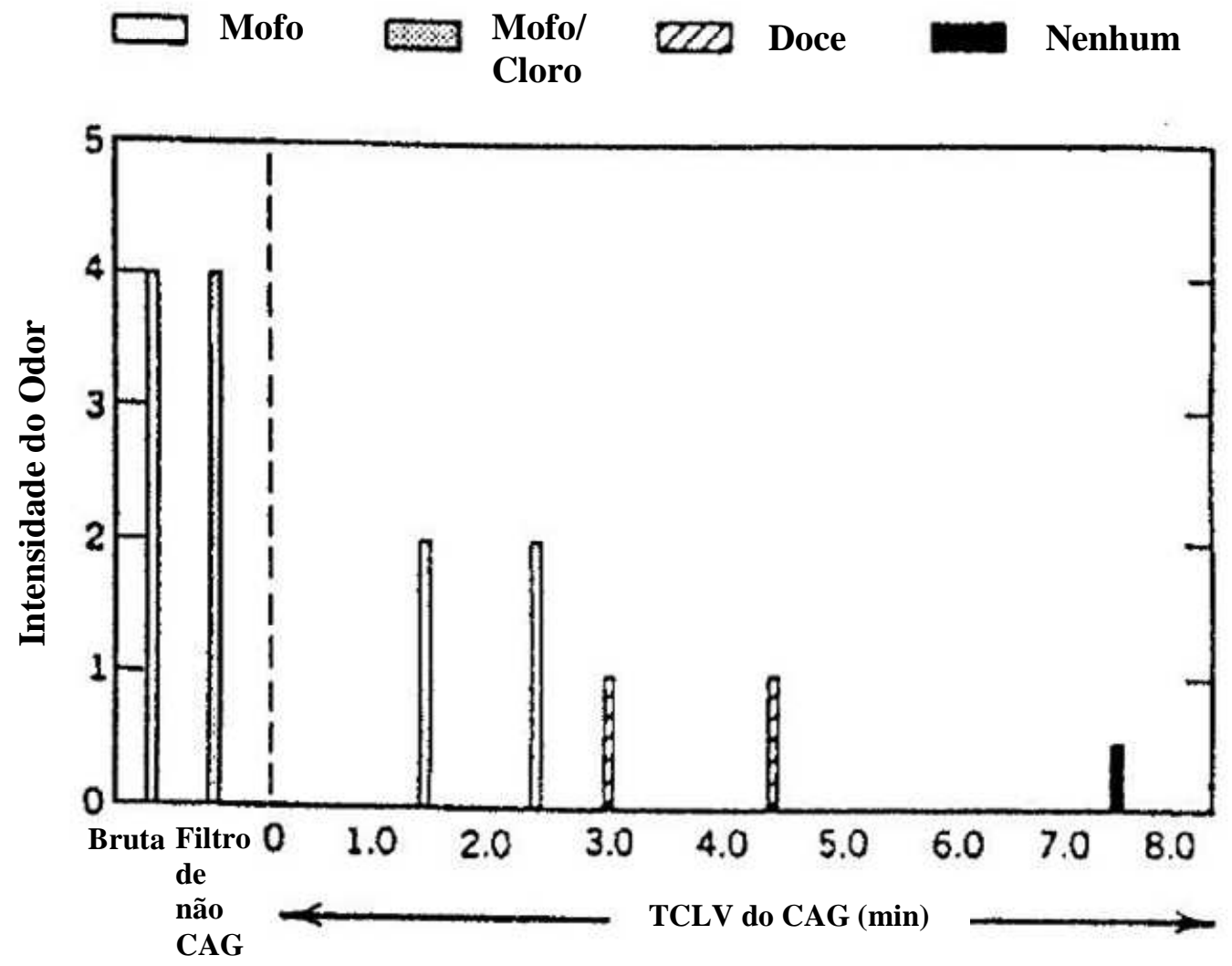

Figura 3.1.4 - Remoção de odor pelo processo de adsorção por CAG (KAWAMURA, 2000). 
Tabela 3.1.6 - Resumo de estudos de biofiltração para remoção de MIB.

\begin{tabular}{|c|c|c|c|c|c|c|}
\hline Reator/Meio & $\begin{array}{c}\text { Taxa de } \\
\text { aplicação } \\
(\mathrm{m} / \mathrm{h})\end{array}$ & $\begin{array}{c}\text { Tempo de } \\
\text { contato } \\
\text { (min) }\end{array}$ & $\begin{array}{c}\text { COT da } \\
\text { água bruta } \\
\text { (mg/L) }\end{array}$ & $\begin{array}{l}\text { Concentração } \\
\text { inicial (ng/L) }\end{array}$ & $\begin{array}{c}\text { Remoção } \\
\text { biológica } \\
(\%)\end{array}$ & Fonte \\
\hline \multirow[t]{2}{*}{ Filtro lento de areia } & $x$ & $x$ & $x$ & 69 & 100 & Yagi et al. \\
\hline & & & & 25 & 88 & \\
\hline Filtro lento de areia & 0,025 & $480^{a}$ & $8-9$ & 50 & $>95$ & $\begin{array}{c}\text { Lundgren et } \\
\text { al. }\end{array}$ \\
\hline \multirow[t]{2}{*}{$\begin{array}{l}\text { RMC com biofilme e } \\
\text { esferas de vidro }\end{array}$} & $0,25^{\mathrm{b}}$ & 19,8 & 1,1 & $10^{5}$ & 43,6 & $\begin{array}{c}\text { Namkung e } \\
\text { Rittmann }\end{array}$ \\
\hline & & & & $10^{6}$ & 16,7 & \\
\hline $\begin{array}{l}\text { Biofiltro de CAG em } \\
\text { escala de bancada }\end{array}$ & 0,0083 & 2,4 & $x$ & $1,6-1,7$ & $56-58$ & Yagi et al. \\
\hline \multirow[t]{2}{*}{$\begin{array}{l}\text { Biofiltro tubular em } \\
\text { forma de colméia }\end{array}$} & $\begin{array}{c}0,0026- \\
0,0101\end{array}$ & 120 & 2,6 & 114 & 46 & Hattori \\
\hline & & & & 98 & 33 & \\
\hline $\begin{array}{c}\text { Biofiltro rápido de } \\
\text { areia }\end{array}$ & 10 & 8,3 & $x$ & $20-120$ & $8-54$ & $\begin{array}{c}\text { Ashitani et } \\
\text { al. }\end{array}$ \\
\hline $\begin{array}{l}\text { Biofiltro piloto com } \\
\text { poros granulares } \\
\text { cerâmicos }\end{array}$ & 7,1 & 12,7 & $x$ & $50-750$ & $60-80$ & $\begin{array}{c}\text { Terauchi et } \\
\text { al. }\end{array}$ \\
\hline \multirow{3}{*}{$\begin{array}{l}\text { Biofiltro rápido de } \\
\text { CAG com pré- } \\
\text { ozonização }\end{array}$} & $7,7(3 / 8 / 98)$ & $14,4 / 9,6^{c}$ & 2,0 & 17 & 46 & Nerenberg; \\
\hline & $5,5(10 / 8 / 98)$ & $20,2 / 13,4$ & & 9 & $29-64$ & $\begin{array}{c}\text { Rittmann e } \\
\text { Soucie, }\end{array}$ \\
\hline & $7,1(17 / 8 / 98)$ & $15,6 / 10,4$ & & 14 & 26 & 2000 \\
\hline
\end{tabular}

Fonte: Nerenberg; Rittmann; Soucie, 2000.

a: Valor estimado baseado no volume do reator, taxa de aplicação e assumindo uma porosidade de 0,4 .

b: RMC - Reator de Mistura Completa.

c: Para uma altura de 1,83 m de meio filtrante total, com 1,22 m de CAG. 
Outros estudos, realizados por Gillogly et al. (1999), em laboratório e escala piloto, mostraram que a adsorção pelo CAG sozinho forneceu, na maioria das vezes, proteção insuficiente contra episódios de MIB, gosto e odor. Para menores tempos de contato (4 min de TCLV) o CAG virgem controlou apenas concentrações $\leq 30$ $\mathrm{ng} / \mathrm{L}$ de MIB e que inclusive para tempos de contato mais longos (cerca de $10 \mathrm{~min}$ ), $30 \mathrm{ng} / \mathrm{L}$ foi o máximo valor que conseguiu ser reduzido até níveis aceitáveis ( 5 ng/L), para carvões em serviço durante um ano. Foi também observado que, o cloro reduziu a habilidade do CAG em remover MIB e que quanto maior era a quantidade de cloro $(\leq 1,0 \mathrm{mg} / \mathrm{L})$ que reagia com o carvão, menor quantidade de MIB era removida. Nas Figuras 3.1.6 e 3.1.7 estão apresentadas as remoções de geosmina e MIB para testes com filtros de CAG e antracito (ELHADI; HUCK; SLAWSON, 2006). MIB e geosmina foram adicionados continuamente durante 62 dias a uma concentração igual a $100 \mathrm{ng} / \mathrm{L}$. As barras da esquerda referem-se às amostras com temperatura de $20^{\circ} \mathrm{C}$ e as da direita, de $8^{\circ} \mathrm{C}$. O alto valor de MOB investigado foi de $280 \mu \mathrm{g} / \mathrm{L}$ de carbono e, o baixo, igual a $28 \mu \mathrm{g} / \mathrm{L}$.

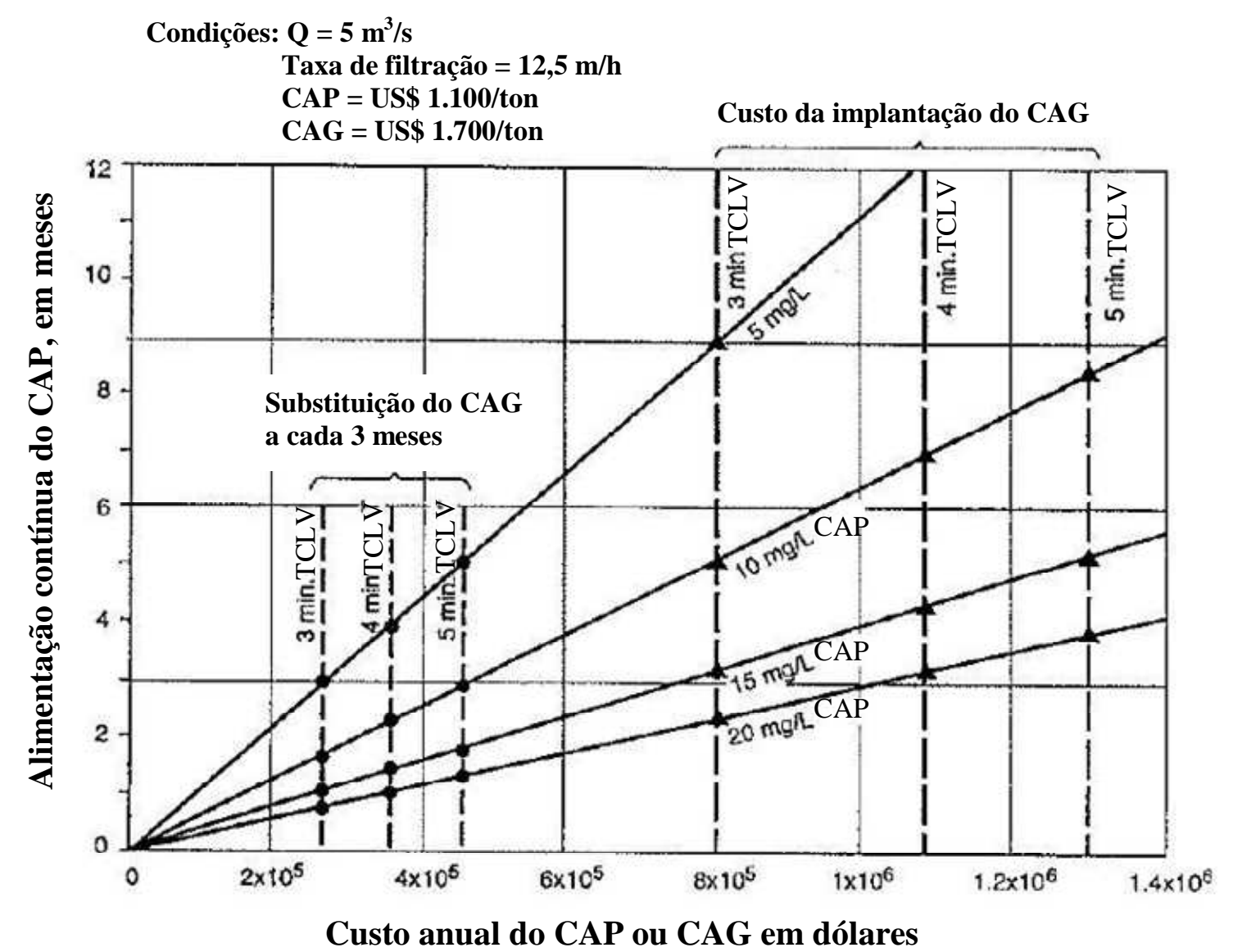

Figura 3.1.5 - Escolha do CAP ou CAG para o controle de gosto e odor (KAWAMURA, 2000). 
Tabela 3.1.7 - Exemplo de taxa de remoção de MIB e geosmina pelo CAP, $\mathrm{KMnO}_{4}, \mathrm{Cl}_{2}, \mathrm{H}_{2} \mathrm{O}_{2}$ e $\mathrm{O}_{3}$.

\begin{tabular}{cccc} 
Produto Químico & Dosagem $(\mathrm{mg} / \mathrm{L})$ & \multicolumn{2}{c}{ Taxa de Remoção (\%) } \\
\cline { 3 - 4 } & & Geosmina & MIB \\
\hline Carvão Ativado em Pó & 10 & 40 & 62 \\
Carvão Ativado em Pó & 25 & 52 & 65 \\
Permanganato de Potássio & 0,8 & 42 & 33 \\
Cloro & 2 & 45 & 72 \\
Peróxido de Hidrogênio & 1 & 50 & 77 \\
Ozônio & 2,5 & 94 & 95 \\
\hline
\end{tabular}

Fonte: Adaptado de Kawamura, 2000.

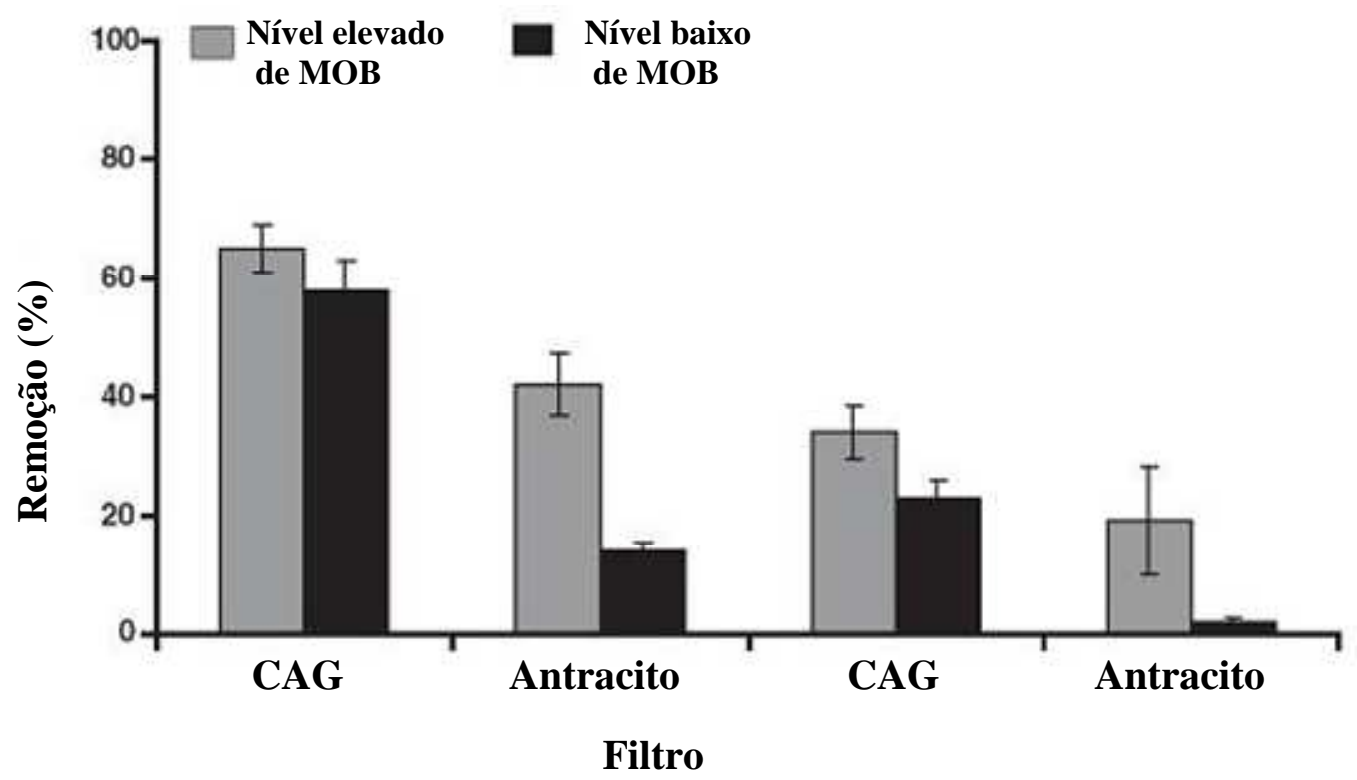

Figura 3.1.6 - Porcentagem de remoção de geosmina em filtros de CAG e antracito (ELHADI; HUCK; SLAWSON, 2006). 


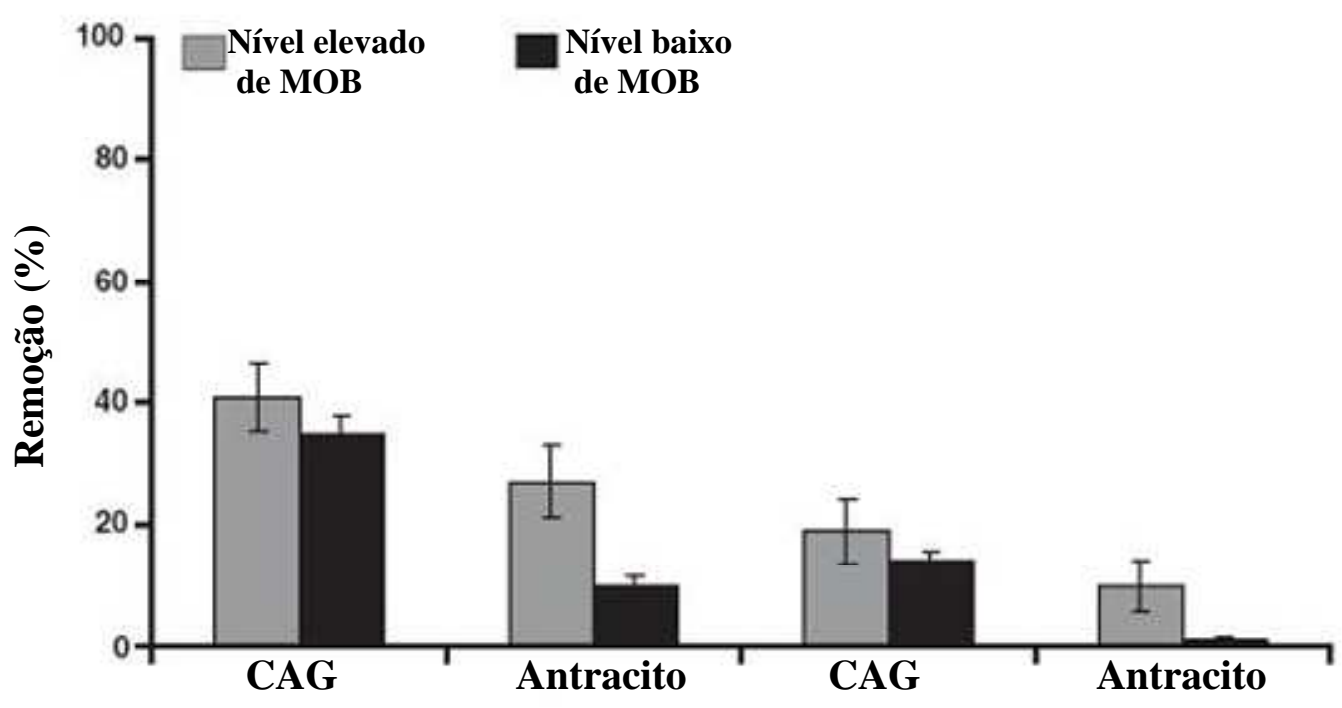

Filtro

Figura 3.1.7 - Porcentagem de remoção de MIB em filtros de CAG e antracito (ELHADI; HUCK; SLAWSON, 2006).

A temperatura afetou as remoções de geosmina e MIB, especialmente nos filtros de CAG. A diminuição na temperatura de $20{ }^{\circ} \mathrm{C}$ para $8{ }^{\circ} \mathrm{C}$ resultou numa diminuição das remoções, para ambos os níveis de MOB na amostra efluente dos filtros.

O tipo de leito teve um efeito significativo sobre as remoções de geosmina e MIB, tanto para uma temperatura de $20{ }^{\circ} \mathrm{C}$, quanto para uma de $8{ }^{\circ} \mathrm{C}$, particularmente para a concentração mais baixa de MOB. A $20^{\circ} \mathrm{C}$, as remoções de geosmina alcançaram 24 e 44 pontos de porcentagem mais altos em filtros de CAG do que de antracito, para os níveis alto e baixo de $\mathrm{MOB}$, respectivamente. Tendências similares foram observadas para as remoções de MIB. A $8{ }^{\circ} \mathrm{C}$, um efeito semelhante também foi verificado, tanto para MIB quanto para geosmina, em ambos níveis de MOB, com maiores remoções ocorrendo nos leitos de CAG.

\subsubsection{CONTROLE NO SISTEMA DE DISTRIBUIÇÃO}

Problemas de gosto e odor também podem ocorrer no sistema de distribuição, especialmente devido à corrosão do material da tubulação e ao do crescimento de ferro bactérias como a Crenothrix e Leptothrix dentro da rede de água. Adicionalmente, nos casos onde a quantidade de sulfato na água é alta e esta 
permanece em tubulações de canto morto, problemas de gosto e odor podem ser agravados por bactérias redutoras de sulfato.

Estes problemas geralmente são retificados com a minimização de projetos de tubulações com cantos mortos e do fornecimento de dispositivos de limpeza e deslocamento em pontos estratégicos da rede de distribuição. Além disso, equipes de manutenção costumam manter as redes de água limpas através das descargas periódicas de depósitos e microrganismos que vão se acumulando. Estações de tratamento também costumam minimizar problemas de gosto e odor mantendo um adequado nível de cloro residual no sistema de distribuição para combater as bactérias ou adotar medidas anticorrosivas, tais como, ajuste do $\mathrm{pH}$ da água pelo índice de saturação ou adição de um inibidor de corrosão à água final. 


\subsection{ADSORÇÃO POR CARVÃO ATIVADO GRANULAR}

\subsubsection{GENERALIDADES}

O carvão ativado granular tem sido utilizado recentemente como substituto de meios filtrantes granulares ou como um processo adicional no tratamento convencional, para a remoção de compostos orgânicos, incluindo: subprodutos da desinfecção, compostos causadores de gosto e odor, pesticidas e outros compostos orgânicos sintéticos.

O leito filtrante de CAG é capaz de funcionar da mesma maneira que filtros comuns, isto é, removendo a matéria suspensa, mas também removendo compostos orgânicos. Na Europa, empregam-se leitos de adsorção de CAG para a remoção de gosto e odor, compostos orgânicos e carbono orgânico total, posicionando estes leitos após os filtros convencionais (na maioria dos casos) e precedidos por um processo de pré-ozonização.

Nos últimos anos a indústria da água nos EUA tem dado grande atenção ao processo de adsorção por CAG, especialmente para melhorar a sua qualidade estética, através da redução de cor; gosto e odor objetáveis e torná-la mais segura. No entanto, os custos de operação e manutenção são significativamente mais elevados, devido principalmente a necessidade de regeneração do CAG.

\subsubsection{CARACTERÍSTICAS DO CAG}

O carvão ativado granular pode ser fabricado a partir de uma variedade de materiais, como: madeira, casca de nozes, carvão, turfa ou resíduos de petróleo; contudo, o CAG usado no tratamento de água é geralmente produzido do carvão betuminoso ou de lignina; muito embora ensaios de durabilidade realizados com carvões à base de madeira e de carvão tenham apresentado resultados similares durante cinco 
anos, mantendo-se as mesmas condições de contra lavagem (GRENS; WERTH, 2001).

Os carvões à base de lignina e betuminoso são produzidos através de aquecimento em fornos, sob condições anaeróbicas. Esta ausência de oxigênio assegura que o carvão não queime, mas que seja transformado em um material poroso, que é ativado por exposição a uma mistura de vapor e ar a uma temperatura de $815^{\circ} \mathrm{C}$. Este processo de ativação oxida a superfície dos poros do carvão, permitindo que esta atraia e mantenha os compostos orgânicos. Testes realizados por Mackenzie; Tennant e Mazyck (2005) em águas livres de matéria orgânica, investigaram o tempo de trespasse de três tipos diferentes de CAG, em relação a MIB (Figura 3.2.1). Os carvões virgens ensaiados eram à base de lignina (CAG $A$ ), betuminoso (CAG B) e de madeira (CAG C).

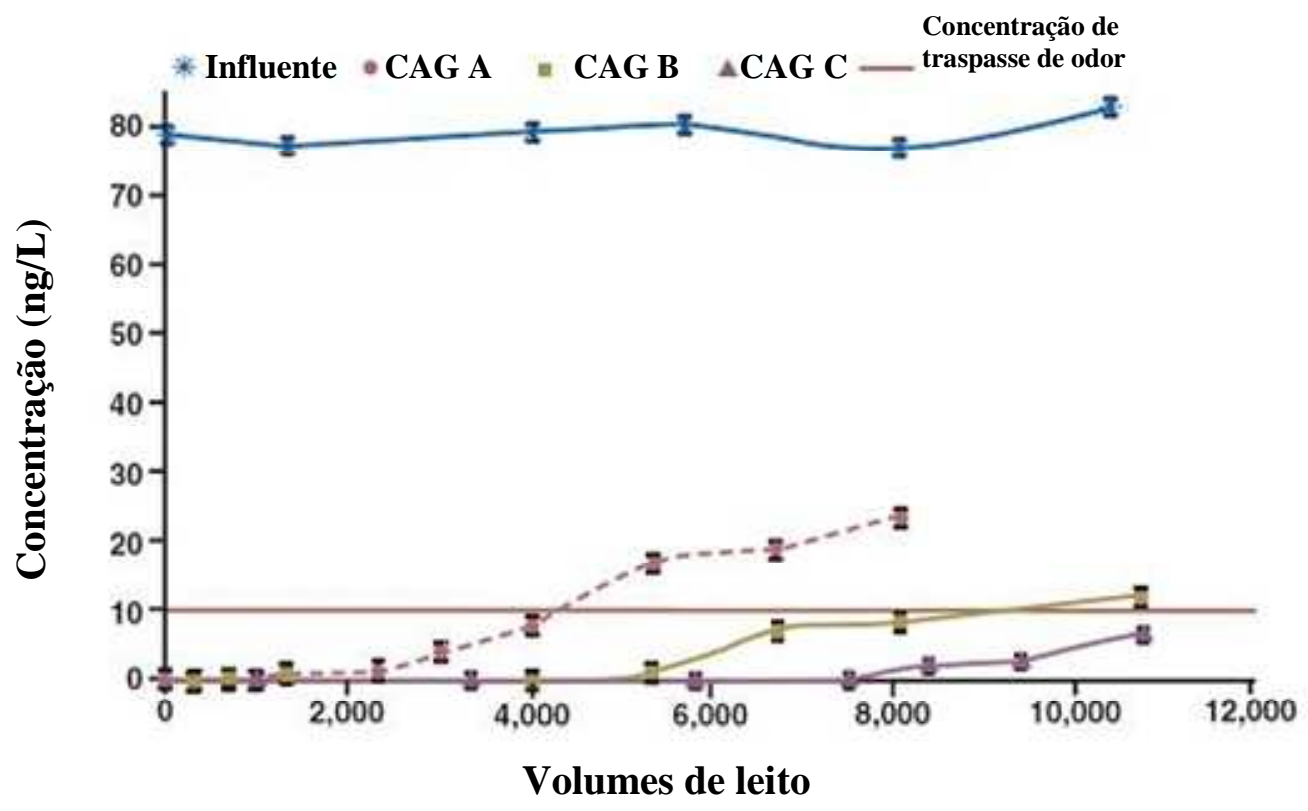

Figura 3.2.1 - Curvas de traspasse de MIB para carvões ativados granulares disponíveis no mercado (MACKENZIE; TENNANT; MAZYCK, 2005).

Dos três tipos de carvões investigados, aquele a base de madeira foi o que apresentou maiores volumes de leito (volume de filtração/volume do meio filtrante) antes de aparecer na água alguma quantidade de MIB e fosse atingida a concentração limiar de odor. Sua combinação de microporosidade e mesoporosidade, resultando em uma elevada área superficial, poderia ser uma das razões de seu melhor desempenho com relação ao carvão betuminoso. O que mostrou o mais rápido traspasse foi o à base de lignina. 
Em um outro estudo, conduzido por Najm; Kennedy e Naylor (2005) foi comparado o desempenho de CAG de lignina em relação a CAG betuminoso para biofiltração na ETA Sweeney em Wilmington, EUA. Os resultados apontaram que ambos os tipos removeram igualmente bem a turbidez e tiveram um bom desempenho em relação à biofiltração. No entanto, uma vantagem que o de lignina apresentou, foi com relação a sua menor densidade, o que requeriu uma menor taxa de contra lavagem e uma menor quantidade de quilos para encher o volume do filtro, o que reduziu os custos.

De acordo com o boletim técnico da empresa Calgon Carbon, as propriedades de um CAG são:

- Área total superficial do CAG - 890 a $900 \mathrm{~m}^{2} / \mathrm{g}$.

- Densidade do CAG molhado $-480 \mathrm{~kg} / \mathrm{m}^{3}$.

- Densidade do CAG seco $-450 \mathrm{~kg} / \mathrm{m}^{3}$.

- Densidade de partícula - 1,4 a $1,5 \mathrm{~g} / \mathrm{cm}^{3}$.

- Tamanho efetivo - 0,8 a 1,0 mm para o Filtrasorb $100 ; 0,55$ a $0,75 \mathrm{~mm}$ para o Filtrasorb 200.

- Coeficiente de uniformidade - 2,1 para o Filtrasorb 100; 1,9 para o Filtrasorb 200.

- $\quad$ Número de iodo - 850 a 875.

- Número de abrasão - 70 a 86.

- Umidade (embalado) - 0,5 a $2 \%$.

Na Figura 3.2.2 têm-se ilustradas as características hidráulicas de um leito de CAG, com a taxa ótima de contra lavagem igual a 20-30 \% de expansão (devido ao leve peso específico do material). Esses leitos de CAG são contra lavados periodicamente para remover microrganismos e matéria suspensa, muito embora esta ação destrua a zona de transferência de massa. Na Figura 3.2.3 vê-se relacionada a perda de carga ao longo de um leito limpo de CAG, segundo diversas taxas de filtração. 
Expansão do Leito Durante a Contra Lavagem

Velocidade superficial $(\mathrm{cm} / \mathrm{s})$

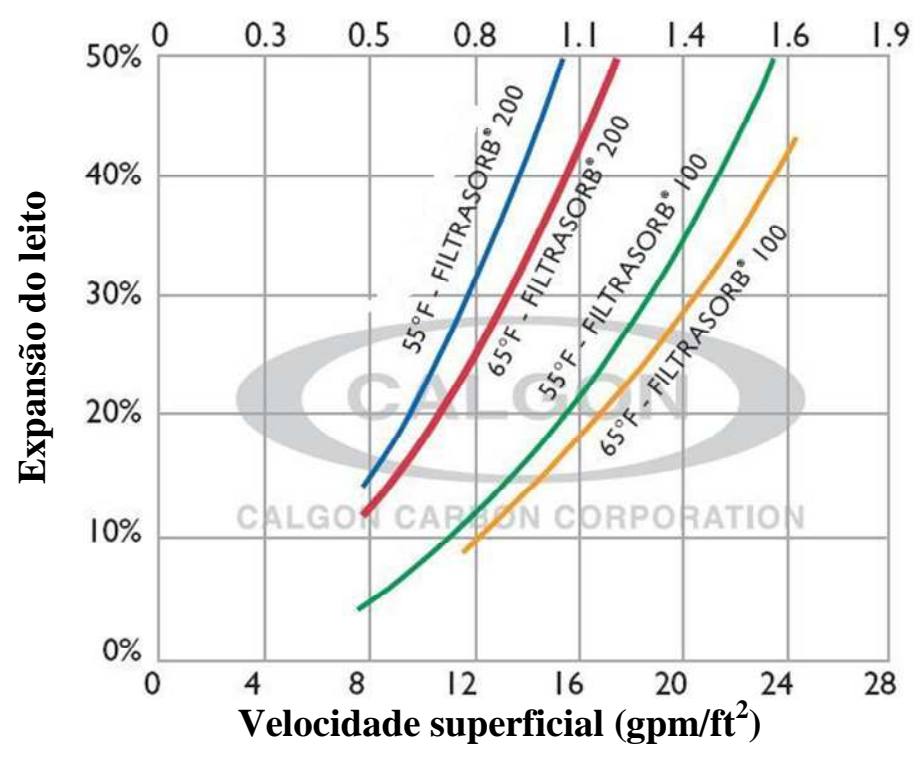

Figura 3.2.2 - Taxas de contra lavagem versus taxas de expansão de leitos de CAG (adaptado do boletim da Calgon, 2006).

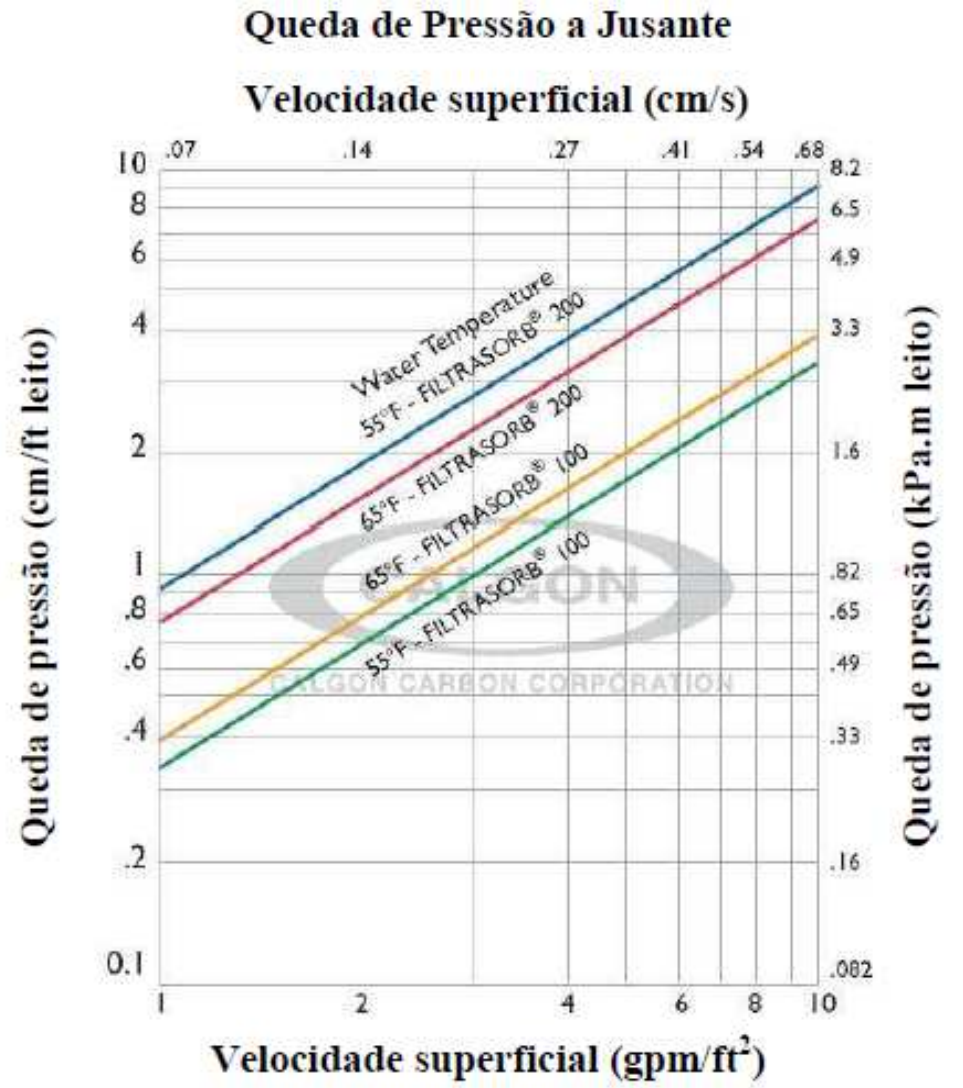

Figura 3.2.3 - Perdas de carga versus taxas de contra lavagem para leitos de CAG (adaptado do boletim da Calgon, 2006). 


\subsubsection{CONSIDERAÇÕES DE PROJETO}

As principais considerações de projeto para leitos de CAG são: (1) vazão e perdas de carga disponíveis para o processo; (2) natureza e quantidade dos compostos orgânicos presentes na água; (3) níveis máximos de contaminação regulamentados para estes compostos orgânicos; (4) processo global de tratamento da estação e de cada uma de suas unidades; (5) tipo e tamanho do CAG; (6) taxa de filtração (geralmente entre 120 e $300 \mathrm{~m}^{3} / \mathrm{m}^{2} . \mathrm{d}$ ); (7) tempo de contato no leito vazio; (8) localização dos leitos de CAG na cadeia do tratamento e; (9) freqüência e método de regeneração do CAG. Adiante se descrevem algumas destas considerações.

\subsubsection{NATUREZA E QUANTIDADE DOS COMPOSTOS ORGÂNICOS}

Tanto as propriedades físicas quanto as químicas dos compostos orgânicos afetam fortemente o tipo e nível do tratamento que antecede os leitos de adsorção de CAG. A coagulação-floculação realizada com um sal de alumínio, seguida de clarificação é um processo eficiente para compostos orgânicos de alta massa molecular; já os compostos de baixa massa molecular, altamente voláteis, podem ser removidos por "air stripping" a montante dos leitos de CAG.

Estudos realizados por Owen et al. (1995) mostraram que o CAG inicialmente remove MON húmica e de maior peso molecular e alguma quantidade da matéria não húmica, de baixa massa. No entanto, na medida que processo de traspasse do CAG progride, também ocorre o traspasse desses compostos, sendo aconselhável a otimização da remoção da MON pela coagulação (reduzindo conseqüentemente o carregamento sobre o CAG) e a ozonização, para promover a formação de MON biodegradável e subseqüente remoção pelo carvão, operando como biologicamente ativo. 


\subsubsection{LEITOS DE CAG COMO PROCESSO DE FILTRAÇÃO E ADSORÇÃO}

Projetos de filtros mais recentes, dispostos após a pré-ozonização, utilizam meios de CAG ao invés dos tradicionais areia e antracito para remover subprodutos carcinogênicos da ozonização e reduzir os altos níveis de COA (carbono orgânico assimilável) da água ozonizada. Além disso, a substituição de meios filtrantes convencionais pelo CAG e a adição de uma camada de CAG sobre leitos já existentes, tem sido avaliada e implementada em muitas plantas na Europa e EUA, não somente pela pré-ozonização, mas também pelo o controle de gosto e odor ou remoção de substâncias químicas orgânicas sintéticas, encontradas na agricultura e em descartes industriais e urbanos.

A remoção de subprodutos da ozonização por leitos de CAG depende muito do crescimento de microrganismos neste leito, que passa a ser denominado filtro biologicamente ativo ou biofiltro. Em estudos de biofiltração realizados por Liu; Hucker e Slawson (2001), um período mínimo de 20 a 40 dias foi necessário para que os biofiltros (operados à $20 \stackrel{\circ}{\circ}$ ) atingissem remoções estáveis de compostos mais facilmente biodegradáveis.

Filtros comuns de areia e antracito também podem se tornar biologicamente ativos por meio de uma adequada pré-ozonização, porém a concentração de biomassa será menor do que aquela formada em leitos de CAG. Estudos realizados por Wang; Summers e Miltner (1995) mostraram que meios de CAG foram capazes de reter mais biomassa do que meios filtrantes de areia ou antracito, apresentando de três a oito vezes mais biomassa. Adicionalmente, a biomassa dos leitos convencionais é facilmente arrastada durante a contra lavagem realizado com cloro residual, ao contrário dos de CAG, que conseguem reter a maior parte da biomassa.

Com relação aos compostos orgânicos, como a maior remoção de carbono orgânico total (COT) é alcançada nos primeiros $15-20 \mathrm{~cm}$ da camada do leito (implicando em um TCLV de cerca de 1,5 min) onde a quantidade de biomassa é maior, muitas estações adicionam uma camada de CAG acima do leito filtrante existente e reduzem o tempo de lavagem para 2-3 min de maneira a não remover a biomassa. 
Para o processo de adsorção, é preferível um CAG de pequeno tamanho e de alto coeficiente de uniformidade; já para o processo de filtração, são requeridos grãos de tamanho maior com um pequeno coeficiente de uniformidade, o que é essencial para obter-se uma carreira de filtração mais longa e um efluente de boa qualidade.

Projetos de filtros mais recentes, incluindo os com leito de CAG, são compostos de camadas com tamanho efetivo de 1,2 a 1,5 mm; coeficiente de uniformidade $<1,4 \mathrm{e}$ profundidade no leito de 1,8 a 2,1 m; com ou sem uma pequena camada de areia no fundo. Esta fina camada de areia (profundidade de $25 \mathrm{~cm}$ e tamanho efetivo de 0,55 a $0,60 \mathrm{~mm}$ ) serve como uma barreira contra possíveis passagens de bactérias, protozoários, rotíferos e até mesmo nematóides, pelo CAG carregado desta biomassa. Prefere-se utilizar CAG de carvão ao invés de madeira como meio filtrante e para remoção do COT.

Existem três principais questões operacionais relacionadas aos filtros de CAG: (1) controle da biomassa; (2) controle da dosagem de determinados produtos químicos antes da entrada no filtro e (3) controle das condições anaeróbicas dentro do meio.

A ozonização de águas com alto teor de MON (COT) produzem uma elevada concentração de biomassa quando a temperatura da água é mais elevada. Mesmo com contra lavagem ar e água, a perda de carga aumenta mais rapidamente com o tempo, reduzindo a carreira de filtração. Assim, as estações de tratamento adicionam cloro $(0,3$ a $0,5 \mathrm{mg} / \mathrm{L})$ à contra lavagem até que a perda de carga se normalize. No entanto, a contra-lavagem de um filtro com água não clorada é preferível devido à concentração de biomassa mais elevada e ao melhor controle de aldeídos, COA, COT e precursores dos DBP (MILTNER; SUMMERS; WANG, 1995). A contra lavagem a ar não parece ser prejudicial ao desempenho da biofiltração (AHMAD et al., 1998; LIU; HUCK; SLAWSON, 2002) e à remoção de COT, conforme apresentado na Figura 3.2.4 (EMELKO et al., 2006). 


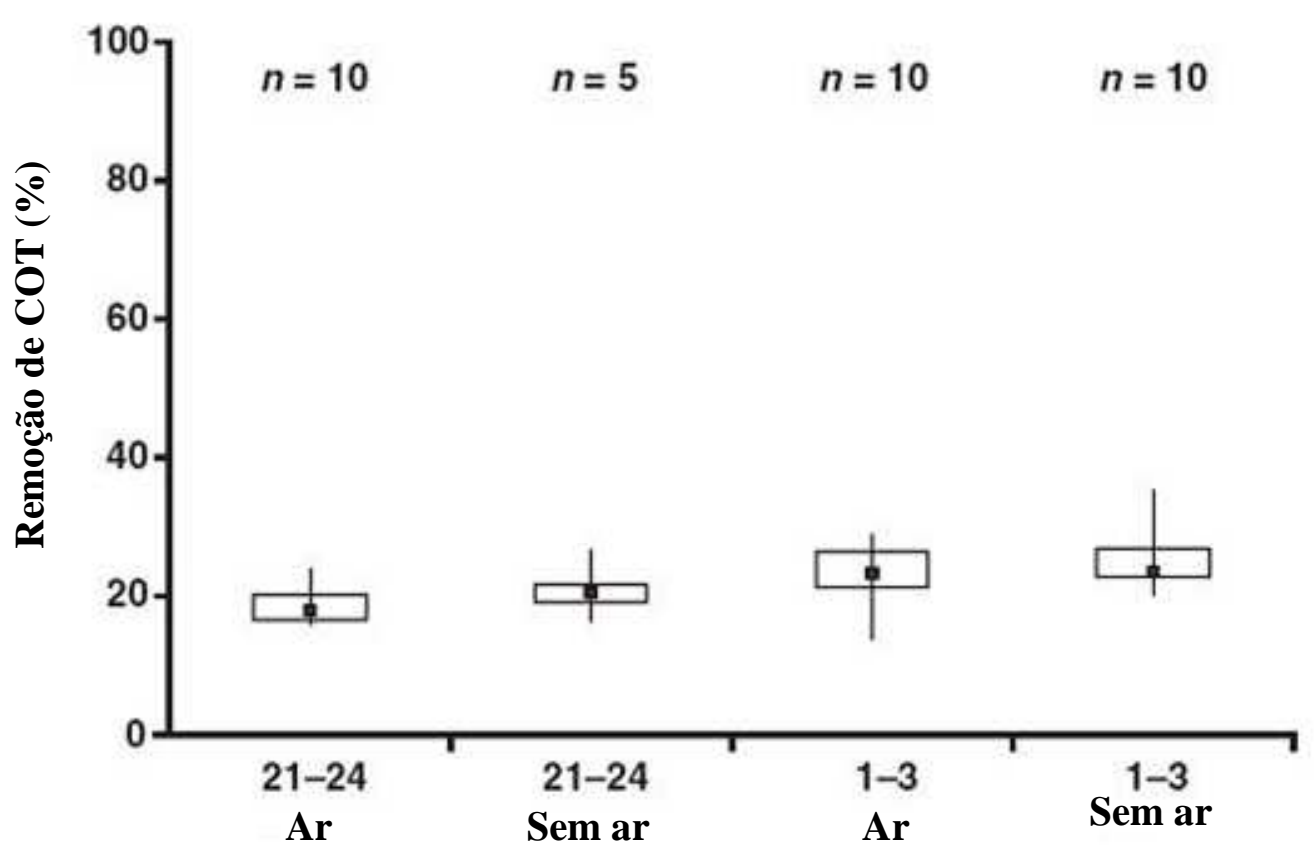

Estratégia de contra lavagem e temperatura da água - ${ }^{\circ} \mathrm{C}$

Figura 3.2.4: Remoção de COT em filtros de CAG (EMELKO et al., 2006).

A aceitabilidade do cloro na água de contra lavagem dos filtros pode depender dos objetivos do tratamento. Se o objetivo é remover componentes facilmente biodegradáveis (subprodutos da ozonização e COA), a presença do cloro na contra lavagem pode ser aceitável. O que pode não ser verdade se a biofiltração destina-se a remover a demanda de cloro, os precursores dos subprodutos da cloração, ou ambos (URFER et al., 1997).

Literaturas disponíveis sugerem que a contra lavagem de filtros biológicos, com ou sem ar, pode levar a perdas não significativas da biomassa alojada; uma vez que a bactéria parece se ligar mais fortemente ao meio filtrante do que às partículas não biológicas.

Outros cuidados tomados pelas estações de tratamento dizem respeito à seleção do tipo de produto químico que alimenta um filtro de CAG. A adição de polímero como auxiliar de filtração é uma prática bastante comum em filtros convencionais de alta taxa, mas que diminui significativamente a capacidade de adsorção do CAG, podendo liberar monômeros de acrilamida (carcinogênicos) através da quebra da cadeia do polímero pela biomassa. 
O permanganato de potássio é adicionado para o controle de ferro, manganês, gosto e odor, porém se praticado por longos períodos de tempo, os grãos de CAG ficam cobertos pelo óxido de manganês, reduzindo ou até perdendo a sua capacidade de adsorção.

A terceira questão operacional diz respeito a deixar o filtro de CAG em "standby" (fora de operação) durante um longo período, sem drenar a água parada. Esta situação cria uma condição anaeróbica dentro do filtro, que quando este é posto em serviço, gera um problema de gosto e odor, além de liberar ferro e manganês solúveis. O problema de gosto e odor é resultado da matéria orgânica em decomposição e do sulfeto de hidrogênio. O ferro e o manganês reduzidos, liberados pelo CAG, irão produzir uma alta coloração quando o cloro for adicionado à água durante o estágio final de desinfecção. Dessa forma, as estações costumam aplicar ar de tempos em tempos em filtros já drenados de CAG, que ficam sem operar por mais de duas a três semanas.

\subsubsection{TAMANHO DO CAG}

O tamanho do CAG influencia fortemente, tanto a profundidade, quanto à perda de carga no leito, para uma taxa de filtração específica.

Carvões ativados granulares maiores apresentam vantagens para aplicação de filtros de camada profunda sob altas taxas de filtração. No entanto, carvões menores caracterizam-se por taxas de adsorção mais elevadas, dado um determinado nível equivalente de atividade, com um leito mais raso.

\subsubsection{TEMPO DE CONTATO DE LEITO VAZIO}

Tempos de contato de leito vazio costumam variar entre 7,5 e $10 \mathrm{~min}$. Valores menores podem ser empregados na remoção de COS, já que são facilmente 
adsorvidos. Entretanto, tempos de contato mais longos são usados na remoção de compostos mais solúveis e menos adsorvíveis. Na Figura 3.2.5 encontra-se indicado o aumento dos THM para tempos de 5; 7,5 e 15 min; além da importância de um tempo de detenção mínimo de 15 min (dado um ciclo razoável de regeneração). Aumentando-se o TCLV de 7,5 para $15 \mathrm{~min}$; aumenta-se significativamente a vida do carvão. Outros resultados similares tem sido obtidos em diversos testes piloto (EPA, 1981).

A maioria dos parâmetros de projeto para filtros de CAG são avaliados por estudos piloto (dependendo do tempo e dinheiro disponíveis), uma vez que cada água bruta contem uma combinação única e diferente de sólidos suspensos, compostos orgânicos e inorgânicos.

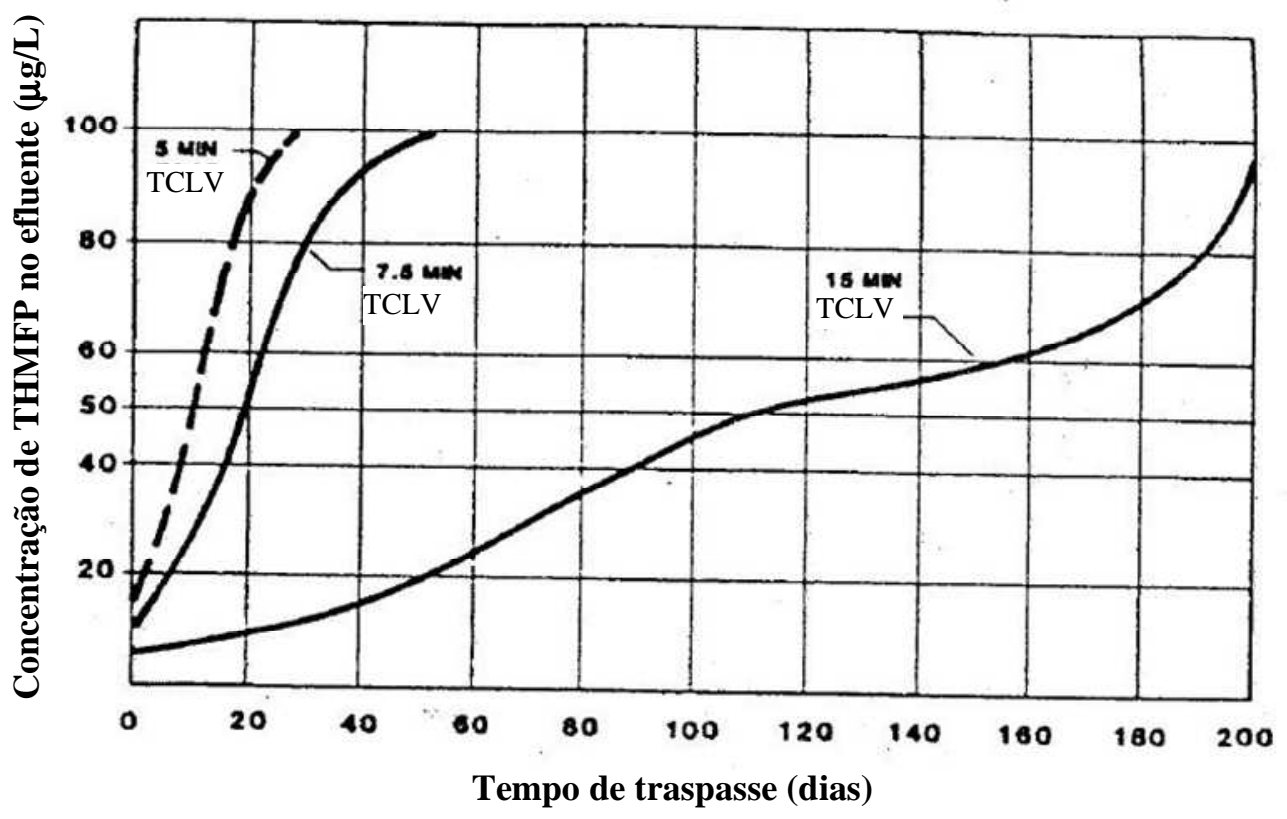

Figura 3.2.5: Aumento dos THM ao longo do tempo (AWWA, 1987).

\subsubsection{LOCALIZAÇÃO DOS LEITOS DE CAG NA CADEIA DO TRATAMENTO}

Leitos de CAG podem ser posicionados a montante do processo de floculação ou antes e depois de filtros convencionais, dependendo da natureza da substância a ser removida e o resultado dos testes piloto. 


\subsection{CONTROLE DE SUBPRODUTOS DA DESINFECÇÃO}

Um dos dilemas enfrentados pelo setor do tratamento de água diz respeito à minimização dos riscos potenciais dos subprodutos da desinfecção, mantendo-se, ao mesmo tempo, a proteção microbiana através do emprego de desinfetantes adequados. Aumentando-se a quantidade de desinfetante aplicado, diminui-se o risco microbiano, mas elevam-se os riscos dos DBP.

Os maiores subprodutos da desinfecção pelo cloro são os trialometanos (THM) e os ácidos haloacéticos $\left(\mathrm{HAA}_{5}\right)$; já os compostos orgânicos voláteis sintéticos (COVS), são resíduos industriais freqüentemente encontrados em águas subterrâneas. Todos estas substâncias são consideradas uma ameaça à saúde pública, ponderadas, supostamente, como carcinogênicas.

\subsubsection{TRIALOMETANOS}

Os THM são formados pela cloração da MON, que é muitas vezes descrita como um precursor orgânico (substâncias húmicas e ácidos flúvicos), pelo cloro livre residual. As cloraminas também são capazes de produzir THM, mas a níveis tão baixos que são considerados desprezíveis.

São denominados de THMT (trialometanos totais) a soma dos trialometanos $\left(\mathrm{CHCl}_{3}\right)$, tribromometanos $\left(\mathrm{CHBr}_{3}\right)$, bromodiclorometanos $\left(\mathrm{CHBrCl}_{2}\right)$ e dibromoclorometanos $\left(\mathrm{CHBr}_{2} \mathrm{Cl}\right)$.

As quatro definições básicas para os THM são:

- THM instantâneo - concentração de THM no momento da amostragem.

- THM final - concentração de THM no ponto mais afastado da rede de distribuição. 
- Potencial de Formação de THM (THMFP) - determinado pela diferença entre o THM instantâneo e o THM final.

- Potencial máximo total de THM - concentração máxima de THM, segundo as condições mais favoráveis de formação.

A taxa de formação de THM e a concentração de THM final dependem de seis grandes fatores: (1) quantidade de precursores orgânicos; (2) nível de cloro livre residual; (3) temperatura da água; (4) pH da água; (5) concentração de brometo na água e, (6) tempo de contato do cloro.

\subsubsection{PRECURSORES}

Caso não haja precursores orgânicos presentes na água, não haverá formação de THM; assim, a concentração e tipo de precursor têm um impacto direto em sua formação.

\subsubsection{NÍVEL DE CLORO LIVRE RESIDUAL}

Como os THM são subprodutos da cloração, a quantidade de cloro residual influencia diretamente o seu grau de formação; como também, as condições iniciais de mistura e a configuração do tanque de contato.

\subsubsection{TEMPERATURA E pH DA ÁGUA}

A temperatura da água afeta diretamente a taxa de formação dos THM; uma temperatura mais elevada leva a uma reação mais rápida e portanto, numa formação maior. 
Também para o $\mathrm{pH}$, quanto mais alto for o seu valor, mais rápida a taxa de reação e mais elevados são os níveis de THM; acredita-se que este fenômeno seja devido a mudanças induzidas de $\mathrm{pH}$ nos grupos funcionais das moléculas precursoras.

\subsubsection{TEMPO DE CONTATO DO CLORO}

Os níveis de THM são uma função do tempo de contato do cloro; quanto mais longo o tempo de contato, mas alta é a concentração de THM. Este fenômeno é particularmente verificado durante as primeiras horas de reação, reduzindo-se ao longo de dois a três dias.

\subsubsection{MEDIDAS DE CONTROLE DOS THM}

Medidas de controle dos THM são implementadas usualmente em duas situações: quando do projeto de uma nova estação de tratamento de água e durante a modificação de uma estação existente. Em ambos os casos, as estratégias de controle dos THM são as mesmas:

- Procura por locais alternativos de captação (caso estes não existam ou sejam economicamente inviáveis, avaliam-se as opções abaixo);

- Melhora da floculação e sedimentação para aumentar a remoção de precursores orgânicos;

- Mudança nos pontos de aplicação da cloração, para diminuir o tempo de contato;

- Substituição da pré-cloração pelo permanganato de potássio;

- Usar cloraminas como um desinfetante alternativo, isto é, adicionar amônia de 10 a 20 min após a aplicação do cloro; 
- Dosar CAP para remover precursores e THM.

Quando alguma das opções acima torna-se factível após testes em escala de bancada, realizam-se testes em escala piloto para confirmar sua eficácia e antecipar seus custos. Porém, quando todas as opções acima falham, as estações de tratamento costumam ponderar técnicas de tratamento mais drásticas e caras:

- Uso da pré-ozonização para oxidar e remover precursores orgânicos;

- Emprego de uma torre de aeração para remover os THM;

- Utilizar a nanofiltração ou osmose reversa para remover os THM.

O uso do ozônio com leitos de adsorção de CAG tem sido relatado como um meio eficiente de controle dos níveis de THM desde a metade da década de 70. Na Figura 3.3.1 tem-se mostrado o controle eficiente dos THM pelo leito de CAG, sendo a pósozonização necessária para combater o vazamento significativo de microrganismos deste leito.

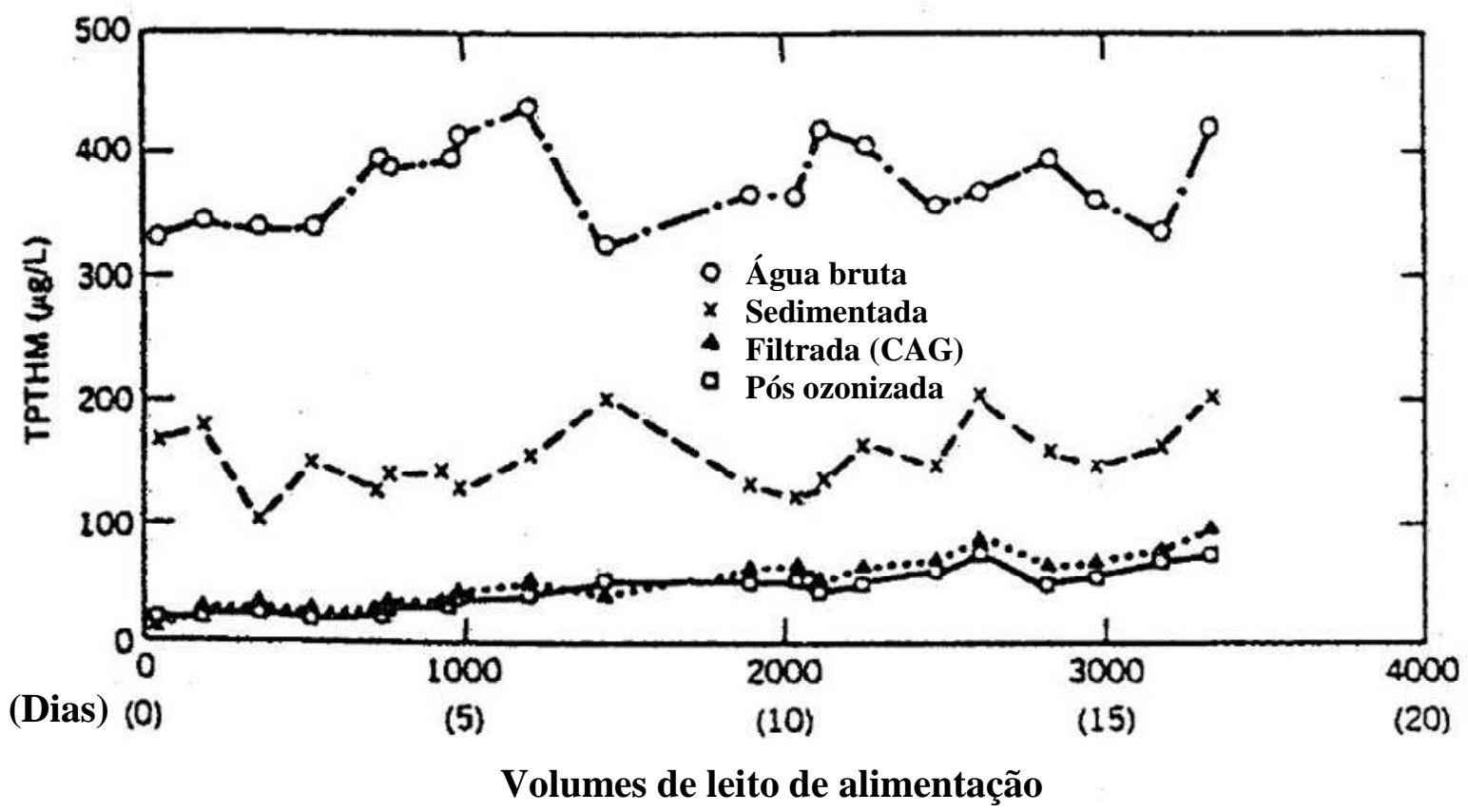

Figura 3.3.1 - Redução do potencial total de trialometanos através de processos em escala piloto (KAWAMURA, 2000). 
Na Figura 3.3.2 encontram-se discriminados perfis de potencial de formação de trialometanos para ensaios piloto de ozonização intermediária e filtração biológica (CHAIKET et al., 2002).

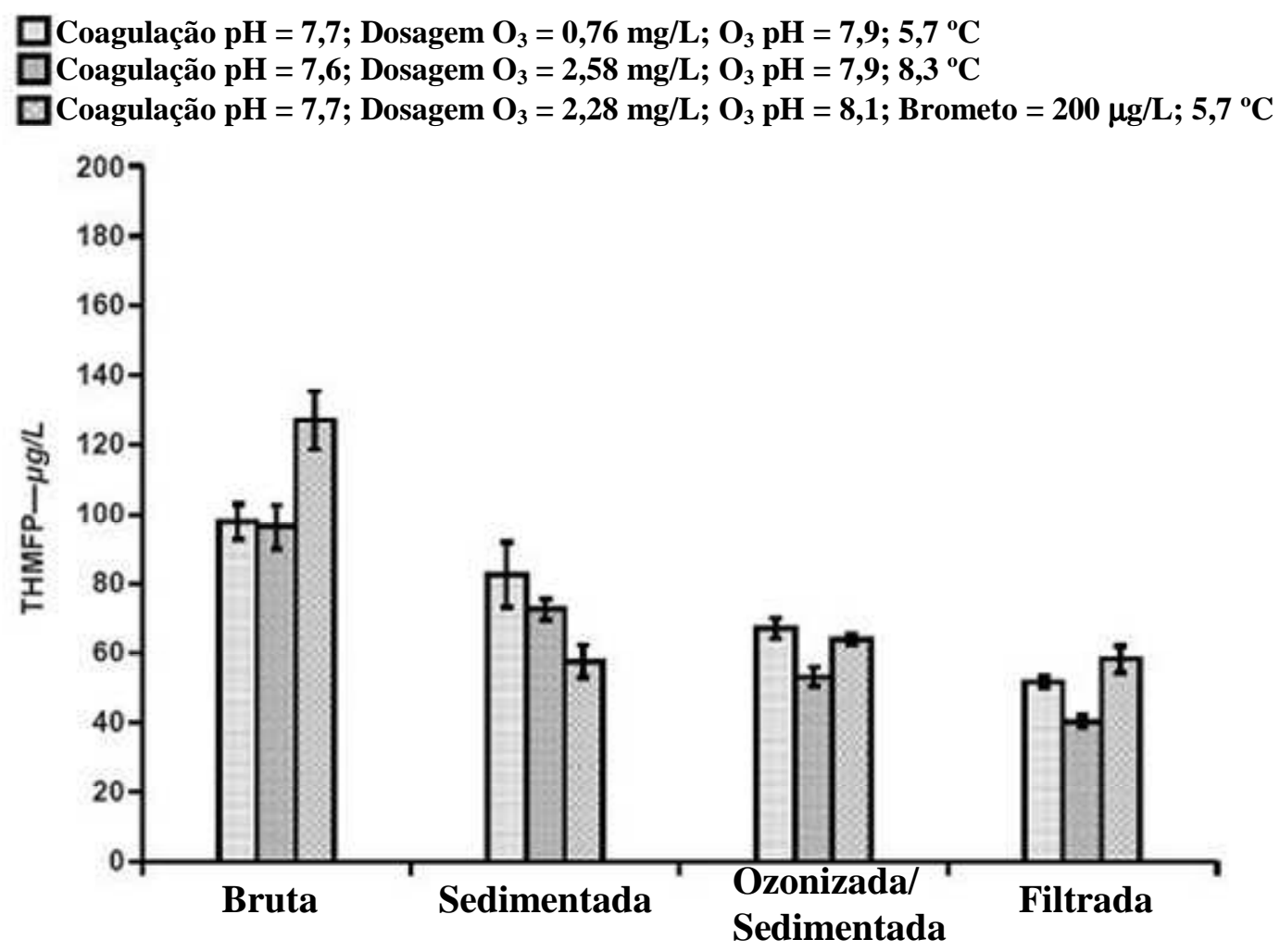

\section{Localização}

Figura 3.3.2 - Perfis de THMFP para ensaios de ozonização intermediária (CHAIKET et al., 2002).

De maneira geral, a ozonização intermediária removeu de 47 a 58 \% dos 100-140 $\mu \mathrm{g} / \mathrm{L}$ de THMFP da água bruta. A maior remoção ocorreu nos estágios de ozonização e coagulação, com cada uma responsável por 20 \% de remoção. Adicionalmente, até $16 \%$ dos precursores dos THM foram removidos pela biofiltração. Nenhuma diferença de desempenho entre os filtros de antracito e CAG pôde ser comprovada.

Em outros ensaios de filtração com filtros de CAG e dupla camada (antracito e areia) (Figura 3.3.3), as maiores remoções dos THM ocorreram em águas ozonizadas. A porcentagem de remoção dos THM após 2 e 5 dias variaram de 25 a $40 \%$ e de 30 a $40 \%$, respectivamente. Além disso, os filtros de CAG apresentaram maiores 
remoções do que os de dupla camada, o que foi atribuído a sua atividade biológica mais elevada.

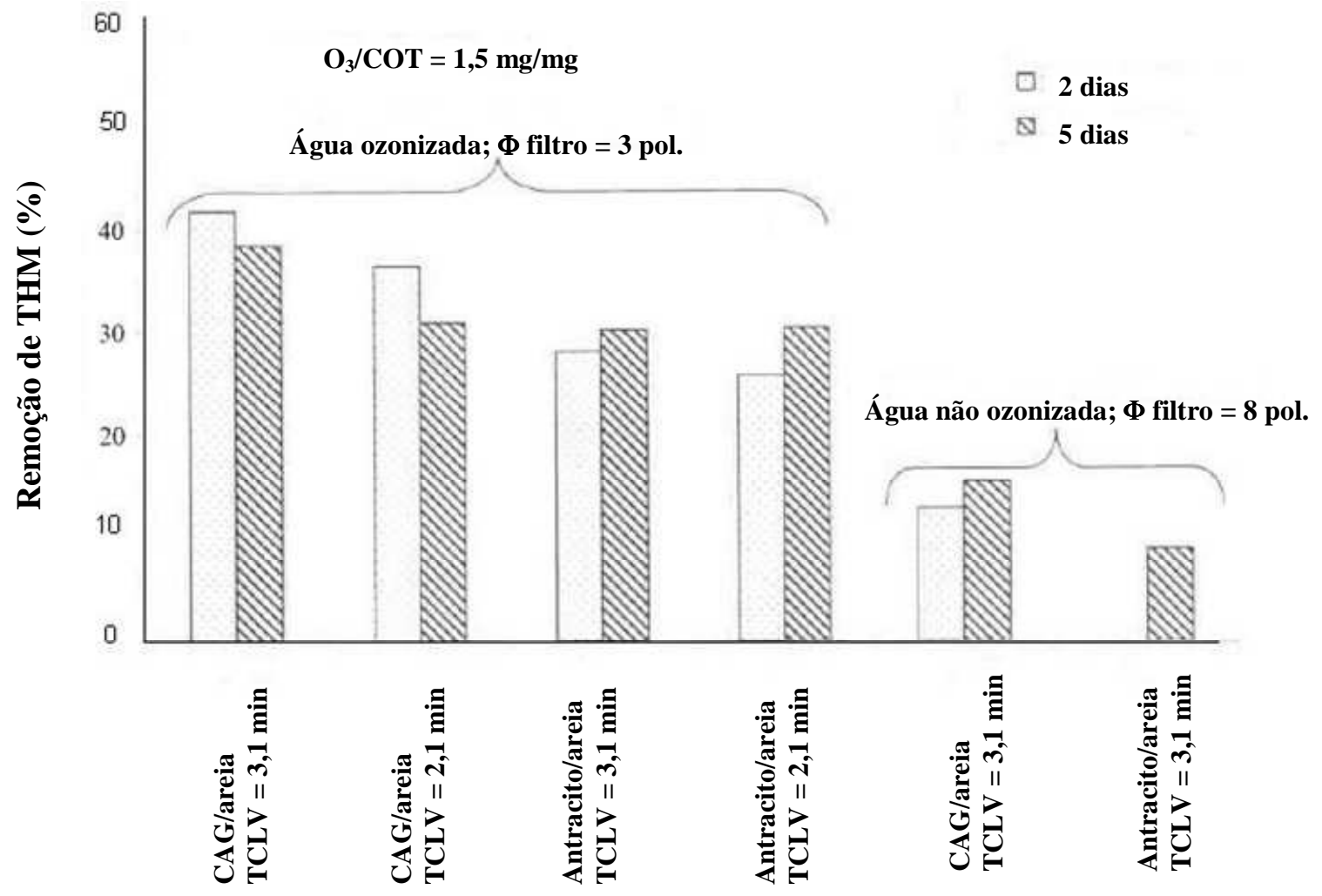

Figura 3.3.3 - Remoção de THM em filtros alimentados por águas decantadas e/ou ozonizadas (AWWARF, 2005). 


\subsection{OZONIZAÇÃO EM ÁGUAS DE ABASTECIMENTO}

O ozônio é um forte oxidante e um desinfetante poderoso que tem sido usado continuamente no tratamento da água para abastecimento a mais de 100 anos, começando em Nice, na França, em 1906 e depois em diversos outros países. Desde a década de 60, milhares de estações de tratamento de água na Europa têm empregado o ozônio para alcançar requisitos específicos de desinfecção e oxidação.

Nos EUA, o ozônio foi primeiramente utilizado em 1908, com um crescimento mínimo até 1985. Em 1980, havia menos de 10 estações operando, porém nas últimas duas décadas este número ultrapassou os 300 .

Atualmente, a ozonização é uma alternativa de desinfecção já provada e estabelecida, assim como o emprego do ozônio na pré-oxidação, para o controle dos

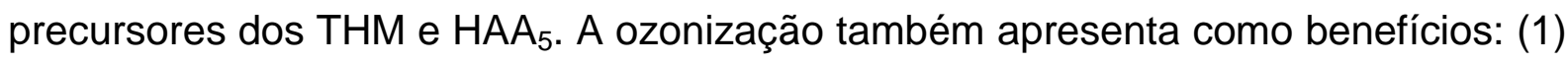
oxidação e volatilização de orgânicos; (2) controle de algas e de seus compostos causadores de gosto e odor; (3) desestabilização (microfloculação) de certos tipos de turbidez; (4) remoção de compostos causadores de cor; (5) oxidação de ferro e manganês; (6) pequenos tempos de desinfecção para todos os patogênicos, incluindo Cryptosporidium e (7) oxidação parcial de orgânicos para subseqüente remoção por microrganismos.

Os quatro principais componentes de um sistema de ozonização empregados no tratamento da água estão mostrados na Figura 3.4.1. Estes incluem: fornecimento de gás, gerador de ozônio, tanque de contato e unidade destruidora de "off-gas" do ozônio.

\subsubsection{PROPRIEDADES FÍSICAS E QUÍMICAS DO OZÔNIO}

O ozônio é uma molécula de gás instável que forma uma camada em volta da Terra acima da atmosfera e que também é encontrado após tempestades com raios e 
como resultado de certas atividades humanas, incluindo a fotocópia e eventos que causam a poluição do ar.

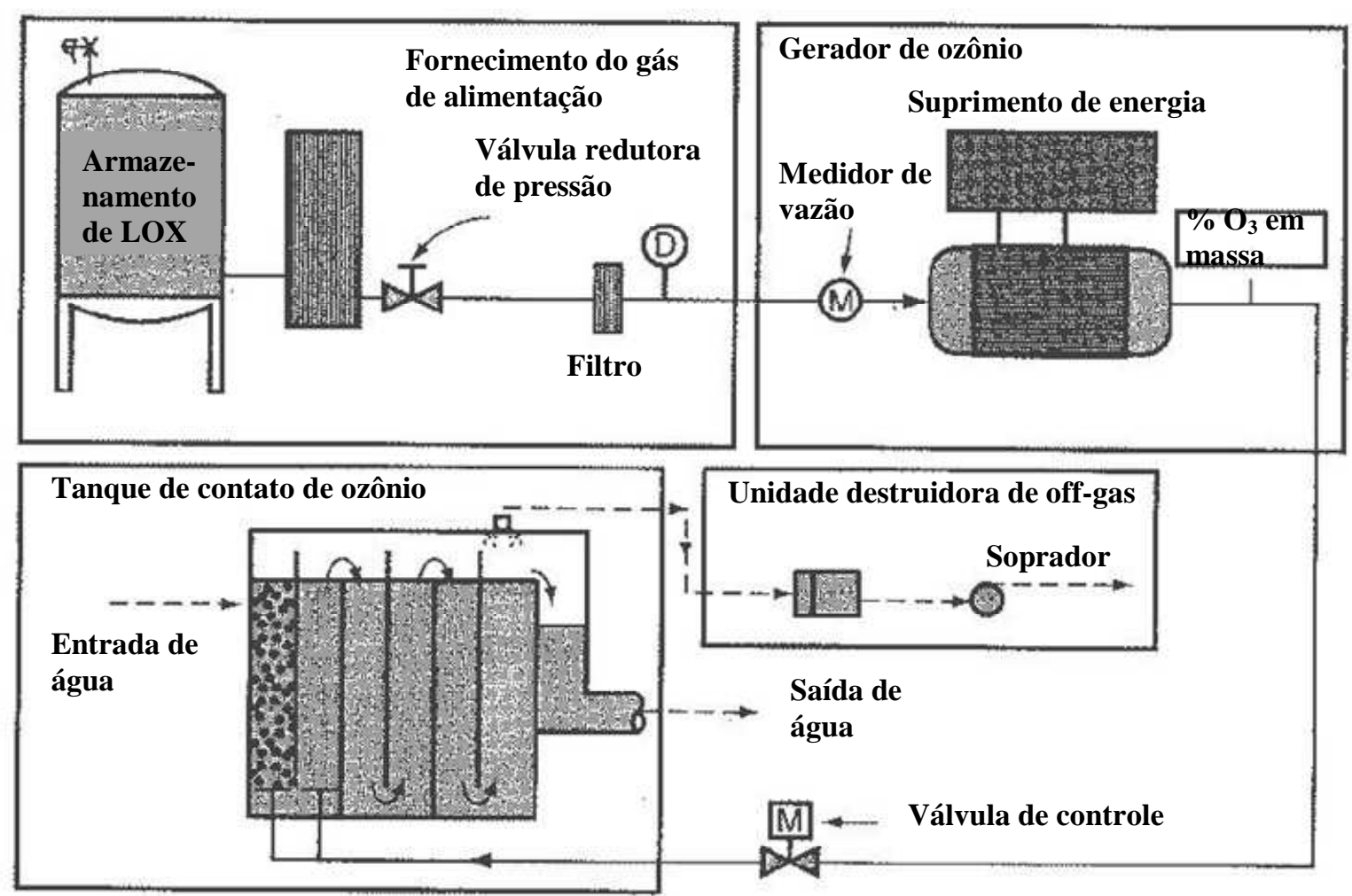

Figura 3.4.1 - Quatro componentes principais do sistema de ozonização: gás de alimentação, gerador de ozônio, tanque de contato e unidade destruidora de off-gas (RAKNESS, K. L., 2005).

O ozônio pode ser produzido comercialmente segundo condições de descarga elétrica controlada; isto é, fazendo a energia elétrica passar através de uma fenda estreita (0,3 a $3 \mathrm{~mm}$ ) cheia com oxigênio. Como resultado, este terá suas moléculas divididas em átomos de oxigênio (O), que se combinam com outras moléculas de oxigênio $\left(\mathrm{O}_{2}\right)$ formando o ozônio $\left(\mathrm{O}_{3}\right)$; que é um gás instável, não podendo ser armazenado, pois reverte-se novamente em moléculas de oxigênio.

A freqüência elétrica típica é de $60 \mathrm{~Hz}$ em geradores de ozônio alimentados a ar de baixa freqüência, e de 350 a $6.000 \mathrm{~Hz}$ em geradores alimentados a oxigênio de média freqüência. A concentração de ozônio para geradores alimentados a ar varia de 1 a $4 \%$ em massa (geralmente entre 1 e 2,5\%) e para os geradores alimentados a oxigênio, de 6 a $16 \%$ em massa (tipicamente entre 8 e $12 \%$ ). Na Figura 3.4.2 é apontado o consumo de energia necessário para a produção do ozônio, utilizandose como gás de alimentação o ar e o oxigênio. 


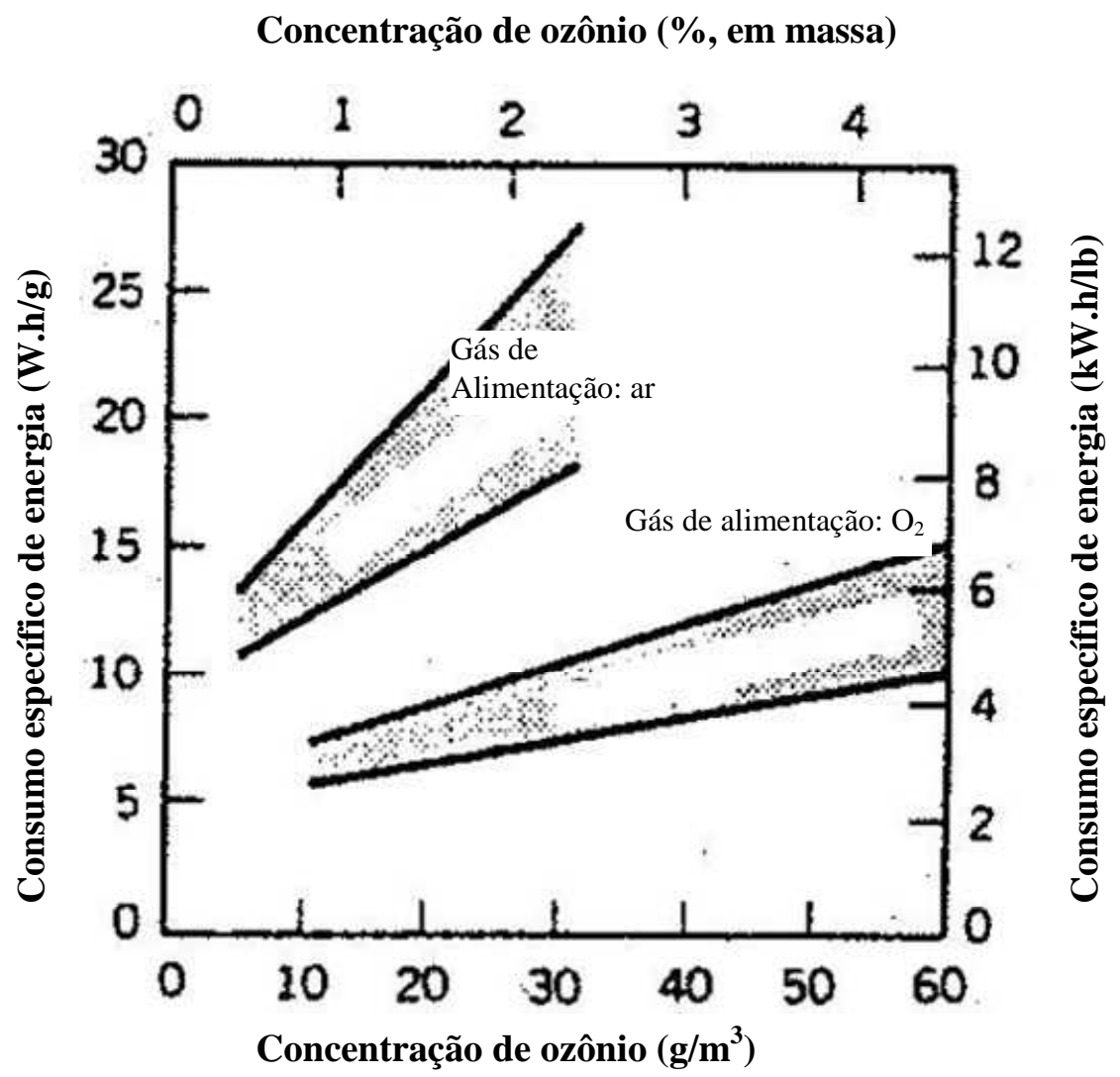

Figura 3.4.2 - Produção de ozônio versus consumo de energia (KAWAMURA, 2000).

Sistemas de ozônio alimentados a ar são bastante complexos pois usam compressores, secadores refrigerados e equipamentos de adsorção para secar o gás. Já os sistemas de ozônio alimentados a oxigênio líquido (LOX) são menos complicados, pois são transformados em oxigênio gasoso por vaporizadores. $\mathrm{Na}$ Tabela 3.4.1 encontram-se apresentadas as principais características físicas do ozônio.

\subsubsection{ESTABILIDADE DO OZÔNIO NA ÁGUA}

O ozônio é instável na água, decaindo rapidamente através de uma complicada cadeia de processos (Figura 3.4.3), que pode ser iniciada pelo hidróxido, MON, peróxido de hidrogênio ou outras substâncias; a matéria orgânica também pode consumir a molécula de ozônio diretamente sem a produção de espécies radicais. 
Conforme o ozônio decai, radicais hidroxila ( $\mathrm{HO}$ ) de grande poder oxidativo, são formados e a MON, carbonatos e outros compostos orgânicos e inorgânicos podem capturá-lo, formando espécies de radicais secundários. A vida do ozônio e o nível de HO produzido dependem da qualidade da água.

Tabela 3.4.1 - Características físicas do ozônio.

\begin{tabular}{|c|c|c|}
\hline Propriedades & Unidade nos EUA & Unidade no SI \\
\hline Massa molar & 48 & 48 \\
\hline Peso específico do gás $(\operatorname{ar}=1,0)$ & 1,66 & 1,66 \\
\hline Ponto de ebulição a 1 atm & $-169,4^{\circ} \mathrm{F}$ & $-111,9^{\circ} \mathrm{C}$ \\
\hline Ponto de fusão a $1 \mathrm{~atm}$ & $-314,5^{\circ} \mathrm{F}$ & $-192,5^{\circ} \mathrm{C}$ \\
\hline Temperatura crítica & $10,2^{\circ} \mathrm{F}$ & $-12,1^{\circ} \mathrm{C}$ \\
\hline Pressão crítica & 791,9 psia & $5.460 \mathrm{kPa}$ \\
\hline Densidade crítica & $33,7 \mathrm{lb} / \mathrm{ft}^{3}$ & $540 \mathrm{~kg} / \mathrm{m}^{3}$ \\
\hline Calor latente do gás no ponto de ebulição a 1 atm & $127 \mathrm{Btu} / \mathrm{lb}$ & 297 kJ/kg \\
\hline Calor específico do gás a $32^{\circ} \mathrm{F}\left(0^{\circ} \mathrm{C}\right)$ & $0,183 \mathrm{Btu} / \mathrm{lb}\left({ }^{\circ} \mathrm{F}\right)$ & $0,767 \mathrm{~kJ} / \mathrm{kg}\left({ }^{\circ} \mathrm{C}\right)$ \\
\hline Solubilidade em água, vol/vol a $32^{\circ} \mathrm{F}\left(0^{\circ} \mathrm{C}\right)$ & 0,64 & 0,64 \\
\hline Peso do líquido no ponto de ebulição & $84,4 \mathrm{lb} / \mathrm{ft}^{3}$ & $1.352 \mathrm{~kg} / \mathrm{m}^{3}$ \\
\hline
\end{tabular}

Fonte: Compressed Gas Association, Inc., 2001.

\subsubsection{OXIDAÇÃO DE MICROPOLUENTES ORGÂNICOS}

Conforme discriminado na Figura 3.4.4, o ozônio pode reagir com os compostos presentes na água através de dois caminhos: (1) oxidação direta pela molécula de ozônio $\left(\mathrm{O}_{3}\right)$ ou, (2) oxidação indireta pelo $\mathrm{HO}$, produzido durante a decomposição do ozônio. Ambos os caminhos de oxidação competem por substrato. A oxidação direta com o ozônio aquoso é relativamente lenta, mas a sua concentração é alta; enquanto que, a reação com o radical hidroxila é rápida, porém a sua concentração é baixa. 


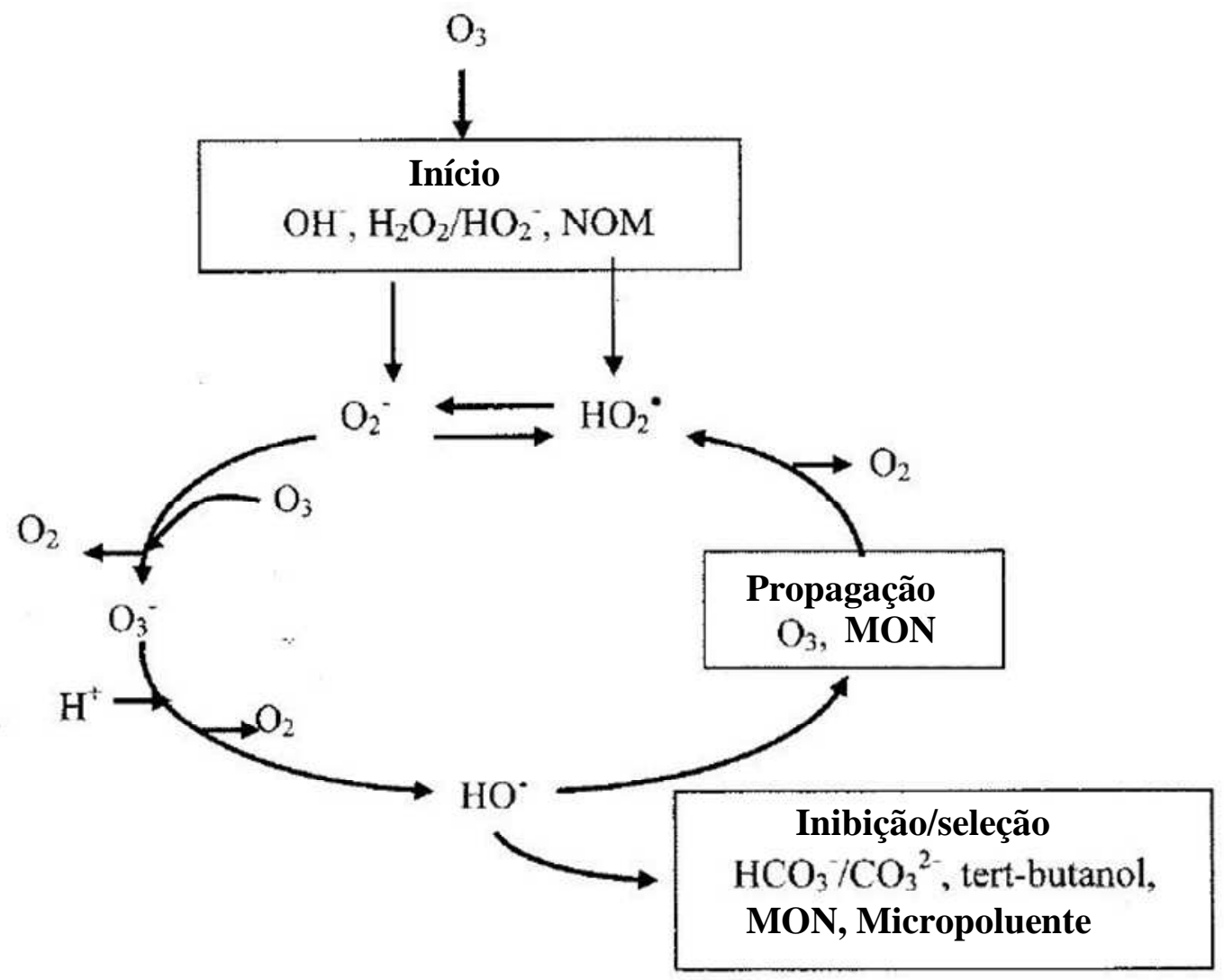

Figura 3.4.3 - Mecanismos de decomposição do ozônio na água (LANGLAIS; RECKHOW; BRINK, 1991).

Reações diretas do ozônio molecular com compostos orgânicos e inorgânicos tendem a ser altamente seletivas, enquanto que reações do HO são menos. A oxidação relativa de um micropoluente varia em função de sua reatividade, da concentração do $\mathrm{O}_{3}$ e $\mathrm{HO}$ e da presença de capturadores de $\mathrm{HO}$.

Estudos realizados por Cipparone; Diehl e Speitel Jr. (1997) mostraram que a remoção de COT através da ozonização geralmente aumenta com o aumento da dosagem de ozônio; muito mais pela oxidação direta do que pelo aumento na formação de material biodegradável.

No entanto, ensaios em escala real realizados por Escobar e Randall (2001) para estudar os efeitos da ozonização a longo prazo na Estação de Tratamento de Água Pine Hills nos EUA, mostraram que as concentrações de COA na saída da ETA aumentaram em $112 \%$, se comparados com os resultados antes da aplicação do ozônio e, ao longo do sistema de distribuição em 105 \% (Figura 3.4.5). Na saída da estação e no sistema de distribuição, antes da ozonização, os valores da contagem 
de placas heterotróficas $(\mathrm{CPH})$ variavam entre 3 e $7 \mathrm{ufc} / \mathrm{mL}$, passando a medir entre 8 a 15 ufc/mL, após a sua aplicação (4,7 mg/L), (Figura 3.4.6).

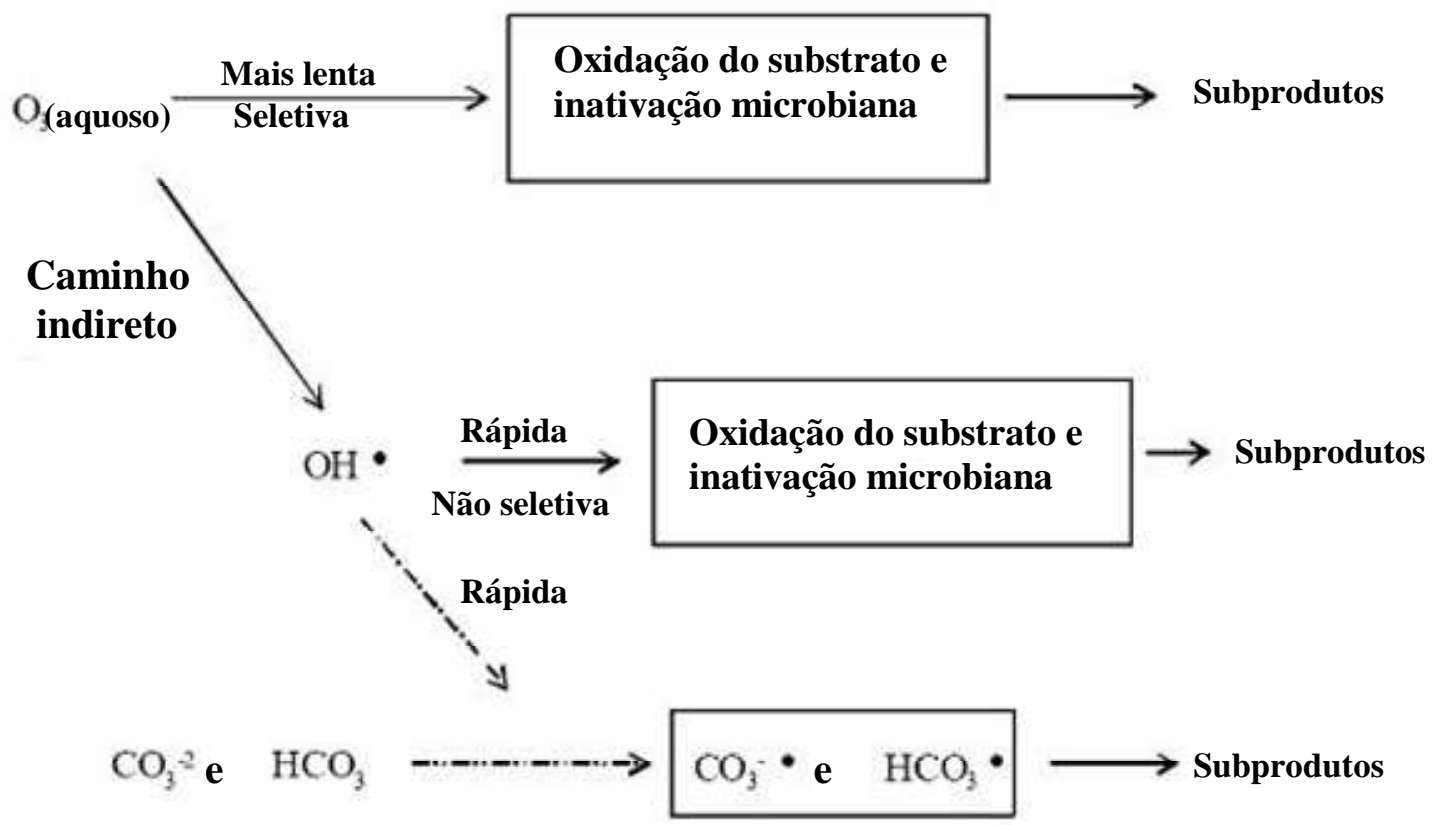

Figura 3.4.4 - Caminhos de reação do ozônio na água (LANGLAIS; RECKHOW; BRINK, 1991).

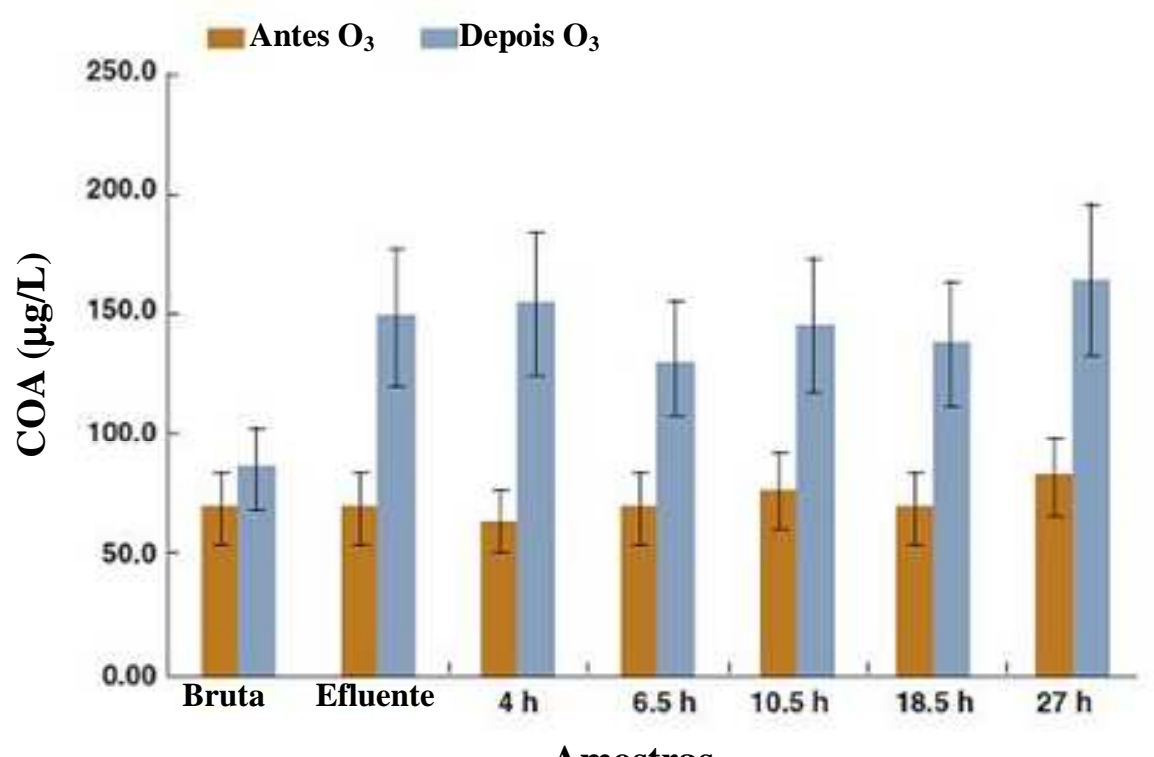

Amostras mensais de Maio/1997 a Maio/1999.

13 amostras antes do $\mathrm{O}_{3} .8$ amostras depois do $\mathrm{O}_{3}$.

Figura 3.4.5 - Efeitos a longo prazo da introdução do ozônio nas concentrações de COA (ESCOBAR; RANDOM, 2001). 


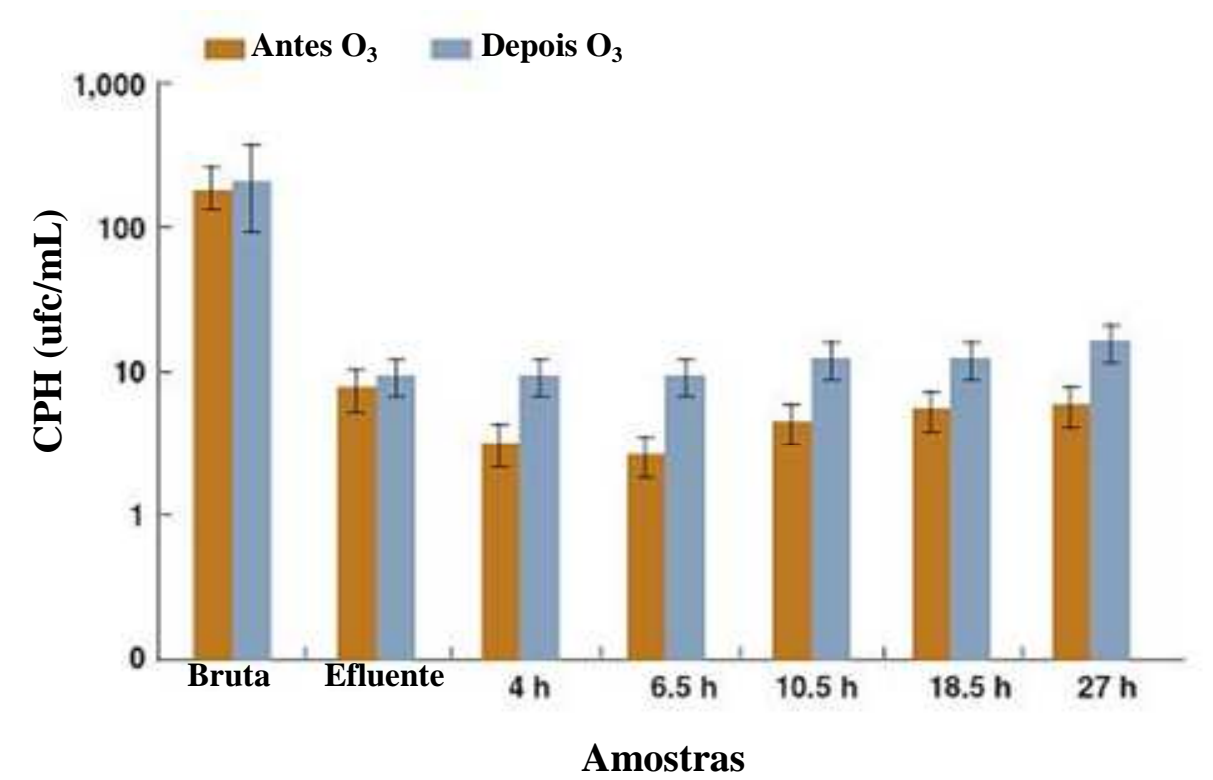

Amostras mensais de Maio/1997 a Maio/1999.

13 amostras antes do $\mathrm{O}_{3} .8$ amostras depois do $\mathrm{O}_{3}$. CPH em escala logarítmica.

Figura 3.4.6 - Efeitos a longo prazo da introdução do ozônio nas concentrações de CPH (ESCOBAR; RANDOM, 2001).

Uma avaliação do sistema antes e depois da ozonização mostrou que embora os valores de COA tenham subido significativamente, o crescimento bacteriano no sistema de distribuição permaneceu baixo devido à elevada adição de cloro (2 $\mathrm{mg} / \mathrm{L})$.

\subsubsection{DESINFECÇÃO}

O ozônio é um oxidante poderoso capaz de obter a desinfecção em menor quantidade e tempo de contato do que todos os outros desinfetantes mais fracos, como o cloro, dióxido de cloro e monocloramina. No entanto, ele não pode ser empregado como desinfetante primário visto que não é capaz de manter um residual no sistema de distribuição.

A ozonização pode converter grandes moléculas orgânicas em moléculas menores mais biodegradáveis, comumentes quantificadas como COA (fração do COT que é mais rapidamente utilizada pela bactéria, resultando num aumento mensurável na concentração da biomassa) ou carbono orgânico dissolvido biodegradável (CODB, 
fração do COD que foi assimilada e mineralizada por uma flora heterotrófica), que pode servir de fonte de "alimento" para as bactérias presentes na água e biofilmes das tubulações ao longo do sistema de distribuição, resultando em um potencial crescimento microbiano.

Uma série de experimentos conduzidos na ETA David L. Tippin, EUA (MARDA et al., 2008), levaram à conclusão de que a matéria particulada produzida nos filtros biológicos, decorrência da excessiva atividade microbiológica e contra lavagem inadequada do meio, conduziram a um rápido decaimento da monocloramina na saída da estação; entretanto, a modificação do procedimento de contra lavagem, com o aumento da vazão de ar e o tempo de lavagem, resultaram na estabilização desta monocloramina.

\subsubsection{OXIDAÇÃO DO FERRO E MANGANÊS}

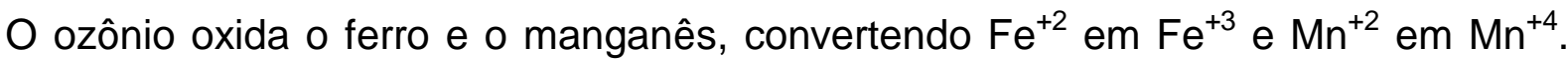
Essas formas oxidadas precipitam-se como hidróxido férrico e hidróxido de manganês. A composição química total do precipitado depende da natureza da água, temperatura e $\mathrm{pH}$. A dosagem requerida para a oxidação do ferro e do manganês é de 0,43 $\mathrm{mg} \mathrm{O}_{3} / \mathrm{mg}$ Fe e 0,88 $\mathrm{mg} \mathrm{O}_{3} / \mathrm{mg} \mathrm{Mn} \mathrm{(CULP;} \mathrm{WESNER;} \mathrm{CULP,}$ 1986), respectivamente; com o ferro podendo ser oxidado em um $\mathrm{pH}$ variando entre 6 e 9, e o manganês, ao redor de 8 (RECKHOW, et al.,1991). Embora uma super ozonização não tenha efeito sobre o ferro, ela irá ressolubilizar o manganês, que deverá ser reduzido a dióxido de manganês mais a jusante na estação.

\subsubsection{OXIDAÇÃO DE MIB E GEOSMINA}

A ozonização é geralmente considerada bastante eficaz na redução das concentrações de MIB e geosmina e por conseguinte, nas avaliações sensoriais de gosto e odor. Na Tabela 3.4.2 têm-se resumidos alguns dados comparativos de diversos estudos: (1) o ozônio remove quantidades iguais ou maiores de geosmina 
do que MIB; (2) os resultados são bem diferentes dependendo da fonte de água e; (3) processos de oxidação avançada $\left(\mathrm{O}_{3}+\mathrm{H}_{2} \mathrm{O}_{2}\right)$ são mais eficientes.

Tabela 3.4.2 - Remoções de MIB e geosmina obtidas em testes.

\begin{tabular}{|c|c|c|c|c|}
\hline Amostra & $\begin{array}{l}\text { Dosagem de } \\
\text { ozônio (mg/L) }\end{array}$ & $\begin{array}{l}\text { Remoção } \\
\text { de MIB (\%) }\end{array}$ & $\begin{array}{c}\text { Remoção de } \\
\text { geosmina (\%) }\end{array}$ & Referência \\
\hline \multirow[t]{2}{*}{ Água destilada } & 2 & 15 a 30 & 15 a 30 & Lalezary et al., 1986 \\
\hline & 33 & 50 & 50 & \\
\hline \multirow[t]{2}{*}{$\begin{array}{c}\text { Água de superfície adicionada de } 50 \\
\text { ng/L de MIB e geosmina }\end{array}$} & 1,5 & 35 a 95 & 35 a 95 & $\begin{array}{l}\text { Lundgren et al., } \\
\qquad 1988\end{array}$ \\
\hline & 7,0 & $>95$ & $>95$ & \\
\hline \multirow[t]{2}{*}{ Água de superfície da Califórnia } & 4 & $75 a>99$ & $75 a>99$ & Glaze et al., 1990 \\
\hline & 2 & 40 & 35 & \\
\hline Água do rio Colorado & 4 & 78 & 89 & Glaze et al., 1990 \\
\hline \multirow[t]{2}{*}{ Água de superfície } & 4 & 90 & 90 & $\begin{array}{l}\text { Ferguson et al., } \\
1990\end{array}$ \\
\hline & $2+1 \mathrm{mg} / \mathrm{L} \mathrm{H}_{2} \mathrm{O}_{2}$ & $>90$ & $>90$ & \\
\hline \multirow[t]{2}{*}{$\begin{array}{l}\text { Água de superfície durante diferentes } \\
\text { estações do ano }\end{array}$} & 1,5 a $2,0\left(27^{\circ} \mathrm{C}\right)$ & 85 & & $\begin{array}{l}\text { Carollo Engineers, } \\
\qquad 2000\end{array}$ \\
\hline & 1,5 a $2,0\left(19^{\circ} \mathrm{C}\right)$ & 10 & & \\
\hline \multirow[t]{6}{*}{$\begin{array}{l}\text { State Project Water - SPW (água do } \\
\text { rio Colorado), Califórnia }\end{array}$} & 1 & 58 & & Koch et al., 1992 \\
\hline & 2 & 65 & & \\
\hline & 4 & 75 & & \\
\hline & $1+0,2 \mathrm{mg} / \mathrm{L} \mathrm{H}_{2} \mathrm{O}_{2}$ & 72 & & \\
\hline & $2+0,4 \mathrm{mg} / \mathrm{L} \mathrm{H}_{2} \mathrm{O}_{2}$ & 88 & & \\
\hline & $4+0,8 \mathrm{mg} / \mathrm{L} \mathrm{H}_{2} \mathrm{O}_{2}$ & 98 & & \\
\hline
\end{tabular}

Fonte: AWWARF, 2005. 
Em ensaios de ozonização realizados com a água clarificada da ETA ABV, localizada em São Paulo, Ferreira Filho et al. (2002) obtiveram remoções de MIB entre 80 e $90 \%$ para uma dosagem de $3,0 \mathrm{mg} / \mathrm{L}$.

Nas Figuras 3.4.7 e 3.4.8 estão discriminadas as porcentagens de remoção de MIB e geosmina alcançadas por meio da ozonização seguida de filtração biológica para dez Estações de Tratamento de Água nos EUA (AWWARF, 2005) entre os anos de 2002 e 2003. As remoções de MIB ficaram entre 50 e $90 \%$ e as remoções de geosmina entre 70 e $>90 \%$.

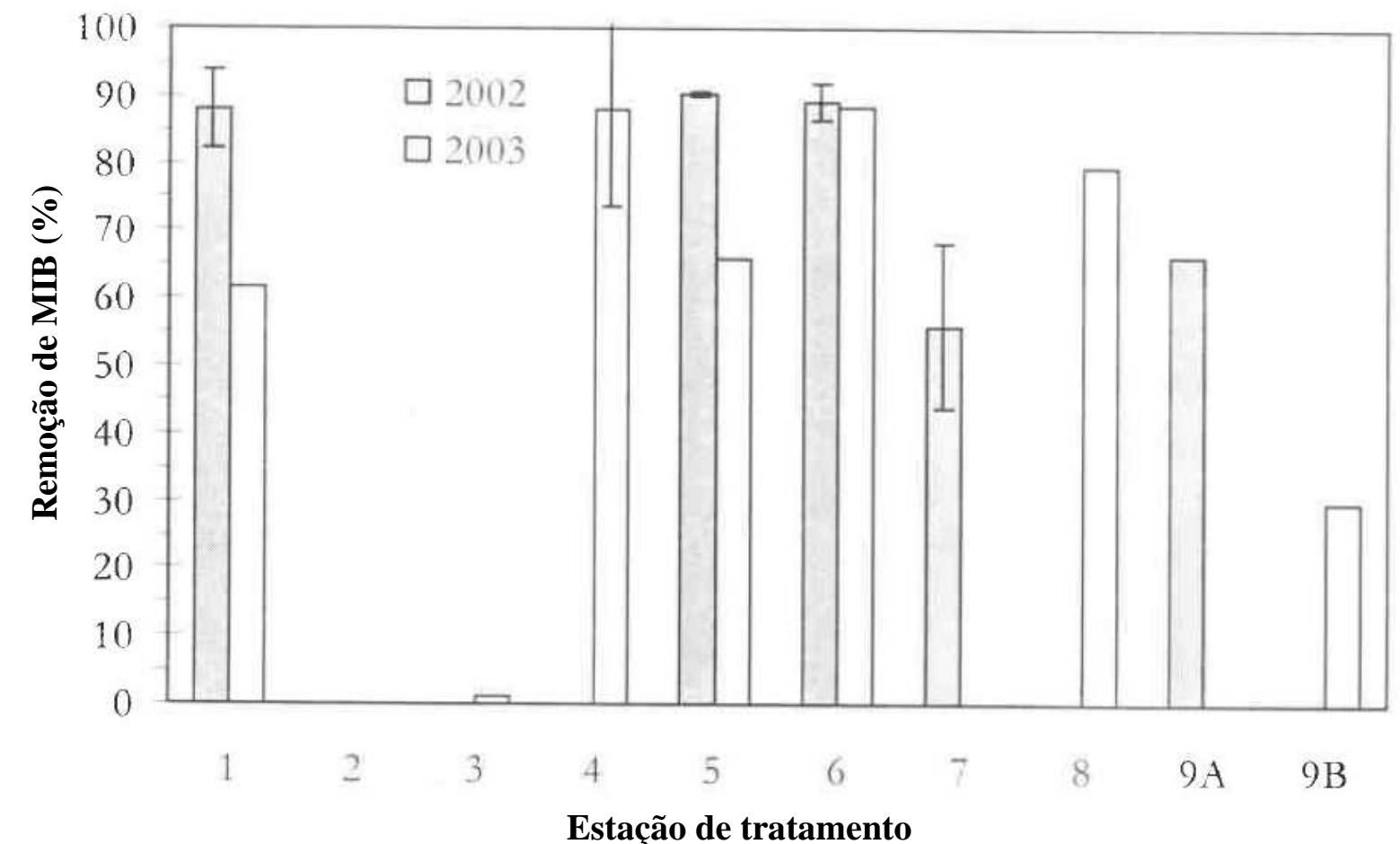

Figura 3.4.7 - Remoção de MIB por ozonização e biofiltração em Estações de Tratamento de Água (AWWARF, 2005).

\subsubsection{CONTROLE DE PRECURSORES DOS SUBPRODUTOS DA DESINFECÇÃO}

As principais variáveis que parecem determinar o efeito do ozônio são: dosagem, $\mathrm{pH}$, alcalinidade e, acima de tudo, a natureza da matéria orgânica. Em valores baixos de $\mathrm{pH}$, a destruição de precursores pelo ozônio é bastante eficiente; entretanto, acima de alguns valores críticos de pH, o ozônio torna-se menos eficaz e, 
algumas vezes, chega até a aumentar a quantidade de precursores dos subprodutos da cloração. Para a maioria das substâncias húmicas este pH crítico é de 7,5, que é o valor aproximado no qual a decomposição do ozônio em radicais livre hidroxila aumenta rapidamente; crescendo desse modo também a taxa de oxidação dos orgânicos.

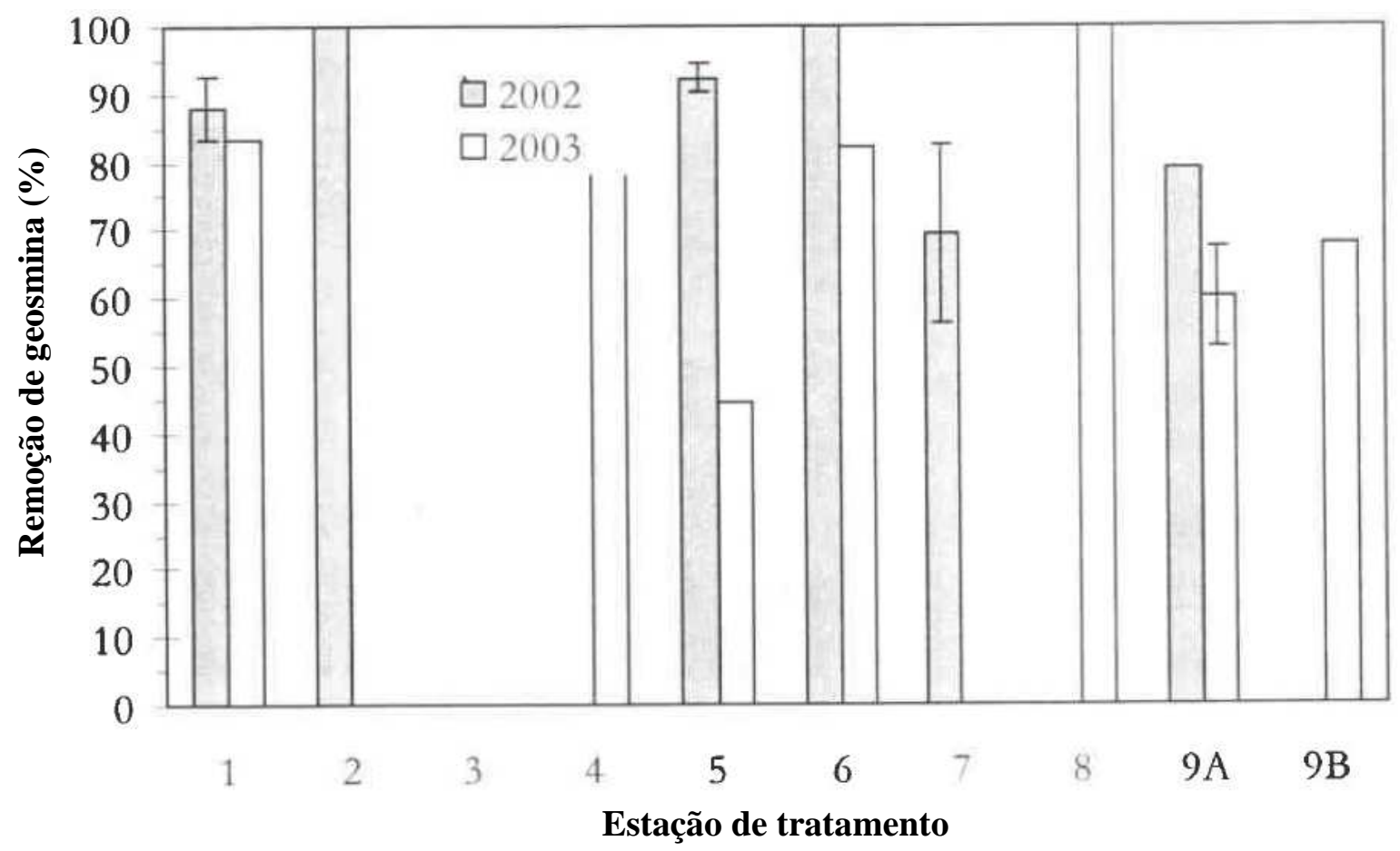

Figura 3.4.8 - Remoção de geosmina por ozonização e biofiltração em Estações de Tratamento de Água (AWWARF, 2005).

Assim, em valores de $\mathrm{pH}$ entre 6 e 7, as moléculas de ozônio predominam em relação aos radicais livre hidroxila e os subprodutos iniciais dos precursores de THM são de natureza diferente dos formados pelos radicais hidroxila.

O aumento da alcalinidade tem um efeito benéfico sobre o potencial de formação dos THM; isso porque ela captura qualquer radical livre hidroxila formado durante a ozonização, deixando o ozônio molecular como o único oxidante, que é somente capaz de oxidar os precursores orgânicos a uma menor seqüência de oxidação do que o radical livre hidroxila. Em pH neutros e moderados, com níveis de alcalinidade ao bicarbonato, obtém-se reduções dos THMFP de 3 a $20 \%$ para dosagens de ozônio variando entre 0,2 a 1,6 mg O글 carbono (GEORGESON; KARIMI, 1988).

Ensaios realizados por Cipparone; Diehl e Speitel Jr. (1997) comprovaram que a formação de THM e $\mathrm{HAA}_{5}$ geralmente diminuiu com o aumento da dosagem de 
ozônio e que a completa biodegradação da água após a ozonização, reduziu ainda mais suas concentrações, particularmente para dosagens $\leq 3 \mathrm{mg} \mathrm{O} / \mathrm{mg} \mathrm{COT}$.

\subsubsection{FILTRAÇÃO BIOLOGICAMENTE ATIVA}

A ozonização aumenta, tipicamente, a biodegradabilidade da MON na água pois que muitas das moléculas orgânicas grandes são convertidas em pequenas, facilmente biodegradáveis. Este aumento do CODB pode levar ao crescimento bacteriano acelerado na rede de distribuição, se este não for removido na estação de tratamento. Avaliações realizadas por LeChevallier et al. (1992) mostraram que os níveis de COA necessários para controlar o recrescimento bacteriano na rede de distribuição devem ser inferiores a 100 ppb.

Quando a ozonização é colocada à montante da filtração e as condições existentes, tais como, oxigênio dissolvido, $\mathrm{pH}$ e temperatura são favoráveis, a atividade microbiológica no filtro aumenta e cresce a remoção de CODB/COA. A adição do ozônio não só melhora a biodegradabilidade dos orgânicos dissolvidos, como também introduz grandes quantidades de oxigênio à água, criando assim um excelente ambiente para o crescimento biológico no meio filtrante. As vantagens da filtração biologicamente ativa são (PRICE, 1994):

- Remoção da MON que pode servir como precursora para a formação de subprodutos (resultado da desinfecção residual com cloro livre ou combinado).

- A oxidação com o ozônio como desinfetante primário antes da filtração biologicamente ativa reduz a concentração de CODB na água final.

- Redução da demanda residual de desinfetante na água tratada de maneira que o seu limite máximo, proposto pelos órgãos regulatórios, seja cumprido.

- Remoção ou controle dos subprodutos da desinfecção. 
- Produção de uma água biologicamente estável que não promova excessivo crescimento ou recrescimento bacteriano no sistema de distribuição. $O$ aumento da MOB com a ozonização, amplamente reportado, pode levar a problemas de crescimento microbiano no sistema de distribuição se esta não vier seguida da biofiltração. Assim, a ozonização e a biofiltração devem ser consideradas como um processo associado.

Estudos em escala piloto realizados por Carlson e Amy (1998) mostraram que se a profundidade do leito é muito rasa ou a taxa hidráulica de aplicação muito alta (elevada MOB) então, a quantidade de biomassa cultivada será menor do que aquela que poderia ser adequadamente formada e o desempenho do processo de biofiltração será sub-otimizado. Além disso, biofiltros operados adequadamente não devem limitar a remoção do CODB, ao contrário, é a sua disponibilidade que limita a remoção da $\mathrm{MOB}$ durante a biofiltração.

$\mathrm{Na}$ Figura 3.4.9 encontram-se discriminados as porcentagens acumuladas da remoção de diversos compostos com relação a TCLV otimizados, para biofiltros em escala piloto (CARLSON; AMY, 2001).

Quando o TCLV era otimizado para diferentes objetivos de tratamento, remoções ótimas de $\mathrm{COD}$ e $\mathrm{MOB}$ exigiam tempos de contato significativamente mais longos do que para a remoção dos subprodutos da ozonização (OBP).

Em outro estudo de filtração biológica, porém em escala de laboratório, Hozalski; Goel e Bouwer (1995) verificaram a remoção de COT para águas contendo três tipos diferentes de MON: Dismal Swamp Water (DSW), Florida Groundwater (FGW) e água contendo cianobactéria Anabena sp. (Ana EX) (Figura 3.4.10).

A quantidade de ozônio aplicada influenciou a remoção de COT para a água DSW: quanto maior a dosagem, maior a remoção. Não houve diferença de remoção significativa para as águas DSW (reciclada) e FGW, já que estas continham características de MON similares. A água contendo Ana EX apresentou maiores remoções de COT comparativamente a água FGW, apesar das dosagens de ozônio similares. Isto porque seus valores da razão entre UV/COT eram menores. Todas as remoções ocorreram sem significante variação do TCLV, devido especialmente à 
elevada temperatura da água $\left(22,5^{\circ} \mathrm{C}\right)$ e altas dosagens de ozônio aplicadas (2 a 4 $\mathrm{mg} \mathrm{O}_{3} / \mathrm{mg} \mathrm{COT}$ ).
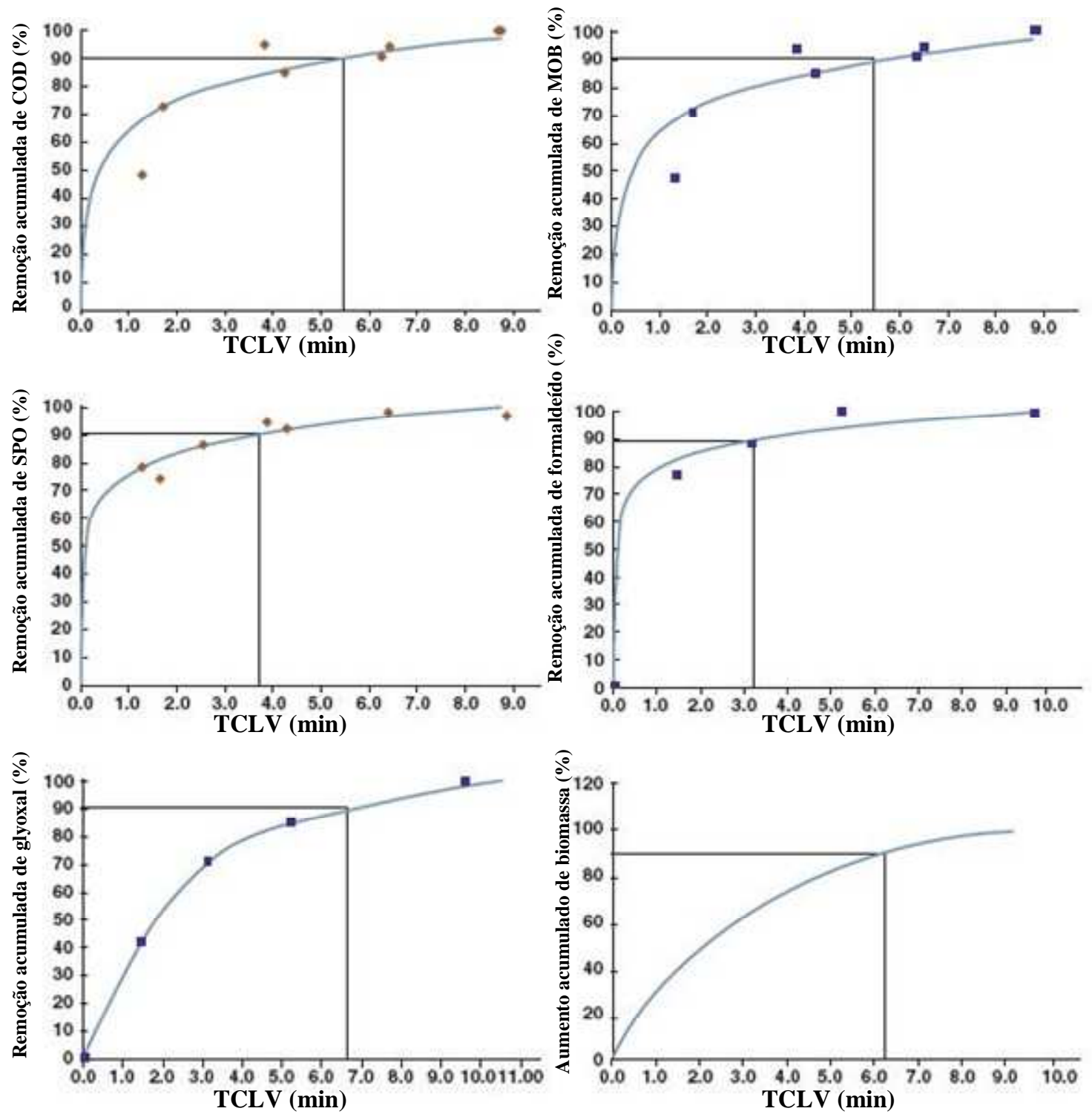

Figura 3.4.9 - Remoções de compostos e acúmulo de biomassa versus TCLV (CARLSON; AMY, 2001).

\subsubsection{SUBSTRATOS PRIMÁRIOS E SECUNDÁRIOS}

Processos biológicos requerem substratos doadores de elétrons e aceptores de elétrons. Os substratos que transferem elétrons do doador para o aceptor e que 
fornecem energia para crescer e manter as bactérias, bem como suas funções metabólicas principais, são definidos como substratos primários.

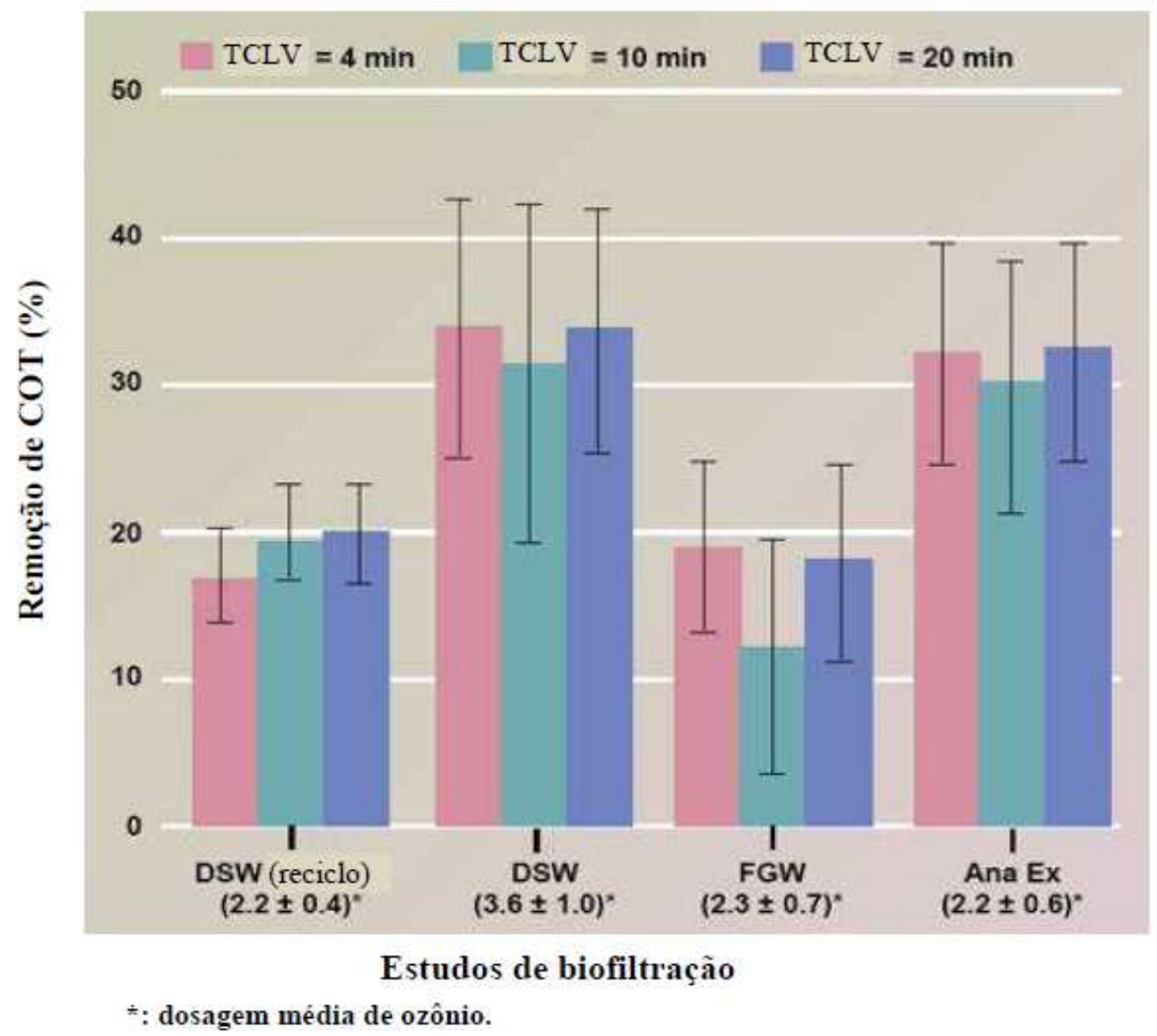

Figura 3.4.10 - Efeitos da fonte de MON e TCLV na remoção de COT em biofiltros (HOSALSKI; GOEL; BOUWER, 1995).

Esta fração da matéria orgânica facilmente biodegradável pode ser aproximadamente estimada através de testes de CODB ou COA.

Com relação aos compostos causadores de gosto e odor, como o limiar da percepção de odor para MIB e geosmina é muito baixo $(<10 \mathrm{ng} / \mathrm{L})$, a presença destes compostos na água bruta não mantém o crescimento de microrganismos nos biofiltros. Portanto, MIB e geosmina comportam-se como substratos secundários e os microrganismos são mantidos pelos substratos primários.

Entretanto, estes microrganismos têm de estar presentes e possuir enzimas apropriadas para biodegradar o MIB e a geosmina. A taxa de biodegradação é função da biomassa total do biofilme, do tipo de microrganismo mantido pelo substrato primário e a natureza química do substrato secundário (RITTMAN; GANTZER; MONTIEL, 1995). 


\subsubsection{DESEMPENHO DA BIOFILTRAÇÃO}

A atividade biológica pode ser sustentada sobre a areia, o antracito ou o CAG, pois estes meios fornecem uma superfície para a bactéria se fixar; sendo que no CAG, a biomassa se desenvolve a níveis mais elevados devido a sua superfície mais grosseira.

Na Tabela 3.4.3 têm-se resumidos diversos sistemas de biofiltração com o ozônio. Filtros de CAG geralmente apresentam um desempenho melhor do que os de antracito e areia, devido a habilidade do CAG adsorver, remover e reter os componentes biodegradáveis que podem ser degradados pela bactéria fixada.

Tabela 3.4.3 - Parâmetros que influenciam a filtração biológica.

\begin{tabular}{|c|c|c|c|c|}
\hline \multirow[t]{2}{*}{ Parâmetro } & \multicolumn{4}{|c|}{$\begin{array}{l}\text { Influência do parâmetro no controle do odor (1) ou influência } \\
\text { do parâmetro no processo de tratamento que pode afetar a } \\
\text { remoção do odor (2) }\end{array}$} \\
\hline & Nenhuma & Baixa & Média & Alta \\
\hline Tipo do meio & & & 2 & 1 \\
\hline Cloração & & & 1 & 2 \\
\hline Taxa de filtração (TCLV) & & & 1,2 & \\
\hline Método de contra lavagem & & & 2 & \\
\hline Carga de CODB & & 1 & 2 & \\
\hline Temperatura & 1 & & & 2 \\
\hline Tempo de operação desde o start-up & 1 & & & 2 \\
\hline
\end{tabular}

Fonte: HUCK et al., 2000.

Filtros de CAG e areia têm um desempenho superior aos de antracito e areia em vários aspectos: fornecem remoções melhores de aldeído em temperaturas mais baixas; estabelecem remoções mais rápidas da MOB biológica depois de períodos de partida e parada e; são mais resistentes a perturbações temporárias tais como cloração intermitente. Na Tabela 3.4.4 estão indicados os principais parâmetros que influenciam a filtração biológica e o nível esperado de controle no qual uma estação pode ter com relação a cada parâmetro. 
Tabela 3.4.4 - Efeito do meio e do tempo de contato em biofiltros.

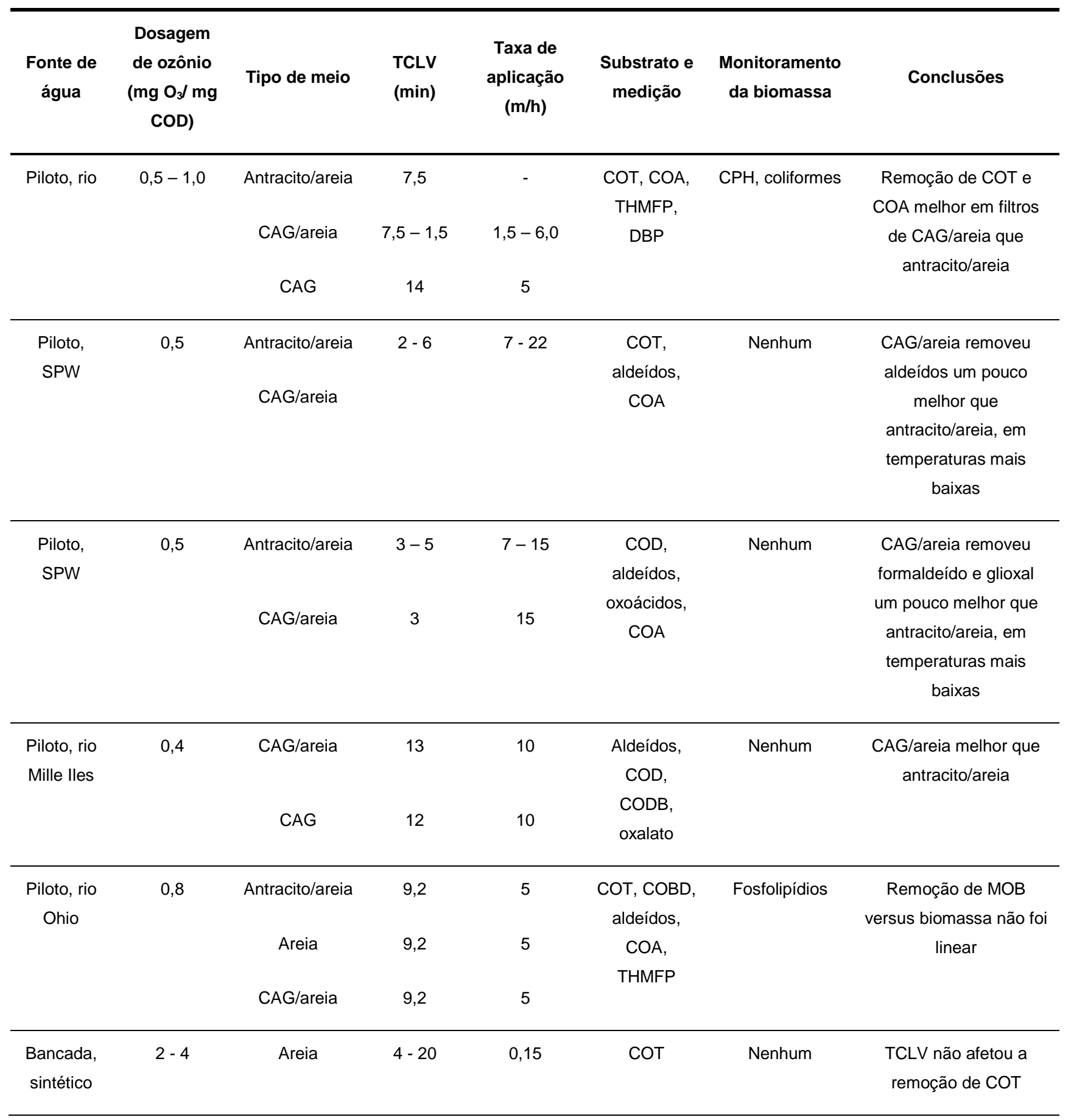

Fonte: adaptado de Urfer et al., 1997.

O tratamento biológico da água por diferentes tipos de biofiltros é relativamente comum na Europa, onde eficiências documentadas na remoção do COT variaram de 5 a 75 \% (BOUWER; CROWE, 1990).

Essas remoções foram afetadas pela origem e características da MON, temperatura de operação e dosagem de ozônio. No entanto, não se mostraram sensíveis a TCLV variando de 4 a $20 \mathrm{~min}$. Na Tabela 3.4.5 destacam-se as porcentagens de remoção 
biológica de MIB para diversos ensaios; sendo menores em biofiltros rápidos de areia e bioreatores de mistura completa; e maiores, nos filtros lentos de areia em laboratório. Já os filtros de CAG, mostraram uma gama média de remoções bastante consistentes, tanto nos resultados de laboratório quanto em escala real.

Em estudos realizados entre os anos de 2002 e 2003 em dez estações de tratamento de água (AWWARF, 2005), somente a biofiltração promoveu remoções de MIB entre 10 e $80 \%$; de geosmina, entre 60 e > $90 \%$ e; de COT, entre 15 e $25 \%$.

Tabela 3.4.5 - Remoção de MIB e geosmina em biofiltros.

\begin{tabular}{|c|c|c|c|c|c|c|}
\hline $\begin{array}{l}\text { Tipo de } \\
\text { reator/meio }\end{array}$ & $\begin{array}{l}\text { Taxa de } \\
\text { aplicação } \\
(\mathbf{m} / \mathbf{h})\end{array}$ & $\begin{array}{l}\text { Tempo de } \\
\text { contato } \\
\text { (min) }\end{array}$ & $\begin{array}{l}\text { COD da } \\
\text { água bruta } \\
\text { (mg/L) }\end{array}$ & $\begin{array}{l}\text { MIB inicial } \\
\quad(\mathrm{ng} / \mathrm{L})\end{array}$ & $\begin{array}{l}\text { Remoção de } \\
\text { MIB (\%) }\end{array}$ & Referência \\
\hline $\begin{array}{l}\text { Filtro lento de } \\
\text { areia, laboratório }\end{array}$ & 0,025 & 480 & $8-9$ & 50 & $>95$ & $\begin{array}{l}\text { Lundgren et } \\
\text { al., } 1988\end{array}$ \\
\hline $\begin{array}{l}\text { RMCB com } \\
\text { esferas de vidro, } \\
\text { laboratório }\end{array}$ & 0,25 & 20 & 1,1 & $10^{5}-10^{6}$ & $17-44$ & \\
\hline $\begin{array}{l}\text { Biofiltro de CAG, } \\
\text { laboratório }\end{array}$ & 0,0083 & 2,4 & & & $56-58$ & $\begin{array}{l}\text { Yagi et al., } \\
1988\end{array}$ \\
\hline $\begin{array}{l}\text { Biofiltro tubular } \\
\text { em colméia, } \\
\text { laboratório }\end{array}$ & $\begin{array}{c}0,0026- \\
0,01\end{array}$ & 120 & 2,6 & $100-115$ & $33-46$ & Hattori, 1988 \\
\hline Biofiltros piloto & 15 & 5 & $1-3$ & 30 & & $\begin{array}{l}\text { Carollo } \\
\text { Engineers, }\end{array}$ \\
\hline Clorados & & & & & 33 & 2000 \\
\hline Antracito & & & & & 50 & \\
\hline CAG & & & & & 48 & \\
\hline $\begin{array}{l}\text { Biofiltro rápido de } \\
\text { areia }\end{array}$ & 10 & 8,3 & & $20-120$ & $8-54$ & $\begin{array}{l}\text { Ashitani et } \\
\text { al., } 1988\end{array}$ \\
\hline $\begin{array}{l}\text { Biofiltro piloto } \\
\text { com poros } \\
\text { granulares } \\
\text { cerâmicos }\end{array}$ & 7,1 & 12,7 & & $50-750$ & $60-80$ & $\begin{array}{l}\text { Terauchi et } \\
\text { al., } 1995\end{array}$ \\
\hline $\begin{array}{l}\text { Filtro rápido de } \\
\text { CAG, real }\end{array}$ & $8,5-7,7$ & $14,4-20,2$ & 2 & $9-17$ & $26-64$ & $\begin{array}{l}\text { Nerenberg et } \\
\text { al., } 2000\end{array}$ \\
\hline $\begin{array}{c}\text { Filtro de CAG, } \\
\text { laboratório }\end{array}$ & 7,5 & 5,6 & $1,0-1,1$ & $25-100$ & $20-40$ & $\begin{array}{c}\text { Elhadi et al., } \\
2003\end{array}$ \\
\hline
\end{tabular}

Fonte: AWWARF, 2005. 
Dados operacionais de campo sugerem que o ozônio é capaz de oxidar de 10 a 90\% de MIB e geosmina, com uma dosagem entre 0,5 e $1,5 \mathrm{mg} \mathrm{O}_{3} / \mathrm{mg}$ COT. A biofiltração sozinha consegue remover $50 \%$.

\subsubsection{INATIVAÇÃO DE PATOGÊNICOS E EFICIÊNCIA DA DESINFECÇÃO}

O ozônio tem uma elevada eficiência germicida contra uma grande variedade de organismos patogênicos incluindo bactérias, protozoários e vírus.

\subsubsection{SUBPRODUTOS DA OZONIZAÇÃO}

O ozônio oxida parcialmente a MON, dando origem a moléculas orgânicas de menor massa molecular (MOB), que são mais facilmente biodegradáveis e medidos pelo COA e CODB. Compostos orgânicos oxigenados específicos biodegradáveis (aldeídos, ácidos, cetoácidos) formam-se durante a ozonização de águas naturais devido a reações com a MON e podem ser responsáveis pelo crescimento de bactérias nos sistemas de distribuição. Estas podem ser controladas se a oxidação biológica ocorre à jusante dos filtros. Na Tabela 3.4.6 vêem-se apontadas algumas classes de subprodutos da ozonização.

A formação do bromato durante a ozonização é uma função da qualidade da água (concentração de brometo, pH, temperatura, amônia e alcalinidade) e de parâmetros operacionais (dosagem de ozônio, tempo de contato).

O ozônio oxida primeiramente o brometo, transformando-o em ácido hipobromoso $(\mathrm{HOBr})$ e íon hipobromito $\left(\mathrm{OBr}^{-}\right)$. Depois, $\mathrm{O}_{3}$ e o $\mathrm{HO}$ reagem preferencialmente com este último para formar o bromato $\left(\mathrm{BrO}_{3}^{-}\right)$. Reduzindo $\mathrm{o} \mathrm{pH}$, muda-se $\mathrm{o}$ equilíbrio de $\mathrm{OBr}^{-}$para $\mathrm{HOBr}$ e reduz-se a formação de bromato. Adicionando amônia antes da ozonização permite-se que o $\mathrm{HOBr} / \mathrm{OBr}^{-}$reaja com ela formando os brominados, ao invés de ser oxidado ainda mais pelo $\mathrm{O}_{3}$ e $\mathrm{HO}$ e formar bromato. $\mathrm{A}$ 
redução no pH e a adição de amônia são estratégias de controle comuns contra a formação de bromatos.

Tabela 3.4.6 - Principais subprodutos conhecidos da ozonização.

\section{Subprodutos da Desinfecção}

\section{Aldeídos}

Formaldeído

Acetaldeído

Propanol

Butanal

Pentanal

Glyoxal

Metil Glioxal

\section{Aldo e Cetoácidos}

Ácido pirúvico

Ácido glioxílico

Ácido cetomalônico

Outros

Peróxido de hidrogênio

COA ou CODB

\section{Subprodutos bromados}

Ácidos acéticos

Íon brometo

Ácidos oxálico

Ácido succínico

Ácido fórmico
Bromofórmio

Ácidos acéticos bromados

Bromopicrin

Acetonitrilas bromadas

Fonte: Singer, 1992.

Segundo estudo realizado por Goel; Hozalski e Bouwer (1995), estações de tratamento de água que consideram empregar a ozonização em conjunto com a biofiltração para obter maiores remoções de COT, devem avaliar a dosagem ótima de ozônio requerida para levar a uma melhora significativa na fração biodegradável da matéria orgânica, já que a MON de baixa massa molecular parece demandar dosagens de ozônio muito elevadas (> 4,0 $\mathrm{mg} \mathrm{O}_{3} / \mathrm{mg}$ COT) para alcançar um enriquecimento expressivo na biodegradação. Essas dosagens, além de serem 
muito caras, podem levar a outros problemas associados à ozonização, isto é, maior formação de compostos bromados durante a desinfecção, conforme a relação brometo-COD aumenta. O potencial de crescimento bacteriano no sistema de distribuição também aumenta, conforme o COT da água torna-se mais biodegradável. 


\subsection{PARTÍCULAS NOS FILTROS}

\subsubsection{CARACTERÍSTICAS GERAIS DOS AFLUENTES E EFLUENTES DOS FILTROS}

Os compostos encontrados nos afluentes e efluentes dos filtros vêm da água bruta ou foram adicionados durante o tratamento químico. Esses compostos são diferentes em origem e incluem compostos inorgânicos, orgânicos e biológicos. Exemplos de materiais inorgânicos abrangem óxidos de ferro, dióxido de sílica, calcitas, argilas, óxidos de alumínio e muitos outros minerais. Compostos inorgânicos são geralmente objetáveis por razões estéticas (gosto, odor, cor) além de fornecer áreas superficiais para a adsorção de matéria orgânica natural, compostos orgânicos solúveis e outras substâncias tóxicas.

Em águas brutas para abastecimento, a maior fração do material orgânico origina-se da degradação de material de plantas e animais. A matéria orgânica pode estar tanto na forma dissolvida ou particulada, podendo reagir com os oxidantes e produzir subprodutos potencialmente carcinogênicos. Esses orgânicos podem ser removidos através de vários processos como: peneiramento, para materiais maiores; coagulação e sedimentação para materiais menores e processos avançados, como adsorção por carvão ativado granular, osmose reversa e nanofiltração (AWWARF; IWSA, 1998).

A biota comumente encontrada em fontes de água bruta compreendem protozoários, vírus, algas e bactérias. Protozoários patogênicos tais como cistos de Giárdia e oocistos de Cryptosporidium são preocupantes devido a sua predominância e resistência ao cloro ou outros oxidantes, quando comparados a bactérias e vírus. As algas são plantas unicelulares variando de tamanho entre 5 a $100 \mu \mathrm{m}$ e que causam problemas de gosto e odor e impactos adversos na operação e desempenho de um filtro. As bactérias são organismos unicelulares variando de tamanho entre 0,1 e 5 $\mu \mathrm{m}$ de diâmetro, cujas de maior preocupação incluem: Salmonella, Shigella, Yersinia Enterocolitica, Legionella, Vribrio cholera e Escherichia coli. 


\subsubsection{TRATAMENTO ANTERIOR AOS FILTROS}

Processos de tratamento como coagulação, sedimentação e pré-oxidação são utilizados para maximizar a remoção de material particulado e biológico antes da filtração, beneficiando o desempenho do filtro e aumentando sua carreira de filtração.

O processo de filtração é tipicamente classificado pelo nível de pré-tratamento empregado e denominado como convencional, direto, em linha ou em dois estágios. O nível do pré-tratamento requerido é determinado pela qualidade da água bruta e pelos recursos da operação da estação de tratamento. Inadequações ou perturbações nos processos de pré-tratamento podem resultar na redução do desempenho de um filtro, como o emprego do coagulante ou oxidante inadequado e em dosagens erradas. Huck et al. (2002), por exemplo, verificaram que a ausência da coagulação pode resultar em uma redução na remoção de patógenos.

Processos de pré-oxidação afetam o desempenho dos processos de coagulação e filtração e variam de acordo com a química da solução, tipo de oxidante, ponto de aplicação e tipo de coagulante. Estudos realizados por Hatukai; Ben-Tzur e Rebhum (1997) mostraram que a otimização da aplicação do pré-tratamento químico pelo cloro e dióxido de cloro, pode retardar o traspasse de partículas maiores (> $5 \mu \mathrm{m}$ ) através de um filtro, após sua maturação; e que a pré-oxidação pode melhorar a remoção de partículas revestidas com MON (BECKER et al., 2004). A oxidação reduziu a estabilidade dessas partículas devido às interações e mudanças no revestimento da MON, embora a oxidação dos compostos não tenha impactado substancialmente a turbidez da água filtrada.

O uso do ozônio no tratamento da água potável como pré-oxidante tem crescido bastante nos EUA devido a avanços tecnológicos e preocupação a respeito dos DBP. A ozonização apresenta diversos benefícios e sua localização na estação de tratamento deve ser escolhida considerando-se seus impactos sobre outros processos, como por exemplo a filtração. Águas filtradas de melhor qualidade, isto é, com menores quantidades de partículas e baixa turbidez, são observadas quando a 
ozonização ocorre antes da filtração, ao invés de mais a montante no trem de tratamento.

Em geral, os impactos da ozonização dependem do tipo de coagulante utilizado e da qualidade da água bruta. O ozônio converte a MON em compostos menores mais oxigenados (ácido oxálico) que podem exercer uma demanda maior de coagulante metálico do que seus compostos semelhantes. Além disso, pelo fato dos polímeros catiônicos reagirem com partículas e matérias orgânicas maiores e não com os compostos menores formados após a ozonização, a dosagem ótima de polímero após a ozonização cresce, o que pode levar a uma sub ou super dosagem de coagulante, podendo prejudicar o desempenho dos processos a jusante. O efeito da ozonização aumenta com o aumento da razão dureza/COT. Segundo Chang e Singer (1988), esta razão deve ser de pelo menos 20, antes que a pré-ozonização exiba um efeito significativo na coagulação das partículas.

\subsubsection{FATORES OPERACIONAIS E DESEMPENHO DOS FILTROS}

A remoção de partículas durante a filtração é função das características das partículas do afluente, pré-tratamento químico, taxa de filtração, produtos químicos e das propriedades do meio filtrante. $O$ desempenho de um filtro é afetado tanto pela distribuição do tamanho das partículas no afluente quanto pela mudança na distribuição do tamanho das partículas ao longo do leito e carreira de filtração.

Estudos de filtração em escala real realizados em 9 estações de tratamento localizadas nos EUA e Canadá (AWWARF, 2007) mostraram que a fração filtrável de material inorgânico aumentou com a carreira de filtração (Figura 3.5.1), associado a um decréscimo na quantidade de material na fração sedimentável. Uma tendência similar foi observada tanto para taxas de aplicação constantes quanto variáveis, indicando que materiais maiores foram removidos, conforme a filtração e a maturação progrediam. 

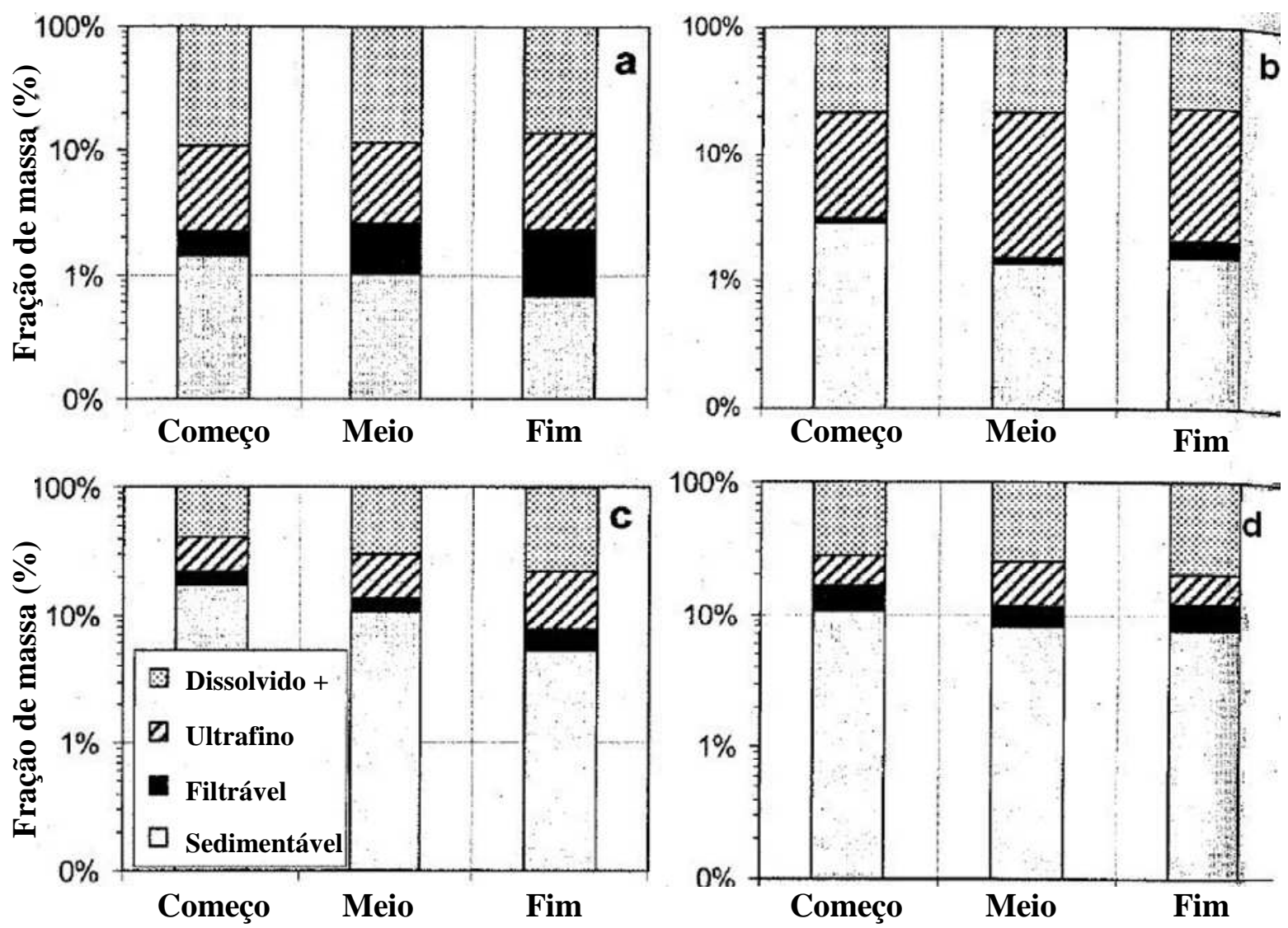

Figura 3.5.1 - Fração das partículas no efluente dos filtros ao longo de suas carreiras de filtração para os materiais inorgânicos, segundo condições de operação variáveis (a) ([metais] $=53$ ppm) e constantes (b) ([metais] = 42 ppm) e para os orgânicos, segundo condições de operação variáveis (c) $([\mathrm{COT}]=2,98 \mathrm{ppm})$ e constantes $(\mathrm{d})([\mathrm{COT}]=2,81 \mathrm{ppm})($ AWWARF, 2007).

Na Figura 3.5.1, a fração de material dissolvido refere-se a faixa de partículas com tamanho < $30 \mathrm{~nm}$; a ultrafina, entre $30 \mathrm{~nm}$ e $0,45 \mu \mathrm{m}$; a filtrável, entre $0,45 \mu \mathrm{m}$ e 260 $\mu \mathrm{m}$ e a sedimentável, $>260 \mu \mathrm{m}$.

A maior parte do material orgânico estava presente na fração dissolvida, seguida pela ultrafina, sedimentável e filtrável. A porcentagem do material orgânico presente na fração sedimentável foi significativamente mais alta do que a do material inorgânico; e a porcentagem de material inorgânico nas faixas dos tamanhos dissolvido e ultrafino de partículas, foi superior ao do material orgânico.

Partículas maiores do que o tamanho efetivo do poro do meio filtrante são removidas por meio de mecanismos de peneiramento e as partículas menores, através de diversos mecanismos. A remoção destas partículas pode ser considerada um processo de duas etapas: transporte até as proximidades dos grãos e ligação; assim, águas caracterizadas por partículas de tamanho grande, pequeno ou 
altamente polidisperso irão experimentar diferentes eficiências de remoção. Carreiras de filtração e desenvolvimento da perda de carga são diferentes dependendo das faixas de tamanho das partículas e suas concentrações.

Durante $o$ desenvolvimento de um filtro, partículas pequenas $(<1 \mu \mathrm{m})$ presentes no afluente melhoram a remoção de partículas maiores, enquanto que a remoção das partículas pequenas não é muito influenciada pela presença de grandes partículas. Isso ocorre pois, partículas menores rapidamente ocupam sítios de deposição favoráveis, resultando em depósitos altamente porosos que finalmente reduzem o tamanho dos poros do filtro e aumentam a remoção das partículas subseqüentes. Isto também fica evidenciado que o amadurecimento de um filtro se dá mais rapidamente quando as partículas no afluente têm um diâmetro de massa-média menor. A temperatura também afeta a remoção das partículas, devido ao seu impacto na viscosidade da água e em outras propriedades. Quanto menor a temperatura, mais viscosa é a água e mais lentamente as partículas se movem até alcançar a superfície do meio e portanto, menor é a eficiência de remoção.

Taxas de filtração elevadas resultam em forças de cisalhamento mais altas, causando o desprendimento de partículas previamente depositadas e levando a menores perdas de carga com o tempo, em conseqüência da redução da deposição das partículas dentro do filtro. A taxa de filtração também impacta a turbidez do efluente; diminuindo com o decréscimo da taxa. Conforme o tamanho do meio aumenta, o tamanho do poro também cresce, resultando em forças de cisalhamento mais altas. Para meios filtrantes mais finos, devido ao tamanho menor dos poros, podem ocorrer colmatações no filtro. Grandes flutuações nas taxas de filtração mostraram prejudicar a qualidade da água filtrada devido ao descolamento de partículas dentro do filtro (FITZPATRICK; CAMPBELL; CABLE, 1999), independentemente da sua duração.

A remoção de partículas e em última análise, a qualidade da água filtrada, também dependem da eficiência do procedimento de contra lavagem adotado. Segundo estudos realizados por Raveendran e Amirtharajah (1995), o desprendimento das partículas do meio filtrante durante a contra lavagem é afetada pelo pré-tratamento e pelas estratégias de filtração adotadas. Por exemplo, a otimização dos processos de filtração através de mudanças nos produtos químicos resulta em ligações mais fortes 
ao meio filtrante, tornando suas remoções mais difíceis durante a contra lavagem. Se estas partículas não forem totalmente removidas, elas podem ser arrastadas do filtro durante a sua re-partida e posteriormente resultar em uma água de baixa qualidade.

As características do meio filtrante que afetam seu desempenho são: tamanho, forma, morfologia, química da sua superfície e uniformidade. O tamanho e tipo do meio filtrante determinam a área superficial total disponível para a remoção e o tamanho dos canais de escoamento. A remoção inicial das partículas será determinada pelo número de sítios de deposição favoráveis no meio filtrante e a taxa na qual estes sítios tornam-se ocupados.

\subsubsection{REMOÇÃO MICROBIOLÓGICA}

O principal objetivo do tratamento para abastecimento é proteger a saúde pública através do fornecimento de uma água livre de contaminantes químicos e microbiológicos. Porém, mesmo com os avanços tecnológicos alcançados na área de tratamento, surtos de doenças de veiculação hídrica continuam a ocorrer (FOX; LYTLE, 1996).

O aparecimento de protozoários parasitas como Giardia lamblia e Cryptosporidium parvum como agentes etiológicos de doenças de veiculação hídrica levou a uma reavaliação da eficiência das estações de tratamento. Embora a desinfecção seja eficiente na redução da ameaça representada por estes parasitas, processos de remoção física, como a filtração, também são importantes. A otimização dos processos de filtração para a remoção destes patógenos é ainda mais necessária devido às crescentes preocupações com relação aos DBP.

Diversos estudos (AWWARF, 2007) que correlacionam a remoção de patógenos com a contagem de partículas no efluente de filtros têm sido usados para otimizar os processos de tratamento. No entanto, os equipamentos de contagem de partículas são essencialmente cegos a materiais presentes na faixa de tamanho $<1 \mu \mathrm{m}$, os 
quais podem inibir a eficiência dos processos de desinfeç̧ão, como a cloração e a irradiação ultravioleta.

Dados conclusivos que relacionam turbidez com concentração de cistos permanecem incompletos, uma vez que os meios para a medição de turbidez não podem distinguir a origem ou tamanho das partículas presentes na água. Diversos estudos reportaram uma boa correlação entre redução de turbidez e contagem de partículas, com a remoção de cistos (DUGAN; WILLIAMS, 2004) enquanto que outros encontraram a turbidez e a contagem de partículas como bons indicadores do desempenho de filtros, mas não da remoção de cistos (HAAS et al., 2001).

De qualquer modo, a remoção de patógenos continua a ser aferida pela turbidez e contagem de partículas, apesar da natureza imprecisa dessas medidas. 


\section{MATERIAIS E MÉTODOS}

\subsection{A ESTAÇÃo DE TRATAMENTO DE ÁGUA ALTO DA BOA VISTA}

A Estação de Tratamento de Água Alto da Boa Vista, responsável por tratar atualmente $14 \mathrm{~m} / \mathrm{s}$, se localiza a Rua Graham Bell, 647, no bairro de mesmo nome. Esta ETA encontra-se implantada em uma área de $150.000 \mathrm{~m}^{2}$, delimitada pelas Ruas Alberto Hodge e Comendador Elias Zarzur no sentido norte-sul e Ruas Graham Bell e Américo Brasiliense no sentido leste-oeste, conforme ilustrado na Figura 4.1.1.

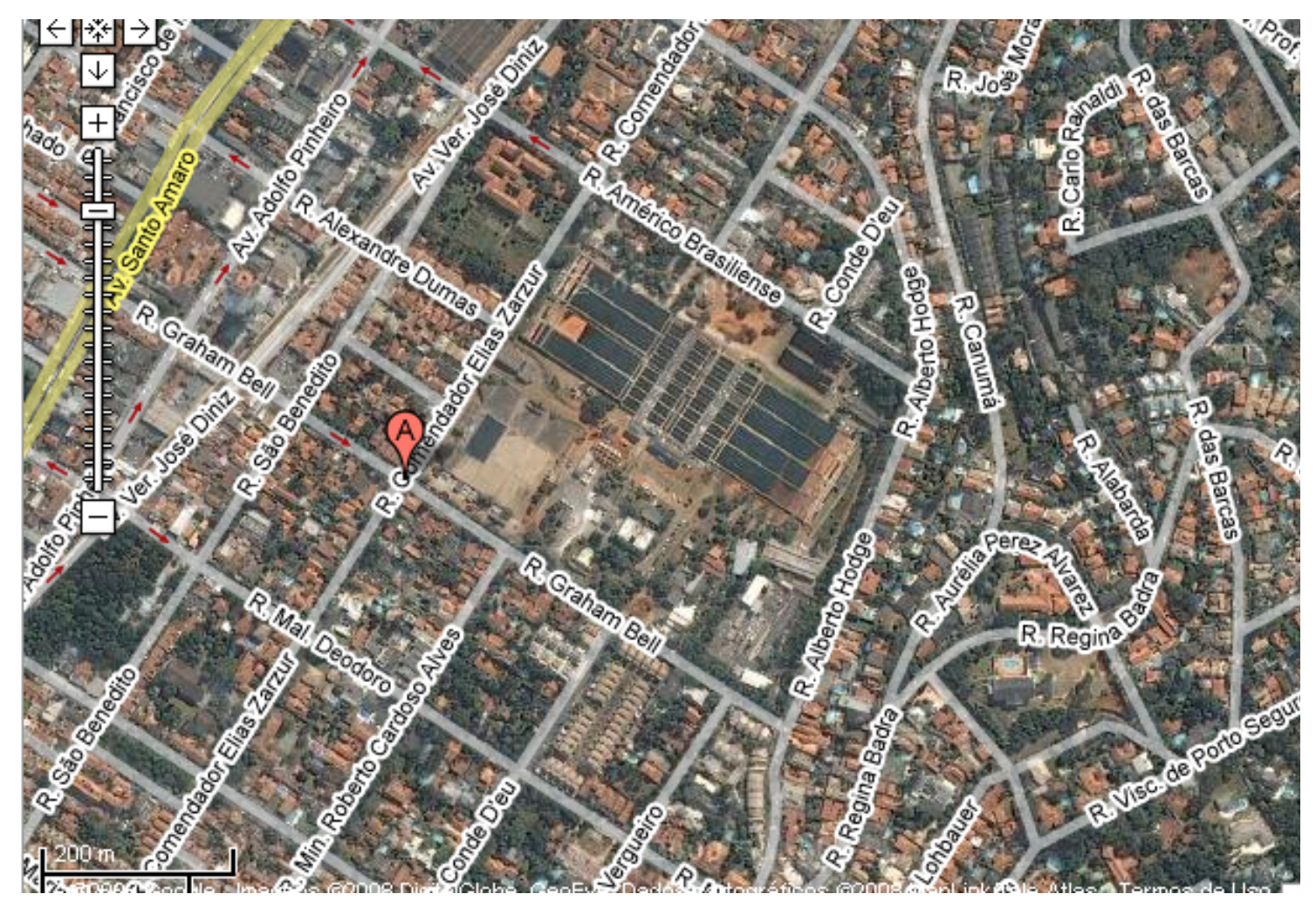

Figura 4.1.1 - ETA ABV, localização e principais acessos (Google Maps, 2008).

A água bruta aduzida do Reservatório Guarapiranga é típica de mananciais urbanos represados, com águas de baixa cor e turbidez, e todas as demais características oriundas da contaminação da bacia por esgotos sanitários.

O início de operação da Estação de Tratamento de Água Alto da Boa Vista ocorreu na década de 40 , tendo sido implantados quatro módulos (dois da ala leste e dois da 
ala oeste) de tratamento, constituídos por 4 baterias de floculadores, 4 decantadores e 16 filtros, para completar a produção aduzida do Reservatório Guarapiranga que até então alimentava exclusivamente a ETA Theodoro A. Ramos.

Ao longo de sua existência e, mais especificamente a partir da década de 70, a ETA ABV foi submetida a uma série de intervenções, e essa seqüência de obras e serviços mantiveram-se (com maior ou menor intensidade) até os dias de hoje. $\mathrm{O}$ processo de tratamento tem sido o convencional completo, precedido de um prétratamento relativo à aplicação eventual de carvão ativado em pó, combinado ou não com o permanganato de potássio, para a redução dos problemas de gosto e odor, verificados nas águas do Reservatório Guarapiranga. No período de testes considerado para a elaboração deste texto (julho/2007 a dezembro/2008), o CAP foi aplicado nos meses de janeiro, maio, agosto, setembro, outubro e novembro/2008, em uma dosagem média de $18 \mathrm{mg} / \mathrm{L}$ e o permanganato, em agosto e setembro/2008, em uma dosagem média de $0,3 \mathrm{mg} / \mathrm{L}$.

O bloco hidráulico principal da ETA encontra-se posicionado na parte mais ao sul, sendo subdividido simetricamente em dois outros blocos secundários conhecidos como alas leste e oeste. Suas principais unidades são: (1) estrutura de chegada de água bruta (Figura 4.1.2); (2) mistura rápida; (3) bacia de tranqüilização; (4) canal de água coagulada; (5) floculadores com agitadores mecânicos de eixo vertical e fluxo axial, em número total de 8 (Figura 4.1.3); (6) decantadores convencionais de fluxo horizontal, em número total de 8 (Figura 4.1.4); (7) canais de água decantada; (8) filtros de dupla camada, antracito e areia do tipo taxa declinante, lavados unicamente com água em contra-corrente e lavagem superficial, em número total de 32 (Figura 4.1.5); (9) canal de água filtrada; (10) reservatório de água tratada; (11) estação elevatória de água tratada; (12) estação elevatória de água de lavagem dos filtros; (13) recuperação de água de lavagem; (14) casa de química/produtos químicos e; (15) utilidades. Atualmente, na mistura rápida, são adicionados o sulfato férrico e a poliamida, em dosagens médias iguais a $27 \mathrm{mg} / \mathrm{L}$ e $0,11 \mathrm{mg} / \mathrm{L}$, respectivamente.

Na Tabela 4.1.1 têm-se apresentados os valores mínimos, médios e máximos dos parâmetros da água bruta da ETA ABV, calculados a partir dos dados disponibilizados pela CETESB para o período compreendido entre os anos de 2000 
e 2007. Os parâmetros fornecidos dizem respeito às amostras pontuais realizadas a cada 2 meses, coletadas no reservatório do Guarapiranga, na captação da SABESP, junto à casa de bombas.

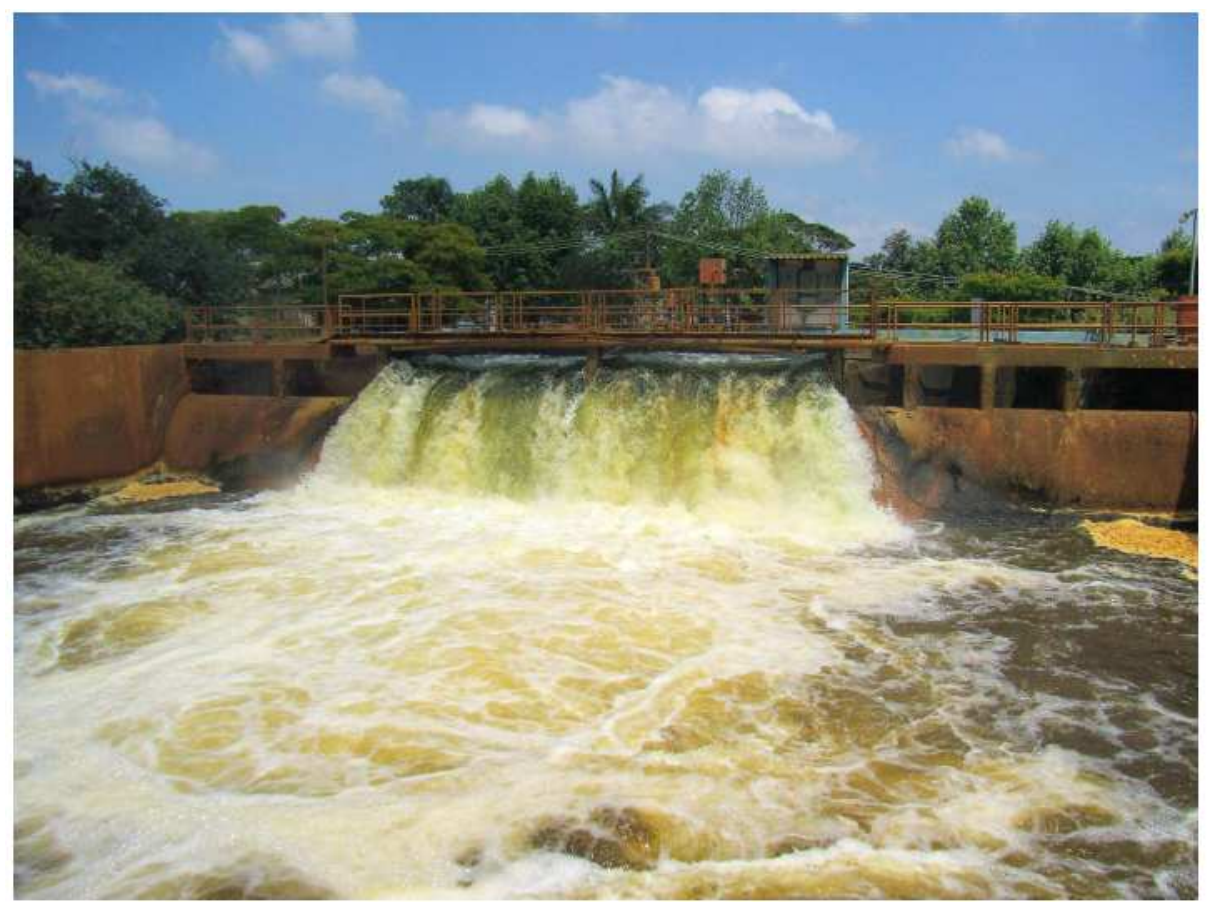

Figura 4.1.2 - Estrutura de chegada de água bruta.

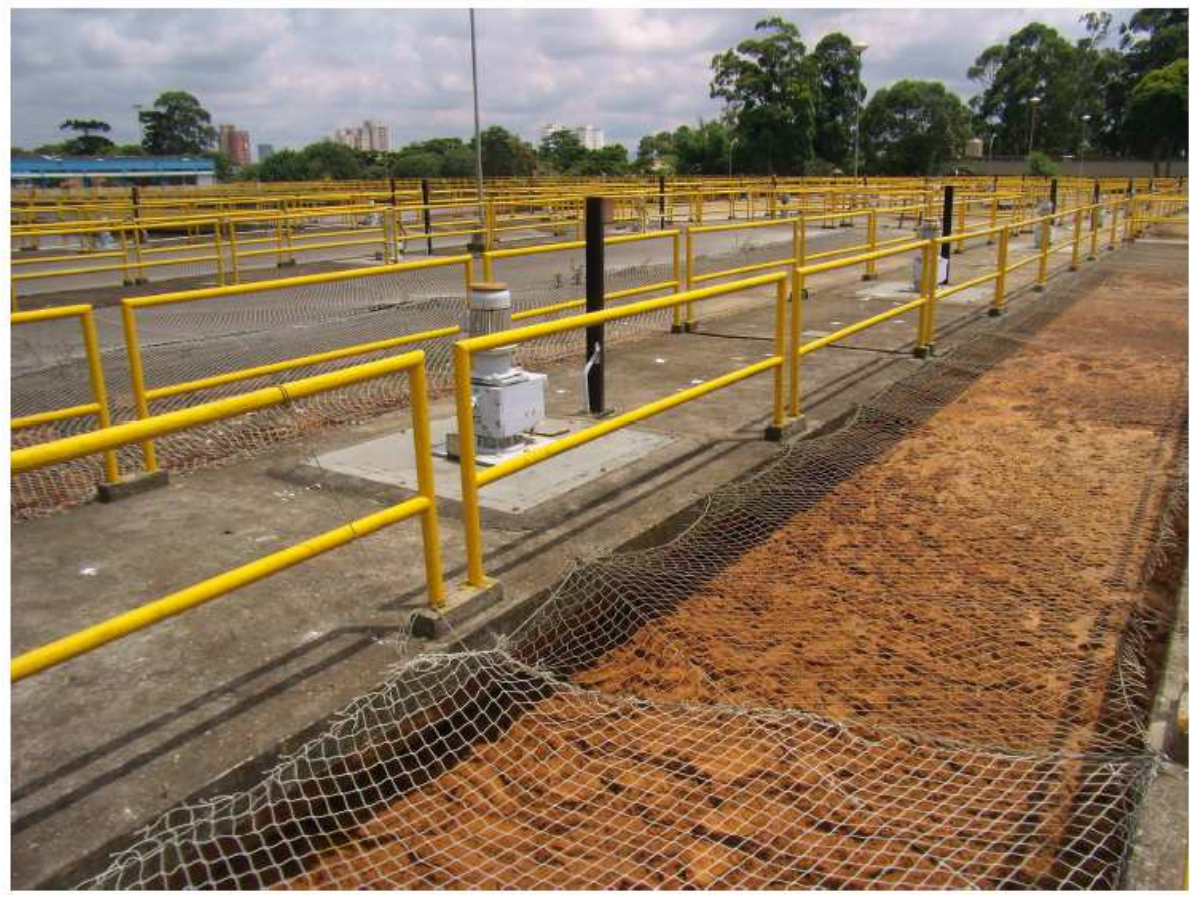

Figura 4.1.3 - Floculadores. 


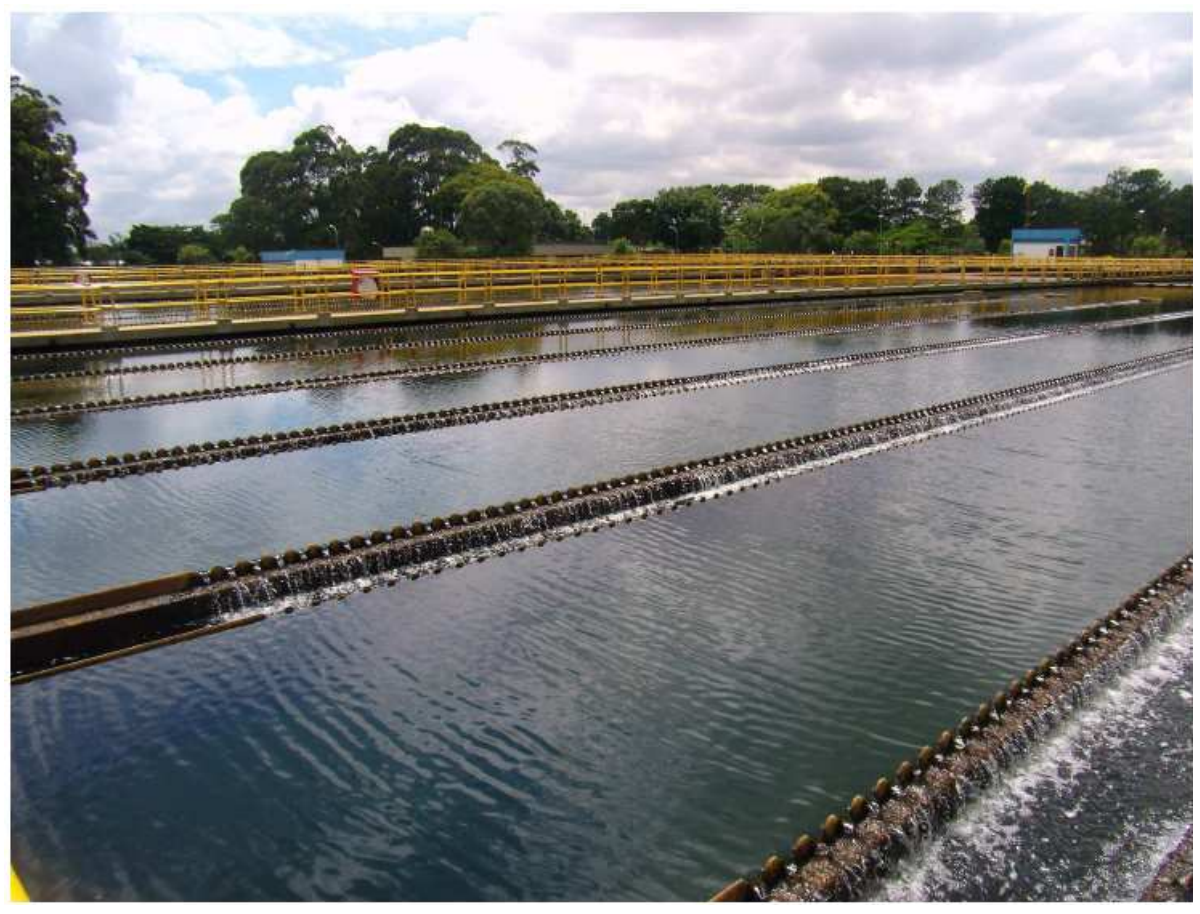

Figura 4.1.4 - Decantadores.

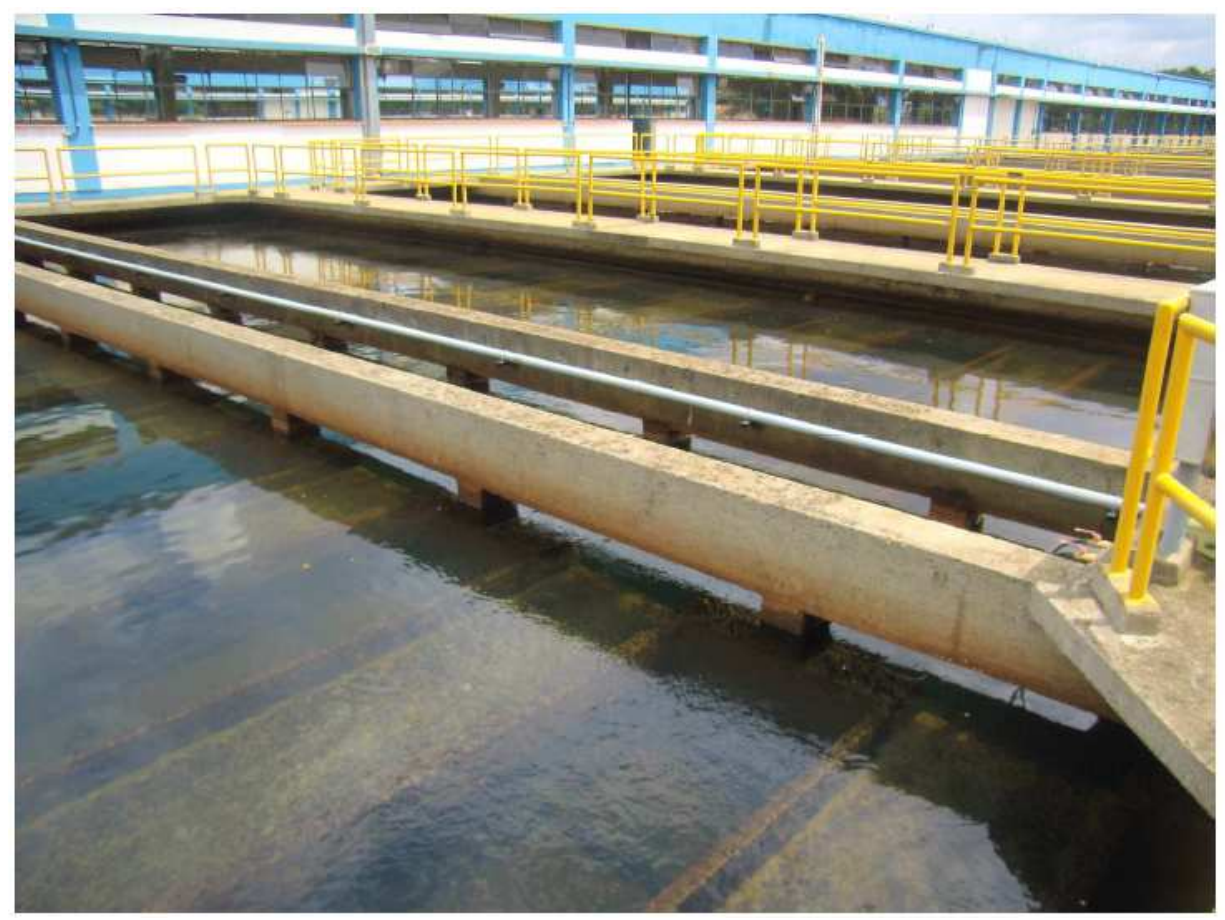

Figura 4.1.5 - Filtros. 
Tabela 4.1.1 - Parâmetros físicos, químicos, microbiológicos e hidrobiológicos da água bruta da ETA ABV - continua.

Parâmetro

De Campo:

$\mathrm{pH}$
Temperatura

Físico-Químicos:

Absorbância no UV

Alumínio total

Alumínio dissolvido

Cádmio

Chumbo

Cloreto

Cobre total

Cobre dissolvido

COD

Condutividade

Cor

Cromo

DBO $(5,20)$

DQO

\section{Unidade Mínimo Médio Máximo Desvio Padrão}


Tabela 4.1.1 - Parâmetros físico-químicos, microbiológicos e hidrobiológicos da água bruta da ETA ABV - continuação.

\begin{tabular}{|c|c|c|c|c|c|}
\hline Fenóis & $\mathrm{mg} / \mathrm{L}$ & $<0,003$ & $<0,003$ & $<0,003$ & 0,000 \\
\hline Ferro total & $\mathrm{mg} / \mathrm{L}$ & 0,07 & 0,18 & 0,50 & 0,09 \\
\hline Ferro dissolvido & $\mathrm{mg} / \mathrm{L}$ & $<0,10$ & 0,11 & 0,14 & 0,01 \\
\hline Fosfato orto solúvel & $\mathrm{mg} / \mathrm{L}$ & $<0,007$ & 0,008 & 0,030 & 0,004 \\
\hline Fósforo & $\mathrm{mg} / \mathrm{L}$ & $<0,02$ & 0,07 & 0,23 & 0,05 \\
\hline Manganês & $\mathrm{mg} / \mathrm{L}$ & 0,02 & 0,08 & 0,39 & 0,07 \\
\hline Mercúrio & $\mathrm{mg} / \mathrm{L}$ & $<0,0001$ & 0,0002 & 0,0010 & 0,0003 \\
\hline Nitrogênio amoniacal & $\mathrm{mg} / \mathrm{L}$ & $<0,02$ & 0,18 & 0,65 & 0,16 \\
\hline Níquel & $\mathrm{mg} / \mathrm{L}$ & $<0,010$ & 0,018 & 0,020 & 0,004 \\
\hline Nitrato & $\mathrm{mg} / \mathrm{L}$ & 0,22 & 0,89 & 4,83 & 1,00 \\
\hline Nitrito & $\mathrm{mg} / \mathrm{L}$ & $<0,004$ & 0,073 & 0,390 & 0,097 \\
\hline NKT & $\mathrm{mg} / \mathrm{L}$ & $<0,03$ & 0,89 & 2,56 & 0,48 \\
\hline OD & $\mathrm{mg} / \mathrm{L}$ & 3,3 & 7,4 & 11,8 & 2,3 \\
\hline THMFP & $\mu g / L$ & 183 & 353 & 607 & 108 \\
\hline SDT & $\mathrm{mg} / \mathrm{L}$ & 2 & 90 & 128 & 30 \\
\hline ST & $\mathrm{mg} / \mathrm{L}$ & 42 & 102 & 142 & 20 \\
\hline Sólidos voláteis & $\mathrm{mg} / \mathrm{L}$ & 6 & 63 & 100 & 37 \\
\hline Sulfato & $\mathrm{mg} / \mathrm{L}$ & $<10$ & 14 & 100 & 19 \\
\hline
\end{tabular}


Tabela 4.1.1 - Parâmetros físico-químicos, microbiológicos e hidrobiológicos da água bruta da ETA ABV - conclusão.

$\begin{array}{llllll}\text { Turbidez } & \text { UNT } & 0,00 & 2,14 & 5,00 & 1,23 \\ \text { Zinco } & \mathrm{mg} / \mathrm{L} & <0,01 & 0,03 & 0,13 & 0,02\end{array}$

Microbiológicos:

$\begin{array}{llllll}\text { Coliformes termotolerantes } & \text { UFC } / 100 \mathrm{~mL} & 1 & 526 & 12.000 & 2.030\end{array}$

Hidrobiológicos:

$\begin{array}{llllll}\text { Clorofila-a } \quad \mu \mathrm{g} / \mathrm{L} & 6,68 & 25,43 & 81,97 & 16,39\end{array}$

$\begin{array}{llllll}\text { Feofitina-a } \quad \mu g / L & 6,66 & 45,20 & 1.023,00 & 168,02\end{array}$

Número de cianobactérias $\quad$ № células $1.400 \quad 20.644 \quad 70.000 \quad 17.849$

Fonte: adaptado de CETESB, 2008.

\subsection{ENSAIOS EXPERIMENTAIS}

Os ensaios experimentais foram conduzidos na própria ETA ABV, nas dependências da estação piloto existente (Figura 4.2.1) e próximos às bombas de água de lavagem dos filtros (Figura 4.2.2). Foram construídas quatro colunas em acrílico com diâmetro interno de 14,2 cm e base em aço pelo CTH (Centro Tecnológico de Hidráulica da USP), para o estudo dos pós-filtros adsorvedores de CAG. A construção destas colunas levou três meses (de março/2007 a maio/2007) e os ajustes e adequações na ETA piloto para o início dos testes, um mês (junho/2007). As bases dos filtros foram construídas em aço para se evitar vazamentos nas tubulações de lavagem a ar, água e saída de água filtrada (Figura 4.2.3).

Para a correta distribuição do ar e água na contra lavagem, o distribuidor de fundo para filtro SF-06 da Degrémont (Figura 4.2.4), foi colocado debaixo da camada suporte dos filtros. As colunas de acrílico foram preenchidas com camada suporte e 
carvão de acordo com as características fornecidas pelos fabricantes e apresentadas nas Tabelas 4.2.1 e 4.2.2. Os filtros foram numerados da esquerda para direita de 1 a 4 (Figura 4.2.5).

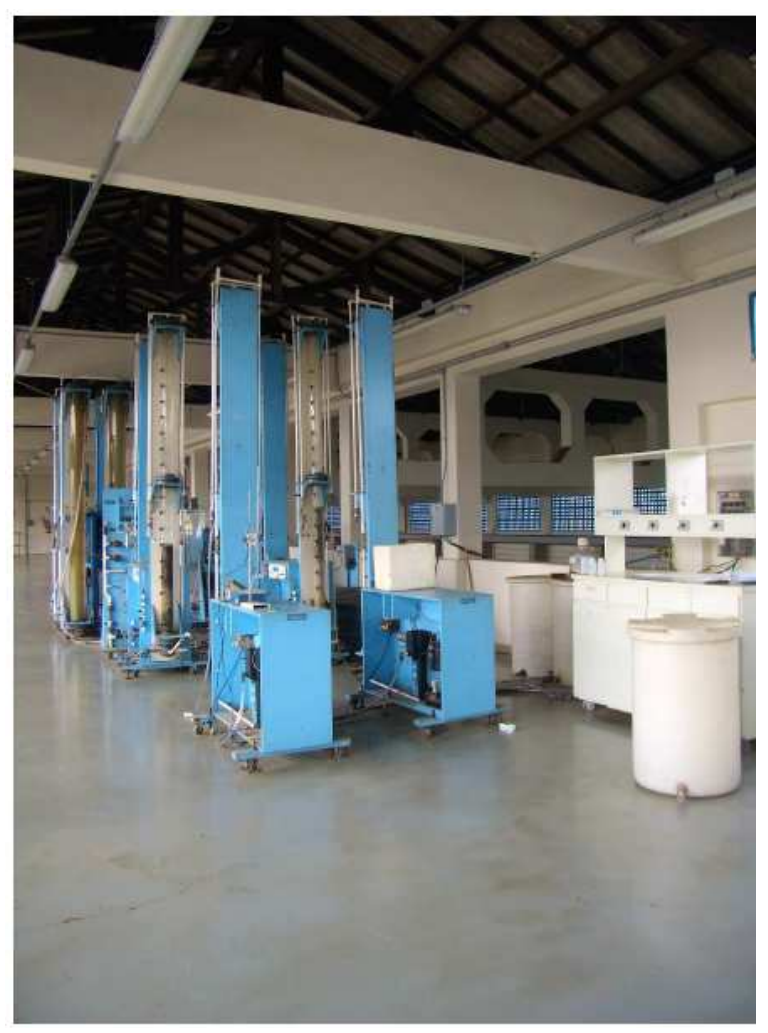

Figura 4.2.1 - ETA piloto ABV.

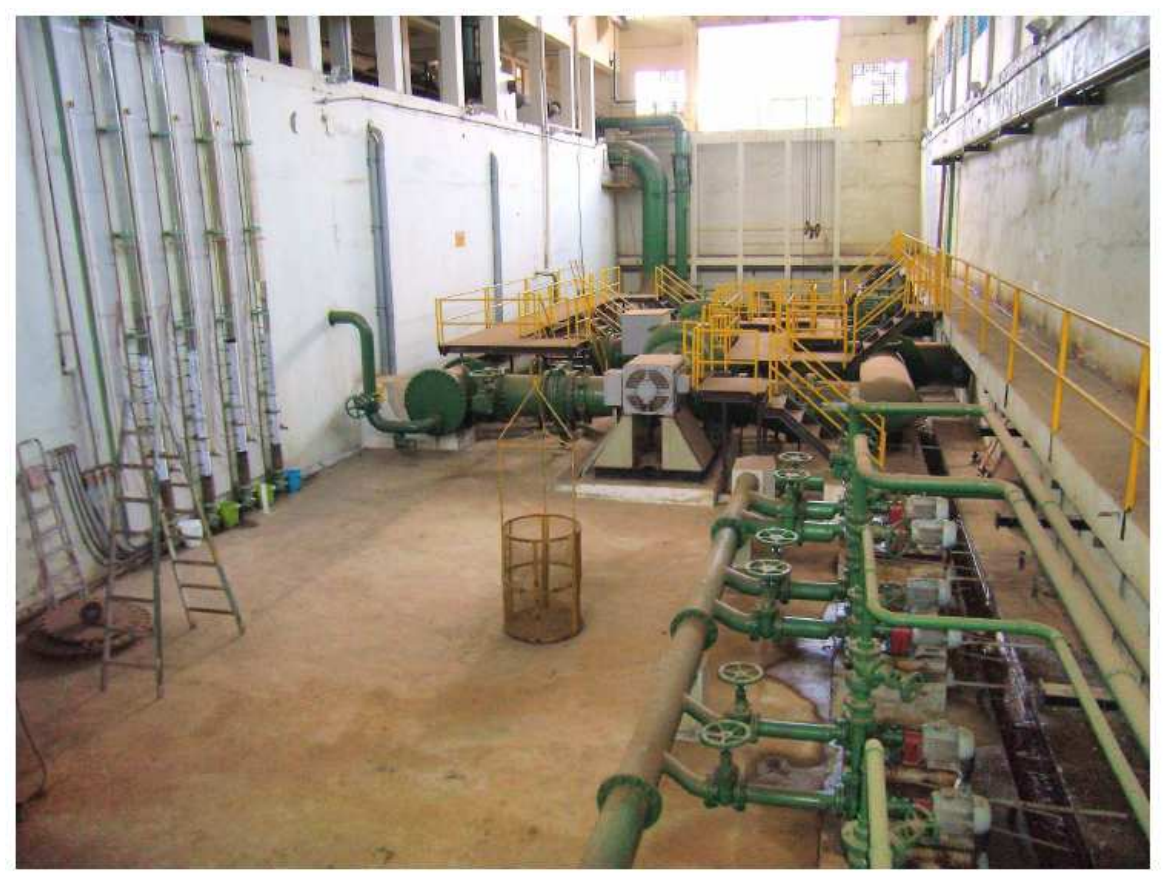

Figura 4.2.2 - Local dos filtros piloto de CAG. 


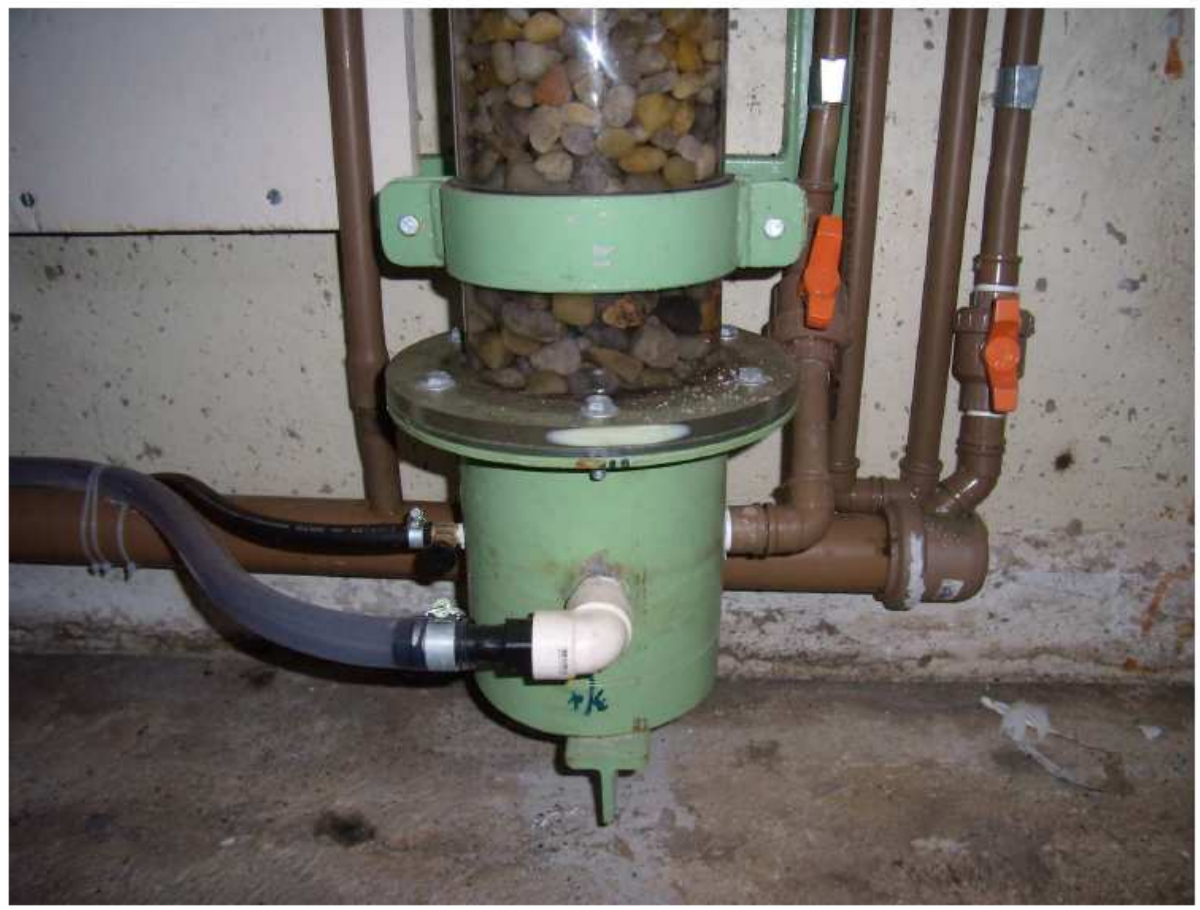

Figura 4.2.3 - Base em aço dos filtros, tubulações de lavagem a ar (mangueira negra), água (mangueira transparente) e saída de água filtrada (PVC).

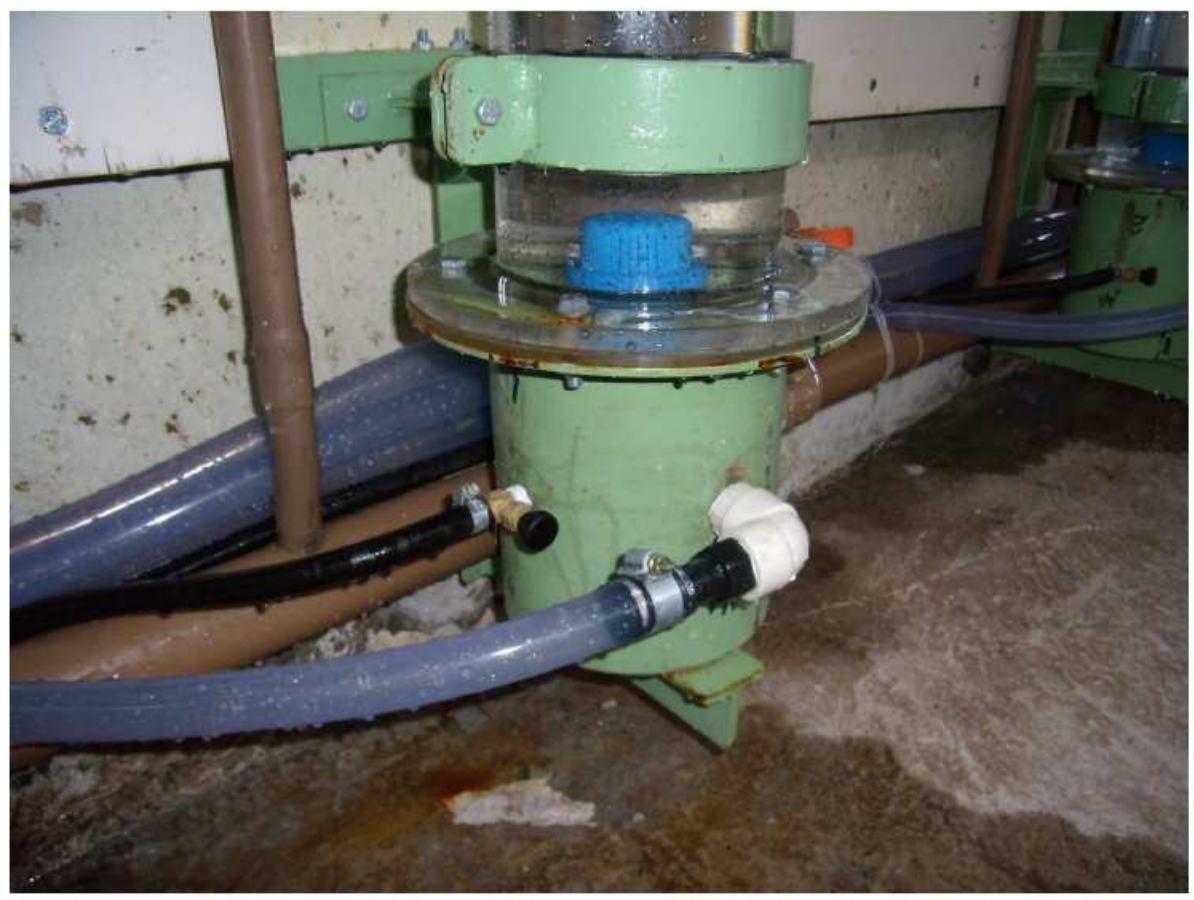

Figura 4.2.4 - Distribuidor de fundo de filtro para lavagem a ar e água (dispositivo em azul). 


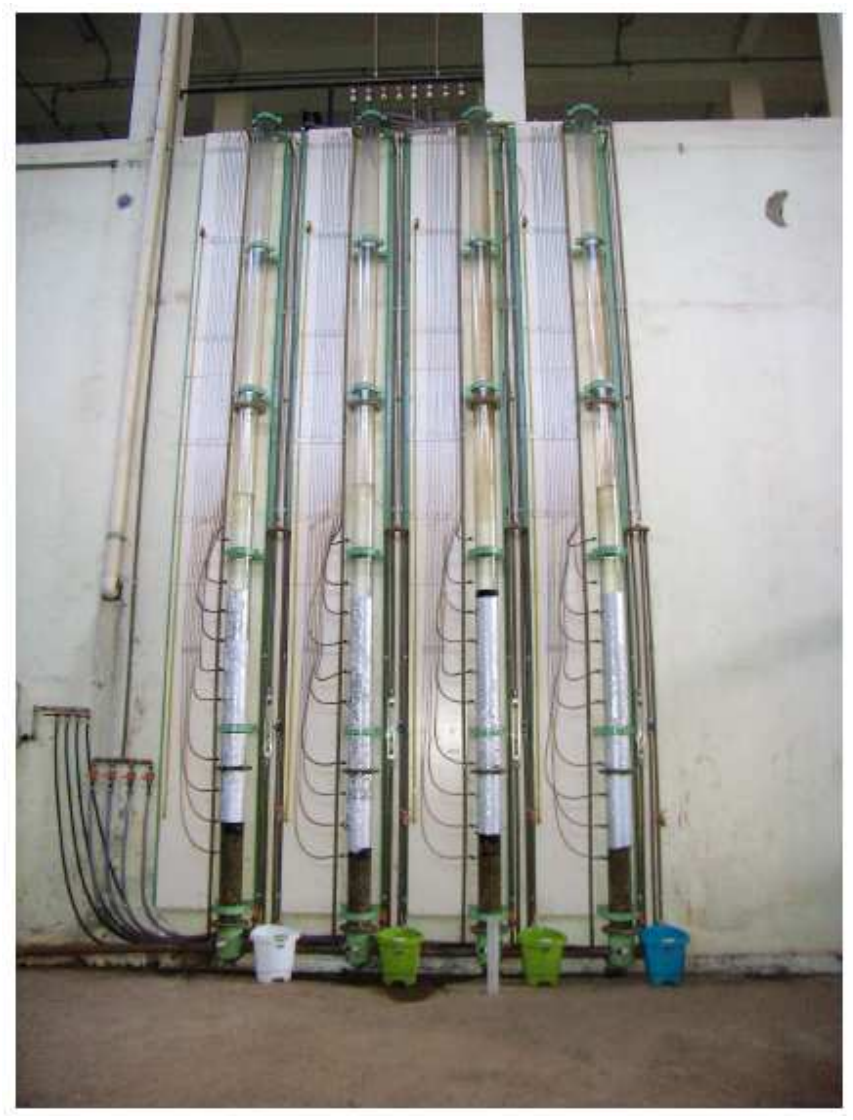

Figura 4.2.5 - Filtros de CAG, identificados da esquerda para direita de 1 a 4 .

Tabela 4.2.1 - Características dos filtros 1 e 3.

\begin{tabular}{|c|c|c|c|}
\hline Camada & Altura & $\begin{array}{c}\text { Coeficiente de } \\
\text { Uniformidade - CU }\end{array}$ & $\begin{array}{c}\text { Faixa de diâmetro } \\
\text { efetivo - Фe }\end{array}$ \\
\hline \multirow{8}{*}{$\begin{array}{c}\text { Suporte: } \\
\text { Pedregulho }\end{array}$} & $10,0 \mathrm{~cm}$ & - & $25,4 \mathrm{~mm}$ a $50,0 \mathrm{~mm}$ \\
\hline & $7,5 \mathrm{~cm}$ & - & $12,7 \mathrm{~mm}$ a $25,4 \mathrm{~mm}$ \\
\hline & $7,5 \mathrm{~cm}$ & - & $6,4 \mathrm{~mm}$ a $12,7 \mathrm{~mm}$ \\
\hline & $7,5 \mathrm{~cm}$ & - & $3,2 \mathrm{~mm}$ a $6,4 \mathrm{~mm}$ \\
\hline & $7,5 \mathrm{~cm}$ & - & $1,7 \mathrm{~mm}$ a $3,2 \mathrm{~mm}$ \\
\hline & $7,5 \mathrm{~cm}$ & - & $3,2 \mathrm{~mm}$ a $6,4 \mathrm{~mm}$ \\
\hline & $7,5 \mathrm{~cm}$ & - & $6,4 \mathrm{~mm}$ a $12,7 \mathrm{~mm}$ \\
\hline & $7,5 \mathrm{~cm}$ & - & $12,7 \mathrm{~mm}$ a $25,4 \mathrm{~mm}$ \\
\hline \multicolumn{4}{|l|}{ Meio Filtrante: CAG } \\
\hline $\begin{array}{c}\text { Filtrasorb } 300 \\
\text { CALGON }\end{array}$ & $150,0 \mathrm{~cm}$ & $<2,1$ & 0,8 a $1,0 \mathrm{~mm}$ \\
\hline
\end{tabular}


Tabela 4.2.2 - Características dos filtros 2 e 4.

\begin{tabular}{cccc}
\hline Camada & Altura & $\begin{array}{c}\text { Coeficiente de } \\
\text { Uniformidade - CU }\end{array}$ & $\begin{array}{c}\text { Faixa de diâmetro } \\
\text { efetivo - } \mathbf{\Phi e}\end{array}$ \\
\hline & $10,0 \mathrm{~cm}$ & - & $25,4 \mathrm{~mm}$ a $50,0 \mathrm{~mm}$ \\
& $7,5 \mathrm{~cm}$ & - & $12,7 \mathrm{~mm}$ a $25,4 \mathrm{~mm}$ \\
Suporte: & $7,5 \mathrm{~cm}$ & - & $6,4 \mathrm{~mm}$ a $12,7 \mathrm{~mm}$ \\
$\begin{array}{c}\text { Pedregulho } \\
\text { (7,5 cm }\end{array}$ & - & $3,2 \mathrm{~mm}$ a $6,4 \mathrm{~mm}$ \\
& $7,5 \mathrm{~cm}$ & - & $1,7 \mathrm{~mm}$ a $3,2 \mathrm{~mm}$ \\
& $7,5 \mathrm{~cm}$ & - & $3,2 \mathrm{~mm}$ a $6,4 \mathrm{~mm}$ \\
& $7,5 \mathrm{~cm}$ & - & $6,4 \mathrm{~mm}$ a $12,7 \mathrm{~mm}$ \\
$\begin{array}{c}\text { Meio Filtrante: CAG } \\
\text { CARBOMAFRA }\end{array}$ & $7,5 \mathrm{~cm}$ & - & $12,7 \mathrm{~mm}$ a $25,4 \mathrm{~mm}$ \\
\hline
\end{tabular}

A camada suporte dos filtros foi selecionada de acordo com as dimensões comumente empregadas em estações de tratamento (KAWAMURA, 2000) e os meios de CAG, fornecidos pelos fabricantes, com a função de remover gosto, odor, DBP e outros compostos orgânicos, de acordo com suas especificações técnicas apresentadas nos ANEXOS A (carvão da CALGON) e B (carvão da CARBOMAFRA). Os piezômetros, dispostos do lado esquerdo dos filtros, foram empregados para a leitura das perdas de carga, através de 10 pontos posicionados ao longo da coluna de filtração (Figura 4.2.6).

Os filtros operaram em paralelo, $24 \mathrm{~h}$ por dia, 7 dias por semana, sendo o 3 e 4 abastecidos com água filtrada da ETA; e 01 e 2, com água ozonizada. A água filtrada da ETA era equalizada em um reservatório (REAF) com capacidade para 1 $\mathrm{m}^{3}$ (Figura 4.2.7) antes de seguir, por gravidade, para os filtros $3(\mathrm{~F} 3)$ e 4 (F4). A água do REAF também era, ao mesmo tempo, bombeada (Figura 4.2.8) para quatro colunas de ozonização feitas em acrílico com diâmetro interno de $12,7 \mathrm{~cm}$, altura útil de 2,83 m e operação em série (Figura 4.2.9). 


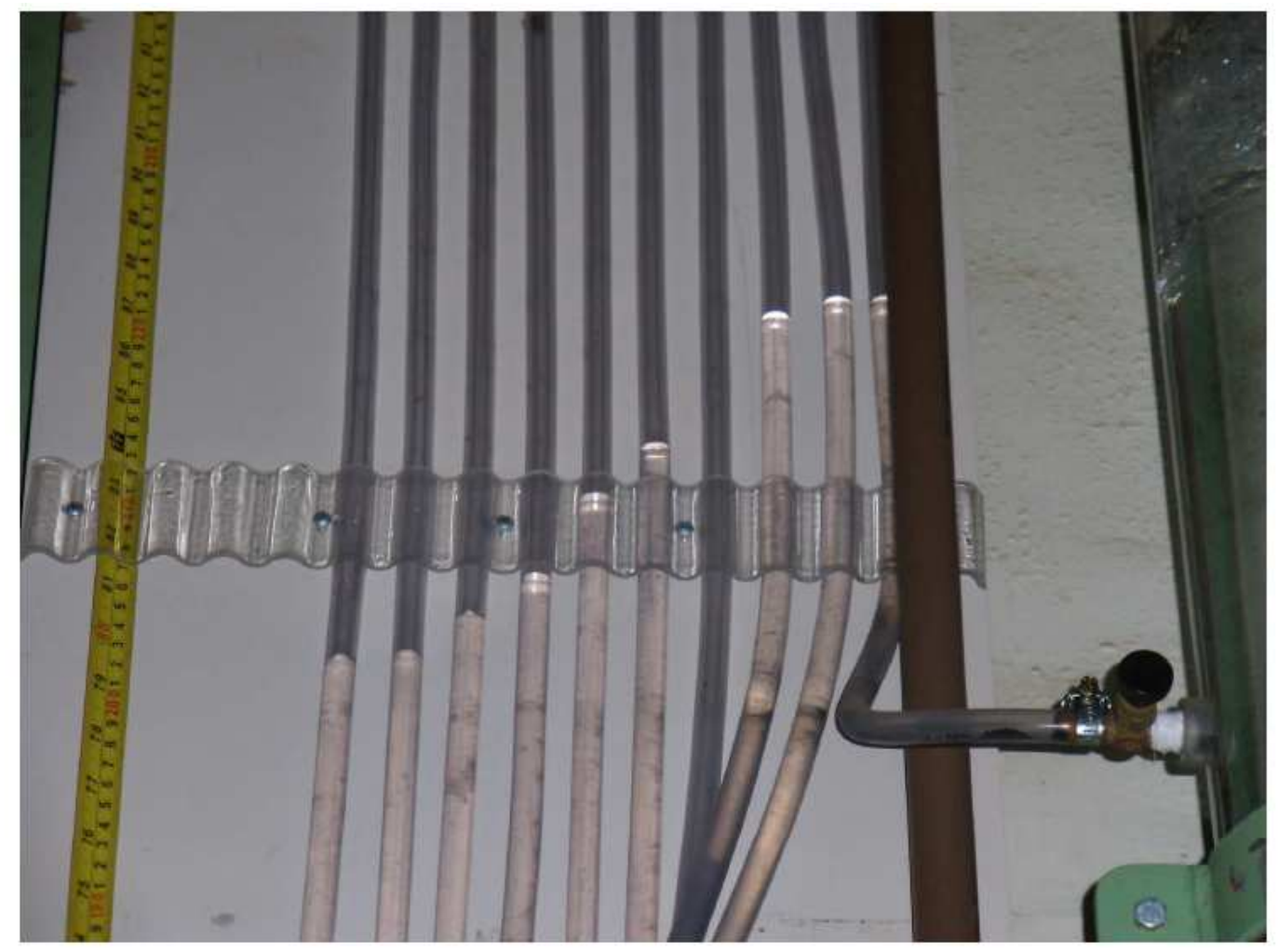

Figura 4.2.6 - Piezômetros para leitura da perda de carga.

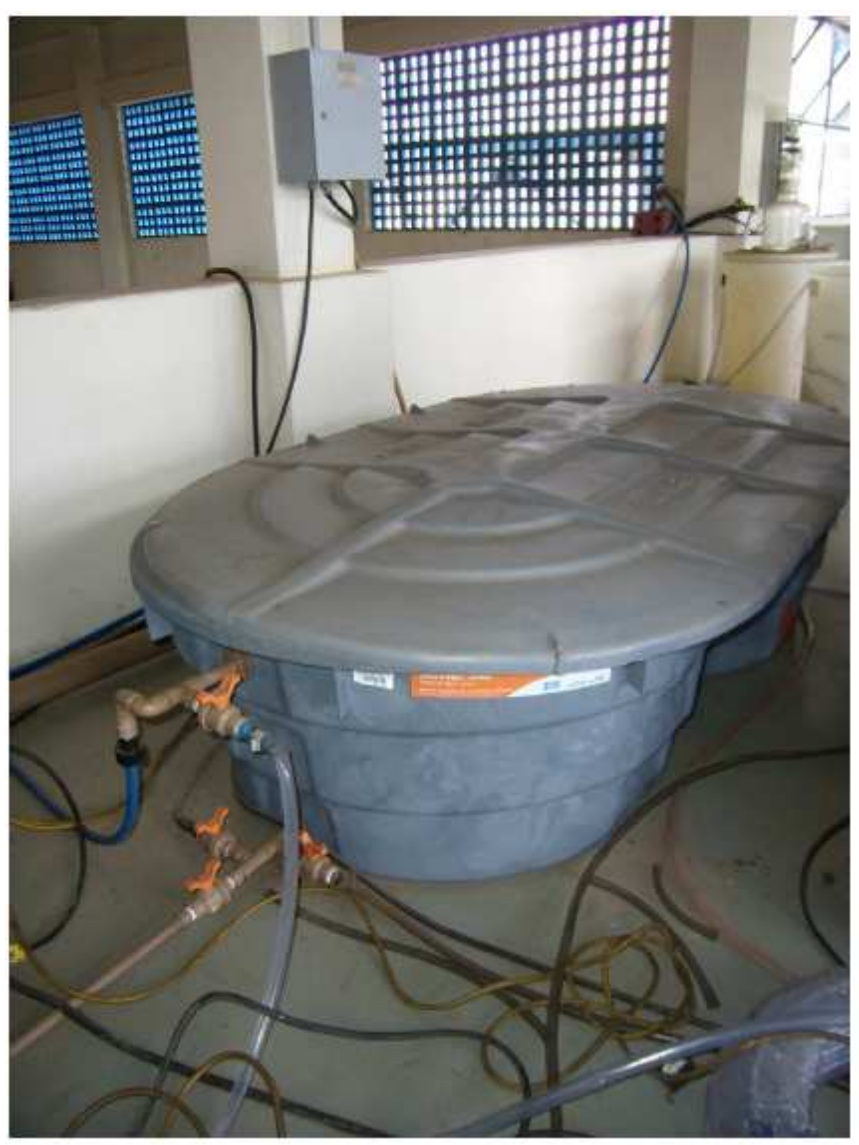

Figura 4.2.7 - Reservatório de equalização de água filtrada. 


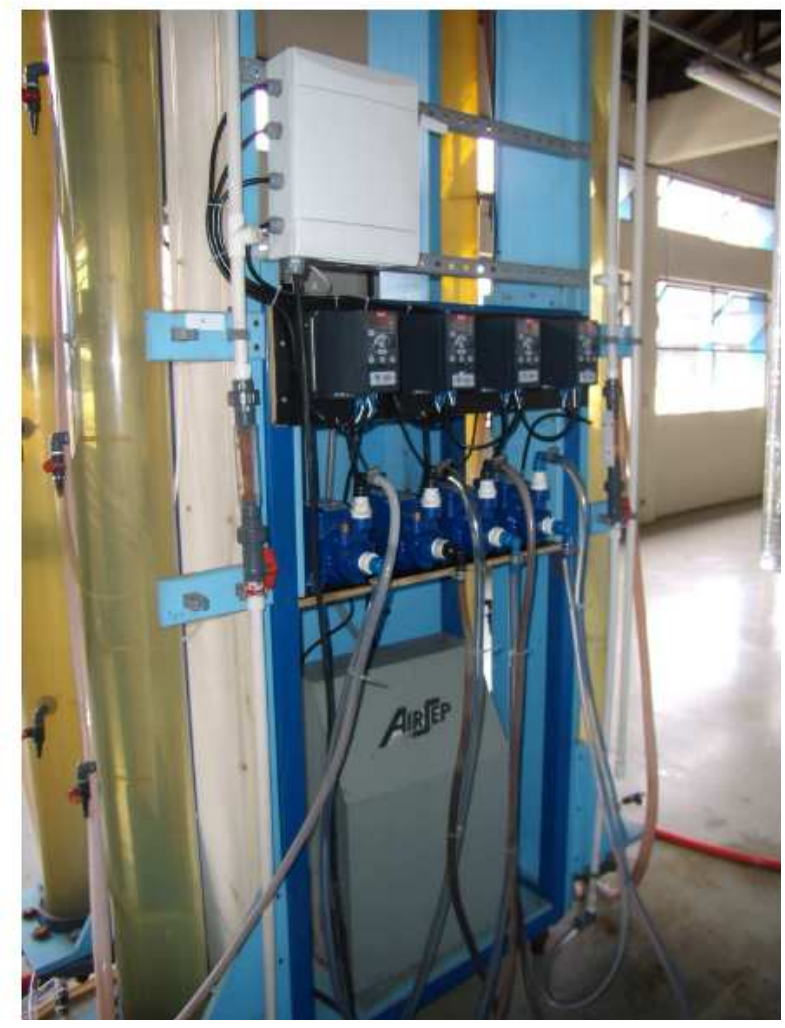

Figura 4.2.8 - Bombas centrífugas (KSB-HYDROBLOC P 500T), nomeadas da esquerda para direita de 1 a 4, com variações de freqüência, para a alimentação das colunas de ozonização.

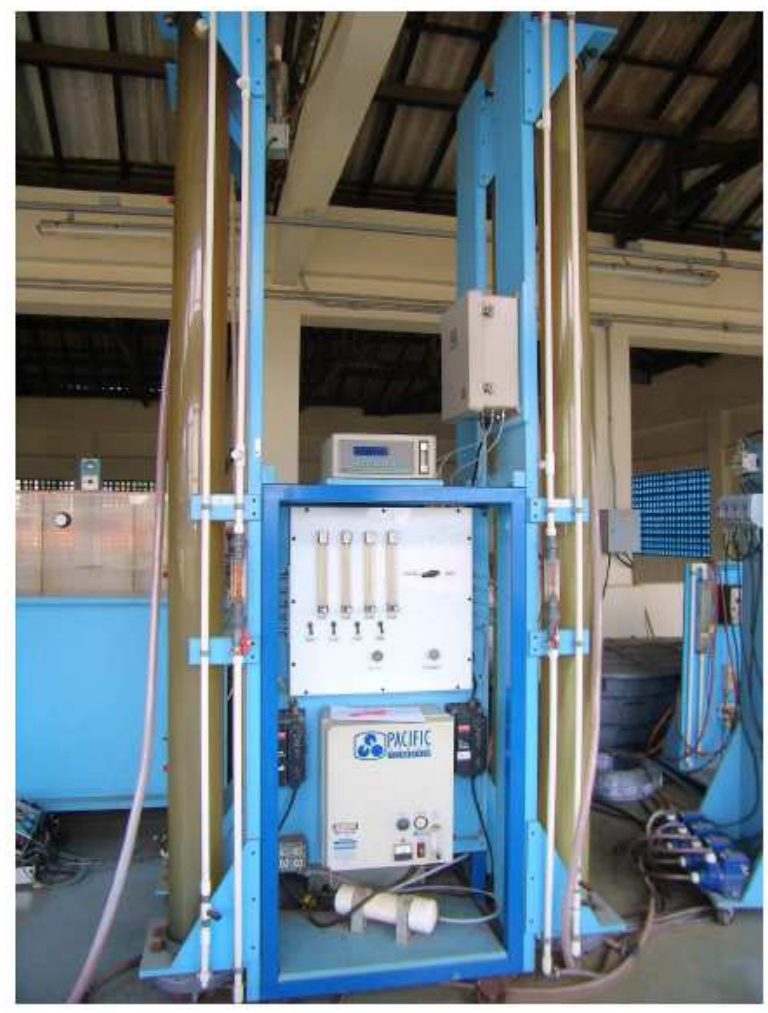

Figura 4.2.9 - Colunas de ozonização. 
A bomba no1 transferia a água filtrada do REAF para a coluna de ozonização 1 (CO1); a bomba ํo2, da CO1 para a coluna de ozonização 2 (CO2); a bomba oㅜ , da CO2 para a coluna de ozonização 3 (CO3) e a bomba no4, da $\mathrm{CO} 3$ para a coluna de ozonização 4 (CO4). Da CO4, a água seguia por gravidade para o reservatório de equalização de água ozonizada (REAO) também com capacidade para $1 \mathrm{~m}^{3}$ (Figura 4.2.10). O ozônio era aplicado nas $\mathrm{CO} 1$ e CO2; a $\mathrm{CO} 3$ e $\mathrm{CO} 4$ operaram apenas como câmaras de contato. Do REAO a água alimentava, por gravidade, os filtros 1 (F1) e 2 (F2).

Para a produção de ozônio foi empregado um gerador de ozônio a ar da PACIFIC OZONE, modelo G22 (Figura 4.2.11), com capacidade para até $28 \mathrm{~g} \mathrm{O}_{3} / \mathrm{h}$. A dosagem de ozônio aplicada na $\mathrm{CO} 1$ e $\mathrm{CO} 2$ foi controlada pela leitura da concentração de ozônio gerada (Figura 4.2.12), a quantidade de gás adicionada nas colunas (Figura 4.2.13) e a vazão de água de alimentação (4.2.14). O "off-gas" era destruído em uma unidade catalítica (Figura 4.2.15).

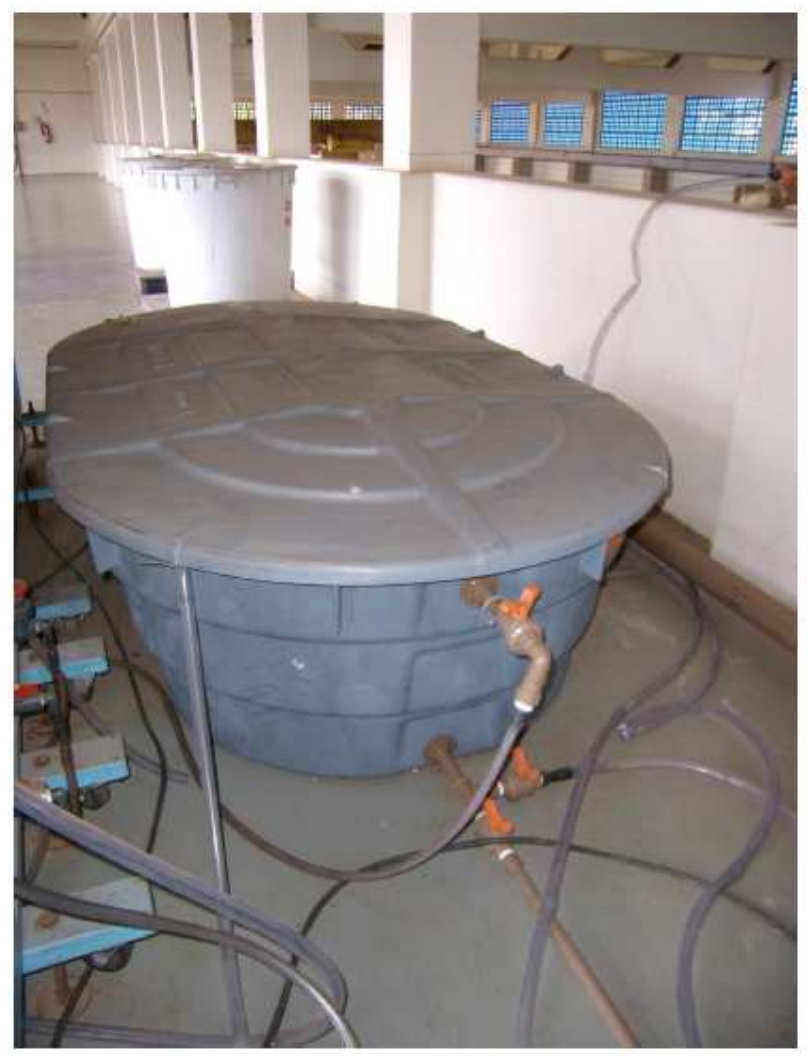

Figura 4.2.10 - Reservatório de equalização de água ozonizada. 


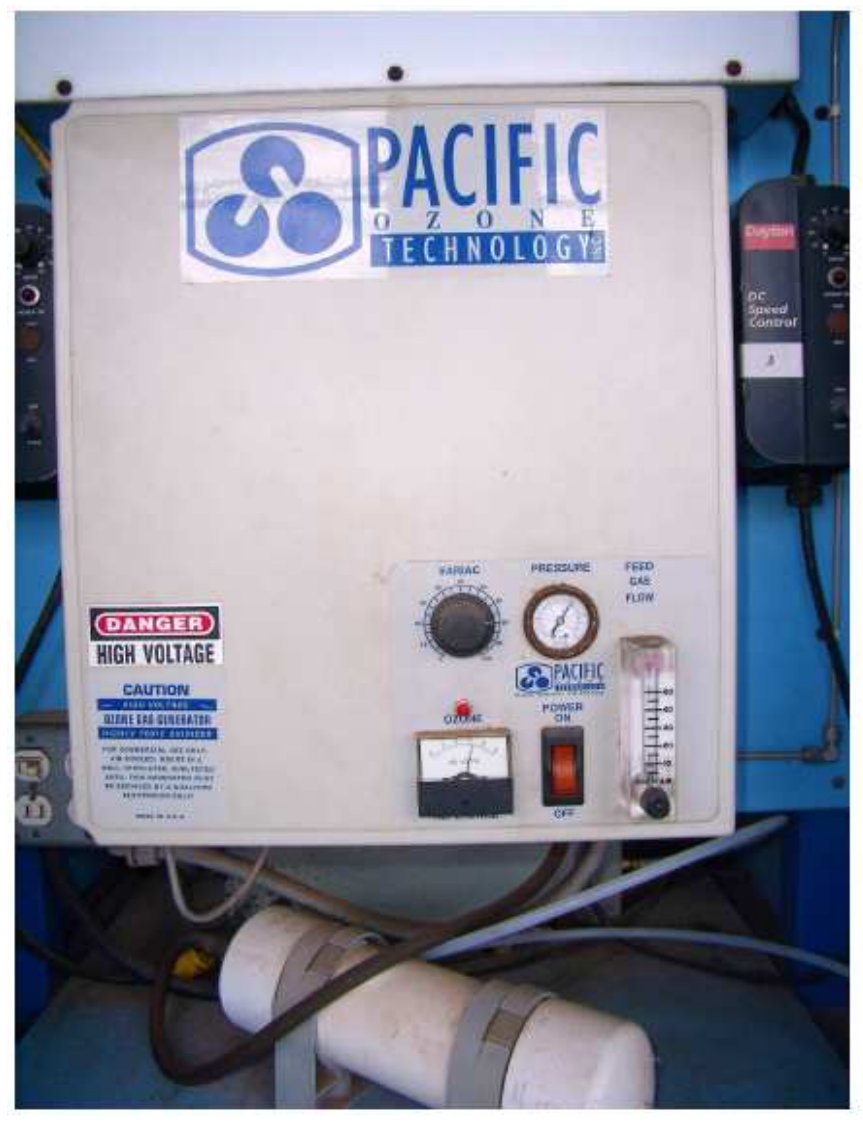

Figura 4.2.11 - Gerador de ozônio.

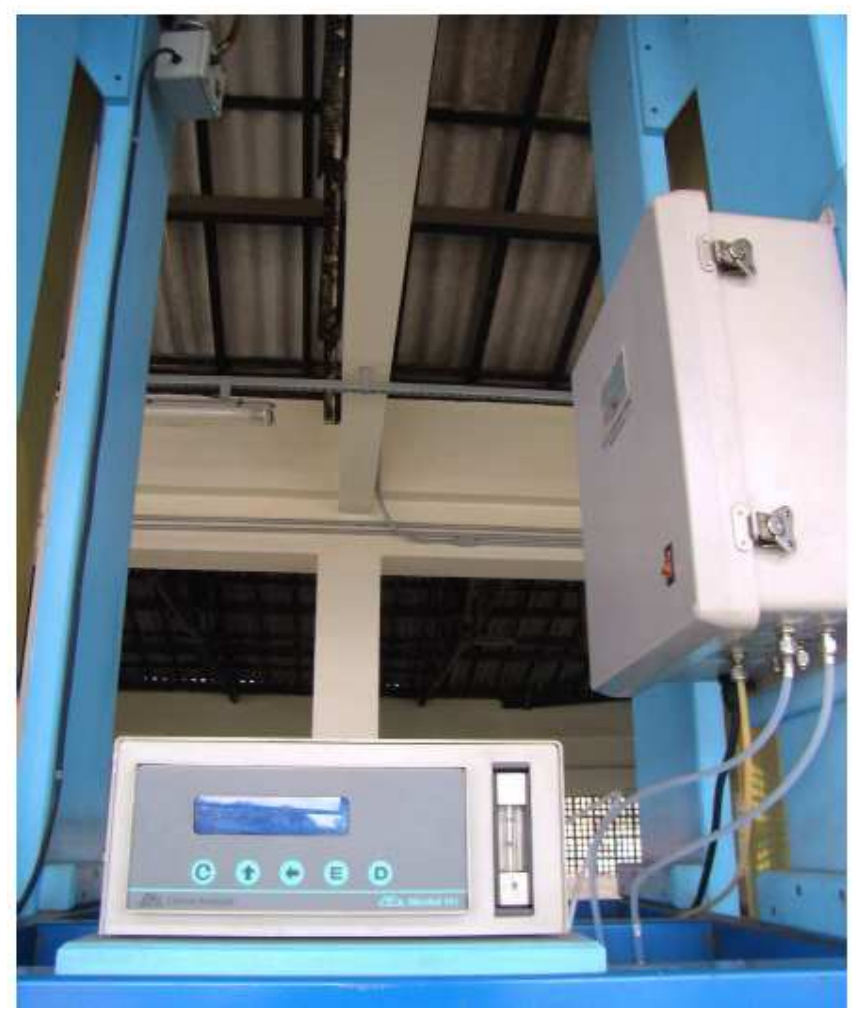

Figura 4.2.12 - Analisador da concentração de ozônio gerado (AFX, modelo H1). 


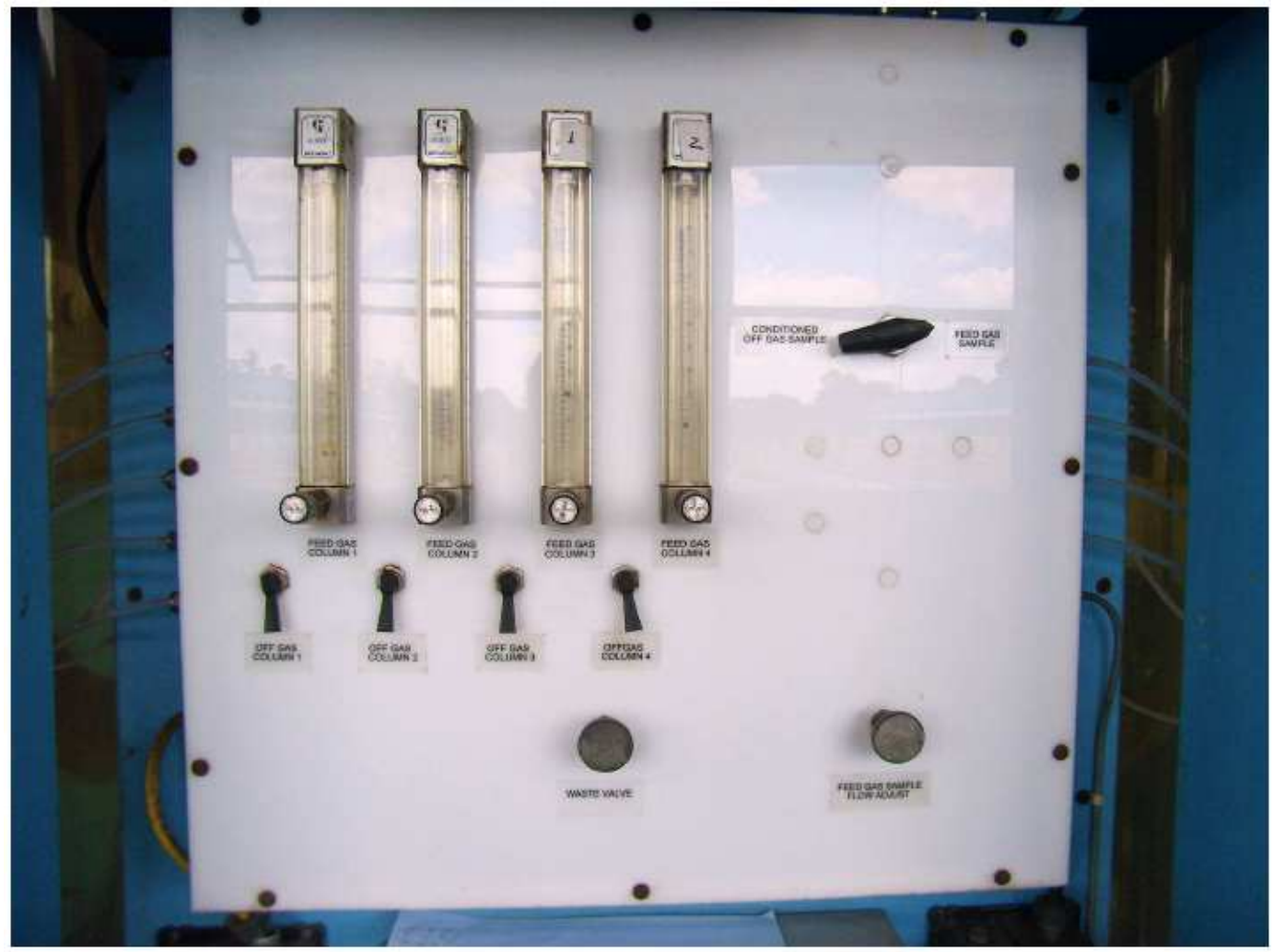

Figura 4.2.13 - Rotâmetros para leitura da vazão de ozônio nas colunas.

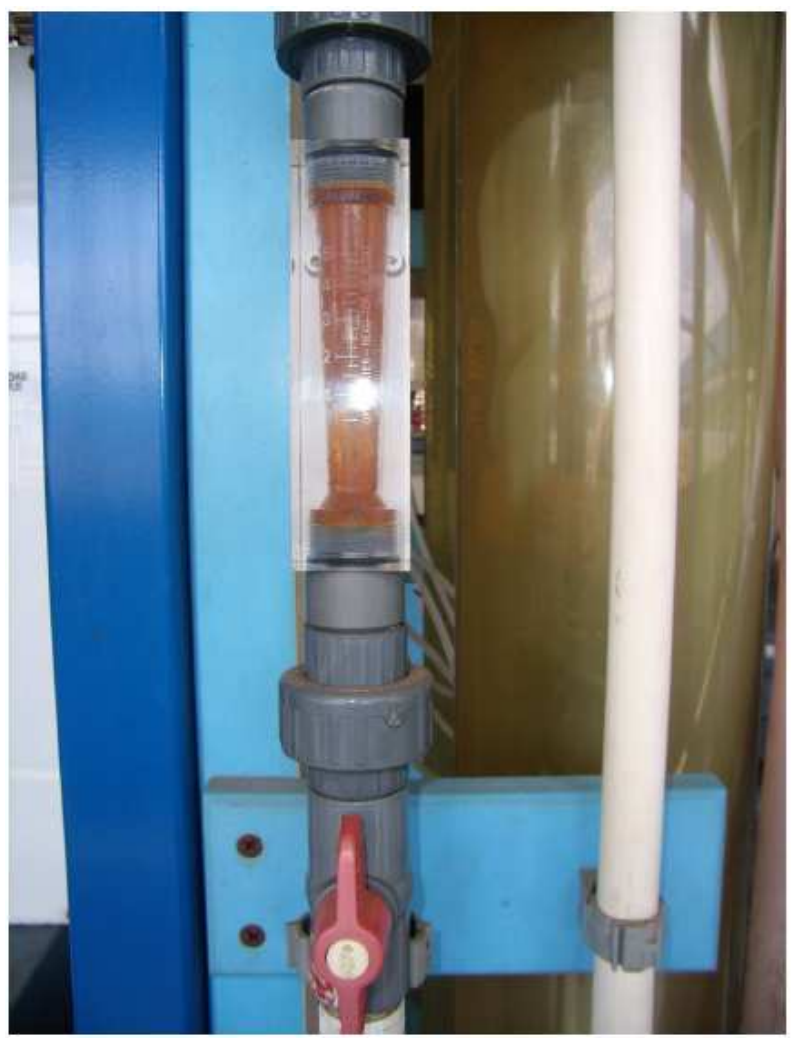

Figura 4.2.14 - Rotâmetro (da KING; leitura entre 0 e $5 \mathrm{gpm}$ ) para a leitura da vazão de água na coluna de ozonização. 


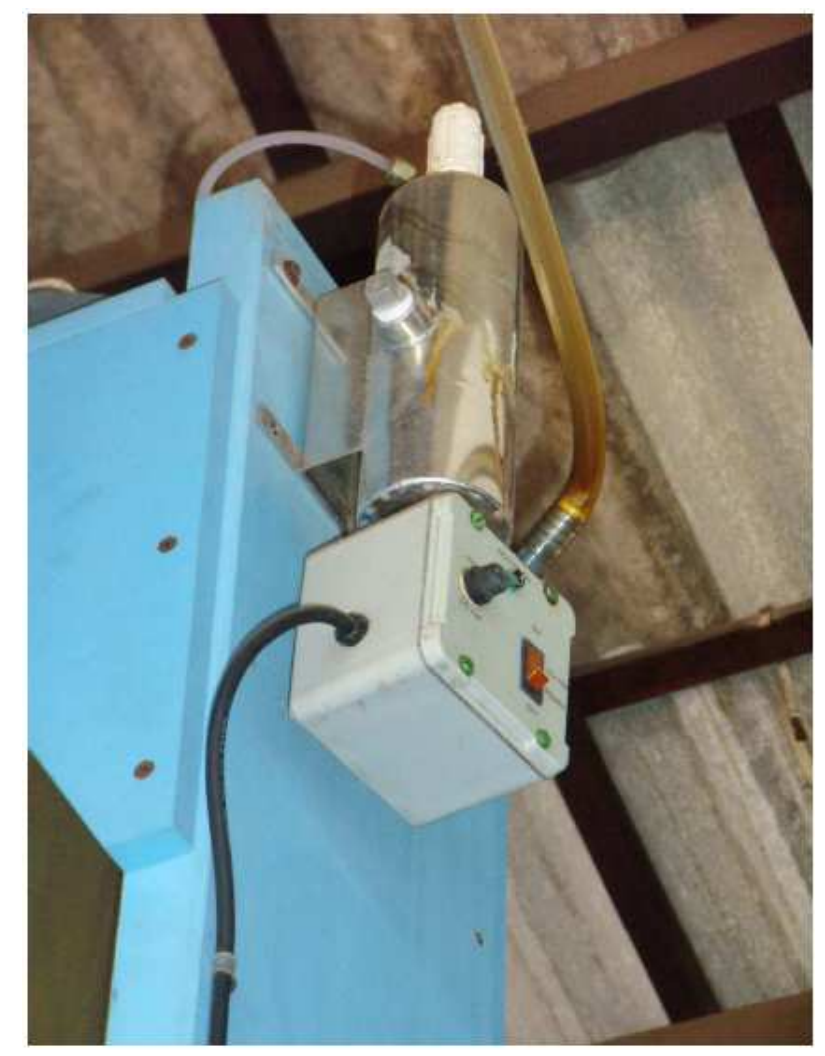

Figura 4.2.15 - Unidade catalítica destruidora de ozônio.

$\mathrm{Na}$ Figura 4.2.16 tem-se o barrilete e as válvulas empregados na distribuição das águas filtrada e ozonizada para os filtros 1, 2 e 3, 4, respectivamente. Na Figura 4.2.17, o tipo de rotâmetro utilizado para leitura da vazão de alimentação e na Figura 4.2.18, um esquema geral simplificado da ETA piloto ABV.

Na Tabela 4.2.3 encontra-se discriminado um resumo dos valores de vazão, tempo de contato no leito vazio e taxa de aplicação empregados nos filtros durante os ensaios experimentais e na Tabela 4.2.4, os valores de vazão, tempo de detenção e dosagem de ozônio empregados nas colunas de ozonização. A listagem completa de todos os valores empregados encontra-se nos APÊNDICES A (dados referentes aos filtros) e $B$ (dados referentes às colunas de ozonização). 


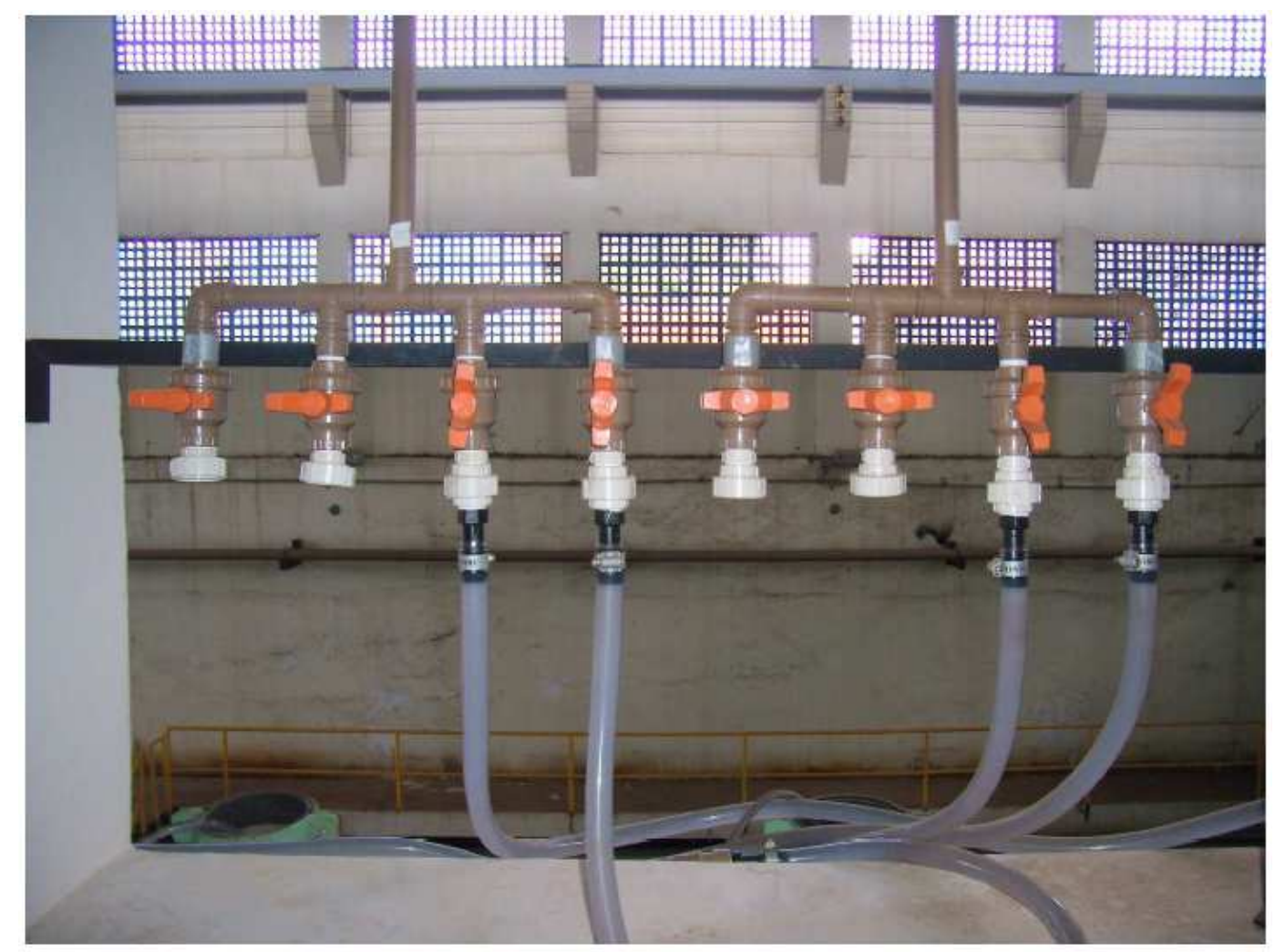

Figura 4.2.16 - Distribuição da água ozonizada para os Filtros 1 e 2 (esquerda) e distribuição da água filtrada para os Filtros 3 e 4 (direita).

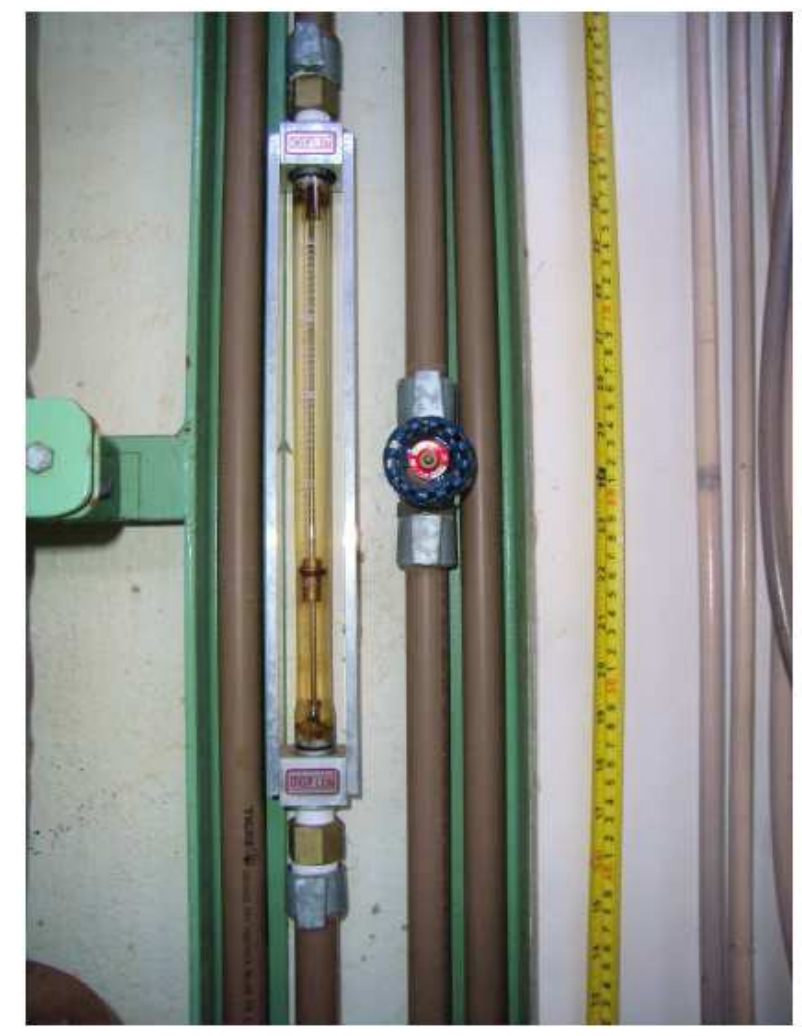

Figura 4.2.17 - Rotâmetro (da DIGIFLOW, faixa de 0 a 500 L/h) para a leitura da vazão de alimentação do filtro. 


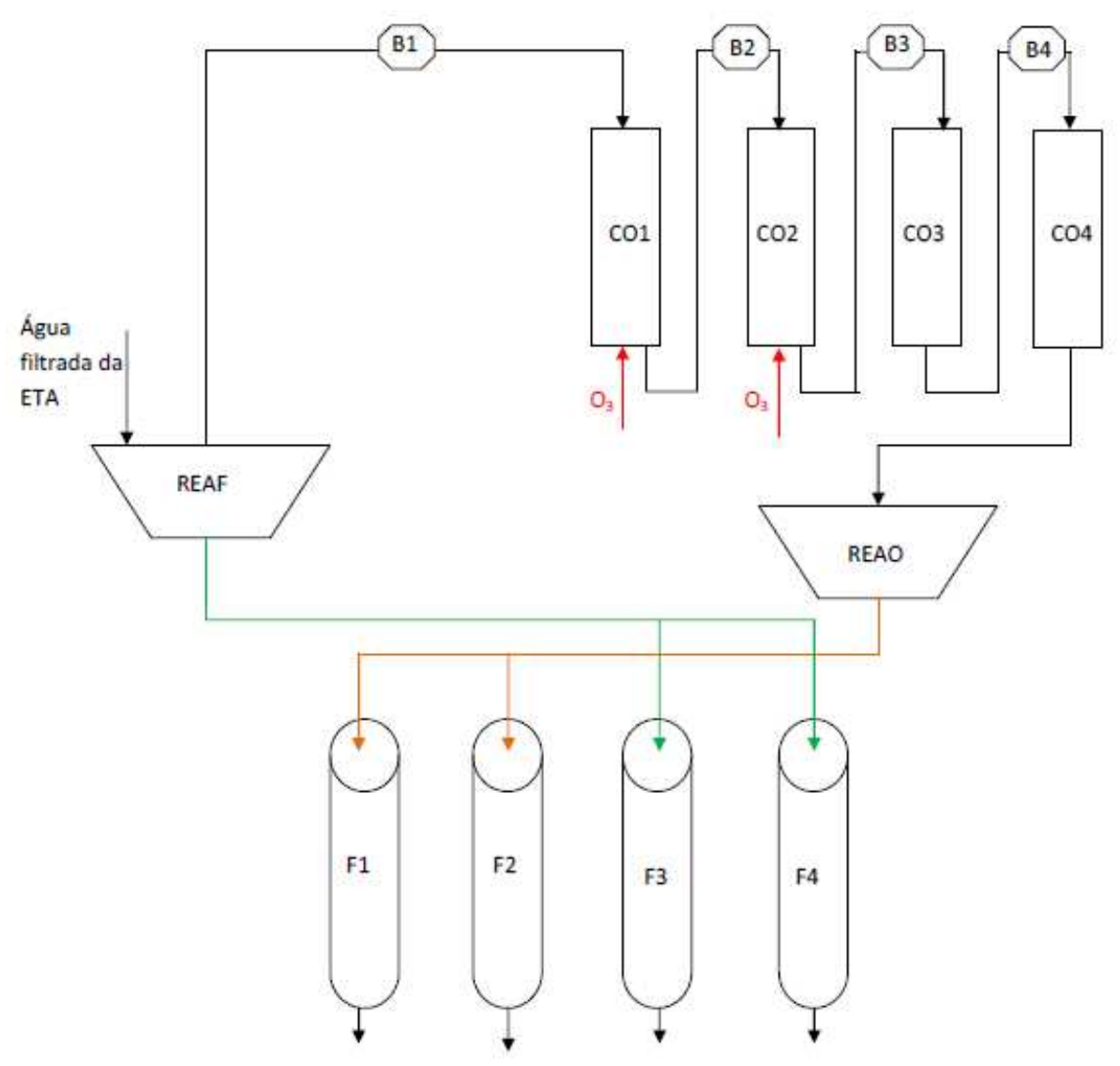

Figura 4.2.18 - Esquema geral simplificado da ETA piloto ABV.

Tabela 4.2.3 - Valores mínimo, médio, máximo e desvio padrão da vazão, tempo de contato no leito vazio e taxa de aplicação empregados nos filtros.

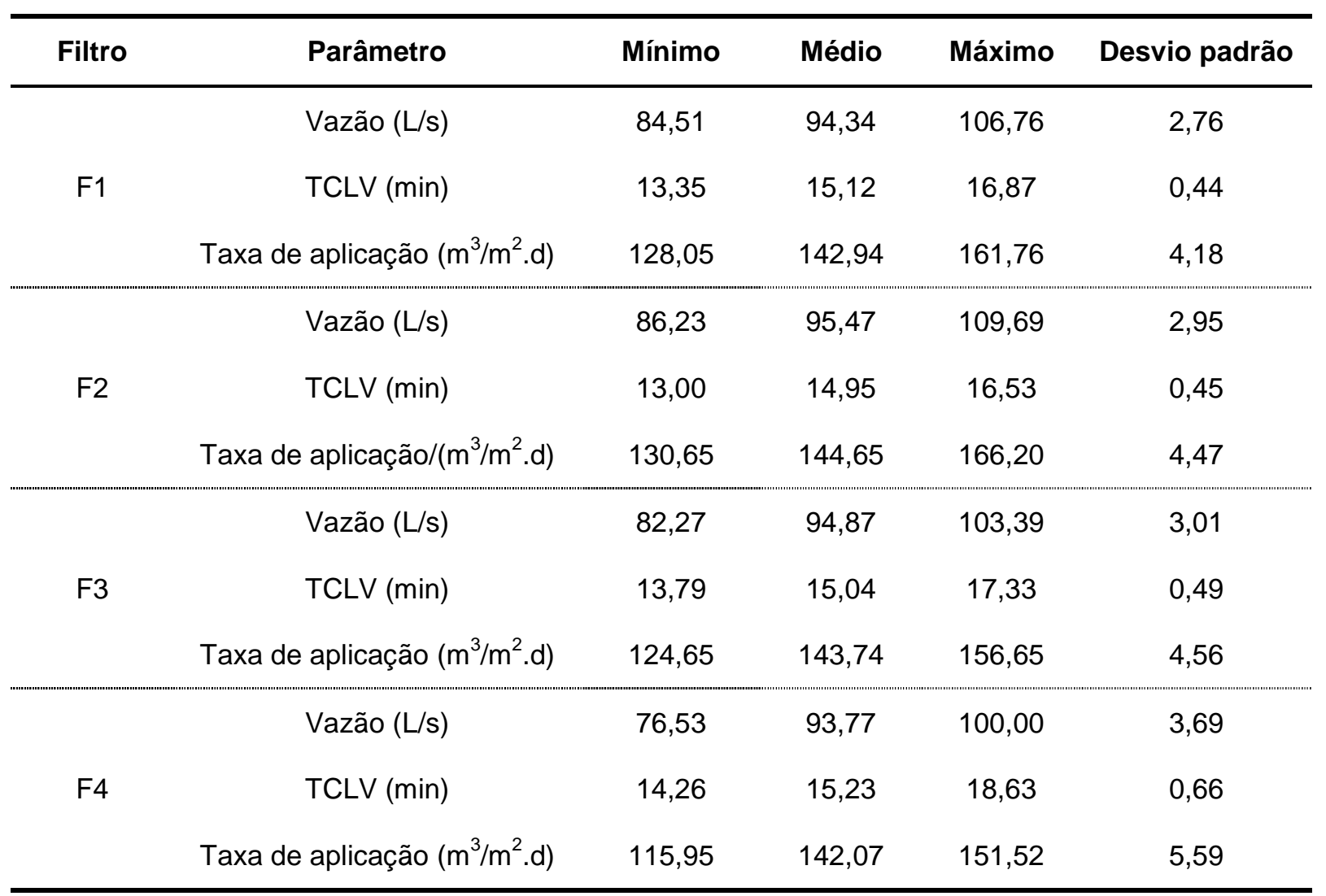


Tabela 4.2.4 - Valores mínimo, médio, máximo e desvio padrão da vazão, tempo de detenção e dosagem de ozônio empregados nas colunas de ozonização.

\begin{tabular}{|c|c|c|c|c|c|}
\hline $\begin{array}{l}\text { Coluna de } \\
\text { Ozonização }\end{array}$ & Parâmetro & Mínimo & Médio & Máximo & Desvio padrão \\
\hline & Vazão (L/h) & 454,20 & 531,16 & 681,30 & 54,39 \\
\hline \multirow[t]{3}{*}{$\mathrm{CO} 1$} & Tempo de detenção (min) & 3,16 & 4,09 & 4,74 & 0,42 \\
\hline & Dosagem de ozônio (mg/L) & 0,06 & 0,57 & 1,82 & 0,39 \\
\hline & Vazão (L/h) & 408,78 & 495,05 & 681,30 & 37,70 \\
\hline \multirow[t]{3}{*}{$\mathrm{CO} 2$} & Tempo de detenção (min) & 3,16 & 4,37 & 5,26 & 0,31 \\
\hline & Dosagem de ozônio (mg/L) & 0,02 & 0,55 & 1,97 & 0,39 \\
\hline & Vazão (L/h) & 227,10 & 398,25 & 596,14 & 77,27 \\
\hline \multirow[t]{3}{*}{$\mathrm{CO} 3$} & Tempo de detenção (min) & 3,61 & 5,62 & 9,47 & 1,15 \\
\hline & Dosagem de ozônio (mg/L) & - & - & - & - \\
\hline & Vazão (L/h) & 222,56 & 340,29 & 567,75 & 66,16 \\
\hline \multirow[t]{2}{*}{$\mathrm{CO} 4$} & Tempo de detenção (min) & 3,79 & 6,56 & 9,66 & 1,30 \\
\hline & Dosagem de ozônio (mg/L) & - & - & - & - \\
\hline \multicolumn{2}{|c|}{ Dosagem total de ozônio (mg/L) } & 0,06 & 1,11 & 3,79 & 0,76 \\
\hline \multicolumn{2}{|c|}{ Tempo de detenção total (min) } & 13,85 & 20,64 & 27,36 & 2,75 \\
\hline
\end{tabular}

A taxa média de aplicação nos filtros durante os ensaios foi de aproximadamente $143 \mathrm{~m} / \mathrm{m}^{2}$.d, o que gerou um tempo de contato no leito vazio médio de $15 \mathrm{~min}$. O tempo médio total de detenção nas colunas de ozonização ficou em cerca de 21 min e a dosagem média total de ozônio aplicada na água filtrada da ETA em 1,11 mg/L.

Embora a ETA piloto continue a operar indefinidamente, foram consideradas, na elaboração deste relatório, as análises realizadas entre julho/2007 e dezembro/2008 com relação a, principalmente, remoções de COT, MIB, geosmina, partículas e THM. Os pontos de coleta das amostras empregados foram: a torneira de amostragem de 
água bruta da ETA (AB) (localizada no laboratório de operação da estação), o REAF, a torneira de amostragem da água efluente da $\mathrm{CO} 2$, o REAO e as torneiras de amostragem das águas efluentes dos filtros 1, 2, 3 e 4. Todas as análises seguiram, preponderantemente, os procedimentos definidos pelo APHA; AWWA e WEF (1998). $\mathrm{Na}$ Tabela 4.2.5 tem-se a rotina das análises realizadas.

Tabela 4.2.5 - Análises realizadas para o estudo de desempenho dos filtros de CAG.

\begin{tabular}{|c|c|c|c|c|c|c|c|c|}
\hline Parâmetro & $A B$ & REAF & $\mathrm{CO} 2$ & REAO & F1 & F2 & F3 & F4 \\
\hline Turbidez (UNT) & $2 S$ & $2 S$ & - & $2 S$ & $2 S$ & $2 S$ & $2 S$ & $2 S$ \\
\hline СОT (mg/L) & $2 S$ & $2 S$ & - & $2 S$ & $2 S$ & $2 S$ & $2 S$ & $2 S$ \\
\hline UV $254 \mathrm{~nm}\left(\mathrm{~cm}^{-1}\right)$ & $2 S$ & $2 S$ & - & $2 S$ & $2 S$ & $2 S$ & $2 S$ & $2 S$ \\
\hline $\mathrm{NP}$ (partículas/mL) & $2 S$ & $2 S$ & - & $2 S$ & $2 S$ & $2 S$ & $2 S$ & $2 S$ \\
\hline $\begin{array}{l}\text { Perda de Carga } \\
(\mathrm{cm})\end{array}$ & - & - & - & - & $2 S$ & $2 S$ & $2 S$ & $2 S$ \\
\hline $\mathrm{O}_{3}$ residual $(\mathrm{mg} / \mathrm{L})$ & - & - & $2 S$ & $2 S$ & - & - & - & - \\
\hline $\begin{array}{c}\mathrm{Cl}_{2} \text { livre residual } \\
(\mathrm{mg} / \mathrm{L})\end{array}$ & - & $2 S$ & - & $2 S$ & - & - & - & - \\
\hline $\mathrm{CBH}(\mathrm{UFC} / \mathrm{mL})$ & - & $1 S$ & - & $1 \mathrm{~S}$ & $1 S$ & $1 S$ & $1 S$ & $1 S$ \\
\hline MIB (ng/L) & - & $1 \mathrm{~S}$ & - & $1 \mathrm{~S}$ & $1 \mathrm{~S}$ & $1 \mathrm{~S}$ & $1 \mathrm{~S}$ & $1 S$ \\
\hline Geosmina (ng/L) & - & $1 S$ & - & $1 S$ & $1 S$ & $1 \mathrm{~S}$ & $1 S$ & $1 S$ \\
\hline $\begin{array}{c}\text { THM instantâneo } \\
(\mu \mathrm{g} / \mathrm{L})\end{array}$ & - & $1 S$ & - & $1 \mathrm{~S}$ & $1 S$ & $1 \mathrm{~S}$ & $1 S$ & $1 S$ \\
\hline $\begin{array}{l}\text { THM na rede de } \\
\text { distribuição ( } \mathrm{gg} / \mathrm{L})\end{array}$ & - & $1 S$ & - & $1 \mathrm{~S}$ & $1 S$ & $1 \mathrm{~S}$ & $1 S$ & $1 S$ \\
\hline $\begin{array}{c}\text { Número total de } \\
\text { análises }\end{array}$ & 407 & 721 & 98 & 816 & 720 & 721 & 721 & 721 \\
\hline
\end{tabular}

Sendo: NP - Número de Partículas $\geq 1,2 \mu \mathrm{m} ; \mathrm{O}_{3}$ - ozônio; $\mathrm{Cl}_{2}$ - cloro; $\mathrm{CBH}$ - Contagem de Bactérias Heterotróficas; $2 S-2$ vezes por semana; $1 S-1$ vez por semana. 
As análises de turbidez foram realizadas no laboratório de operação da ETA ABV empregando-se o turbidímetro da HACH modelo 2100AN (Figura 4.2.19) e as análises de COT, absorção específica da radiação ultravioleta no comprimento de onda igual a $254 \mathrm{~nm}$ (UV $254 \mathrm{~nm}$ ), CP e CBH (método $9215 \mathrm{C}$ ) foram realizadas no laboratório Professor Lucas Nogueira Garcez da EPUSP. Para a leitura do COT foi empregado um analisador de carbono orgânico total, via oxidação por combustão catalítica da SHIMADZU, modelo TOC VCPH (Figura 4.2.20). Para a análise do UV $254 \mathrm{~nm}$ o equipamento Uvmini-1240, também da SHIMADZU (Figura 4.2.21). O contador de partículas empregado foi o da PACIFIC CIENTIFIC, modelo $3000 \mathrm{~A}$ (Figura 4.2.22).

Para a preparação das amostras para a análise dos THM instantâneos, era adicionado, imediatamente após a coleta, o tiossulfato de sódio e para a análise dos THM na rede de distribuição, o cloro era adicionado até atingir-se $2,1 \mathrm{mg} / \mathrm{L}$ de residual, simulando a pós cloração da ETA ABV. Em seguida, o pH das amostras era ajustado em 8,8, também de acordo com a pós alcalinização praticada na estação. Finalmente, essas amostras eram armazenadas em frascos tipo âmbar e em local escuro por $24 \mathrm{~h}$, antes de serem analisadas.

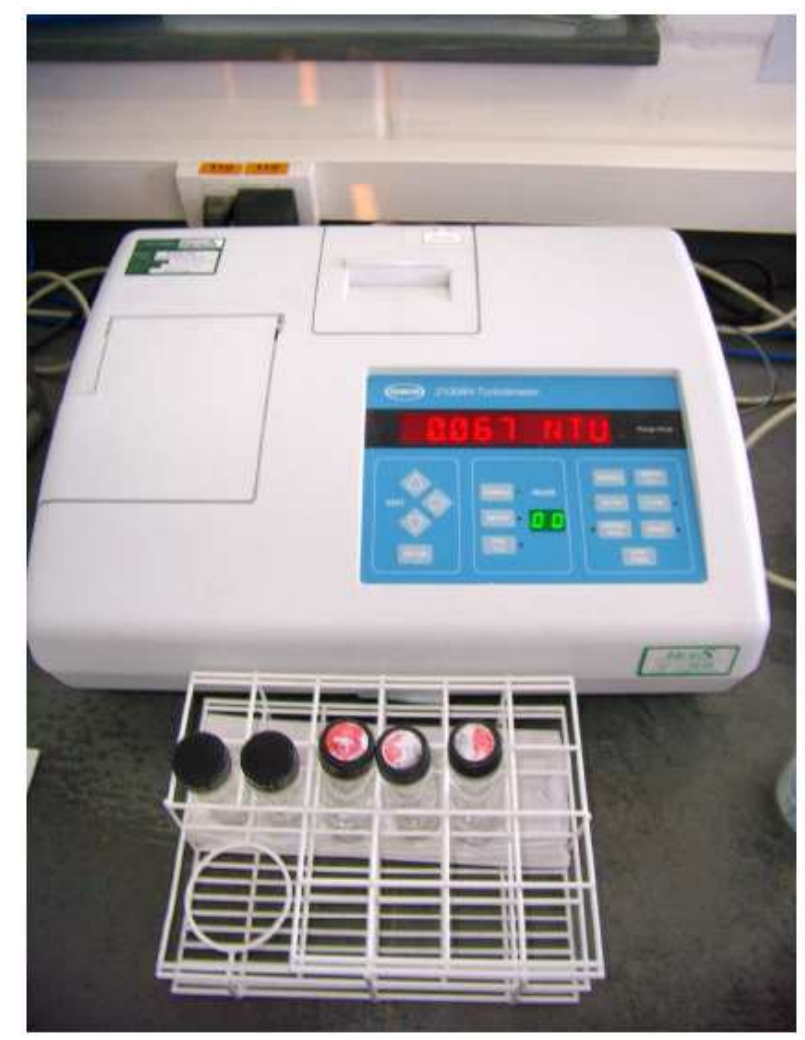

Figura 4.2.19 - Turbidímetro empregado nas análises. 


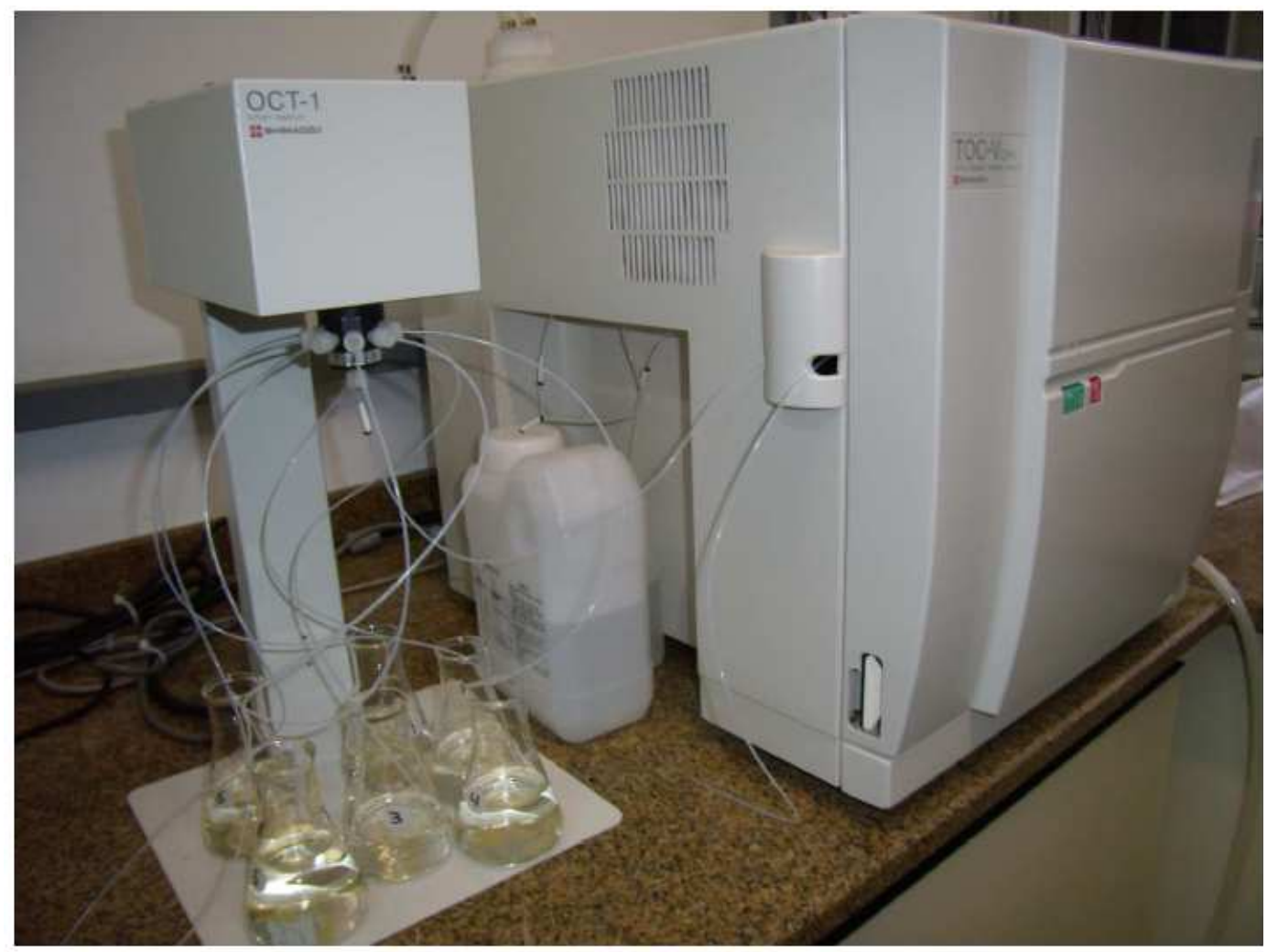

Figura 4.2.20 - Equipamento para análise de COT.

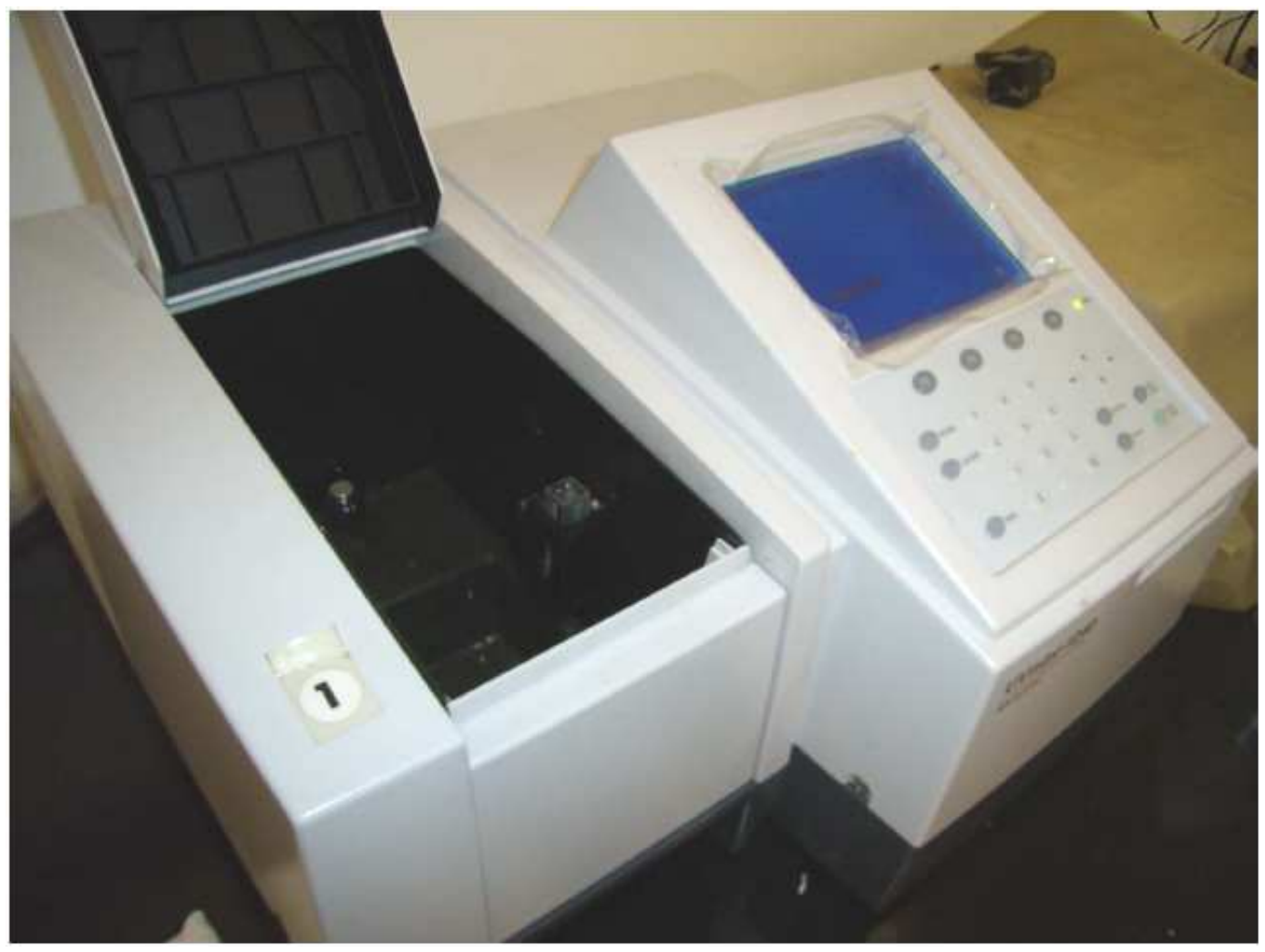

Figura 4.2.21 - Equipamento para análise do UV $254 \mathrm{~nm}$. 


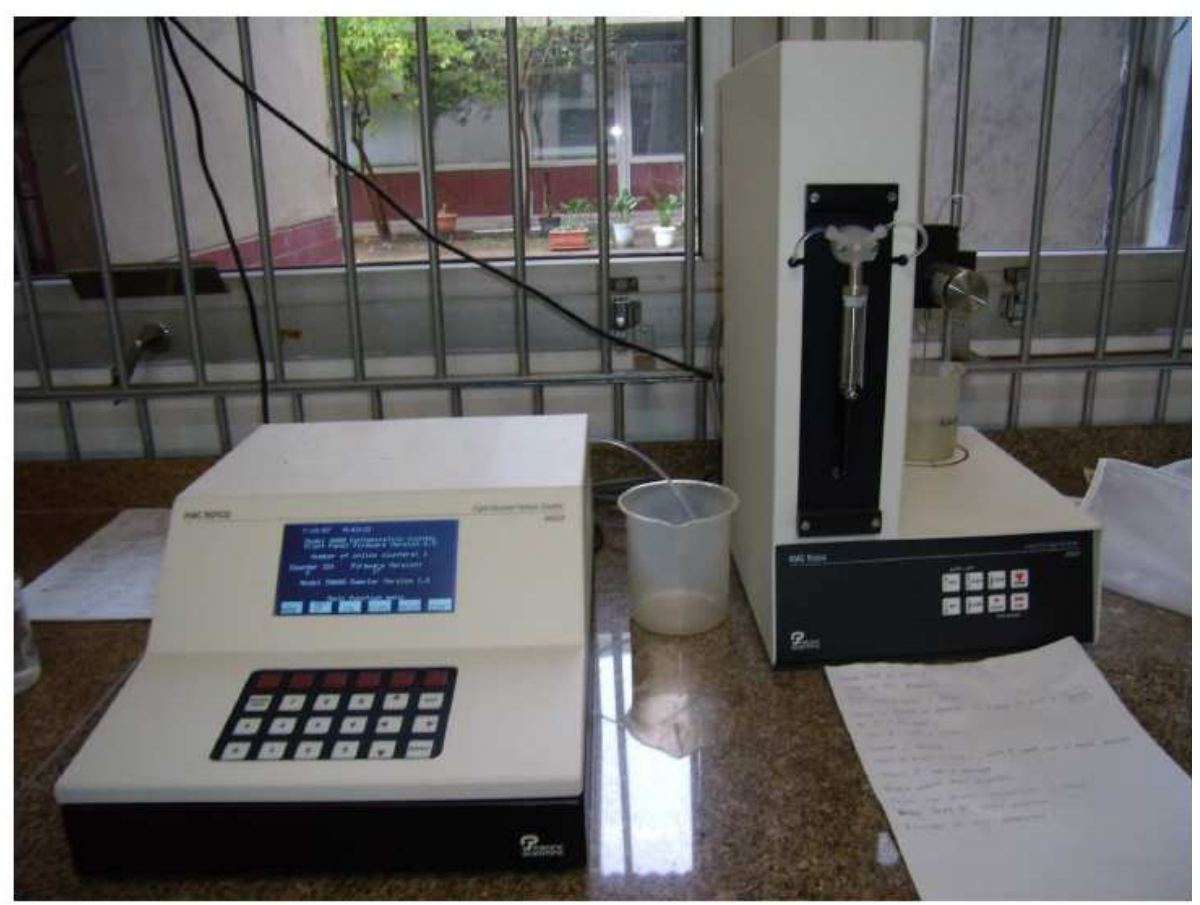

Figura 4.2.22 - Contador de partículas.

Para a determinação do número de partículas das amostras foram selecionadas oito faixas de tamanho $(1,2 \mu \mathrm{m} ; 2,0 \mu \mathrm{m} ; 4,0 \mu \mathrm{m} ; 8,0 \mu \mathrm{m} ; 10,0 \mu \mathrm{m} ; 20 \mu \mathrm{m} ; 40 \mu \mathrm{m}$ e 50 $\mu \mathrm{m})$ mais comumente empregadas em análise de águas filtradas (AWWARF, 1992) e correspondentes ao tamanho de algas, algumas bactérias, partículas orgânicas, flocos bacterianos, cistos de Giardia Lamblia e oocistos de Cryptosporidium.

As análises de MIB, geosmina e THM foram efetuadas de acordo com os métodos 6040 D (APHA; AWWA; WEF, 2005) e EPA 8260 C / 5021 (EPA, 2008), respectivamente, no laboratório de química orgânica da SABESP empregando-se um cromatógrafo em fase gasosa equipado com detector de espectrometria de massas da VARIAN, modelo Saturn 2100TA (Figura 4.2.23). O amostrador automático utilizado foi o combiPAL, equipado com um módulo SPME (micro extração em fase sólida), para as análises de MIB e geosmina, e um módulo Headspace, para as análises de THM. Para o controle e garantia da qualidade das análises foram empregados: (1) padrões internos com compostos diferentes de MIB, geosmina e THM, em concentrações conhecidas $(40 \mathrm{ng} / \mathrm{L}$ e $10 \mu \mathrm{g} / \mathrm{L}$, respectivamente); (2) padrões de trabalho, com concentrações conhecidas de MIB, geosmina e THM e; (3) substitutos de compostos diferentes de MIB, geosmina e THM, com concentrações conhecidas e de acordo com os procedimentos de cada método de análise. 
Os limites de detecção para as análises de MIB e geosmina foram de $<2 \mathrm{ng} / \mathrm{L}$ e máximo de $1.000 \mathrm{ng} / \mathrm{L}$. Para as análises de THM, foram < 0,5 $\mu \mathrm{g} / \mathrm{L}$ e máximo de 200 $\mu \mathrm{g} / \mathrm{L}$.

As análises de cloro livre residual e ozônio residual foram realizadas na ETA Piloto. O método empregado na análise do cloro foi o $4500 \mathrm{Cl} F$ (Figura 4.2.24) e para a análise do ozônio residual, empregou-se um colorímetro portátil da $\mathrm{HACH}$, modelo DR/890 (Figura 4.2.25).

Todos os filtros eram lavados quando a turbidez da água efluente, de qualquer um deles, era maior ou igual a 0,3 UNT (EPA, 2009) ou a perda de carga ultrapassava $2,5 \mathrm{~m}$. Este valor corresponde à perda de carga máxima geralmente considerada no projeto do filtro de uma ETA (KAWAMURA, 2000). A contra lavagem ocorria em duas etapas consecutivas: $1^{\mathrm{a}}$ ) ar e, $2^{\mathrm{a}}$ ) água.

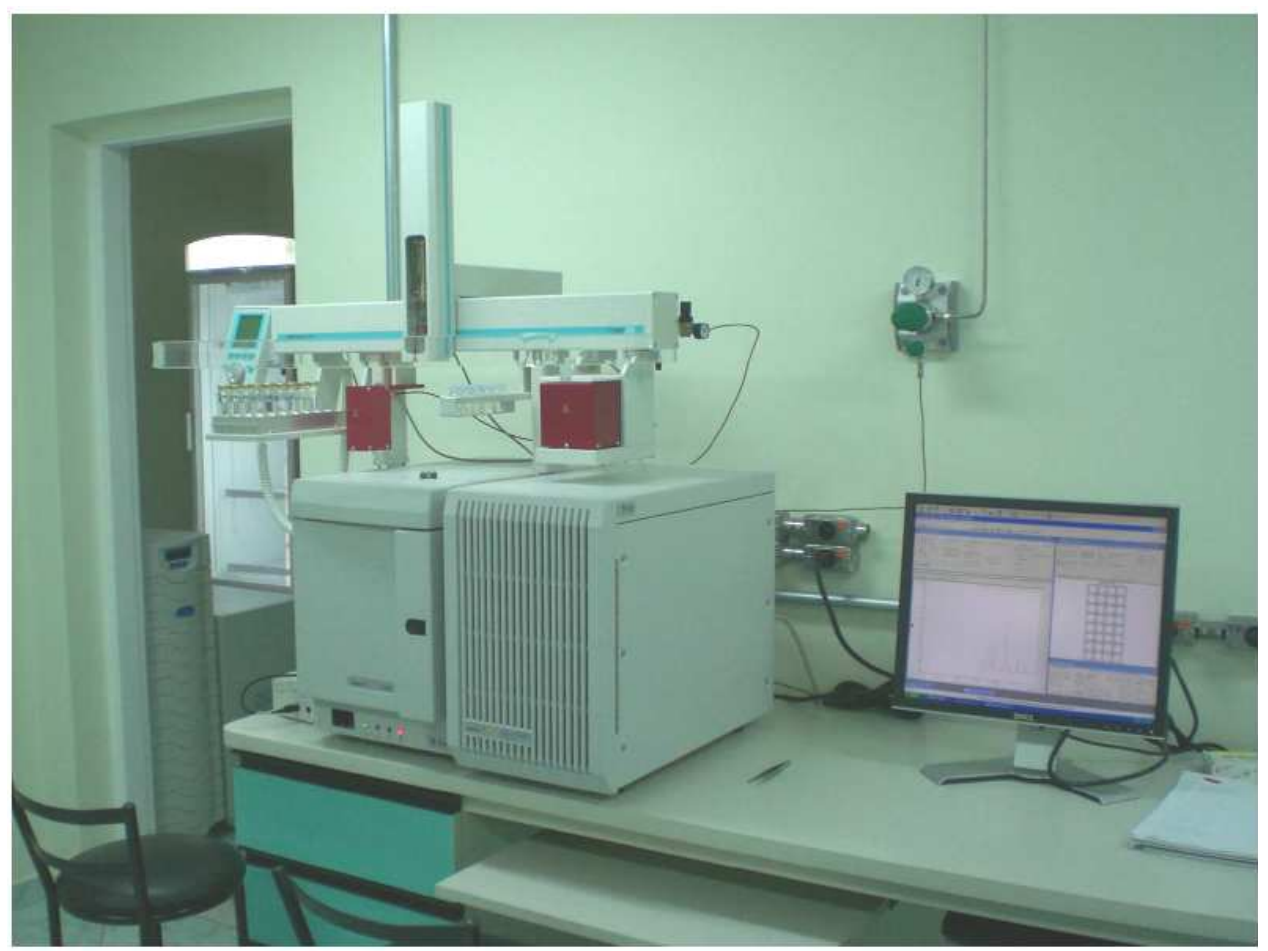

Figura 4.2.23 - Cromatógrafo associado a espectrômetro de massas.

Na contra-lavagem à água, a expansão dos leitos foi mantida entre 20 e 30 \% por 15 minutos, conforme a recomendação da AWWA e ASCE (1998) e a vazão de ar, foi baseada em estudo desenvolvido por Niquette et al. (1998), com duração de 5 minutos e vazão de $20 \mathrm{~L} / \mathrm{min}$. 


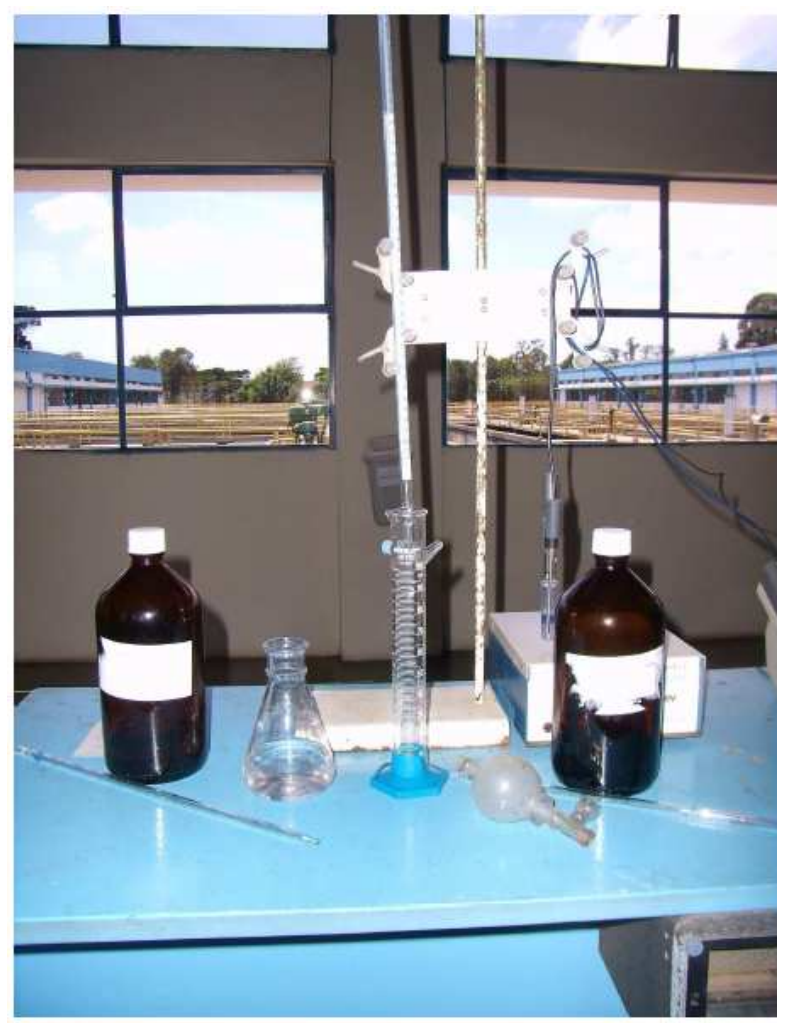

Figura 4.2.24 - Aparelhagem para análise de cloro livre residual.

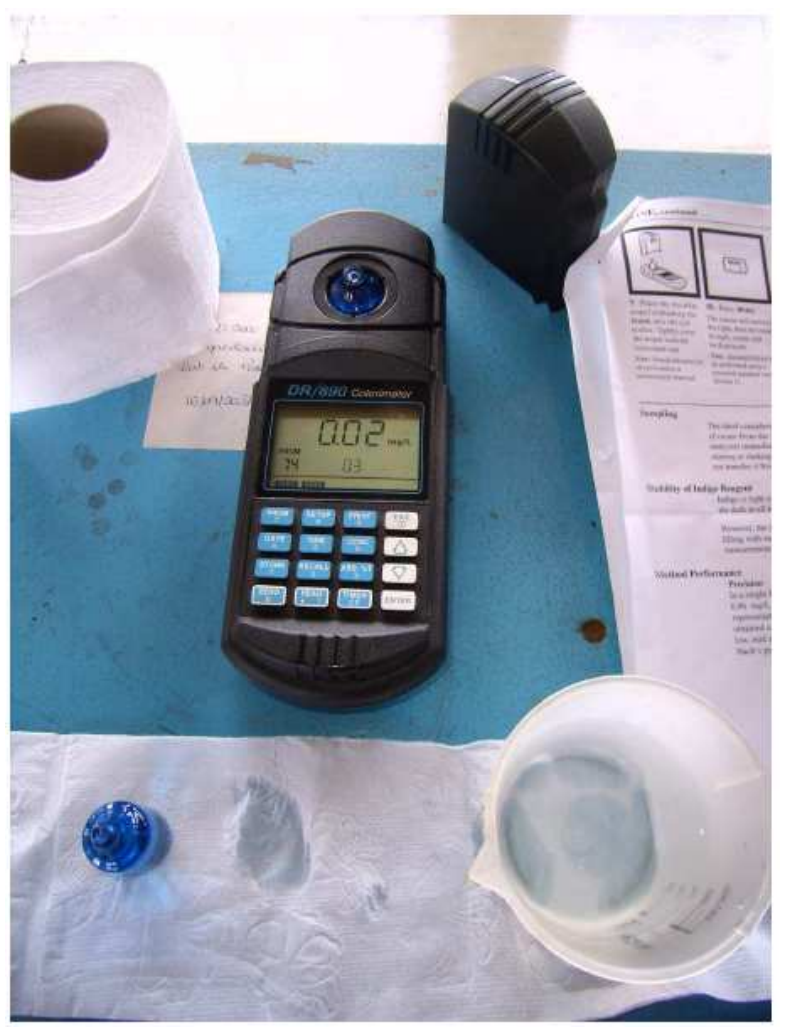

Figura 4.2.25 - DR/890 utilizado para a análise de ozônio residual. 


\subsubsection{ENSAIOS DE CARACTERIZAÇÃO DOS CARVÕES}

Os ensaios para a caracterização dos carvões Filtrasorb 300 da CALGON e 119 $12 \times 25$ da CARBOMAFRA, utilizados como meios filtrantes, foram conduzidos no Laboratório de Mecânica dos Solos da EPUSP no período compreendido entre 02/02/09 e 05/02/09. Os resultados encontram-se descritos no item 5.1. 


\section{APRESENTAÇÃO E ANÁLISE DOS RESULTADOS EXPERIMENTAIS}

A partir das análises realizadas para o estudo de desempenho dos filtros de CAG (Tabela 4.2.5) foram obtidos os resultados listados nos APÊNDICES C (valores de turbidez, COT, UV $254 \mathrm{~nm}$, Perda de Carga, $\mathrm{O}_{3}$ residual e $\mathrm{Cl}_{2}$ livre residual), D (valores de NP $\geq 2,0 \mu \mathrm{m} ; 1,2 \mu \mathrm{m} \leq \mathrm{NP}<2,0 \mu \mathrm{m}$ e $\mathrm{CBH}$ ), $\mathrm{E}$ (valores de MIB e geosmina) e $F$ (valores de THM instantâneos e na rede de distribuição). O resumo destes resultados e as discussões inerentes encontram-se descritos neste capítulo.

\subsection{APRESENTACÃO E ANÁLISE DOS RESULTADOS DOS ENSAIOS DE CARACTERIZAÇẨO DOS CARVÕES}

A análise granulométrica dos grãos foi realizada de acordo com os procedimentos da norma NBR 7181, ilustrados nas Figuras 5.1.1, 5.1.2, 5.1.3 e 5.1.4.

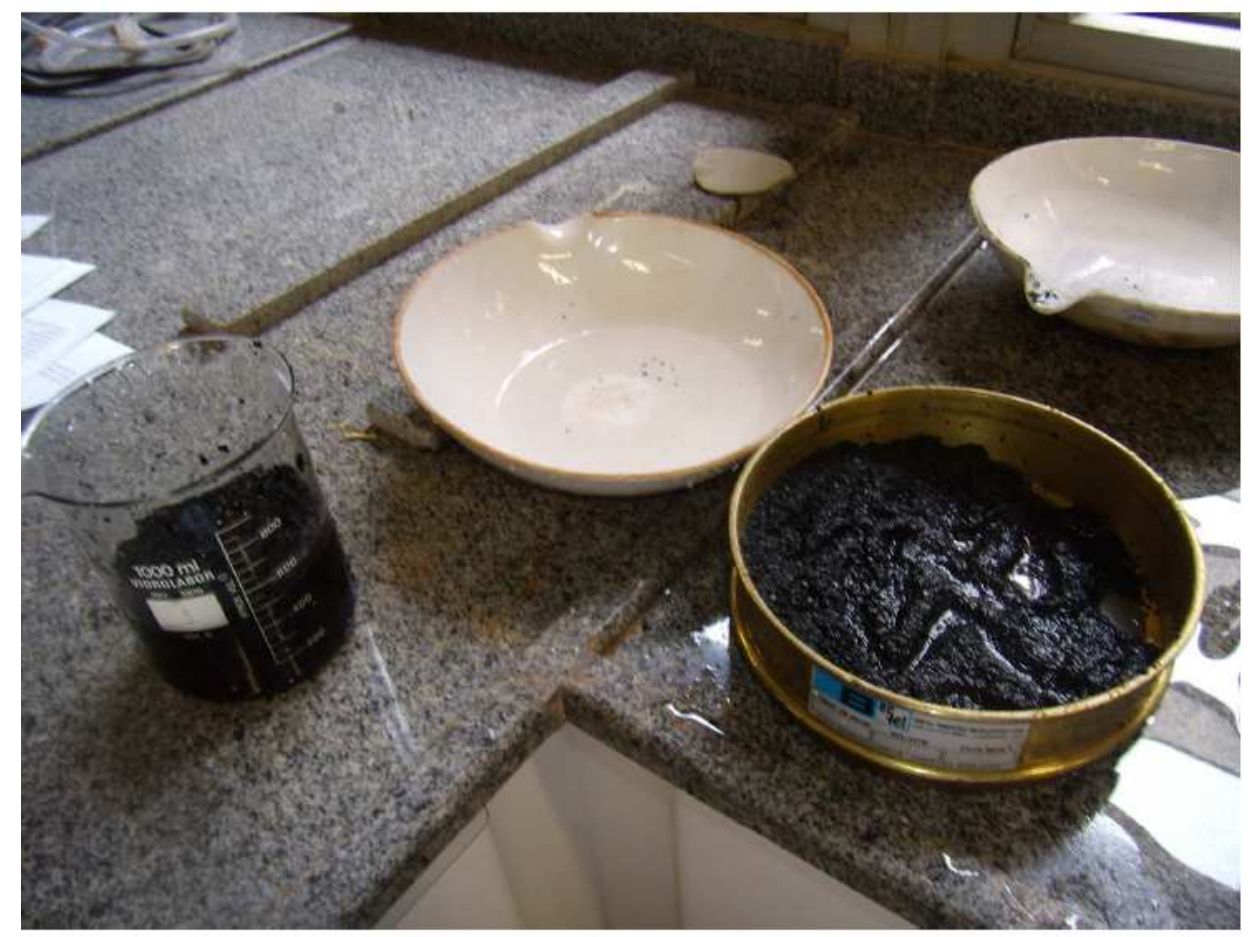

Figura 5.1.1 - Lavagem dos carvões. 


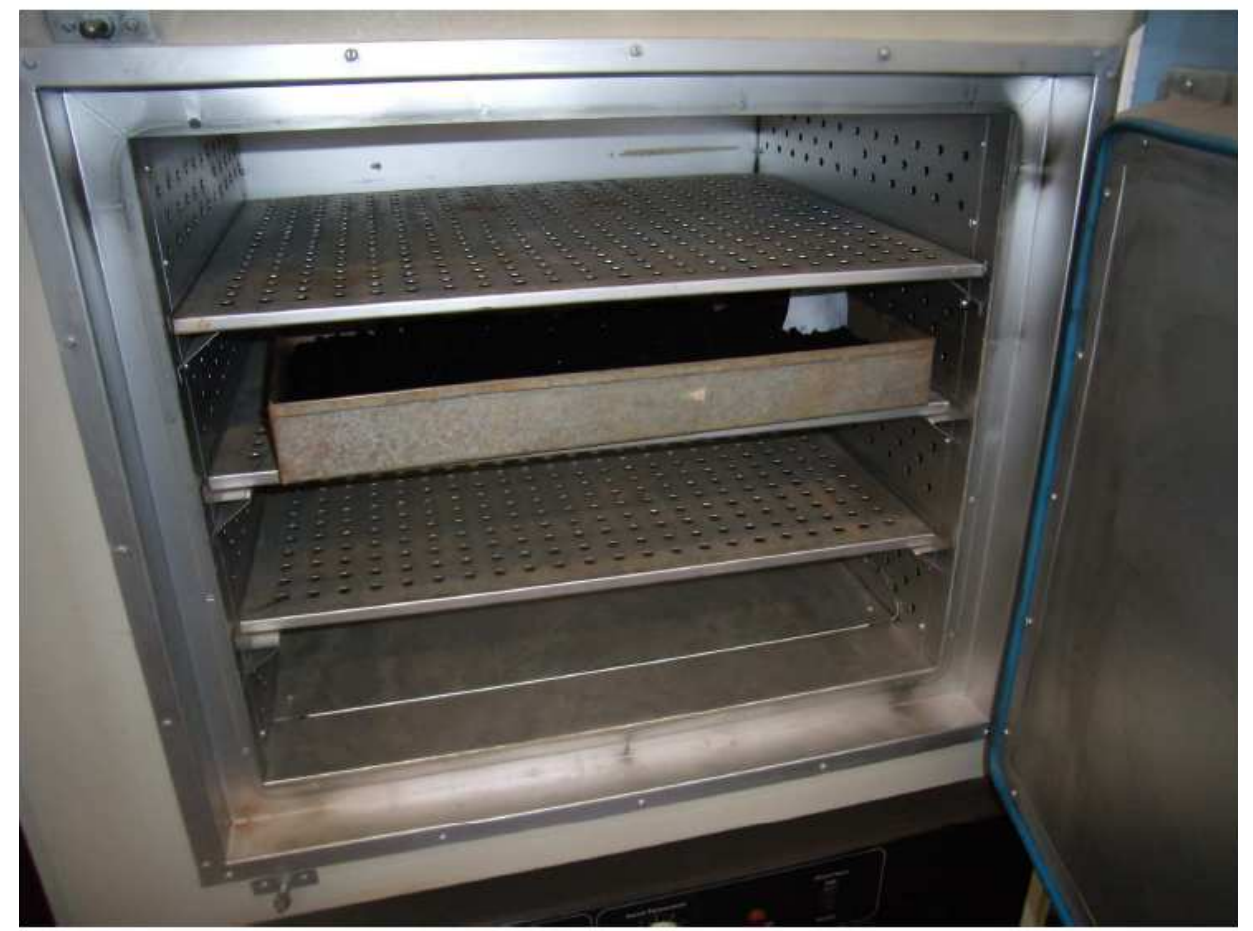

Figura 5.1.2 - Secagem dos carvões em estufa.

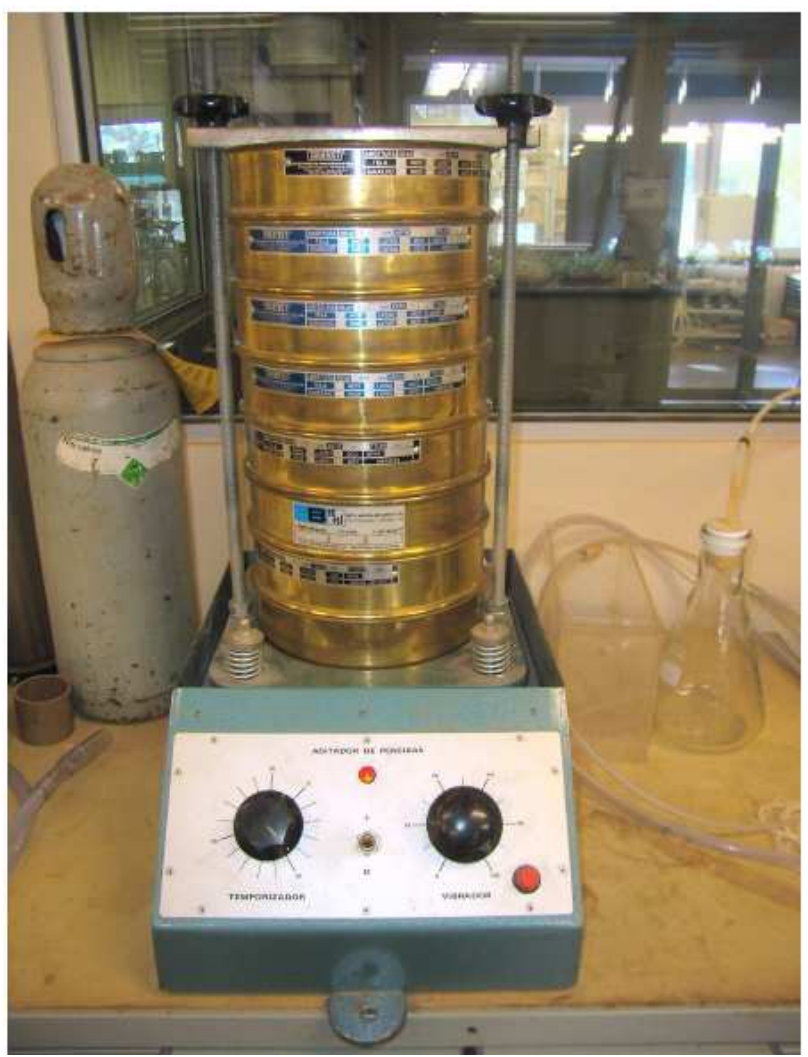

Figura 5.1.3 - Agitador de peneiras para análise granulométrica dos carvões. 


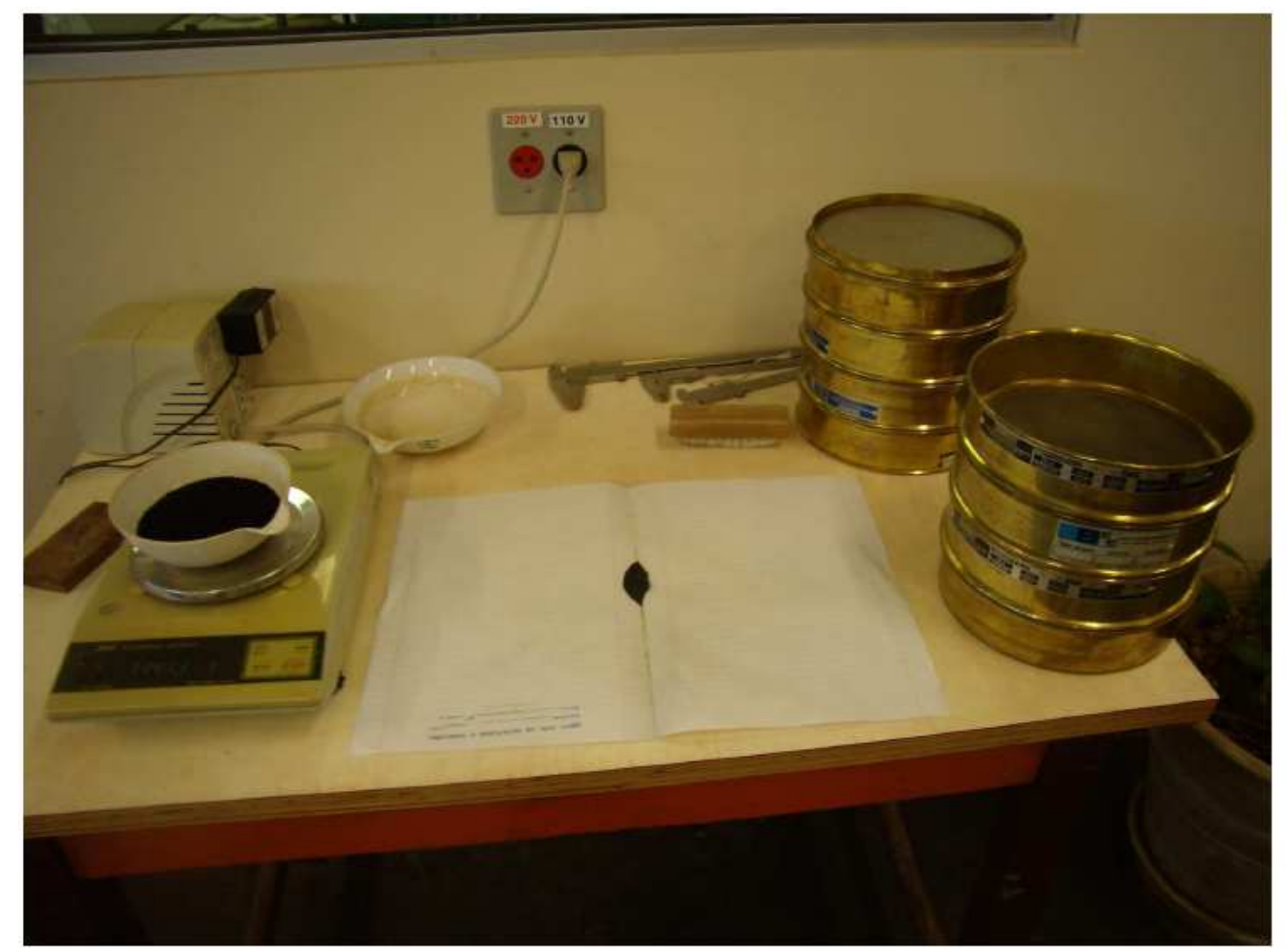

Figura 5.1.4 - Pesagem dos carvões, por peneira, para análise granulométrica.

Na Tabela 5.1.1 e Figura 5.1.5 têm-se os resultados dos ensaios granulométricos dos carvões.

As caracterizações granulométricas mostram que o CAG da CARBOMAFRA apresenta um maior número de grãos finos que o CAG da CALGON e que o tamanho efetivo ou $d_{10}(\mathrm{MWH}, 2005)$ dos carvões são de 0,67 mm e 0,69 mm, respectivamente. Ambos tamanhos encontram-se abaixo dos valores fornecidos pelos fabricantes (Tabela 4.2.1 e 4.2.2); também, os valores dos coeficientes de uniformidade calculados, isto é, $d_{60} / d_{10}(M W H, 2005)$ são maiores dos que os apresentados pelos fabricantes: 1,75 (CARBOMAFRA) e 2,22 (CALGON).

Para a obtenção da massa específica dos carvões foi empregada a norma NBR 6508, exemplificada nas Figuras 5.1.6, 5.1.7 e 5.1.8. 
Tabela 5.1.1 - Distribuição granulométrica dos carvões.

\begin{tabular}{|c|c|c|c|c|c|}
\hline \multirow{2}{*}{ № Peneira } & \multirow{2}{*}{$\begin{array}{c}\text { Diâmetro } \\
\text { (mm) }\end{array}$} & \multicolumn{2}{|c|}{ CALGON } & \multicolumn{2}{|c|}{ CARBOMAFRA } \\
\hline & & Massa retida $(\mathrm{g})$ & $\%$ Retida & Massa retida $(\mathrm{g})$ & $\%$ Retida \\
\hline 10 & 2 & 13,07 & 11,33 & 0,09 & 0,08 \\
\hline 16 & 1,2 & 64,70 & 56,07 & 37,68 & 34,13 \\
\hline 30 & 0,60 & 114,12 & 98,90 & 109,76 & 99,41 \\
\hline 40 & 0,42 & 115,24 & 99,87 & 109,99 & 99,62 \\
\hline 50 & 0,30 & 115,28 & 99,90 & 110,03 & 99,66 \\
\hline 100 & 0,15 & 115,31 & 99,93 & 110,18 & 99,79 \\
\hline 200 & 0,075 & 115,35 & 99,97 & 110,35 & 99,95 \\
\hline \multicolumn{2}{|c|}{ Fundo } & 115,39 & 100,00 & 110,41 & 100,00 \\
\hline
\end{tabular}

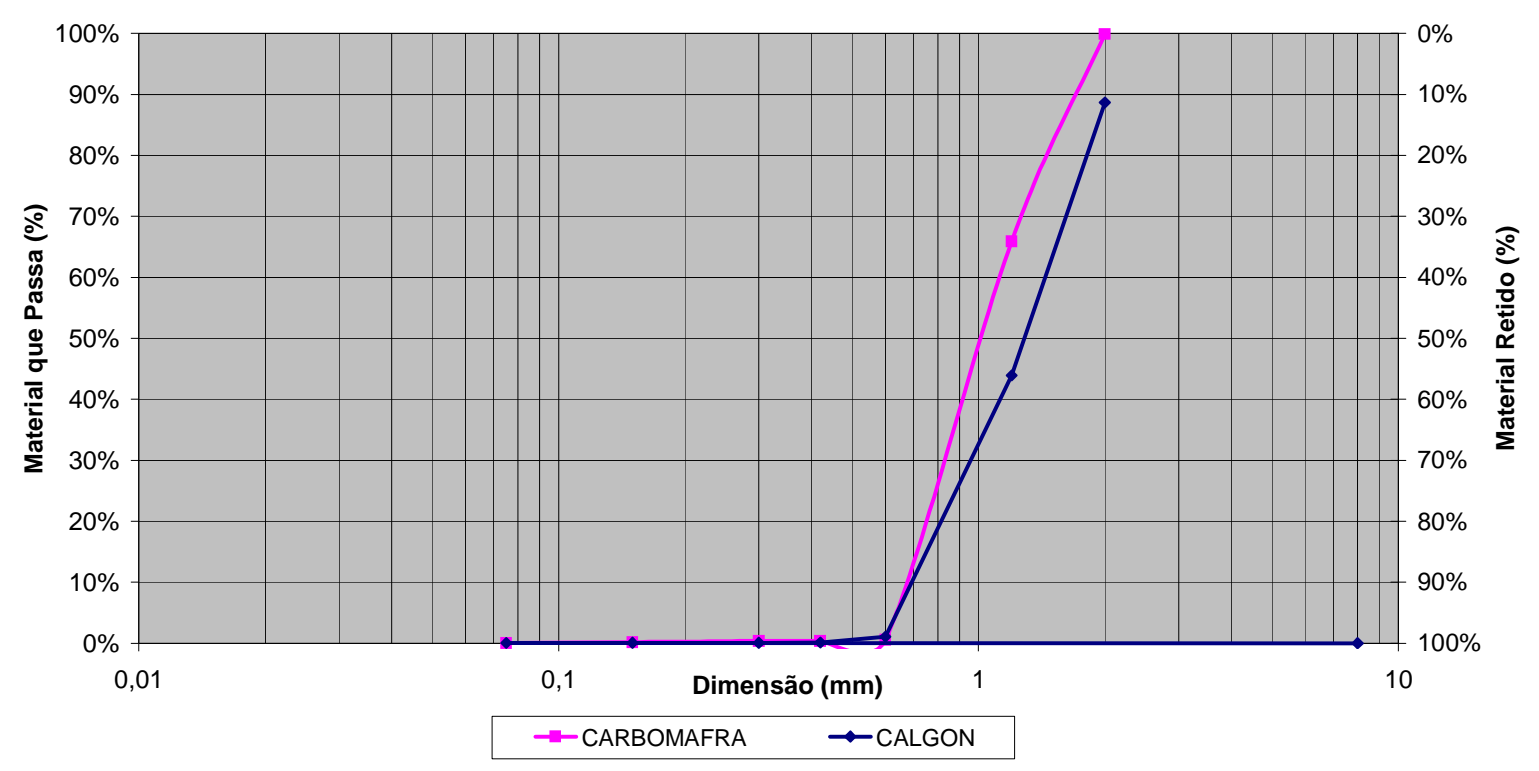

Figura 5.1.5 - Porcentagem de material retido nas peneiras. 


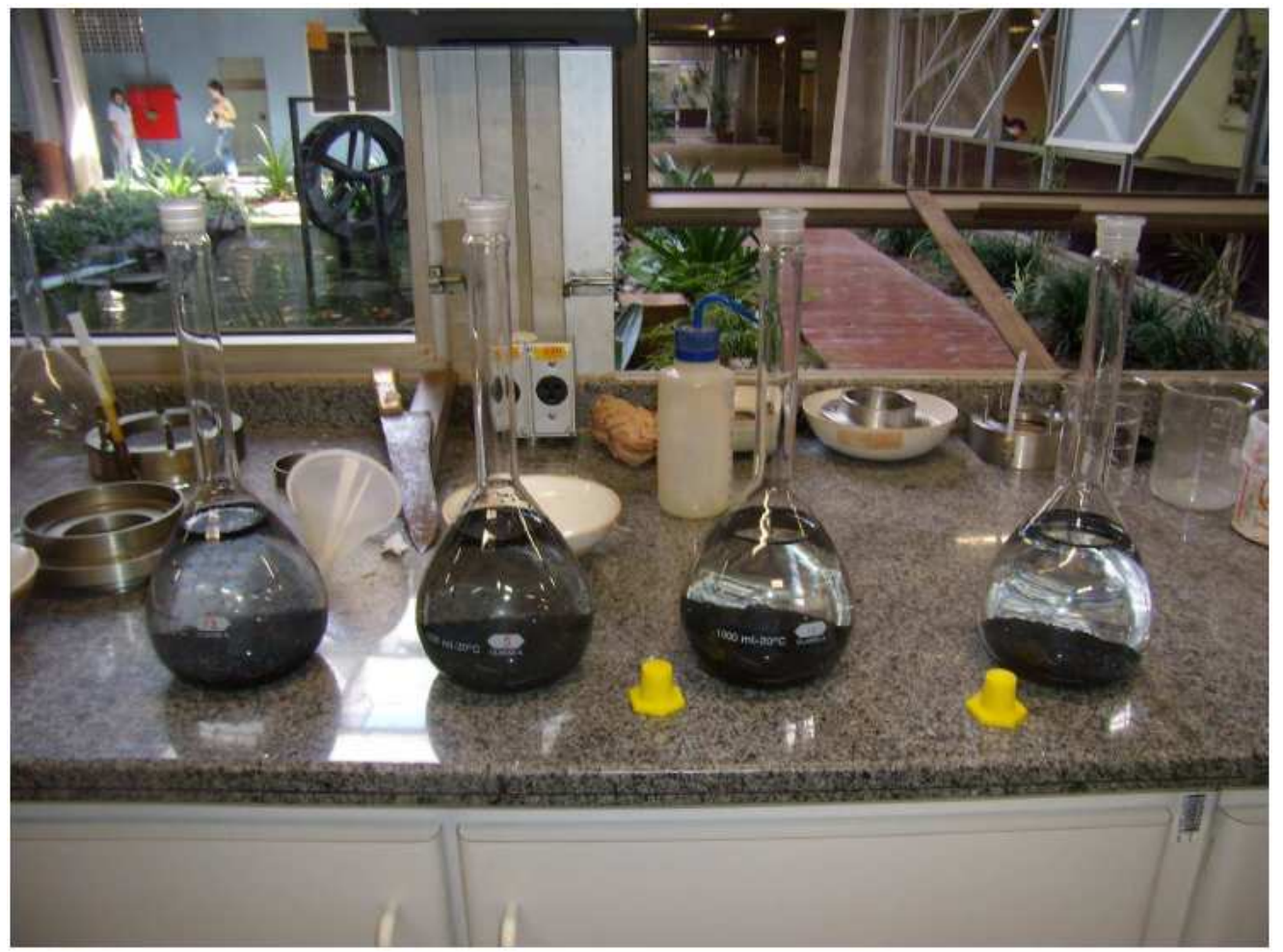

Figura 5.1.6 - Amostras de carvão em picnômetros com água destilada.

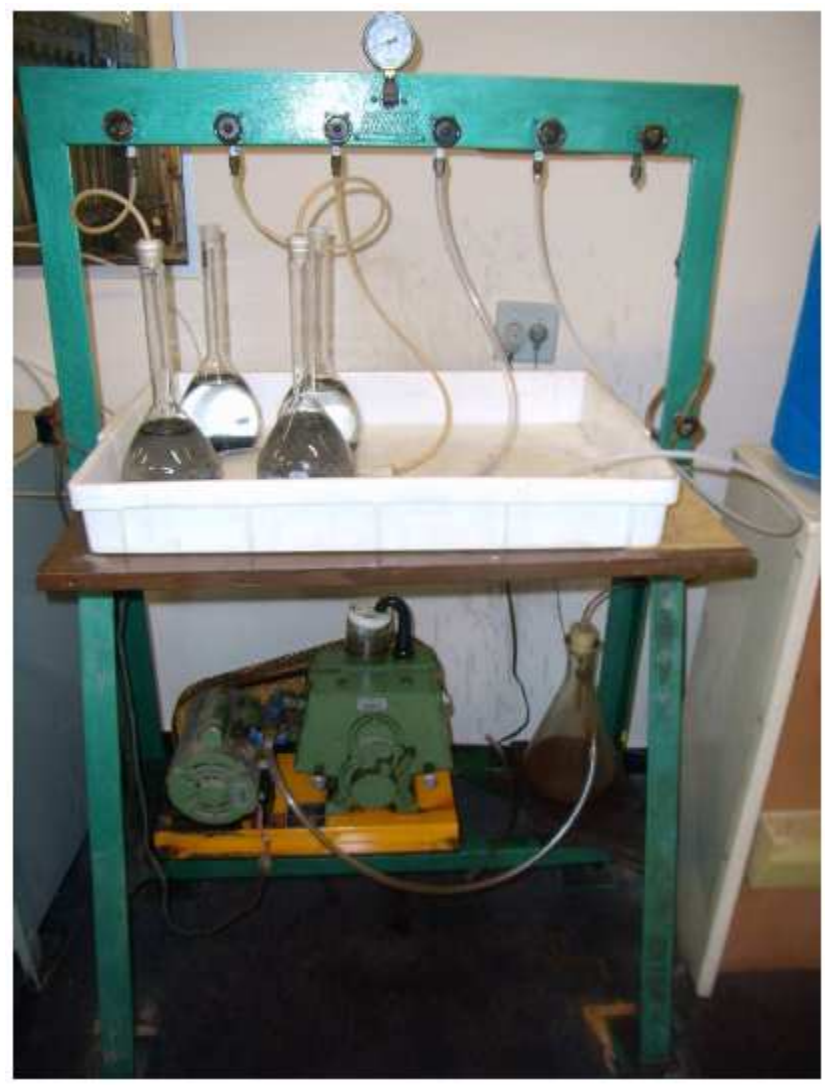

Figura 5.1.7 - Aplicação de vácuo nas amostras por $24 \mathrm{~h}$ para o preenchimento dos vazios internos das partículas. 


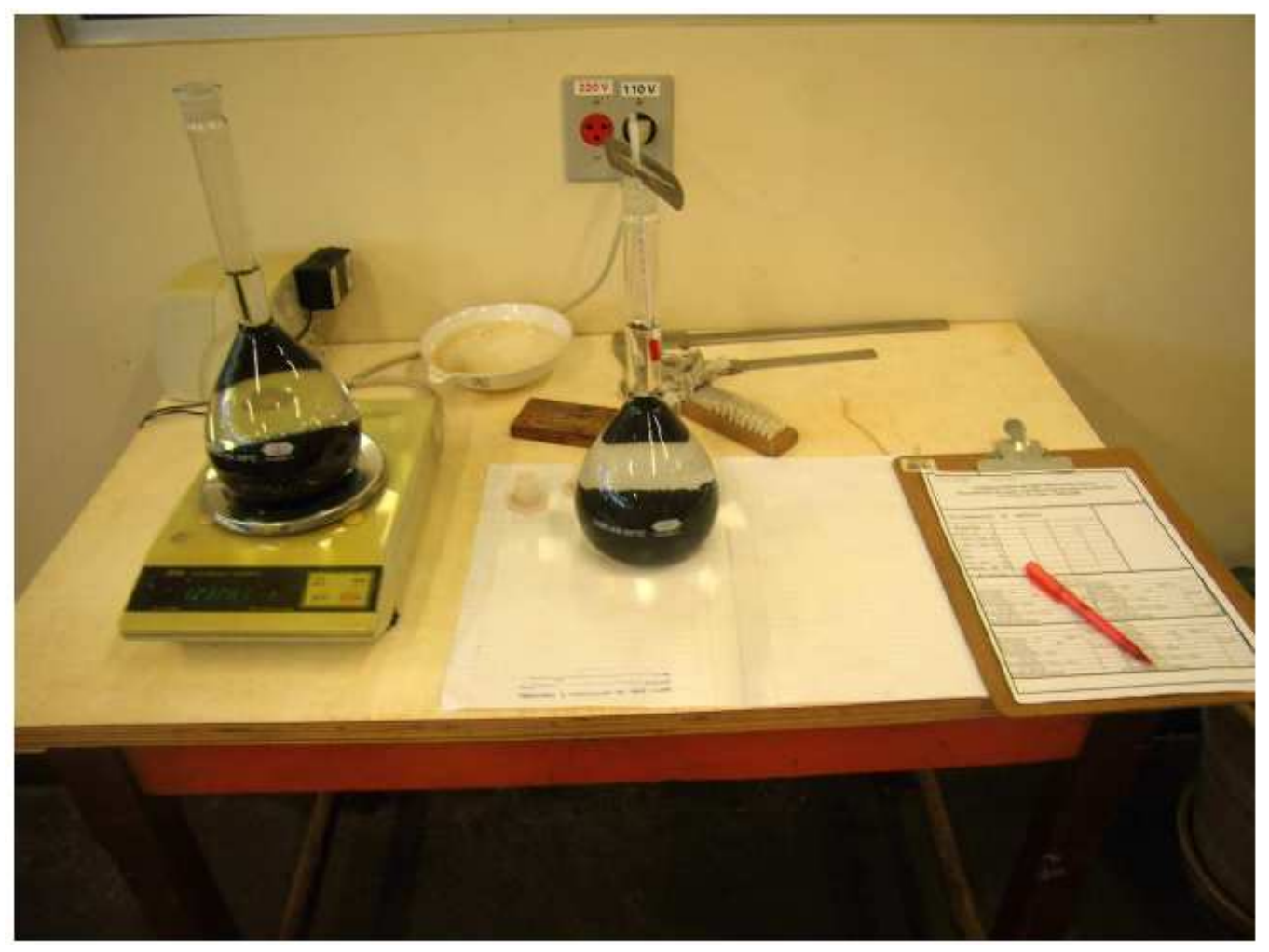

Figura 5.1.8 - Pesagem das amostras após a aplicação de vácuo, para a determinação da massa específica do material.

Na Tabela 5.1.2 encontram-se discriminados as massas registradas para a obtenção da massa específica dos carvões, cujos resultados foram bastante similares.

Para a obtenção da massa específica das partículas e porosidade interna dos carvões (Tabela 5.1.3), o material saturado, proveniente de cada picnômetro, foi superficialmente seco e pesado (Figura 5.1.9).

Para minimizar a influência das perdas de material na secagem superficial, os carvões foram mantidos em estufa à $105-110^{\circ} \mathrm{C}$ por $24 \mathrm{~h}$, para a determinação de suas massas secas (SONTHEIMER; CRITTENDEN; SUMMER, 1988). As eq.(1) e eq.(2) foram empregadas na obtenção da massa específica das partículas e porosidade interna dos carvões. 
Tabela 5.1.2 - Massa específica dos carvões.

\begin{tabular}{|c|c|c|c|c|}
\hline \multirow{2}{*}{ Amostras } & \multicolumn{2}{|c|}{ CALGON } & \multicolumn{2}{|c|}{ CARBOMAFRA } \\
\hline & 1 & 2 & 3 & 4 \\
\hline Material seco $(\mathrm{g})$ & 54,59 & 50,44 & 50,39 & 51,29 \\
\hline Picnômetro & 2 & 10 & 5 & 12 \\
\hline Temperatura água $\left({ }^{\circ} \mathrm{C}\right)$ & 25,5 & 25 & 25,5 & 25,5 \\
\hline Picnômetro + água (g) & $1.207,35$ & $1.225,40$ & $1.230,40$ & $1.219,10$ \\
\hline Picnômetro + água + massa seca $(\mathrm{g})$ & $1.261,94$ & $1.275,84$ & $1.280,79$ & $1.270,39$ \\
\hline (Picnômetro + água + massa seca) pesados (g) & $1.232,87$ & $1.248,84$ & $1.253,21$ & $1.242,96$ \\
\hline Volume deslocado $\left(\mathrm{cm}^{3}\right)$ & 29,07 & 27,00 & 27,58 & 27,43 \\
\hline Massa específica do material $\left(\mathrm{g} / \mathrm{cm}^{3}\right)$ - A & 1,878 & 1,868 & 1,827 & 1,870 \\
\hline
\end{tabular}

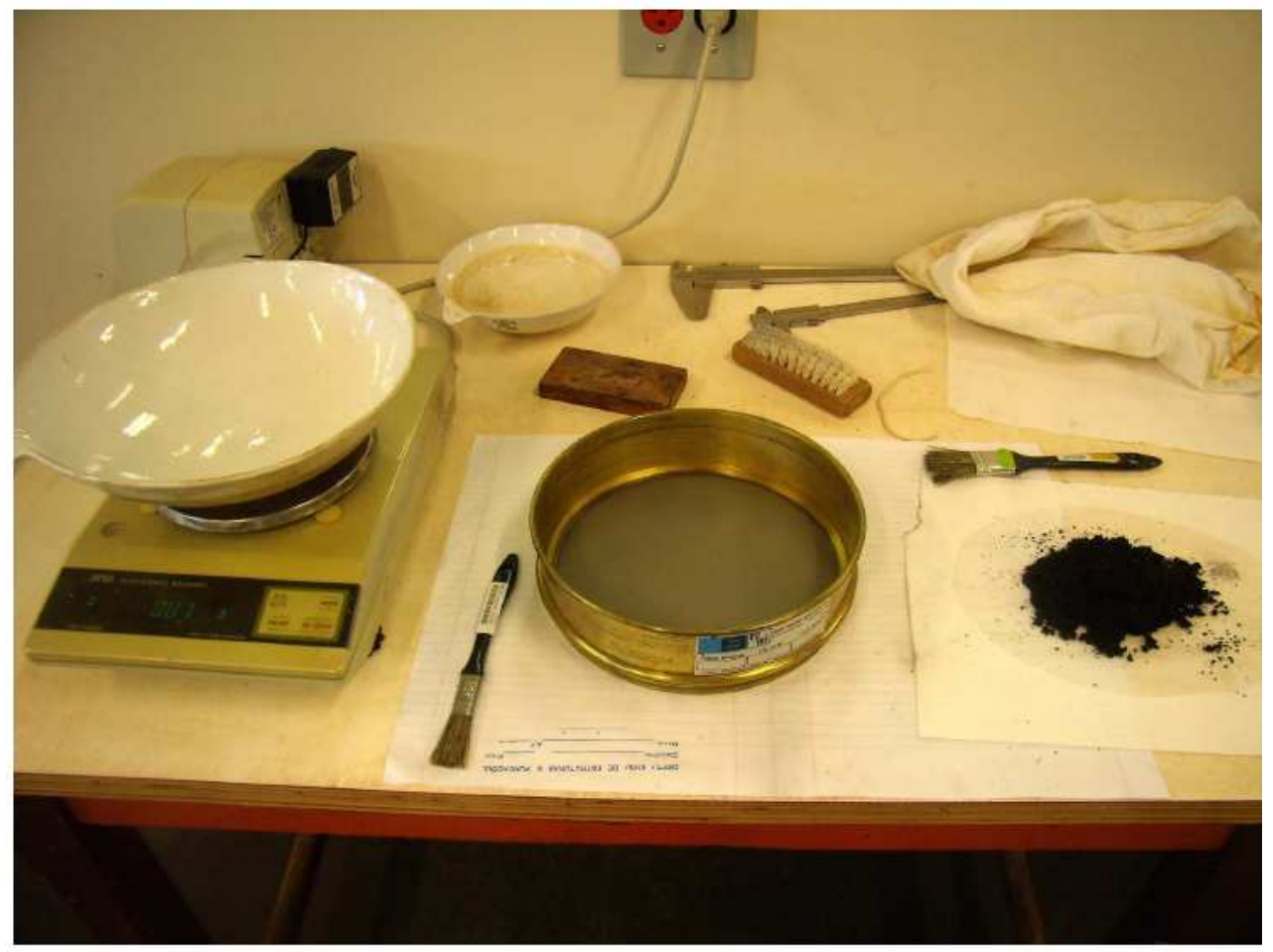

Figura 5.1.9 - Pesagem do carvão superficialmente seco. 
Tabela 5.1.3 - Massa específica das partículas e porosidade interna dos carvões.

\begin{tabular}{ccc}
\hline Amostras & CALGON & CARBOMAFRA \\
\hline Material seco + água interna $(\mathrm{g})-\mathbf{B}$ & 89,64 & $\mathbf{8 5 , 9 1}$ \\
Massa específica das partículas $\left(\mathbf{g} / \mathbf{c m}^{\mathbf{3}}\right)$ - D & $\mathbf{0 , 8 4}$ & 50,39 \\
Porosidade interna (\%) - E & $\mathbf{5 5}$ & $\mathbf{0 , 8 1}$ \\
\hline
\end{tabular}

$$
\begin{aligned}
& \text { Massa específica das partículas }=\left[\frac{C}{C / A+(B-C)}\right] \\
& \text { Porosidade }=\left[\frac{B-C}{C / A+(B-C)}\right]
\end{aligned}
$$

Pela Tabela 5.1.3 é possível verificar que a massa específica das partículas do carvão da CALGON é maior do que a do carvão da CARBOMAFRA, ao contrário de sua porosidade, que é menor.

Para a determinação dos índices em filtro, foi utilizado um permeâmetro ( $\Phi$ int $=81$ $\mathrm{mm}$ ) com possibilidade de injeção de água no sentido ascendente para representar a real situação do meio filtrante após a sua contra lavagem com água.

Amostras de $600 \mathrm{~mL}$ de cada carvão foram lavadas com água desionizada e saturadas em vácuo por 24 h (Figura 5.1.10). Após o preenchimento de $60 \%$ do volume do cilindro com água (Figuras 5.1 .11 e 5.1.12), cada carvão foi lentamente disposto no permeâmetro com o auxílio de um funil (Figura 5.1.13). 


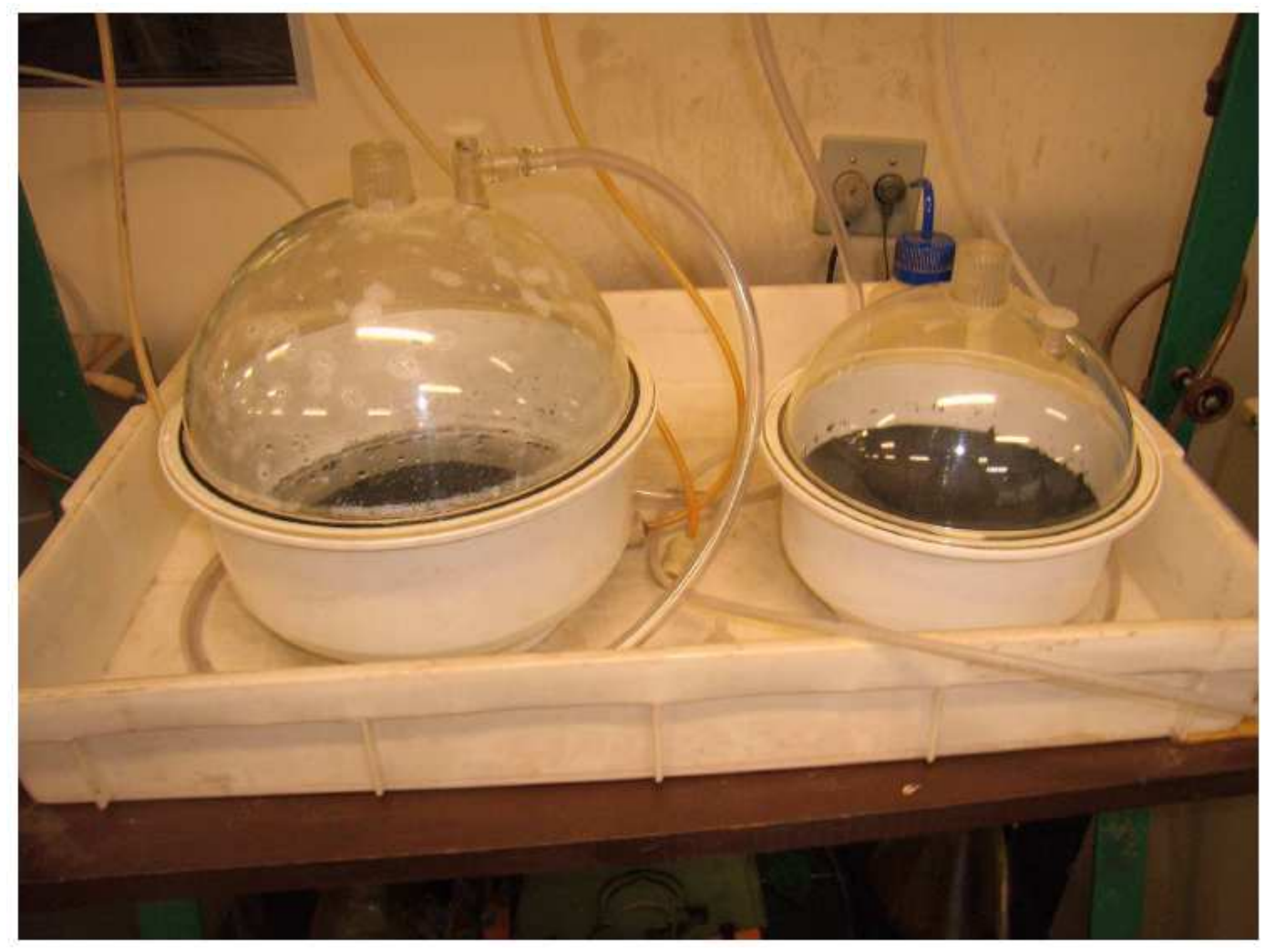

Figura 5.1.10 - Saturação das amostras em vácuo por 24 h.

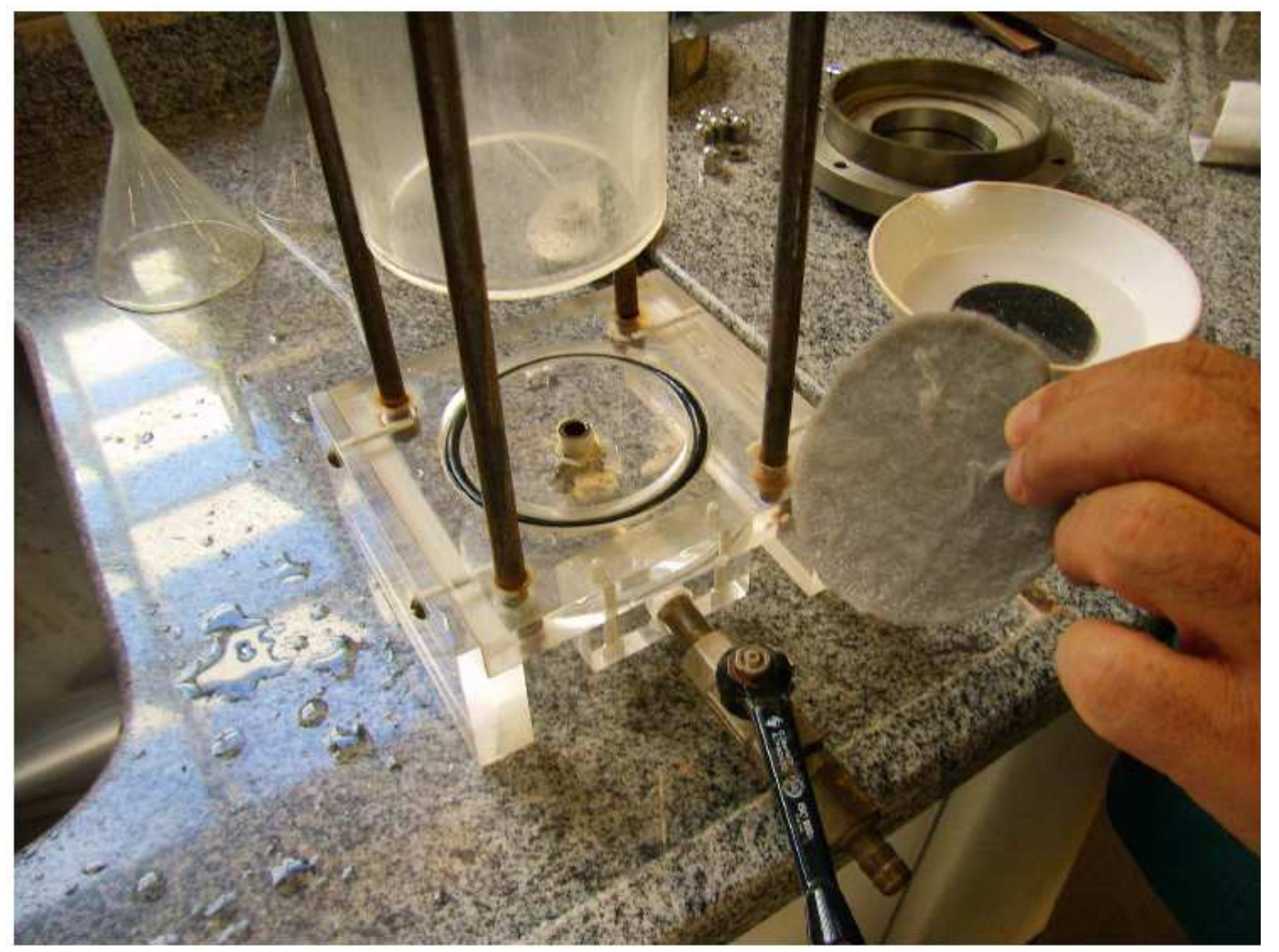

Figura 5.1.11 - Manta de bidim, como camada suporte dos carvões. 


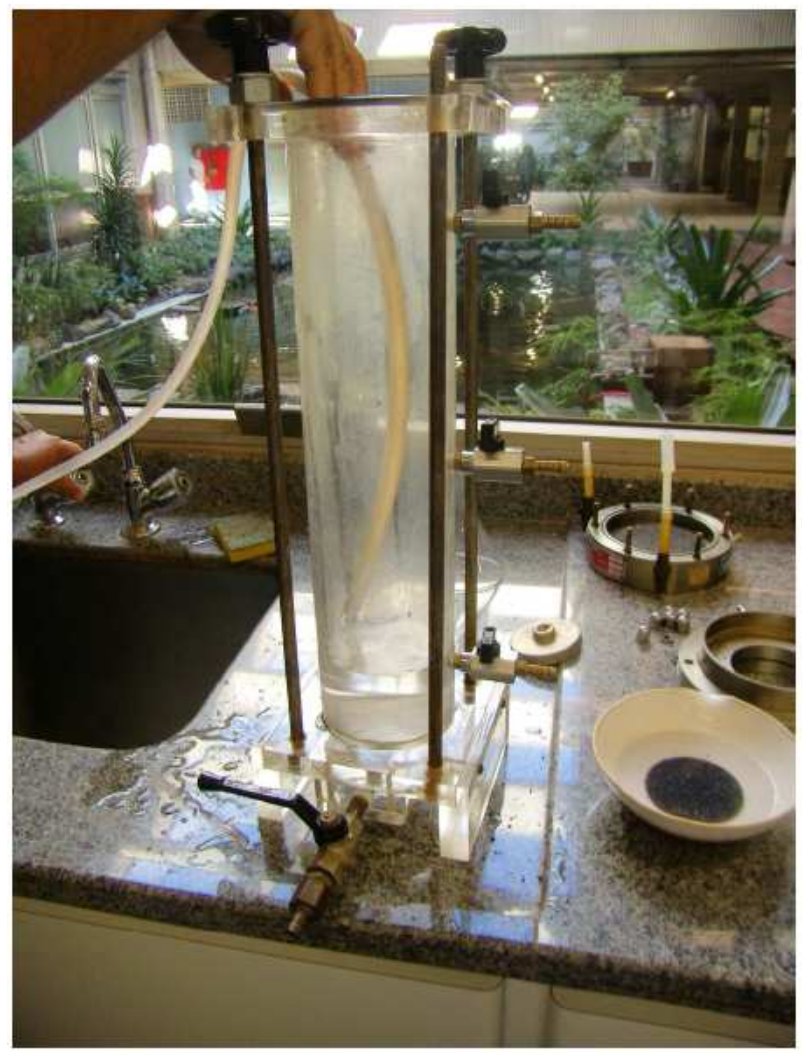

Figura 5.1.12 - Preenchimento de $60 \%$ do volume do permeâmetro com água.

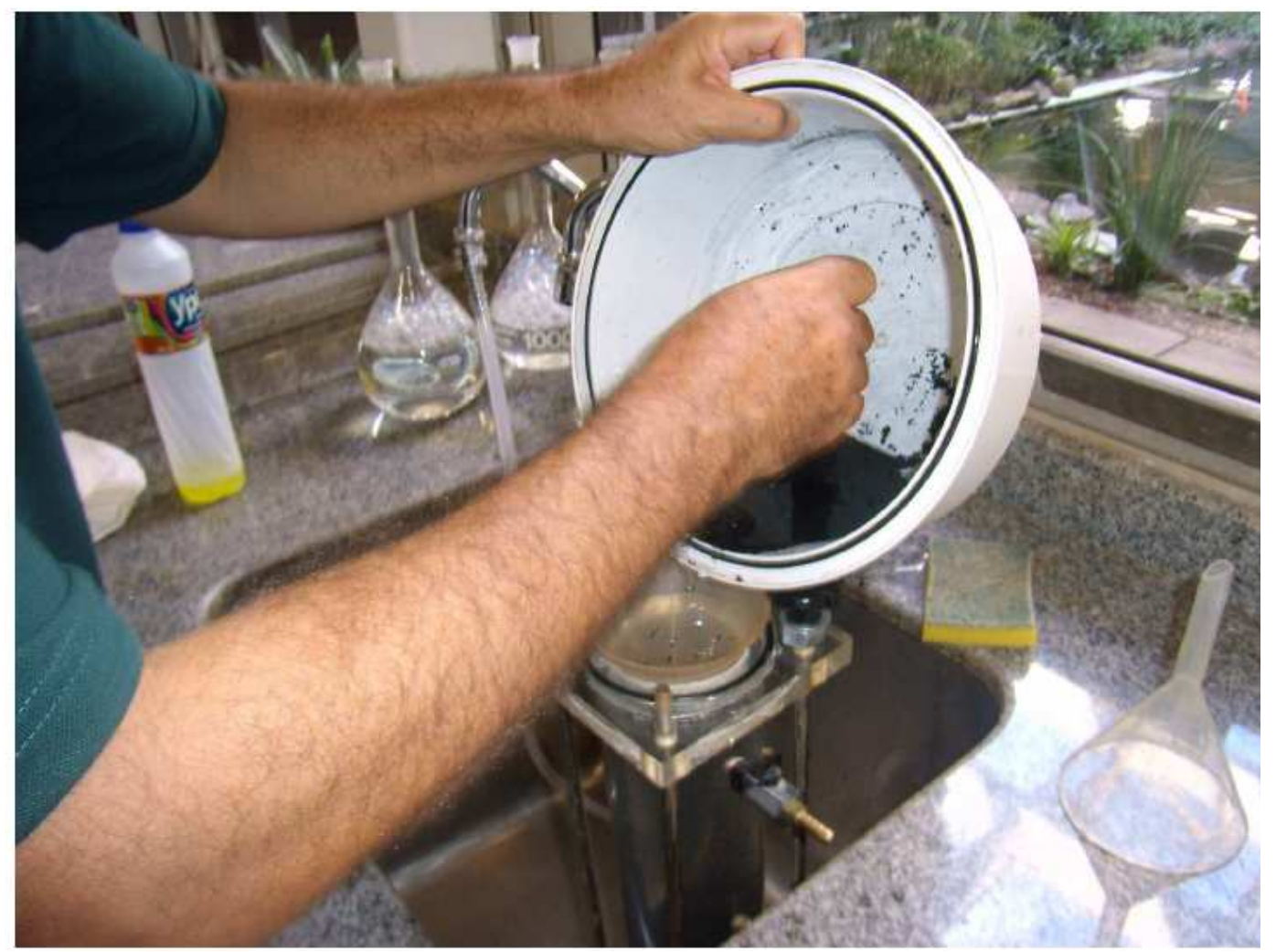

Figura 5.1.13 - Colocação do carvão no permeâmetro. 
Em seguida, foram realizadas cinco injeções de água no sentido ascendente, para a expansão dos carvões em cerca de $30 \%$ de seu volume inicial. Percebeu-se que a quantidade de água necessária para expandir o CAG da CALGON foi um pouco maior do que para expandir o CAG da CARBOMAFRA.

Após um minuto de expansão, o registro era fechado lentamente para a correta acomodação das partículas (Figura 5.1.14). Com o auxílio de uma régua, anotou-se a altura ocupada pelos carvões (SONTHEIMER; CRITTENDEN; SUMMER, 1988). O último passo foi a retirada do carvão do cilindro e sua secagem em estufa por $24 \mathrm{~h}$, para a determinação de sua massa seca.

As eq.(3), eq.(4), eq.(5), eq.(6) e eq.(7) foram utilizadas na obtenção da massa específica dos carvões em filtro, massa específica aparente em filtro, massa específica aparente seca e porosidade, respectivamente. $\mathrm{Na}$ Tabela 5.1.4 encontram-se discriminados os valores obtidos nesta etapa dos ensaios.

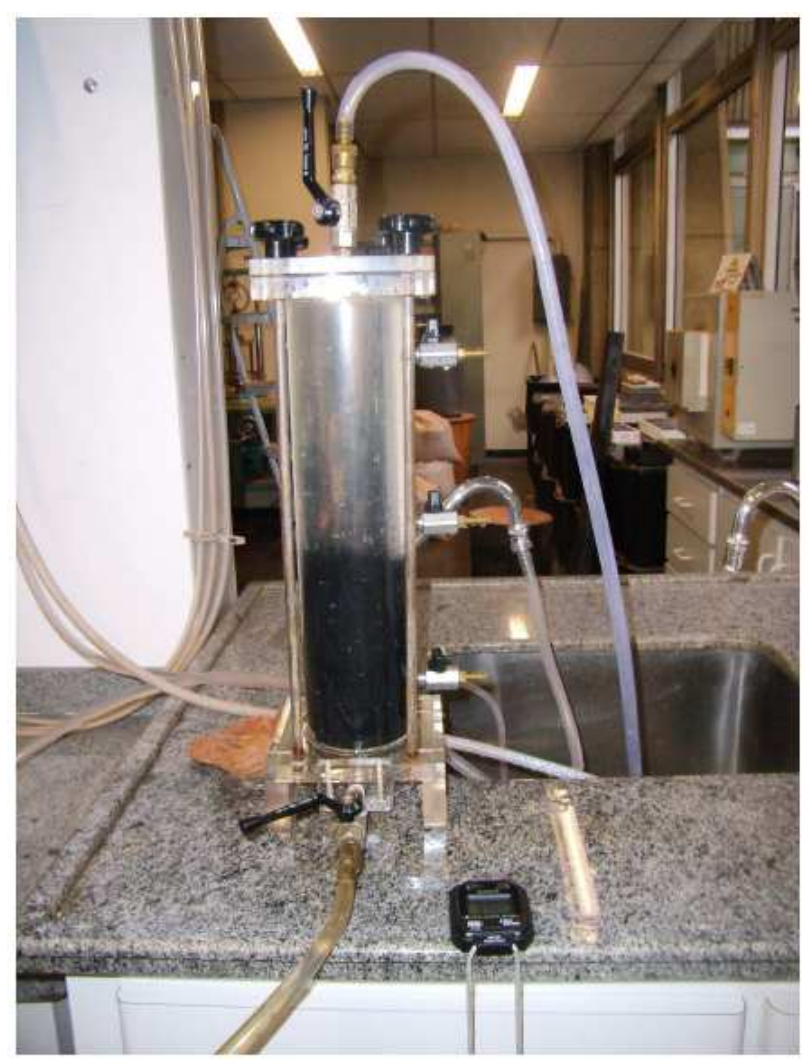

Figura 5.1.14 - Expansão de 30\% do volume do carvão. 
Volume aparente em filtro $=\frac{\pi \cdot \phi \mathrm{int}^{2}}{4} \cdot$ h médio

Massa específica em filtro $=D+E$

Massa específica aparente em filtro $=\frac{G+(G / D) \cdot E}{F}$

Massa específica aparente $\sec a=G / F$

Porosidade $=\frac{G / D}{F}$

Tabela 5.1.4 - Características dos índices físicos em filtro dos carvões.

\section{Parâmetros}

Altura (h) da 1ํe expansão (mm)

h da $2^{\circ}$ expansão $(\mathrm{mm})$

h da $3^{\circ}$ expansão $(\mathrm{mm})$

h da $4^{\circ}$ expansão $(\mathrm{mm})$

h da $5^{\circ}$ expansão $(\mathrm{mm})$

$\mathrm{h}$ médio $(\mathrm{mm})$

Volume aparente em filtro $\left(\mathrm{cm}^{3}\right)$ - F

Material seco' (g) - G

Massa específica em filtro $\left(\mathrm{g} / \mathrm{cm}^{3}\right)$

Massa específica aparente em filtro $\left(\mathrm{g} / \mathrm{cm}^{3}\right)$

Massa específica aparente seca $\left(\mathrm{g} / \mathrm{cm}^{3}\right)$
CALGON

130

131

132

129

129

130

671

347,88

1,39

1,38

0,86

0,79

0,52

0,46

140

142

141

139

139

140

722

334,45

62 
Os resultados dos índices físicos indicam que a massa específica dos dois tipos de carvão são semelhantes. Além disso, consultando os ANEXOS A e B verifica-se que os dados de massa específica aparente obtidos nos testes são similares aos valores fornecidos pelos fabricantes: $0,48-0,56 \mathrm{~g} / \mathrm{cm}^{3}$ para o CAG da CALGON e 0,50 $\pm 0,05 \mathrm{~g} / \mathrm{cm}^{3}$ para o CAG da CARBOMAFRA. A massa específica aparente em filtro, a massa específica aparente seca e a porosidade do Filtrasorb 300 (CALGON) são superiores aos valores do 119 12x25 (CARBOMAFRA). Nas Figuras 5.1.15 e 5.1.16 têm-se os índices físicos e os índices físicos em filtro dos carvões.

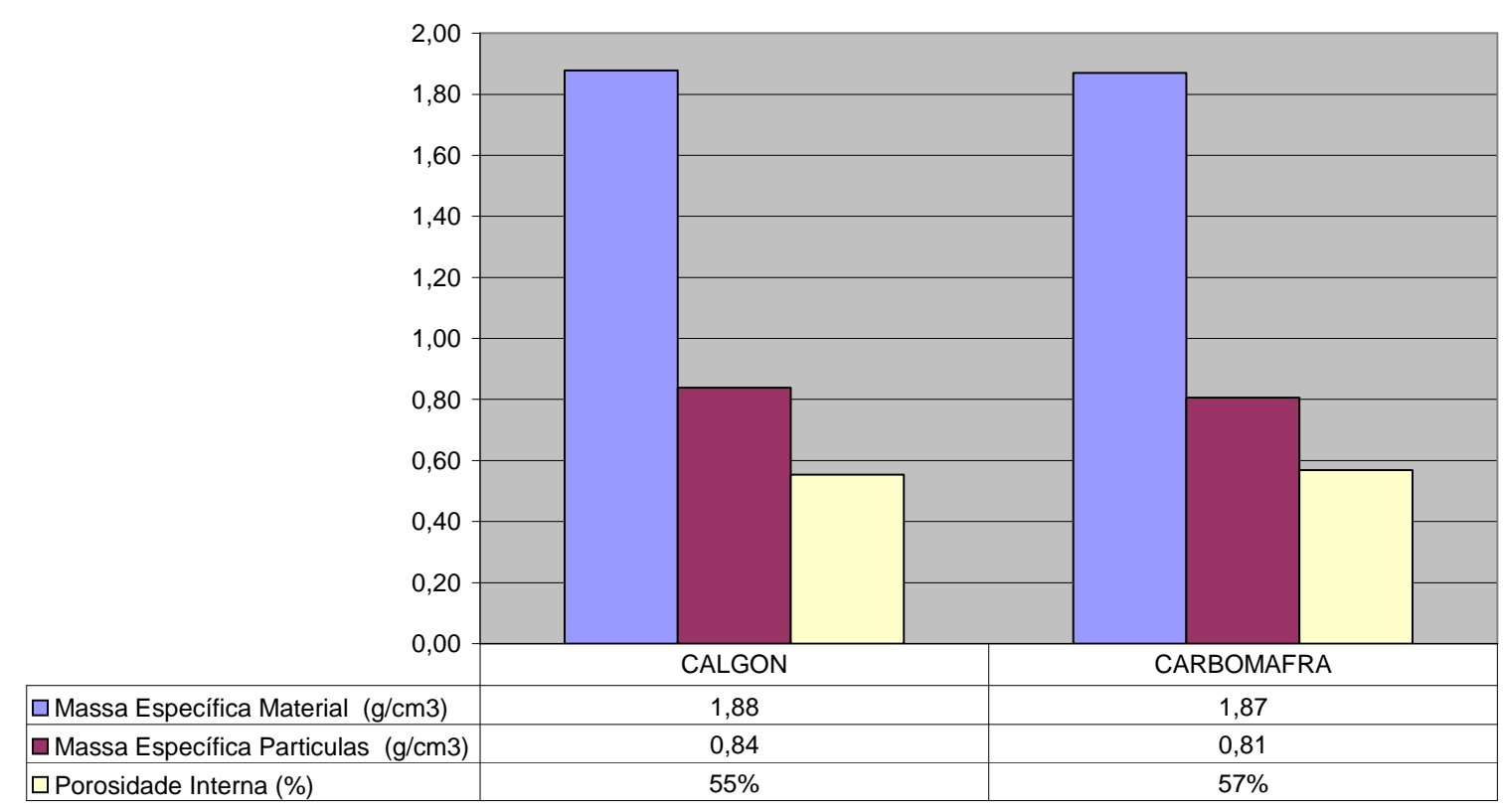

Figura 5.1.15 - Características dos índices físicos dos carvões. 


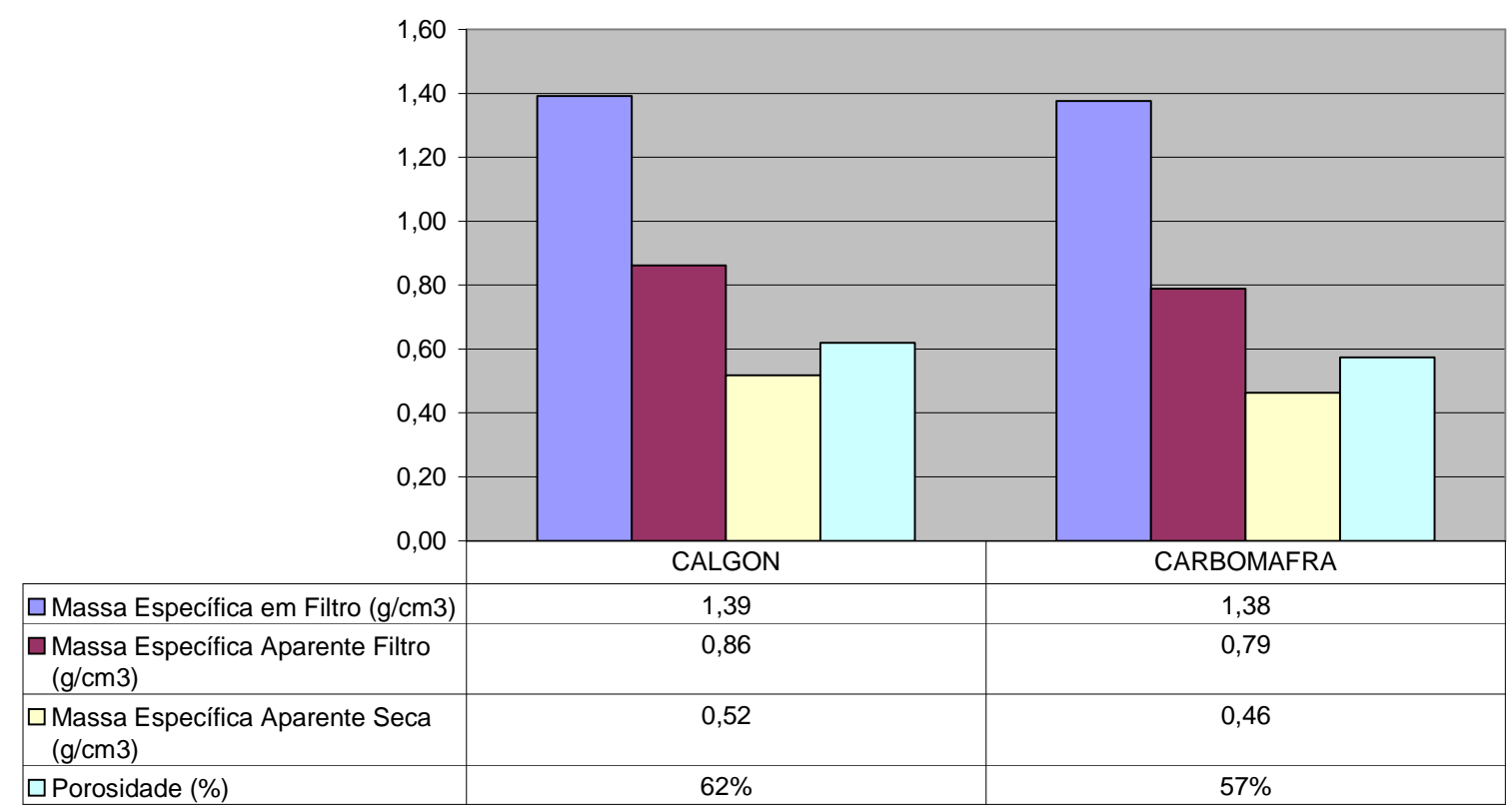

Figura 5.1.16 - Características dos índices físicos em filtro dos carvões.

\subsection{APRESENTAÇÃO E ANÁLISE DOS RESULTADOS DE TURBIDEZ E PERDA DE CARGA}

Os valores mínimo, médio, máximo e desvio padrão dos resultados de turbidez e perda de carga nos filtros encontram-se nas Tabelas 5.2.1 e 5.2.2. As porcentagens de remoção de turbidez estão indicadas na Tabela 5.2.3.

Tabela 5.2.1 - Valores mínimo, médio, máximo e desvio padrão da turbidez.

\begin{tabular}{cccccccc}
\hline & \multicolumn{7}{c}{ Turbidez (UNT) } \\
\cline { 2 - 8 } Valores & $\begin{array}{c}\text { Água } \\
\text { bruta }\end{array}$ & REAF & REAO & F1 & F2 & F3 & F4 \\
\hline Mínimo & 1,54 & 0,103 & 0,100 & 0,098 & 0,099 & 0,106 & 0,100 \\
Médio* & 3,80 & 0,207 & 0,283 & 0,226 & 0,244 & 0,174 & 0,188 \\
Máximo & 11,90 & 0,548 & 0,789 & 0,555 & 1,050 & 0,400 & 0,395 \\
Desvio Padrão & 1,77 & 0,080 & 0,137 & 0,094 & 0,129 & 0,050 & 0,051 \\
\hline
\end{tabular}

*: Valores médios obtidos a partir dos dados do APÊNDICE C. 
Tabela 5.2.2 - Valores mínimo, médio, máximo e desvio padrão da perda de carga.

\begin{tabular}{ccccc}
\hline \multirow{2}{*}{ Valores } & \multicolumn{4}{c}{ Perda de carga $(\mathbf{c m})$} \\
\cline { 2 - 5 } & F1 & F2 & F3 & F4 \\
\hline Mínimo & 7 & 9 & 12 & 11 \\
Médio* & 19 & 22 & 105 & 36 \\
Máximo & 46 & 57 & 279 & 142 \\
Desvio Padrão & 8 & 9 & 75 & 26 \\
\hline
\end{tabular}

*: Valores médios obtidos a partir dos dados do APÊNDICE C.

Tabela 5.2.3 - Valores mínimo, médio, máximo e desvio padrão da porcentagem de remoção da turbidez.

\begin{tabular}{ccccc}
\hline & \multicolumn{4}{c}{ Porcentagem de remoção da turbidez (\%) } \\
\cline { 2 - 5 } Valores & F1 & F2 & F3 & F4 \\
\hline Mínimo & 1,82 & 1,88 & 1,26 & 0,40 \\
Médio* & 25,68 & 22,54 & 22,61 & 23,33 \\
Máximo & 66,60 & 67,45 & 68,43 & 68,80 \\
Desvio Padrão & 15,16 & 15,48 & 15,74 & 16,23 \\
\hline
\end{tabular}

*: Valores médios obtidos a partir dos dados do APÊNDICE C.

Os menores valores médios de turbidez (0,226 UNT e 0,174 UNT) ocorreram nas águas efluentes dos filtros de CAG betuminoso (F1 e F3, respectivamente). As maiores remoções médias de turbidez verificadas foram nos filtros $1(25,68 \%)$ e 4 $(23,33 \%)$.

Os menores valores de perdas de carga registrados foram aqueles referentes aos filtros alimentados com água ozonizada (F1 e F2) e dentre eles, as menores perdas foram às do filtro de CAG betuminoso $(\mathrm{F} 1)$. Dentre todos os filtros, o 3 (CAG betuminoso) é que apresentou as maiores perdas de carga, com um valor médio de $105 \mathrm{~cm}$. Uma possível explicação para este fato seria a melhor capacidade adsortiva do filtro de CAG betuminoso (F3) com relação ao filtro de CAG vegetal (F4), o que levaria a redução mais rápida do seu número de poros livres com o passar do tempo, aumentando sua perda de carga. As Figuras 5.2.1 e 5.2.2 apresentam o comportamento dos filtros com relação à turbidez e à perda de carga, ao longo do tempo. 


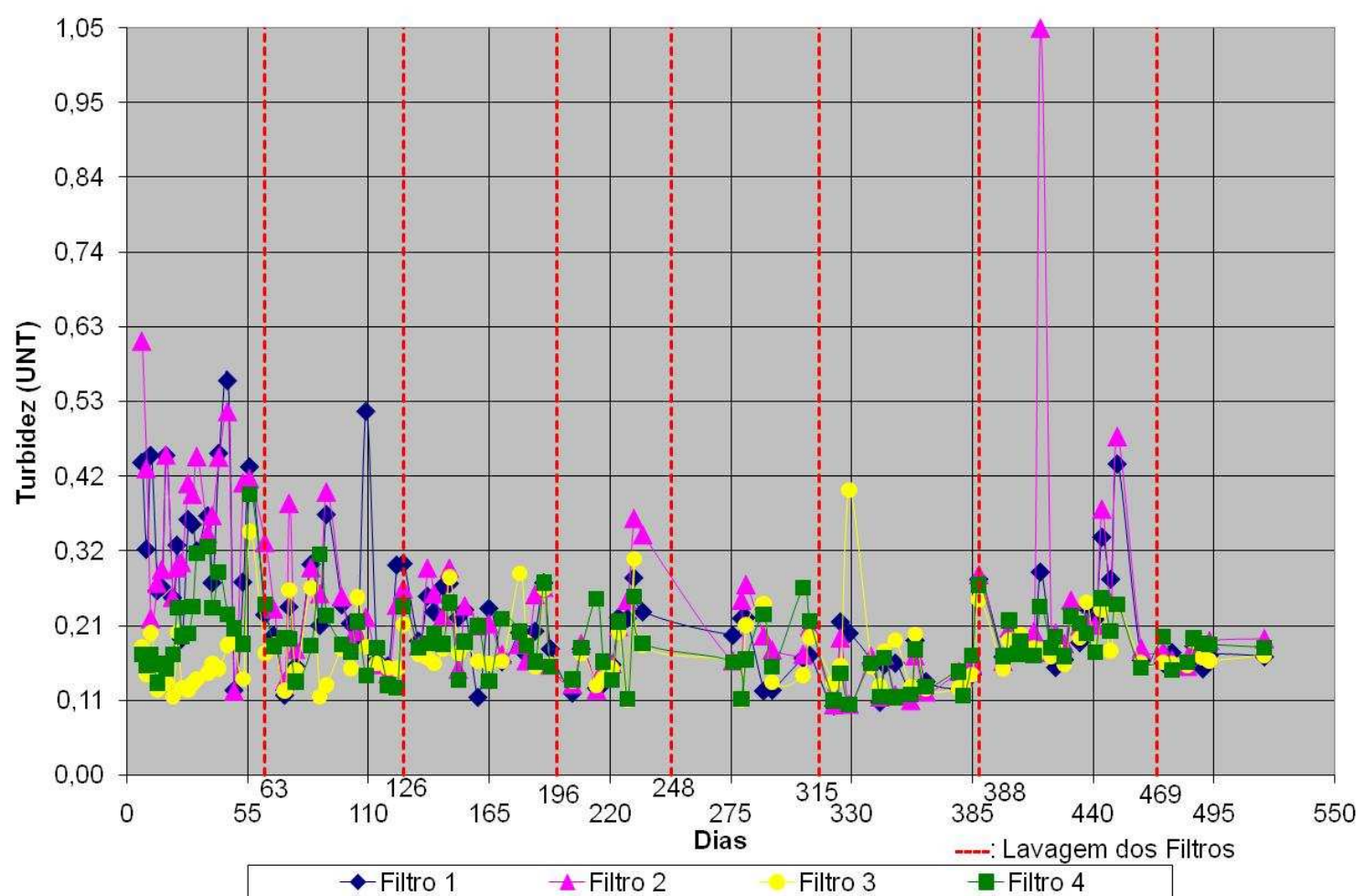

Figura 5.2.1 - Turbidez das águas efluentes dos filtros, ao longo do tempo.

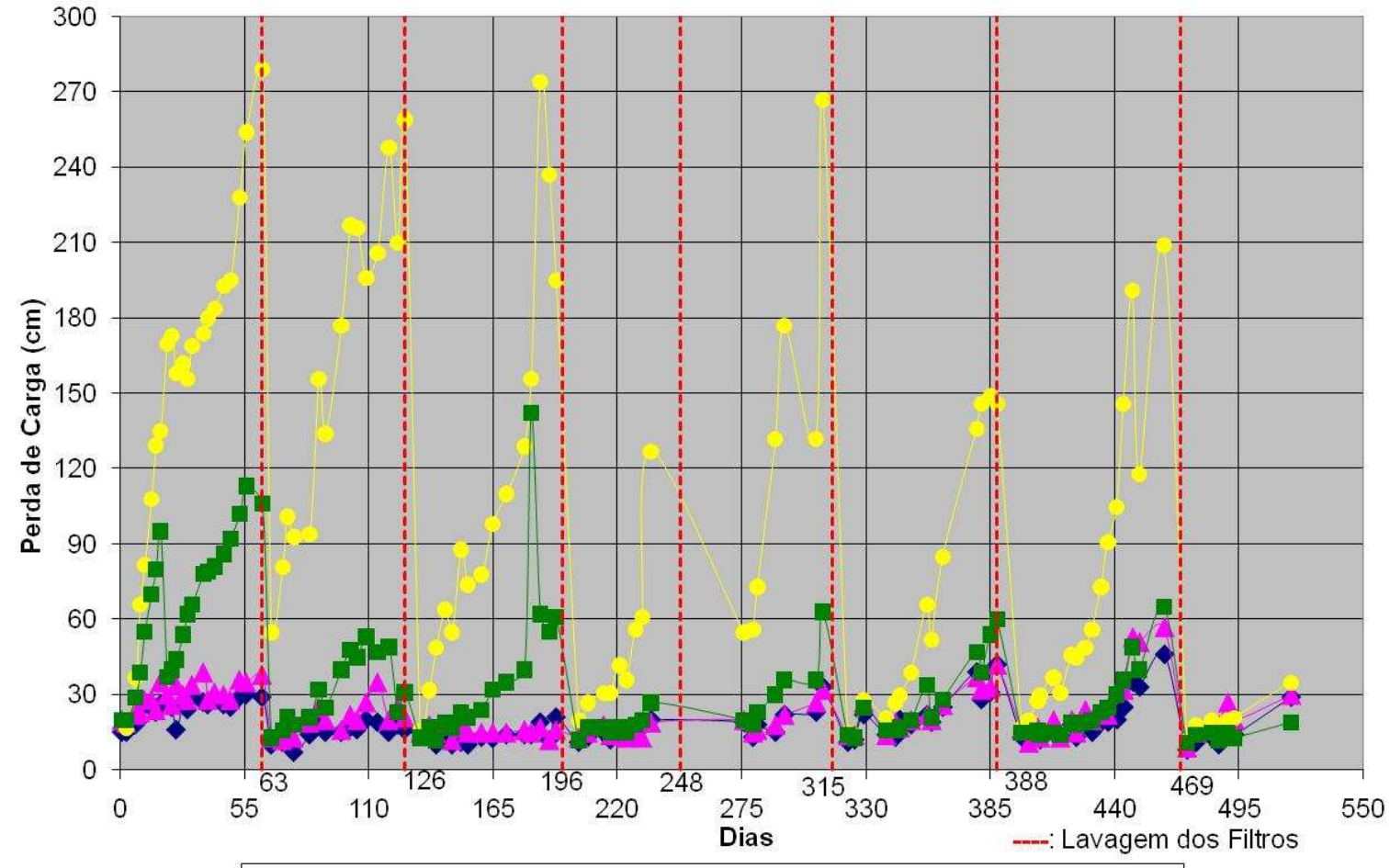

Filtro 1

-Filtro 2

Filtro 3

-Filtro 4

Figura 5.2.2 - Perda de carga dos filtros, ao longo do tempo. 
Pela Figura 5.2.1 é possível perceber que os valores de turbidez das águas efluentes dos filtros mantiveram-se sempre dentro de uma determinada faixa de leitura $(0,11$ UNT $\leq$ turbidez $\leq 0,53$ UNT), mesmo após a lavagem dos mesmos.

A Figura 5.2.2 mostra que a perda de carga dos filtros alimentados com água não ozonizada (F3 e F4), em particular, o filtro de CAG betuminoso (F3), reduziu-se após as operações de lavagem. Os filtros alimentados com água ozonizada mantiveram suas perdas de carga inferiores a $60 \mathrm{~cm}$. A Figura 5.2 .3 relaciona a perda de carga nos filtros com a turbidez da água tratada.

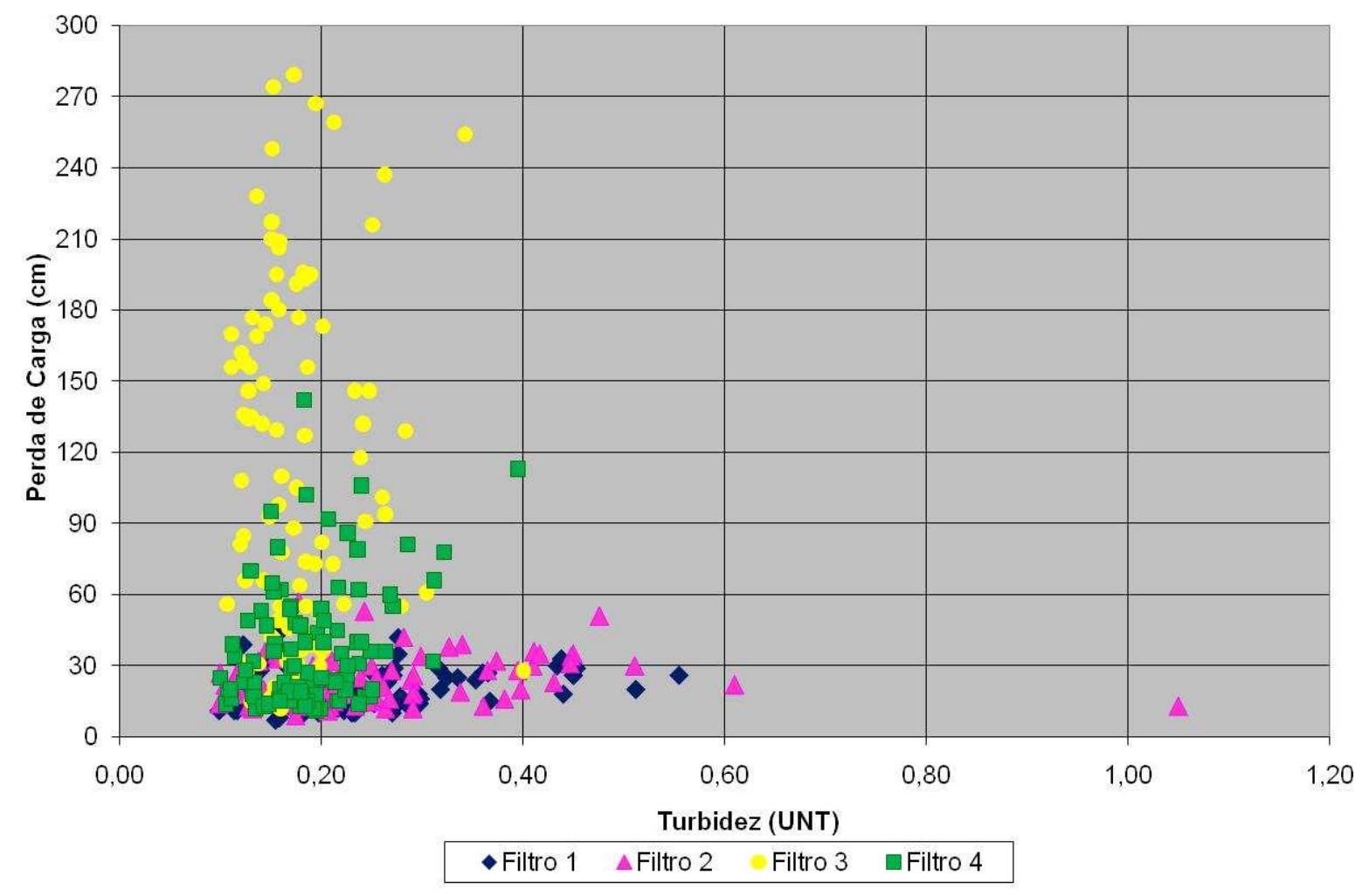

Figura 5.2.3 - Perda de carga nos filtros versus turbidez da água tratada.

Observa-se da Figura 5.2.3 que para uma mesma faixa de turbidez $(0,10$ UNT $\leq$ turbidez $\leq$ 0,40 UNT) a perda de carga durante a operação dos filtros foi maior para aqueles alimentados com água não ozonizada, sendo superior no filtro 3 (CAG betuminoso). Já para os filtros alimentados com água ozonizada (F1 e F2), a perda de carga manteve-se praticamente constante, independentemente da origem do carvão (betuminoso ou vegetal). 


\subsection{APRESENTAÇÃO E ANÁLISE DOS RESULTADOS DE CARBONO ORGÂNICO TOTAL E ABSORÇÃO ESPECÍFICA DA RADIAÇÃO ULTRAVIOLETA NO COMPRIMENTO DE ONDA IGUAL A 254 NM}

Os valores mínimo, médio, máximo e desvio padrão dos resultados de COT e absorção do UV no $254 \mathrm{~nm}$ encontram-se nas Tabelas 5.3.1 e 5.3.2. As porcentagens de remoção de COT e absorção do UV no $254 \mathrm{~nm}$ estão indicadas nas Tabelas 5.3.3 e 5.3.4.

Tabela 5.3.1 - Valores mínimo, médio, máximo e desvio padrão do COT.

\begin{tabular}{cccccccc}
\hline & \multicolumn{7}{c}{ COT (mg/L) } \\
\cline { 2 - 8 } Valores & $\begin{array}{c}\text { Água } \\
\text { bruta }\end{array}$ & REAF & REAO & F1 & F2 & F3 & F4 \\
\hline Mínimo & 2,64 & 0,22 & 0,10 & 0,20 & 0,67 & 0,14 & 0,84 \\
Médio* & 4,45 & 2,21 & 2,20 & 1,42 & 1,91 & 1,62 & 2,14 \\
Máximo & 6,76 & 4,01 & 5,41 & 5,45 & 8,16 & 10,74 & 10,36 \\
Desvio Padrão & 0,62 & 0,39 & 0,50 & 0,66 & 0,80 & 1,06 & 0,92 \\
\hline
\end{tabular}

*: Valores médios obtidos a partir dos dados do APÊNDICE C.

Tabela 5.3.2 - Valores mínimo, médio, máximo e desvio padrão da absorção do UV no 254 nm.

\begin{tabular}{cccccccc}
\hline \multirow{2}{*}{ Valores } & \multicolumn{7}{c}{ UV $254 \mathbf{~ n m ~ ( \mathbf { c m } ^ { - 1 } )}$} \\
\cline { 2 - 8 } & $\begin{array}{c}\text { Água } \\
\text { bruta }\end{array}$ & REAF & REAO & F1 & F2 & F3 & F4 \\
\hline Mínimo & 0,011 & 0,000 & 0,000 & 0,000 & 0,000 & 0,000 & 0,000 \\
Médio* & 0,105 & 0,029 & 0,021 & 0,015 & 0,017 & 0,017 & 0,023 \\
Máximo & 0,259 & 0,150 & 0,270 & 0,170 & 0,158 & 0,154 & 0,167 \\
Desvio Padrão & 0,028 & 0,021 & 0,029 & 0,026 & 0,019 & 0,018 & 0,018 \\
\hline
\end{tabular}

*: Valores médios obtidos a partir dos dados do APÊNDICE C.

Observando-se o valor médio de COT na água do $\operatorname{REAF~}(2,21 \mathrm{mg} / \mathrm{L})$, verifica-se que o processo de tratamento da ETA ABV foi responsável pela remoção de 50,24 \% do COT médio presente na água bruta $(4,45 \mathrm{mg} / \mathrm{L})$. No entanto, a aplicação do ozônio na água filtrada da ETA (REAF) não alterou seu valor $(2,20 \mathrm{mg} / \mathrm{L})$, uma vez que o carbono orgânico foi apenas convertido em assimilável (ver Figura 5.3.1). 
Tabela 5.3.3 - Valores mínimo, médio, máximo e desvio padrão da porcentagem de remoção do COT.

\begin{tabular}{ccccccc}
\hline \multirow{2}{*}{ Valores } & \multicolumn{5}{c}{ Porcentagem de remoção do COT (\%) } \\
\cline { 2 - 7 } & REAF & REAO & F1 & F2 & F3 & F4 \\
\hline Mínimo & 37,05 & 0,18 & 2,60 & 1,68 & 2,09 & 0,74 \\
Médio* & 50,24 & 7,22 & 38,61 & 19,32 & 33,06 & 12,78 \\
Máximo & 95,69 & 95,35 & 92,14 & 73,60 & 94,60 & 66,90 \\
Desvio Padrão & 6,75 & 14,01 & 21,22 & 11,24 & 23,38 & 10,43 \\
\hline
\end{tabular}

*: Valores médios obtidos a partir dos dados do APÊNDICE C.

Tabela 5.3.4 - Valores mínimo, médio, máximo e desvio padrão da porcentagem de remoção da absorção do UV no $254 \mathrm{~nm}$.

\begin{tabular}{ccccccc}
\hline \multirow{2}{*}{ Valores } & \multicolumn{5}{c}{ Porcentagem de remoção da absorção do UV no 254 nm (\%) } \\
\cline { 2 - 7 } & REAF & REAO & F1 & F2 & F3 & F4 \\
\hline Mínimo & 40,54 & 3,45 & 4,17 & 4,35 & 10,34 & 3,45 \\
Médio* & 73,38 & 44,05 & 48,78 & 34,99 & 50,75 & 31,07 \\
Máximo & 100,00 & 93,75 & 100,00 & 100,00 & 96,67 & 100,00 \\
Desvio Padrão & 12,52 & 21,41 & 24,91 & 25,95 & 23,99 & 22,52 \\
\hline
\end{tabular}

*: Valores médios obtidos a partir dos dados do APÊNDICE C.

Os valores médios de COT nas águas efluentes dos filtros 1 e 3 (1,42 mg/L e 1,62 $\mathrm{mg} / \mathrm{L})$ foram menores do que os dos filtros 2 e 4 (1,91 mg/L e 2,14 mg/L), indicando que os carvões ativados granulares de origem betuminosa apresentaram uma melhor remoção de COT do que os carvões de origem vegetal (ver Figura 5.3.2): média de $38,61 \%$ e 33,06 \%, respectivamente.

A maior remoção média de COT foi verificada na água efluente do filtro 1 , alimentado com água ozonizada, indicando que a biofiltração contribui na redução do COT. Estudos de biofiltração realizados por Bouwer; Crowe (1990) e AWWARF (2005) mostraram faixas de remoções de COT (entre 5 e $75 \%$ e entre 15 e 25 \%, respectivamente) dentro dos valores aqui obtidos.

Com relação aos valores da absorção do UV no $254 \mathrm{~nm}$, o processo de tratamento da ETA foi responsável por uma remoção de 73,38 \%, considerando-se o valor 
médio da água bruta $\left(0,105 \mathrm{~cm}^{-1}\right)$. A ozonização da água filtrada da ETA (REAF) reduziu o valor médio da absorção do UV no $254 \mathrm{~nm}$ de $0,029 \mathrm{~cm}^{-1}$ para $0,021 \mathrm{~cm}^{-1}$ e a filtração pelos filtros 1 e 2, isto é, aqueles alimentados com água ozonizada, em 48,78 \% e 34,99 \%, respectivamente. O valor médio da absorção do UV no 254 nm na água efluente do filtro 3 foi igual ao do filtro $2\left(0,017 \mathrm{~cm}^{-1}\right)$, apesar de sua maior porcentagem de remoção $(50,75 \%)$; e a água efluente do filtro 4 , foi a que apresentou o maior valor médio: $0,023 \mathrm{~cm}^{-1}$.

A exemplo dos valores de COT, os filtros betuminosos de CAG (1 e 3) também propiciaram melhores remoções nos valores da absorção do UV no $254 \mathrm{~nm}$, em relação aos vegetais (2 e 4). As Figuras 5.3.1 e 5.3.2 apresentam os valores de COT ao longo do tempo, para as águas filtrada (REAF), ozonizada (REAO) e efluentes dos filtros 1, 2, 3 e 4, respectivamente.

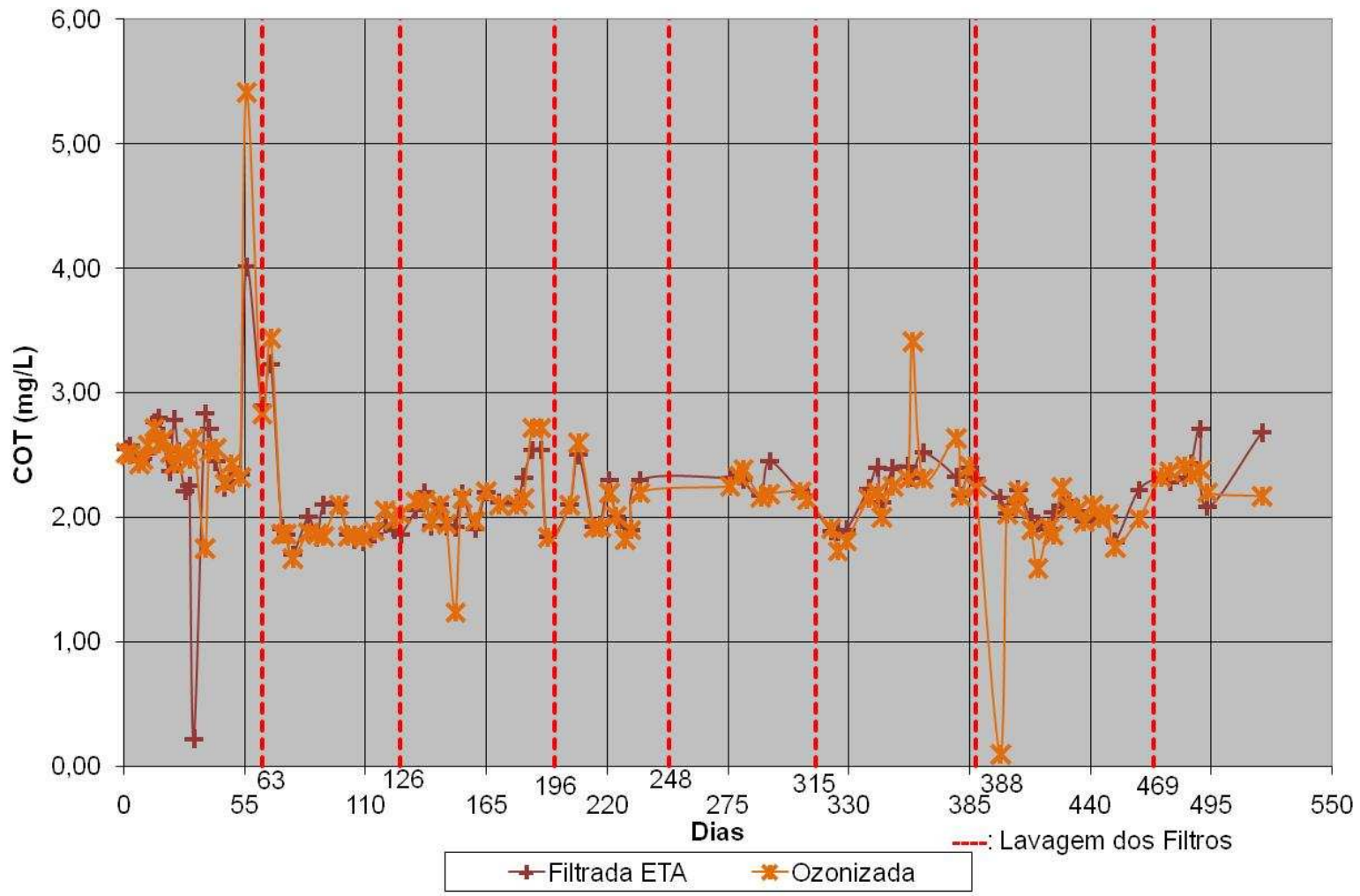

Figura 5.3.1 - Valores de COT para a água filtrada e ozonizada, ao longo do tempo. 


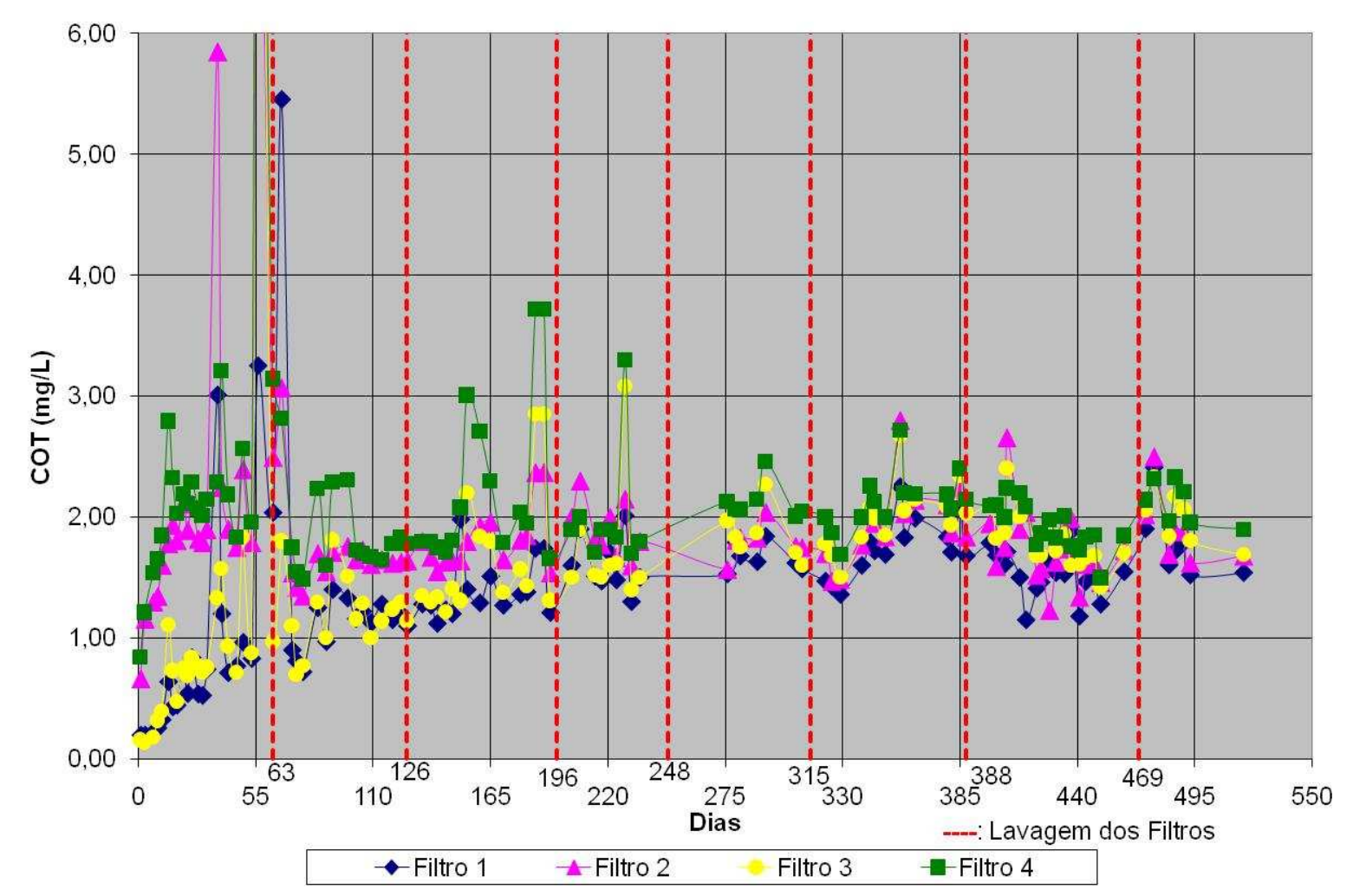

Figura 5.3.2 - Valores de COT nas águas efluentes dos filtros, ao longo do tempo.

\subsection{APRESENTAÇÃO E ANÁLISE DOS RESULTADOS DE OZÔNIO E CLORO LIVRE RESIDUAL}

Os valores mínimo, médio, máximo e desvio padrão dos resultados de cloro livre residual e ozônio residual encontram-se na Tabela 5.4.1. Observa-se que a quantidade de cloro livre residual foi reduzida em $49,8 \%$ (de $0,62 \mathrm{mg} / \mathrm{L}$ para 0,32 $\mathrm{mg} / \mathrm{L}$ ), mostrando que o ozônio reagiu com o cloro.

A Figura 5.4.1 relaciona os valores de ozônio residual medidos na saída da coluna 2 (CO2) e no REAO com a dosagem de ozônio aplicada; e a Figura 5.4.2, a turbidez da água ozonizada, com a dosagem de ozônio aplicada. 
Tabela 5.4.1- Valores mínimo, médio, máximo e desvio padrão do cloro livre residual e ozônio residual.

\begin{tabular}{cccccc}
\hline Parâmetro & $\begin{array}{c}\text { Ponto de } \\
\text { amostragem }\end{array}$ & Mínimo & Médio* & Máximo & $\begin{array}{c}\text { Desvio } \\
\text { Padrão }\end{array}$ \\
\hline $\begin{array}{c}\mathbf{C l}_{2} \text { livre } \\
\text { residual } \\
(\mathbf{m g} / \mathbf{L})\end{array}$ & REAF & 0,10 & 0,62 & 1,30 & 0,24 \\
\hline $\begin{array}{c}\mathbf{O}_{3} \text { residual } \\
(\mathbf{m g} / \mathbf{L})\end{array}$ & REAO & 0,05 & 0,32 & 0,90 & 0,19 \\
\hline
\end{tabular}

*: Valores médios obtidos a partir dos dados do APÊNDICE C.

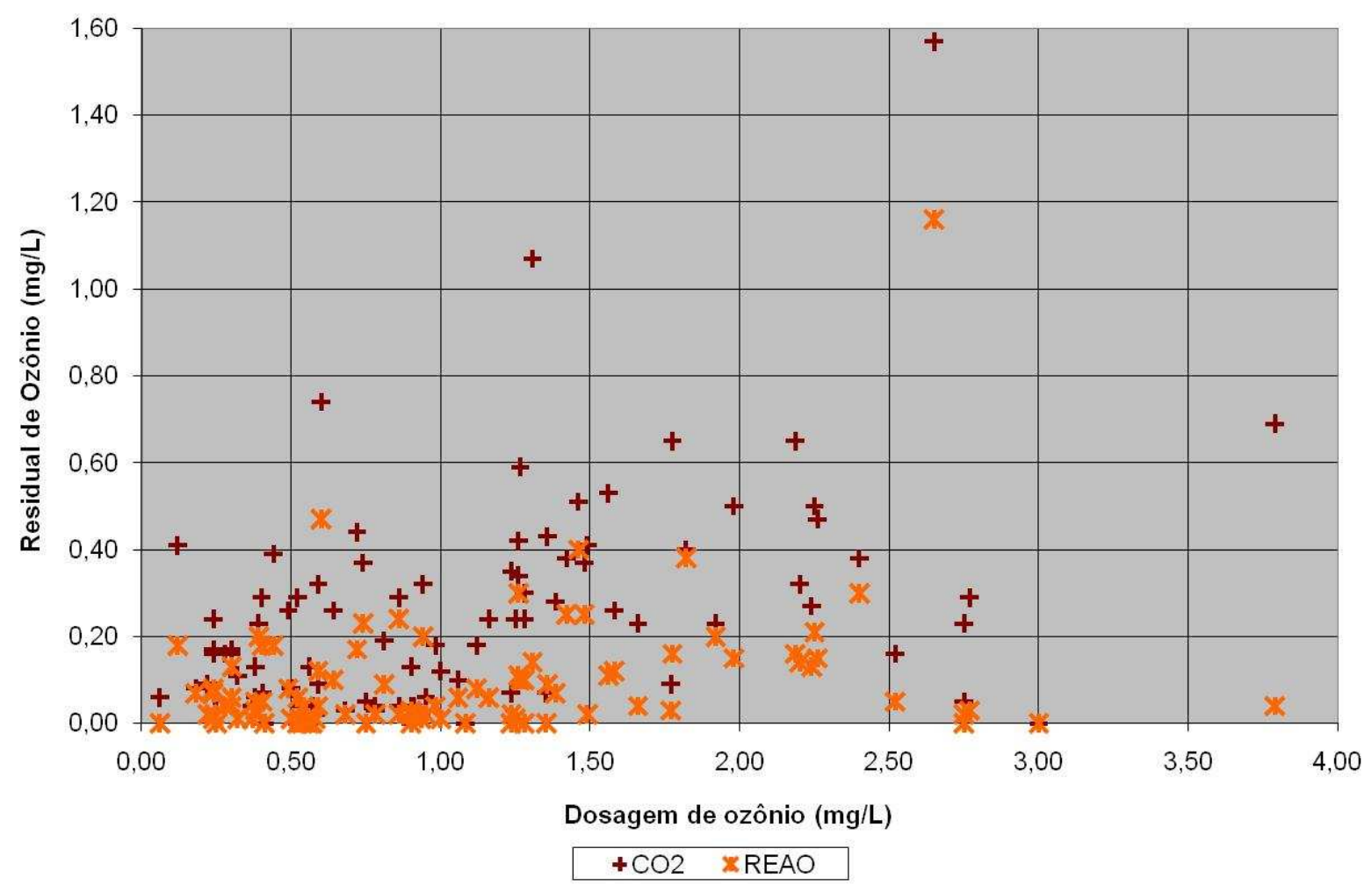

Figura 5.4.1 - Residual de ozônio versus dosagem de ozônio aplicada.

Com o aumento da dosagem de ozônio aplicada nas colunas 1 e 2, verificou-se um aumento no valor do ozônio residual, tanto na saída da coluna de ozonização 2 (CO2) quanto no reservatório de água ozonizada (REAO). Os valores do ozônio residual encontrados no REAO mantiveram-se inferiores aos da $\mathrm{CO} 2$, já que o tempo de detenção era superior no primeiro do que no segundo. 


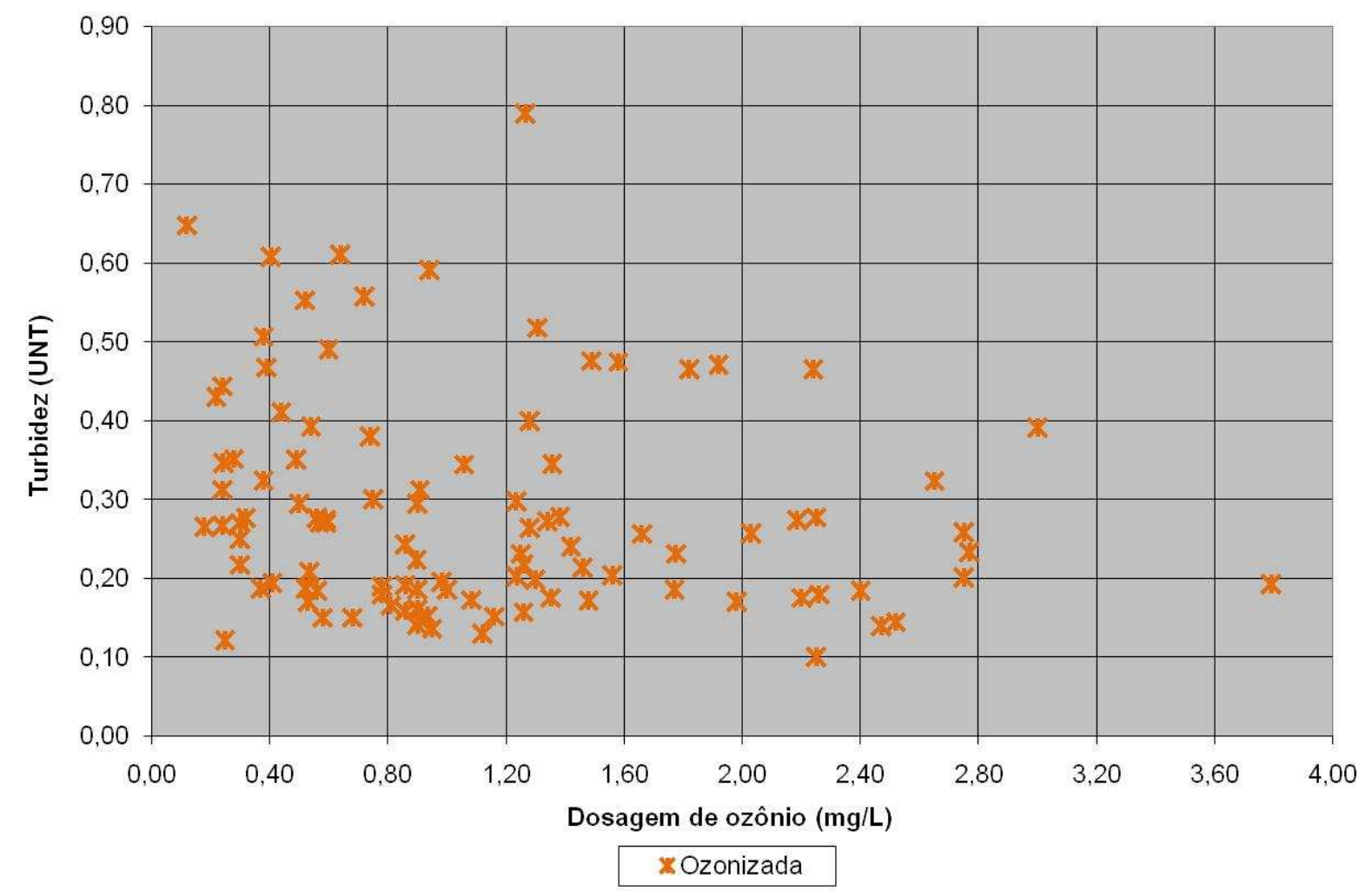

Figura 5.4.2 - Turbidez da água ozonizada versus dosagem de ozônio aplicada.

Pela Figura 5.4.2 é possível perceber que o aumento na dosagem de ozônio aplicada não levou a uma significativa redução nos valores de turbidez da água ozonizada.

\subsection{APRESENTAÇÃO E ANÁLISE DOS RESULTADOS DE CONTAGEM DE PARTÍCULAS E CONTAGEM DE BACTÉRIAS HETEROTRÓFICAS}

Os valores mínimo, médio, máximo e desvio padrão dos resultados das análises de contagem de partículas $\geq 2,0 \mu \mathrm{m}$, contagem de partículas entre $1,2 \mu \mathrm{m}$ e 2,0 $\mu \mathrm{m}$ e contagem de bactérias heterotróficas encontram-se nas Tabelas 5.5.1, 5.5.2 e 5.5.3.

As porcentagens de remoção do número de partículas $\geq 2,0 \mu \mathrm{m}$ estão indicadas na Tabelas 5.5.4. Para o número de partículas entre 1,2 $\mu \mathrm{m}$ e 2,0 $\mu \mathrm{m}$, houve um aumento ao invés de uma redução (com exceção das amostras do REAF), conforme discriminado na Tabela 5.5.5. 
Tabela 5.5.1 - Valores mínimo, médio, máximo e desvio padrão do número de partículas $\geq 2,0 \mu \mathrm{m}$.

\begin{tabular}{cccccccc}
\hline & \multicolumn{7}{c}{ Número de partículas $\geq 2,0 \mu \mathrm{m}$} \\
\cline { 2 - 8 } Valores & $\begin{array}{c}\text { Água } \\
\text { bruta }\end{array}$ & REAF & REAO & F1 & F2 & F3 & F4 \\
\hline Mínimo & 3.897 & 17 & 11 & 12 & 18 & 3 & 11 \\
Médio* & 16.421 & 404 & 175 & 141 & 193 & 125 & 203 \\
Máximo & 37.960 & 1.886 & 1.345 & 1.870 & 3.792 & 1.682 & 2.225 \\
Desvio Padrão & 7.040 & 253 & 220 & 224 & 511 & 204 & 293 \\
\hline
\end{tabular}

*: Valores médios obtidos a partir dos dados do APÊNDICE D.

Tabela 5.5.2 - Valores mínimo, médio, máximo e desvio padrão do número de partículas entre 1,2 $\mu \mathrm{m}$ e $2,0 \mu \mathrm{m}$.

\begin{tabular}{cccccccc}
\hline & \multicolumn{7}{c}{ Número de partículas entre 1,2 $\mu \mathrm{m}$ e 2,0 $\mu \mathrm{m}$} \\
\cline { 2 - 8 } Valores & $\begin{array}{c}\text { Água } \\
\text { bruta }\end{array}$ & REAF & REAO & F1 & F2 & F3 & F4 \\
\hline Mínimo & 8.338 & 71 & 112 & 57 & 80 & 33 & 66 \\
Médio* & 25.891 & 2.552 & 3.426 & 3.412 & 4.869 & 2.978 & 4.150 \\
Máximo & 284.808 & 10.013 & 20.787 & 40.795 & 100.019 & 16.123 & 62.788 \\
Desvio Padrão & 26.453 & 2.021 & 2.950 & 4.146 & 9.750 & 2.583 & 6.267 \\
\hline
\end{tabular}

*: Valores médios obtidos a partir dos dados do APÊNDICE D.

Tabela 5.5.3 - Valores mínimo, médio, máximo e desvio padrão da contagem de bactérias heterotróficas.

\begin{tabular}{ccccccc}
\hline \multirow{2}{*}{ Valores } & \multicolumn{6}{c}{ Contagem de bactérias heterotróficas (UFC/mL) } \\
\cline { 2 - 6 } & REAF & REAO & F1 & F2 & F3 & F4 \\
\hline Mínimo & 0 & 0 & 0 & 1 & 0 & 0 \\
Médio* & 2 & 15 & 537 & 485 & 95 & 170 \\
Máximo & 40 & 260 & 1.300 & 1.900 & 1.000 & 2.000 \\
Desvio Padrão & 9 & 60 & 454 & 493 & 230 & 483 \\
\hline
\end{tabular}

*: Valores médios obtidos a partir dos dados do APÊNDICE D. 
Tabela 5.5.4 - Valores mínimo, médio, máximo e desvio padrão da porcentagem de remoção do número de partículas $\geq 2,0 \mu \mathrm{m}$.

\begin{tabular}{ccccccc}
\hline \multirow{2}{*}{ Valores } & \multicolumn{5}{c}{ Porcentagem de remoção do número de partículas $\geq \mathbf{2 , 0} \boldsymbol{\mu m}$ (\%) } \\
\cline { 2 - 7 } & REAF & REAO & F1 & F2 & F3 & F4 \\
\hline Mínimo & 86,6 & 7,7 & 2,4 & 0,3 & 0,1 & 2,6 \\
Médio* & 97,5 & 66,2 & 48,4 & 44,3 & 74,9 & 68,6 \\
Máximo & 99,7 & 95,1 & 94,8 & 93,2 & 98,8 & 96,1 \\
Desvio Padrão & 1,4 & 21,5 & 25,1 & 27,9 & 18,3 & 20,8 \\
\hline
\end{tabular}

*: Valores médios obtidos a partir dos dados do APÊNDICE D.

Tabela 5.5.5 - Valores mínimo, médio, máximo e desvio padrão da porcentagem do aumento do número de partículas entre $1,2 \mu \mathrm{m}$ e $2,0 \mu \mathrm{m}$.

\begin{tabular}{ccccccc}
\hline \multirow{2}{*}{ Valores } & \multicolumn{5}{c}{ Porcentagem de aumento do número de partículas entre $\mathbf{1 , 2} \boldsymbol{\mu m}$ e 2,0 $\boldsymbol{\mu m}(\%)$} \\
\cline { 2 - 7 } & REAF (a) & REAO & F1 & F2 & F3 & F4 \\
\hline Mínimo & 50,1 & 0,2 & 3,3 & 4,7 & 0,3 & 5,7 \\
Médio* & 89,0 & 45,4 & 30,0 & 35,5 & 37,0 & 45,1 \\
Máximo & 99,1 & 90,9 & 84,9 & 88,4 & 90,8 & 93,5 \\
Desvio Padrão & 7,9 & 27,8 & 18,1 & 19,4 & 20,7 & 25,0 \\
\hline
\end{tabular}

(a): Valores referentes à remoção.

*: Valores médios obtidos a partir dos dados do APÊNDICE C.

Os valores do número de partículas $\geq 2,0 \mu \mathrm{m}$ na água do REAF (média de 404 partículas $/ \mathrm{mL}$ ) foram superiores aos da água do REAO (média de 175 partículas $/ \mathrm{mL}) ;$ ao contrário dos valores do número de partículas entre 1,2 $\mu \mathrm{m}$ e 2,0 $\mu \mathrm{m}$, que foram inferiores (média de 2.552 partículas $/ \mathrm{mL}$ contra 3.426 partículas $/ \mathrm{mL}$ ), assim como seus valores de $\mathrm{CBH}$, isto é, média de $2 \mathrm{UFC} / \mathrm{mL}$ versus $15 \mathrm{UFC} / \mathrm{mL}$ (Tabelas 5.5.1, 5.5.2 e 5.5.3).

Comparando-se os filtros alimentados com água ozonizada (F2 e F1) observa-se que tanto os valores do número de partículas $\geq 2,0 \mu \mathrm{m}$, quanto os valores do número de partículas entre 1,2 $\mu \mathrm{m}$ e 2,0 $\mu \mathrm{m}$, foram superiores na água efluente do filtro de CAG vegetal (193 partículas $/ \mathrm{mL}$ versus 141 partículas $/ \mathrm{mL}$ e 4.869 partículas $/ \mathrm{mL}$ versus 3.412 partículas $/ \mathrm{mL}$, respectivamente). No entanto, o valor médio da $\mathrm{CBH}$ na 
água efluente do filtro 1 (537 UFC/mL) foi superior ao da água efluente do filtro 2 (485 UFC/mL).

Dentre os quatro filtros, aquele que apresentou os menores valores do número de partículas, foi o alimentado com água filtrada da ETA (REAF) e CAG betuminoso (F3). Em segundo lugar, foi o CAG betuminoso alimentado com água ozonizada (F1). Os maiores valores médios da $\mathrm{CBH}$ ocorreram nas águas efluentes dos filtros 1 e 2. O que indiretamente indica a formação de um biofilme, devido à ozonização. Um aumento nos valores da $\mathrm{CBH}$, devido à ozonização, também foi verificado por Escobar e Random (2001).

O processo de tratamento da ETA ABV foi responsável por uma remoção média do $\mathrm{NP} \geq 2,0 \mu \mathrm{m}$ igual a $97,5 \%$ e um pouco menor ( $89 \%$ ) para o número de partículas compreendido entre 1,2 $\mu \mathrm{m}$ e 2,0 $\mu \mathrm{m}$, como mostram os valores apresentados nas Tabelas 5.5.4 e 5.5.5. Houve uma remoção média de $48,4 \%$ no NP $\geq 2,0 \mu \mathrm{m}$ e um aumento de $30 \%$ no NP entre 1,2 $\mu \mathrm{m}$ e 2,0 $\mu \mathrm{m}$ na água efluente do filtro $1 \mathrm{em}$ relação à água do REAO. Os valores do número de partículas entre 1,2 $\mu \mathrm{m}$ e 2,0 $\mu \mathrm{m}$ no efluente do filtro 2 foram superiores aos seus valores de entrada (REAO); assim como também o NP nas águas efluentes dos filtros 3 e 4, em relação à água do REAF.

Na Figura 5.5.1 têm-se os valores do número de partículas $\geq 2,0 \mu \mathrm{m}$ ao longo do tempo para a água do REAF e REAO e na Figura 5.5.2, o NP para as águas efluentes dos filtros. Os valores do número de partículas $\geq 2,0 \mu \mathrm{m}$ para a água filtrada da ETA foram um pouco superiores aos da água filtrada ozonizada. O que significa dizer que a ozonização diminuiu os valores do número de partículas $\geq 2,0$ $\mu \mathrm{m}$.

Pela Figura 5.5.2 é possível verificar que os valores do número de partículas $\geq 2,0$ $\mu \mathrm{m}$ ao longo do tempo, para todos os filtros, mantiveram-se, preponderantemente, inferiores a 1.000 partículas/mL, mesmo após suas lavagens.

Na Figura 5.5.3 apresentam-se os valores do número de partículas entre 1,2 $\mu \mathrm{m}$ e 2,0 $\mu \mathrm{m}$, ao longo do tempo, para a água do REAF e REAO e na Figura 5.5.4, para as águas efluentes dos filtros. 


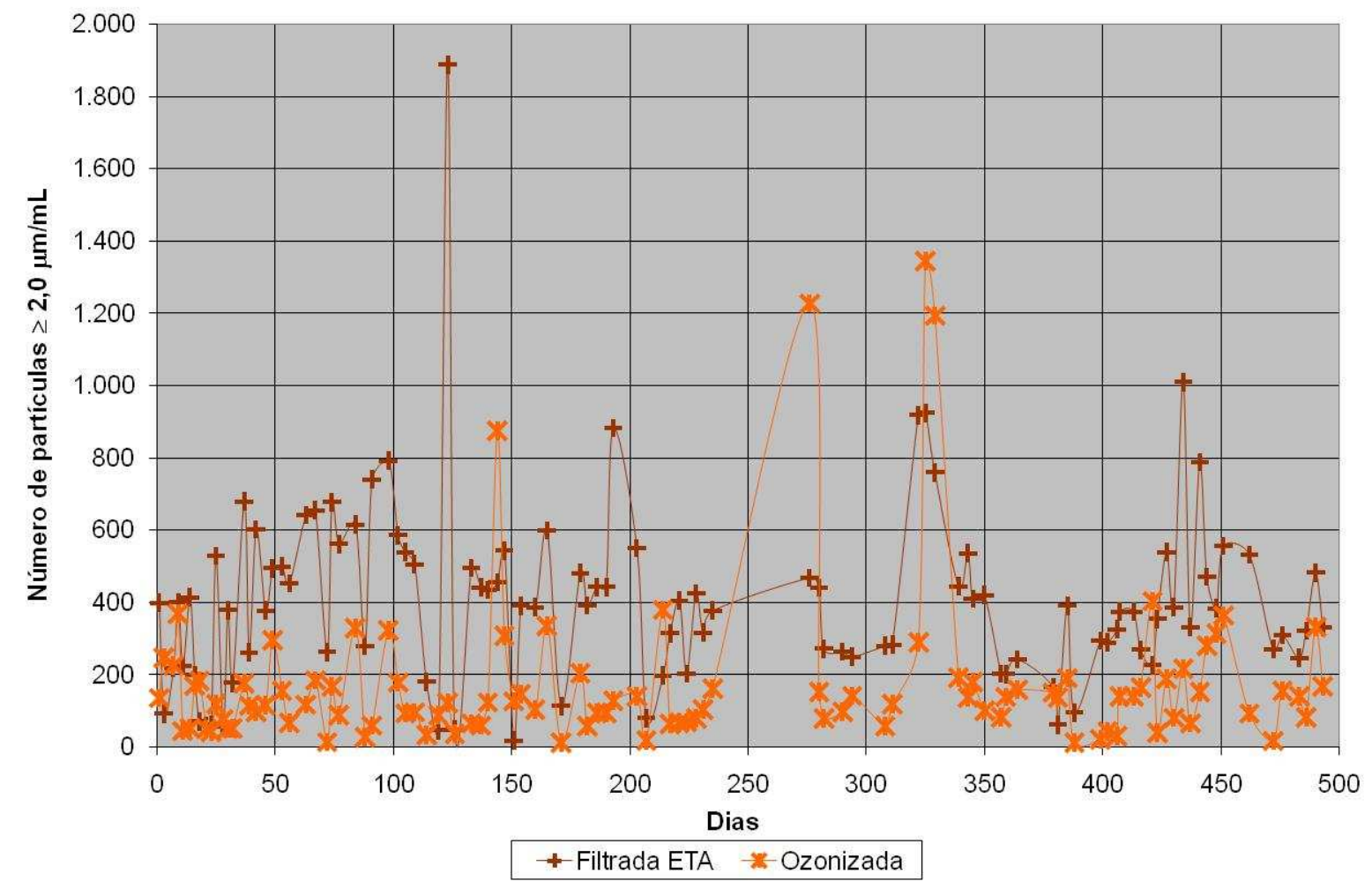

Figura 5.5.1 - Valores do número de partículas $\geq 2,0 \mu \mathrm{m}$ ao longo do tempo, para a água do REAF e REAO.

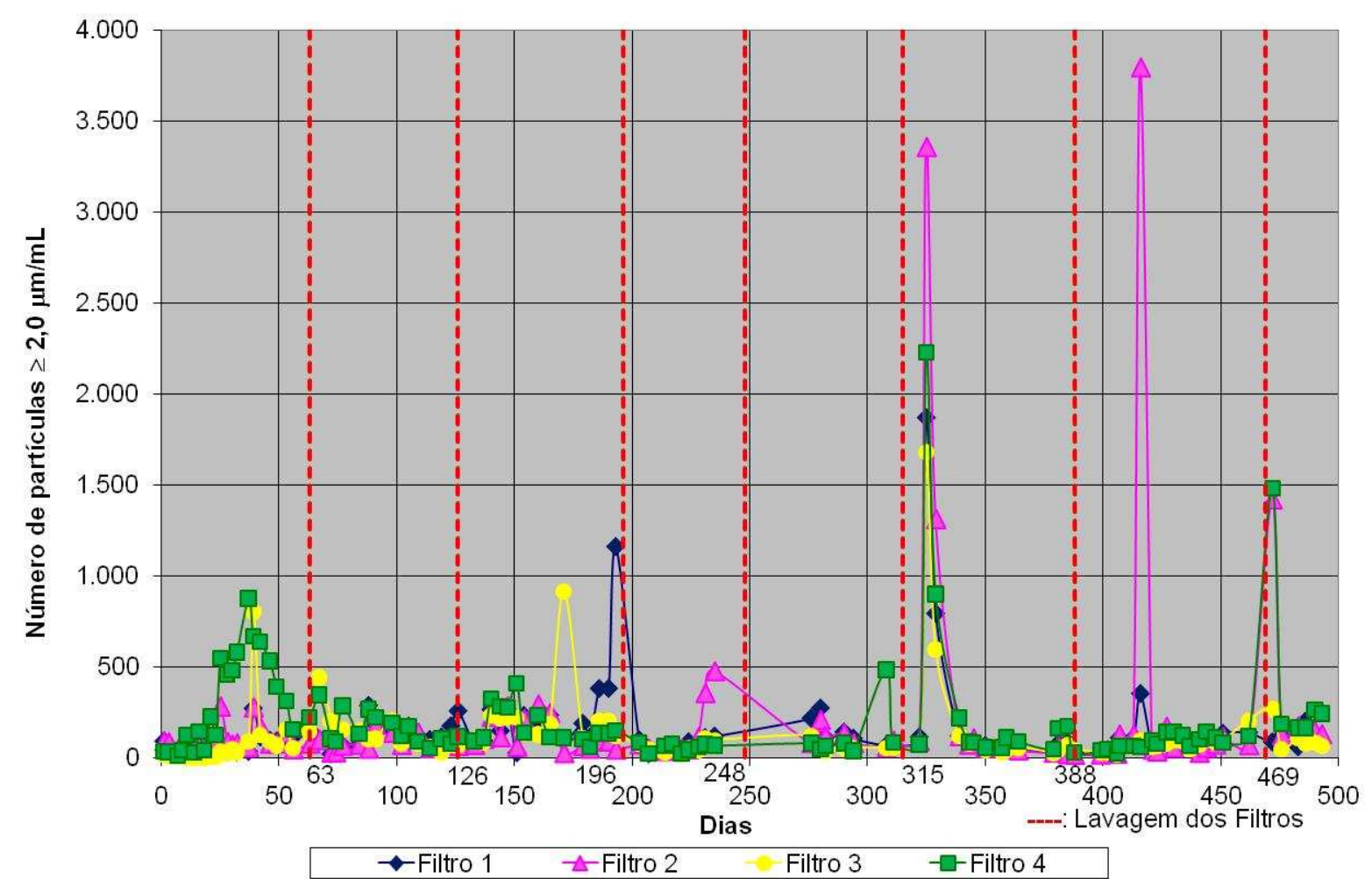

Figura 5.5.2 - Valores do número de partículas $\geq 2,0 \mu \mathrm{m}$ ao longo do tempo, para as águas efluentes dos filtros. 


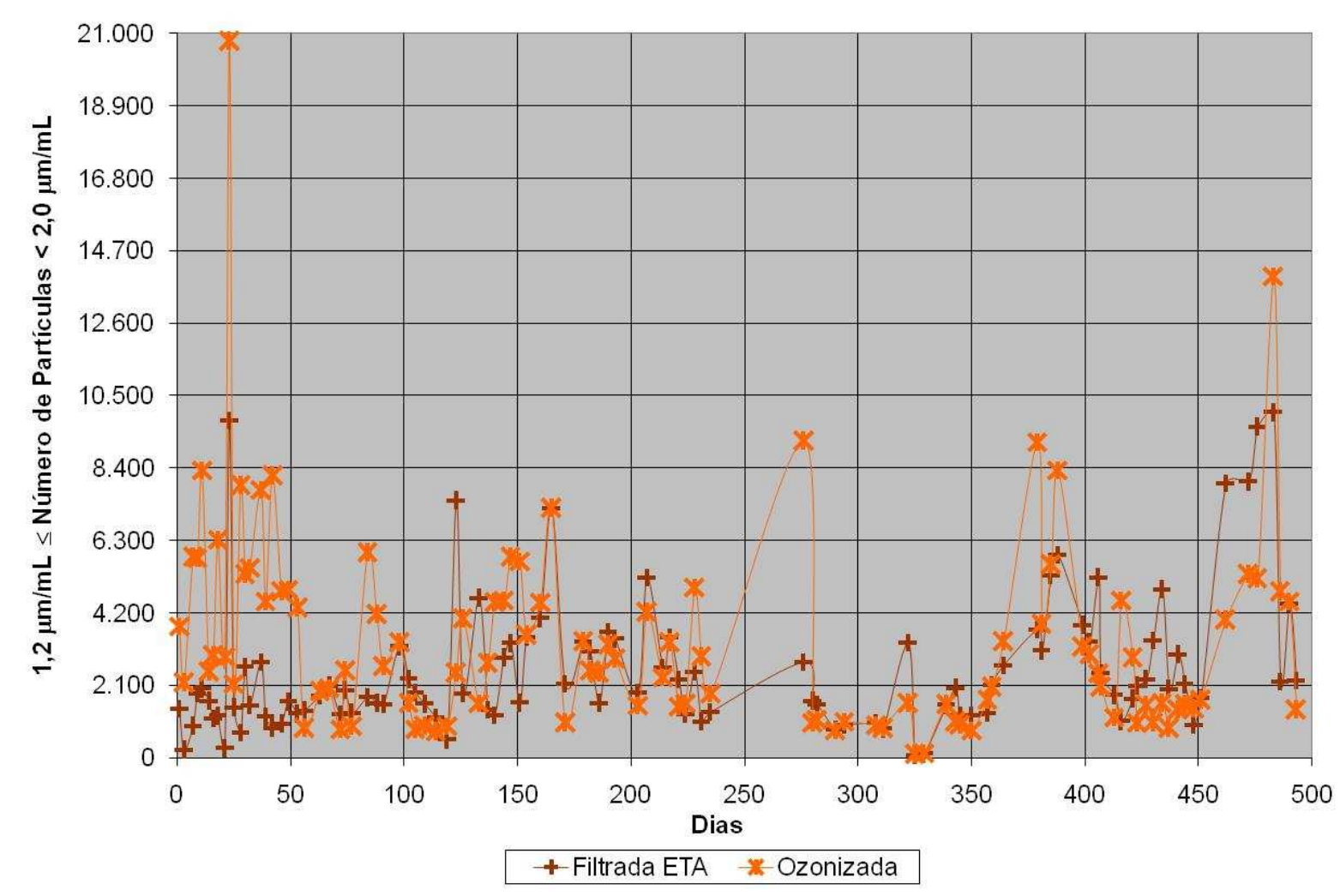

Figura 5.5.3 - Valores do número de partículas entre 1,2 $\mu \mathrm{m}$ e 2,0 $\mu \mathrm{m}$, ao longo do tempo, para a água do REAF e REAO.

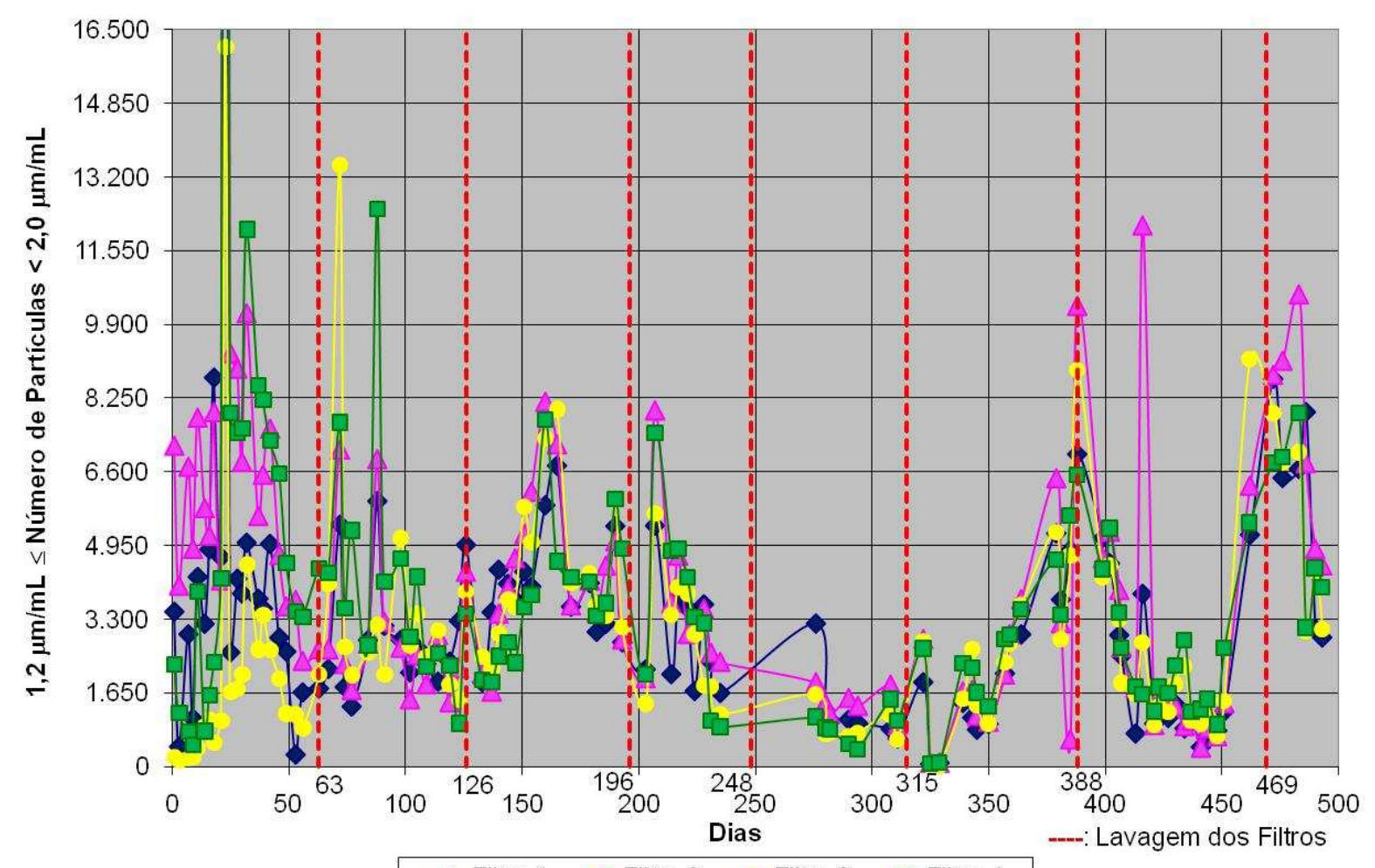

Figura 5.5.4 - Valores do número de partículas entre 1,2 $\mu \mathrm{m}$ e 2,0 $\mu \mathrm{m}$, ao longo do tempo, para as águas efluentes dos filtros. 
A Figura 5.5.3 mostra que os valores do número de partículas entre 1,2 $\mu$ m e 2,0 $\mu \mathrm{m}$, para ambas as águas (REAF e REAO), foram semelhantes, permanecendo na maioria dos casos inferiores a 10.500 partículas $/ \mathrm{mL}$. Além disso, comparando-se esta figura com a Figura 5.5.1 nota-se que o número de partículas entre 1,2 $\mu \mathrm{m}$ e 2,0 $\mu \mathrm{m}$ foi maior do que o número de partículas $\geq 2,0 \mu \mathrm{m}$, para as águas do REAF $\mathrm{e}$ REAO, fato este já verificado em literatura (AWWARF, 2000).

Segundo a Figura 5.5.4 os valores do número de partículas entre 1,2 $\mu \mathrm{m}$ e 2,0 $\mu \mathrm{m}$, para todos os filtros, permaneceram (usualmente) inferiores a 11.550 partículas $/ \mathrm{mL}$, mesmo após suas lavagens. Semelhantemente as águas do REAF e REAO, também para os filtros, o número de partículas entre 1,2 $\mu \mathrm{m}$ e 2,0 $\mu \mathrm{m}$ foi maior do que o número de partículas $\geq 2,0 \mu \mathrm{m}$.

Na Figura 5.5.5 encontram-se discriminados os valores da $\mathrm{CBH}$ ao longo do tempo para as águas do REAF, REAO e efluentes dos filtros.

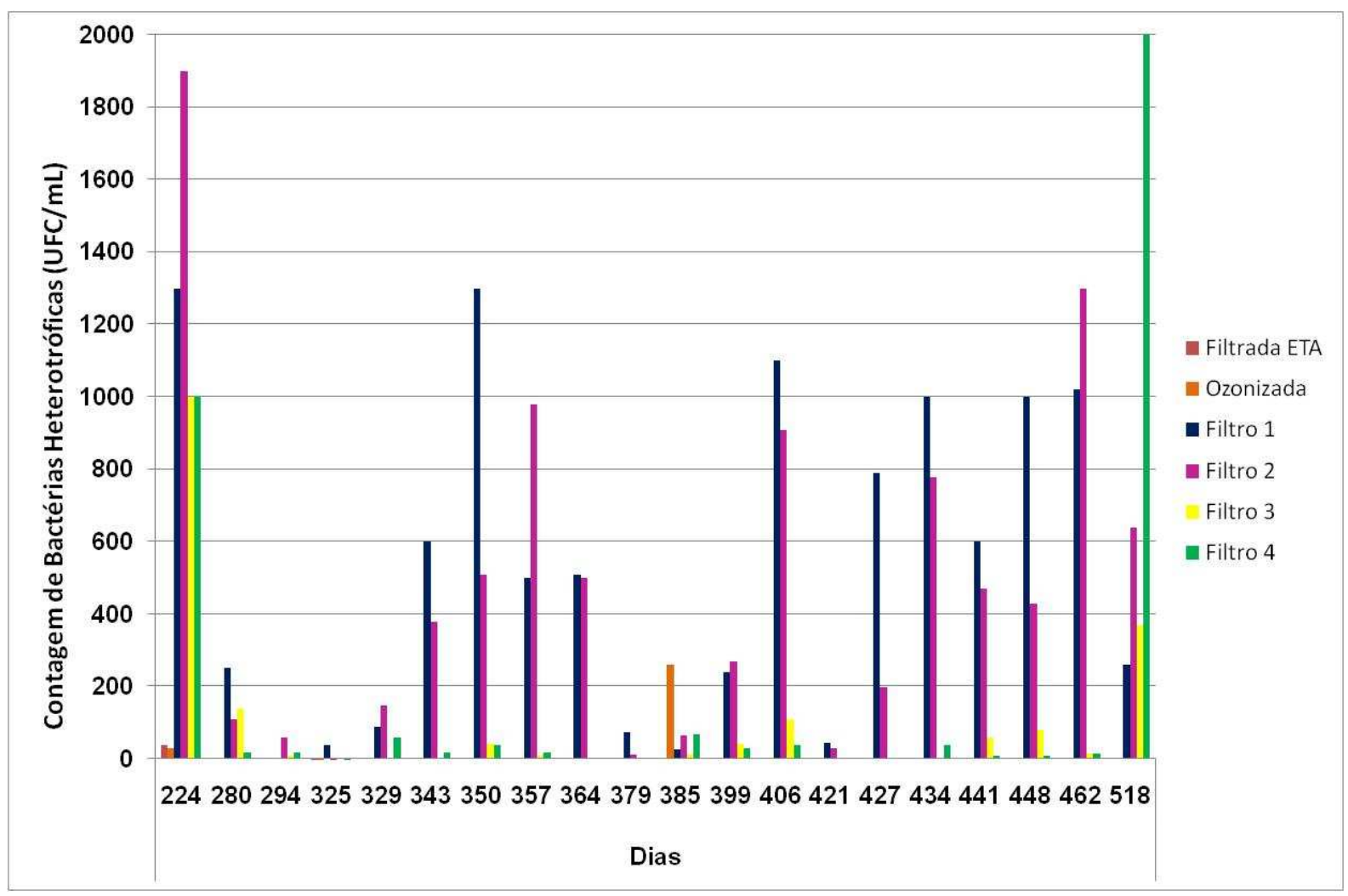

Figura 5.5.5 - Valores de $\mathrm{CBH}$, ao longo do tempo, para as águas do REAF, REAO e efluentes dos filtros. 
Os maiores valores de $\mathrm{CBH}$ foram observados nas águas efluentes dos filtros 1 e 2 , isto é, alimentados com água ozonizada; fato este justificado pela formação de biofilmes.

As Figuras 5.5 .6 e 5.5.7 relacionam os valores do número de partículas $\geq 2,0 \mu \mathrm{m}$ e entre 1,2 $\mu \mathrm{m}$ e 2,0 $\mu \mathrm{m}$, na água ozonizada, com a dosagem de ozônio aplicada.

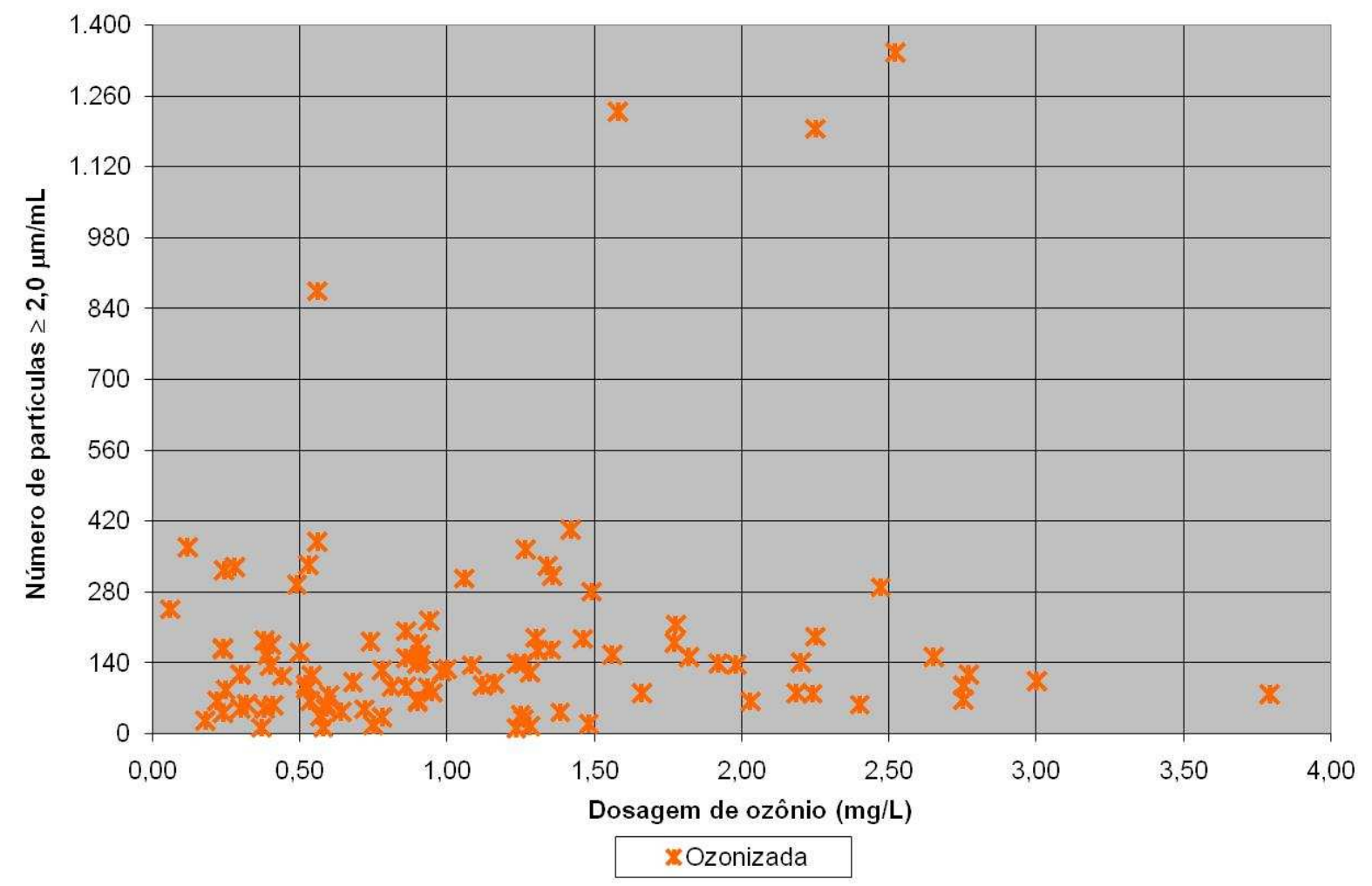

Figura 5.5.6 - Valores do número de partículas $\geq 2,0 \mu \mathrm{m}$ na água ozonizada versus dosagem de ozônio aplicada.

O aumento na dosagem de ozônio não levou a uma redução significativa no número de partículas $\geq 2,0 \mu \mathrm{m}$ (permanecendo $<420$ partículas $/ \mathrm{mL}$ ) e nem no número de partículas entre 1,2 $\mu \mathrm{m}$ e 2,0 $\mu \mathrm{m}$ (permanecendo < 10.500 partículas $/ \mathrm{mL}$ )

As Figuras 5.5 .8 e 5.5.9 relacionam, respectivamente, para as águas efluentes dos filtros, o número de partículas $\geq 2,0 \mu \mathrm{m}$ e entre 1,2 $\mu \mathrm{m}$ e 2,0 $\mu \mathrm{m}$, com a turbidez. 


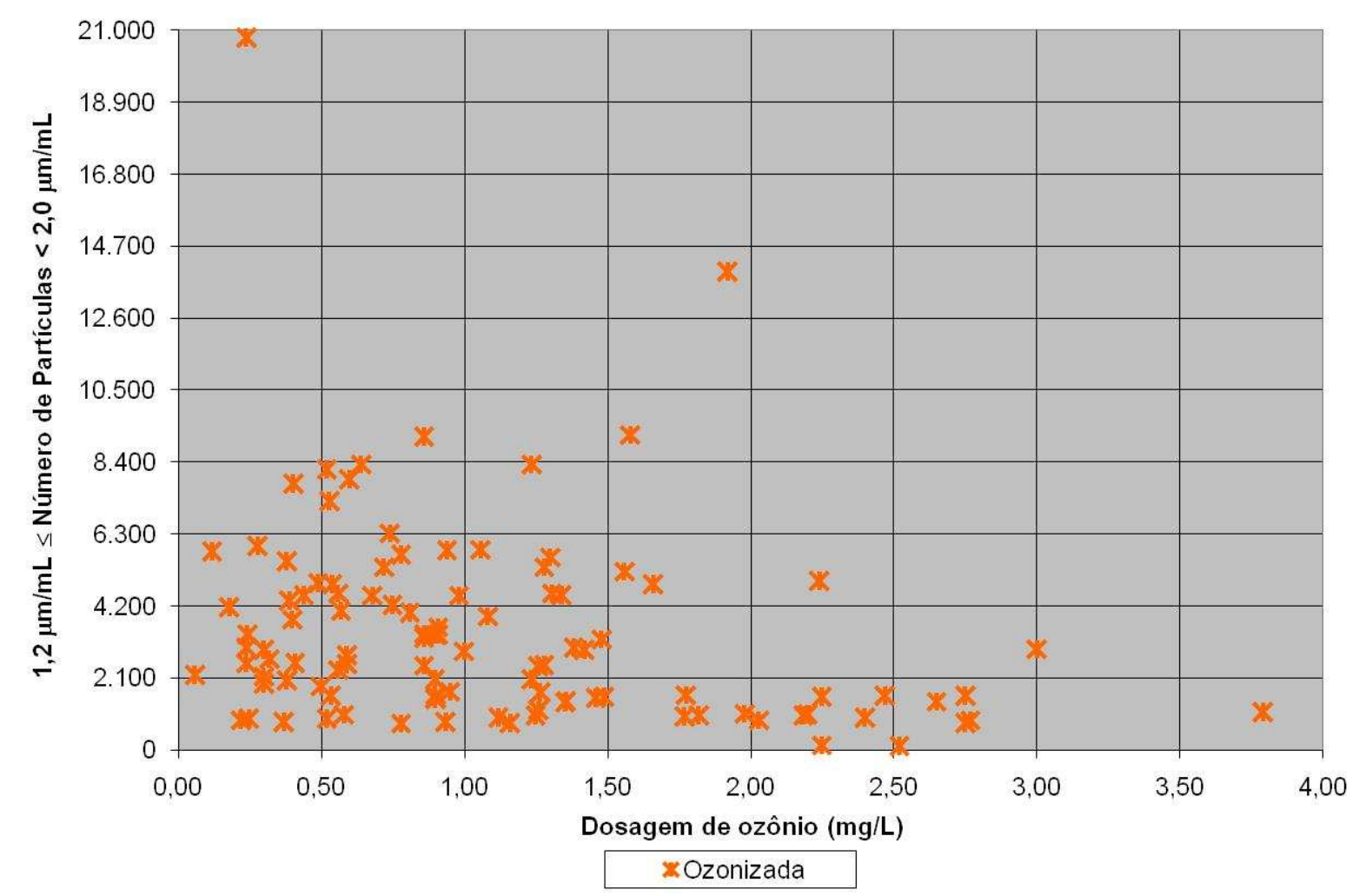

Figura 5.5.7 - Valores do número de partículas entre 1,2 $\mu \mathrm{m}$ e 2,0 $\mu \mathrm{m}$ na água ozonizada versus dosagem de ozônio aplicada.

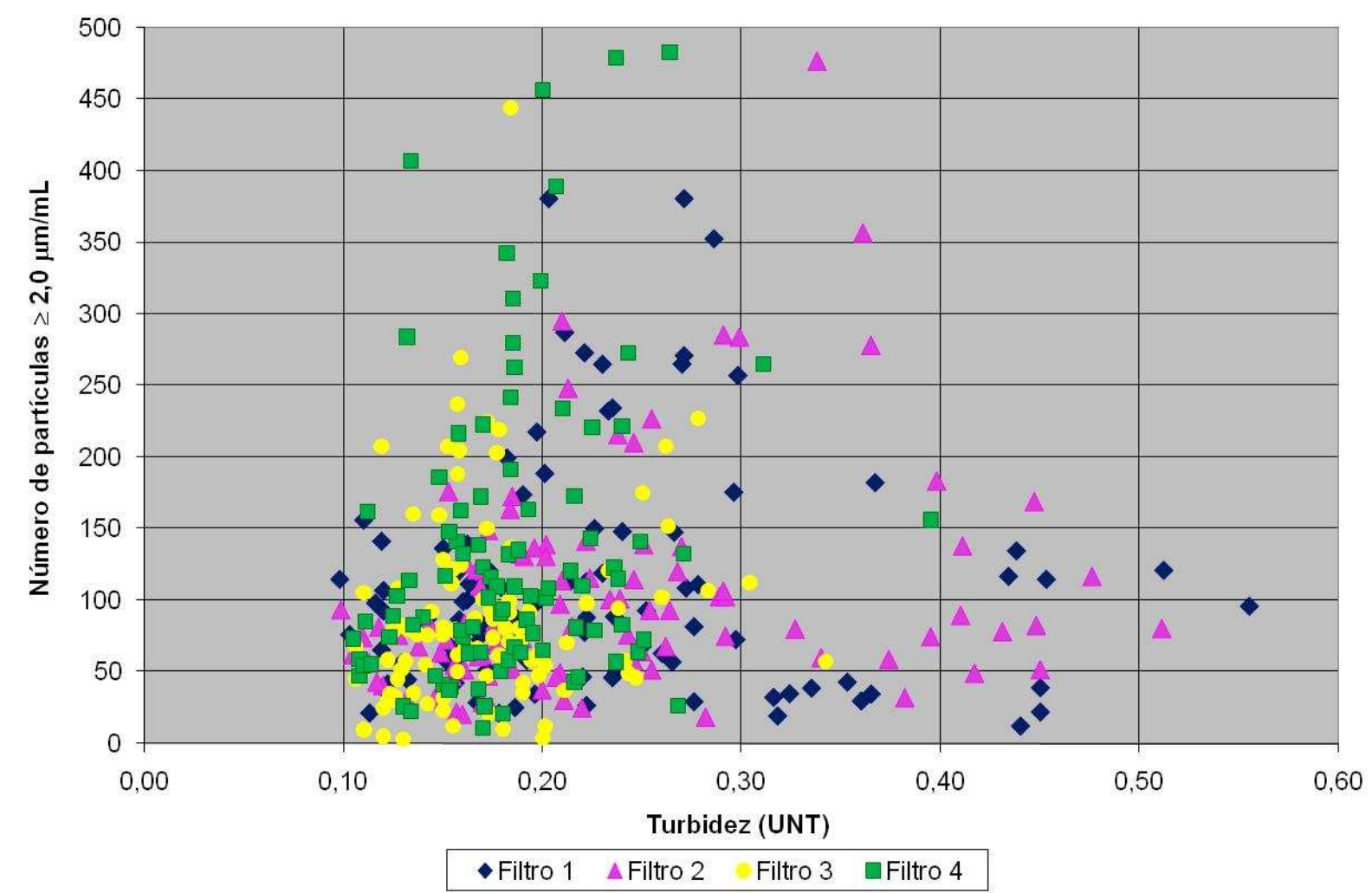

Figura 5.5.8 - Relação entre o número de partículas $\geq 2,0 \mu \mathrm{m}$ versus a turbidez, para as águas efluentes dos filtros. 
Pela Figura 5.5.8 é possível perceber que a turbidez nas águas efluentes dos filtros 1 e 2 variaram mais $(0,10$ UNT < turbidez < 0,50 UNT) do que nas águas efluentes dos filtros 3 e 4 (0,10 UNT < turbidez < 0,30 UNT) para uma mesma faixa de número de partículas (NP < 300 partículas $/ \mathrm{mL}$ ). Essa maior variação também pode ser observada para as partículas entre 1,2 $\mu \mathrm{m}$ e 2,0 $\mu \mathrm{m}$ (Figura 5.5.9); isto é, a turbidez nas águas efluentes dos filtros 1 e 2 variaram mais $(0,10$ UNT < turbidez $<0,50$ UNT) do que nas águas efluentes dos filtros 3 e 4 (0,10 UNT < turbidez < 0,30 UNT) para uma mesma faixa de número de partículas (NP $<9.000$ partículas/mL).

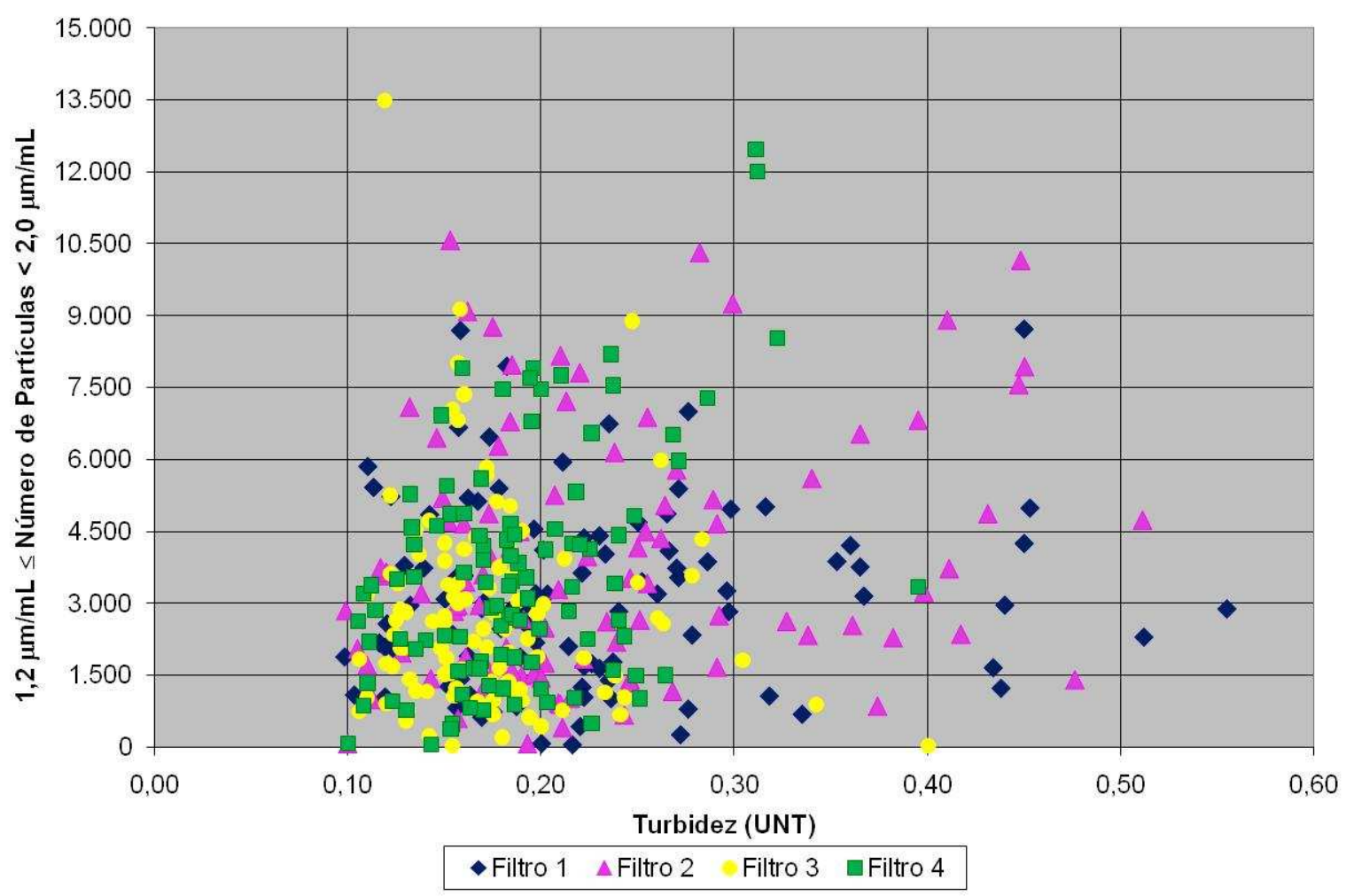

Figura 5.5.9 - Relação do número de partículas entre 1,2 $\mu \mathrm{m}$ e 2,0 $\mu \mathrm{m}$ versus a turbidez, para as águas efluentes dos filtros.

As Figuras 5.5.10 e 5.5.11 relacionam, respectivamente, os valores do número de partículas $\geq 2,0 \mu \mathrm{m}$ e entre 1,2 $\mu \mathrm{m}$ e 2,0 $\mu \mathrm{m}$ na entrada dos filtros, com os seus valores de saída. 


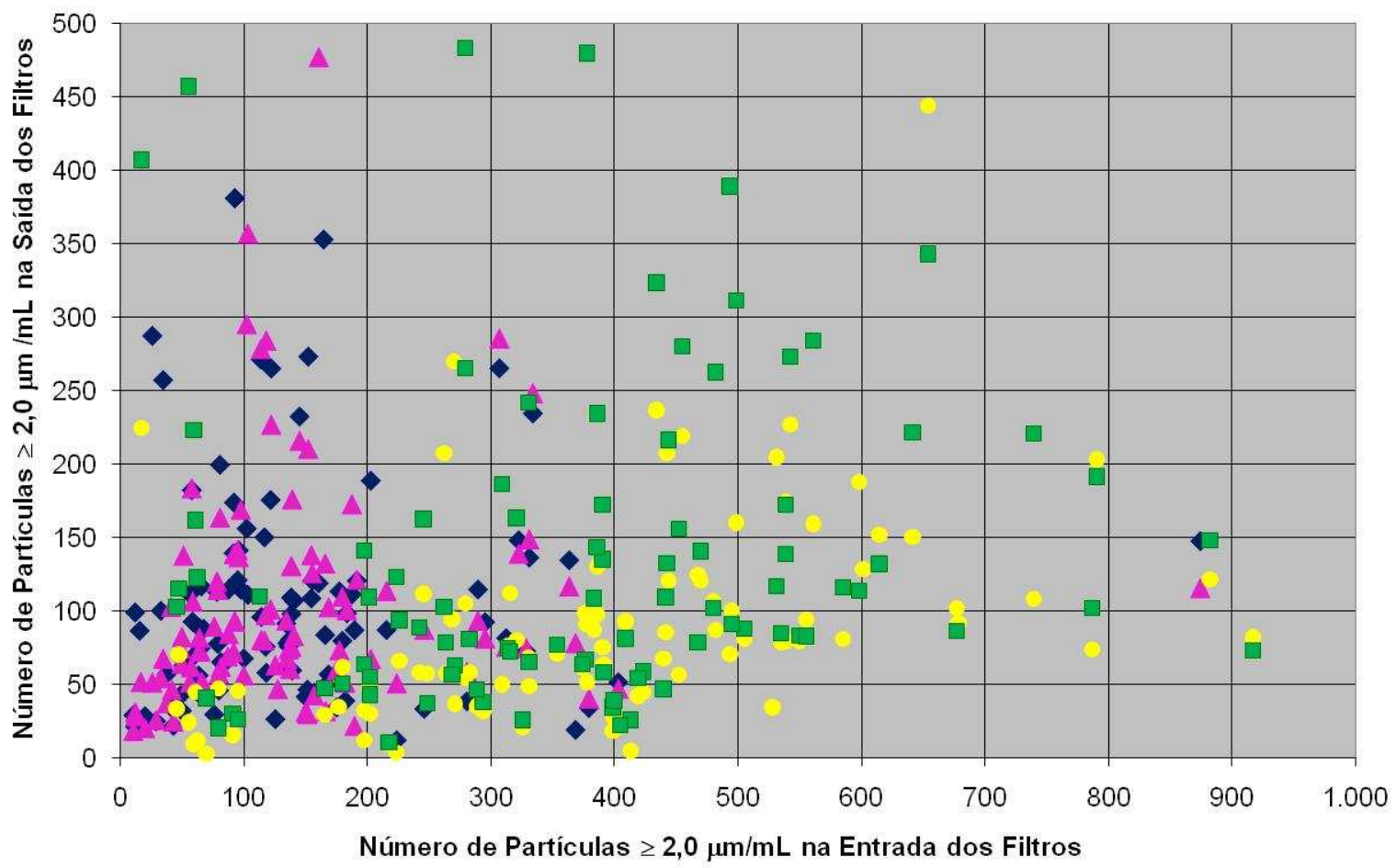

$\begin{array}{rlll}\bullet \text { Filtro } 1 & \Delta \text { Filtro } 2 & \text { Filtro } 3 & \text { afiltro } 4\end{array}$

Figura 5.5.10 - Valores do número de partículas $\geq 2,0 \mu \mathrm{m}$ na entrada versus saída dos filtros.

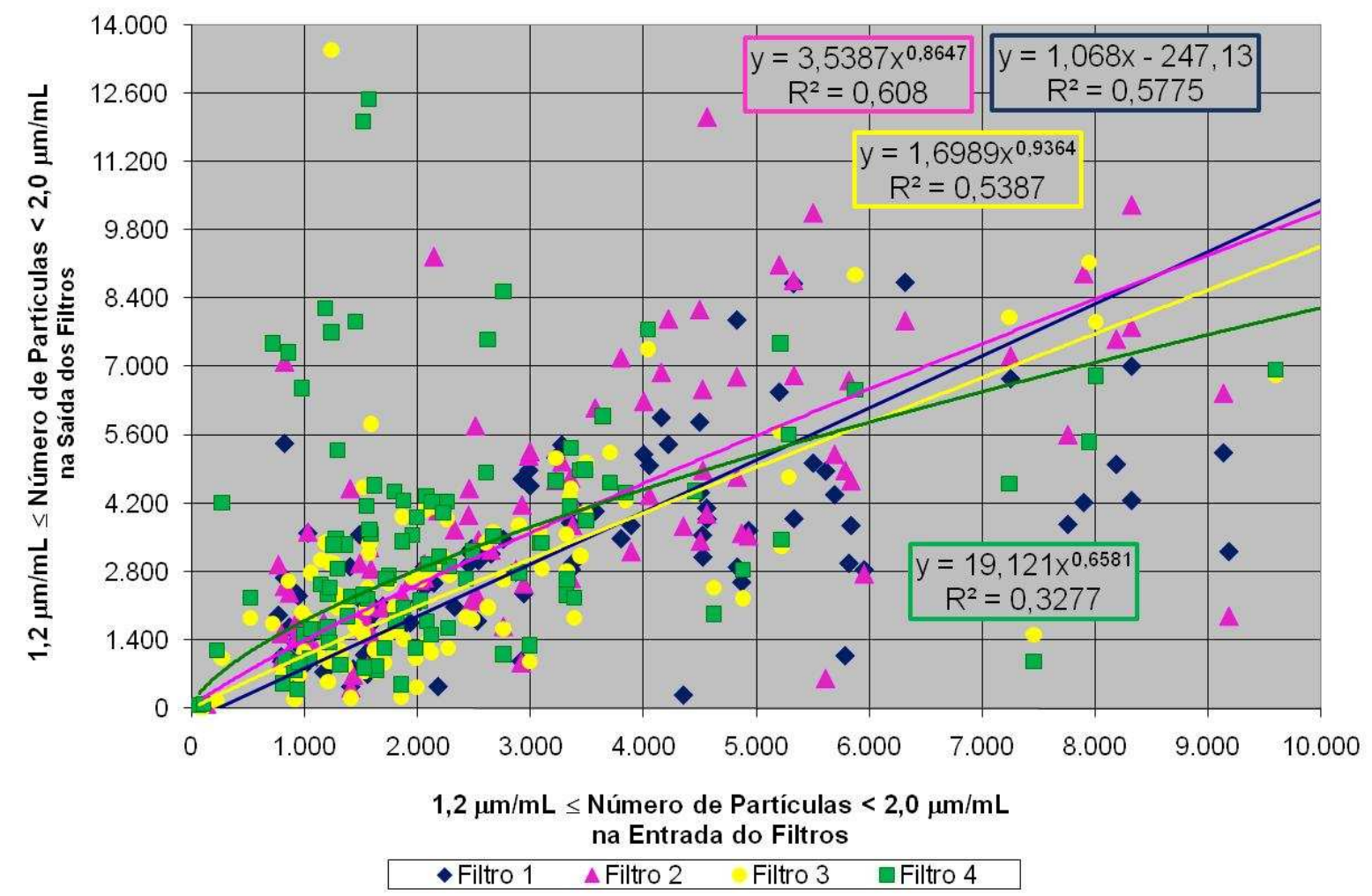

Figura 5.5.11 - Valores do número de partículas entre 1,2 $\mu \mathrm{m}$ e 2,0 $\mu \mathrm{m}$ na entrada versus saída dos filtros. 
Através da Figura 5.5.10 é possível observar que, embora o número de partículas na entrada dos filtros 1 e 2 (água ozonizada) tenha sido menor (NP $<400$ partículas $/ \mathrm{mL}$ ) do que o número de partículas na entrada dos filtros 3 e 4 (água filtrada da ETA), isto é, NP < 900 partículas $/ \mathrm{mL}$, as águas efluentes de todos os filtros apresentaram um NP $<500$ partículas $/ \mathrm{mL}$.

Já com relação à Figura 5.5.11, aumentando-se o número de partículas, entre 1,2 $\mu \mathrm{m}$ e 2,0 $\mu \mathrm{m}$ na entrada dos filtros, o número de partículas efluente dos filtros também aumentou; sendo este aumento mais significativo para os filtros alimentados com água ozonizada (F1 e F2).

A Figura 5.5.12 apresenta, para as águas efluentes dos filtros, a relação entre o número de partículas $\geq 2,0 \mu \mathrm{m}$ e o número de partículas entre 1,2 $\mu \mathrm{m}$ e 2,0 $\mu \mathrm{m}$; e as Figuras 5.5 .13 e 5.5.14 indicam, também para as águas efluentes dos filtros, respectivamente, a relação dos valores de COT com o número de partículas $\geq 2,0$ $\mu \mathrm{m}$, e o número de partículas entre 1,2 $\mu \mathrm{m}$ e 2,0 $\mu \mathrm{m}$.

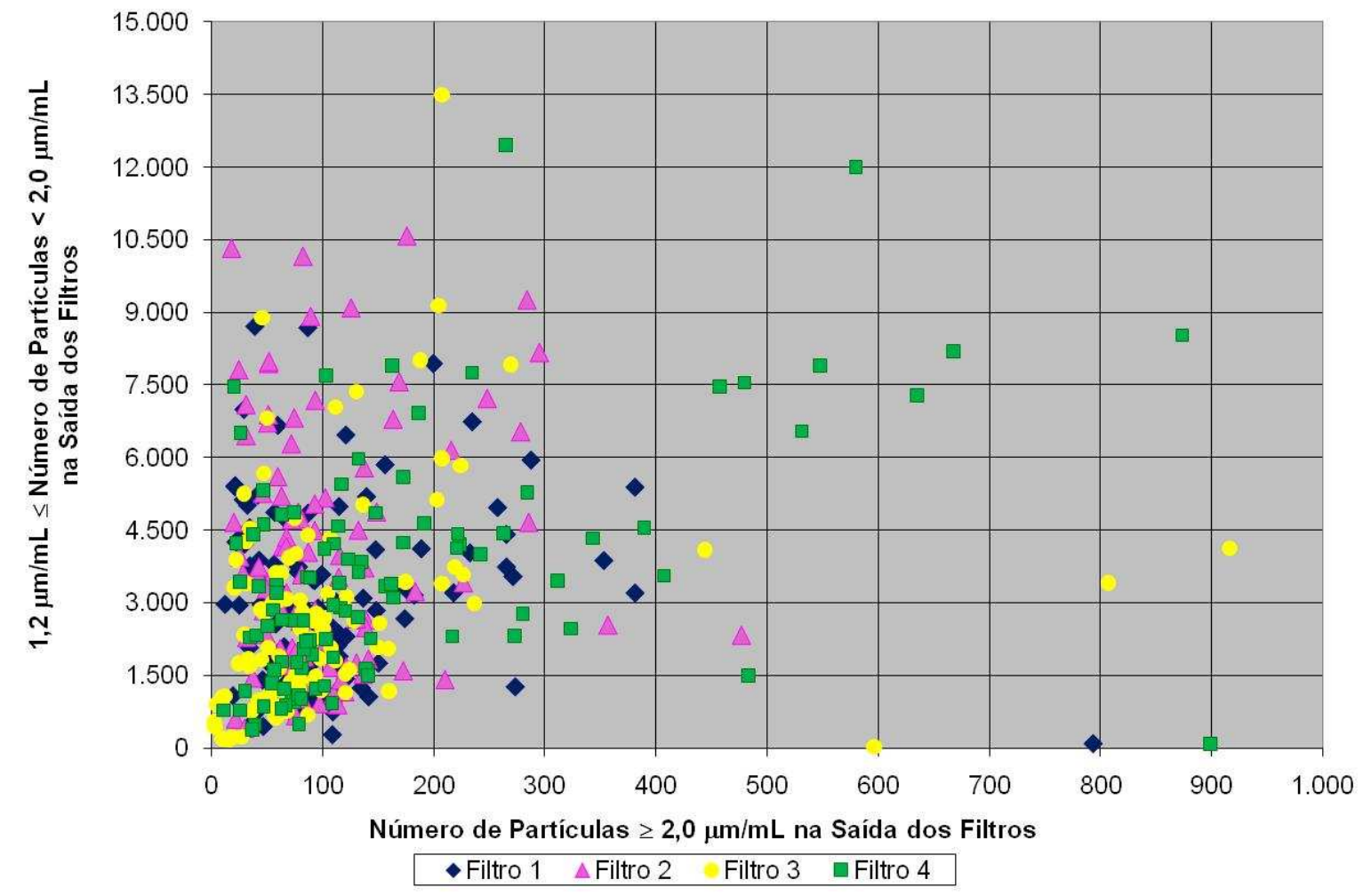

Figura 5.5.12 - Valores do número de partículas entre 1,2 $\mu \mathrm{m}$ e 2,0 $\mu \mathrm{m}$ versus o número de partículas $\geq 2,0 \mu \mathrm{m}$, nas águas efluentes dos filtros. 


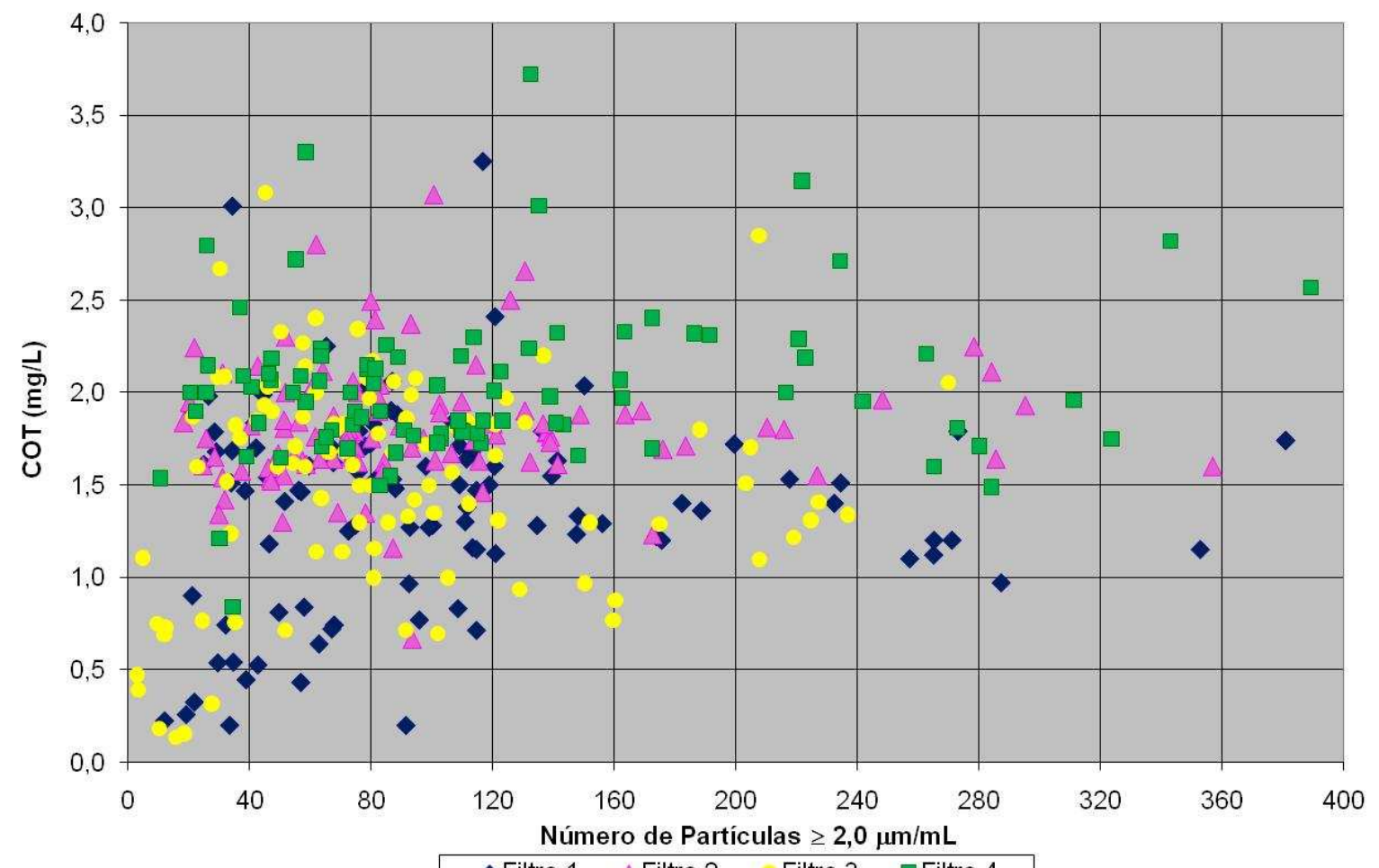

$\begin{array}{llll}\text { - Filtro } 1 \Delta \text { Filtro } 2 & \text { Filtro } 3 & \square \text { Filtro } 4\end{array}$

Figura 5.5.13 - Valores de COT versus o número de partículas $\geq 2,0 \mu \mathrm{m}$, nas águas efluentes dos filtros.

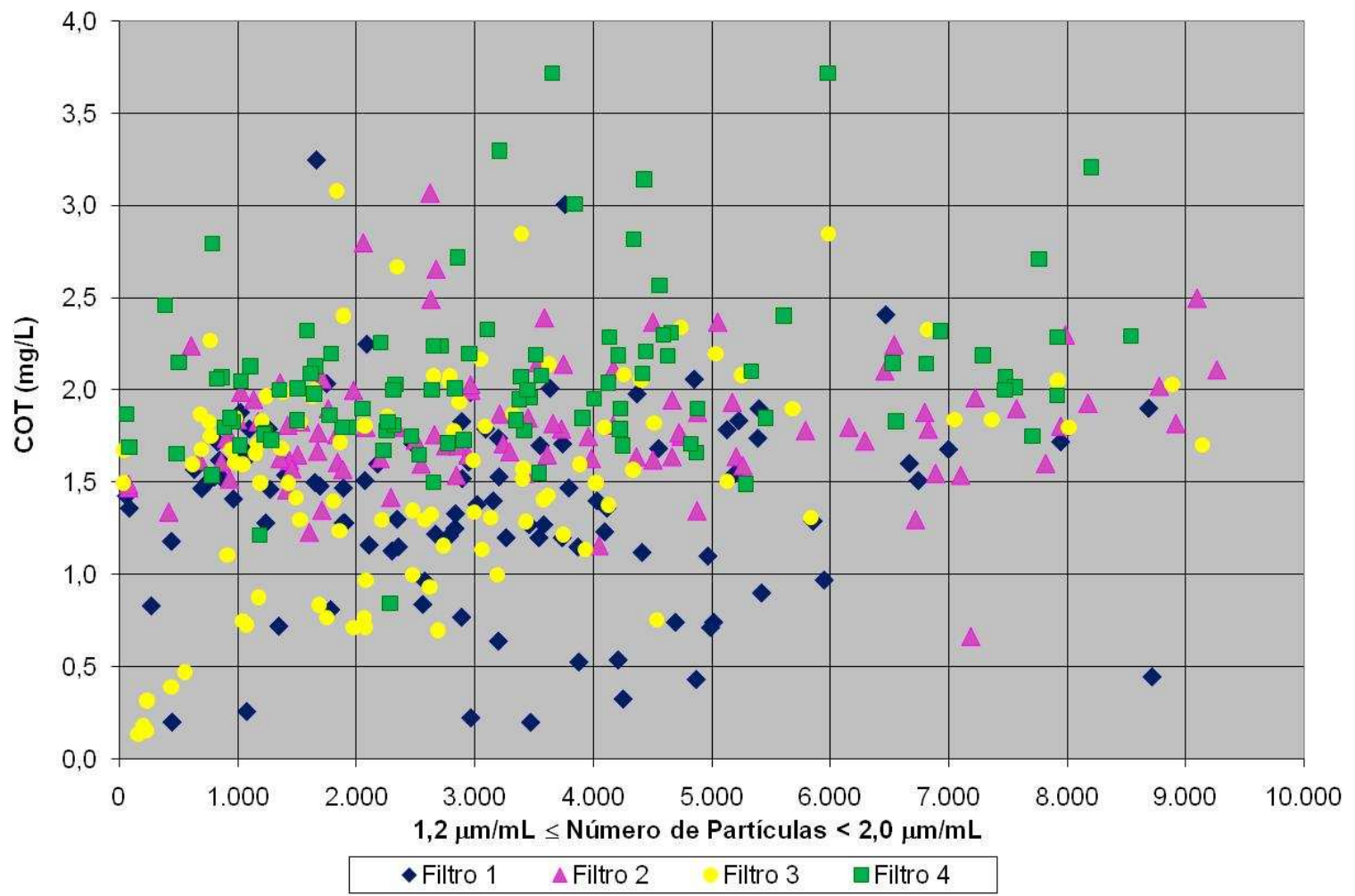

Figura 5.5.14 - Valores de COT versus o número de partículas entre 1,2 $\mu \mathrm{m}$ e 2,0 $\mu \mathrm{m}$, nas águas efluentes dos filtros. 
Segundo as Figuras 5.5.12, 5.5 .13 e 5.5.14 não foi possível estabelecer, para as águas efluentes dos filtros, uma correlação entre: o número de partículas $\geq 2,0 \mu \mathrm{m}$ e o número de partículas entre $1,2 \mu \mathrm{m}$ e $2,0 \mu \mathrm{m}$; os valores do número de partículas $\geq$ 2,0 $\mu \mathrm{m}$ e os valores de COT e; o número de partículas entre 1,2 $\mu \mathrm{m}$ e 2,0 $\mu \mathrm{m}$ e os valores de COT.

Pela Figura 5.5.12 é possível observar que, nas águas efluentes dos filtros, a maior parte do número de partículas $\geq 2,0 \mu \mathrm{m}$ manteve-se abaixo de 400 partículas $/ \mathrm{mL}$, enquanto que o número de partículas entre 1,2 $\mu \mathrm{m}$ e 2,0 $\mu \mathrm{m}$ permaneceu inferior a 10.500 partículas $/ \mathrm{mL}$.

Os valores de COT, nas águas efluentes dos filtros, permaneceram, na maioria dos casos, entre 1,0 e 2,5 mg/L, independentemente do número de partículas, de acordo com as Figuras 5.5.13 e 5.5.14.

Nas Figuras 5.5.15 e 5.5.16 estão indicadas as porcentagens de remoção do número de partículas $\geq 2,0 \mu \mathrm{m}$ e entre $1,2 \mu \mathrm{m}$ e $2,0 \mu \mathrm{m}$, alcançadas nos filtros. Notase que para valores inferiores a 1.000 partículas $/ \mathrm{mL}$ (Figura 5.5.15), a porcentagem de remoção variou de 0 a 100 \%, não sendo possível estabelecer uma correlação entre os dados. Para as partículas entre 1,2 $\mu \mathrm{m}$ e 2,0 $\mu \mathrm{m}$ (Figura 5.5.16), a porcentagem de remoção também variou de 0 a $100 \%$, para valores inferiores a 10.500 partículas/mL; também não sendo possível estabelecer uma correlação.

As relações entre a perda de carga e o número de partículas nos filtros encontramse discriminadas nas Figuras 5.5.17 e 5.5.18. Independentemente do número de partículas, a perda de carga nos filtros alimentados com água ozonizada permaneceu inferior a $60 \mathrm{~cm}$ (F1 e F2). O filtro de CAG vegetal alimentado com água filtrada da ETA manteve a sua perda de carga inferior a $150 \mathrm{~cm}(\mathrm{~F} 4)$ e o filtro de CAG betuminoso (F3) foi o que apresentou a maior variação (inferior a $300 \mathrm{~cm}$ ). 


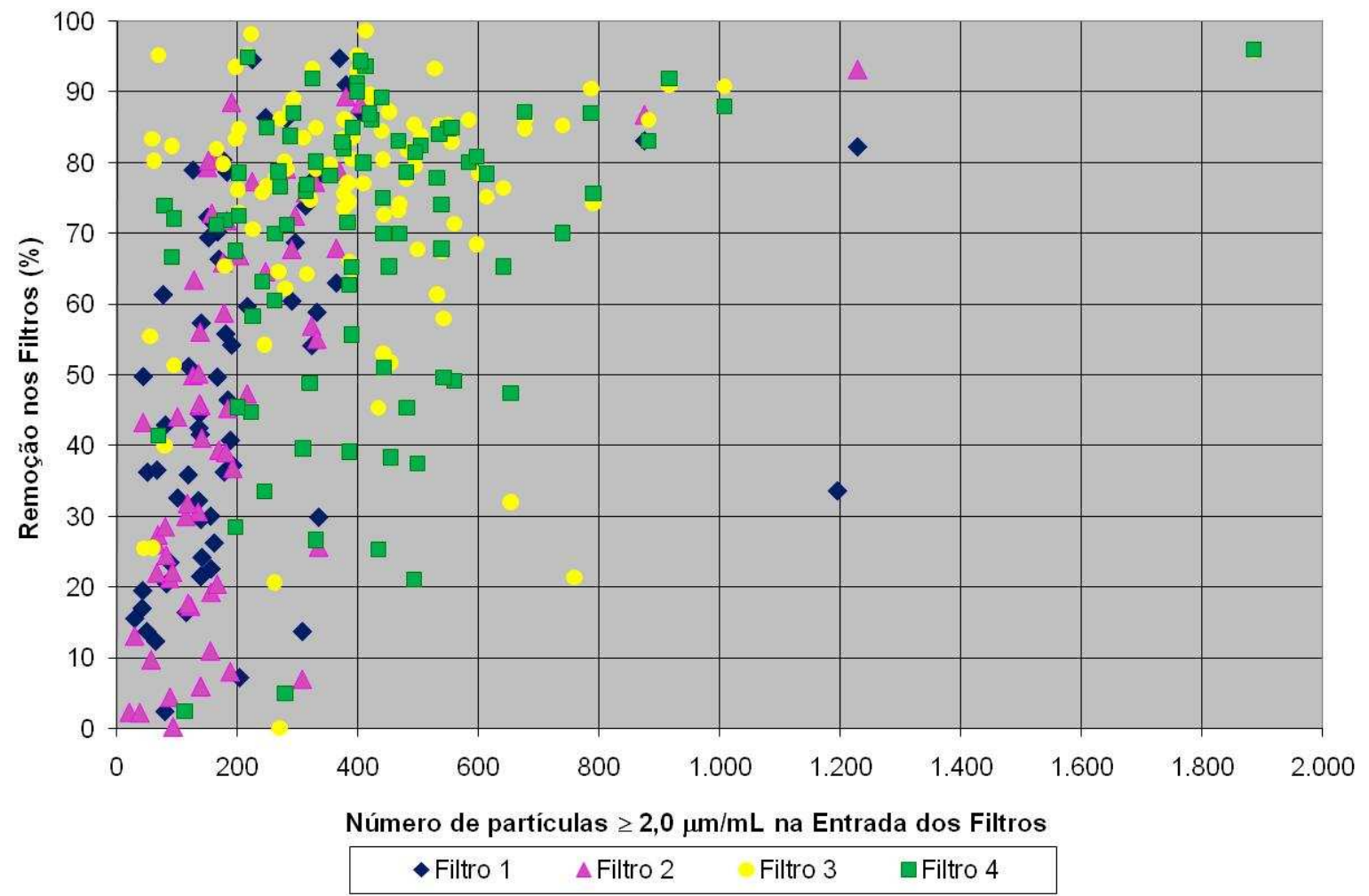

Figura 5.5.15 - Porcentagem de remoção nos filtros, do número de partículas $\geq 2,0 \mu \mathrm{m}$.

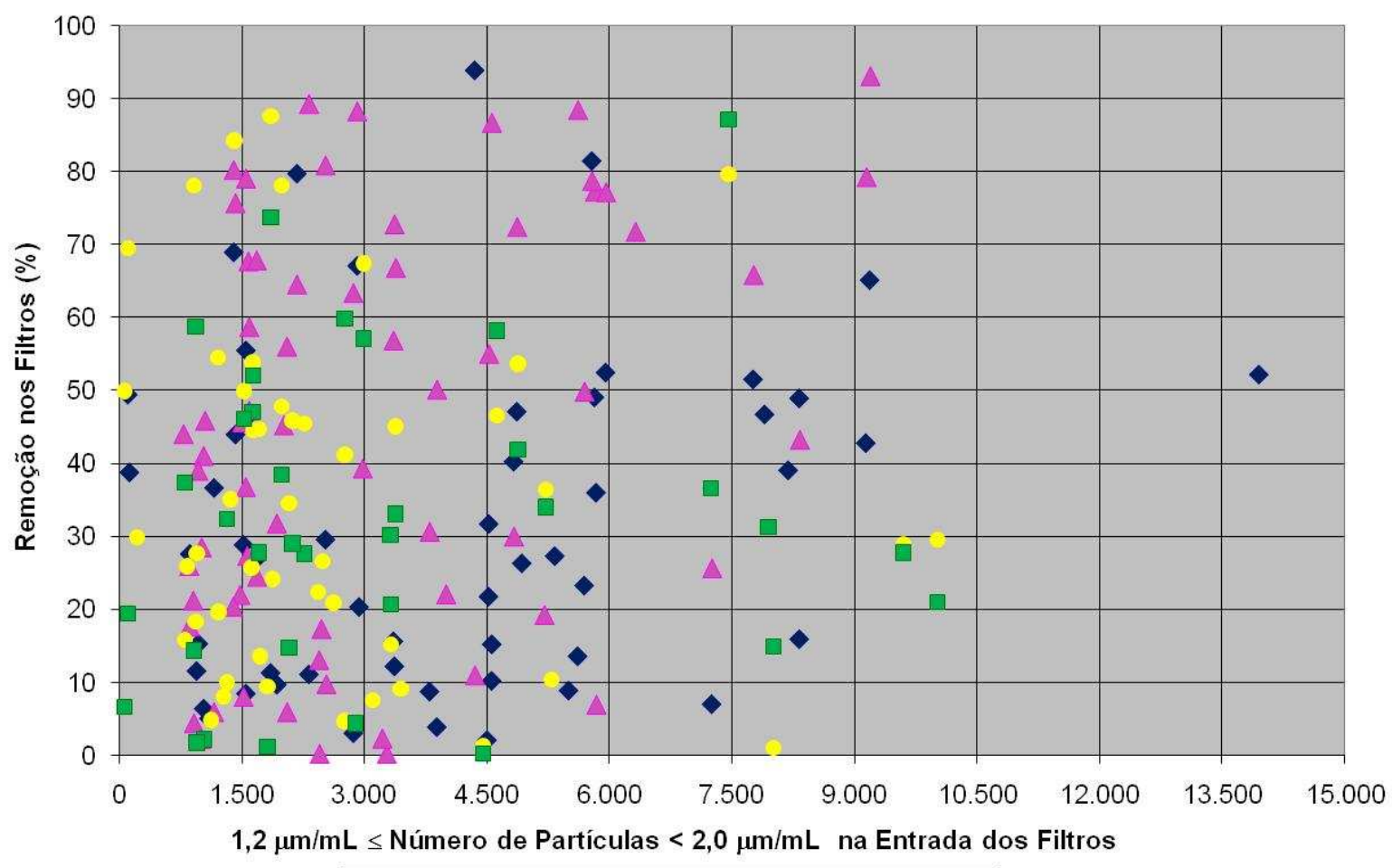

Figura 5.5.16 - Porcentagem de remoção nos filtros, do número de partículas entre 1,2 $\mu \mathrm{m}$ e 2,0 $\mu \mathrm{m}$. 


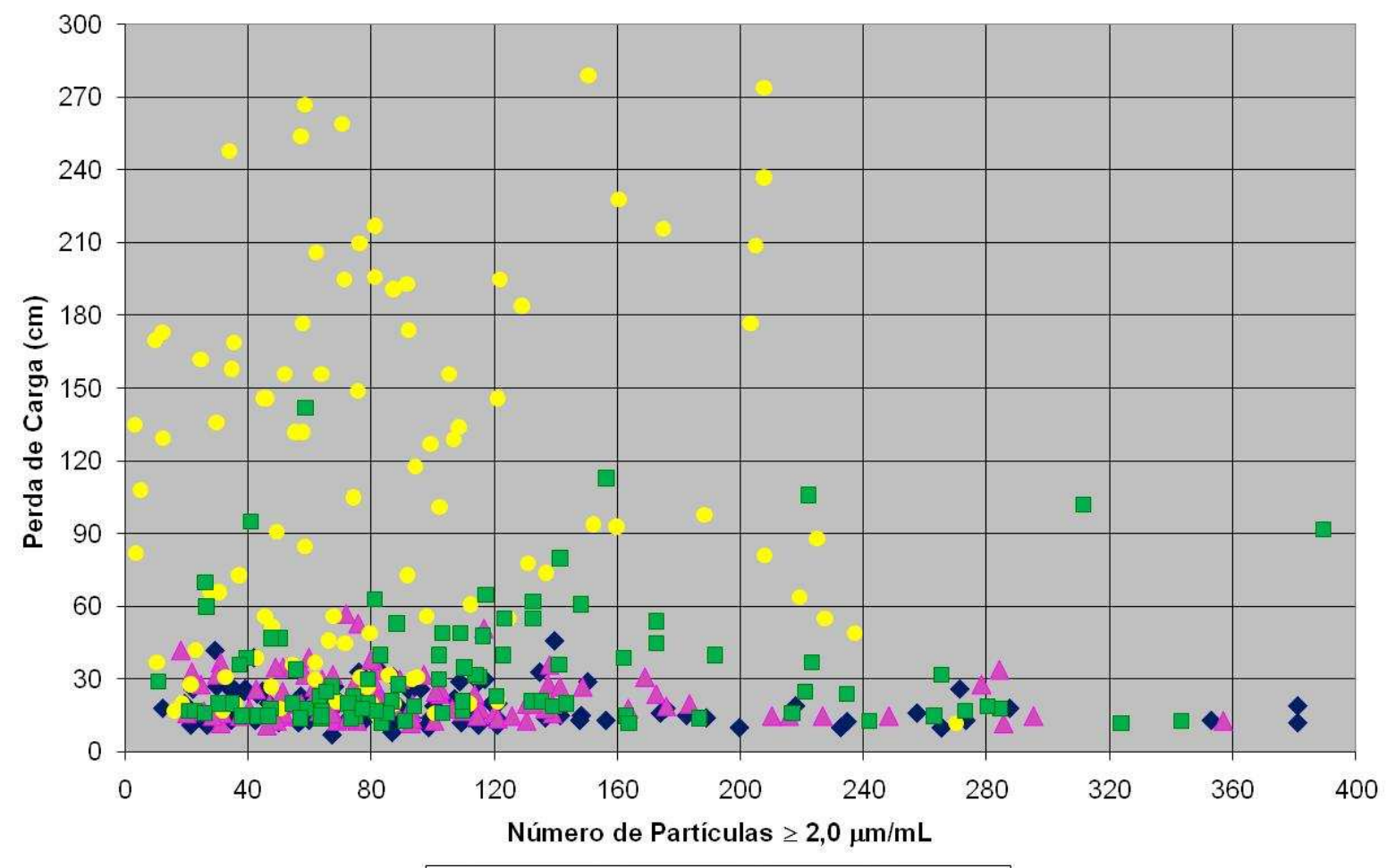

- Filtro $1 \quad \Delta$ Filtro $2 \quad$ Filtro $3 \quad$ a Filtro 4

Figura 5.5.17 - Perda de carga nos filtros versus número de partículas $\geq 2,0 \mu \mathrm{m}$.

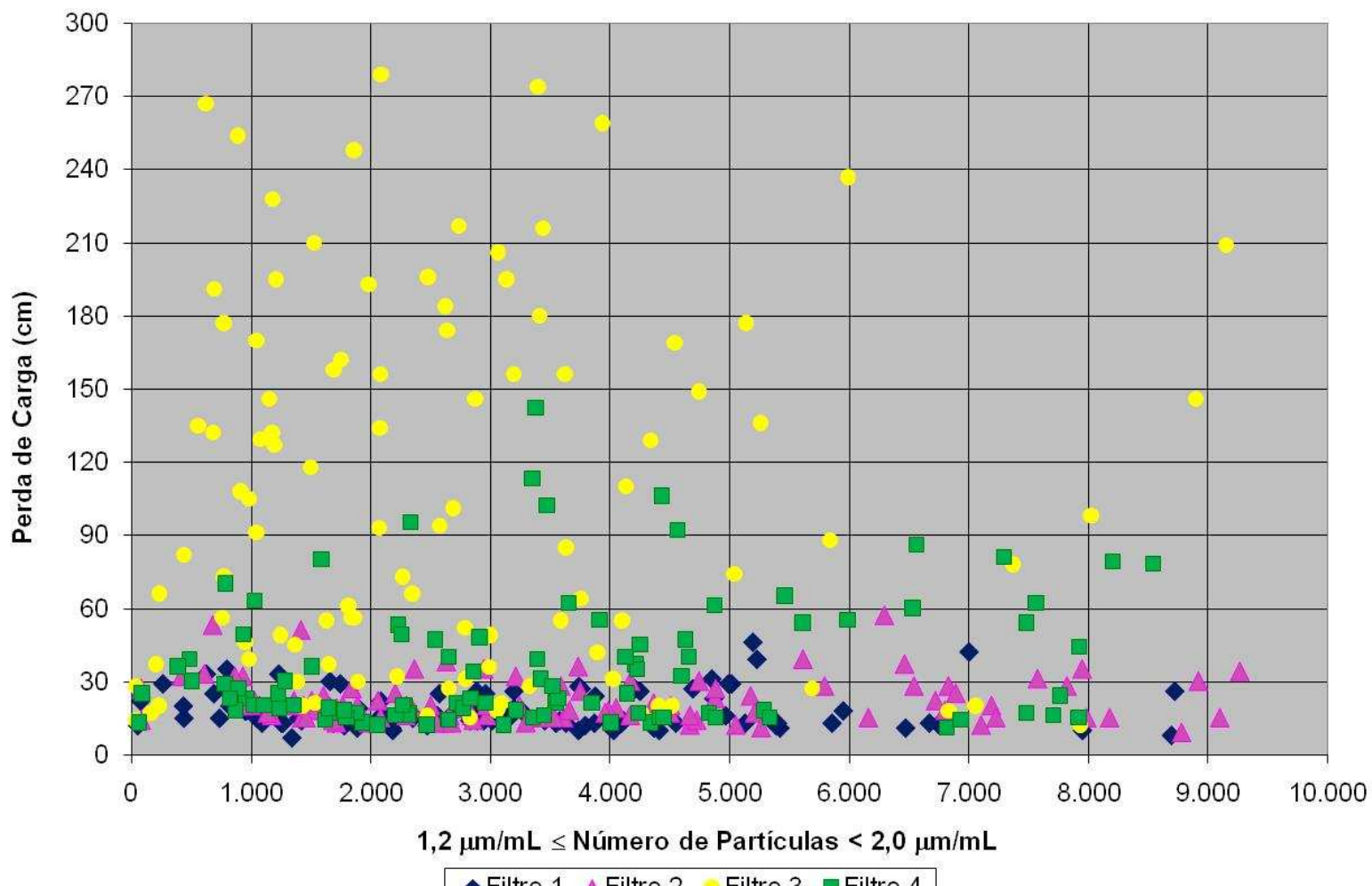

- Filtro $1 \Delta$ Filtro 2 Filtro $3 \backsim$ Filtro 4

Figura 5.5.18 - Perda de carga nos filtros versus número de partículas entre 1,2 $\mu \mathrm{m}$ e 2,0 $\mu \mathrm{m}$. 


\subsection{APRESENTAÇÃO E ANÁLISE dOS RESULTADOS DE MIB E GEOSMINA}

Os valores mínimo, médio, máximo e desvio padrão dos resultados das análises de MIB e geosmina encontram-se resumidos nas Tabelas 5.6.1 e 5.6.2. As porcentagens de remoção de MIB e geosmina estão indicadas na Tabelas 5.6 .3 e 5.6.4.

Tabela 5.6.1 - Valores mínimo, médio, máximo e desvio padrão de MIB.

\begin{tabular}{ccccccc}
\hline \multirow{2}{*}{ Valores } & \multicolumn{7}{c}{ MIB (ng/L) } \\
\cline { 2 - 7 } & REAF & REAO & F1 & F2 & F3 & F4 \\
\hline Mínimo & $<2,0$ & $<2,0$ & $<2,0$ & $<2,0$ & $<2,0$ & $<2,0$ \\
Médio* & 57,1 & 21,2 & 8,2 & 16,5 & 16,9 & 42,4 \\
Máximo & 563 & 411 & 64 & 234 & 144 & 366 \\
Desvio Padrão & 132,9 & 63,2 & 11,7 & 38,4 & 29,5 & 89 \\
\hline
\end{tabular}

*: Valores médios obtidos a partir dos dados do APÊNDICE E.

Tabela 5.6.2 - Valores mínimo, médio, máximo e desvio padrão de geosmina.

\begin{tabular}{ccccccc}
\hline \multirow{2}{*}{ Valores } & \multicolumn{7}{c}{ Geosmina (ng/L) } \\
\cline { 2 - 7 } & REAF & REAO & F1 & F2 & F3 & F4 \\
\hline Mínimo & $<2,0$ & $<2,0$ & $<2,0$ & $<2,0$ & $<2,0$ & $<2,0$ \\
Médio* & 5,3 & 2,9 & 2,0 & 2,0 & 2,0 & 2,8 \\
Máximo & 56,0 & 13,0 & 2,0 & 2,5 & 2,0 & 14,0 \\
Desvio Padrão & 8,5 & 2,3 & 0,0 & 0,1 & 0,0 & 2,1 \\
\hline
\end{tabular}

*: Valores médios obtidos a partir dos dados do APÊNDICE E.

Os valores de MIB na água do REAF foram superiores aos do REAO, indicando que a ozonização contribuiu para a redução da concentração (média de 53,4 \%) deste composto. Nerenberg; Rittman e Soucie (2000) também relataram obter remoções de MIB desta magnitude através da ozonização. Para remoções acima de $60 \%$ seria necessário aplicar dosagens superiores a $2,0 \mathrm{mg} / \mathrm{L}$ ou utilizar processos de oxidação avançada $\left(\mathrm{O}_{3}+\mathrm{H}_{2} \mathrm{O}_{2}\right)$. O filtro que apresentou os menores valores de MIB foi o CAG betuminoso, alimentado com água ozonizada (F1), com uma remoção média de 50,6 
\%. Em estudo compilado pela AWWARF (2005) a biofiltração por CAG também demonstrou remoções semelhantes (entre 26 e $64 \%$ ). Para obter-se remoções maiores com a biofiltração seria necessário diminuir a taxa de aplicação nos filtros. $O$ único filtro que apresentou valores médios de MIB abaixo da concentração limiar de odor ( $<9,0 \mathrm{ng} / \mathrm{L})$ foi o filtro 1 e o filtro que apresentou os maiores valores de MIB, foi o 4 (CAG vegetal alimentado com água filtrada da ETA).

Tabela 5.6.3 - Valores mínimo, médio, máximo e desvio padrão da porcentagem de remoção de MIB.

\begin{tabular}{cccccc}
\hline \multirow{2}{*}{ Valores } & \multicolumn{5}{c}{ Porcentagem de remoção de MIB (\%) } \\
\cline { 2 - 6 } & REAO & F1 & F2 & F3 & F4 \\
\hline Mínimo & 1,6 & 16,7 & 16,7 & 7,1 & 4,8 \\
Médio* & 53,4 & 50,6 & 34,3 & 56,8 & 30,4 \\
Máximo & 99,3 & 93,0 & 78,7 & 90,5 & 83,3 \\
Desvio Padrão & 29,8 & 23,9 & 15,9 & 25,3 & 17,8 \\
\hline
\end{tabular}

*: Valores médios obtidos a partir dos dados do APÊNDICE E.

Tabela 5.6.4 - Valores mínimo, médio, máximo e desvio padrão da porcentagem de remoção de geosmina.

\begin{tabular}{cccccc}
\hline \multirow{2}{*}{ Valores } & \multicolumn{5}{c}{ Porcentagem de remoção de geosmina (\%) } \\
\cline { 2 - 6 } & REAO & F1 & F2 & F3 & F4 \\
\hline Mínimo & 3,3 & 13,0 & 13,0 & 4,8 & 4,8 \\
Médio* & 39,2 & 43,9 & 42,8 & 52,1 & 41,3 \\
Máximo & 96,4 & 84,6 & 84,6 & 96,4 & 88,2 \\
Desvio Padrão & 26,1 & 25,8 & 26,2 & 28,8 & 20,7 \\
\hline
\end{tabular}

*: Valores médios obtidos a partir dos dados do APÊNDICE E.

Apesar das águas efluentes dos filtros 2 e 3 apresentarem praticamente os mesmos valores médios de MIB a porcentagem de remoção alcançada pelo CAG betuminoso (média de 56,8\%) foi superior ao de CAG vegetal (34,3\%). Além disso, o valor máximo de MIB verificado na água efluente do filtro 3 foi inferior ao do filtro 2 (144 e $234 \mathrm{ng} / \mathrm{L}$, respectivamente). 
Os valores de geosmina na água do REAO foram inferiores aos da água do REAF, indicando que a ozonização contribuiu para a redução deste composto (redução média de 39,2\%). Os valores médios de geosmina verificados nas águas efluentes aos filtros 1, 2 e 3 foram semelhantes (2,0 ng/L). No entanto, a maior remoção encontrada foi no filtro de CAG betuminoso, alimentado com água não ozonizada (52,1\%). A água efluente do filtro 4 (CAG vegetal) foi a que apresentou os maiores valores de geosmina. Nas Figuras 5.6.1 e 5.6.2 são apresentadas, respectivamente, os valores de MIB e geosmina nas águas filtrada da ETA, ozonizada e efluentes dos filtros 1, 2, 3 e 4 .

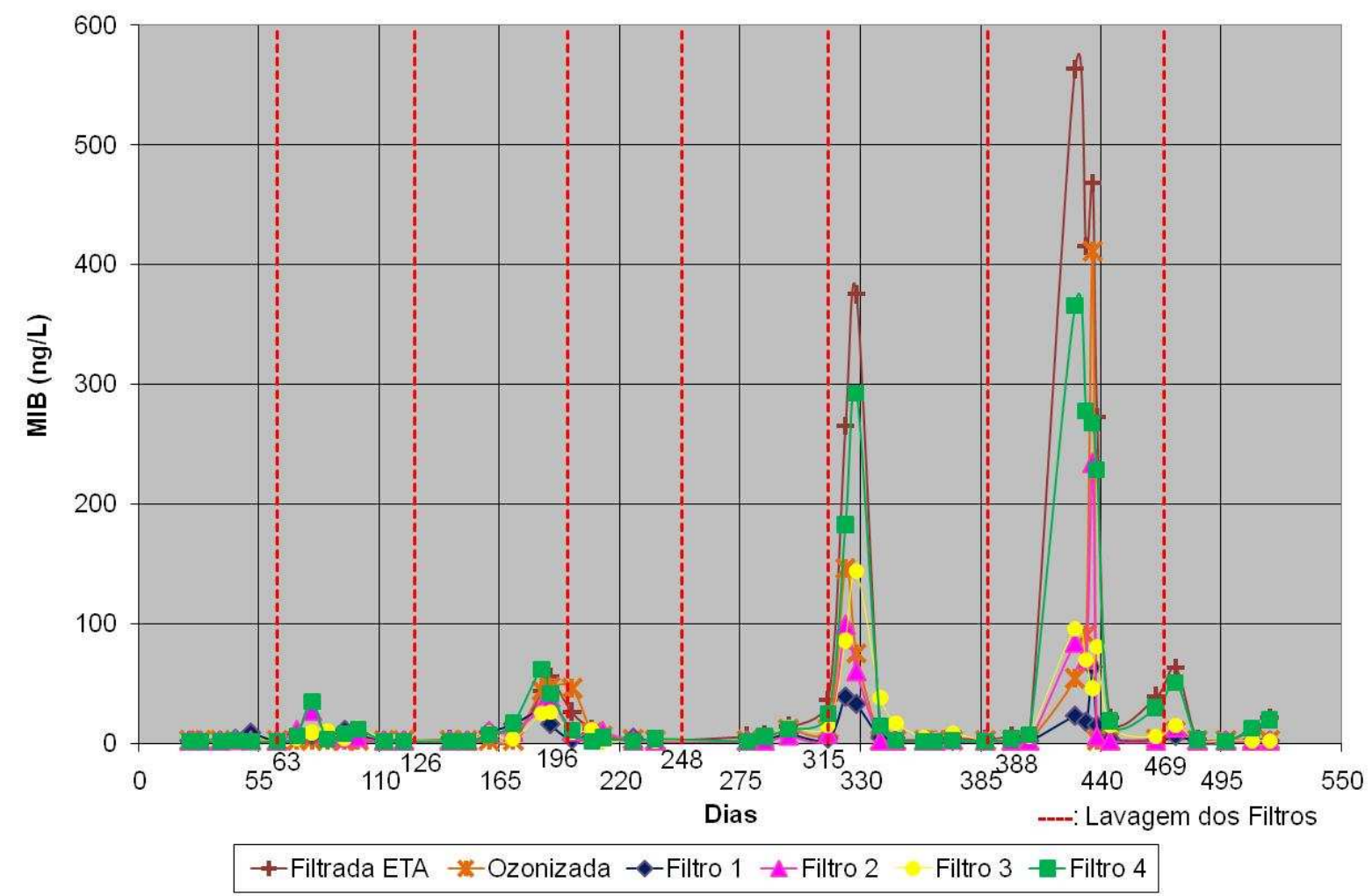

Figura 5.6.1 - Valores de MIB ao longo do tempo.

Os valores de MIB permaneceram, na maior parte do tempo, abaixo dos $100 \mathrm{ng} / \mathrm{L}$ e os valores de geosmina, abaixo de $10 \mathrm{ng} / \mathrm{L}$. A lavagem dos filtros pareceu não alterar o desempenho dos filtros com relação a remoção destes compostos.

As Figuras 5.6.3 e 5.6.4 indicam a porcentagem de remoção de MIB e geosmina, respectivamente. 


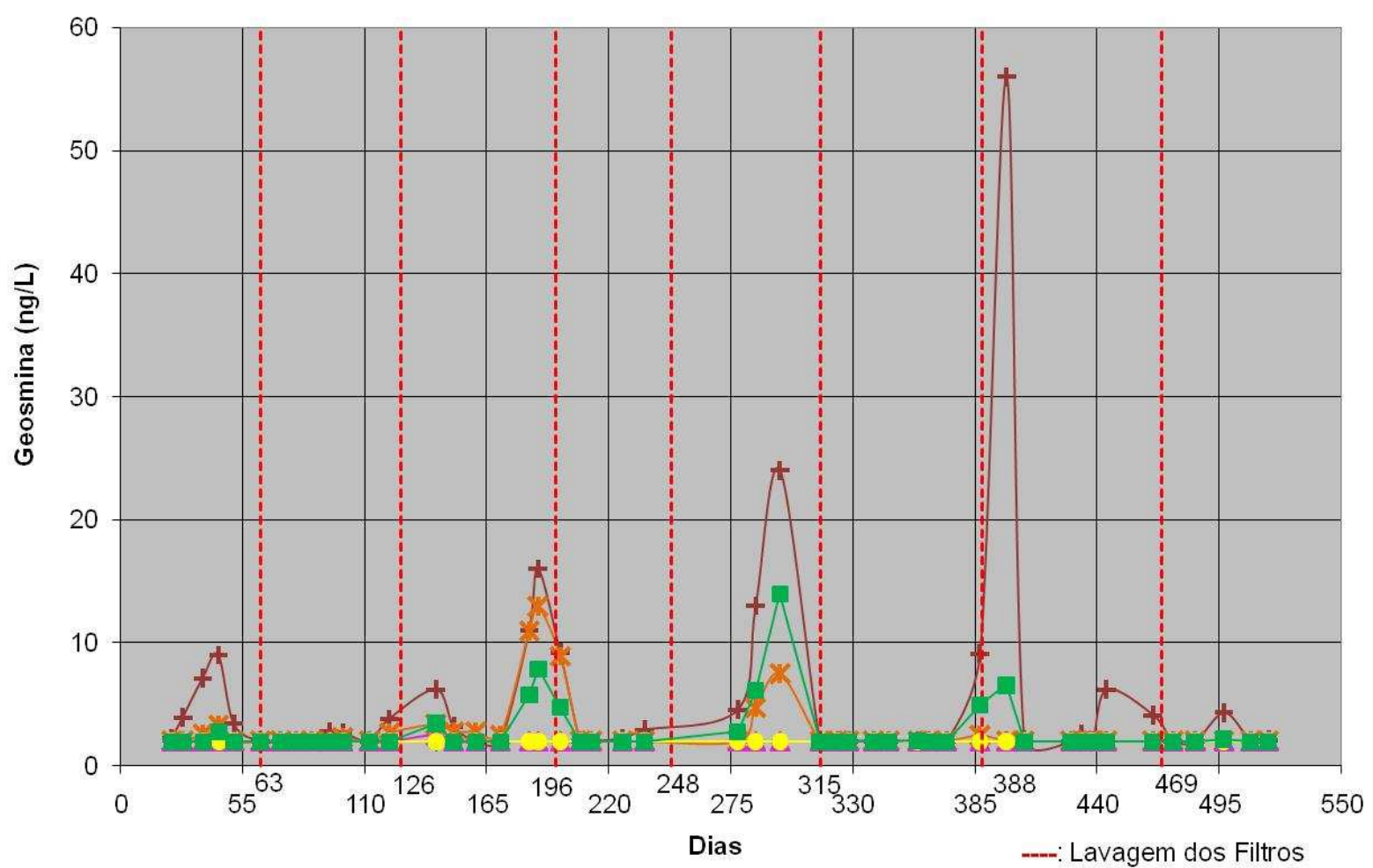

+-Filtrada ETA $\rightarrow$ Ozonizada $\rightarrow$ Filtro $1-$ Filtro $2-$ Filtro $3-$-Filtro 4

Figura 5.6.2 - Valores de geosmina ao longo do tempo.

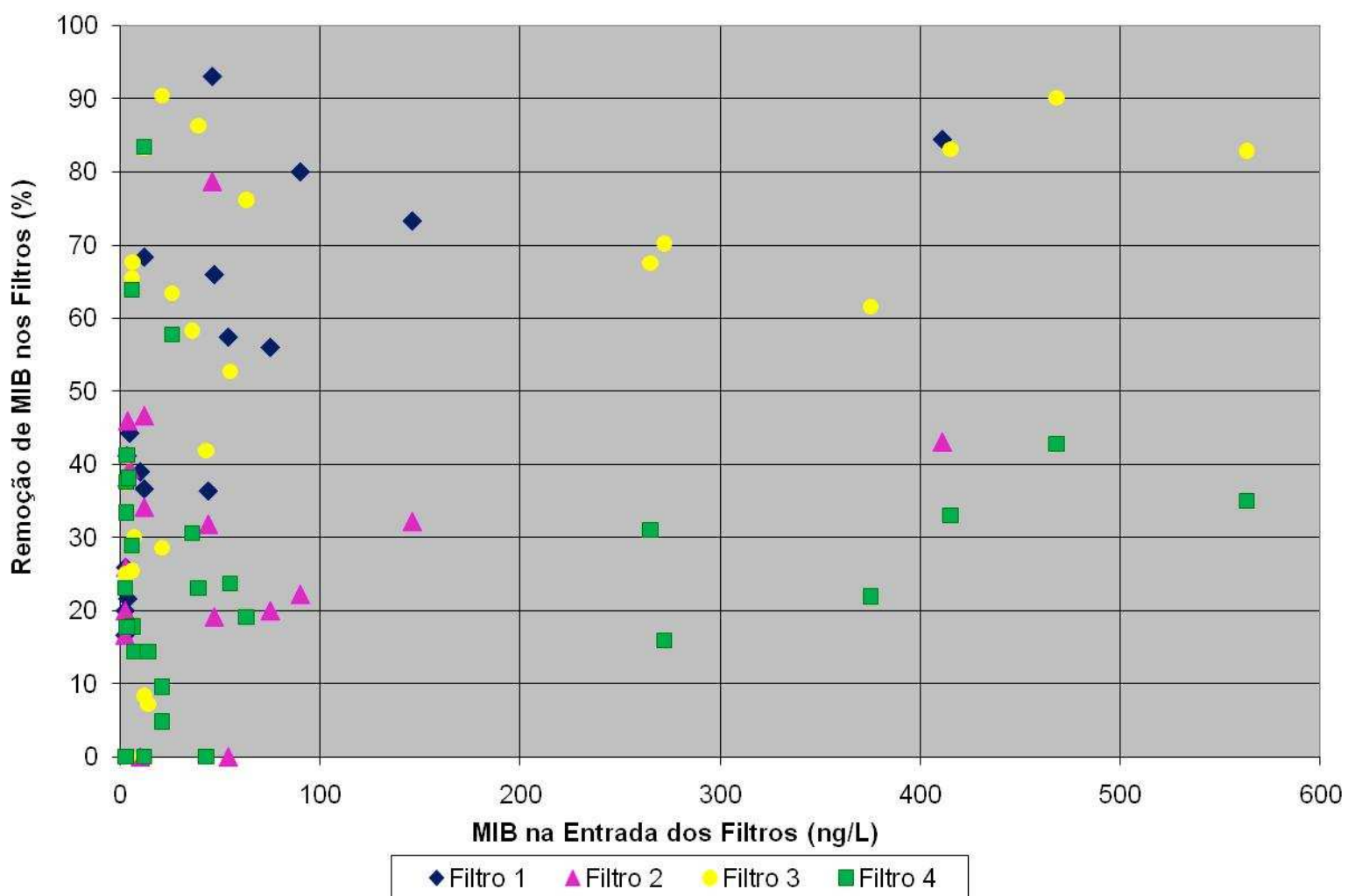

Figura 5.6.3 - Porcentagem de remoção de MIB nos filtros. 


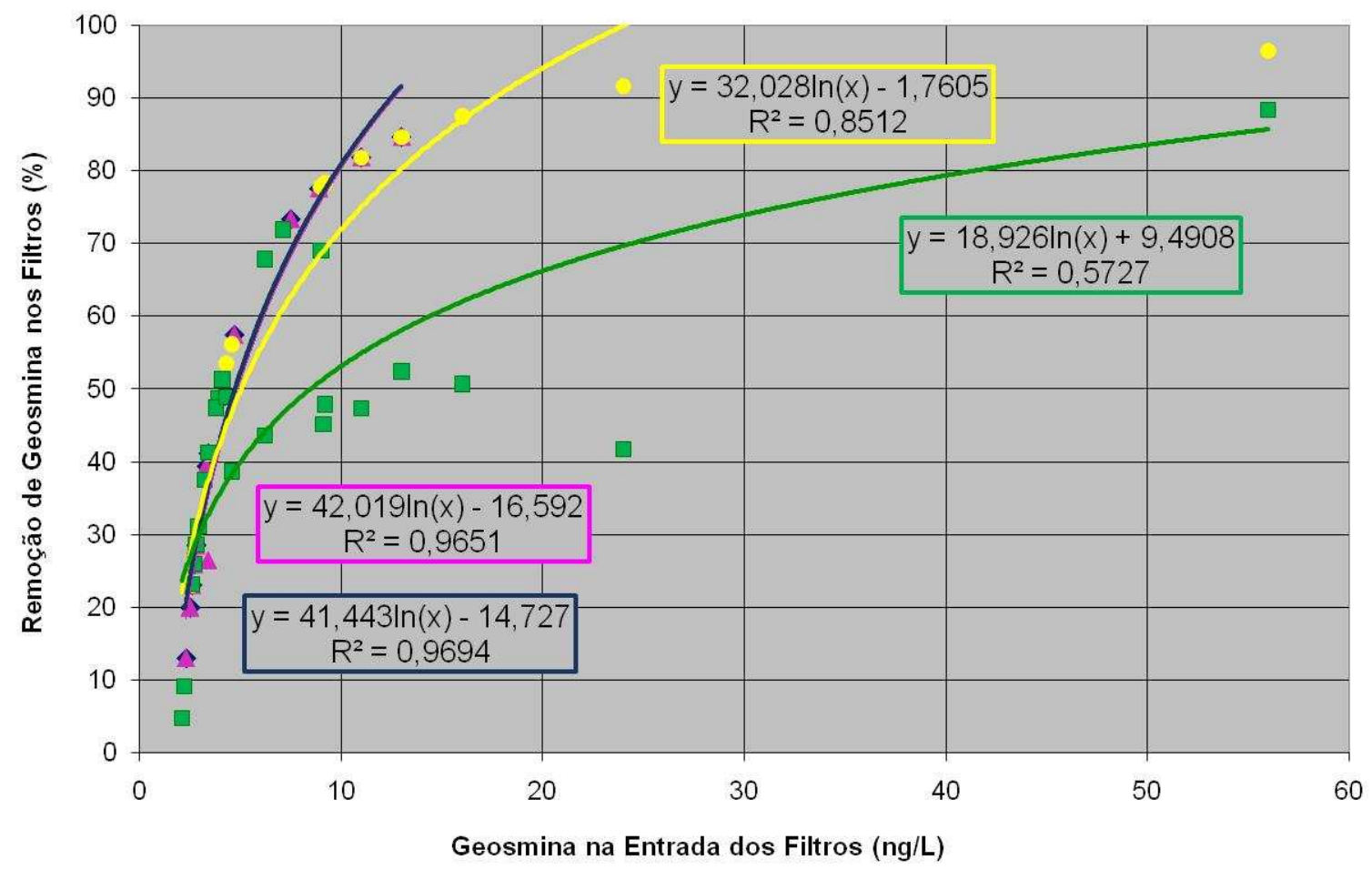

•Filtro $1 \triangle$ Filtro 2 Filtro 3 ailtro 4

Figura 5.6.4 - Porcentagem de remoção de geosmina nos filtros.

Não foi possível estabelecer uma relação entre a porcentagem de remoção de MIB nos filtros, com seus valores de entrada (Figura 5.6.3). Já a porcentagem de remoção de geosmina (Figura 5.6.4) cresceu com o aumento dos valores de entrada, observando-se remoções maiores nos filtros alimentados com água ozonizada (F1 e F2), e menores no filtro de CAG vegetal, alimentado com água filtrada da ETA (F4).

As relações entre a porcentagem de remoção de MIB e geosmina com a dosagem de ozônio aplicada encontram-se discriminadas nas Figuras 5.6.5 e 5.6.6.

Segundo apresentado na Figura 5.6.5, aumentando-se dosagem de ozônio, aumentou-se a remoção de MIB; conforme também documentado por Kawamura (2000) (ver Figura 3.1.1). No entanto, não foi possível verificar esta mesma relação para as remoções de geosmina (Figura 5.6.6).

Nas Figuras 5.6 .7 e 5.6 .8 estão relacionados os valores de MIB e geosmina nas águas efluentes dos filtros com a razão volume de filtração/volume do meio filtrante de CAG. 


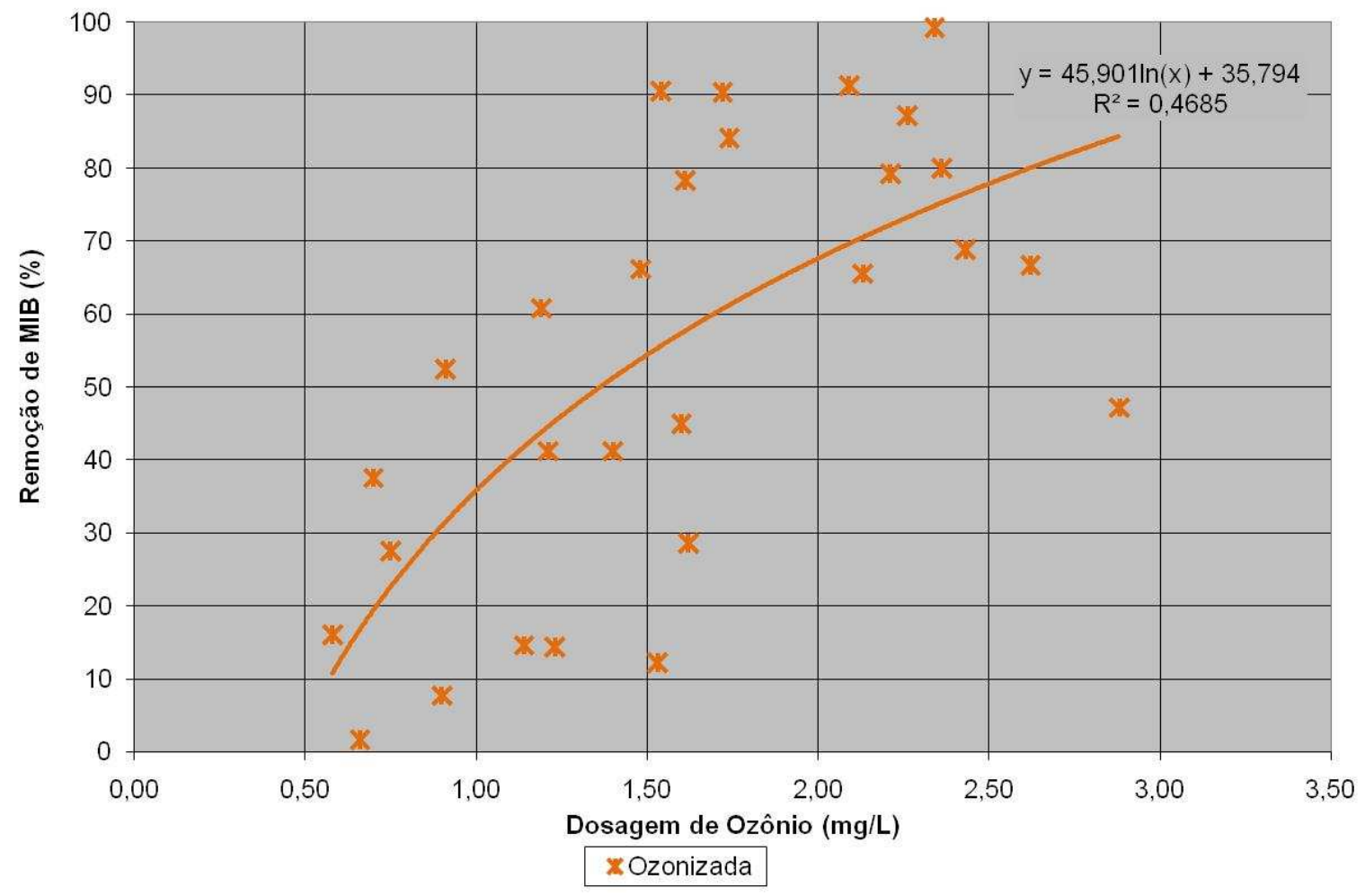

Figura 5.6.5 - Remoção de MIB versus dosagem de ozônio aplicada.

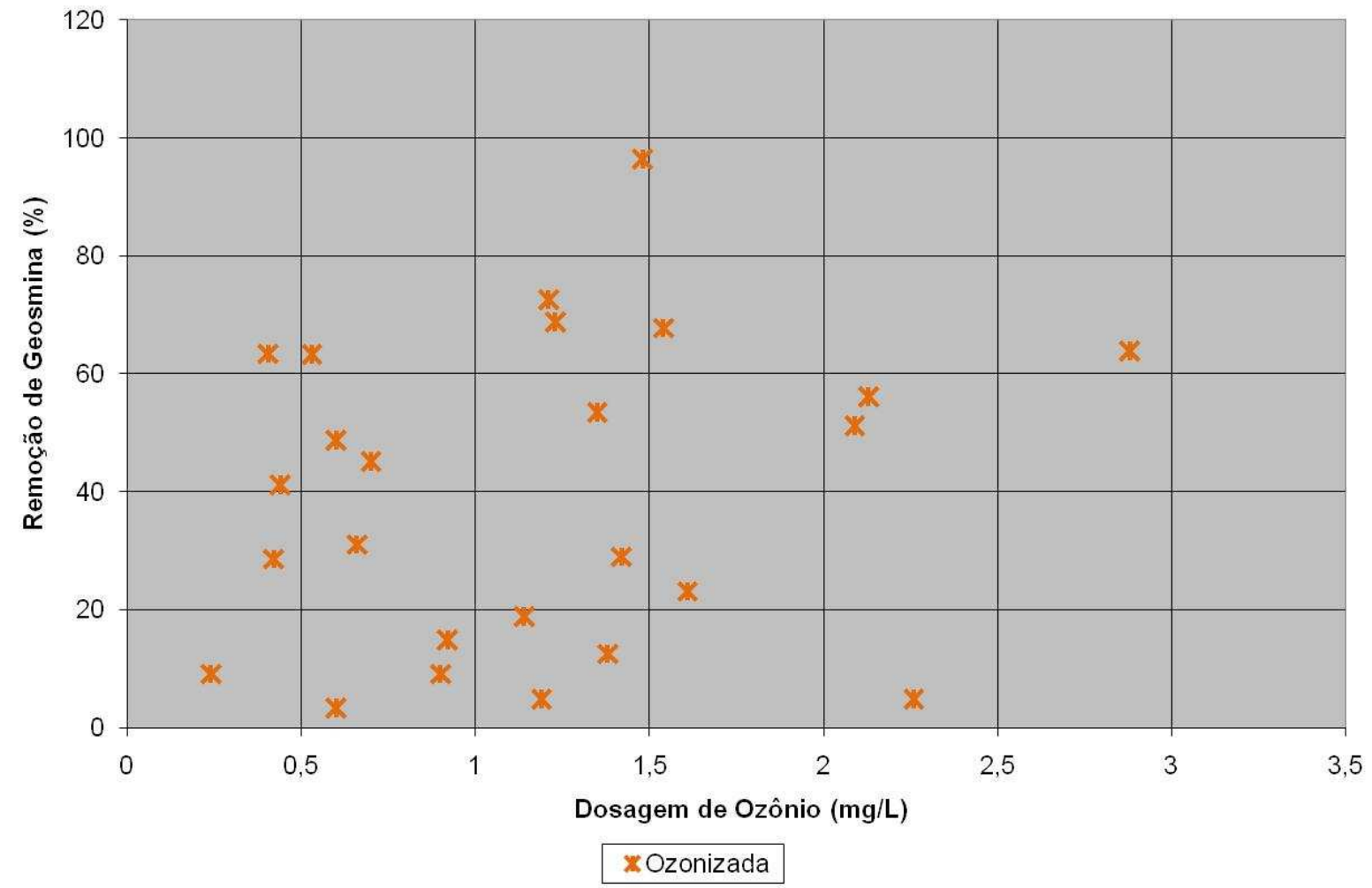

Figura 5.6.6 - Remoção de geosmina versus dosagem de ozônio aplicada. 


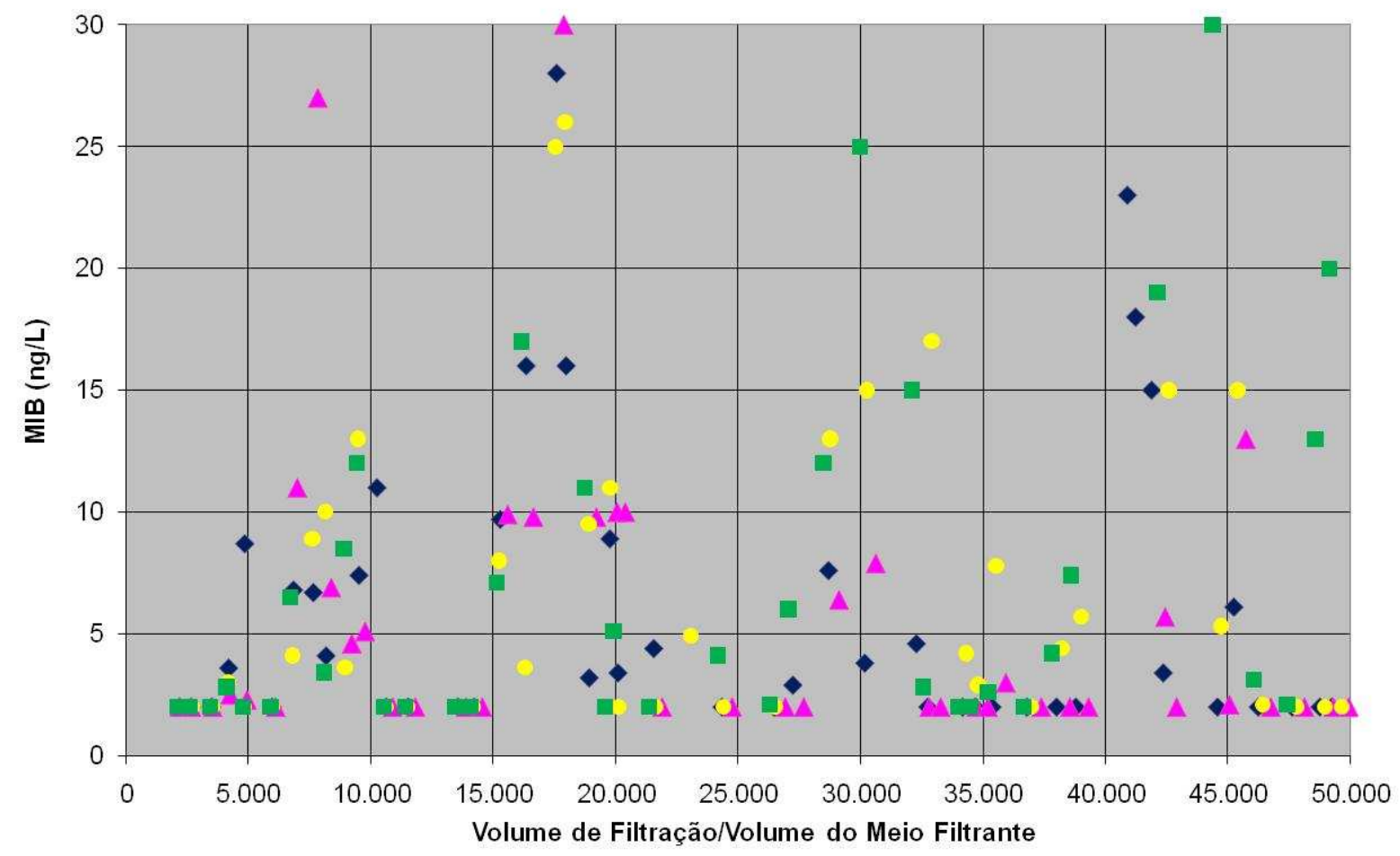

- Filtro 1 a Filtro 2 Filtro 3 EFiltro 4

Figura 5.6.7 - Valores de MIB nas águas efluentes dos filtros versus a razão volume de filtração/volume do meio filtrante.

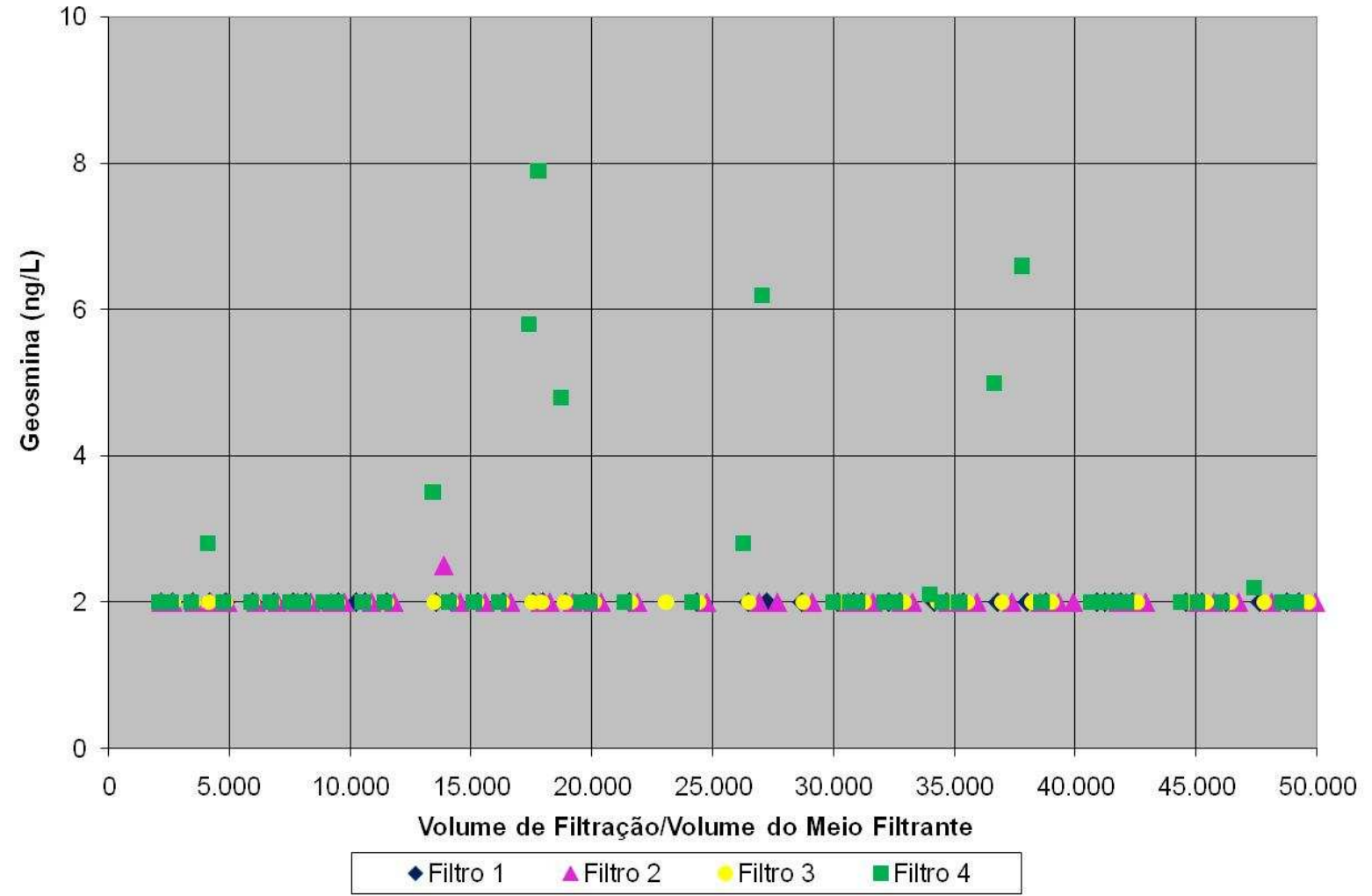

Figura 5.6.8 - Valores de geosmina nas águas efluentes dos filtros versus a razão volume de filtração/volume do meio filtrante. 
Com o aumento da razão volume de filtração/volume de CAG os valores de MIB na saída dos filtros permaneceram, em sua maioria, menores que $10 \mathrm{ng} / \mathrm{L}$ e os valores de geosmina, em 2 ng/L. Não foi possível estabelecer uma relação entre os valores de MIB e geosmina nas águas efluentes dos filtros com a razão volume de filtração/volume de CAG.

\subsection{APRESENTAÇÃO E ANÁLISE DOS RESULTADOS DE THM INSTANTÂNEOS E NA REDE DE DISTRIBUIÇÃO}

Os valores mínimo, médio, máximo e desvio padrão dos resultados das análises de THM instantâneos e na rede de distribuição encontram-se resumidos nas Tabelas 5.7.1 e 5.7.2. As porcentagens de remoção de THM instantâneos e na rede de distribuição estão indicadas na Tabelas 5.7.3 e 5.7.4.

Tabela 5.7.1 - Valores mínimo, médio, máximo e desvio padrão de THM instantâneos.

\begin{tabular}{ccccccc}
\hline \multirow{2}{*}{ Valores } & \multicolumn{7}{c}{ THM instantâneos $(\mu \mathrm{g} / \mathrm{L})$} \\
\cline { 2 - 7 } & REAF & REAO & F1 & F2 & F3 & F4 \\
\hline Mínimo & 3,8 & 3,7 & $<0,5$ & $<0,5$ & $<0,5$ & 4,0 \\
Médio* & 17,8 & 17,8 & 11,1 & 8,8 & 8,9 & 8,3 \\
Máximo & 28 & 29,0 & 22,0 & 14,0 & 17,0 & 13,0 \\
Desvio Padrão & 5,6 & 5,6 & 5,7 & 2,9 & 4,2 & 2,4 \\
\hline
\end{tabular}

*: Valores médios obtidos a partir dos dados do APÊNDICE F.

Tabela 5.7.2 - Valores mínimo, médio, máximo e desvio padrão de THM na rede de distribuição.

\begin{tabular}{ccccccc}
\hline \multirow{2}{*}{ Valores } & \multicolumn{5}{c}{ THM na rede de distribuição $(\mu \mathrm{g} / \mathrm{L})$} \\
\cline { 2 - 7 } & REAF & REAO & F1 & F2 & F3 & F4 \\
\hline Mínimo & 28,0 & 5,9 & 5,1 & 4,8 & 4,3 & 20,0 \\
Médio* & 58,9 & 59,9 & 30,0 & 35,9 & 27,2 & 39,1 \\
Máximo & 94,0 & 97,0 & 47,0 & 56,0 & 47,0 & 74,0 \\
Desvio Padrão & 17,5 & 19,4 & 10,2 & 10,5 & 11,4 & 12,1 \\
\hline
\end{tabular}

*: Valores médios obtidos a partir dos dados do APÊNDICE F. 
Tabela 5.7.3 - Valores mínimo, médio, máximo e desvio padrão da porcentagem de remoção de THM instantâneos.

\begin{tabular}{cccccc}
\hline \multirow{2}{*}{ Valores } & \multicolumn{5}{c}{ Porcentagem de remoção de THM instantâneos (\%) } \\
\cline { 2 - 6 } & REAO & F1 & F2 & F3 & F4 \\
\hline Mínimo & 0,8 & 15,1 & 7,1 & 1,7 & 3,4 \\
Médio* & 11,8 & 43,0 & 50,8 & 51,8 & 52,6 \\
Máximo & 52,0 & 97,4 & 96,9 & 97,1 & 76,5 \\
Desvio Padrão & 10,9 & 24,6 & 18,7 & 25,8 & 19,7 \\
\hline
\end{tabular}

*: Valores médios obtidos a partir dos dados do APÊNDICE F.

Tabela 5.7.4 - Valores mínimo, médio, máximo e desvio padrão da porcentagem de remoção de THM na rede de distribuição.

\begin{tabular}{cccccc}
\hline \multirow{2}{*}{ Valores } & \multicolumn{5}{c}{ Porcentagem de remoção de THM na rede de distribuição (\%) } \\
\cline { 2 - 6 } & REAO & F1 & F2 & F3 & F4 \\
\hline Mínimo & 1,8 & 7,1 & 4,5 & 11,1 & 16,1 \\
Médio* & 18,7 & 50,1 & 44,2 & 52,7 & 38,2 \\
Máximo & 89,1 & 91,2 & 91,6 & 93,5 & 68,4 \\
Desvio Padrão & 22,2 & 18,4 & 16,6 & 20,5 & 11,2 \\
\hline
\end{tabular}

*: Valores médios obtidos a partir dos dados do APÊNDICE F.

A remoção média dos trialometanos pelo processo de ozonização foi de 11,8 \% (Tabela 5.7.3) enquanto que a biofiltração foi responsável por remoções médias de $43 \%$ (filtro 1) e 50,8 \% (filtro 2). Valores estes um pouco superiores aos verificados em estudo publicado pela AWWARF (2005) para a biofiltração (entre 25 e 40 \%). No entanto, os filtros 3 e 4, alimentados com água não ozonizada, apresentaram remoções médias ainda maiores (51,8 \% e 52,6 \%, respectivamente), indicando que o processo de ozonização não levou a uma melhora significativa na remoção dos THM. Os menores valores médios de THM registrados foram dos filtros 2 e 4 (8,8 $\mu \mathrm{g} / \mathrm{L}$ e 8,3 $\mu \mathrm{g} / \mathrm{L}$, respectivamente). 
Em estudo divulgado por Chaiket et al. (2002), o processo de ozonização foi responsável por uma remoção de aproximadamente $20 \%$ dos THM na rede de distribuição, valor muito próximo a média aqui obtida (18,7 \%).

Os menores valores médios de THM na rede de distribuição encontrados foram nas águas efluentes dos filtros de CAG betuminoso, isto é F1 e F3 (30 $\mu \mathrm{g} / \mathrm{L}$ e 27,2 $\mu \mathrm{g} / \mathrm{L}$, respectivamente). 


\section{CONCLUSÕES}

A partir do estudo de desempenho dos pós-filtros adsorvedores de CAG de origem mineral (betuminoso) e vegetal (casca de coco), alimentados com água filtrada da ETA ABV, seguida ou não de ozonização, foi possível concluir que:

- Os menores valores médios de turbidez (0,226 UNT e 0,174 UNT) ocorreram nas águas efluentes dos filtros de CAG betuminoso (F1 e $F 3$, respectivamente);

- Os valores médios de COT nas águas efluentes dos filtros 1 e $3(1,42 \mathrm{mg} / \mathrm{L}$ e $1,62 \mathrm{mg} / \mathrm{L})$ foram menores do que os dos filtros 2 e 4 (1,91 mg/L e 2,14 mg/L), indicando que os carvões de origem betuminosa apresentaram uma melhor remoção de COT do que os de origem vegetal. A maior remoção média de COT foi verificada na água efluente do filtro 1, alimentado com água ozonizada, indicando que a biofiltração contribui na redução do COT;

- Comparando-se os filtros alimentados com água ozonizada (F2 e F1) observou-se que tanto os valores do número de partículas $\geq 2,0 \mu \mathrm{m}$, quanto os valores do número de partículas entre 1,2 $\mu \mathrm{m}$ e 2,0 $\mu \mathrm{m}$, foram superiores na água efluente do filtro de CAG vegetal (193 partículas/mL versus 141 partículas $/ \mathrm{mL}$ e 4.869 partículas $/ \mathrm{mL}$ versus 3.412 partículas $/ \mathrm{mL}$, respectivamente). No entanto, o valor médio da $\mathrm{CBH}$ na água efluente do filtro 1 (537 UFC/mL) foi superior ao da água efluente do filtro 2 (485 UFC/mL);

- Os maiores valores médios de $\mathrm{CBH}$ ocorreram nas águas efluentes dos filtros 1 e 2. O que indiretamente indica a formação de um biofilme, devido à ozonização;

- Houve uma remoção média de 48,4 \% no NP $\geq 2,0 \mu \mathrm{m}$ e um aumento de 30 \% no NP entre 1,2 $\mu \mathrm{m}$ e 2,0 $\mu \mathrm{m}$ na água efluente do filtro 1 em relação à água do REAO. Os valores do número de partículas entre 1,2 $\mu \mathrm{m}$ e 2,0 $\mu \mathrm{m}$ no efluente do filtro 2 foram superiores aos seus valores de entrada (REAO); 
assim como também o NP nas águas efluentes dos filtros 3 e 4, em relação à água do REAF;

- O aumento na dosagem de ozônio não levou a uma redução significativa no número de partículas $\geq 2,0 \mu \mathrm{m}$ (permanecendo $<420$ partículas $/ \mathrm{mL}$ ) e nem no número de partículas entre 1,2 $\mu \mathrm{m}$ e 2,0 $\mu \mathrm{m}$ (permanecendo < 10.500 partículas $/ \mathrm{mL})$;

- Os valores de COT, nas águas efluentes dos filtros, mantiveram-se, na maioria dos casos, entre 1,0 e $2,5 \mathrm{mg} / \mathrm{L}$, independentemente do número de partículas;

- Independentemente do número de partículas, a perda de carga nos filtros alimentados com água ozonizada permaneceu inferior a $60 \mathrm{~cm}$ (F1 e F2). $\mathrm{O}$ filtro de CAG vegetal alimentado com água filtrada da ETA manteve a sua perda de carga inferior a $150 \mathrm{~cm}(\mathrm{~F} 4)$ e o filtro de CAG betuminoso (F3) foi o que apresentou a maior variação (inferior a $300 \mathrm{~cm}$ );

- Os valores de MIB na água do REAF foram superiores aos do REAO, indicando que a ozonização contribuiu para a redução (média de 53,4 \%) deste composto. Para remoções acima de $60 \%$ seria necessário aplicar dosagens superiores a 2,0 mg/L ou utilizar processos de oxidação avançada $\left(\mathrm{O}_{3}+\mathrm{H}_{2} \mathrm{O}_{2}\right)$

- O filtro que apresentou os menores valores de MIB foi o CAG betuminoso, alimentado com água ozonizada (F1), com uma remoção média de 50,6 \%. Além disso, foi o único filtro que apresentou valores médios de MIB abaixo da concentração limiar de odor (<9,0 ng/L). O filtro que apresentou os maiores valores de MIB, foi o 4 (CAG vegetal alimentado com água filtrada da ETA);

- Para obter-se remoções maiores com a biofiltração seria necessário diminuir a taxa de aplicação nos filtros;

- Apesar das águas efluentes dos filtros 2 e 3 apresentarem praticamente os mesmos valores médios de MIB, a porcentagem de remoção alcançada pelo CAG betuminoso (média de 56,8 \%) foi superior ao do CAG vegetal (34,3\%); 
- Os valores de geosmina na água do REAO foram inferiores aos da água do REAF, indicando que a ozonização contribuiu para a redução deste composto (redução média de 39,2\%). Os valores médios de geosmina verificados nas águas efluentes dos filtros 1, 2 e 3 foram semelhantes (2,0 ng/L). No entanto, a maior remoção encontrada foi no filtro de CAG betuminoso, alimentado com água não ozonizada (52,1\%). A água efluente do filtro 4 (CAG vegetal) foi a que apresentou os maiores valores de geosmina;

- Aumentando-se a dosagem de ozônio, aumentou-se a remoção de MIB. No entanto, não foi possível verificar esta mesma relação para a remoção de geosmina;

- A remoção média dos trialometanos instantâneos pelo processo de ozonização foi de $11,8 \%$, enquanto que a biofiltração foi responsável por remoções médias de $43 \%$ (filtro 1) e 50,8 \% (filtro 2). Os filtros 3 e 4 , alimentados com água não ozonizada, apresentaram remoções médias ainda maiores $(51,8 \%$ e $52,6 \%$, respectivamente), indicando que o processo de ozonização não levou a uma melhora significativa na remoção dos THM. Os menores valores médios de THM instantâneos registrados foram nos filtros 2 e 4 ( $8,8 \mu \mathrm{g} / \mathrm{L}$ e $8,3 \mu \mathrm{g} / \mathrm{L}$, respectivamente);

- A ozonização foi responsável por uma remoção média de 18,7 \% nos THM na rede de distribuição;

- Os menores valores médios dos THM na rede de distribuição encontrados foram nas águas efluentes dos filtros de CAG betuminoso, isto é F1 e F3 (30 $\mu \mathrm{g} / \mathrm{L}$ e $27,2 \mu \mathrm{g} / \mathrm{L}$, respectivamente). 


\section{REFERÊNCIAS BIBLIOGRÁFICAS}

AHMAD, R. et al. Effects of Backwashing on Biological Filters. AWWA Journal, v. 90, n.12, p. 62-73, 1998.

AMERICAN PUBLIC HEALTH ASSOCIATION; AMERICAN WATER WORKS ASSOCIATION; WATER ENVIRONMENTAL FEDERATION. Standard Methods for the Examination of Water and Wastewater. 20th ed. Washington, D.C.: APHA, 1998.

AMERICAN PUBLIC HEALTH ASSOCIATION; AMERICAN WATER WORKS ASSOCIATION; WATER ENVIRONMENTAL FEDERATION. Standard Methods for the Examination of Water and Wastewater. 21th ed. Washington, D.C.: APHA, 2005.

AMERICAN WATER WORKS ASSOCIATION; AMERICAN SOCIETY OF CIVIL ENGINEERS. Water Treatment Plant Design. 3rd ed. New York: McGraw Hill, 1998.

AMERICAN WATER WORKS ASSOCIATION SEMINAR PROCEEDINGS. 1987, Kansas. GAC Installations: Conception to Operation. Denver: AWWA, 1987.

AMERICAN WATER WORKS ASSOCIATION RESEARCH FOUNDATION. Evaluation of Particle Counting as a Measure of Treatment Plant Performance. Denver: AWWA, 1992. 319 p.

AMERICAN WATER WORKS ASSOCIATION RESEARCH FOUNDATION. Fundamentals of Drinking Water Particle Counting. Denver: AWWA, 2000. 290 p.

AMERICAN WATER WORKS ASSOCIATION RESEARCH FOUNDATION. OzoneEnhanced Biofiltration for Geosmin and MIB Removal. Denver: AWWA, 2005. $188 \mathrm{p}$. 
AMERICAN WATER WORKS ASSOCIATION RESEARCH FOUNDATION. Characterization of Particles in Filter Effluents. Denver: AWWA, 2007. 178 p.

AMERICAN WATER WORKS ASSOCIATION RESEARCH FOUNDATION.; INTERNATIONAL WATER SUPPLY ASSOCIATION. Treatment Process Selection for Particle Removal. Denver: AWWA, 1998.

BECKER, W. C. et al. Using Oxidants to Enhance Filter Performance. Denver: AWWARF, 2004. $160 \mathrm{p}$.

CALGON CARBON CORPORATION. Filtrasorb 100 \& 200. Granular Activated Carbons for Potable Water. Pittsburgh: CALGON, 2006. 2 p. Catalog.

CARLSON, K. H.; AMY, G. L. BOM Removal During Biofiltration. AWWA Journal, v. 90, n.12, p. 42-52, 1998.

CARLSON, K. H.; AMY, G. L. Ozone and Biofiltration Optimization for Multiple Objectives. AWWA Journal, v. 93, n.1, p. 88-98, 2001.

CETESB. Resultados dos Parâmetros e Indicadores de Qualidade das Águas. São Paulo: 2008.2 Disponível em: $<$ http://www.cetesb.sp.gov.br/Agua/rios/publicacoes.asp>. Acesso em 15 jun. 2008.

CHAIKET, T. et al. Effectiveness of coagulation, ozonation, and Biofiltration in Controlling DBPs. AWWA Journal, v. 94, n. 12, p. 81-95, 2002.

CHANG, S. D.; SINGER, P. C. The Impact of Ozonation on Particle Stability and the Removal of TOC and THM Precursors. AWWA Journal, v. 83, n. 3, p. 71-79, 1991.

CIPPARONE, L. A.; DIEHL, A. C.; SPEITEL JR. G. E. Ozonation and BDOC Removal: Effect on Water Quality. AWWA Journal, v. 89, n. 2, p. 84-97, 1997. 
COMPRESSED GAS ASSOCIATION, INC. Safe Handling of Ozone-Containing Mixtures Including the Installation and Operation of Ozone-Generating Equipment. Chantilly: CGA, 2001.

CULP; WESNER; CULP. Handbook of Public Water Systems. New York: Van Nostrand Reinhold Company, 1986.

DUGAN, N. R.; WILLIAMS, D. J. Removal of Cryptosporidium by in-lines Filtration: Effects of Coagulant Type, Filter Loading Rate and Temperature. Journal of Water Supply: Research and Technology, v. 53, n. 1, p. 1-15, 2004.

ELHADI, S. L. N.; HUCK, P. M.; SLAWSON R. M. Factors Affecting the Removal of Geosmin and MIB in Drinking Water Biofilters. AWWA Journal, v. 98, n. 8, p. 108119, 2006.

ESCOBAR, I. C.; RANDALL, A. A. Case Study: Ozonation and Distribution System Biostability. AWWA Journal, v. 93, n. 10, p. 77-89, 2001.

FERREIRA FILHO, S. S. et al. Taste and Odor Control for Drinking Water Supply: a Combined Solution of Chemical Oxidation and Powdered Activated Carbon Adsorption. 1st ed. London: IWA Publishing, 2002. p. 109-117. v. 1.

FITZPATRICK, C. S. B.; CAMPBELL, A. T.; CABLE C. J. The Effect of Filtration Rate Changes on Filtrate Particle Counts. In: AMERICAN WATER WORKS ASSOCIATION WATER QUALITY \& TECHNOLOGY, 1999, Tampa. Proceedings....Denver: AWWA, 1999.

FOX, K. R.; LYTLE D. A. Milwaukee's Crypto Outbreak: Investigations and Recommendations. AWWA Journal, v. 88, n. 9, p. 87-94, 1996.

GEORGESON, D. L.; KARIMI, A. A. Water Quality Improvements with the Use of Ozone at the Los Angeles Water Treatment Plant. Ozone Science Engineering, v. 10 , n. 3, p. 255-276, 1988. 
GILLOGLY, T. E. T. et al. Determining GAC Bed Life. AWWA Journal, v. 91, n. 8, p. 98-110, 1999.

GOEL, S.; HOZALSKI, R. M.; BOUWER E. J. Biodegradation of NOM: Effect of NOM Source and Ozone Dose. AWWA Journal, v. 87, n. 1, p. 90-105, 1995.

GOOGLE MAPS. Rua Graham Bell. São Paulo: 2008. Escala 1:200. Disponível em: <http://maps.google.com.br/maps>. Acesso em 15 jun. 2008.

GRENS, B. K.; WERTH C. J. Durability of Wood-Based Versus Coal-Based GAC. AWWA Journal, v. 93, n. 4, p. 175-181, 2001.

HAAS, C. N. et al. Data Review on the Physical/Chemical Removal of Cryptosporidium. Denver: AWWARF, 2001.

HATUKAI, S.; BEN-TZUR, Y.; REBHUM M. Particle Counts and Size Distribution in System Design for Removal of Turbidity by Granular Deep Bed Filtration. Water Science and Technology, v. 36, n. 4, p. 225-230, 1997.

HOZALSKI, R. M.; GOEL, S.; BOUWER E. J. TOC Removal in Biological Filters. AWWA Journal, v. 87, n. 12, p. 40-54, 1995.

HUCK, P. M. et al. Optimizing Filtration in Biological Filters. Denver: AWWARF, 2000. 259 p.

HUCK, P. M. et al. Filter Operation Effects on Pathogen Removal. Denver: AWWARF, 2002.

KAWAMURA, S. Integrated Design and Operation of Water Treatment Facilities. 2nd ed. New Jersey: John Wiley \& Sons, Inc., 2000. 691 p.

LANGLAIS, B.; RECKHOW, D. A.; BRONK, D. R. Ozone in Water Treatment: Application and Engineering. 1st ed. Chelsea: Lewis Publishers, 1991. 569 p. 
LECHEVALLIER, M. W. et al. Evaluating the Performance of Biologically Active Rapid Filters. AWWA Journal, v. 84, n. 4, p. 136-146, 1992.

LIU, X.; HUCK, P. M.; SLAWSON R. M. Factors Affecting Drinking Water Biofiltration. AWWA Journal, v. 93, n. 12, p. 90-101, 2001.

MACKENZIE. J. A.; TENNANT, M. F.; MAZYCK, D. W. Tailored GAC for Effective Control of 2-Methylisoborneol. AWWA Journal, v. 97, n. 6, p. 76-87, 2005.

MARDA, S. et al. Plant Conversion Experience: Ozone BAC Process Installation and Disinfectant Residual Control. AWWA Journal, v. 100, n. 4, p. 117-128, 2008.

McGUIRE, M. J. et al. Closed-Loop Stripping Analysis as a Tool for Solving Taste and Odor Problems. AWWA Journal, v. 73, p. 530-537, 1981.

MILTNER R. J.; SUMMERS, R. S.; WANG, J. Z. Biofiltration Performance: Part 2, Effects of Backwashing. AWWA Journal, v. 87, n. 12, p. 64-70, 1995.

MWH. Water Treatment: Principles and Design. 2nd ed. New Jersey: John Wiley \& Sons, Inc., 2005. 1948 p.

NAJM I.; KENNEDY, M.; TAYLOR, W. Lignite versus Bituminous GAC for Biofiltration - a Case Study. AWWA Journal, v. 97, n. 2, p. 94-101, 2005.

NERENBERG R.; RITTMANN, B. E.; SOUCIE, W. J. Ozone/Biofiltration for Removing MIB and Geosmin. AWWA Journal, v. 92, n. 12, p. 85-95, 2000.

NIQUETTE P. et al. Backwashing First-Stage Sand - BAC Filters. AWWA Journal, v. 90 , n. 1, p. 86-97, 1998.

OWEN, D. M. et al. NOM Characterization and Treatability. AWWA Journal, v. 87, n. 1, p. 46-63, 1995. 
PALMER, C. M. Algae in Water Supplies: An Illustrated Manual on the Identification, Significance and Control of Algae in Water Supplies. Washington D.C.: U.S. Department of Health, Education, and Welfare, 1962. 87 p.

PRICE, M. L. Ozone and Biological Treatment for DBP Control and Biological Stability. Denver: AWWARF, AWWA, 1994. 252 p.

RAKNESS, K. L. Ozone in Drinking Water Treatment: Process Design, Operation and Optimization. 1st ed. Denver: AWWA, 2005. 302 p.

RAVEENDRAN, P.; AMIRTHARAJAH, A. Role of Short-Range Forces in Particle Detachment During Filter Backwashing. Journal of Environmental Engineering. $\mathrm{n}$. 12, p. 860-868, 1995.

RECKHOW, D. A. et al. Oxidation of Iron and Manganese by Ozonation. Ozone Science and Engineering. v. 13, n. 6, p. 675-695, 1991.

RITTMAN, B. E.; GANTZER, C.; MONTIEL, A. Biological Treatment to Control Taste and Odor Compounds in Drinking Water Treatment. Denver: AWWARF, 1995. 209-246 p.

SONTHEIMER, H.; CRITTENDEN, J. C.; SUMMER, R. S. Activated Carbon for Water Treatment. 2nd ed. Karlsruhe: DVGW-Forschungsstelle, 1988, 722 p.

UNIVERSIDADE DE SÃO PAULO. SISTEMA INTEGRADO DE BIBLIOTECAS SIBi-USP. Diretrizes para apresentação de dissertações e teses da USP: documento eletrônico e impresso. Parte I (ABNT). 2. ed. São Paulo: Sistema Inegrado de Bibliotecas da USP, 2009. 102 p.

URFER, D. et al. Biological Filtration for BOM and Particle Removal: a Critical Review. AWWA Journal, v. 89, n. 12, p. 83-98, 1997.

U.S. Environmental Protection Agency. Treatment Techniques for Controlling THM's in Drinking Water. Washington, D.C.: EPA, 1981. 
U.S. Environmental Protection Agency. Interim Enhanced Surface Water Treatment Rule: A Quick Reference Guide. Washington, D.C.: EPA, 2001.

U.S. Environmental Protection Agency. Long Term 2 Enhanced Surface Water Treatment Rule. Toolbox Guidance Manual. Washington, D.C.: EPA, 2003.

U.S. Environmental Protection Agency. New Test Methods On-Line. Washington, D.C.: $2008 . \quad$ Disponível em: < http://www.epa.gov/osw/hazard/testmethods/pdfs/8260c.pdf>. Acesso em 15 jun. 2008.

U.S. Environmental Protection Agency. National Primary Drinking Water Regulations. Washington, D.C.: 2009. Disponível em: < http://www.epa.gov/safewater/consumer/pdf/mcl.pdf> . Acesso em 03 jul. 2009.

WANG, J. Z.; SUMMERS, R. S.; MILTNER R. J. Biofiltration Performance: Part 1, Relationship to Biomass. AWWA Journal, v. 87, n. 12, p. 55-63, 1995. 


\section{APÊNDICE A - Vazões, Tempos de Contato no Leito Vazio e Taxas de Aplicação nos Filtros}

\begin{tabular}{|c|c|c|c|}
\hline \multirow[b]{2}{*}{ Data } & \multicolumn{3}{|c|}{ Filtro 1} \\
\hline & $\begin{array}{l}\text { Vazão } \\
\text { (L/h) }\end{array}$ & $\begin{array}{l}\text { TCLV } \\
(\min )\end{array}$ & $\begin{array}{c}\text { Taxa de Aplicação } \\
\left(\mathrm{m}^{3} / \mathrm{m}^{2} . \mathrm{d}\right)\end{array}$ \\
\hline $10 / 07 / 07$ & 88,40 & 16,13 & 133,94 \\
\hline $12 / 07 / 07$ & 94,44 & 15,10 & 143,09 \\
\hline 16/07/07 & 96,72 & 14,74 & 146,55 \\
\hline 18/07/07 & 87,70 & 16,26 & 132,88 \\
\hline $20 / 07 / 07$ & 96,00 & 14,85 & 145,45 \\
\hline $23 / 07 / 07$ & 93,02 & 15,33 & 140,94 \\
\hline $25 / 07 / 07$ & 92,74 & 15,37 & 140,52 \\
\hline $27 / 07 / 07$ & 92,50 & 15,41 & 140,15 \\
\hline $30 / 07 / 07$ & 92,69 & 15,38 & 140,44 \\
\hline $01 / 08 / 07$ & 92,69 & 15,38 & 140,44 \\
\hline $03 / 08 / 07$ & 93,31 & 15,28 & 141,38 \\
\hline $06 / 08 / 07$ & 95,85 & 14,87 & 145,23 \\
\hline $08 / 08 / 07$ & 91,14 & 15,64 & 138,09 \\
\hline $10 / 08 / 07$ & 92,54 & 15,41 & 140,21 \\
\hline $15 / 08 / 07$ & 90,91 & 15,68 & 137,74 \\
\hline $17 / 08 / 07$ & 94,44 & 15,10 & 143,09 \\
\hline $20 / 08 / 07$ & 106,76 & 13,35 & 161,76 \\
\hline $24 / 08 / 07$ & 93,07 & 15,32 & 141,02 \\
\hline $27 / 08 / 07$ & 84,51 & 16,87 & 128,05 \\
\hline $31 / 08 / 07$ & 94,24 & 15,13 & 142,79 \\
\hline $03 / 09 / 07$ & 92,69 & 15,38 & 140,44 \\
\hline 10/09/07 & 98,47 & 14,48 & 149,20 \\
\hline 14/09/07 & 94,64 & 15,06 & 143,39 \\
\hline 19/09/07 & 95,49 & 14,93 & 144,68 \\
\hline $21 / 09 / 07$ & 95,39 & 14,94 & 144,53 \\
\hline $24 / 09 / 07$ & 92,64 & 15,39 & 140,36 \\
\hline $01 / 10 / 07$ & 96,31 & 14,80 & 145,92 \\
\hline $05 / 10 / 07$ & 95,85 & 14,87 & 145,23 \\
\hline $08 / 10 / 07$ & 94,39 & 15,10 & 143,02 \\
\hline 15/10/07 & 94,94 & 15,02 & 143,85 \\
\hline 19/10/07 & 93,75 & 15,21 & 142,05 \\
\hline 22/10/07 & 96,15 & 14,83 & 145,68 \\
\hline $26 / 10 / 07$ & 95,39 & 14,94 & 144,53 \\
\hline $31 / 10 / 07$ & 95,14 & 14,98 & 144,15 \\
\hline $05 / 11 / 07$ & 91,28 & 15,62 & 138,30 \\
\hline $09 / 11 / 07$ & 96,77 & 14,73 & 146,62 \\
\hline $12 / 11 / 07$ & 97,30 & 14,65 & 147,42 \\
\hline $19 / 11 / 07$ & 97,72 & 14,59 & 148,06 \\
\hline $23 / 11 / 07$ & 94,69 & 15,06 & 143,47 \\
\hline $26 / 11 / 07$ & 94,84 & 15,03 & 143,70 \\
\hline $30 / 11 / 07$ & 91,84 & 15,52 & 139,15 \\
\hline $03 / 12 / 07$ & 94,74 & 15,05 & 143,55 \\
\hline $07 / 12 / 07$ & 92,78 & 15,37 & 140,58 \\
\hline 10/12/07 & 96,31 & 14,80 & 145,92 \\
\hline $16 / 12 / 07$ & 96,41 & 14,79 & 146,08 \\
\hline $21 / 12 / 07$ & 95,09 & 14,99 & 144,08 \\
\hline $27 / 12 / 07$ & 93,51 & 15,25 & 141,68 \\
\hline $04 / 01 / 08$ & 93,60 & 15,23 & 141,82 \\
\hline $07 / 01 / 08$ & 98,68 & 14,45 & 149,52 \\
\hline
\end{tabular}




\begin{tabular}{|c|c|c|c|}
\hline \multirow[b]{2}{*}{ Data } & \multicolumn{3}{|c|}{ Filtro 1} \\
\hline & $\begin{array}{l}\text { Vazão } \\
\text { (L/h) }\end{array}$ & $\begin{array}{l}\text { TCLV } \\
(\min )\end{array}$ & $\begin{array}{l}\text { Taxa de Aplicação } \\
\left(\mathrm{m}^{3} / \mathrm{m}^{2} . \mathrm{d}\right)\end{array}$ \\
\hline $11 / 01 / 08$ & 97,04 & 14,69 & 147,03 \\
\hline $15 / 01 / 08$ & 91,32 & 15,61 & 138,36 \\
\hline $18 / 01 / 08$ & 93,51 & 15,25 & 141,68 \\
\hline $28 / 01 / 08$ & 91,51 & 15,58 & 138,65 \\
\hline $01 / 02 / 08$ & 94,19 & 15,14 & 142,71 \\
\hline $08 / 02 / 08$ & 92,26 & 15,45 & 139,79 \\
\hline $11 / 02 / 08$ & 92,93 & 15,34 & 140,80 \\
\hline $15 / 02 / 08$ & 94,04 & 15,16 & 142,48 \\
\hline $18 / 02 / 08$ & 93,60 & 15,23 & 141,82 \\
\hline $22 / 02 / 08$ & 92,31 & 15,44 & 139,86 \\
\hline $25 / 02 / 08$ & 95,90 & 14,87 & 145,30 \\
\hline $29 / 02 / 08$ & 93,36 & 15,27 & 141,45 \\
\hline $10 / 04 / 08$ & 96,51 & 14,77 & 146,23 \\
\hline $14 / 04 / 08$ & 92,31 & 15,44 & 139,86 \\
\hline $16 / 04 / 08$ & 93,95 & 15,17 & 142,35 \\
\hline $24 / 04 / 08$ & 100,78 & 14,15 & 152,70 \\
\hline $28 / 04 / 08$ & 95,60 & 14,91 & 144,85 \\
\hline $12 / 05 / 08$ & 92,90 & 15,35 & 140,76 \\
\hline $15 / 05 / 08$ & 93,85 & 15,19 & 142,20 \\
\hline $26 / 05 / 08$ & 93,31 & 15,28 & 141,38 \\
\hline $29 / 05 / 08$ & 93,26 & 15,29 & 141,30 \\
\hline $02 / 06 / 08$ & 92,21 & 15,46 & 139,71 \\
\hline $12 / 06 / 08$ & 91,51 & 15,58 & 138,65 \\
\hline $16 / 06 / 08$ & 92,21 & 15,46 & 139,71 \\
\hline 18/06/08 & 96,80 & 14,73 & 146,67 \\
\hline $23 / 06 / 08$ & 92,59 & 15,40 & 140,29 \\
\hline $30 / 06 / 08$ & 92,60 & 15,40 & 140,30 \\
\hline $02 / 07 / 08$ & 96,90 & 14,71 & 146,82 \\
\hline 07/07/08 & 93,90 & 15,18 & 142,27 \\
\hline $22 / 07 / 08$ & 92,50 & 15,41 & 140,15 \\
\hline $24 / 07 / 08$ & 93,75 & 15,21 & 142,05 \\
\hline $28 / 07 / 08$ & 94,40 & 15,10 & 143,03 \\
\hline $31 / 07 / 08$ & 96,67 & 14,75 & 146,47 \\
\hline $11 / 08 / 08$ & 96,00 & 14,85 & 145,45 \\
\hline $14 / 08 / 08$ & 99,50 & 14,33 & 150,76 \\
\hline $18 / 08 / 08$ & 95,10 & 14,99 & 144,09 \\
\hline $19 / 08 / 08$ & 95,59 & 14,91 & 144,83 \\
\hline $25 / 08 / 08$ & 95,34 & 14,95 & 144,45 \\
\hline $28 / 08 / 08$ & 99,78 & 14,29 & 151,18 \\
\hline $02 / 09 / 08$ & 97,00 & 14,70 & 146,97 \\
\hline $04 / 09 / 08$ & 96,98 & 14,70 & 146,94 \\
\hline 08/09/08 & 95,95 & 14,86 & 145,38 \\
\hline $11 / 09 / 08$ & 93,56 & 15,24 & 141,76 \\
\hline $15 / 09 / 08$ & 93,07 & 15,32 & 141,02 \\
\hline $18 / 09 / 08$ & 91,46 & 15,59 & 138,58 \\
\hline $22 / 09 / 08$ & 94,04 & 15,16 & 142,48 \\
\hline $25 / 09 / 08$ & 101,60 & 14,03 & 153,94 \\
\hline $29 / 09 / 08$ & 92,69 & 15,38 & 140,44 \\
\hline $02 / 10 / 08$ & 95,40 & 14,94 & 144,55 \\
\hline $13 / 10 / 08$ & 93,80 & 15,20 & 142,12 \\
\hline $23 / 10 / 08$ & 93,90 & 15,18 & 142,27 \\
\hline $27 / 10 / 08$ & 94,64 & 15,06 & 143,39 \\
\hline $03 / 11 / 08$ & 94,39 & 15,10 & 143,02 \\
\hline
\end{tabular}




\begin{tabular}{|c|c|c|c|}
\hline \multirow{2}{*}{ Data } & \multicolumn{3}{|c|}{ Filtro 1 } \\
\cline { 2 - 4 } & $\begin{array}{c}\text { Vazão } \\
(\mathbf{L} / \mathbf{h})\end{array}$ & $\begin{array}{c}\text { TCLV } \\
(\mathbf{m i n})\end{array}$ & $\begin{array}{c}\text { Taxa de Aplicação } \\
\left(\mathbf{m}^{\mathbf{3}} / \mathbf{m}^{\mathbf{2}} \text {.d) }\right.\end{array}$ \\
\hline $06 / 11 / 08$ & 91,46 & 15,59 & 138,58 \\
\hline $10 / 11 / 08$ & 92,88 & 15,35 & 140,73 \\
\hline $13 / 11 / 08$ & 91,46 & 15,59 & 138,58 \\
\hline $08 / 12 / 08$ & 93,65 & 15,22 & 141,89 \\
\hline
\end{tabular}




\begin{tabular}{|c|c|c|c|}
\hline \multirow[b]{2}{*}{ Data } & \multicolumn{3}{|c|}{ Filtro 2} \\
\hline & $\begin{array}{l}\text { Vazão } \\
\text { (L/h) }\end{array}$ & $\begin{array}{l}\text { TCLV } \\
(\min )\end{array}$ & $\begin{array}{c}\text { Taxa de Aplicação } \\
\left(\mathrm{m}^{3} / \mathrm{m}^{2} . \mathrm{d}\right)\end{array}$ \\
\hline $10 / 07 / 07$ & 88,50 & 16,11 & 134,09 \\
\hline $12 / 07 / 07$ & 94,89 & 15,02 & 143,77 \\
\hline $16 / 07 / 07$ & 96,88 & 14,72 & 146,79 \\
\hline $18 / 07 / 07$ & 86,23 & 16,53 & 130,65 \\
\hline $20 / 07 / 07$ & 94,19 & 15,14 & 142,71 \\
\hline $23 / 07 / 07$ & 93,70 & 15,21 & 141,97 \\
\hline $25 / 07 / 07$ & 93,17 & 15,30 & 141,17 \\
\hline $27 / 07 / 07$ & 95,09 & 14,99 & 144,08 \\
\hline $30 / 07 / 07$ & 95,90 & 14,87 & 145,30 \\
\hline $01 / 08 / 07$ & 95,90 & 14,87 & 145,30 \\
\hline $03 / 08 / 07$ & 96,26 & 14,81 & 145,85 \\
\hline $06 / 08 / 07$ & 93,99 & 15,17 & 142,41 \\
\hline $08 / 08 / 07$ & 97,72 & 14,59 & 148,06 \\
\hline $10 / 08 / 07$ & 94,09 & 15,15 & 142,56 \\
\hline $15 / 08 / 07$ & 103,45 & 13,78 & 156,74 \\
\hline $17 / 08 / 07$ & 93,26 & 15,29 & 141,30 \\
\hline $20 / 08 / 07$ & 109,69 & 13,00 & 166,20 \\
\hline $24 / 08 / 07$ & 92,54 & 15,41 & 140,21 \\
\hline $27 / 08 / 07$ & 96,57 & 14,76 & 146,32 \\
\hline $31 / 08 / 07$ & 92,78 & 15,37 & 140,58 \\
\hline $03 / 09 / 07$ & 97,46 & 14,63 & 147,67 \\
\hline $10 / 09 / 07$ & 103,33 & 13,80 & 156,56 \\
\hline $14 / 09 / 07$ & 92,54 & 15,41 & 140,21 \\
\hline 19/09/07 & 97,56 & 14,61 & 147,82 \\
\hline $21 / 09 / 07$ & 96,10 & 14,83 & 145,61 \\
\hline $24 / 09 / 07$ & 98,90 & 14,41 & 149,85 \\
\hline $01 / 10 / 07$ & 98,90 & 14,41 & 149,85 \\
\hline $05 / 10 / 07$ & 94,79 & 15,04 & 143,62 \\
\hline $08 / 10 / 07$ & 98,63 & 14,45 & 149,44 \\
\hline $15 / 10 / 07$ & 99,83 & 14,28 & 151,26 \\
\hline 19/10/07 & 93,02 & 15,33 & 140,94 \\
\hline $22 / 10 / 07$ & 97,77 & 14,58 & 148,14 \\
\hline $26 / 10 / 07$ & 97,04 & 14,69 & 147,03 \\
\hline $31 / 10 / 07$ & 96,77 & 14,73 & 146,62 \\
\hline $05 / 11 / 07$ & 95,85 & 14,87 & 145,23 \\
\hline $09 / 11 / 07$ & 95,54 & 14,92 & 144,76 \\
\hline $12 / 11 / 07$ & 98,79 & 14,43 & 149,68 \\
\hline 19/11/07 & 96,83 & 14,72 & 146,71 \\
\hline $23 / 11 / 07$ & 96,77 & 14,73 & 146,62 \\
\hline $26 / 11 / 07$ & 97,99 & 14,55 & 148,47 \\
\hline $30 / 11 / 07$ & 93,12 & 15,31 & 141,09 \\
\hline $03 / 12 / 07$ & 94,89 & 15,02 & 143,77 \\
\hline $07 / 12 / 07$ & 96,62 & 14,75 & 146,39 \\
\hline $10 / 12 / 07$ & 91,09 & 15,65 & 138,02 \\
\hline $16 / 12 / 07$ & 96,93 & 14,71 & 146,86 \\
\hline $21 / 12 / 07$ & 92,78 & 15,37 & 140,58 \\
\hline $27 / 12 / 07$ & 93,90 & 15,18 & 142,27 \\
\hline $04 / 01 / 08$ & 96,21 & 14,82 & 145,77 \\
\hline $07 / 01 / 08$ & 93,70 & 15,21 & 141,97 \\
\hline $11 / 01 / 08$ & 97,83 & 14,57 & 148,23 \\
\hline $15 / 01 / 08$ & 93,12 & 15,31 & 141,09 \\
\hline $18 / 01 / 08$ & 92,78 & 15,37 & 140,58 \\
\hline
\end{tabular}




\begin{tabular}{|c|c|c|c|}
\hline \multirow[b]{2}{*}{ Data } & \multicolumn{3}{|c|}{ Filtro 2} \\
\hline & $\begin{array}{c}\text { Vazão } \\
\text { (L/h) }\end{array}$ & $\begin{array}{l}\text { TCLV } \\
(\min )\end{array}$ & $\begin{array}{c}\text { Taxa de Aplicação } \\
\left(\mathrm{m}^{3} / \mathrm{m}^{2} . \mathrm{d}\right)\end{array}$ \\
\hline $28 / 01 / 08$ & 93,56 & 15,24 & 141,76 \\
\hline $01 / 02 / 08$ & 92,74 & 15,37 & 140,52 \\
\hline $08 / 02 / 08$ & 95,39 & 14,94 & 144,53 \\
\hline $11 / 02 / 08$ & 97,56 & 14,61 & 147,82 \\
\hline $15 / 02 / 08$ & 96,93 & 14,71 & 146,86 \\
\hline $18 / 02 / 08$ & 99,12 & 14,38 & 150,18 \\
\hline $22 / 02 / 08$ & 94,29 & $\overline{15,12}$ & 142,86 \\
\hline $25 / 02 / 08$ & 95,95 & 14,86 & 145,38 \\
\hline $29 / 02 / 08$ & 95,90 & 14,87 & 145,30 \\
\hline 10/04/08 & 92,98 & 15,33 & 140,88 \\
\hline $14 / 04 / 08$ & 94,29 & 15,12 & 142,86 \\
\hline $16 / 04 / 08$ & 93,17 & 15,30 & 141,17 \\
\hline $24 / 04 / 08$ & 95,69 & 14,90 & 144,98 \\
\hline $28 / 04 / 08$ & 95,39 & 14,94 & 144,53 \\
\hline $12 / 05 / 08$ & 96,50 & 14,77 & 146,21 \\
\hline $15 / 05 / 08$ & 96,40 & 14,79 & 146,06 \\
\hline $26 / 05 / 08$ & 96,26 & 14,81 & 145,85 \\
\hline $29 / 05 / 08$ & 93,60 & 15,23 & 141,82 \\
\hline $02 / 06 / 08$ & 96,80 & 14,73 & 146,67 \\
\hline $12 / 06 / 08$ & 92,74 & 15,37 & 140,52 \\
\hline 16/06/08 & 92,45 & 15,42 & 140,08 \\
\hline 18/06/08 & 97,83 & 14,57 & 148,23 \\
\hline $23 / 06 / 08$ & 96,62 & 14,75 & 146,39 \\
\hline $30 / 06 / 08$ & 93,07 & 15,32 & 141,02 \\
\hline $02 / 07 / 08$ & 92,74 & 15,37 & 140,52 \\
\hline $07 / 07 / 08$ & 96,98 & 14,70 & 146,94 \\
\hline $22 / 07 / 08$ & 93,51 & 15,25 & 141,68 \\
\hline $24 / 07 / 08$ & 96,00 & 14,85 & 145,45 \\
\hline $28 / 07 / 08$ & 92,90 & 15,35 & 140,76 \\
\hline $31 / 07 / 08$ & 92,50 & 15,41 & 140,15 \\
\hline $11 / 08 / 08$ & 93,90 & 15,18 & 142,27 \\
\hline 14/08/08 & 93,22 & 15,29 & 141,24 \\
\hline $18 / 08 / 08$ & 96,40 & 14,79 & 146,06 \\
\hline 19/08/08 & 97,67 & 14,60 & 147,98 \\
\hline $25 / 08 / 08$ & 96,77 & 14,73 & 146,62 \\
\hline $28 / 08 / 08$ & 100,00 & 14,26 & 151,52 \\
\hline $02 / 09 / 08$ & 92,40 & 15,43 & 140,00 \\
\hline $04 / 09 / 08$ & 99,01 & 14,40 & 150,02 \\
\hline $08 / 09 / 08$ & 96,62 & 14,75 & 146,39 \\
\hline $11 / 09 / 08$ & 96,10 & 14,83 & 145,61 \\
\hline $15 / 09 / 08$ & 94,89 & 15,02 & 143,77 \\
\hline $18 / 09 / 08$ & 91,79 & 15,53 & 139,08 \\
\hline $22 / 09 / 08$ & 92,78 & 15,37 & 140,58 \\
\hline $25 / 09 / 08$ & 94,20 & 15,13 & 142,73 \\
\hline $29 / 09 / 08$ & 92,50 & 15,41 & 140,15 \\
\hline $02 / 10 / 08$ & 92,64 & 15,39 & 140,36 \\
\hline $13 / 10 / 08$ & 92,74 & 15,37 & 140,52 \\
\hline $23 / 10 / 08$ & 96,77 & 14,73 & 146,62 \\
\hline $27 / 10 / 08$ & 96,67 & 14,75 & 146,47 \\
\hline $03 / 11 / 08$ & 94,84 & 15,03 & 143,70 \\
\hline
\end{tabular}




\begin{tabular}{|c|c|c|c|}
\hline \multirow{2}{*}{ Data } & \multicolumn{3}{|c|}{ Filtro 2 } \\
\cline { 2 - 4 } & $\begin{array}{c}\text { Vazão } \\
(\mathbf{L} / \mathbf{h})\end{array}$ & $\begin{array}{c}\text { TCLV } \\
(\mathbf{m i n})\end{array}$ & $\begin{array}{c}\text { Taxa de Aplicação } \\
\left(\mathbf{m}^{3} / \mathbf{m}^{2} . \mathbf{d}\right)\end{array}$ \\
\hline $06 / 11 / 08$ & 98,47 & 14,48 & 149,20 \\
\hline $10 / 11 / 08$ & 97,19 & 14,67 & 147,26 \\
\hline $13 / 11 / 08$ & 96,88 & 14,72 & 146,79 \\
\hline $08 / 12 / 08$ & 92,98 & 15,33 & 140,88 \\
\hline
\end{tabular}




\begin{tabular}{|c|c|c|c|}
\hline \multirow[b]{2}{*}{ Data } & \multicolumn{3}{|c|}{ Filtro 3} \\
\hline & $\begin{array}{l}\text { Vazão } \\
\text { (L/h) }\end{array}$ & $\begin{array}{l}\text { TCLV } \\
(\min ) \\
\end{array}$ & $\begin{array}{c}\text { Taxa de Aplicação } \\
\left(\mathrm{m}^{3} / \mathrm{m}^{2} . \mathrm{d}\right)\end{array}$ \\
\hline $10 / 07 / 07$ & 95,60 & 14,91 & 144,85 \\
\hline $12 / 07 / 07$ & 95,60 & 14,91 & 144,85 \\
\hline $16 / 07 / 07$ & 93,95 & 15,17 & 142,35 \\
\hline $18 / 07 / 07$ & 87,17 & 16,35 & 132,08 \\
\hline $20 / 07 / 07$ & 92,78 & 15,37 & 140,58 \\
\hline $23 / 07 / 07$ & 93,99 & 15,17 & 142,41 \\
\hline $25 / 07 / 07$ & 93,75 & 15,21 & 142,05 \\
\hline $27 / 07 / 07$ & 97,19 & 14,67 & 147,26 \\
\hline $30 / 07 / 07$ & 92,93 & 15,34 & 140,80 \\
\hline $01 / 08 / 07$ & 92,93 & 15,34 & 140,80 \\
\hline $03 / 08 / 07$ & 96,46 & $\begin{array}{l}14,78 \\
\end{array}$ & 146,15 \\
\hline $06 / 08 / 07$ & 96,05 & 14,84 & 145,53 \\
\hline $08 / 08 / 07$ & 92,50 & 15,41 & 140,15 \\
\hline $10 / 08 / 07$ & 92,02 & 15,49 & 139,42 \\
\hline $15 / 08 / 07$ & 88,58 & 16,09 & 134,21 \\
\hline 17/08/07 & 92,31 & 15,44 & 139,86 \\
\hline $20 / 08 / 07$ & 92,88 & 15,35 & 140,73 \\
\hline $24 / 08 / 07$ & 93,31 & 15,28 & 141,38 \\
\hline $27 / 08 / 07$ & 91,09 & 15,65 & 138,02 \\
\hline $31 / 08 / 07$ & 96,51 & 14,77 & 146,23 \\
\hline $03 / 09 / 07$ & 95,14 & 14,98 & 144,15 \\
\hline $10 / 09 / 07$ & 82,27 & 17,33 & 124,65 \\
\hline $14 / 09 / 07$ & 95,69 & 14,90 & 144,98 \\
\hline $19 / 09 / 07$ & 96,31 & 14,80 & 145,92 \\
\hline $21 / 09 / 07$ & 94,94 & 15,02 & 143,85 \\
\hline $24 / 09 / 07$ & 92,69 & 15,38 & 140,44 \\
\hline $01 / 10 / 07$ & 98,09 & 14,53 & 148,62 \\
\hline $05 / 10 / 07$ & 96,31 & 14,80 & 145,92 \\
\hline $08 / 10 / 07$ & 92,78 & 15,37 & 140,58 \\
\hline $15 / 10 / 07$ & 98,36 & 14,49 & 149,03 \\
\hline 19/10/07 & 93,56 & 15,24 & 141,76 \\
\hline $22 / 10 / 07$ & 101,29 & 14,07 & 153,47 \\
\hline $26 / 10 / 07$ & 92,21 & 15,46 & 139,71 \\
\hline $31 / 10 / 07$ & 91,60 & 15,56 & 138,79 \\
\hline $05 / 11 / 07$ & 103,39 & 13,79 & 156,65 \\
\hline $09 / 11 / 07$ & 97,19 & 14,67 & 147,26 \\
\hline 12/11/07 & 88,24 & 16,16 & 133,70 \\
\hline $19 / 11 / 07$ & 91,79 & 15,53 & 139,08 \\
\hline $23 / 11 / 07$ & 94,59 & 15,07 & 143,32 \\
\hline $26 / 11 / 07$ & 98,36 & 14,49 & 149,03 \\
\hline $30 / 11 / 07$ & 95,09 & 14,99 & 144,08 \\
\hline $03 / 12 / 07$ & 95,39 & 14,94 & 144,53 \\
\hline $07 / 12 / 07$ & 96,36 & 14,79 & 146,00 \\
\hline 10/12/07 & 96,83 & 14,72 & 146,71 \\
\hline $16 / 12 / 07$ & 93,99 & 15,17 & 142,41 \\
\hline $21 / 12 / 07$ & 93,70 & 15,21 & 141,97 \\
\hline $27 / 12 / 07$ & 97,09 & 14,68 & 147,11 \\
\hline $04 / 01 / 08$ & 95,29 & 14,96 & 144,38 \\
\hline $07 / 01 / 08$ & 94,79 & 15,04 & 143,62 \\
\hline $11 / 01 / 08$ & 94,44 & 15,10 & 143,09 \\
\hline $15 / 01 / 08$ & 90,59 & 15,74 & 137,26 \\
\hline $18 / 01 / 08$ & 96,77 & 14,73 & 146,62 \\
\hline
\end{tabular}




\begin{tabular}{|c|c|c|c|}
\hline \multirow[b]{2}{*}{ Data } & \multicolumn{3}{|c|}{ Filtro 3} \\
\hline & $\begin{array}{c}\text { Vazão } \\
\text { (L/h) }\end{array}$ & $\begin{array}{l}\text { TCLV } \\
(\min ) \\
\end{array}$ & $\begin{array}{c}\text { Taxa de Aplicação } \\
\left(\mathrm{m}^{3} / \mathrm{m}^{2} . \mathrm{d}\right)\end{array}$ \\
\hline $28 / 01 / 08$ & 98,31 & 14,50 & 148,95 \\
\hline $01 / 02 / 08$ & 96,00 & 14,85 & 145,45 \\
\hline $08 / 02 / 08$ & 96,41 & 14,79 & 146,08 \\
\hline $11 / 02 / 08$ & 94,59 & 15,07 & 143,32 \\
\hline $15 / 02 / 08$ & 95,19 & 14,98 & 144,23 \\
\hline $18 / 02 / 08$ & 96,62 & 14,75 & 146,39 \\
\hline $22 / 02 / 08$ & 94,79 & 15,04 & 143,62 \\
\hline $25 / 02 / 08$ & 97,72 & 14,59 & 148,06 \\
\hline $29 / 02 / 08$ & 92,40 & 15,43 & 140,00 \\
\hline $10 / 04 / 08$ & 94,29 & 15,12 & 142,86 \\
\hline $14 / 04 / 08$ & 94,79 & 15,04 & 143,62 \\
\hline $16 / 04 / 08$ & 97,83 & 14,57 & 148,23 \\
\hline $24 / 04 / 08$ & 97,99 & 14,55 & 148,47 \\
\hline $28 / 04 / 08$ & 96,70 & 14,74 & 146,52 \\
\hline $12 / 05 / 08$ & 98,40 & 14,49 & 149,09 \\
\hline $15 / 05 / 08$ & 93,70 & 15,21 & 141,97 \\
\hline $26 / 05 / 08$ & 95,80 & 14,88 & 145,15 \\
\hline $29 / 05 / 08$ & 97,93 & 14,56 & 148,38 \\
\hline $02 / 06 / 08$ & 94,10 & 15,15 & 142,58 \\
\hline $12 / 06 / 08$ & 98,20 & 14,52 & 148,79 \\
\hline $16 / 06 / 08$ & 93,10 & 15,31 & 141,06 \\
\hline $18 / 06 / 08$ & 93,85 & 15,19 & 142,20 \\
\hline $23 / 06 / 08$ & 91,05 & 15,66 & 137,95 \\
\hline $30 / 06 / 08$ & 92,40 & 15,43 & 140,00 \\
\hline $02 / 07 / 08$ & 96,93 & 14,71 & 146,86 \\
\hline $07 / 07 / 08$ & 96,31 & 14,80 & 145,92 \\
\hline $22 / 07 / 08$ & 92,88 & 15,35 & 140,73 \\
\hline $24 / 07 / 08$ & 91,80 & 15,53 & 139,09 \\
\hline $28 / 07 / 08$ & 96,30 & 14,80 & 145,91 \\
\hline $31 / 07 / 08$ & 100,00 & 14,26 & 151,52 \\
\hline $11 / 08 / 08$ & 92,30 & 15,45 & 139,85 \\
\hline $14 / 08 / 08$ & 102,74 & 13,88 & 155,67 \\
\hline $18 / 08 / 08$ & 95,24 & 14,97 & 144,30 \\
\hline 19/08/08 & 99,61 & 14,31 & 150,92 \\
\hline $25 / 08 / 08$ & 96,80 & 14,73 & 146,67 \\
\hline $28 / 08 / 08$ & 96,30 & 14,80 & 145,91 \\
\hline $02 / 09 / 08$ & 92,80 & 15,36 & 140,61 \\
\hline $04 / 09 / 08$ & 93,60 & 15,23 & 141,82 \\
\hline $08 / 09 / 08$ & 92,69 & 15,38 & 140,44 \\
\hline $11 / 09 / 08$ & 91,05 & 15,66 & 137,95 \\
\hline $15 / 09 / 08$ & 96,26 & 14,81 & 145,85 \\
\hline $18 / 09 / 08$ & 95,95 & 14,86 & 145,38 \\
\hline $22 / 09 / 08$ & 95,29 & 14,96 & 144,38 \\
\hline $25 / 09 / 08$ & 95,60 & 14,91 & 144,85 \\
\hline $29 / 09 / 08$ & 93,70 & 15,21 & 141,97 \\
\hline $02 / 10 / 08$ & 92,00 & 15,50 & 139,39 \\
\hline $13 / 10 / 08$ & 92,50 & 15,41 & 140,15 \\
\hline $23 / 10 / 08$ & 93,60 & 15,23 & 141,82 \\
\hline $27 / 10 / 08$ & 96,40 & 14,79 & 146,06 \\
\hline $03 / 11 / 08$ & 96,72 & 14,74 & 146,55 \\
\hline
\end{tabular}




\begin{tabular}{|c|c|c|c|}
\hline \multirow{2}{*}{ Data } & \multicolumn{3}{|c|}{ Filtro 3 } \\
\cline { 2 - 4 } & $\begin{array}{c}\text { Vazão } \\
(\mathbf{L} / \mathbf{h})\end{array}$ & $\begin{array}{c}\text { TCLV } \\
(\mathbf{m i n})\end{array}$ & $\begin{array}{c}\text { Taxa de Aplicação } \\
\left(\mathbf{m}^{\mathbf{3}} / \mathbf{m}^{\mathbf{2}} \mathbf{. d}\right)\end{array}$ \\
\hline $06 / 11 / 08$ & 92,36 & 15,44 & 139,94 \\
\hline $10 / 11 / 08$ & 97,04 & 14,69 & 147,03 \\
\hline $13 / 11 / 08$ & 99,50 & 14,33 & 150,76 \\
\hline $08 / 12 / 08$ & 96,77 & 14,73 & 146,62 \\
\hline
\end{tabular}




\begin{tabular}{|c|c|c|c|}
\hline \multirow[b]{2}{*}{ Data } & \multicolumn{3}{|c|}{ Filtro 4} \\
\hline & $\begin{array}{l}\text { Vazão } \\
\text { (L/h) }\end{array}$ & $\begin{array}{l}\text { TCLV } \\
(\min ) \\
\end{array}$ & $\begin{array}{c}\text { Taxa de Aplicação } \\
\left(\mathrm{m}^{3} / \mathrm{m}^{2} . \mathrm{d}\right)\end{array}$ \\
\hline $10 / 07 / 07$ & 84,60 & 16,85 & 128,18 \\
\hline $12 / 07 / 07$ & 84,60 & 16,85 & 128,18 \\
\hline $16 / 07 / 07$ & 95,39 & 14,94 & 144,53 \\
\hline $18 / 07 / 07$ & 77,75 & 18,34 & 117,80 \\
\hline $20 / 07 / 07$ & 96,51 & 14,77 & 146,23 \\
\hline $23 / 07 / 07$ & 93,02 & 15,33 & 140,94 \\
\hline $25 / 07 / 07$ & 93,65 & 15,22 & 141,89 \\
\hline $27 / 07 / 07$ & 96,62 & 14,75 & 146,39 \\
\hline $30 / 07 / 07$ & 92,74 & 15,37 & 140,52 \\
\hline $01 / 08 / 07$ & 92,74 & 15,37 & 140,52 \\
\hline $03 / 08 / 07$ & 96,46 & $\begin{array}{l}4,78 \\
\end{array}$ & 146,15 \\
\hline $06 / 08 / 07$ & 93,41 & 15,26 & 141,53 \\
\hline $08 / 08 / 07$ & 89,60 & 15,91 & 135,76 \\
\hline $10 / 08 / 07$ & 92,31 & 15,44 & 139,86 \\
\hline $15 / 08 / 07$ & 90,23 & 15,80 & 136,71 \\
\hline 17/08/07 & 97,24 & 14,66 & 147,33 \\
\hline $20 / 08 / 07$ & 99,01 & 14,40 & 150,02 \\
\hline $24 / 08 / 07$ & 96,57 & 14,76 & 146,32 \\
\hline $27 / 08 / 07$ & 91,42 & 15,59 & 138,52 \\
\hline $31 / 08 / 07$ & 93,75 & 15,21 & 142,05 \\
\hline $03 / 09 / 07$ & 95,39 & 14,94 & 144,53 \\
\hline $10 / 09 / 07$ & 76,53 & 18,63 & 115,95 \\
\hline $14 / 09 / 07$ & 94,49 & 15,09 & 143,17 \\
\hline $19 / 09 / 07$ & 95,69 & 14,90 & 144,98 \\
\hline $21 / 09 / 07$ & 96,98 & 14,70 & 146,94 \\
\hline $24 / 09 / 07$ & 96,21 & 14,82 & 145,77 \\
\hline $01 / 10 / 07$ & 96,36 & 14,79 & 146,00 \\
\hline $05 / 10 / 07$ & 95,44 & 14,94 & 144,61 \\
\hline $08 / 10 / 07$ & 93,36 & 15,27 & 141,45 \\
\hline $15 / 10 / 07$ & 98,58 & 14,46 & 149,36 \\
\hline $19 / 10 / 07$ & 95,09 & 14,99 & 144,08 \\
\hline $22 / 10 / 07$ & 96,51 & 14,77 & 146,23 \\
\hline $26 / 10 / 07$ & 94,04 & 15,16 & 142,48 \\
\hline $31 / 10 / 07$ & 91,28 & 15,62 & 138,30 \\
\hline $05 / 11 / 07$ & 91,74 & 15,54 & 139,00 \\
\hline $09 / 11 / 07$ & 92,64 & 15,39 & 140,36 \\
\hline 12/11/07 & 95,85 & 14,87 & 145,23 \\
\hline $19 / 11 / 07$ & 94,19 & 15,14 & 142,71 \\
\hline $23 / 11 / 07$ & 92,31 & 15,44 & 139,86 \\
\hline $26 / 11 / 07$ & 97,93 & 14,56 & 148,38 \\
\hline $30 / 11 / 07$ & 92,78 & 15,37 & 140,58 \\
\hline $03 / 12 / 07$ & 95,69 & 14,90 & 144,98 \\
\hline $07 / 12 / 07$ & 93,56 & 15,24 & 141,76 \\
\hline $10 / 12 / 07$ & 92,69 & 15,38 & 140,44 \\
\hline $16 / 12 / 07$ & 92,64 & 15,39 & 140,36 \\
\hline $21 / 12 / 07$ & 92,21 & 15,46 & 139,71 \\
\hline $27 / 12 / 07$ & 94,99 & 15,01 & 143,92 \\
\hline $04 / 01 / 08$ & 93,26 & 15,29 & 141,30 \\
\hline $07 / 01 / 08$ & 95,69 & 14,90 & 144,98 \\
\hline $11 / 01 / 08$ & 97,04 & 14,69 & 147,03 \\
\hline $15 / 01 / 08$ & 90,50 & 15,75 & 137,12 \\
\hline $18 / 01 / 08$ & 93,70 & 15,21 & 141,97 \\
\hline
\end{tabular}




\begin{tabular}{|c|c|c|c|}
\hline \multirow[b]{2}{*}{ Data } & \multicolumn{3}{|c|}{ Filtro 4} \\
\hline & $\begin{array}{c}\text { Vazão } \\
\text { (L/h) }\end{array}$ & $\begin{array}{l}\text { TCLV } \\
\text { (min) }\end{array}$ & $\begin{array}{c}\text { Taxa de Aplicação } \\
\left(\mathrm{m}^{3} / \mathrm{m}^{2} . \mathrm{d}\right)\end{array}$ \\
\hline $28 / 01 / 08$ & 90,45 & 15,76 & 137,05 \\
\hline $01 / 02 / 08$ & 92,54 & 15,41 & 140,21 \\
\hline $08 / 02 / 08$ & 93,17 & 15,30 & 141,17 \\
\hline $11 / 02 / 08$ & 94,14 & 15,14 & 142,64 \\
\hline $15 / 02 / 08$ & 93,90 & 15,18 & 142,27 \\
\hline $18 / 02 / 08$ & 91,98 & 15,50 & 139,36 \\
\hline $22 / 02 / 08$ & 92,26 & 15,45 & 139,79 \\
\hline $25 / 02 / 08$ & 97,09 & 14,68 & 147,11 \\
\hline 29/02/08 & 93,26 & 15,29 & 141,30 \\
\hline $10 / 04 / 08$ & 94,04 & 15,16 & 142,48 \\
\hline $14 / 04 / 08$ & 92,26 & 15,45 & 139,79 \\
\hline $16 / 04 / 08$ & 95,74 & 14,89 & 145,06 \\
\hline $24 / 04 / 08$ & 95,59 & 14,91 & 144,83 \\
\hline $28 / 04 / 08$ & 93,80 & 15,20 & 142,12 \\
\hline $12 / 05 / 08$ & 92,60 & 15,40 & 140,30 \\
\hline $15 / 05 / 08$ & 98,70 & 14,44 & 149,55 \\
\hline $26 / 05 / 08$ & 93,17 & 15,30 & 141,17 \\
\hline $29 / 05 / 08$ & 91,00 & 15,67 & 137,88 \\
\hline $02 / 06 / 08$ & 92,50 & 15,41 & 140,15 \\
\hline $12 / 06 / 08$ & 91,84 & 15,52 & 139,15 \\
\hline $16 / 06 / 08$ & 81,23 & 17,55 & 123,08 \\
\hline $18 / 06 / 08$ & 96,26 & 14,81 & 145,85 \\
\hline $23 / 06 / 08$ & 94,94 & 15,02 & 143,85 \\
\hline $30 / 06 / 08$ & 95,85 & 14,87 & 145,23 \\
\hline $02 / 07 / 08$ & 96,05 & 14,84 & 145,53 \\
\hline $07 / 07 / 08$ & 95,14 & 14,98 & 144,15 \\
\hline $22 / 07 / 08$ & 97,20 & 14,67 & 147,27 \\
\hline $24 / 07 / 08$ & 95,80 & 14,88 & 145,15 \\
\hline $28 / 07 / 08$ & 96,90 & $\overline{14,71}$ & 146,82 \\
\hline $31 / 07 / 08$ & 90,90 & 15,68 & 137,73 \\
\hline $11 / 08 / 08$ & 93,50 & 15,25 & 141,67 \\
\hline $14 / 08 / 08$ & 100,00 & 14,26 & 151,52 \\
\hline $18 / 08 / 08$ & 93,30 & 15,28 & 141,36 \\
\hline 19/08/08 & 94,69 & 15,06 & 143,47 \\
\hline $25 / 08 / 08$ & 94,10 & 15,15 & 142,58 \\
\hline $28 / 08 / 08$ & 97,99 & 14,55 & 148,47 \\
\hline $02 / 09 / 08$ & 94,79 & 15,04 & 143,62 \\
\hline $04 / 09 / 08$ & 95,60 & 14,91 & 144,85 \\
\hline $08 / 09 / 08$ & 96,70 & 14,74 & 146,52 \\
\hline $11 / 09 / 08$ & 92,70 & 15,38 & 140,45 \\
\hline $15 / 09 / 08$ & 92,50 & 15,41 & 140,15 \\
\hline $18 / 09 / 08$ & 89,70 & 15,89 & 135,91 \\
\hline $22 / 09 / 08$ & 92,70 & 15,38 & 140,45 \\
\hline $25 / 09 / 08$ & 97,60 & 14,61 & 147,88 \\
\hline $29 / 09 / 08$ & 96,00 & 14,85 & 145,45 \\
\hline $02 / 10 / 08$ & 97,40 & 14,64 & 147,58 \\
\hline $13 / 10 / 08$ & 96,10 & 14,83 & 145,61 \\
\hline $23 / 10 / 08$ & 92,50 & 15,41 & 140,15 \\
\hline $27 / 10 / 08$ & 96,80 & 14,73 & 146,67 \\
\hline $03 / 11 / 08$ & 92,31 & 15,44 & 139,86 \\
\hline
\end{tabular}




\begin{tabular}{|c|c|c|c|}
\hline \multirow{2}{*}{ Data } & \multicolumn{3}{|c|}{ Filtro 4 } \\
\cline { 2 - 4 } & $\begin{array}{c}\text { Vazão } \\
\text { (L/h) }\end{array}$ & $\begin{array}{c}\text { TCLV } \\
(\mathbf{m i n})\end{array}$ & $\begin{array}{c}\text { Taxa de Aplicação } \\
\left(\mathbf{m}^{3} / \mathbf{m}^{2} \mathbf{. d}\right)\end{array}$ \\
\hline $06 / 11 / 08$ & 91,70 & 15,55 & 138,94 \\
\hline $10 / 11 / 08$ & 96,62 & 14,75 & 146,39 \\
\hline $13 / 11 / 08$ & 93,70 & 15,21 & 141,97 \\
\hline $08 / 12 / 08$ & 97,19 & 14,67 & 147,26 \\
\hline
\end{tabular}




\section{APÊNDICE B - Vazões, Tempos de Detenção e Dosagens de Ozônio nas Colunas de Ozonização}

\begin{tabular}{|c|c|c|c|}
\hline \multirow[b]{2}{*}{ Data } & \multicolumn{3}{|c|}{ Coluna de Ozonização 1} \\
\hline & $\begin{array}{c}\text { Vazão } \\
(\mathrm{L} / \mathrm{h})\end{array}$ & $\begin{array}{c}\text { Tempo de detenção } \\
\text { (min) }\end{array}$ & $\begin{array}{l}\text { Dosagem de } \\
\text { ozônio (mg/L) }\end{array}$ \\
\hline 10/07/07 & 454,20 & 4,74 & 0,20 \\
\hline 12/07/07 & 454,20 & 4,74 & 0,30 \\
\hline 16/07/07 & 454,20 & 4,74 & 0,48 \\
\hline $18 / 07 / 07$ & 488,27 & 4,41 & 0,06 \\
\hline 20/07/07 & 454,20 & 4,74 & 0,37 \\
\hline $23 / 07 / 07$ & 454,20 & 4,74 & 0,33 \\
\hline $25 / 07 / 07$ & 482,59 & 4,46 & 0,13 \\
\hline $27 / 07 / 07$ & 454,20 & 4,74 & 0,41 \\
\hline 30/07/07 & 476,91 & 4,51 & 0,15 \\
\hline 01/08/07 & 482,59 & 4,46 & 0,14 \\
\hline 03/08/07 & 454,20 & 4,74 & 0,15 \\
\hline 06/08/07 & 454,20 & 4,74 & 0,30 \\
\hline 08/08/07 & 482,59 & 4,46 & 0,36 \\
\hline 10/08/07 & 681,30 & 3,16 & 0,19 \\
\hline 15/08/07 & 510,98 & 4,21 & 0,20 \\
\hline 17/08/07 & 510,98 & 4,21 & 0,27 \\
\hline 20/08/07 & 510,98 & 4,21 & 0,25 \\
\hline $24 / 08 / 07$ & 482,59 & 4,46 & 0,27 \\
\hline $27 / 08 / 07$ & 488,27 & 4,41 & 0,25 \\
\hline $31 / 08 / 07$ & 488,27 & 4,41 & 0,20 \\
\hline 03/09/07 & 488,27 & 4,41 & 0,20 \\
\hline 10/09/07 & 482,59 & 4,46 & 0,11 \\
\hline 14/09/07 & 482,59 & 4,46 & 0,38 \\
\hline 19/09/07 & 499,62 & 4,31 & 0,37 \\
\hline $21 / 09 / 07$ & 454,20 & 4,74 & 0,16 \\
\hline $24 / 09 / 07$ & 499,62 & 4,31 & 0,20 \\
\hline $01 / 10 / 07$ & 510,98 & 4,21 & 0,11 \\
\hline 05/10/07 & 454,20 & 4,74 & 0,12 \\
\hline 08/10/07 & 454,20 & 4,74 & 0,16 \\
\hline $15 / 10 / 07$ & 482,59 & 4,46 & 0,09 \\
\hline 19/10/07 & 454,20 & 4,74 & 0,45 \\
\hline $22 / 10 / 07$ & 499,62 & 4,31 & 0,47 \\
\hline $26 / 10 / 07$ & 482,59 & 4,46 & 0,56 \\
\hline $31 / 10 / 07$ & 510,98 & 4,21 & 0,39 \\
\hline $05 / 11 / 07$ & 545,04 & 3,95 & 0,25 \\
\hline $09 / 11 / 07$ & 567,75 & 3,79 & 0,64 \\
\hline $12 / 11 / 07$ & 567,75 & 3,79 & 0,26 \\
\hline 19/11/07 & 567,75 & 3,79 & 0,25 \\
\hline $23 / 11 / 07$ & 567,75 & 3,79 & 0,23 \\
\hline $26 / 11 / 07$ & 567,75 & 3,79 & 0,47 \\
\hline $30 / 11 / 07$ & 567,75 & 3,79 & 0,26 \\
\hline $03 / 12 / 07$ & 567,75 & 3,79 & 0,49 \\
\hline $07 / 12 / 07$ & 522,33 & 4,12 & 0,39 \\
\hline 10/12/07 & 567,75 & 3,79 & 0,44 \\
\hline $16 / 12 / 07$ & 499,62 & 4,31 & 0,34 \\
\hline $21 / 12 / 07$ & 482,59 & 4,46 & 0,32 \\
\hline $27 / 12 / 07$ & 499,62 & 4,31 & 0,29 \\
\hline $04 / 01 / 08$ & 454,20 & 4,74 & 0,43 \\
\hline $07 / 01 / 08$ & 454,20 & 4,74 & 0,13 \\
\hline
\end{tabular}




\begin{tabular}{|c|c|c|c|}
\hline \multirow[b]{2}{*}{ Data } & \multicolumn{3}{|c|}{ Coluna de ozonização 1} \\
\hline & $\begin{array}{l}\text { Vazão } \\
\text { (L/h) }\end{array}$ & $\begin{array}{c}\text { Tempo de detenção } \\
\text { (min) }\end{array}$ & $\begin{array}{l}\text { Dosagem de } \\
\text { ozônio (mg/L) }\end{array}$ \\
\hline $11 / 01 / 08$ & 454,20 & 4,74 & 0,65 \\
\hline $15 / 01 / 08$ & 482,59 & 4,46 & 0,34 \\
\hline $18 / 01 / 08$ & 476,91 & 4,51 & 0,50 \\
\hline $28 / 01 / 08$ & 510,98 & 4,21 & 0,45 \\
\hline $01 / 02 / 08$ & 510,98 & 4,21 & 0,30 \\
\hline $08 / 02 / 08$ & 482,59 & 4,46 & 0,28 \\
\hline $11 / 02 / 08$ & 510,98 & 4,21 & 0,40 \\
\hline $15 / 02 / 08$ & 510,98 & 4,21 & 0,45 \\
\hline $18 / 02 / 08$ & 481,45 & 4,47 & 1,23 \\
\hline $22 / 02 / 08$ & 454,20 & 4,74 & 1,12 \\
\hline $25 / 02 / 08$ & 454,20 & 4,74 & 1,43 \\
\hline $29 / 02 / 08$ & 454,20 & 4,74 & 0,25 \\
\hline $10 / 04 / 08$ & 567,75 & 3,79 & 0,79 \\
\hline $14 / 04 / 08$ & 567,75 & 3,79 & 0,91 \\
\hline $16 / 04 / 08$ & 590,46 & 3,64 & 1,82 \\
\hline $24 / 04 / 08$ & 567,75 & 3,79 & 1,22 \\
\hline $28 / 04 / 08$ & 567,75 & 3,79 & 1,10 \\
\hline $12 / 05 / 08$ & 567,75 & 3,79 & 1,10 \\
\hline $15 / 05 / 08$ & 590,46 & 3,64 & 1,41 \\
\hline $26 / 05 / 08$ & 567,75 & 3,79 & 1,30 \\
\hline $29 / 05 / 08$ & 601,82 & 3,57 & 1,18 \\
\hline $02 / 06 / 08$ & 567,75 & 3,79 & 1,05 \\
\hline $12 / 06 / 08$ & 601,82 & 3,57 & 1,21 \\
\hline $16 / 06 / 08$ & 567,75 & 3,79 & 1,09 \\
\hline $18 / 06 / 08$ & 601,82 & 3,57 & 0,85 \\
\hline $23 / 06 / 08$ & 567,75 & 3,79 & 0,55 \\
\hline $30 / 06 / 08$ & 590,46 & 3,64 & 0,45 \\
\hline $02 / 07 / 08$ & 590,46 & 3,64 & 0,43 \\
\hline $07 / 07 / 08$ & 567,75 & 3,79 & 0,43 \\
\hline $22 / 07 / 08$ & 567,75 & 3,79 & 0,42 \\
\hline $24 / 07 / 08$ & 567,75 & 3,79 & 0,50 \\
\hline $28 / 07 / 08$ & 567,75 & 3,79 & 0,61 \\
\hline $31 / 07 / 08$ & 567,75 & 3,79 & 0,56 \\
\hline $11 / 08 / 08$ & 567,75 & 3,79 & 0,70 \\
\hline $14 / 08 / 08$ & 545,04 & 3,95 & 0,68 \\
\hline $18 / 08 / 08$ & 613,17 & 3,51 & 0,60 \\
\hline $19 / 08 / 08$ & 613,17 & 3,51 & 0,56 \\
\hline $25 / 08 / 08$ & 567,75 & 3,79 & 0,60 \\
\hline $28 / 08 / 08$ & 613,17 & 3,51 & 0,59 \\
\hline $02 / 09 / 08$ & 567,75 & 3,79 & 0,67 \\
\hline $04 / 09 / 08$ & 590,46 & 3,64 & 0,57 \\
\hline $08 / 09 / 08$ & 567,75 & 3,79 & 0,69 \\
\hline $11 / 09 / 08$ & 567,75 & 3,79 & 1,35 \\
\hline $15 / 09 / 08$ & 567,75 & 3,79 & 1,23 \\
\hline $18 / 09 / 08$ & 567,75 & 3,79 & 1,42 \\
\hline $22 / 09 / 08$ & 567,75 & 3,79 & 1,75 \\
\hline $25 / 09 / 08$ & 567,75 & 3,79 & 0,78 \\
\hline $29 / 09 / 08$ & 567,75 & 3,79 & 0,73 \\
\hline $02 / 10 / 08$ & 567,75 & 3,79 & 0,68 \\
\hline $13 / 10 / 08$ & 567,75 & 3,79 & 0,41 \\
\hline $23 / 10 / 08$ & 652,91 & 3,29 & 0,72 \\
\hline $27 / 10 / 08$ & 567,75 & 3,79 & 0,78 \\
\hline $03 / 11 / 08$ & 567,75 & 3,79 & 1,02 \\
\hline
\end{tabular}




\begin{tabular}{|c|c|c|c|}
\hline \multirow{2}{*}{ Data } & \multicolumn{3}{|c|}{ Coluna de ozonização 1 } \\
\cline { 2 - 4 } & $\begin{array}{c}\text { Vazão } \\
\text { (L/h) }\end{array}$ & $\begin{array}{c}\text { Tempo de detenção } \\
\text { (min) }\end{array}$ & $\begin{array}{c}\text { Dosagem de } \\
\text { ozônio (mg/L) }\end{array}$ \\
\hline $06 / 11 / 08$ & 590,46 & 3,64 & 0,82 \\
\hline $10 / 11 / 08$ & 567,75 & 3,79 & 0,67 \\
\hline $13 / 11 / 08$ & 624,53 & 3,44 & 0,70 \\
\hline $08 / 12 / 08$ & 567,75 & 3,79 & 1,17 \\
\hline
\end{tabular}




\begin{tabular}{|c|c|c|c|}
\hline \multirow[b]{2}{*}{ Data } & \multicolumn{3}{|c|}{ Coluna de ozonização 2} \\
\hline & $\begin{array}{l}\text { Vazão } \\
(\mathrm{L} / \mathrm{h})\end{array}$ & $\begin{array}{c}\text { Tempo de detenção } \\
\text { (min) }\end{array}$ & $\begin{array}{l}\text { Dosagem de } \\
\text { ozônio (mg/L) }\end{array}$ \\
\hline $10 / 07 / 07$ & 454,20 & 4,74 & 0,20 \\
\hline $12 / 07 / 07$ & 454,20 & 4,74 & 0,03 \\
\hline $16 / 07 / 07$ & 454,20 & 4,74 & 0,46 \\
\hline $18 / 07 / 07$ & 476,91 & 4,51 & 0,06 \\
\hline $20 / 07 / 07$ & 454,20 & 4,74 & 0,27 \\
\hline $23 / 07 / 07$ & 454,20 & 4,74 & 0,26 \\
\hline $25 / 07 / 07$ & 482,59 & 4,46 & 0,11 \\
\hline $27 / 07 / 07$ & 454,20 & 4,74 & 0,33 \\
\hline $30 / 07 / 07$ & 454,20 & 4,74 & 0,15 \\
\hline $01 / 08 / 07$ & 454,20 & 4,74 & 0,10 \\
\hline $03 / 08 / 07$ & 454,20 & 4,74 & 0,15 \\
\hline $06 / 08 / 07$ & 454,20 & 4,74 & 0,30 \\
\hline $08 / 08 / 07$ & 482,59 & 4,46 & 0,36 \\
\hline $10 / 08 / 07$ & 454,20 & 4,74 & 0,19 \\
\hline $15 / 08 / 07$ & 482,59 & 4,46 & 0,21 \\
\hline $17 / 08 / 07$ & 482,59 & 4,46 & 0,17 \\
\hline $20 / 08 / 07$ & 510,98 & 4,21 & 0,27 \\
\hline $24 / 08 / 07$ & 482,59 & 4,46 & 0,27 \\
\hline $27 / 08 / 07$ & 479,18 & 4,49 & 0,24 \\
\hline $31 / 08 / 07$ & 408,78 & 5,26 & 0,19 \\
\hline $03 / 09 / 07$ & 408,78 & 5,26 & 0,02 \\
\hline $10 / 09 / 07$ & 482,59 & 4,46 & 0,09 \\
\hline $14 / 09 / 07$ & 482,59 & 4,46 & 0,00 \\
\hline 19/09/07 & 499,62 & 4,31 & 0,00 \\
\hline $21 / 09 / 07$ & 454,20 & 4,74 & 0,08 \\
\hline $24 / 09 / 07$ & 482,59 & 4,46 & 0,05 \\
\hline $01 / 10 / 07$ & 510,98 & 4,21 & 0,17 \\
\hline $05 / 10 / 07$ & 483,72 & 4,45 & 0,06 \\
\hline $08 / 10 / 07$ & 482,59 & 4,46 & 0,16 \\
\hline $15 / 10 / 07$ & 482,59 & 4,46 & 0,15 \\
\hline 19/10/07 & 454,20 & 4,74 & 0,45 \\
\hline $22 / 10 / 07$ & 482,59 & 4,46 & 0,46 \\
\hline $26 / 10 / 07$ & 482,59 & 4,46 & 0,56 \\
\hline $31 / 10 / 07$ & 510,98 & 4,21 & 0,39 \\
\hline $05 / 11 / 07$ & 499,62 & 4,31 & 0,27 \\
\hline $09 / 11 / 07$ & 483,72 & 4,45 & 0,64 \\
\hline $12 / 11 / 07$ & 482,59 & 4,46 & 0,31 \\
\hline 19/11/07 & 482,59 & 4,46 & 0,29 \\
\hline $23 / 11 / 07$ & 510,98 & 4,21 & 0,36 \\
\hline $26 / 11 / 07$ & 510,98 & 4,21 & 0,52 \\
\hline $30 / 11 / 07$ & 454,20 & 4,74 & 0,26 \\
\hline $03 / 12 / 07$ & 482,59 & 4,46 & 0,57 \\
\hline $07 / 12 / 07$ & 510,98 & 4,21 & 0,39 \\
\hline $10 / 12 / 07$ & 482,59 & 4,46 & 0,47 \\
\hline $16 / 12 / 07$ & 499,62 & 4,31 & 0,34 \\
\hline $21 / 12 / 07$ & 482,59 & 4,46 & 0,21 \\
\hline $27 / 12 / 07$ & 499,62 & 4,31 & 0,29 \\
\hline $04 / 01 / 08$ & 454,20 & 4,74 & 0,43 \\
\hline $07 / 01 / 08$ & 420,14 & 5,12 & 0,28 \\
\hline $11 / 01 / 08$ & 454,20 & 4,74 & 0,65 \\
\hline $15 / 01 / 08$ & 482,59 & 4,46 & 0,52 \\
\hline $18 / 01 / 08$ & 454,20 & 4,74 & 0,50 \\
\hline
\end{tabular}




\begin{tabular}{|c|c|c|c|}
\hline \multirow[b]{2}{*}{ Data } & \multicolumn{3}{|c|}{ Coluna de ozonização 2} \\
\hline & $\begin{array}{c}\text { Vazão } \\
\text { (L/h) }\end{array}$ & $\begin{array}{c}\text { Tempo de detenção } \\
\text { (min) }\end{array}$ & $\begin{array}{l}\text { Dosagem de } \\
\text { ozônio (mg/L) }\end{array}$ \\
\hline $28 / 01 / 08$ & 510,98 & 4,21 & 0,45 \\
\hline $01 / 02 / 08$ & 510,98 & 4,21 & 0,45 \\
\hline 08/02/08 & 482,59 & 4,46 & 0,28 \\
\hline $11 / 02 / 08$ & 481,45 & 4,47 & 0,50 \\
\hline $15 / 02 / 08$ & 454,20 & 4,74 & 0,45 \\
\hline $18 / 02 / 08$ & 510,98 & 4,21 & 1,52 \\
\hline $22 / 02 / 08$ & 454,20 & 4,74 & 1,12 \\
\hline $25 / 02 / 08$ & 454,20 & 4,74 & 1,57 \\
\hline $29 / 02 / 08$ & 454,20 & 4,74 & 0,25 \\
\hline $10 / 04 / 08$ & 510,98 & 4,21 & 0,79 \\
\hline $14 / 04 / 08$ & 510,98 & 4,21 & 0,91 \\
\hline $16 / 04 / 08$ & 522,33 & 4,12 & 1,97 \\
\hline $24 / 04 / 08$ & 510,98 & 4,21 & 1,53 \\
\hline $28 / 04 / 08$ & 510,98 & 4,21 & 1,10 \\
\hline $12 / 05 / 08$ & 510,98 & 4,21 & 1,30 \\
\hline $15 / 05 / 08$ & 510,98 & 4,21 & 1,36 \\
\hline $26 / 05 / 08$ & 510,98 & 4,21 & 1,17 \\
\hline $29 / 05 / 08$ & 510,98 & 4,21 & 1,34 \\
\hline $02 / 06 / 08$ & 510,98 & 4,21 & 1,15 \\
\hline $12 / 06 / 08$ & 522,33 & 4,12 & 1,22 \\
\hline $16 / 06 / 08$ & 510,98 & 4,21 & 0,89 \\
\hline $18 / 06 / 08$ & 510,98 & 4,21 & 0,92 \\
\hline $23 / 06 / 08$ & 510,98 & 4,21 & 0,61 \\
\hline $30 / 06 / 08$ & 510,98 & 4,21 & 0,50 \\
\hline $02 / 07 / 08$ & 510,98 & 4,21 & 0,47 \\
\hline $07 / 07 / 08$ & 510,98 & 4,21 & 0,48 \\
\hline $22 / 07 / 08$ & 510,98 & 4,21 & 0,46 \\
\hline $24 / 07 / 08$ & 510,98 & 4,21 & 0,59 \\
\hline $28 / 07 / 08$ & 510,98 & 4,21 & 0,69 \\
\hline $31 / 07 / 08$ & 510,98 & 4,21 & 0,68 \\
\hline $11 / 08 / 08$ & 510,98 & 4,21 & 0,78 \\
\hline $14 / 08 / 08$ & 510,98 & 4,21 & 0,70 \\
\hline $18 / 08 / 08$ & 499,62 & 4,31 & 0,66 \\
\hline $19 / 08 / 08$ & 499,62 & 4,31 & 0,68 \\
\hline $25 / 08 / 08$ & 510,98 & 4,21 & 0,66 \\
\hline $28 / 08 / 08$ & 499,62 & 4,31 & 0,72 \\
\hline $02 / 09 / 08$ & 510,98 & 4,21 & 0,75 \\
\hline $04 / 09 / 08$ & 499,62 & 4,31 & 0,68 \\
\hline $08 / 09 / 08$ & 510,98 & 4,21 & 0,77 \\
\hline $11 / 09 / 08$ & 510,98 & 4,21 & 0,84 \\
\hline $15 / 09 / 08$ & 510,98 & 4,21 & 0,55 \\
\hline $18 / 09 / 08$ & 510,98 & 4,21 & 0,61 \\
\hline $22 / 09 / 08$ & 510,98 & 4,21 & 0,90 \\
\hline $25 / 09 / 08$ & 510,98 & 4,21 & 0,71 \\
\hline $29 / 09 / 08$ & 510,98 & 4,21 & 0,62 \\
\hline $02 / 10 / 08$ & 499,62 & 4,31 & 0,59 \\
\hline $13 / 10 / 08$ & 510,98 & 4,21 & 0,40 \\
\hline $23 / 10 / 08$ & 681,30 & 3,16 & 0,56 \\
\hline $27 / 10 / 08$ & 567,75 & 3,79 & 0,78 \\
\hline $03 / 11 / 08$ & 567,75 & 3,79 & 0,90 \\
\hline
\end{tabular}




\begin{tabular}{|c|c|c|c|}
\hline \multirow{2}{*}{ Data } & \multicolumn{3}{|c|}{ Coluna de ozonizção 2 } \\
\cline { 2 - 4 } & $\begin{array}{c}\text { Vazão } \\
\text { (L/h) }\end{array}$ & $\begin{array}{c}\text { Tempo de detenção } \\
\text { (min) }\end{array}$ & $\begin{array}{c}\text { Dosagem de } \\
\text { ozônio (mg/L) }\end{array}$ \\
\hline $06 / 11 / 08$ & 567,75 & 3,79 & 0,82 \\
\hline $10 / 11 / 08$ & 567,75 & 3,79 & 0,67 \\
\hline $13 / 11 / 08$ & 624,53 & 3,44 & 0,65 \\
\hline $08 / 12 / 08$ & 567,75 & 3,79 & 1,09 \\
\hline
\end{tabular}




\begin{tabular}{|c|c|c|c|c|}
\hline \multirow[b]{2}{*}{ Data } & \multicolumn{2}{|c|}{ Coluna de Ozonização 3} & \multicolumn{2}{|c|}{ Coluna de Ozonização 4} \\
\hline & $\begin{array}{l}\text { Vazão } \\
\text { (L/h) }\end{array}$ & $\begin{array}{c}\text { Tempo de detenção } \\
\text { (min) }\end{array}$ & $\begin{array}{l}\text { Vazão } \\
\text { (L/h) }\end{array}$ & $\begin{array}{l}\text { Tempo de detenção } \\
\text { (min) }\end{array}$ \\
\hline 10/07/07 & 340,65 & 6,31 & 340,65 & 6,31 \\
\hline $12 / 07 / 07$ & 340,65 & 6,31 & 340,65 & 6,31 \\
\hline $16 / 07 / 07$ & 295,23 & 7,29 & 283,88 & 7,58 \\
\hline $18 / 07 / 07$ & 265,71 & 8,10 & 263,44 & 8,17 \\
\hline $20 / 07 / 07$ & 340,65 & 6,31 & 340,65 & 6,31 \\
\hline 23/07/07 & 340,65 & 6,31 & 340,65 & 6,31 \\
\hline $25 / 07 / 07$ & 369,04 & 5,83 & 340,65 & 6,31 \\
\hline $27 / 07 / 07$ & 340,65 & 6,31 & 340,65 & 6,31 \\
\hline $30 / 07 / 07$ & 340,65 & 6,31 & 317,94 & 6,77 \\
\hline $01 / 08 / 07$ & 340,65 & 6,31 & 312,26 & 6,89 \\
\hline $03 / 08 / 07$ & 340,65 & 6,31 & 283,88 & 7,58 \\
\hline $06 / 08 / 07$ & 283,88 & 7,58 & 283,88 & 7,58 \\
\hline $08 / 08 / 07$ & 312,26 & 6,89 & 272,52 & 7,89 \\
\hline $10 / 08 / 07$ & 283,88 & 7,58 & 227,10 & 9,47 \\
\hline 15/08/07 & 369,04 & 5,83 & 369,04 & 5,83 \\
\hline $17 / 08 / 07$ & 340,65 & 6,31 & 283,88 & 7,58 \\
\hline $20 / 08 / 07$ & 312,26 & 6,89 & 370,74 & 5,80 \\
\hline $24 / 08 / 07$ & 283,88 & 7,58 & 283,88 & 7,58 \\
\hline $27 / 08 / 07$ & 492,81 & 4,36 & 365,63 & 5,88 \\
\hline $31 / 08 / 07$ & 363,36 & 5,92 & 227,10 & 9,47 \\
\hline 03/09/07 & 363,36 & 5,92 & 227,10 & 9,47 \\
\hline 10/09/07 & 340,65 & 6,31 & 312,26 & 6,89 \\
\hline 14/09/07 & 397,43 & 5,41 & 340,65 & 6,31 \\
\hline 19/09/07 & 374,72 & 5,74 & 286,15 & 7,52 \\
\hline $21 / 09 / 07$ & 340,65 & 6,31 & 283,88 & 7,58 \\
\hline $24 / 09 / 07$ & 363,36 & 5,92 & 312,26 & 6,89 \\
\hline $01 / 10 / 07$ & 227,10 & 9,47 & 227,10 & 9,47 \\
\hline $05 / 10 / 07$ & 313,40 & 6,86 & 256,62 & 8,38 \\
\hline 08/10/07 & 312,26 & 6,89 & 256,62 & 8,38 \\
\hline $15 / 10 / 07$ & 283,88 & 7,58 & 255,49 & 8,42 \\
\hline 19/10/07 & 283,88 & 7,58 & 283,88 & 7,58 \\
\hline 22/10/07 & 312,26 & 6,89 & 255,49 & 8,42 \\
\hline $26 / 10 / 07$ & 283,88 & 7,58 & 255,49 & 8,42 \\
\hline $31 / 10 / 07$ & 397,43 & 5,41 & 283,88 & 7,58 \\
\hline 05/11/07 & 340,65 & 6,31 & 283,88 & 7,58 \\
\hline 09/11/07 & 313,40 & 6,86 & 272,52 & 7,89 \\
\hline $12 / 11 / 07$ & 312,26 & 6,89 & 272,52 & 7,89 \\
\hline 19/11/07 & 312,26 & 6,89 & 255,49 & 8,42 \\
\hline $23 / 11 / 07$ & 313,40 & 6,86 & 249,81 & 8,61 \\
\hline $26 / 11 / 07$ & 312,26 & 6,89 & 249,81 & 8,61 \\
\hline $30 / 11 / 07$ & 340,65 & 6,31 & 227,10 & 9,47 \\
\hline $03 / 12 / 07$ & 283,88 & 7,58 & 283,88 & 7,58 \\
\hline $07 / 12 / 07$ & 340,65 & 6,31 & 227,10 & 9,47 \\
\hline $10 / 12 / 07$ & 255,49 & 8,42 & 222,56 & 9,66 \\
\hline $16 / 12 / 07$ & 454,20 & 4,74 & 340,65 & 6,31 \\
\hline 21/12/07 & 340,65 & 6,31 & 340,65 & 6,31 \\
\hline $27 / 12 / 07$ & 397,43 & 5,41 & 340,65 & 6,31 \\
\hline $04 / 01 / 08$ & 397,43 & 5,41 & 340,65 & 6,31 \\
\hline $07 / 01 / 08$ & 363,36 & 5,92 & 295,23 & 7,29 \\
\hline $11 / 01 / 08$ & 340,65 & 6,31 & 340,65 & 6,31 \\
\hline $15 / 01 / 08$ & 431,49 & 4,99 & 408,78 & 5,26 \\
\hline $18 / 01 / 08$ & 397,43 & 5,41 & 397,43 & 5,41 \\
\hline
\end{tabular}




\begin{tabular}{|c|c|c|c|c|}
\hline \multirow[b]{2}{*}{ Data } & \multicolumn{2}{|c|}{ Coluna de Ozonização 3} & \multicolumn{2}{|c|}{ Coluna de ozonização 4} \\
\hline & $\begin{array}{l}\text { Vazão } \\
\text { (L/h) }\end{array}$ & $\begin{array}{c}\text { Tempo de detenção } \\
\text { (min) }\end{array}$ & $\begin{array}{l}\text { Vazão } \\
\text { (L/h) }\end{array}$ & $\begin{array}{c}\text { Tempo de detenção } \\
(\mathrm{min})\end{array}$ \\
\hline $28 / 01 / 08$ & 431,49 & 4,99 & 431,49 & 4,99 \\
\hline $01 / 02 / 08$ & 397,43 & 5,41 & 397,43 & $\overline{5,41}$ \\
\hline $08 / 02 / 08$ & 397,43 & $\overline{5,41}$ & 340,65 & 6,31 \\
\hline $11 / 02 / 08$ & 397,43 & $\overline{5,41}$ & 340,65 & 6,31 \\
\hline $15 / 02 / 08$ & 397,43 & $\overline{5,41}$ & 340,65 & 6,31 \\
\hline $18 / 02 / 08$ & 370,17 & $\overline{5,81}$ & 340,65 & 6,31 \\
\hline $22 / 02 / 08$ & 340,65 & 6,31 & 340,65 & 6,31 \\
\hline $25 / 02 / 08$ & 397,43 & 5,41 & 397,43 & 5,41 \\
\hline 29/02/08 & 340,65 & 6,31 & 340,65 & 6,31 \\
\hline $10 / 04 / 08$ & 454,20 & 4,74 & 397,43 & 5,41 \\
\hline $14 / 04 / 08$ & 454,20 & 4,74 & 397,43 & $\overline{5,41}$ \\
\hline $16 / 04 / 08$ & 476,91 & 4,51 & 397,43 & $\overline{5,41}$ \\
\hline $24 / 04 / 08$ & 488,27 & 4,41 & 386,07 & 5,57 \\
\hline $28 / 04 / 08$ & 454,20 & 4,74 & 397,43 & 5,41 \\
\hline $12 / 05 / 08$ & 454,20 & 4,74 & 397,43 & $\overline{5,41}$ \\
\hline $15 / 05 / 08$ & 490,54 & 4,38 & 374,72 & $\overline{5,74}$ \\
\hline $26 / 05 / 08$ & 454,20 & 4,74 & 397,43 & $\overline{5,41}$ \\
\hline $29 / 05 / 08$ & 490,54 & 4,38 & 374,72 & $\overline{5,74}$ \\
\hline $02 / 06 / 08$ & 454,20 & $\overline{4,74}$ & 340,65 & 6,31 \\
\hline $12 / 06 / 08$ & 488,27 & 4,41 & 374,72 & 5,74 \\
\hline $16 / 06 / 08$ & 454,20 & 4,74 & 340,65 & 6,31 \\
\hline $18 / 06 / 08$ & 490,54 & 4,38 & 363,36 & 5,92 \\
\hline $23 / 06 / 08$ & 454,20 & 4,74 & 340,65 & 6,31 \\
\hline $30 / 06 / 08$ & 490,54 & 4,38 & 363,36 & 5,92 \\
\hline $02 / 07 / 08$ & 490,54 & 4,38 & 363,36 & $\overline{5,92}$ \\
\hline$\overline{07 / 07 / 08}$ & 454,20 & 4,74 & 363,36 & 5,92 \\
\hline $22 / 07 / 08$ & 454,20 & 4,74 & 363,36 & 5,92 \\
\hline $24 / 07 / 08$ & 454,20 & 4,74 & 363,36 & $\overline{5,92}$ \\
\hline $28 / 07 / 08$ & 454,20 & 4,74 & 363,36 & $\overline{5,92}$ \\
\hline $31 / 07 / 08$ & 454,20 & 4,74 & 363,36 & 5,92 \\
\hline $11 / 08 / 08$ & 454,20 & 4,74 & 340,65 & 6,31 \\
\hline $14 / 08 / 08$ & 431,49 & 4,99 & 352,01 & 6,11 \\
\hline $18 / 08 / 08$ & 408,78 & 5,26 & 340,65 & 6,31 \\
\hline $19 / 08 / 08$ & 408,78 & 5,26 & 340,65 & 6,31 \\
\hline $25 / 08 / 08$ & 454,20 & 4,74 & 340,65 & 6,31 \\
\hline $28 / 08 / 08$ & 431,49 & 4,99 & 340,65 & 6,31 \\
\hline $02 / 09 / 08$ & 454,20 & 4,74 & 340,65 & 6,31 \\
\hline $04 / 09 / 08$ & 431,49 & 4,99 & 340,65 & 6,31 \\
\hline $08 / 09 / 08$ & 454,20 & 4,74 & 397,43 & 5,41 \\
\hline $11 / 09 / 08$ & 476,91 & 4,51 & 374,72 & 5,74 \\
\hline $15 / 09 / 08$ & 454,20 & 4,74 & 397,43 & $\overline{5,41}$ \\
\hline $18 / 09 / 08$ & 488,27 & 4,41 & 395,15 & $\overline{5,44}$ \\
\hline $22 / 09 / 08$ & 488,27 & 4,41 & 395,15 & 5,44 \\
\hline $25 / 09 / 08$ & 476,91 & 4,51 & 363,36 & 5,92 \\
\hline $29 / 09 / 08$ & 454,20 & 4,74 & 340,65 & 6,31 \\
\hline $02 / 10 / 08$ & 499,62 & 4,31 & 340,65 & 6,31 \\
\hline $13 / 10 / 08$ & 454,20 & 4,74 & 397,43 & 5,41 \\
\hline $23 / 10 / 08$ & 596,14 & 3,61 & 567,75 & 3,79 \\
\hline $27 / 10 / 08$ & 567,75 & 3,79 & 510,98 & 4,21 \\
\hline $03 / 11 / 08$ & 454,20 & 4,74 & 454,20 & 4,74 \\
\hline
\end{tabular}




\begin{tabular}{|c|c|c|c|c|}
\hline \multirow{2}{*}{ Data } & \multicolumn{2}{|c|}{ Coluna de Ozonização 3 } & \multicolumn{2}{c|}{ Coluna de ozonização 4 } \\
\cline { 2 - 5 } & $\begin{array}{c}\text { Vazão } \\
\text { (L/h) }\end{array}$ & $\begin{array}{c}\text { Tempo de detenção } \\
(\mathbf{m i n})\end{array}$ & $\begin{array}{c}\text { Vazão } \\
(\mathbf{L} / \mathbf{h})\end{array}$ & $\begin{array}{c}\text { Tempo de detenção } \\
\text { (min) }\end{array}$ \\
\hline $06 / 11 / 08$ & 454,20 & 4,74 & 454,20 & 4,74 \\
\hline $10 / 11 / 08$ & 510,98 & 4,21 & 510,98 & 4,21 \\
\hline $13 / 11 / 08$ & 510,98 & 4,21 & 510,98 & 4,21 \\
\hline $08 / 12 / 08$ & 579,11 & 3,71 & 454,20 & 4,74 \\
\hline
\end{tabular}




\begin{tabular}{|c|c|c|}
\hline \multirow[b]{2}{*}{ Data } & \multicolumn{2}{|c|}{ Colunas de Ozonização } \\
\hline & $\begin{array}{c}\text { Tempo de detenção } \\
\text { total (min) }\end{array}$ & $\begin{array}{c}\text { Dosagem total } \\
\text { de ozônio (mg/L) }\end{array}$ \\
\hline $10 / 07 / 07$ & 22,10 & 0,40 \\
\hline 12/07/07 & 22,10 & 0,06 \\
\hline $16 / 07 / 07$ & 24,33 & 0,94 \\
\hline $18 / 07 / 07$ & 25,18 & 0,12 \\
\hline $20 / 07 / 07$ & 22,10 & 0,64 \\
\hline 23/07/07 & 22,10 & 0,59 \\
\hline $25 / 07 / 07$ & 21,06 & 0,24 \\
\hline $27 / 07 / 07$ & 22,10 & 0,74 \\
\hline $30 / 07 / 07$ & 22,33 & 0,30 \\
\hline $01 / 08 / 07$ & 22,40 & 0,24 \\
\hline 03/08/07 & 23,36 & 0,30 \\
\hline $06 / 08 / 07$ & 24,63 & 0,60 \\
\hline $08 / 08 / 07$ & 23,70 & 0,72 \\
\hline $10 / 08 / 07$ & 24,94 & 0,38 \\
\hline 15/08/07 & 20,32 & 0,40 \\
\hline $17 / 08 / 07$ & 22,56 & 0,44 \\
\hline $20 / 08 / 07$ & 21,11 & 0,52 \\
\hline $24 / 08 / 07$ & 24,07 & 0,54 \\
\hline $27 / 08 / 07$ & 19,14 & 0,49 \\
\hline $31 / 08 / 07$ & 25,06 & 0,39 \\
\hline 03/09/07 & 25,06 & 0,22 \\
\hline 10/09/07 & 22,12 & 0,30 \\
\hline 14/09/07 & 20,64 & 0,38 \\
\hline 19/09/07 & 21,87 & 0,37 \\
\hline $21 / 09 / 07$ & 23,36 & 0,24 \\
\hline $24 / 09 / 07$ & 21,57 & 0,25 \\
\hline $01 / 10 / 07$ & 27,36 & 0,28 \\
\hline $05 / 10 / 07$ & 24,43 & 0,18 \\
\hline 08/10/07 & 24,46 & 0,32 \\
\hline $15 / 10 / 07$ & 24,91 & 0,24 \\
\hline 19/10/07 & 24,63 & 0,90 \\
\hline $22 / 10 / 07$ & 24,07 & 0,94 \\
\hline $26 / 10 / 07$ & 24,91 & 1,12 \\
\hline $31 / 10 / 07$ & 21,41 & 0,78 \\
\hline 05/11/07 & 22,14 & 0,52 \\
\hline 09/11/07 & 22,99 & 1,28 \\
\hline 12/11/07 & 23,03 & 0,57 \\
\hline 19/11/07 & 23,55 & 0,54 \\
\hline $23 / 11 / 07$ & 23,47 & 0,59 \\
\hline $26 / 11 / 07$ & 23,50 & 0,98 \\
\hline $30 / 11 / 07$ & 24,31 & 0,56 \\
\hline 03/12/07 & 23,40 & 1,06 \\
\hline 07/12/07 & 24,11 & 0,78 \\
\hline $10 / 12 / 07$ & 26,33 & 0,91 \\
\hline 16/12/07 & 19,66 & 0,68 \\
\hline $21 / 12 / 07$ & 21,54 & 0,53 \\
\hline $27 / 12 / 07$ & 20,34 & 0,58 \\
\hline $04 / 01 / 08$ & 21,20 & 0,86 \\
\hline $07 / 01 / 08$ & 23,06 & 0,41 \\
\hline $11 / 01 / 08$ & 22,10 & 0,86 \\
\hline $15 / 01 / 08$ & 19,16 & 0,86 \\
\hline $18 / 01 / 08$ & 20,07 & 1,00 \\
\hline
\end{tabular}




\begin{tabular}{|c|c|c|}
\hline \multirow[b]{2}{*}{ Data } & \multicolumn{2}{|c|}{ Colunas de Ozonização } \\
\hline & $\begin{array}{c}\text { Tempo de detenção } \\
\text { total (min) }\end{array}$ & $\begin{array}{c}\text { Dosagem total } \\
\text { de ozônio }(\mathrm{mg} / \mathrm{L})\end{array}$ \\
\hline $28 / 01 / 08$ & 18,39 & 0,90 \\
\hline $01 / 02 / 08$ & 19,24 & 0,75 \\
\hline $08 / 02 / 08$ & 20,64 & 0,56 \\
\hline $11 / 02 / 08$ & 20,40 & $\overline{0,90}$ \\
\hline $15 / 02 / 08$ & 20,67 & 0,90 \\
\hline $18 / 02 / 08$ & 20,80 & 2,75 \\
\hline $22 / 02 / 08$ & 22,10 & 2,24 \\
\hline $25 / 02 / 08$ & 20,30 & 3,00 \\
\hline $29 / 02 / 08$ & 22,10 & 0,50 \\
\hline $10 / 04 / 08$ & 18,15 & 1,58 \\
\hline $14 / 04 / 08$ & 18,15 & 1,82 \\
\hline $16 / 04 / 08$ & 17,68 & 3,79 \\
\hline $24 / 04 / 08$ & 17,98 & 2,75 \\
\hline $28 / 04 / 08$ & 18,15 & 2,20 \\
\hline $12 / 05 / 08$ & 18,15 & 2,40 \\
\hline $15 / 05 / 08$ & 17,98 & 2,77 \\
\hline $26 / 05 / 08$ & 18,15 & 2,47 \\
\hline $29 / 05 / 08$ & 17,91 & 2,52 \\
\hline $02 / 06 / 08$ & 19,05 & 2,25 \\
\hline $12 / 06 / 08$ & 17,84 & 2,25 \\
\hline $16 / 06 / 08$ & 19,05 & 1,98 \\
\hline $18 / 06 / 08$ & 18,09 & 1,77 \\
\hline $23 / 06 / 08$ & 19,05 & 1,16 \\
\hline $30 / 06 / 08$ & 18,16 & 0,95 \\
\hline $02 / 07 / 08$ & 18,16 & 0,90 \\
\hline $07 / 07 / 08$ & 18,65 & 0,91 \\
\hline $22 / 07 / 08$ & 18,65 & 0,86 \\
\hline $24 / 07 / 08$ & 18,65 & 1,08 \\
\hline $28 / 07 / 08$ & 18,65 & 1,30 \\
\hline $31 / 07 / 08$ & 18,65 & 1,24 \\
\hline $11 / 08 / 08$ & 19,05 & 1,48 \\
\hline $14 / 08 / 08$ & 19,25 & 1,38 \\
\hline $18 / 08 / 08$ & 19,39 & 1,26 \\
\hline $19 / 08 / 08$ & 19,39 & 1,24 \\
\hline $25 / 08 / 08$ & 19,05 & 1,26 \\
\hline $28 / 08 / 08$ & 19,11 & 1,31 \\
\hline $02 / 09 / 08$ & 19,05 & 1,42 \\
\hline 04/09/08 & 19,25 & 1,25 \\
\hline 08/09/08 & 18,15 & 1,46 \\
\hline $11 / 09 / 08$ & 18,25 & 2,19 \\
\hline $15 / 09 / 08$ & 18,15 & 1,78 \\
\hline $18 / 09 / 08$ & 17,85 & 2,03 \\
\hline $22 / 09 / 08$ & 17,85 & 2,65 \\
\hline $25 / 09 / 08$ & 18,43 & 1,49 \\
\hline 29/09/08 & 19,05 & 1,36 \\
\hline $02 / 10 / 08$ & 18,71 & 1,27 \\
\hline $13 / 10 / 08$ & 18,15 & 0,81 \\
\hline $23 / 10 / 08$ & 13,85 & 1,28 \\
\hline $27 / 10 / 08$ & 15,58 & 1,56 \\
\hline $03 / 11 / 08$ & 17,05 & 1,92 \\
\hline
\end{tabular}




\begin{tabular}{|c|c|c|}
\hline \multirow{2}{*}{ Data } & \multicolumn{2}{|c|}{ Colunas de Ozonização } \\
\cline { 2 - 3 } & $\begin{array}{c}\text { Tempo de detenção } \\
\text { total (min) }\end{array}$ & $\begin{array}{c}\text { Dosagem total } \\
\text { de ozônio (mg/L) }\end{array}$ \\
\hline $06 / 11 / 08$ & 16,90 & 1,66 \\
\hline $10 / 11 / 08$ & 16,00 & 1,34 \\
\hline $13 / 11 / 08$ & 15,31 & 1,35 \\
\hline $08 / 12 / 08$ & 16,03 & 2,26 \\
\hline
\end{tabular}




\section{APÊNDICE C - Valores de Turbidez, COT, UV 254, Perda de Carga, $\mathrm{O}_{3}$ Residual e $\mathrm{Cl}_{2}$ Livre Residual}

\begin{tabular}{|c|c|c|c|}
\hline \multirow{2}{*}{ Data } & \multicolumn{3}{|c|}{ Água Bruta da ETA } \\
\cline { 2 - 4 } & $\begin{array}{c}\text { Turbidez } \\
\text { (UNT) }\end{array}$ & $\begin{array}{c}\text { COT } \\
\text { (mg/L) }\end{array}$ & $\begin{array}{c}\text { UV 254 } \\
\text { (cm }^{-1}\end{array}$ \\
\hline $10 / 07 / 07$ & 3,90 & 4,82 & 0,140 \\
\hline $12 / 07 / 07$ & 4,10 & 4,89 & 0,122 \\
\hline $16 / 07 / 07$ & 3,70 & 5,24 & 0,112 \\
\hline $18 / 07 / 07$ & 5,80 & 4,86 & 0,118 \\
\hline $20 / 07 / 07$ & 4,20 & 4,88 & 0,104 \\
\hline $23 / 07 / 07$ & 3,80 & 5,06 & 0,117 \\
\hline $25 / 07 / 07$ & - & 4,84 & 0,067 \\
\hline $27 / 07 / 07$ & 3,65 & 5,02 & 0,100 \\
\hline $30 / 07 / 07$ & 3,90 & 4,83 & 0,099 \\
\hline $01 / 08 / 07$ & - & 5,08 & 0,108 \\
\hline $03 / 08 / 07$ & 3,15 & 5,44 & 0,095 \\
\hline $06 / 08 / 07$ & 2,90 & 5,23 & 0,092 \\
\hline $08 / 08 / 07$ & - & 4,98 & 0,089 \\
\hline $10 / 08 / 07$ & 3,03 & 5,12 & 0,090 \\
\hline $15 / 08 / 07$ & - & 2,64 & 0,133 \\
\hline $17 / 08 / 07$ & 2,72 & 5,43 & 0,092 \\
\hline $20 / 08 / 07$ & - & 5,39 & 0,115 \\
\hline $24 / 08 / 07$ & 2,76 & 5,23 & 0,105 \\
\hline $27 / 08 / 07$ & 2,64 & 5,15 & 0,097 \\
\hline $31 / 08 / 07$ & 3,16 & 5,01 & 0,091 \\
\hline $03 / 09 / 07$ & 4,10 & 6,76 & 0,077 \\
\hline $10 / 09 / 07$ & 4,33 & 5,42 & 0,107 \\
\hline $14 / 09 / 07$ & 4,94 & 5,84 & 0,172 \\
\hline $19 / 09 / 07$ & 3,90 & 3,50 & 0,119 \\
\hline $21 / 09 / 07$ & 4,62 & 3,55 & 0,095 \\
\hline $24 / 09 / 07$ & 3,93 & 3,46 & 0,108 \\
\hline $01 / 10 / 07$ & 3,90 & 3,57 & 0,105 \\
\hline $05 / 10 / 07$ & - & 3,59 & 0,100 \\
\hline $08 / 10 / 07$ & 5,56 & 3,86 & 0,104 \\
\hline $15 / 10 / 07$ & 5,90 & 3,80 & 0,113 \\
\hline $19 / 10 / 07$ & 3,70 & 3,57 & 0,115 \\
\hline $22 / 10 / 07$ & 4,04 & 3,73 & 0,095 \\
\hline $26 / 10 / 07$ & 3,56 & 3,35 & 0,105 \\
\hline $31 / 10 / 07$ & 4,17 & 3,87 & 0,089 \\
\hline $05 / 11 / 07$ & 3,42 & 4,01 & 0,080 \\
\hline $09 / 11 / 07$ & 3,17 & 3,96 & 0,108 \\
\hline $12 / 11 / 07$ & 4,23 & 3,89 & 0,112 \\
\hline $19 / 11 / 07$ & 3,78 & 4,27 & 0,114 \\
\hline $23 / 11 / 07$ & 5,79 & 4,50 & 0,124 \\
\hline $26 / 11 / 07$ & 4,67 & 4,82 & 0,111 \\
\hline $30 / 11 / 07$ & 4,40 & 5,12 & 0,142 \\
\hline $03 / 12 / 07$ & 2,89 & 4,26 & 0,111 \\
\hline $07 / 12 / 07$ & - & 4,11 & 0,116 \\
\hline $10 / 12 / 07$ & 3,20 & 4,63 & 0,113 \\
\hline $16 / 12 / 07$ & 4,05 & 4,67 & 0,106 \\
\hline $21 / 12 / 07$ & 4,68 & 4,53 & 0,064 \\
\hline $27 / 12 / 07$ & 4,09 & 4,16 & 0,076 \\
\hline $04 / 01 / 08$ & 3,38 & 5,15 & 0,089 \\
\hline $07 / 01 / 08$ & 5,07 & 5,07 & 0,105 \\
\hline & & & \\
\hline
\end{tabular}




\begin{tabular}{|c|c|c|c|}
\hline \multirow{2}{*}{ Data } & \multicolumn{3}{|c|}{ Água Bruta da ETA } \\
\cline { 2 - 4 } & $\begin{array}{c}\text { Turbidez } \\
\text { (UNT) }\end{array}$ & $\begin{array}{c}\text { COT } \\
\text { (mg/L) }\end{array}$ & $\begin{array}{c}\text { UV 254 } \\
\text { (cm }^{-1} \text { ) }\end{array}$ \\
\hline $11 / 01 / 08$ & 2,95 & 4,95 & 0,098 \\
\hline $15 / 01 / 08$ & 3,81 & 4,95 & 0,116 \\
\hline $18 / 01 / 08$ & 7,47 & 4,30 & 0,106 \\
\hline $28 / 01 / 08$ & 3,47 & 4,20 & 0,117 \\
\hline $01 / 02 / 08$ & 3,20 & 4,50 & 0,099 \\
\hline $08 / 02 / 08$ & 2,57 & 4,03 & 0,111 \\
\hline $11 / 02 / 08$ & 2,46 & 4,01 & 0,116 \\
\hline $15 / 02 / 08$ & 2,94 & 5,50 & 0,128 \\
\hline $18 / 02 / 08$ & 2,70 & 4,11 & 0,118 \\
\hline $22 / 02 / 08$ & 3,05 & 4,03 & 0,131 \\
\hline $25 / 02 / 08$ & 2,76 & 4,60 & 0,121 \\
\hline $29 / 02 / 08$ & 3,33 & 4,80 & 0,096 \\
\hline $10 / 04 / 08$ & 2,14 & 4,21 & 0,101 \\
\hline $14 / 04 / 08$ & 3,05 & 4,94 & 0,117 \\
\hline $16 / 04 / 08$ & 2,24 & 4,40 & 0,102 \\
\hline $24 / 04 / 08$ & 2,28 & 3,98 & 0,107 \\
\hline $28 / 04 / 08$ & 1,80 & 4,02 & 0,102 \\
\hline $12 / 05 / 08$ & 2,81 & 4,72 & 0,121 \\
\hline $15 / 05 / 08$ & 2,68 & 4,27 & 0,106 \\
\hline $26 / 05 / 08$ & 1,98 & 3,80 & 0,113 \\
\hline $29 / 05 / 08$ & 8,42 & - & - \\
\hline $02 / 06 / 08$ & - & - & - \\
\hline $12 / 06 / 08$ & 2,51 & 4,43 & 0,108 \\
\hline $16 / 06 / 08$ & 2,75 & 4,20 & 0,103 \\
\hline $18 / 06 / 08$ & 2,48 & 4,10 & 0,107 \\
\hline $23 / 06 / 08$ & 2,57 & 4,08 & 0,096 \\
\hline $30 / 06 / 08$ & 1,54 & 4,07 & 0,090 \\
\hline $02 / 07 / 08$ & 1,59 & 4,60 & 0,093 \\
\hline $07 / 07 / 08$ & 1,70 & 4,00 & 0,095 \\
\hline $22 / 07 / 08$ & 2,06 & 4,19 & 0,118 \\
\hline $24 / 07 / 08$ & 2,11 & 4,07 & 0,084 \\
\hline $28 / 07 / 08$ & 1,75 & 3,92 & 0,094 \\
\hline $31 / 07 / 08$ & 1,83 & 4,06 & 0,085 \\
\hline $11 / 08 / 08$ & 3,72 & 3,89 & 0,011 \\
\hline $14 / 08 / 08$ & 4,00 & 4,40 & 0,082 \\
\hline $18 / 08 / 08$ & 3,37 & 4,07 & 0,104 \\
\hline $19 / 08 / 08$ & - & 4,84 & 0,257 \\
\hline $25 / 08 / 08$ & 3,48 & 4,90 & 0,107 \\
\hline $28 / 08 / 08$ & 2,65 & 3,70 & 0,096 \\
\hline $02 / 09 / 08$ & 11,90 & 3,90 & 0,108 \\
\hline $04 / 09 / 08$ & 3,90 & 4,10 & 0,259 \\
\hline $08 / 09 / 08$ & 4,16 & 4,46 & 0,097 \\
\hline $11 / 09 / 08$ & 3,86 & 3,86 & 0,107 \\
\hline $15 / 09 / 08$ & 11,00 & 4,50 & 0,085 \\
\hline $18 / 09 / 08$ & 2,79 & 3,97 & 0,093 \\
\hline $22 / 09 / 08$ & 10,20 & 4,34 & 0,074 \\
\hline $25 / 09 / 08$ & 2,51 & - & 0,083 \\
\hline $29 / 09 / 08$ & 2,52 & 4,97 & 0,087 \\
\hline $02 / 10 / 08$ & 2,68 & 3,88 & 0,090 \\
\hline $13 / 10 / 08$ & 4,42 & 4,29 & 0,097 \\
\hline $23 / 10 / 08$ & 4,45 & 4,15 & 0,106 \\
\hline $27 / 10 / 08$ & 3,63 & 4,35 & 0,081 \\
\hline $03 / 11 / 08$ & 4,89 & 4,01 & 0,094 \\
\hline
\end{tabular}




\begin{tabular}{|c|c|c|c|}
\hline \multirow{2}{*}{ Data } & \multicolumn{3}{|c|}{ Água Bruta da ETA } \\
\cline { 2 - 4 } & $\begin{array}{c}\text { Turbidez } \\
\text { (UNT) }\end{array}$ & $\begin{array}{c}\text { COT } \\
\text { (mg/L) }\end{array}$ & $\begin{array}{c}\text { UV 254 } \\
\text { (cm }^{-1} \text { ) }\end{array}$ \\
\hline $06 / 11 / 08$ & 4,89 & 4,79 & 0,082 \\
\hline $10 / 11 / 08$ & 4,77 & 5,14 & 0,097 \\
\hline $13 / 11 / 08$ & 5,80 & 4,29 & 0,104 \\
\hline $08 / 12 / 08$ & 5,29 & 5,22 & 0,099 \\
\hline
\end{tabular}




\begin{tabular}{|c|c|c|c|c|}
\hline & \multicolumn{3}{|c|}{ Reservatório de Equalização de Água Filtrada } \\
\cline { 2 - 5 } Data & Turbidez & $\begin{array}{c}\text { COT } \\
\text { (UNG/L) }\end{array}$ & $\begin{array}{c}\text { UV } \mathbf{2 5 4} \\
\text { (cm }^{-1} \text { ) }\end{array}$ & $\begin{array}{c}\text { Cl }_{\mathbf{2}} \text { livre } \\
\text { residual (mg/L) }\end{array}$ \\
\hline $10 / 07 / 07$ & 0,140 & 2,55 & 0,026 & 0,70 \\
\hline $12 / 07 / 07$ & 0,160 & 2,58 & 0,038 & 1,00 \\
\hline $16 / 07 / 07$ & 0,200 & 2,45 & 0,027 & 0,90 \\
\hline $18 / 07 / 07$ & 0,140 & 2,47 & 0,020 & 0,80 \\
\hline $20 / 07 / 07$ & 0,230 & 2,51 & 0,030 & 1,10 \\
\hline $23 / 07 / 07$ & 0,190 & 2,76 & 0,043 & 0,60 \\
\hline $25 / 07 / 07$ & 0,229 & 2,80 & 0,002 & 0,50 \\
\hline $27 / 07 / 07$ & 0,160 & 2,65 & 0,033 & 0,70 \\
\hline $30 / 07 / 07$ & 0,120 & 2,37 & 0,022 & 0,90 \\
\hline $01 / 08 / 07$ & 0,362 & 2,78 & 0,033 & 0,90 \\
\hline $03 / 08 / 07$ & 0,187 & 2,53 & 0,034 & 1,20 \\
\hline $06 / 08 / 07$ & 0,150 & 2,21 & 0,028 & 0,70 \\
\hline $08 / 08 / 07$ & 0,207 & 2,25 & 0,001 & 0,95 \\
\hline $10 / 08 / 07$ & 0,150 & 0,22 & 0,028 & 0,70 \\
\hline $15 / 08 / 07$ & 0,328 & 2,84 & 0,046 & 0,65 \\
\hline $17 / 08 / 07$ & 0,145 & 2,71 & 0,018 & 0,90 \\
\hline $20 / 08 / 07$ & 0,277 & 2,45 & 0,023 & 0,80 \\
\hline $24 / 08 / 07$ & 0,115 & 2,24 & 0,011 & 0,70 \\
\hline $27 / 08 / 07$ & 0,200 & 2,29 & 0,016 & 0,65 \\
\hline $31 / 08 / 07$ & 0,126 & 2,34 & 0,016 & 0,60 \\
\hline $03 / 09 / 07$ & 0,409 & 4,01 & 0,025 & 0,65 \\
\hline $10 / 09 / 07$ & 0,283 & 2,90 & 0,017 & 0,60 \\
\hline $14 / 09 / 07$ & 0,176 & 3,23 & 0,035 & 0,80 \\
\hline $19 / 09 / 07$ & 0,121 & 1,91 & 0,028 & 1,00 \\
\hline $21 / 09 / 07$ & 0,243 & 1,86 & 0,011 & 0,80 \\
\hline $24 / 09 / 07$ & 0,313 & 1,70 & 0,022 & 0,95 \\
\hline $01 / 10 / 07$ & 0,138 & 2,00 & 0,023 & 1,10 \\
\hline $05 / 10 / 07$ & 0,113 & 1,84 & 0,025 & 0,70 \\
\hline $08 / 10 / 07$ & 0,133 & 2,10 & 0,032 & 0,55 \\
\hline $15 / 10 / 07$ & 0,328 & 2,10 & 0,043 & 0,85 \\
\hline $19 / 10 / 07$ & 0,167 & 1,86 & 0,037 & 0,40 \\
\hline $22 / 10 / 07$ & 0,174 & 1,82 & 0,030 & 0,75 \\
\hline $26 / 10 / 07$ & 0,148 & 1,80 & 0,036 & 0,80 \\
\hline $31 / 10 / 07$ & 0,103 & 1,86 & 0,034 & 0,70 \\
\hline $05 / 11 / 07$ & 0,119 & 1,94 & 0,001 & 1,00 \\
\hline $09 / 11 / 07$ & 0,386 & 1,90 & 0,042 & 0,50 \\
\hline $12 / 11 / 07$ & 0,249 & 1,86 & 0,051 & 0,35 \\
\hline $19 / 11 / 07$ & 0,339 & 2,06 & 0,032 & 0,60 \\
\hline $23 / 11 / 07$ & 0,183 & 2,20 & 0,040 & 0,70 \\
\hline $26 / 11 / 07$ & 0,193 & 1,93 & 0,024 & 0,90 \\
\hline $30 / 11 / 07$ & 0,182 & 2,10 & 0,041 & 1,30 \\
\hline $03 / 12 / 07$ & 0,254 & 1,93 & 0,066 & 0,51 \\
\hline $07 / 12 / 07$ & 0,121 & 1,92 & 0,029 & 0,80 \\
\hline $10 / 12 / 07$ & 0,251 & 2,19 & 0,023 & 0,60 \\
\hline $16 / 12 / 07$ & 0,170 & 1,91 & 0,009 & 0,70 \\
\hline $21 / 12 / 07$ & 0,156 & 2,20 & 0,006 & 0,50 \\
\hline $27 / 12 / 07$ & 0,130 & 2,12 & 0,000 & 1,00 \\
\hline $04 / 01 / 08$ & 0,208 & 2,11 & 0,000 & 0,60 \\
\hline $07 / 01 / 08$ & 0,228 & 2,32 & 0,000 & 0,70 \\
\hline $11 / 01 / 08$ & 0,125 & 2,54 & 0,000 & 0,60 \\
\hline $15 / 01 / 08$ & 0,173 & 2,54 & 0,000 & 0,30 \\
\hline $18 / 01 / 08$ & 0,168 & 1,84 & 0,000 & 0,50 \\
\hline & & & & \\
\hline
\end{tabular}




\begin{tabular}{|c|c|c|c|c|}
\hline \multirow{2}{*}{ Data } & \multicolumn{5}{|c|}{ Reservatório de Equalização de Água Filtrada } \\
\cline { 2 - 5 } & $\begin{array}{c}\text { Turbidez } \\
\text { (UNT) }\end{array}$ & $\begin{array}{c}\text { COT } \\
\text { (mg/L) }\end{array}$ & $\begin{array}{c}\text { UV 254 } \\
\text { (cm }^{-1} \text { ) }\end{array}$ & $\begin{array}{c}\text { Cl }_{\text { livre }} \\
\text { residual (mg/L) }\end{array}$ \\
\hline $28 / 01 / 08$ & 0,148 & 2,10 & 0,025 & 0,70 \\
\hline $01 / 02 / 08$ & 0,214 & 2,50 & 0,030 & 0,70 \\
\hline $08 / 02 / 08$ & 0,130 & 1,92 & 0,029 & 0,40 \\
\hline $11 / 02 / 08$ & 0,196 & 1,94 & 0,029 & - \\
\hline $15 / 02 / 08$ & 0,172 & 2,30 & 0,035 & 0,50 \\
\hline $18 / 02 / 08$ & 0,248 & 2,01 & 0,030 & 0,75 \\
\hline $22 / 02 / 08$ & 0,154 & 1,92 & 0,033 & 0,40 \\
\hline $25 / 02 / 08$ & 0,135 & 1,90 & 0,021 & 0,75 \\
\hline $29 / 02 / 08$ & 0,171 & 2,30 & 0,027 & 0,80 \\
\hline $10 / 04 / 08$ & 0,248 & 2,32 & 0,048 & 0,60 \\
\hline $14 / 04 / 08$ & 0,154 & 2,33 & 0,036 & 0,50 \\
\hline $16 / 04 / 08$ & 0,271 & 2,30 & 0,034 & 0,62 \\
\hline $24 / 04 / 08$ & 0,354 & 2,17 & 0,033 & 0,61 \\
\hline $28 / 04 / 08$ & 0,176 & 2,45 & 0,038 & 0,50 \\
\hline $12 / 05 / 08$ & 0,159 & 2,21 & 0,046 & 0,50 \\
\hline $15 / 05 / 08$ & 0,449 & 2,17 & 0,031 & 0,77 \\
\hline $26 / 05 / 08$ & 0,110 & 1,89 & 0,030 & 0,40 \\
\hline $29 / 05 / 08$ & 0,224 & 1,88 & 0,017 & 0,25 \\
\hline $02 / 06 / 08$ & 0,200 & 1,90 & 0,024 & 0,60 \\
\hline $12 / 06 / 08$ & 0,230 & 2,23 & 0,029 & 0,86 \\
\hline $16 / 06 / 08$ & 0,148 & 2,40 & 0,022 & 0,20 \\
\hline $18 / 06 / 08$ & 0,231 & 2,12 & 0,026 & 0,35 \\
\hline $23 / 06 / 08$ & 0,167 & 2,39 & 0,032 & 0,40 \\
\hline $30 / 06 / 08$ & 0,107 & 2,41 & 0,022 & 0,70 \\
\hline $02 / 07 / 08$ & 0,283 & 2,32 & 0,031 & 0,65 \\
\hline $07 / 07 / 08$ & 0,142 & 2,52 & 0,040 & 0,50 \\
\hline $22 / 07 / 08$ & 0,140 & 2,32 & 0,049 & 0,60 \\
\hline $24 / 07 / 08$ & 0,167 & 2,17 & 0,026 & 0,61 \\
\hline $28 / 07 / 08$ & 0,149 & 2,39 & 0,051 & 0,90 \\
\hline $31 / 07 / 08$ & 0,436 & 2,31 & 0,037 & 0,56 \\
\hline $11 / 08 / 08$ & 0,168 & 2,15 & 0,002 & 0,30 \\
\hline $14 / 08 / 08$ & 0,273 & 2,03 & 0,022 & 0,42 \\
\hline $18 / 08 / 08$ & 0,548 & 2,11 & 0,031 & 0,80 \\
\hline $19 / 08 / 08$ & 0,189 & 2,22 & 0,150 & 0,78 \\
\hline $25 / 08 / 08$ & 0,202 & 2,00 & 0,019 & 0,40 \\
\hline $28 / 08 / 08$ & 0,227 & 1,95 & 0,018 & 0,45 \\
\hline $02 / 09 / 08$ & 0,189 & 1,91 & 0,039 & 0,40 \\
\hline $04 / 09 / 08$ & 0,279 & 2,04 & 0,149 & 0,35 \\
\hline $08 / 09 / 08$ & 0,158 & 2,09 & 0,023 & 0,40 \\
\hline $11 / 09 / 08$ & 0,298 & 2,13 & 0,029 & 0,30 \\
\hline $15 / 09 / 08$ & 0,225 & 2,05 & 0,029 & 0,20 \\
\hline $18 / 09 / 08$ & 0,200 & 1,97 & 0,038 & 0,10 \\
\hline $22 / 09 / 08$ & 0,200 & 2,00 & 0,025 & 0,10 \\
\hline $25 / 09 / 08$ & 0,250 & 1,99 & 0,026 & 0,30 \\
\hline $29 / 09 / 08$ & 0,250 & 2,00 & 0,028 & 0,20 \\
\hline $02 / 10 / 08$ & 0,312 & 1,80 & 0,026 & 0,20 \\
\hline $13 / 10 / 08$ & 0,184 & 2,22 & 0,028 & 0,50 \\
\hline $23 / 10 / 08$ & 0,285 & 2,32 & 0,010 & 0,65 \\
\hline $27 / 10 / 08$ & 0,159 & 2,28 & 0,026 & 0,40 \\
\hline $03 / 11 / 08$ & 0,182 & 2,32 & 0,025 & 0,30 \\
\hline & & & & \\
\hline
\end{tabular}




\begin{tabular}{|c|c|c|c|c|}
\hline \multirow{2}{*}{ Data } & \multicolumn{4}{|c|}{ Reservatório de Equalização de Água Filtrada } \\
\cline { 2 - 5 } & $\begin{array}{c}\text { Turbidez } \\
\text { (UNT) }\end{array}$ & $\begin{array}{c}\text { COT } \\
\text { (mg/L) }\end{array}$ & $\begin{array}{c}\text { UV 254 } \\
\text { (cm }^{-1} \text { ) }\end{array}$ & $\begin{array}{c}\mathbf{C l}_{\mathbf{2}} \text { livre } \\
\text { residual (mg/L) }\end{array}$ \\
\hline $06 / 11 / 08$ & 0,227 & 2,43 & 0,031 & 0,40 \\
\hline $10 / 11 / 08$ & 0,191 & 2,71 & 0,033 & 0,30 \\
\hline $13 / 11 / 08$ & 0,184 & 2,08 & 0,030 & 0,60 \\
\hline $08 / 12 / 08$ & 0,176 & 2,68 & 0,022 & 0,40 \\
\hline
\end{tabular}




\begin{tabular}{|c|c|c|c|c|c|c|}
\hline \multirow[b]{2}{*}{ Data } & \multicolumn{5}{|c|}{ Reservatório de Equalização de Água Ozonizada } & \multirow[b]{2}{*}{$\begin{array}{l}\mathrm{O}_{3} \text { residual } \\
\mathrm{CO} 2(\mathrm{mg} / \mathrm{L})\end{array}$} \\
\hline & $\begin{array}{c}\text { Turbidez } \\
\text { (UNT) }\end{array}$ & $\begin{array}{c}\text { COT } \\
(\mathrm{mg} / \mathrm{L})\end{array}$ & $\begin{array}{l}\text { UV } 254 \\
\left(\mathrm{~cm}^{-1}\right)\end{array}$ & $\begin{array}{c}\mathrm{Cl}_{2} \text { livre } \\
\text { residual (mg/L) }\end{array}$ & $\begin{array}{c}\mathrm{O}_{3} \text { residual } \\
(\mathrm{mg} / \mathrm{L})\end{array}$ & \\
\hline $10 / 07 / 07$ & & 2,52 & 0,025 & 0,50 & 0,29 & 0,18 \\
\hline $12 / 07 / 07$ & & 2,50 & 0,033 & 0,50 & 0,06 & 0,00 \\
\hline $16 / 07 / 07$ & 0,590 & 2,42 & 0,020 & 0,50 & 0,32 & 0,20 \\
\hline $18 / 07 / 07$ & 0,647 & 2,46 & 0,026 & 0,35 & 0,41 & 0,18 \\
\hline $20 / 07 / 07$ & 0,610 & 2,58 & 0,020 & 0,50 & 0,26 & 0,10 \\
\hline $23 / 07 / 07$ & 0,270 & 2,72 & 0,022 & 0,50 & 0,32 & 0,12 \\
\hline $25 / 07 / 07$ & 0,312 & 2,59 & 0,008 & 0,20 & 0,24 & 0,07 \\
\hline $27 / 07 / 07$ & 0,380 & 2,62 & 0,020 & 0,40 & 0,37 & 0,23 \\
\hline $30 / 07 / 07$ & 0,270 & 2,52 & 0,008 & 0,90 & 0,16 & 0,13 \\
\hline $01 / 08 / 07$ & 0,266 & 2,43 & 0,019 & 0,50 & 0,17 & 0,01 \\
\hline $03 / 08 / 07$ & 0,250 & 2,51 & 0,024 & 0,80 & 0,17 & 0,06 \\
\hline $06 / 08 / 07$ & 0,490 & 2,51 & 0,041 & 0,30 & 0,74 & 0,47 \\
\hline $08 / 08 / 07$ & 0,557 & 2,46 & 0,018 & 0,85 & 0,44 & 0,17 \\
\hline $10 / 08 / 07$ & 0,506 & 2,64 & 0,012 & 0,35 & 0,06 & 0,03 \\
\hline $15 / 08 / 07$ & 0,607 & 1,75 & 0,020 & 0,50 & 0,07 & 0,05 \\
\hline $17 / 08 / 07$ & 0,410 & 2,53 & 0,019 & 0,50 & 0,39 & 0,18 \\
\hline $20 / 08 / 07$ & 0,552 & 2,56 & 0,007 & 0,30 & 0,29 & 0,06 \\
\hline $24 / 08 / 07$ & 0,392 & 2,27 & 0,006 & 0,50 & 0,04 & 0,04 \\
\hline $27 / 08 / 07$ & 0,350 & 2,43 & 0,001 & 0,30 & 0,26 & 0,08 \\
\hline $31 / 08 / 07$ & 0,467 & 2,32 & 0,004 & 0,30 & 0,23 & 0,20 \\
\hline $03 / 09 / 07$ & 0,430 & 5,41 & 0,037 & 0,50 & 0,09 & 0,02 \\
\hline $10 / 09 / 07$ & 0,217 & 2,83 & 0,007 & 0,40 & 0,16 & 0,04 \\
\hline $14 / 09 / 07$ & 0,324 & 3,44 & 0,025 & 0,20 & 0,13 & 0,05 \\
\hline $19 / 09 / 07$ & 0,187 & 1,87 & 0,019 & 0,60 & 0,04 & 0,01 \\
\hline $21 / 09 / 07$ & 0,443 & 1,87 & 0,010 & 0,50 & 0,16 & 0,08 \\
\hline $24 / 09 / 07$ & 0,121 & 1,67 & 0,009 & 0,60 & 0,03 & 0,00 \\
\hline $01 / 10 / 07$ & 0,351 & 1,88 & 0,014 & 0,65 & 0,16 & 0,04 \\
\hline $05 / 10 / 07$ & 0,265 & 1,87 & 0,014 & 0,20 & 0,08 & 0,07 \\
\hline $08 / 10 / 07$ & 0,276 & 1,85 & 0,022 & 0,30 & 0,11 & 0,01 \\
\hline $15 / 10 / 07$ & 0,346 & 2,10 & 0,047 & 0,50 & 0,03 & 0,02 \\
\hline $19 / 10 / 07$ & 0,294 & 1,85 & 0,034 & 0,30 & 0,13 & 0,02 \\
\hline $22 / 10 / 07$ & 0,152 & 1,86 & 0,030 & 0,50 & 0,02 & 0,01 \\
\hline $26 / 10 / 07$ & 0,130 & 1,84 & 0,029 & 0,40 & 0,18 & 0,08 \\
\hline $31 / 10 / 07$ & 0,190 & 1,89 & 0,024 & 0,50 & 0,03 & 0,02 \\
\hline $05 / 11 / 07$ & 0,187 & 2,06 & 0,001 & 0,60 & 0,00 & 0,00 \\
\hline $09 / 11 / 07$ & 0,399 & 1,98 & 0,018 & 0,20 & 0,24 & 0,10 \\
\hline $12 / 11 / 07$ & 0,270 & 2,03 & 0,029 & 0,15 & 0,04 & 0,00 \\
\hline $19 / 11 / 07$ & 0,208 & 2,13 & 0,024 & 0,45 & 0,00 & 0,00 \\
\hline $23 / 11 / 07$ & 0,274 & 2,14 & 0,031 & 0,40 & 0,09 & 0,04 \\
\hline $26 / 11 / 07$ & 0,195 & 1,96 & 0,023 & 0,25 & 0,18 & 0,04 \\
\hline $30 / 11 / 07$ & 0,276 & 2,10 & 0,023 & - & 0,13 & 0,00 \\
\hline $03 / 12 / 07$ & 0,344 & 1,95 & 0,041 & 0,15 & 0,10 & 0,06 \\
\hline $07 / 12 / 07$ & 0,179 & 1,24 & 0,019 & 0,40 & 0,04 & 0,02 \\
\hline $10 / 12 / 07$ & 0,312 & 2,15 & 0,021 & 0,40 & 0,04 & 0,02 \\
\hline $16 / 12 / 07$ & 0,150 & 1,97 & 0,007 & 0,60 & 0,03 & 0,02 \\
\hline $21 / 12 / 07$ & 0,170 & 2,21 & 0,001 & 0,20 & 0,04 & 0,01 \\
\hline $27 / 12 / 07$ & 0,150 & 2,10 & 0,000 & 0,90 & 0,02 & 0,01 \\
\hline $04 / 01 / 08$ & 0,191 & 2,10 & 0,000 & 0,30 & 0,29 & 0,24 \\
\hline $07 / 01 / 08$ & 0,194 & 2,15 & 0,000 & 0,50 & 0,00 & 0,00 \\
\hline $11 / 01 / 08$ & 0,158 & 2,72 & 0,000 & 0,20 & 0,04 & 0,02 \\
\hline $15 / 01 / 08$ & 0,243 & 2,72 & 0,000 & 0,05 & 0,04 & 0,02 \\
\hline $18 / 01 / 08$ & 0,185 & 1,84 & 0,000 & 0,20 & 0,12 & 0,01 \\
\hline
\end{tabular}




\begin{tabular}{|c|c|c|c|c|c|c|}
\hline \multirow[b]{2}{*}{ Data } & \multicolumn{5}{|c|}{ Reservatório de Equalização de Água Ozonizada } & \multirow[b]{2}{*}{$\begin{array}{l}\mathrm{O}_{3} \text { residual } \\
\mathrm{CO} 2(\mathrm{mg} / \mathrm{L})\end{array}$} \\
\hline & $\begin{array}{c}\text { Turbidez } \\
\text { (UNT) }\end{array}$ & $\begin{array}{c}\mathrm{COT} \\
(\mathrm{mg} / \mathrm{L})\end{array}$ & $\begin{array}{l}\text { UV } 254 \\
\left(\mathrm{~cm}^{-1}\right)\end{array}$ & $\begin{array}{c}\mathrm{Cl}_{2} \text { livre } \\
\text { residual (mg/L) }\end{array}$ & $\begin{array}{c}\mathrm{O}_{3} \text { residual } \\
(\mathrm{mg} / \mathrm{L})\end{array}$ & \\
\hline $28 / 01 / 08$ & 0,140 & 2,10 & 0,022 & 0,50 & 0,04 & 0,03 \\
\hline $01 / 02 / 08$ & 0,300 & 2,60 & 0,028 & 0,30 & 0,05 & 0 \\
\hline $08 / 02 / 08$ & 0,184 & 1,92 & 0,030 & 0,20 & - & - \\
\hline $11 / 02 / 08$ & 0,185 & 1,92 & 0,028 & - & 0,00 & 0 \\
\hline $15 / 02 / 08$ & 0,160 & 2,20 & 0,026 & 0,30 & 0,00 & 0 \\
\hline $18 / 02 / 08$ & 0,258 & 2,01 & 0,014 & 0,30 & 0,05 & 0 \\
\hline $22 / 02 / 08$ & 0,465 & 1,82 & 0,021 & 0,20 & 0,27 & 0,13 \\
\hline $25 / 02 / 08$ & 0,391 & 1,90 & 0,012 & 0,45 & 0,00 & 0 \\
\hline $29 / 02 / 08$ & 0,294 & 2,20 & 0,020 & 0,50 & 0,08 & 0,01 \\
\hline $10 / 04 / 08$ & 0,474 & 2,25 & 0,038 & 0,20 & 0,26 & 0,12 \\
\hline $14 / 04 / 08$ & 0,465 & 2,33 & 0,017 & 0,20 & 0,40 & 0,38 \\
\hline $16 / 04 / 08$ & 0,192 & 2,38 & 0,012 & 0,10 & 0,69 & 0,04 \\
\hline $24 / 04 / 08$ & 0,201 & 2,16 & 0,016 & 0,10 & 0,23 & 0,02 \\
\hline $28 / 04 / 08$ & 0,175 & 2,19 & 0,025 & 0,15 & 0,32 & 0,14 \\
\hline $12 / 05 / 08$ & 0,184 & 2,21 & 0,028 & 0,20 & 0,38 & 0,3 \\
\hline $15 / 05 / 08$ & 0,233 & 2,14 & 0,016 & 0,15 & 0,29 & 0,03 \\
\hline $26 / 05 / 08$ & 0,139 & 1,91 & 0,016 & 0,30 & - & - \\
\hline $29 / 05 / 08$ & 0,144 & 1,73 & 0,005 & 0,15 & 0,16 & 0,05 \\
\hline $02 / 06 / 08$ & 0,100 & 1,81 & 0,006 & 0,40 & 0,50 & 0,21 \\
\hline $12 / 06 / 08$ & 0,277 & 2,15 & 0,012 & 0,35 & 0,50 & 0,21 \\
\hline $16 / 06 / 08$ & 0,170 & 2,20 & 0,006 & 0,10 & 0,50 & 0,15 \\
\hline $18 / 06 / 08$ & 0,185 & 2,00 & 0,018 & 0,05 & 0,09 & 0,03 \\
\hline $23 / 06 / 08$ & 0,151 & 2,25 & 0,033 & 0,20 & 0,24 & 0,06 \\
\hline $30 / 06 / 08$ & 0,136 & 2,31 & 0,007 & 0,40 & 0,06 & 0,02 \\
\hline $02 / 07 / 08$ & 0,223 & 3,41 & 0,270 & 0,45 & - & - \\
\hline $07 / 07 / 08$ & 0,146 & 2,31 & 0,025 & 0,20 & - & - \\
\hline $22 / 07 / 08$ & 0,158 & 2,63 & 0,027 & 0,30 & - & - \\
\hline $24 / 07 / 08$ & 0,172 & 2,17 & 0,016 & 0,25 & 0,00 & 0 \\
\hline $28 / 07 / 08$ & 0,198 & 2,41 & 0,013 & 0,20 & - & - \\
\hline $31 / 07 / 08$ & 0,297 & 2,24 & 0,019 & 0,15 & 0,07 & 0 \\
\hline $11 / 08 / 08$ & 0,171 & 0,10 & 0,004 & 0,20 & 0,37 & 0,25 \\
\hline $14 / 08 / 08$ & 0,278 & 2,03 & 0,010 & 0,10 & 0,28 & 0,07 \\
\hline $18 / 08 / 08$ & 0,218 & 2,08 & 0,019 & 0,30 & 0,42 & 0,3 \\
\hline 19/08/08 & 0,202 & 2,21 & 0,137 & 0,37 & 0,35 & 0,02 \\
\hline $25 / 08 / 08$ & 0,157 & 1,90 & 0,007 & 0,20 & 0,34 & 0,11 \\
\hline $28 / 08 / 08$ & 0,517 & 1,59 & 0,003 & 0,15 & 1,07 & 0,14 \\
\hline $02 / 09 / 08$ & 0,240 & 1,92 & 0,008 & 0,10 & 0,38 & 0,25 \\
\hline $04 / 09 / 08$ & 0,231 & 1,86 & 0,010 & 0,15 & 0,24 & 0,01 \\
\hline $08 / 09 / 08$ & 0,213 & 2,24 & 0,026 & 0,20 & 0,51 & 0,4 \\
\hline $11 / 09 / 08$ & 0,273 & 2,08 & 0,008 & 0,20 & 0,65 & 0,16 \\
\hline $15 / 09 / 08$ & 0,231 & 2,06 & 0,017 & 0,10 & 0,65 & 0,16 \\
\hline $18 / 09 / 08$ & 0,257 & 1,96 & 0,045 & 0,05 & - & - \\
\hline $22 / 09 / 08$ & 0,323 & 2,10 & 0,007 & 0,30 & 1,57 & 1,16 \\
\hline $25 / 09 / 08$ & 0,475 & 1,99 & 0,014 & 0,20 & 0,41 & 0,02 \\
\hline $29 / 09 / 08$ & 0,345 & 2,03 & 0,015 & 0,20 & 0,43 & 0,09 \\
\hline $02 / 10 / 08$ & 0,789 & 1,76 & 0,015 & 0,05 & 0,10 & 0,59 \\
\hline $13 / 10 / 08$ & 0,165 & 1,99 & 0,015 & 0,35 & 0,09 & 0,19 \\
\hline $23 / 10 / 08$ & 0,264 & 2,32 & 0,013 & 0,35 & 0,00 & 0,3 \\
\hline $27 / 10 / 08$ & 0,204 & 2,37 & 0,011 & 0,30 & 0,11 & 0,53 \\
\hline $03 / 11 / 08$ & 0,470 & 2,41 & 0,012 & 0,10 & 0,20 & 0,23 \\
\hline
\end{tabular}




\begin{tabular}{|c|c|c|c|c|c|c|}
\hline \multirow[b]{2}{*}{ Data } & \multicolumn{5}{|c|}{ Reservatório de Equalização de Água Ozonizada } & \\
\hline & $\begin{array}{c}\text { Turbidez } \\
\text { (UNT) }\end{array}$ & $\begin{array}{c}\mathrm{COT} \\
(\mathrm{mg} / \mathrm{L})\end{array}$ & $\begin{array}{l}\text { UV } 254 \\
\left(\mathrm{~cm}^{-1}\right)\end{array}$ & $\begin{array}{c}\mathrm{Cl}_{2} \text { livre } \\
\text { residual (mg/L) }\end{array}$ & $\begin{array}{c}\mathrm{O}_{3} \text { residual } \\
(\mathrm{mg} / \mathrm{L})\end{array}$ & $\begin{array}{l}\mathrm{O}_{3} \text { residual } \\
\mathrm{CO} 2(\mathrm{mg} / \mathrm{L}\end{array}$ \\
\hline $06 / 11 / 08$ & 0,256 & 2,34 & 0,018 & 0,10 & 0,04 & 0,23 \\
\hline $10 / 11 / 08$ & 0,272 & 2,38 & 0,017 & 0,10 & - & - \\
\hline $13 / 11 / 08$ & 0,175 & 2,20 & 0,014 & 0,25 & 0,00 & 0,07 \\
\hline $08 / 12 / 08$ & 0,179 & 2,17 & 0,014 & 0,10 & 0,15 & 0,47 \\
\hline
\end{tabular}




\begin{tabular}{|c|c|c|c|c|}
\hline \multirow{2}{*}{ Data } & \multicolumn{3}{|c|}{ Água Efluente do Filtro 1 } \\
\cline { 2 - 5 } & $\begin{array}{c}\text { Turbidez } \\
\text { (UNT) }\end{array}$ & $\begin{array}{c}\text { COT } \\
\text { (mg/L) }\end{array}$ & $\begin{array}{c}\text { UV 254 } \\
\text { (cm }^{-1} \text { ) }\end{array}$ & $\begin{array}{c}\text { Perda de } \\
\text { carga (cm) }\end{array}$ \\
\hline $10 / 07 / 07$ & - & 0,20 & 0,001 & 15 \\
\hline $12 / 07 / 07$ & - & 0,20 & 0,011 & 15 \\
\hline $16 / 07 / 07$ & 0,440 & 0,22 & 0,005 & 18 \\
\hline $18 / 07 / 07$ & 0,318 & 0,26 & 0,001 & 20 \\
\hline $20 / 07 / 07$ & 0,450 & 0,32 & 0,005 & 26 \\
\hline $23 / 07 / 07$ & 0,260 & 0,64 & 0,005 & 26 \\
\hline $25 / 07 / 07$ & 0,265 & 0,43 & 0,025 & 23 \\
\hline $27 / 07 / 07$ & 0,450 & 0,45 & 0,008 & 26 \\
\hline $30 / 07 / 07$ & 0,250 & 0,74 & 0,005 & 27 \\
\hline $01 / 08 / 07$ & 0,324 & 0,54 & 0,005 & 25 \\
\hline $03 / 08 / 07$ & 0,192 & 0,84 & 0,023 & 16 \\
\hline $06 / 08 / 07$ & 0,360 & 0,54 & 0,054 & 27 \\
\hline $08 / 08 / 07$ & 0,353 & 0,53 & 0,026 & 24 \\
\hline $10 / 08 / 07$ & 0,316 & 0,74 & 0,029 & 29 \\
\hline $15 / 08 / 07$ & 0,365 & 3,01 & 0,010 & 27 \\
\hline $17 / 08 / 07$ & 0,271 & 1,20 & 0,008 & 26 \\
\hline $20 / 08 / 07$ & 0,453 & 0,71 & 0,008 & 29 \\
\hline $24 / 08 / 07$ & 0,555 & 0,77 & 0,001 & 26 \\
\hline $27 / 08 / 07$ & 0,120 & 0,96 & 0,001 & 25 \\
\hline $31 / 08 / 07$ & 0,272 & 0,83 & 0,003 & 29 \\
\hline $03 / 09 / 07$ & 0,434 & 3,25 & 0,011 & 30 \\
\hline $10 / 09 / 07$ & 0,226 & 2,04 & 0,000 & 29 \\
\hline $14 / 09 / 07$ & 0,197 & 5,45 & 0,018 & 10 \\
\hline $19 / 09 / 07$ & 0,113 & 0,90 & 0,007 & 11 \\
\hline $21 / 09 / 07$ & 0,237 & 0,81 & 0,000 & 12 \\
\hline $24 / 09 / 07$ & 0,154 & 0,72 & 0,000 & 7 \\
\hline $01 / 10 / 07$ & 0,297 & 1,25 & 0,004 & 14 \\
\hline $05 / 10 / 07$ & 0,211 & 0,97 & 0,005 & 18 \\
\hline $08 / 10 / 07$ & 0,367 & 1,40 & 0,020 & 15 \\
\hline $15 / 10 / 07$ & 0,240 & 1,33 & 0,033 & 15 \\
\hline $19 / 10 / 07$ & 0,214 & 1,16 & 0,015 & 17 \\
\hline $22 / 10 / 07$ & 0,190 & 1,22 & 0,018 & 16 \\
\hline $26 / 10 / 07$ & 0,512 & 1,13 & 0,015 & 20 \\
\hline $31 / 10 / 07$ & 0,162 & 1,28 & 0,008 & 19 \\
\hline $05 / 11 / 07$ & 0,154 & 1,15 & 0,000 & 15 \\
\hline $09 / 11 / 07$ & 0,296 & 1,20 & 0,009 & 18 \\
\hline $12 / 11 / 07$ & 0,298 & 1,10 & 0,024 & 16 \\
\hline $19 / 11 / 07$ & 0,189 & 1,28 & 0,016 & 15 \\
\hline $23 / 11 / 07$ & 0,252 & 1,27 & 0,016 & 14 \\
\hline $26 / 11 / 07$ & 0,230 & 1,12 & 0,006 & 10 \\
\hline $30 / 11 / 07$ & 0,266 & 1,23 & 0,012 & 13 \\
\hline $03 / 12 / 07$ & 0,270 & 1,20 & 0,020 & 10 \\
\hline $07 / 12 / 07$ & 0,222 & 1,98 & 0,029 & 11 \\
\hline $10 / 12 / 07$ & 0,233 & 1,40 & 0,006 & 10 \\
\hline $16 / 12 / 07$ & 0,110 & 1,29 & 0,001 & 13 \\
\hline $21 / 12 / 07$ & 0,235 & 1,51 & 0,000 & 13 \\
\hline $27 / 12 / 07$ & 0,160 & 1,27 & 0,000 & 14 \\
\hline $04 / 01 / 08$ & 0,201 & 1,36 & 0,000 & 14 \\
\hline $07 / 01 / 08$ & 0,170 & 1,38 & 0,000 & 14 \\
\hline $11 / 01 / 08$ & 0,203 & 1,74 & 0,000 & 19 \\
\hline $15 / 01 / 08$ & 0,271 & 1,74 & 0,000 & 12 \\
\hline $18 / 01 / 08$ & 0,178 & 1,21 & 0,000 & 21 \\
\hline & & & & \\
\hline
\end{tabular}




\begin{tabular}{|c|c|c|c|c|}
\hline \multirow{2}{*}{ Data } & \multicolumn{3}{|c|}{ Água Efluente do Filtro 1 } \\
\cline { 2 - 5 } & $\begin{array}{c}\text { Turbidez } \\
\text { (UNT) }\end{array}$ & $\begin{array}{c}\text { COT } \\
\text { (mg/L) }\end{array}$ & $\begin{array}{c}\text { UV 254 } \\
\text { (cm }^{-1} \text { ) }\end{array}$ & $\begin{array}{c}\text { Perda de } \\
\text { carga (cm) }\end{array}$ \\
\hline $28 / 01 / 08$ & 0,116 & 1,60 & 0,012 & 11 \\
\hline $01 / 02 / 08$ & 0,178 & 1,90 & 0,013 & 13 \\
\hline $08 / 02 / 08$ & 0,123 & 1,51 & 0,018 & 15 \\
\hline $11 / 02 / 08$ & 0,129 & 1,47 & 0,020 & 12 \\
\hline $15 / 02 / 08$ & 0,156 & 1,70 & 0,017 & 13 \\
\hline $18 / 02 / 08$ & 0,222 & 1,48 & 0,013 & 13 \\
\hline $22 / 02 / 08$ & 0,221 & 2,01 & 0,010 & 13 \\
\hline $25 / 02 / 08$ & 0,278 & 1,30 & 0,008 & 17 \\
\hline $29 / 02 / 08$ & 0,230 & 1,50 & 0,013 & 20 \\
\hline $10 / 04 / 08$ & 0,197 & 1,53 & 0,021 & 19 \\
\hline $14 / 04 / 08$ & 0,221 & 1,79 & 0,012 & 13 \\
\hline $16 / 04 / 08$ & 0,222 & 1,68 & 0,010 & 18 \\
\hline $24 / 04 / 08$ & 0,119 & 1,63 & 0,013 & 15 \\
\hline $28 / 04 / 08$ & 0,120 & 1,84 & 0,016 & 22 \\
\hline $12 / 05 / 08$ & 0,165 & 1,62 & 0,021 & 23 \\
\hline $15 / 05 / 08$ & 0,169 & 1,57 & 0,012 & 33 \\
\hline $26 / 05 / 08$ & 0,098 & 1,47 & 0,012 & 11 \\
\hline $29 / 05 / 08$ & 0,216 & 1,43 & 0,004 & 12 \\
\hline $02 / 06 / 08$ & 0,200 & 1,36 & 0,002 & 22 \\
\hline $12 / 06 / 08$ & 0,158 & 1,60 & 0,009 & 14 \\
\hline $16 / 06 / 08$ & 0,103 & 1,79 & 0,001 & 13 \\
\hline $18 / 06 / 08$ & 0,156 & 1,72 & 0,010 & 20 \\
\hline $23 / 06 / 08$ & 0,158 & 1,69 & 0,013 & 18 \\
\hline $30 / 06 / 08$ & 0,119 & 2,25 & 0,002 & 22 \\
\hline $02 / 07 / 08$ & 0,190 & 1,83 & 0,170 & 19 \\
\hline $07 / 07 / 08$ & 0,132 & 1,99 & 0,026 & 25 \\
\hline $22 / 07 / 08$ & 0,122 & 1,84 & 0,024 & 39 \\
\hline $24 / 07 / 08$ & 0,139 & 1,71 & 0,006 & 28 \\
\hline $28 / 07 / 08$ & 0,142 & 2,06 & 0,006 & 31 \\
\hline $31 / 07 / 08$ & 0,276 & 1,68 & 0,023 & 42 \\
\hline $11 / 08 / 08$ & 0,167 & 1,79 & 0,007 & 13 \\
\hline $14 / 08 / 08$ & 0,196 & 1,68 & 0,002 & 13 \\
\hline $18 / 08 / 08$ & 0,186 & 1,61 & 0,014 & 14 \\
\hline $19 / 08 / 08$ & 0,179 & 1,71 & 0,148 & 12 \\
\hline $25 / 08 / 08$ & 0,175 & 1,50 & 0,005 & 15 \\
\hline $28 / 08 / 08$ & 0,286 & 1,15 & 0,003 & 13 \\
\hline $02 / 09 / 08$ & 0,172 & 1,41 & 0,006 & 18 \\
\hline $04 / 09 / 08$ & 0,152 & 1,46 & 0,149 & 13 \\
\hline $08 / 09 / 08$ & 0,163 & 1,64 & 0,016 & 19 \\
\hline $11 / 09 / 08$ & 0,235 & 1,54 & 0,006 & 15 \\
\hline $15 / 09 / 08$ & 0,187 & 1,53 & 0,012 & 19 \\
\hline $18 / 09 / 08$ & 0,236 & 1,88 & 0,022 & 19 \\
\hline $22 / 09 / 08$ & 0,220 & 1,18 & 0,005 & 20 \\
\hline $25 / 09 / 08$ & 0,335 & 1,47 & 0,027 & 25 \\
\hline $29 / 09 / 08$ & 0,276 & 1,53 & 0,010 & 35 \\
\hline $02 / 10 / 08$ & 0,438 & 1,28 & 0,008 & 33 \\
\hline $13 / 10 / 08$ & 0,162 & 1,55 & 0,013 & 46 \\
\hline $23 / 10 / 08$ & 0,158 & 1,90 & 0,016 & 8 \\
\hline $27 / 10 / 08$ & 0,173 & 2,41 & 0,015 & 11 \\
\hline $03 / 11 / 08$ & 0,157 & 1,60 & 0,008 & 13 \\
\hline & & & & \\
\hline
\end{tabular}




\begin{tabular}{|c|c|c|c|c|}
\hline \multirow{2}{*}{ Data } & \multicolumn{4}{|c|}{ Água Efluente do Filtro 1 } \\
\cline { 2 - 5 } & $\begin{array}{c}\text { Turbidez } \\
\text { (UNT) }\end{array}$ & $\begin{array}{c}\text { COT } \\
\text { ( mg/L) }\end{array}$ & $\begin{array}{c}\text { UV 254 } \\
\text { (cm }^{-1} \text { ) }\end{array}$ & $\begin{array}{c}\text { Perda de } \\
\text { carga (cm) }\end{array}$ \\
\hline $06 / 11 / 08$ & 0,182 & 1,72 & 0,012 & 10 \\
\hline $10 / 11 / 08$ & 0,150 & 1,79 & 0,011 & 14 \\
\hline $13 / 11 / 08$ & 0,169 & 1,52 & 0,008 & 14 \\
\hline $08 / 12 / 08$ & 0,167 & 1,54 & 0,009 & 29 \\
\hline
\end{tabular}




\begin{tabular}{|c|c|c|c|c|}
\hline \multirow[b]{2}{*}{ Data } & \multicolumn{4}{|c|}{ Água Efluente do Filtro 2} \\
\hline & $\begin{array}{c}\text { Turbidez } \\
\text { (UNT) }\end{array}$ & $\begin{array}{c}\text { COT } \\
(\mathrm{mg} / \mathrm{L})\end{array}$ & $\begin{array}{c}\text { UV } 254 \\
\left(\mathrm{~cm}^{-1}\right)\end{array}$ & $\begin{array}{l}\text { Perda de } \\
\text { carga }(\mathrm{cm})\end{array}$ \\
\hline $10 / 07 / 07$ & - & 0,67 & 0,001 & 20 \\
\hline $12 / 07 / 07$ & - & 1,16 & 0,018 & 19 \\
\hline $16 / 07 / 07$ & 0,610 & 1,30 & 0,013 & 22 \\
\hline $18 / 07 / 07$ & 0,431 & 1,35 & 0,001 & 23 \\
\hline $20 / 07 / 07$ & 0,220 & 1,60 & 0,011 & 28 \\
\hline $23 / 07 / 07$ & 0,270 & 1,78 & 0,015 & 28 \\
\hline $25 / 07 / 07$ & 0,289 & 1,94 & 0,016 & 24 \\
\hline $27 / 07 / 07$ & 0,450 & 1,81 & 0,015 & 35 \\
\hline $30 / 07 / 07$ & 0,250 & 2,12 & 0,004 & 30 \\
\hline $01 / 08 / 07$ & 0,292 & 1,89 & 0,013 & 26 \\
\hline $03 / 08 / 07$ & 0,299 & 2,11 & 0,109 & 34 \\
\hline $06 / 08 / 07$ & 0,410 & 1,82 & 0,042 & 30 \\
\hline $08 / 08 / 07$ & 0,395 & 1,79 & 0,036 & 28 \\
\hline $10 / 08 / 07$ & 0,448 & 1,90 & 0,017 & 34 \\
\hline $15 / 08 / 07$ & 0,340 & 5,85 & 0,036 & 39 \\
\hline $17 / 08 / 07$ & 0,365 & 2,25 & 0,011 & 28 \\
\hline $20 / 08 / 07$ & 0,447 & 1,90 & 0,008 & 31 \\
\hline $24 / 08 / 07$ & 0,511 & 1,75 & 0,007 & 30 \\
\hline $27 / 08 / 07$ & 0,118 & 2,39 & 0,005 & 28 \\
\hline $31 / 08 / 07$ & 0,411 & 1,79 & 0,003 & 36 \\
\hline $03 / 09 / 07$ & 0,417 & 8,16 & 0,026 & 35 \\
\hline $10 / 09 / 07$ & 0,327 & 2,49 & 0,005 & 38 \\
\hline $14 / 09 / 07$ & 0,234 & 3,07 & 0,010 & 13 \\
\hline $19 / 09 / 07$ & 0,132 & 1,54 & 0,018 & 12 \\
\hline $21 / 09 / 07$ & 0,382 & 1,42 & 0,000 & 16 \\
\hline $24 / 09 / 07$ & 0,177 & 1,35 & 0,007 & 13 \\
\hline $01 / 10 / 07$ & 0,292 & 1,70 & 0,018 & 19 \\
\hline $05 / 10 / 07$ & 0,255 & 1,55 & 0,017 & 25 \\
\hline $08 / 10 / 07$ & 0,398 & 1,71 & 0,024 & 20 \\
\hline $15 / 10 / 07$ & 0,251 & 1,76 & 0,039 & 16 \\
\hline $19 / 10 / 07$ & 0,190 & 1,65 & 0,025 & 22 \\
\hline $22 / 10 / 07$ & 0,202 & 1,73 & 0,031 & 20 \\
\hline $26 / 10 / 07$ & 0,222 & 1,61 & 0,024 & 27 \\
\hline $31 / 10 / 07$ & 0,156 & 1,65 & 0,016 & 35 \\
\hline $05 / 11 / 07$ & 0,143 & 1,62 & 0,000 & 20 \\
\hline $09 / 11 / 07$ & 0,239 & 1,63 & 0,020 & 25 \\
\hline $12 / 11 / 07$ & 0,262 & 1,64 & 0,036 & 21 \\
\hline $19 / 11 / 07$ & 0,182 & 1,80 & 0,022 & 15 \\
\hline $23 / 11 / 07$ & 0,291 & 1,67 & 0,019 & 18 \\
\hline $26 / 11 / 07$ & 0,255 & 1,55 & 0,014 & 15 \\
\hline $30 / 11 / 07$ & 0,224 & 1,63 & 0,022 & 18 \\
\hline $03 / 12 / 07$ & 0,291 & 1,64 & 0,024 & 12 \\
\hline $07 / 12 / 07$ & 0,149 & 1,64 & 0,014 & 17 \\
\hline $10 / 12 / 07$ & 0,238 & 1,80 & 0,010 & 15 \\
\hline $16 / 12 / 07$ & 0,210 & 1,93 & 0,003 & 15 \\
\hline $21 / 12 / 07$ & 0,213 & 1,96 & 0,000 & 15 \\
\hline $27 / 12 / 07$ & 0,170 & 1,65 & 0,000 & 15 \\
\hline $04 / 01 / 08$ & 0,184 & 1,81 & 0,000 & 16 \\
\hline $07 / 01 / 08$ & 0,161 & 1,85 & 0,000 & 15 \\
\hline $11 / 01 / 08$ & 0,254 & 2,37 & 0,000 & 17 \\
\hline $15 / 01 / 08$ & 0,264 & 2,37 & 0,000 & 12 \\
\hline $18 / 01 / 08$ & 0,155 & 1,54 & 0,000 & 16 \\
\hline
\end{tabular}




\begin{tabular}{|c|c|c|c|c|}
\hline \multirow{2}{*}{ Data } & \multicolumn{3}{|c|}{ Água Efluente do Filtro 2 } \\
\cline { 2 - 5 } & $\begin{array}{c}\text { Turbidez } \\
\text { (UNT) }\end{array}$ & $\begin{array}{c}\text { COT } \\
\text { (mg/L) }\end{array}$ & $\begin{array}{c}\text { UV 254 } \\
\text { (cm }^{-1} \text { ) }\end{array}$ & $\begin{array}{c}\text { Perda de } \\
\text { carga (cm) }\end{array}$ \\
\hline $28 / 01 / 08$ & 0,128 & 2,00 & 0,022 & 13 \\
\hline $01 / 02 / 08$ & 0,185 & 2,30 & 0,023 & 15 \\
\hline $08 / 02 / 08$ & 0,120 & 1,82 & 0,025 & 18 \\
\hline $11 / 02 / 08$ & 0,152 & 1,77 & 0,030 & 14 \\
\hline $15 / 02 / 08$ & 0,157 & 2,00 & 0,026 & 16 \\
\hline $18 / 02 / 08$ & 0,209 & 1,67 & 0,024 & 13 \\
\hline $22 / 02 / 08$ & 0,246 & 2,15 & 0,013 & 15 \\
\hline $25 / 02 / 08$ & 0,361 & 1,60 & 0,012 & 13 \\
\hline $29 / 02 / 08$ & 0,338 & 1,80 & 0,023 & 19 \\
\hline $10 / 04 / 08$ & 0,161 & 1,57 & 0,019 & 20 \\
\hline $14 / 04 / 08$ & 0,246 & 1,81 & 0,016 & 15 \\
\hline $16 / 04 / 08$ & 0,268 & 1,83 & 0,011 & 16 \\
\hline $24 / 04 / 08$ & 0,196 & 1,83 & 0,015 & 18 \\
\hline $28 / 04 / 08$ & 0,176 & 2,04 & 0,019 & 22 \\
\hline $12 / 05 / 08$ & 0,170 & 1,76 & 0,022 & 27 \\
\hline $15 / 05 / 08$ & 0,209 & 1,75 & 0,022 & 32 \\
\hline $26 / 05 / 08$ & 0,099 & 1,70 & 0,015 & 14 \\
\hline $29 / 05 / 08$ & 0,193 & 1,47 & 0,005 & 14 \\
\hline $02 / 06 / 08$ & 0,100 & 1,49 & 0,008 & 27 \\
\hline $12 / 06 / 08$ & 0,167 & 1,77 & 0,014 & 14 \\
\hline $16 / 06 / 08$ & 0,110 & 2,06 & 0,004 & 19 \\
\hline $18 / 06 / 08$ & 0,169 & 1,95 & 0,013 & 17 \\
\hline $23 / 06 / 08$ & 0,113 & 1,84 & 0,013 & 20 \\
\hline $30 / 06 / 08$ & 0,105 & 2,80 & 0,006 & 22 \\
\hline $02 / 07 / 08$ & 0,168 & 2,03 & 0,022 & 20 \\
\hline $07 / 07 / 08$ & 0,117 & 2,14 & 0,050 & 26 \\
\hline $22 / 07 / 08$ & 0,146 & 2,11 & 0,025 & 37 \\
\hline $24 / 07 / 08$ & 0,138 & 1,87 & 0,007 & 32 \\
\hline $28 / 07 / 08$ & 0,157 & 2,24 & 0,011 & 33 \\
\hline $31 / 07 / 08$ & 0,282 & 1,84 & 0,017 & 42 \\
\hline $11 / 08 / 08$ & 0,160 & 1,95 & 0,009 & 16 \\
\hline $14 / 08 / 08$ & 0,207 & 1,59 & 0,002 & 11 \\
\hline $18 / 08 / 08$ & 0,174 & 1,75 & 0,017 & 17 \\
\hline $19 / 08 / 08$ & 0,191 & 2,66 & 0,158 & 13 \\
\hline $25 / 08 / 08$ & 0,202 & 1,90 & 0,006 & 20 \\
\hline $28 / 08 / 08$ & 1,050 & 2,04 & 0,021 & 13 \\
\hline $02 / 09 / 08$ & 0,173 & 1,52 & 0,006 & 20 \\
\hline $04 / 09 / 08$ & 0,200 & 1,58 & 0,010 & 15 \\
\hline $08 / 09 / 08$ & 0,185 & 1,23 & 0,010 & 24 \\
\hline $11 / 09 / 08$ & 0,246 & 1,63 & 0,006 & 20 \\
\hline $15 / 09 / 08$ & 0,210 & 1,74 & 0,014 & 24 \\
\hline $18 / 09 / 08$ & 0,215 & 1,99 & 0,027 & 22 \\
\hline $22 / 09 / 08$ & 0,211 & 1,34 & 0,008 & 32 \\
\hline $25 / 09 / 08$ & 0,374 & 1,61 & 0,018 & 32 \\
\hline $29 / 09 / 08$ & 0,243 & 1,62 & 0,013 & 53 \\
\hline $02 / 10 / 08$ & 0,476 & 1,46 & 0,009 & 51 \\
\hline $13 / 10 / 08$ & 0,178 & 1,73 & 0,016 & 57 \\
\hline $23 / 10 / 08$ & 0,175 & 2,02 & 0,008 & 9 \\
\hline $27 / 10 / 08$ & 0,162 & 2,50 & 0,018 & 15 \\
\hline $03 / 11 / 08$ & 0,153 & 1,69 & 0,012 & 19 \\
\hline & & & & \\
\hline
\end{tabular}




\begin{tabular}{|c|c|c|c|c|}
\hline \multirow{2}{*}{ Data } & \multicolumn{4}{|c|}{ Água Efluente do Filtro 2 } \\
\cline { 2 - 5 } & $\begin{array}{c}\text { Turbidez } \\
\text { (UNT) }\end{array}$ & $\begin{array}{c}\text { COT } \\
\text { (mg/L) }\end{array}$ & $\begin{array}{c}\text { UV 254 } \\
\text { (cm }^{-1} \text { ) }\end{array}$ & $\begin{array}{c}\text { Perda de } \\
\text { carga }(\mathbf{c m})\end{array}$ \\
\hline $06 / 11 / 08$ & 0,184 & 1,88 & 0,015 & 18 \\
\hline $10 / 11 / 08$ & 0,173 & 1,88 & 0,015 & 27 \\
\hline $13 / 11 / 08$ & 0,189 & 1,62 & 0,012 & 20 \\
\hline $08 / 12 / 08$ & 0,192 & 1,68 & 0,011 & 30 \\
\hline
\end{tabular}




\begin{tabular}{|c|c|c|c|c|}
\hline \multirow{3}{*}{ Data } & \multicolumn{3}{|c|}{ Água Efluente do Filtro 3 } \\
\cline { 2 - 5 } & $\begin{array}{c}\text { Turbidez } \\
\text { (UNT) }\end{array}$ & $\begin{array}{c}\text { COT } \\
\text { (mg/L) }\end{array}$ & $\begin{array}{c}\text { UV 254 } \\
\text { (cm }^{-1} \text { ) }\end{array}$ & $\begin{array}{c}\text { Perda de } \\
\text { carga (cm) }\end{array}$ \\
\hline $10 / 07 / 07$ & - & 0,16 & 0,001 & 20 \\
\hline $12 / 07 / 07$ & - & 0,14 & 0,010 & 17 \\
\hline $16 / 07 / 07$ & 0,180 & 0,18 & 0,006 & 37 \\
\hline $18 / 07 / 07$ & 0,142 & 0,32 & 0,001 & 66 \\
\hline $20 / 07 / 07$ & 0,200 & 0,39 & 0,001 & 82 \\
\hline $23 / 07 / 07$ & 0,120 & 1,11 & 0,007 & 108 \\
\hline $25 / 07 / 07$ & 0,155 & 0,73 & 0,028 & 130 \\
\hline $27 / 07 / 07$ & 0,130 & 0,48 & 0,003 & 135 \\
\hline $30 / 07 / 07$ & 0,110 & 0,75 & 0,005 & 170 \\
\hline $01 / 08 / 07$ & 0,201 & 0,69 & 0,003 & 173 \\
\hline $03 / 08 / 07$ & 0,123 & 0,84 & 0,034 & 158 \\
\hline $06 / 08 / 07$ & 0,120 & 0,77 & 0,048 & 162 \\
\hline $08 / 08 / 07$ & 0,129 & 0,72 & 0,020 & 156 \\
\hline $10 / 08 / 07$ & 0,135 & 0,76 & 0,001 & 169 \\
\hline $15 / 08 / 07$ & 0,144 & 1,33 & 0,010 & 174 \\
\hline $17 / 08 / 07$ & 0,157 & 1,58 & 0,004 & 180 \\
\hline $20 / 08 / 07$ & 0,150 & 0,94 & 0,005 & 184 \\
\hline $24 / 08 / 07$ & 0,183 & 0,72 & 0,009 & 193 \\
\hline $27 / 08 / 07$ & 0,189 & 1,83 & 0,004 & 195 \\
\hline $31 / 08 / 07$ & 0,135 & 0,88 & 0,003 & 228 \\
\hline $03 / 09 / 07$ & 0,342 & 10,74 & 0,073 & 254 \\
\hline $10 / 09 / 07$ & 0,172 & 0,97 & 0,000 & 279 \\
\hline $14 / 09 / 07$ & 0,184 & 1,80 & 0,000 & 55 \\
\hline $19 / 09 / 07$ & 0,119 & 1,10 & 0,011 & 81 \\
\hline $21 / 09 / 07$ & 0,260 & 0,70 & 0,008 & 101 \\
\hline $24 / 09 / 07$ & 0,148 & 0,77 & 0,000 & 93 \\
\hline $01 / 10 / 07$ & 0,263 & 1,30 & 0,003 & 94 \\
\hline $05 / 10 / 07$ & 0,110 & 1,00 & 0,008 & 156 \\
\hline $08 / 10 / 07$ & 0,127 & 1,81 & 0,026 & 134 \\
\hline $15 / 10 / 07$ & 0,177 & 1,51 & 0,033 & 177 \\
\hline $19 / 10 / 07$ & 0,150 & 1,16 & 0,016 & 217 \\
\hline $22 / 10 / 07$ & 0,250 & 1,29 & 0,019 & 216 \\
\hline $26 / 10 / 07$ & 0,181 & 1,00 & 0,012 & 196 \\
\hline $31 / 10 / 07$ & 0,157 & 1,14 & 0,006 & 206 \\
\hline $05 / 11 / 07$ & 0,151 & 1,24 & 0,000 & 248 \\
\hline $09 / 11 / 07$ & 0,150 & 1,30 & 0,016 & 210 \\
\hline $12 / 11 / 07$ & 0,212 & 1,14 & 0,027 & 259 \\
\hline $19 / 11 / 07$ & 0,170 & 1,35 & 0,014 & 16 \\
\hline $23 / 11 / 07$ & 0,165 & 1,30 & 0,033 & 32 \\
\hline $26 / 11 / 07$ & 0,157 & 1,34 & 0,009 & 49 \\
\hline $30 / 11 / 07$ & 0,178 & 1,22 & 0,017 & 64 \\
\hline $03 / 12 / 07$ & 0,278 & 1,41 & 0,023 & 55 \\
\hline $07 / 12 / 07$ & 0,172 & 1,31 & 0,011 & 88 \\
\hline $10 / 12 / 07$ & 0,184 & 2,20 & 0,020 & 74 \\
\hline $16 / 12 / 07$ & 0,160 & 1,84 & 0,000 & 78 \\
\hline $21 / 12 / 07$ & 0,157 & 1,80 & 0,000 & 98 \\
\hline $27 / 12 / 07$ & 0,160 & 1,38 & 0,000 & 110 \\
\hline $04 / 01 / 08$ & 0,283 & 1,57 & 0,000 & 129 \\
\hline $07 / 01 / 08$ & 0,186 & 1,43 & 0,000 & 156 \\
\hline $11 / 01 / 08$ & 0,152 & 2,85 & 0,000 & 274 \\
\hline $15 / 01 / 08$ & 0,262 & 2,85 & 0,000 & 237 \\
\hline $18 / 01 / 08$ & 0,155 & 1,31 & 0,000 & 195 \\
\hline & & & & \\
\hline
\end{tabular}




\begin{tabular}{|c|c|c|c|c|}
\hline \multirow{2}{*}{ Data } & \multicolumn{3}{|c|}{ Água Efluente do Filtro 3 } \\
\cline { 2 - 5 } & $\begin{array}{c}\text { Turbidez } \\
\text { (UNT) }\end{array}$ & $\begin{array}{c}\text { COT } \\
\text { (mg/L) }\end{array}$ & $\begin{array}{c}\text { UV 254 } \\
\text { (cm }^{-1} \text { ) }\end{array}$ & $\begin{array}{c}\text { Perda de } \\
\text { carga } \mathbf{c m} \text { ) }\end{array}$ \\
\hline $28 / 01 / 08$ & 0,132 & 1,50 & 0,011 & 20 \\
\hline $01 / 02 / 08$ & 0,172 & 1,90 & 0,013 & 27 \\
\hline $08 / 02 / 08$ & 0,126 & 1,52 & 0,030 & 31 \\
\hline $11 / 02 / 08$ & 0,137 & 1,50 & 0,018 & 31 \\
\hline $15 / 02 / 08$ & 0,150 & 1,60 & 0,017 & 42 \\
\hline $18 / 02 / 08$ & 0,201 & 1,62 & 0,017 & 36 \\
\hline $22 / 02 / 08$ & 0,106 & 3,08 & 0,012 & 56 \\
\hline $25 / 02 / 08$ & 0,304 & 1,40 & 0,008 & 61 \\
\hline $29 / 02 / 08$ & 0,183 & 1,50 & 0,015 & 127 \\
\hline $10 / 04 / 08$ & 0,159 & 1,97 & 0,030 & 55 \\
\hline $14 / 04 / 08$ & 0,106 & 1,83 & 0,023 & 56 \\
\hline $16 / 04 / 08$ & 0,211 & 1,75 & 0,018 & 73 \\
\hline $24 / 04 / 08$ & 0,241 & 1,87 & 0,019 & 132 \\
\hline $28 / 04 / 08$ & 0,131 & 2,27 & 0,023 & 177 \\
\hline $12 / 05 / 08$ & 0,141 & 1,71 & 0,026 & 132 \\
\hline $15 / 05 / 08$ & 0,194 & 1,60 & 0,044 & 267 \\
\hline $26 / 05 / 08$ & 0,130 & 1,78 & 0,025 & 15 \\
\hline $29 / 05 / 08$ & 0,154 & 1,68 & 0,014 & 14 \\
\hline $02 / 06 / 08$ & 0,400 & 1,50 & 0,014 & 28 \\
\hline $12 / 06 / 08$ & 0,153 & 1,83 & 0,020 & 21 \\
\hline $16 / 06 / 08$ & 0,125 & 2,08 & 0,031 & 27 \\
\hline $18 / 06 / 08$ & 0,174 & 1,99 & 0,020 & 30 \\
\hline $23 / 06 / 08$ & 0,190 & 1,85 & 0,016 & 39 \\
\hline $30 / 06 / 08$ & 0,124 & 2,67 & 0,008 & 66 \\
\hline $02 / 07 / 08$ & 0,198 & 2,05 & 0,024 & 52 \\
\hline $07 / 07 / 08$ & 0,122 & 2,14 & 0,035 & 85 \\
\hline $22 / 07 / 08$ & 0,122 & 2,08 & 0,021 & 136 \\
\hline $24 / 07 / 08$ & 0,127 & 1,94 & 0,015 & 146 \\
\hline $28 / 07 / 08$ & 0,142 & 2,34 & 0,019 & 149 \\
\hline $31 / 07 / 08$ & 0,247 & 2,03 & 0,039 & 146 \\
\hline $11 / 08 / 08$ & 0,150 & 2,09 & 0,048 & 17 \\
\hline $14 / 08 / 08$ & 0,190 & 1,83 & 0,006 & 20 \\
\hline $18 / 08 / 08$ & 0,173 & 1,87 & 0,025 & 28 \\
\hline $19 / 08 / 08$ & 0,198 & 2,40 & 0,154 & 30 \\
\hline $25 / 08 / 08$ & 0,178 & 2,00 & 0,015 & 37 \\
\hline $28 / 08 / 08$ & 0,176 & 2,08 & 0,013 & 31 \\
\hline $02 / 09 / 08$ & 0,167 & 1,68 & 0,021 & 46 \\
\hline $04 / 09 / 08$ & 0,183 & 1,69 & 0,016 & 45 \\
\hline $08 / 09 / 08$ & 0,156 & 1,97 & 0,014 & 49 \\
\hline $11 / 09 / 08$ & 0,222 & 1,72 & 0,012 & 56 \\
\hline $15 / 09 / 08$ & 0,193 & 1,86 & 0,026 & 73 \\
\hline $18 / 09 / 08$ & 0,243 & 1,60 & 0,024 & 91 \\
\hline $22 / 09 / 08$ & 0,175 & 1,61 & 0,015 & 105 \\
\hline $25 / 09 / 08$ & 0,233 & 1,66 & 0,016 & 146 \\
\hline $29 / 09 / 08$ & 0,175 & 1,68 & 0,019 & 191 \\
\hline $02 / 10 / 08$ & 0,238 & 1,42 & 0,016 & 118 \\
\hline $13 / 10 / 08$ & 0,158 & 1,70 & 0,014 & 209 \\
\hline $23 / 10 / 08$ & 0,159 & 2,05 & 0,015 & 12 \\
\hline $27 / 10 / 08$ & 0,157 & 2,33 & 0,023 & 18 \\
\hline $03 / 11 / 08$ & 0,154 & 1,84 & 0,027 & 20 \\
\hline & & & & \\
\hline
\end{tabular}




\begin{tabular}{|c|c|c|c|c|}
\hline \multirow{2}{*}{ Data } & \multicolumn{4}{|c|}{ Água Efluente do Filtro 3 } \\
\cline { 2 - 5 } & $\begin{array}{c}\text { Turbidez } \\
\text { (UNT) }\end{array}$ & $\begin{array}{c}\text { COT } \\
\text { (mg/L) }\end{array}$ & $\begin{array}{c}\text { UV 254 } \\
\text { (cm }^{-1} \text { ) }\end{array}$ & $\begin{array}{c}\text { Perda de } \\
\text { carga (cm) }\end{array}$ \\
\hline $06 / 11 / 08$ & 0,188 & 2,17 & 0,022 & 18 \\
\hline $10 / 11 / 08$ & 0,166 & 2,06 & 0,024 & 20 \\
\hline $13 / 11 / 08$ & 0,161 & 1,81 & 0,021 & 21 \\
\hline $08 / 12 / 08$ & 0,168 & 1,69 & 0,015 & 35 \\
\hline
\end{tabular}




\begin{tabular}{|c|c|c|c|c|}
\hline \multirow{2}{*}{ Data } & \multicolumn{3}{|c|}{ Água Efluente do Filtro 4 } \\
\cline { 2 - 5 } & $\begin{array}{c}\text { Turbidez } \\
\text { (UNT) }\end{array}$ & $\begin{array}{c}\text { COT } \\
\text { (mg/L) }\end{array}$ & $\begin{array}{c}\text { UV 254 } \\
\text { (cm }^{-1} \text { ) }\end{array}$ & $\begin{array}{c}\text { Perda de } \\
\text { carga (cm) }\end{array}$ \\
\hline $10 / 07 / 07$ & - & 0,84 & 0,001 & 20 \\
\hline $12 / 07 / 07$ & - & 1,21 & 0,029 & 20 \\
\hline $16 / 07 / 07$ & 0,170 & 1,54 & 0,022 & 29 \\
\hline $18 / 07 / 07$ & 0,154 & 1,65 & 0,009 & 39 \\
\hline $20 / 07 / 07$ & 0,170 & 1,85 & 0,016 & 55 \\
\hline $23 / 07 / 07$ & 0,130 & 2,80 & 0,033 & 70 \\
\hline $25 / 07 / 07$ & 0,157 & 2,32 & 0,008 & 80 \\
\hline $27 / 07 / 07$ & 0,150 & 2,03 & 0,026 & 95 \\
\hline $30 / 07 / 07$ & 0,170 & 2,19 & 0,011 & 37 \\
\hline $01 / 08 / 07$ & 0,236 & 2,12 & 0,016 & 40 \\
\hline $03 / 08 / 07$ & 0,196 & 2,29 & 0,002 & 44 \\
\hline $06 / 08 / 07$ & 0,200 & 2,07 & 0,034 & 54 \\
\hline $08 / 08 / 07$ & 0,237 & 2,02 & 0,024 & 62 \\
\hline $10 / 08 / 07$ & 0,312 & 2,15 & 0,012 & 66 \\
\hline $15 / 08 / 07$ & 0,322 & 2,29 & 0,015 & 78 \\
\hline $17 / 08 / 07$ & 0,236 & 3,21 & 0,015 & 79 \\
\hline $20 / 08 / 07$ & 0,286 & 2,19 & 0,010 & 81 \\
\hline $24 / 08 / 07$ & 0,226 & 1,83 & 0,002 & 86 \\
\hline $27 / 08 / 07$ & 0,207 & 2,57 & 0,016 & 92 \\
\hline $31 / 08 / 07$ & 0,185 & 1,96 & 0,012 & 102 \\
\hline $03 / 09 / 07$ & 0,395 & 10,36 & 0,058 & 113 \\
\hline $10 / 09 / 07$ & 0,240 & 3,14 & 0,010 & 106 \\
\hline $14 / 09 / 07$ & 0,182 & 2,82 & 0,000 & 13 \\
\hline $19 / 09 / 07$ & 0,194 & 1,75 & 0,024 & 16 \\
\hline $21 / 09 / 07$ & 0,192 & 1,55 & 0,021 & 21 \\
\hline $24 / 09 / 07$ & 0,132 & 1,49 & 0,017 & 18 \\
\hline $01 / 10 / 07$ & 0,183 & 2,24 & 0,022 & 21 \\
\hline $05 / 10 / 07$ & 0,311 & 1,60 & 0,021 & 32 \\
\hline $08 / 10 / 07$ & 0,225 & 2,29 & 0,045 & 25 \\
\hline $15 / 10 / 07$ & 0,184 & 2,31 & 0,056 & 40 \\
\hline $19 / 10 / 07$ & 0,174 & 1,73 & 0,028 & 48 \\
\hline $22 / 10 / 07$ & 0,216 & 1,70 & 0,035 & 45 \\
\hline $26 / 10 / 07$ & 0,140 & 1,68 & 0,027 & 53 \\
\hline $31 / 10 / 07$ & 0,179 & 1,65 & 0,018 & 47 \\
\hline $05 / 11 / 07$ & 0,127 & 1,78 & 0,000 & 49 \\
\hline $09 / 11 / 07$ & 0,123 & 1,83 & 0,026 & 23 \\
\hline $12 / 11 / 07$ & 0,238 & 1,78 & 0,035 & 31 \\
\hline $19 / 11 / 07$ & 0,179 & 1,80 & 0,023 & 13 \\
\hline $23 / 11 / 07$ & 0,186 & 1,80 & 0,011 & 17 \\
\hline $26 / 11 / 07$ & 0,199 & 1,75 & 0,020 & 12 \\
\hline $30 / 11 / 07$ & 0,185 & 1,71 & 0,024 & 19 \\
\hline $03 / 12 / 07$ & 0,243 & 1,81 & 0,028 & 17 \\
\hline $07 / 12 / 07$ & 0,134 & 2,08 & 0,018 & 23 \\
\hline $10 / 12 / 07$ & 0,188 & 3,01 & 0,016 & 21 \\
\hline $16 / 12 / 07$ & 0,210 & 2,71 & 0,008 & 24 \\
\hline $21 / 12 / 07$ & 0,133 & 2,30 & 0,000 & 32 \\
\hline $27 / 12 / 07$ & 0,220 & 1,79 & 0,000 & 35 \\
\hline $04 / 01 / 08$ & 0,202 & 2,04 & 0,000 & 40 \\
\hline $07 / 01 / 08$ & 0,183 & 1,95 & 0,000 & 142 \\
\hline $11 / 01 / 08$ & 0,160 & 3,72 & 0,000 & 62 \\
\hline $15 / 01 / 08$ & 0,271 & 3,72 & 0,000 & 55 \\
\hline $18 / 01 / 08$ & 0,153 & 1,66 & 0,000 & 61 \\
\hline & & & & \\
\hline
\end{tabular}




\begin{tabular}{|c|c|c|c|c|}
\hline \multirow{2}{*}{ Data } & \multicolumn{3}{|c|}{ Água Efluente do Filtro 4 } \\
\cline { 2 - 5 } & $\begin{array}{c}\text { Turbidez } \\
\text { (UNT) }\end{array}$ & $\begin{array}{c}\text { COT } \\
\text { (mg/L) }\end{array}$ & $\begin{array}{c}\text { UV 254 } \\
\text { (cm }^{-1} \text { ) }\end{array}$ & $\begin{array}{c}\text { Perda de } \\
\text { carga (cm) }\end{array}$ \\
\hline $28 / 01 / 08$ & 0,135 & 1,90 & 0,020 & 12 \\
\hline $01 / 02 / 08$ & 0,180 & 2,00 & 0,023 & 17 \\
\hline $08 / 02 / 08$ & 0,248 & 1,71 & 0,028 & 17 \\
\hline $11 / 02 / 08$ & 0,160 & 1,90 & 0,030 & 15 \\
\hline $15 / 02 / 08$ & 0,134 & 1,90 & 0,028 & 17 \\
\hline $18 / 02 / 08$ & 0,216 & 1,84 & 0,028 & 15 \\
\hline $22 / 02 / 08$ & 0,108 & 3,30 & 0,036 & 18 \\
\hline $25 / 02 / 08$ & 0,251 & 1,70 & 0,017 & 20 \\
\hline $29 / 02 / 08$ & 0,186 & 1,80 & 0,026 & 27 \\
\hline $10 / 04 / 08$ & 0,159 & 2,13 & 0,036 & 20 \\
\hline $14 / 04 / 08$ & 0,108 & 2,07 & 0,031 & 18 \\
\hline $16 / 04 / 08$ & 0,163 & 2,06 & 0,029 & 23 \\
\hline $24 / 04 / 08$ & 0,226 & 2,15 & 0,028 & 30 \\
\hline $28 / 04 / 08$ & 0,153 & 2,46 & 0,034 & 36 \\
\hline $12 / 05 / 08$ & 0,264 & 2,01 & 0,037 & 36 \\
\hline $15 / 05 / 08$ & 0,217 & 2,05 & 0,032 & 63 \\
\hline $26 / 05 / 08$ & 0,105 & 2,00 & 0,027 & 14 \\
\hline $29 / 05 / 08$ & 0,143 & 1,87 & 0,010 & 13 \\
\hline $02 / 06 / 08$ & 0,100 & 1,69 & 0,017 & 25 \\
\hline $12 / 06 / 08$ & 0,158 & 2,00 & 0,024 & 16 \\
\hline $16 / 06 / 08$ & 0,111 & 2,26 & 0,023 & 16 \\
\hline $18 / 06 / 08$ & 0,165 & 2,13 & 0,025 & 17 \\
\hline $23 / 06 / 08$ & 0,110 & 2,00 & 0,026 & 20 \\
\hline $30 / 06 / 08$ & 0,114 & 2,72 & 0,014 & 34 \\
\hline $02 / 07 / 08$ & 0,177 & 2,20 & 0,029 & 21 \\
\hline $07 / 07 / 08$ & 0,125 & 2,19 & 0,038 & 28 \\
\hline $22 / 07 / 08$ & 0,146 & 2,19 & 0,028 & 47 \\
\hline $24 / 07 / 08$ & 0,112 & 2,07 & 0,036 & 39 \\
\hline $28 / 07 / 08$ & 0,169 & 2,40 & 0,029 & 54 \\
\hline $31 / 07 / 08$ & 0,268 & 2,15 & 0,041 & 60 \\
\hline $11 / 08 / 08$ & 0,168 & 2,09 & 0,024 & 15 \\
\hline $14 / 08 / 08$ & 0,218 & 2,10 & 0,011 & 15 \\
\hline $18 / 08 / 08$ & 0,171 & 2,00 & 0,029 & 16 \\
\hline $19 / 08 / 08$ & 0,189 & 2,24 & 0,167 & 14 \\
\hline $25 / 08 / 08$ & 0,169 & 2,20 & 0,020 & 15 \\
\hline $28 / 08 / 08$ & 0,237 & 2,09 & 0,016 & 14 \\
\hline $02 / 09 / 08$ & 0,180 & 1,77 & 0,023 & 19 \\
\hline $04 / 09 / 08$ & 0,195 & 1,87 & 0,031 & 18 \\
\hline $08 / 09 / 08$ & 0,168 & 1,98 & 0,017 & 19 \\
\hline $11 / 09 / 08$ & 0,224 & 1,83 & 0,018 & 20 \\
\hline $15 / 09 / 08$ & 0,214 & 2,01 & 0,026 & 23 \\
\hline $18 / 09 / 08$ & 0,200 & 1,76 & 0,030 & 25 \\
\hline $22 / 09 / 08$ & 0,173 & 1,73 & 0,016 & 30 \\
\hline $25 / 09 / 08$ & 0,249 & 1,84 & 0,022 & 36 \\
\hline $29 / 09 / 08$ & 0,203 & 1,85 & 0,028 & 49 \\
\hline $02 / 10 / 08$ & 0,240 & 1,50 & 0,021 & 40 \\
\hline $13 / 10 / 08$ & 0,151 & 1,85 & 0,019 & 65 \\
\hline $23 / 10 / 08$ & 0,195 & 2,14 & 0,018 & 11 \\
\hline $27 / 10 / 08$ & 0,148 & 2,32 & 0,018 & 14 \\
\hline $03 / 11 / 08$ & 0,159 & 1,97 & 0,027 & 15 \\
\hline & & & & \\
\hline
\end{tabular}




\begin{tabular}{|c|c|c|c|c|}
\hline \multirow{2}{*}{ Data } & \multicolumn{4}{|c|}{ Água Efluente do Filtro 4 } \\
\cline { 2 - 5 } & $\begin{array}{c}\text { Turbidez } \\
\text { (UNT) }\end{array}$ & $\begin{array}{c}\text { COT } \\
\text { (mg/L) }\end{array}$ & $\begin{array}{c}\text { UV 254 } \\
\left.\text { (cm }^{-1}\right)\end{array}$ & $\begin{array}{c}\text { Perda de } \\
\text { carga (cm) }\end{array}$ \\
\hline $06 / 11 / 08$ & 0,193 & 2,33 & 0,024 & 12 \\
\hline $10 / 11 / 08$ & 0,186 & 2,21 & 0,027 & 15 \\
\hline $13 / 11 / 08$ & 0,184 & 1,96 & 0,027 & 13 \\
\hline $08 / 12 / 08$ & 0,180 & 1,90 & 0,022 & 19 \\
\hline
\end{tabular}




\section{APÊNDICE D - Valores de CP $\geq 2,0 \mu \mathrm{m} ; 1,2 \mu \mathrm{m} \leq \mathrm{CP}<2,0 \mu \mathrm{m}$ e $\mathrm{CBH}$}

\begin{tabular}{|c|c|c|}
\hline \multirow[b]{2}{*}{ Data } & \multicolumn{2}{|c|}{ Água Bruta da ETA } \\
\hline & $\begin{array}{c}\mathrm{CP} \geq 2,0 \mu \mathrm{m} \\
(\mathrm{n} \% / \mathrm{mL})\end{array}$ & $\begin{array}{c}1,2 \mu \mathrm{m} \leq \mathrm{CP}<2,0 \mu \mathrm{m} \\
(\mathrm{n} \div / \mathrm{mL})\end{array}$ \\
\hline $10 / 07 / 07$ & $17.755,1$ & $25.998,1$ \\
\hline $12 / 07 / 07$ & $20.745,3$ & $25.656,6$ \\
\hline $16 / 07 / 07$ & $20.306,7$ & $25.224,9$ \\
\hline $18 / 07 / 07$ & $28.356,9$ & $23.585,6$ \\
\hline $20 / 07 / 07$ & $7.449,5$ & $28.733,9$ \\
\hline 23/07/07 & $16.826,0$ & $25.641,3$ \\
\hline $25 / 07 / 07$ & $25.671,4$ & $20.276,1$ \\
\hline $27 / 07 / 07$ & $10.031,1$ & $28.718,1$ \\
\hline $30 / 07 / 07$ & $21.414,7$ & $21.545,6$ \\
\hline $01 / 08 / 07$ & $8.287,6$ & $284.808,0$ \\
\hline 03/08/07 & $19.345,3$ & $17.539,0$ \\
\hline $06 / 08 / 07$ & $11.333,4$ & $24.352,8$ \\
\hline 08/08/07 & $11.188,2$ & $27.796,3$ \\
\hline 10/08/07 & $6.740,5$ & $27.594,8$ \\
\hline $15 / 08 / 07$ & $22.382,2$ & $12.032,2$ \\
\hline $17 / 08 / 07$ & $8.068,7$ & $16.165,8$ \\
\hline 20/08/07 & $26.850,9$ & $8.337,6$ \\
\hline $24 / 08 / 07$ & $17.213,6$ & $21.121,2$ \\
\hline $27 / 08 / 07$ & $17.505,3$ & $21.399,7$ \\
\hline $31 / 08 / 07$ & $18.618,6$ & $23.510,8$ \\
\hline 03/09/07 & $22.307,0$ & $24.394,6$ \\
\hline $10 / 09 / 07$ & $23.596,5$ & $24.881,2$ \\
\hline 14/09/07 & $27.369,5$ & $23.597,4$ \\
\hline 19/09/07 & $13.333,8$ & $33.208,4$ \\
\hline $21 / 09 / 07$ & $23.157,7$ & $26.494,5$ \\
\hline $24 / 09 / 07$ & $26.336,7$ & $24.581,8$ \\
\hline $01 / 10 / 07$ & $26.202,4$ & $23.633,4$ \\
\hline $05 / 10 / 07$ & $13.793,4$ & $32.398,4$ \\
\hline 08/10/07 & $31.807,4$ & $20.003,7$ \\
\hline $15 / 10 / 07$ & $26.137,8$ & $22.654,2$ \\
\hline 19/10/07 & $21.033,2$ & $23.044,5$ \\
\hline $22 / 10 / 07$ & $23.104,2$ & $23.301,2$ \\
\hline $26 / 10 / 07$ & $20.424,6$ & $20.834,0$ \\
\hline $31 / 10 / 07$ & $9.305,8$ & $24.487,4$ \\
\hline $05 / 11 / 07$ & $17.885,6$ & $11.172,2$ \\
\hline $09 / 11 / 07$ & $14.041,3$ & $14.950,9$ \\
\hline $12 / 11 / 07$ & $9.681,7$ & $27.731,2$ \\
\hline 19/11/07 & $15.415,9$ & $16.364,3$ \\
\hline $23 / 11 / 07$ & $20.772,4$ & $15.465,3$ \\
\hline $26 / 11 / 07$ & $19.510,6$ & $12.377,8$ \\
\hline $30 / 11 / 07$ & $17.540,7$ & $17.922,7$ \\
\hline $03 / 12 / 07$ & $14.785,8$ & $22.011,2$ \\
\hline $07 / 12 / 07$ & $5.595,5$ & $34.802,7$ \\
\hline 10/12/07 & $18.355,2$ & $16.315,8$ \\
\hline $16 / 12 / 07$ & $18.238,6$ & $23.636,7$ \\
\hline $21 / 12 / 07$ & $22.117,2$ & $21.613,3$ \\
\hline $27 / 12 / 07$ & $5.431,0$ & $38.848,7$ \\
\hline $04 / 01 / 08$ & $19.014,0$ & $26.604,2$ \\
\hline $07 / 01 / 08$ & $18.799,0$ & $29.778,6$ \\
\hline
\end{tabular}




\begin{tabular}{|c|c|c|}
\hline \multirow[b]{2}{*}{ Data } & \multicolumn{2}{|c|}{ Água Bruta da ETA } \\
\hline & $\begin{array}{c}\mathrm{CP} \geq 2,0 \mu \mathrm{m} \\
(\mathrm{n} \% / \mathrm{mL})\end{array}$ & $\begin{array}{c}1,2 \mu \mathrm{m} \leq \mathrm{CP}<2,0 \mu \mathrm{m} \\
(\mathrm{n}=/ \mathrm{mL})\end{array}$ \\
\hline $11 / 01 / 08$ & $20.681,7$ & $28.302,6$ \\
\hline $15 / 01 / 08$ & $20.681,7$ & $27.944,2$ \\
\hline $18 / 01 / 08$ & $32.459,2$ & $20.748,1$ \\
\hline $28 / 01 / 08$ & $37.959,9$ & $17.403,3$ \\
\hline $01 / 02 / 08$ & $3.897,4$ & $36.321,7$ \\
\hline $08 / 02 / 08$ & $4.723,1$ & $28.335,5$ \\
\hline $11 / 02 / 08$ & $12.743,4$ & $22.016,6$ \\
\hline $15 / 02 / 08$ & $10.429,2$ & $11.972,9$ \\
\hline $18 / 02 / 08$ & $7.784,0$ & $27.189,0$ \\
\hline $22 / 02 / 08$ & $13.667,9$ & $22.112,1$ \\
\hline $25 / 02 / 08$ & $14.311,2$ & $17.793,8$ \\
\hline 29/02/08 & $13.842,3$ & $19.051,0$ \\
\hline $10 / 04 / 08$ & $8.781,9$ & $25.983,6$ \\
\hline $14 / 04 / 08$ & $12.672,1$ & $21.378,9$ \\
\hline $16 / 04 / 08$ & $10.835,8$ & $23.697,2$ \\
\hline $24 / 04 / 08$ & $11.968,3$ & $18.603,5$ \\
\hline $28 / 04 / 08$ & $8.943,0$ & $16.648,9$ \\
\hline $12 / 05 / 08$ & $12.079,6$ & $22.087,7$ \\
\hline $15 / 05 / 08$ & $12.269,9$ & $21.694,9$ \\
\hline $26 / 05 / 08$ & $18.917,6$ & $21.189,6$ \\
\hline $29 / 05 / 08$ & - & - \\
\hline $02 / 06 / 08$ & - & - \\
\hline $12 / 06 / 08$ & $18.587,3$ & $21.454,6$ \\
\hline $16 / 06 / 08$ & $19.384,8$ & $19.976,0$ \\
\hline $18 / 06 / 08$ & $18.013,3$ & $17.991,3$ \\
\hline $23 / 06 / 08$ & $18.679,7$ & $14.821,4$ \\
\hline $30 / 06 / 08$ & $6.875,5$ & $20.031,0$ \\
\hline $02 / 07 / 08$ & $6.712,9$ & $25.333,8$ \\
\hline 07/07/08 & $9.691,2$ & $24.586,5$ \\
\hline $22 / 07 / 08$ & $6.898,0$ & $31.995,9$ \\
\hline $24 / 07 / 08$ & $16.002,8$ & $25.243,4$ \\
\hline $28 / 07 / 08$ & $10.981,0$ & $28.223,5$ \\
\hline $31 / 07 / 08$ & $4.494,9$ & $34.310,1$ \\
\hline $11 / 08 / 08$ & $14.956,6$ & $23.953,0$ \\
\hline $14 / 08 / 08$ & $14.579,8$ & $25.022,2$ \\
\hline $18 / 08 / 08$ & $11.365,1$ & $20.927,1$ \\
\hline 19/08/08 & $17.820,9$ & $19.066,8$ \\
\hline $25 / 08 / 08$ & $17.820,9$ & $23.369,3$ \\
\hline $28 / 08 / 08$ & $14.839,3$ & $23.948,1$ \\
\hline $02 / 09 / 08$ & $35.245,6$ & $20.262,1$ \\
\hline $04 / 09 / 08$ & $16.572,7$ & $25.441,5$ \\
\hline 08/09/08 & $19.664,2$ & $18.806,6$ \\
\hline $11 / 09 / 08$ & $12.216,9$ & $25.914,1$ \\
\hline $15 / 09 / 08$ & $31.769,3$ & $21.811,4$ \\
\hline $18 / 09 / 08$ & $13.315,4$ & $22.704,7$ \\
\hline $22 / 09 / 08$ & $29.450,9$ & $24.005,4$ \\
\hline $25 / 09 / 08$ & $15.865,4$ & $18.131,4$ \\
\hline $29 / 09 / 08$ & $15.288,6$ & $11.807,2$ \\
\hline $02 / 10 / 08$ & $12.872,2$ & $15.163,7$ \\
\hline $13 / 10 / 08$ & $16.429,3$ & $25.463,1$ \\
\hline $23 / 10 / 08$ & $11.496,3$ & $27.253,7$ \\
\hline $27 / 10 / 08$ & $10.103,3$ & $30.551,7$ \\
\hline $03 / 11 / 08$ & $10.142,0$ & $32.085,2$ \\
\hline
\end{tabular}




\begin{tabular}{|c|c|c|}
\hline \multirow{2}{*}{ Data } & \multicolumn{2}{|c|}{ Água Bruta da ETA } \\
\cline { 2 - 3 } & $\begin{array}{c}\mathbf{C P} \geq \mathbf{2 , 0} \boldsymbol{\mu m} \\
(\mathbf{n} \% / \mathbf{m L})\end{array}$ & $\begin{array}{c}\mathbf{1 , 2} \boldsymbol{\mu m} \leq \mathbf{C P}<\mathbf{2 , 0} \boldsymbol{\mu m} \\
(\mathbf{n} \% / \mathbf{m L})\end{array}$ \\
\hline $06 / 11 / 08$ & $14.395,6$ & $37.333,9$ \\
\hline $10 / 11 / 08$ & $14.784,2$ & $39.576,1$ \\
\hline $13 / 11 / 08$ & $13.195,5$ & $32.615,9$ \\
\hline $08 / 12 / 08$ & - & - \\
\hline
\end{tabular}




\begin{tabular}{|c|c|c|c|}
\hline \multirow[b]{2}{*}{ Data } & \multicolumn{3}{|c|}{ Reservatório de Equalização de Água Filtrada } \\
\hline & $\begin{array}{c}C P \geq 2,0 \mu \mathrm{m} \\
(\mathrm{n} \% / \mathrm{mL})\end{array}$ & $\begin{array}{c}1,2 \mu \mathrm{m} \leq \mathrm{CP}<2,0 \mu \mathrm{m} \\
(\mathrm{n} \% / \mathrm{mL})\end{array}$ & $\begin{array}{c}\text { CBH } \\
\text { (UFC/mL) }\end{array}$ \\
\hline 10/07/07 & 398,5 & $1.414,0$ & - \\
\hline $12 / 07 / 07$ & 91,1 & 225,6 & - \\
\hline $16 / 07 / 07$ & 217,3 & 914,3 & - \\
\hline $18 / 07 / 07$ & 399,6 & $1.856,8$ & - \\
\hline $20 / 07 / 07$ & 223,4 & $1.994,9$ & - \\
\hline $23 / 07 / 07$ & 413,0 & $1.639,3$ & - \\
\hline $25 / 07 / 07$ & 197,7 & $1.125,8$ & - \\
\hline $27 / 07 / 07$ & 69,7 & $1.209,4$ & - \\
\hline $30 / 07 / 07$ & 59,3 & 273,1 & - \\
\hline $01 / 08 / 07$ & 62,2 & $9.777,0$ & - \\
\hline $03 / 08 / 07$ & 527,9 & $1.455,6$ & - \\
\hline $06 / 08 / 07$ & 55,5 & 721,4 & - \\
\hline $08 / 08 / 07$ & 377,9 & $2.623,0$ & - \\
\hline $10 / 08 / 07$ & 176,4 & $1.519,8$ & - \\
\hline 15/08/07 & 678,2 & $2.761,7$ & - \\
\hline $17 / 08 / 07$ & 260,6 & $1.186,2$ & - \\
\hline $20 / 08 / 07$ & 601,3 & 857,6 & - \\
\hline $24 / 08 / 07$ & 376,6 & 978,0 & - \\
\hline $27 / 08 / 07$ & 493,5 & $1.621,9$ & - \\
\hline $31 / 08 / 07$ & 498,4 & $1.278,4$ & - \\
\hline 03/09/07 & 451,9 & $1.360,9$ & - \\
\hline $10 / 09 / 07$ & 641,0 & $1.797,7$ & - \\
\hline $14 / 09 / 07$ & 653,5 & $2.082,3$ & - \\
\hline 19/09/07 & 261,9 & $1.241,0$ & - \\
\hline $21 / 09 / 07$ & 676,6 & $1.957,3$ & - \\
\hline $24 / 09 / 07$ & 560,5 & $1.297,8$ & - \\
\hline $01 / 10 / 07$ & 614,2 & $1.751,6$ & - \\
\hline $05 / 10 / 07$ & 279,4 & $1.574,3$ & - \\
\hline $08 / 10 / 07$ & 739,1 & $1.550,9$ & - \\
\hline $15 / 10 / 07$ & 790,5 & $3.227,6$ & - \\
\hline $19 / 10 / 07$ & 584,7 & $2.282,4$ & - \\
\hline $22 / 10 / 07$ & 538,6 & $1.880,0$ & - \\
\hline $26 / 10 / 07$ & 505,1 & $1.560,5$ & - \\
\hline $31 / 10 / 07$ & 179,5 & $1.147,9$ & - \\
\hline $05 / 11 / 07$ & 45,6 & 525,4 & - \\
\hline $09 / 11 / 07$ & $1.885,6$ & $7.458,6$ & - \\
\hline $12 / 11 / 07$ & 47,5 & $1.867,5$ & - \\
\hline $19 / 11 / 07$ & 494,9 & $4.623,6$ & - \\
\hline $23 / 11 / 07$ & 441,2 & $1.383,8$ & - \\
\hline $26 / 11 / 07$ & 433,8 & $1.226,7$ & - \\
\hline $30 / 11 / 07$ & 454,8 & $2.901,1$ & - \\
\hline $03 / 12 / 07$ & 542,3 & $3.322,2$ & - \\
\hline $07 / 12 / 07$ & 17,3 & $1.591,2$ & - \\
\hline $10 / 12 / 07$ & 390,1 & $3.494,9$ & - \\
\hline $16 / 12 / 07$ & 385,9 & $4.042,2$ & - \\
\hline $21 / 12 / 07$ & 597,7 & $7.240,6$ & - \\
\hline $27 / 12 / 07$ & 113,1 & $2.129,5$ & - \\
\hline $04 / 01 / 08$ & 479,9 & $3.352,5$ & - \\
\hline $07 / 01 / 08$ & 391,3 & $3.083,9$ & - \\
\hline $11 / 01 / 08$ & 442,2 & $1.576,1$ & - \\
\hline $15 / 01 / 08$ & 442,2 & $3.643,9$ & - \\
\hline $18 / 01 / 08$ & 881,8 & $3.444,8$ & - \\
\hline
\end{tabular}




\begin{tabular}{|c|c|c|c|}
\hline \multirow[b]{2}{*}{ Data } & \multicolumn{3}{|c|}{ Reservatório de Equalização de Água Filtrada } \\
\hline & $\begin{array}{c}\mathrm{CP} \geq 2,0 \mu \mathrm{m} \\
(\mathrm{n} \% / \mathrm{mL})\end{array}$ & $\begin{array}{c}1,2 \mu \mathrm{m} \leq \mathrm{CP}<2,0 \mu \mathrm{m} \\
(\mathrm{n} / \mathrm{mL})\end{array}$ & $\begin{array}{c}\text { CBH } \\
\text { (UFC/mL) }\end{array}$ \\
\hline $28 / 01 / 08$ & 549,7 & $1.878,9$ & - \\
\hline $01 / 02 / 08$ & 79,4 & $5.215,1$ & - \\
\hline $08 / 02 / 08$ & 197,2 & $2.611,3$ & - \\
\hline $11 / 02 / 08$ & 313,3 & $3.483,8$ & - \\
\hline $15 / 02 / 08$ & 404,4 & $2.261,2$ & - \\
\hline $18 / 02 / 08$ & 202,2 & $1.259,2$ & 40 \\
\hline $22 / 02 / 08$ & 423,2 & $2.493,6$ & - \\
\hline $25 / 02 / 08$ & 315,4 & $1.045,3$ & - \\
\hline $29 / 02 / 08$ & 376,4 & $1.319,4$ & - \\
\hline $10 / 04 / 08$ & 467,3 & $2.763,0$ & - \\
\hline $14 / 04 / 08$ & 439,4 & $1.637,3$ & 0 \\
\hline $16 / 04 / 08$ & 271,1 & $1.534,7$ & - \\
\hline $24 / 04 / 08$ & 263,2 & 808,1 & - \\
\hline $28 / 04 / 08$ & 248,6 & 940,4 & 0 \\
\hline $12 / 05 / 08$ & 279,0 & 996,2 & - \\
\hline $15 / 05 / 08$ & 282,3 & 833,1 & - \\
\hline $26 / 05 / 08$ & 916,5 & $3.327,9$ & - \\
\hline $29 / 05 / 08$ & 923,3 & 70,7 & $\overline{1}$ \\
\hline $02 / 06 / 08$ & 759,0 & 107,5 & 0 \\
\hline $12 / 06 / 08$ & 443,6 & $1.523,4$ & - \\
\hline $16 / 06 / 08$ & 534,9 & $2.024,1$ & 0 \\
\hline $18 / 06 / 08$ & 408,9 & $1.210,8$ & - \\
\hline $23 / 06 / 08$ & 418,9 & $1.219,0$ & 0 \\
\hline $30 / 06 / 08$ & 202,2 & $1.297,2$ & - \\
\hline $02 / 07 / 08$ & 201,4 & $2.102,0$ & - \\
\hline $07 / 07 / 08$ & 242,1 & $2.673,5$ & 0 \\
\hline $22 / 07 / 08$ & 165,5 & $3.703,9$ & 0 \\
\hline $24 / 07 / 08$ & 60,6 & $3.103,3$ & - \\
\hline $28 / 07 / 08$ & 390,2 & $5.289,1$ & 0 \\
\hline $31 / 07 / 08$ & 94,9 & $5.877,8$ & - \\
\hline $11 / 08 / 08$ & 293,6 & $3.845,5$ & 0 \\
\hline $14 / 08 / 08$ & 288,3 & $3.361,8$ & - \\
\hline $18 / 08 / 08$ & 325,4 & $5.225,5$ & 0 \\
\hline 19/08/08 & 373,7 & $2.434,6$ & - \\
\hline $25 / 08 / 08$ & 373,7 & $1.815,0$ & - \\
\hline $28 / 08 / 08$ & 268,6 & $1.055,7$ & - \\
\hline $02 / 09 / 08$ & 225,9 & $1.709,7$ & 0 \\
\hline $04 / 09 / 08$ & 353,6 & $2.083,7$ & - \\
\hline 08/09/08 & 538,6 & $2.274,1$ & 0 \\
\hline $11 / 09 / 08$ & 385,6 & $3.387,4$ & - \\
\hline $15 / 09 / 08$ & $1.007,9$ & $4.883,1$ & 0 \\
\hline $18 / 09 / 08$ & 330,7 & $1.987,9$ & - \\
\hline $22 / 09 / 08$ & 786,8 & $2.993,8$ & 0 \\
\hline $25 / 09 / 08$ & 469,9 & $2.122,1$ & - \\
\hline $29 / 09 / 08$ & 383,3 & 952,1 & 0 \\
\hline $02 / 10 / 08$ & 555,4 & $1.726,0$ & - \\
\hline $13 / 10 / 08$ & 531,2 & $7.947,8$ & 0 \\
\hline $23 / 10 / 08$ & 270,2 & $8.006,2$ & - \\
\hline $27 / 10 / 08$ & 309,0 & $9.596,8$ & - \\
\hline $03 / 11 / 08$ & 245,3 & $10.013,3$ & - \\
\hline
\end{tabular}




\begin{tabular}{|c|c|c|c|}
\hline \multirow[b]{2}{*}{ Data } & \multicolumn{3}{|c|}{ Reservatório de Equalização de Água Filtrada } \\
\hline & $\begin{array}{l}\mathrm{CP} \geq 2,0 \mu \mathrm{m} \\
(\mathrm{n} \% / \mathrm{mL})\end{array}$ & $\begin{array}{c}1,2 \mu \mathrm{m} \leq \mathrm{CP}<2,0 \mu \mathrm{m} \\
(\mathrm{n} \% / \mathrm{mL})\end{array}$ & $\begin{array}{c}\text { CBH } \\
\text { (UFC/mL) }\end{array}$ \\
\hline 06/11/08 & 320,6 & $2.192,8$ & - \\
\hline $10 / 11 / 08$ & 481,7 & $4.457,6$ & - \\
\hline $13 / 11 / 08$ & 330,1 & $2.228,9$ & - \\
\hline $08 / 12 / 08$ & - & - & $\overline{0}$ \\
\hline
\end{tabular}




\begin{tabular}{|c|c|c|c|}
\hline \multirow[b]{2}{*}{ Data } & \multicolumn{3}{|c|}{ Reservatório de Equalização de Água Ozonizada } \\
\hline & $\begin{array}{c}C P \geq 2,0 \mu m \\
(n \circ / m L)\end{array}$ & $\begin{array}{c}1,2 \mu \mathrm{m} \leq \mathrm{CP}<2,0 \mu \mathrm{m} \\
(\mathrm{n} \% / \mathrm{mL})\end{array}$ & $\begin{array}{c}\mathrm{CBH} \\
(\mathrm{UFC} / \mathrm{mL})\end{array}$ \\
\hline 10/07/07 & 135,0 & $3.802,9$ & - \\
\hline $12 / 07 / 07$ & 246,5 & $2.181,8$ & - \\
\hline 16/07/07 & 224,3 & $5.822,3$ & - \\
\hline $18 / 07 / 07$ & 368,9 & $5.788,3$ & - \\
\hline 20/07/07 & 43,6 & $8.326,3$ & - \\
\hline $23 / 07 / 07$ & 51,8 & $2.513,1$ & - \\
\hline $25 / 07 / 07$ & 169,2 & $2.985,1$ & - \\
\hline $27 / 07 / 07$ & 182,6 & $6.319,7$ & - \\
\hline $30 / 07 / 07$ & 50,1 & $2.925,8$ & - \\
\hline $01 / 08 / 07$ & 41,8 & $20.787,0$ & - \\
\hline 03/08/07 & 118,8 & $2.144,4$ & - \\
\hline $06 / 08 / 07$ & 76,6 & $7.902,7$ & - \\
\hline $08 / 08 / 07$ & 49,6 & $5.335,2$ & - \\
\hline 10/08/07 & 50,5 & $5.505,1$ & - \\
\hline 15/08/07 & 175,6 & $7.762,0$ & - \\
\hline $17 / 08 / 07$ & 114,4 & $4.525,2$ & - \\
\hline 20/08/07 & 98,1 & $8.191,5$ & - \\
\hline $24 / 08 / 07$ & 114,7 & $4.832,8$ & - \\
\hline $27 / 08 / 07$ & 295,8 & $4.871,8$ & - \\
\hline $31 / 08 / 07$ & 155,2 & $4.356,0$ & - \\
\hline 03/09/07 & 66,3 & 864,9 & - \\
\hline 10/09/07 & 117,3 & $1.935,7$ & - \\
\hline 14/09/07 & 184,0 & $2.021,4$ & - \\
\hline 19/09/07 & 12,8 & 821,3 & - \\
\hline $21 / 09 / 07$ & 166,9 & $2.530,0$ & - \\
\hline $24 / 09 / 07$ & 87,7 & 915,1 & - \\
\hline $01 / 10 / 07$ & 329,0 & $5.957,4$ & - \\
\hline $05 / 10 / 07$ & 26,6 & $4.160,4$ & - \\
\hline 08/10/07 & 58,5 & $2.651,4$ & - \\
\hline 15/10/07 & 323,0 & $3.361,5$ & - \\
\hline 19/10/07 & 177,9 & $1.598,1$ & - \\
\hline $22 / 10 / 07$ & 92,6 & 821,0 & - \\
\hline 26/10/07 & 95,7 & 943,0 & - \\
\hline $31 / 10 / 07$ & 33,5 & 766,7 & - \\
\hline $05 / 11 / 07$ & 88,3 & 922,9 & - \\
\hline $09 / 11 / 07$ & 122,3 & $2.478,7$ & - \\
\hline 12/11/07 & 35,3 & $4.053,2$ & - \\
\hline 19/11/07 & 65,6 & $1.582,3$ & - \\
\hline $23 / 11 / 07$ & 59,2 & $2.760,0$ & - \\
\hline $26 / 11 / 07$ & 122,8 & $4.506,2$ & - \\
\hline $30 / 11 / 07$ & 874,3 & $4.562,6$ & - \\
\hline $03 / 12 / 07$ & 307,3 & $5.840,6$ & - \\
\hline $07 / 12 / 07$ & 126,1 & $5.695,2$ & - \\
\hline 10/12/07 & 145,7 & $3.573,3$ & - \\
\hline 16/12/07 & 103,0 & $4.499,3$ & - \\
\hline $21 / 12 / 07$ & 334,4 & $7.254,5$ & - \\
\hline 27/12/07 & 12,7 & $1.027,9$ & - \\
\hline $04 / 01 / 08$ & 203,3 & $3.389,0$ & - \\
\hline $07 / 01 / 08$ & 56,9 & $2.540,1$ & - \\
\hline $11 / 01 / 08$ & 93,3 & $2.457,8$ & - \\
\hline $15 / 01 / 08$ & 93,3 & $3.278,9$ & - \\
\hline $18 / 01 / 08$ & 128,1 & $2.871,6$ & - \\
\hline
\end{tabular}




\begin{tabular}{|c|c|c|c|}
\hline \multirow[b]{2}{*}{ Data } & \multicolumn{3}{|c|}{ Reservatório de Equalização de Água Ozonizada } \\
\hline & $\begin{array}{c}\mathrm{CP} \geq 2,0 \mu \mathrm{m} \\
(\mathrm{n} \% / \mathrm{mL})\end{array}$ & $\begin{array}{c}1,2 \mu \mathrm{m} \leq \mathrm{CP}<2,0 \mu \mathrm{m} \\
(\mathrm{n} \% / \mathrm{mL})\end{array}$ & $\begin{array}{c}\text { CBH } \\
\text { (UFC/mL) }\end{array}$ \\
\hline 28/01/08 & 139,1 & $1.510,5$ & - \\
\hline $01 / 02 / 08$ & 17,3 & $4.222,1$ & - \\
\hline $08 / 02 / 08$ & 379,7 & $2.328,8$ & - \\
\hline $11 / 02 / 08$ & 64,1 & $3.355,7$ & - \\
\hline $15 / 02 / 08$ & 66,5 & $1.487,0$ & - \\
\hline $18 / 02 / 08$ & 68,1 & $1.574,5$ & 30 \\
\hline $22 / 02 / 08$ & 79,5 & $4.933,2$ & - \\
\hline $25 / 02 / 08$ & 103,9 & $2.941,8$ & - \\
\hline $29 / 02 / 08$ & 161,2 & $1.858,7$ & - \\
\hline 10/04/08 & $1.227,5$ & $9.188,9$ & - \\
\hline $14 / 04 / 08$ & 152,7 & $1.012,7$ & 0 \\
\hline $16 / 04 / 08$ & 78,9 & $1.105,3$ & - \\
\hline $24 / 04 / 08$ & 96,5 & 792,9 & - \\
\hline $28 / 04 / 08$ & 141,0 & $1.039,9$ & 0 \\
\hline $12 / 05 / 08$ & 58,0 & 953,6 & - \\
\hline $15 / 05 / 08$ & 118,2 & 870,3 & - \\
\hline $26 / 05 / 08$ & 290,0 & $1.587,4$ & - \\
\hline $29 / 05 / 08$ & $1.345,2$ & 111,9 & $\overline{1}$ \\
\hline$\overline{02 / 06 / 08}$ & $1.194,2$ & 132,1 & 0 \\
\hline $12 / 06 / 08$ & 192,0 & $1.556,7$ & - \\
\hline $16 / 06 / 08$ & 136,9 & $1.058,8$ & 0 \\
\hline 18/06/08 & 180,3 & 975,2 & - \\
\hline $23 / 06 / 08$ & 100,6 & 795,1 & 0 \\
\hline $30 / 06 / 08$ & 82,1 & $1.693,5$ & - \\
\hline $02 / 07 / 08$ & 138,1 & $2.059,9$ & - \\
\hline $07 / 07 / 08$ & 157,4 & $3.373,7$ & 0 \\
\hline $22 / 07 / 08$ & 150,6 & $9.141,2$ & 0 \\
\hline $24 / 07 / 08$ & 135,8 & $3.892,5$ & - \\
\hline $28 / 07 / 08$ & 190,1 & $5.615,6$ & 260 \\
\hline $31 / 07 / 08$ & 11,2 & $8.327,2$ & - \\
\hline $11 / 08 / 08$ & 20,7 & $3.224,6$ & 0 \\
\hline 14/08/08 & 42,6 & $2.996,8$ & - \\
\hline $18 / 08 / 08$ & 29,6 & $2.451,7$ & 0 \\
\hline 19/08/08 & 139,0 & $2.061,4$ & - \\
\hline $25 / 08 / 08$ & 139,0 & $1.167,8$ & - \\
\hline $28 / 08 / 08$ & 165,2 & $4.565,6$ & - \\
\hline $02 / 09 / 08$ & 403,5 & $2.918,4$ & 0 \\
\hline $04 / 09 / 08$ & 38,2 & $1.010,2$ & - \\
\hline $08 / 09 / 08$ & 188,0 & $1.529,7$ & 0 \\
\hline $11 / 09 / 08$ & 80,4 & $1.017,5$ & - \\
\hline $15 / 09 / 08$ & 216,0 & $1.598,8$ & 0 \\
\hline $18 / 09 / 08$ & 64,6 & 870,8 & - \\
\hline $22 / 09 / 08$ & 152,0 & $1.408,0$ & 0 \\
\hline $25 / 09 / 08$ & 281,0 & $1.557,1$ & - \\
\hline $29 / 09 / 08$ & 312,8 & $1.429,8$ & 0 \\
\hline $02 / 10 / 08$ & 363,8 & $1.689,3$ & - \\
\hline $13 / 10 / 08$ & 92,4 & $4.004,0$ & 0 \\
\hline $23 / 10 / 08$ & 16,3 & $5.330,9$ & - \\
\hline $27 / 10 / 08$ & 156,0 & $5.205,2$ & - \\
\hline $03 / 11 / 08$ & 139,7 & $13.950,6$ & - \\
\hline
\end{tabular}




\begin{tabular}{|c|c|c|c|}
\hline \multirow{2}{*}{ Data } & \multicolumn{3}{|c|}{ Reservatório de Equalização de Água Ozonizada } \\
\cline { 2 - 4 } & $\begin{array}{c}\mathbf{C P} \geq \mathbf{2 , 0} \boldsymbol{\mu} \mathbf{m} \\
(\mathbf{n}=/ \mathbf{m L})\end{array}$ & $\begin{array}{c}\mathbf{1 , 2} \boldsymbol{\mu m} \leq \mathbf{C P}<\mathbf{2 , 0} \boldsymbol{\mu m} \\
(\mathbf{n} \% / \mathbf{m L})\end{array}$ & $\begin{array}{c}\mathbf{C B H} \\
(\mathbf{U F C} / \mathbf{m L})\end{array}$ \\
\hline $06 / 11 / 08$ & 81,3 & $4.829,4$ & - \\
\hline $10 / 11 / 08$ & 331,5 & $4.527,9$ & - \\
\hline $13 / 11 / 08$ & 166,4 & $1.402,8$ & - \\
\hline $08 / 12 / 08$ & - & - & 0 \\
\hline
\end{tabular}




\begin{tabular}{|c|c|c|c|}
\hline \multirow[b]{2}{*}{ Data } & \multicolumn{3}{|c|}{ Água Efluente ao Filtro 1} \\
\hline & $\begin{array}{c}\mathrm{CP} \geq 2,0 \mu \mathrm{m} \\
(\mathrm{n} \% / \mathrm{mL})\end{array}$ & $\begin{array}{c}1,2 \mu \mathrm{m} \leq \mathrm{CP}<2,0 \mu \mathrm{m} \\
(\mathrm{n}-/ \mathrm{mL})\end{array}$ & $\begin{array}{c}\mathrm{CBH} \\
\text { (UFC/mL) }\end{array}$ \\
\hline $10 / 07 / 07$ & 91,5 & $3.471,7$ & - \\
\hline $12 / 07 / 07$ & 33,5 & 442,4 & - \\
\hline $16 / 07 / 07$ & 12,1 & $2.966,4$ & - \\
\hline $18 / 07 / 07$ & 19,2 & $1.073,2$ & - \\
\hline $20 / 07 / 07$ & 21,9 & $4.253,7$ & - \\
\hline $23 / 07 / 07$ & 62,9 & $3.199,7$ & - \\
\hline $25 / 07 / 07$ & 56,9 & $4.870,9$ & - \\
\hline $27 / 07 / 07$ & 38,9 & $8.722,1$ & - \\
\hline $30 / 07 / 07$ & 67,9 & $4.695,1$ & - \\
\hline $01 / 08 / 07$ & 34,7 & $40.795,0$ & - \\
\hline $03 / 08 / 07$ & 58,0 & $2.560,2$ & - \\
\hline $06 / 08 / 07$ & 29,6 & $4.211,0$ & - \\
\hline $08 / 08 / 07$ & 42,8 & $3.879,4$ & - \\
\hline $10 / 08 / 07$ & 32,2 & $5.018,3$ & - \\
\hline $15 / 08 / 07$ & 34,4 & $3.763,0$ & - \\
\hline $17 / 08 / 07$ & 271,1 & $3.542,1$ & - \\
\hline $20 / 08 / 07$ & 114,7 & $4.992,6$ & - \\
\hline $24 / 08 / 07$ & 95,9 & $2.888,4$ & - \\
\hline $27 / 08 / 07$ & 92,5 & $2.577,6$ & - \\
\hline $31 / 08 / 07$ & 108,6 & 266,7 & - \\
\hline $03 / 09 / 07$ & 116,8 & $1.662,5$ & - \\
\hline 10/09/07 & 150,2 & $1.748,7$ & - \\
\hline $14 / 09 / 07$ & 98,5 & $2.187,4$ & - \\
\hline 19/09/07 & 21,2 & $5.423,3$ & - \\
\hline $21 / 09 / 07$ & 49,7 & $1.782,5$ & - \\
\hline $24 / 09 / 07$ & 67,1 & $1.344,5$ & - \\
\hline $01 / 10 / 07$ & 72,6 & $2.832,7$ & - \\
\hline $05 / 10 / 07$ & 287,3 & $5.951,7$ & - \\
\hline $08 / 10 / 07$ & 182,3 & $3.155,7$ & - \\
\hline $15 / 10 / 07$ & 148,1 & $2.837,1$ & - \\
\hline 19/10/07 & 113,4 & $2.107,0$ & - \\
\hline $22 / 10 / 07$ & 173,8 & $2.668,7$ & - \\
\hline $26 / 10 / 07$ & 121,0 & $2.301,0$ & - \\
\hline $31 / 10 / 07$ & 100,2 & $1.902,9$ & - \\
\hline $05 / 11 / 07$ & 114,7 & $2.354,6$ & - \\
\hline 09/11/07 & 175,6 & $3.265,5$ & - \\
\hline 12/11/07 & 257,2 & $4.970,1$ & - \\
\hline 19/11/07 & 74,8 & $1.888,4$ & - \\
\hline $23 / 11 / 07$ & 92,8 & $3.458,3$ & - \\
\hline $26 / 11 / 07$ & 265,1 & $4.413,7$ & - \\
\hline $30 / 11 / 07$ & 147,6 & $4.097,9$ & - \\
\hline $03 / 12 / 07$ & 265,2 & $3.739,4$ & - \\
\hline $07 / 12 / 07$ & 26,5 & $4.370,9$ & - \\
\hline 10/12/07 & 232,4 & $4.033,2$ & - \\
\hline $16 / 12 / 07$ & 156,1 & $5.858,4$ & - \\
\hline $21 / 12 / 07$ & 234,5 & $6.747,1$ & - \\
\hline $27 / 12 / 07$ & 99,1 & $3.582,2$ & - \\
\hline $04 / 01 / 08$ & 188,7 & $4.116,1$ & - \\
\hline $07 / 01 / 08$ & 111,6 & $3.019,1$ & - \\
\hline $11 / 01 / 08$ & 380,9 & $3.200,4$ & - \\
\hline $15 / 01 / 08$ & 380,9 & $5.391,7$ & - \\
\hline $18 / 01 / 08$ & $1.160,8$ & $2.785,2$ & - \\
\hline
\end{tabular}




\begin{tabular}{|c|c|c|c|}
\hline \multirow[b]{2}{*}{ Data } & \multicolumn{3}{|c|}{ Água Efluente ao Filtro 1} \\
\hline & $\begin{array}{l}\mathrm{CP} \geq 2,0 \mu \mathrm{m} \\
(\mathrm{n} \% / \mathrm{mL})\end{array}$ & $\begin{array}{c}1,2 \mu \mathrm{m} \leq \mathrm{CP}<2,0 \mu \mathrm{m} \\
(\mathrm{n} \% / \mathrm{mL})\end{array}$ & $\begin{array}{c}\mathrm{CBH} \\
\text { (UFC/mL) }\end{array}$ \\
\hline $28 / 01 / 08$ & 98,0 & $2.178,9$ & - \\
\hline $01 / 02 / 08$ & 21,1 & $5.401,4$ & - \\
\hline $08 / 02 / 08$ & 34,0 & $2.071,1$ & - \\
\hline $11 / 02 / 08$ & 56,2 & $3.794,9$ & - \\
\hline $15 / 02 / 08$ & 42,2 & $3.551,6$ & - \\
\hline $18 / 02 / 08$ & 88,0 & $1.692,5$ & 1.300 \\
\hline $22 / 02 / 08$ & 77,6 & $3.636,0$ & - \\
\hline $25 / 02 / 08$ & 111,0 & $2.344,2$ & - \\
\hline 29/02/08 & 118,9 & $1.649,2$ & - \\
\hline $10 / 04 / 08$ & 217,7 & $3.205,2$ & - \\
\hline $14 / 04 / 08$ & 273,1 & $1.257,1$ & 250 \\
\hline $16 / 04 / 08$ & 113,1 & $1.049,8$ & - \\
\hline $24 / 04 / 08$ & 141,3 & $1.051,8$ & - \\
\hline $28 / 04 / 08$ & 106,9 & 973,6 & 0 \\
\hline $12 / 05 / 08$ & 67,6 & 843,6 & - \\
\hline $15 / 05 / 08$ & 75,8 & 630,3 & - \\
\hline $26 / 05 / 08$ & 114,7 & $1.889,9$ & - \\
\hline $29 / 05 / 08$ & $1.870,3$ & 56,6 & 38 \\
\hline $02 / 06 / 08$ & 792,9 & 80,9 & 90 \\
\hline $12 / 06 / 08$ & 120,6 & $1.425,4$ & - \\
\hline $16 / 06 / 08$ & 76,0 & $1.094,8$ & 600 \\
\hline $18 / 06 / 08$ & 79,7 & 826,4 & - \\
\hline $23 / 06 / 08$ & 67,8 & 953,7 & 1.300 \\
\hline $30 / 06 / 08$ & 65,3 & $2.087,7$ & 500 \\
\hline $02 / 07 / 08$ & 80,7 & $2.890,6$ & - \\
\hline $07 / 07 / 08$ & 44,5 & $2.963,0$ & 510 \\
\hline $22 / 07 / 08$ & 41,7 & $5.230,6$ & 73 \\
\hline $24 / 07 / 08$ & 78,1 & $3.742,8$ & - \\
\hline $28 / 07 / 08$ & 87,0 & $4.854,6$ & 28 \\
\hline $31 / 07 / 08$ & 29,1 & $7.003,2$ & - \\
\hline $11 / 08 / 08$ & 28,5 & $5.131,9$ & 240 \\
\hline $14 / 08 / 08$ & 34,3 & $4.553,0$ & - \\
\hline $18 / 08 / 08$ & 25,0 & $2.947,1$ & 1.100 \\
\hline $19 / 08 / 08$ & 109,1 & $2.475,6$ & - \\
\hline $25 / 08 / 08$ & 109,1 & 740,0 & - \\
\hline $28 / 08 / 08$ & 352,8 & $3.872,2$ & - \\
\hline $02 / 09 / 08$ & 51,6 & 960,9 & 45 \\
\hline $04 / 09 / 08$ & 57,0 & $1.270,3$ & - \\
\hline $08 / 09 / 08$ & 111,4 & $1.088,8$ & 790 \\
\hline $11 / 09 / 08$ & 45,9 & $1.401,0$ & - \\
\hline $15 / 09 / 08$ & 87,1 & 854,1 & 1.000 \\
\hline $18 / 09 / 08$ & 88,6 & $1.020,6$ & - \\
\hline $22 / 09 / 08$ & 46,5 & 437,5 & 600 \\
\hline $25 / 09 / 08$ & 38,6 & 693,2 & - \\
\hline $29 / 09 / 08$ & 81,6 & 801,2 & 1.000 \\
\hline $02 / 10 / 08$ & 134,6 & $1.234,5$ & - \\
\hline $13 / 10 / 08$ & 139,4 & $5.196,3$ & 1.020 \\
\hline $23 / 10 / 08$ & 86,6 & $8.694,6$ & - \\
\hline $27 / 10 / 08$ & 120,8 & $6.473,1$ & - \\
\hline $03 / 11 / 08$ & 59,6 & $6.672,2$ & - \\
\hline
\end{tabular}




\begin{tabular}{|c|c|c|c|}
\hline \multirow{2}{*}{ Data } & \multicolumn{3}{|c|}{ Água Efluente ao Filtro 1 } \\
\cline { 2 - 4 } & $\begin{array}{c}\mathbf{C P} \geq \mathbf{2 , 0} \boldsymbol{\mu m} \\
(\mathbf{n} \% / \mathbf{m L})\end{array}$ & $\begin{array}{c}\mathbf{1 , 2} \boldsymbol{\mu m} \leq \mathbf{C P}<\mathbf{2 , 0} \boldsymbol{\mu m} \\
(\mathbf{n} \% / \mathbf{m L})\end{array}$ & $\begin{array}{c}\mathbf{C B H} \\
(\mathbf{U F C} / \mathbf{m L})\end{array}$ \\
\hline $06 / 11 / 08$ & 199,5 & $7.950,7$ & - \\
\hline $10 / 11 / 08$ & 136,4 & $3.092,9$ & - \\
\hline $13 / 11 / 08$ & 83,7 & $2.894,7$ & - \\
\hline $08 / 12 / 08$ & - & - & 260 \\
\hline
\end{tabular}




\begin{tabular}{|c|c|c|c|}
\hline \multirow[b]{2}{*}{ Data } & \multicolumn{3}{|c|}{ Água Efluente ao Filtro 2} \\
\hline & $\begin{array}{c}\mathrm{CP} \geq 2,0 \mu \mathrm{m} \\
(\mathrm{n} \% / \mathrm{mL})\end{array}$ & $\begin{array}{c}1,2 \mu \mathrm{m} \leq \mathrm{CP}<2,0 \mu \mathrm{m} \\
(\mathrm{n} \% / \mathrm{mL})\end{array}$ & $\begin{array}{c}\text { CBH } \\
\text { (UFC/mL) }\end{array}$ \\
\hline $10 / 07 / 07$ & 93,5 & $7.188,9$ & - \\
\hline $12 / 07 / 07$ & 87,2 & $4.051,0$ & - \\
\hline $16 / 07 / 07$ & 50,8 & $6.721,2$ & - \\
\hline $18 / 07 / 07$ & 78,1 & $4.877,3$ & - \\
\hline $20 / 07 / 07$ & 24,7 & $7.820,3$ & - \\
\hline $23 / 07 / 07$ & 137,6 & $5.793,2$ & - \\
\hline $25 / 07 / 07$ & 102,5 & $5.175,1$ & - \\
\hline $27 / 07 / 07$ & 51,4 & $7.947,6$ & - \\
\hline $30 / 07 / 07$ & 64,1 & $4.171,6$ & - \\
\hline $01 / 08 / 07$ & 102,6 & $100.019,0$ & - \\
\hline $03 / 08 / 07$ & 284,2 & $9.265,6$ & - \\
\hline $06 / 08 / 07$ & 89,4 & $8.919,1$ & - \\
\hline $08 / 08 / 07$ & 74,5 & $6.829,2$ & - \\
\hline $10 / 08 / 07$ & 82,4 & $10.163,8$ & - \\
\hline $15 / 08 / 07$ & 59,8 & $5.612,6$ & - \\
\hline $17 / 08 / 07$ & 278,4 & $6.541,5$ & - \\
\hline $20 / 08 / 07$ & 169,0 & $7.574,0$ & - \\
\hline $24 / 08 / 07$ & 80,2 & $4.744,3$ & - \\
\hline $27 / 08 / 07$ & 81,3 & $3.589,0$ & - \\
\hline $31 / 08 / 07$ & 138,0 & $3.733,7$ & - \\
\hline $03 / 09 / 07$ & 49,0 & $2.364,4$ & - \\
\hline $10 / 09 / 07$ & 79,9 & $2.631,5$ & - \\
\hline $14 / 09 / 07$ & 100,6 & $2.624,4$ & - \\
\hline 19/09/07 & 31,1 & $7.102,5$ & - \\
\hline $21 / 09 / 07$ & 31,8 & $2.293,4$ & - \\
\hline $24 / 09 / 07$ & 69,0 & $1.711,8$ & - \\
\hline $01 / 10 / 07$ & 74,8 & $2.755,5$ & - \\
\hline $05 / 10 / 07$ & 51,3 & $6.890,2$ & - \\
\hline $08 / 10 / 07$ & 183,5 & $3.241,4$ & - \\
\hline $15 / 10 / 07$ & 139,0 & $2.660,7$ & - \\
\hline 19/10/07 & 73,3 & $1.506,5$ & - \\
\hline $22 / 10 / 07$ & 138,9 & $2.500,8$ & - \\
\hline $26 / 10 / 07$ & 141,4 & $1.842,8$ & - \\
\hline $31 / 10 / 07$ & 54,5 & $2.944,5$ & - \\
\hline $05 / 11 / 07$ & 84,3 & $1.437,5$ & - \\
\hline $09 / 11 / 07$ & 101,0 & $2.203,8$ & - \\
\hline $12 / 11 / 07$ & 67,6 & $4.365,1$ & - \\
\hline 19/11/07 & 72,7 & $2.082,0$ & - \\
\hline $23 / 11 / 07$ & 106,4 & $1.675,3$ & - \\
\hline $26 / 11 / 07$ & 226,8 & $3.424,4$ & - \\
\hline $30 / 11 / 07$ & 115,5 & $3.985,7$ & - \\
\hline $03 / 12 / 07$ & 285,6 & $4.667,3$ & - \\
\hline $07 / 12 / 07$ & 63,1 & $5.208,2$ & - \\
\hline $10 / 12 / 07$ & 215,9 & $6.160,0$ & - \\
\hline $16 / 12 / 07$ & 295,3 & $8.177,1$ & - \\
\hline $21 / 12 / 07$ & 248,3 & $7.225,4$ & - \\
\hline $27 / 12 / 07$ & 28,5 & $3.612,7$ & - \\
\hline $04 / 01 / 08$ & 67,3 & $4.168,8$ & - \\
\hline $07 / 01 / 08$ & 51,3 & $3.451,4$ & - \\
\hline $11 / 01 / 08$ & 93,0 & $4.504,6$ & - \\
\hline $15 / 01 / 08$ & 93,0 & $5.052,2$ & - \\
\hline $18 / 01 / 08$ & 46,8 & $2.847,1$ & - \\
\hline
\end{tabular}




\begin{tabular}{|c|c|c|c|}
\hline \multirow[b]{2}{*}{ Data } & \multicolumn{3}{|c|}{ Água Efluente ao Filtro 2} \\
\hline & $\begin{array}{c}\mathrm{CP} \geq 2,0 \mu \mathrm{m} \\
(\mathrm{n} \div / \mathrm{mL})\end{array}$ & $\begin{array}{c}1,2 \mu \mathrm{m} \leq \mathrm{CP}<2,0 \mu \mathrm{m} \\
(\mathrm{n} / \mathrm{mL})\end{array}$ & $\begin{array}{c}\text { CBH } \\
\text { (UFC/mL) }\end{array}$ \\
\hline $28 / 01 / 08$ & 75,5 & $1.978,7$ & - \\
\hline $01 / 02 / 08$ & 51,8 & $7.985,9$ & - \\
\hline $08 / 02 / 08$ & 40,4 & $3.661,4$ & - \\
\hline $11 / 02 / 08$ & 72,2 & $4.724,9$ & - \\
\hline $15 / 02 / 08$ & 51,8 & $2.969,0$ & - \\
\hline $18 / 02 / 08$ & 49,4 & $3.296,2$ & 1.900 \\
\hline $22 / 02 / 08$ & 114,5 & $3.535,3$ & - \\
\hline $25 / 02 / 08$ & 357,0 & $2.548,9$ & - \\
\hline $29 / 02 / 08$ & 477,2 & $2.342,7$ & - \\
\hline $10 / 04 / 08$ & 83,7 & $1.887,9$ & - \\
\hline $14 / 04 / 08$ & 210,3 & $1.422,9$ & 110 \\
\hline $16 / 04 / 08$ & 120,1 & $1.171,8$ & - \\
\hline $24 / 04 / 08$ & 136,6 & $1.533,0$ & - \\
\hline $28 / 04 / 08$ & 83,0 & $1.358,6$ & 60 \\
\hline $12 / 05 / 08$ & 61,6 & $1.836,0$ & - \\
\hline $15 / 05 / 08$ & 97,2 & 930,2 & - \\
\hline $26 / 05 / 08$ & 93,4 & $2.857,7$ & - \\
\hline $29 / 05 / 08$ & $3.355,4$ & 81,3 & 1 \\
\hline $02 / 06 / 08$ & $1.312,9$ & 80,0 & 150 \\
\hline $12 / 06 / 08$ & 121,2 & $1.680,9$ & - \\
\hline $16 / 06 / 08$ & 74,0 & $1.714,7$ & 380 \\
\hline $18 / 06 / 08$ & 109,8 & $1.134,8$ & - \\
\hline $23 / 06 / 08$ & 56,2 & $1.001,5$ & 510 \\
\hline $30 / 06 / 08$ & 61,9 & $2.060,4$ & 980 \\
\hline $02 / 07 / 08$ & 60,6 & $2.965,7$ & - \\
\hline $07 / 07 / 08$ & 42,7 & $3.750,2$ & 500 \\
\hline $22 / 07 / 08$ & 31,1 & $6.462,5$ & 12 \\
\hline $24 / 07 / 08$ & 67,6 & $3.212,1$ & - \\
\hline $28 / 07 / 08$ & 21,8 & 608,0 & 65 \\
\hline $31 / 07 / 08$ & 18,2 & $10.327,1$ & - \\
\hline $11 / 08 / 08$ & 20,2 & $4.668,2$ & 270 \\
\hline $14 / 08 / 08$ & 46,2 & $5.264,4$ & - \\
\hline $18 / 08 / 08$ & 25,7 & $3.959,6$ & 910 \\
\hline $19 / 08 / 08$ & 130,6 & $2.675,0$ & - \\
\hline $25 / 08 / 08$ & 130,6 & $1.764,4$ & - \\
\hline $28 / 08 / 08$ & $3.792,1$ & $12.130,4$ & - \\
\hline $02 / 09 / 08$ & 47,0 & 932,8 & 30 \\
\hline $04 / 09 / 08$ & 37,3 & $1.457,9$ & - \\
\hline $08 / 09 / 08$ & 172,7 & $1.605,2$ & 200 \\
\hline $11 / 09 / 08$ & 57,4 & $1.358,0$ & - \\
\hline $15 / 09 / 08$ & 113,7 & 903,6 & 780 \\
\hline $18 / 09 / 08$ & 81,8 & $1.027,6$ & - \\
\hline $22 / 09 / 08$ & 29,9 & 418,6 & 470 \\
\hline $25 / 09 / 08$ & 58,6 & 862,6 & - \\
\hline $29 / 09 / 08$ & 75,8 & 677,9 & 430 \\
\hline $02 / 10 / 08$ & 116,7 & $1.415,3$ & - \\
\hline $13 / 10 / 08$ & 71,9 & $6.293,7$ & 1.300 \\
\hline $23 / 10 / 08$ & $1.420,9$ & $8.778,8$ & - \\
\hline $27 / 10 / 08$ & 125,8 & $9.098,2$ & - \\
\hline $03 / 11 / 08$ & 176,0 & $10.582,9$ & - \\
\hline
\end{tabular}




\begin{tabular}{|c|c|c|c|}
\hline \multirow{2}{*}{ Data } & \multicolumn{3}{|c|}{ Água Efluente ao Filtro 2 } \\
\cline { 2 - 4 } & $\begin{array}{c}\mathbf{C P} \geq \mathbf{2 , 0} \boldsymbol{\mu m} \\
(\mathbf{n} \% / \mathbf{m L})\end{array}$ & $\begin{array}{c}\mathbf{1 , 2} \boldsymbol{\mu m} \leq \mathbf{C P}<\mathbf{2 , 0} \boldsymbol{\mu m} \\
(\mathbf{n} \% / \mathbf{m L})\end{array}$ & $\begin{array}{c}\mathbf{C B H} \\
(\mathbf{U F C} / \mathbf{m L})\end{array}$ \\
\hline $06 / 11 / 08$ & 163,6 & $6.799,4$ & - \\
\hline $10 / 11 / 08$ & 148,8 & $4.882,3$ & - \\
\hline $13 / 11 / 08$ & 132,3 & $4.506,6$ & - \\
\hline $08 / 12 / 08$ & - & - & 640 \\
\hline
\end{tabular}




\begin{tabular}{|c|c|c|c|}
\hline \multirow[b]{2}{*}{ Data } & \multicolumn{3}{|c|}{ Água Efluente ao Filtro 3} \\
\hline & $\begin{array}{c}\mathrm{CP} \geq 2,0 \mu \mathrm{m} \\
(\mathrm{n} \% / \mathrm{mL})\end{array}$ & $\begin{array}{c}1,2 \mu \mathrm{m} \leq \mathrm{CP}<2,0 \mu \mathrm{m} \\
(\mathrm{n} \% / \mathrm{mL})\end{array}$ & $\begin{array}{c}\mathrm{CBH} \\
\text { (UFC/mL) }\end{array}$ \\
\hline $10 / 07 / 07$ & 18,7 & 222,7 & - \\
\hline 12/07/07 & 16,0 & 158,2 & - \\
\hline $16 / 07 / 07$ & 10,4 & 200,3 & - \\
\hline $18 / 07 / 07$ & 27,8 & 230,4 & - \\
\hline $20 / 07 / 07$ & 3,7 & 436,0 & - \\
\hline $23 / 07 / 07$ & 5,1 & 908,6 & - \\
\hline $25 / 07 / 07$ & 12,5 & $1.071,8$ & - \\
\hline $27 / 07 / 07$ & 3,3 & 550,4 & - \\
\hline $30 / 07 / 07$ & 9,8 & $1.040,3$ & - \\
\hline $01 / 08 / 07$ & 12,2 & $16.123,0$ & - \\
\hline 03/08/07 & 34,8 & $1.686,9$ & - \\
\hline $06 / 08 / 07$ & 24,7 & $1.750,2$ & - \\
\hline $08 / 08 / 07$ & 52,0 & $2.075,8$ & - \\
\hline 10/08/07 & 35,4 & $4.536,9$ & - \\
\hline $15 / 08 / 07$ & 92,3 & $2.632,6$ & - \\
\hline $17 / 08 / 07$ & 806,8 & $3.410,0$ & - \\
\hline $20 / 08 / 07$ & 129,0 & $2.620,5$ & - \\
\hline $24 / 08 / 07$ & 91,6 & $1.976,8$ & - \\
\hline $27 / 08 / 07$ & 71,2 & $1.204,9$ & - \\
\hline $31 / 08 / 07$ & 160,4 & $1.176,6$ & - \\
\hline 03/09/07 & 57,2 & 883,1 & - \\
\hline 10/09/07 & 150,5 & $2.080,9$ & - \\
\hline 14/09/07 & 444,1 & $4.096,1$ & - \\
\hline 19/09/07 & 207,8 & $13.492,7$ & - \\
\hline $21 / 09 / 07$ & 102,2 & $2.687,2$ & - \\
\hline $24 / 09 / 07$ & 159,7 & $2.064,0$ & - \\
\hline $01 / 10 / 07$ & 152,1 & $2.574,4$ & - \\
\hline 05/10/07 & 105,4 & $3.192,8$ & - \\
\hline 08/10/07 & 108,5 & $2.072,1$ & - \\
\hline 15/10/07 & 203,3 & $5.131,2$ & - \\
\hline 19/10/07 & 81,2 & $2.732,6$ & - \\
\hline $22 / 10 / 07$ & 175,0 & $3.434,1$ & - \\
\hline $26 / 10 / 07$ & 81,1 & $2.473,3$ & - \\
\hline $31 / 10 / 07$ & 62,1 & $3.059,7$ & - \\
\hline 05/11/07 & 34,0 & $1.856,7$ & - \\
\hline 09/11/07 & 76,2 & $1.521,2$ & - \\
\hline 12/11/07 & 70,7 & $3.934,4$ & - \\
\hline 19/11/07 & 100,8 & $2.472,6$ & - \\
\hline $23 / 11 / 07$ & 85,8 & $2.214,3$ & - \\
\hline $26 / 11 / 07$ & 237,1 & $2.995,2$ & - \\
\hline $30 / 11 / 07$ & 219,2 & $3.750,4$ & - \\
\hline $03 / 12 / 07$ & 227,4 & $3.582,3$ & - \\
\hline $07 / 12 / 07$ & 224,8 & $5.836,5$ & - \\
\hline 10/12/07 & 136,8 & $5.034,4$ & - \\
\hline $16 / 12 / 07$ & 130,9 & $7.366,3$ & - \\
\hline $21 / 12 / 07$ & 188,2 & $8.016,6$ & - \\
\hline $27 / 12 / 07$ & 916,0 & $4.129,7$ & - \\
\hline $04 / 01 / 08$ & 106,9 & $4.338,6$ & - \\
\hline $07 / 01 / 08$ & 63,8 & $3.619,2$ & - \\
\hline $11 / 01 / 08$ & 207,7 & $3.394,4$ & - \\
\hline $15 / 01 / 08$ & 207,7 & $5.985,2$ & - \\
\hline $18 / 01 / 08$ & 121,9 & $3.131,7$ & - \\
\hline
\end{tabular}




\begin{tabular}{|c|c|c|c|}
\hline \multirow[b]{2}{*}{ Data } & \multicolumn{3}{|c|}{ Água Efluente ao Filtro 3} \\
\hline & $\begin{array}{c}\mathrm{CP} \geq 2,0 \mu \mathrm{m} \\
(\mathrm{n} \div / \mathrm{mL})\end{array}$ & $\begin{array}{c}1,2 \mu \mathrm{m} \leq \mathrm{CP}<2,0 \mu \mathrm{m} \\
(\mathrm{n} / \mathrm{mL})\end{array}$ & $\begin{array}{c}\text { CBH } \\
\text { (UFC/mL) }\end{array}$ \\
\hline $28 / 01 / 08$ & 80,1 & $1.424,7$ & - \\
\hline $01 / 02 / 08$ & 47,6 & $5.685,7$ & - \\
\hline $08 / 02 / 08$ & 32,7 & $3.406,8$ & - \\
\hline $11 / 02 / 08$ & 76,4 & $4.021,8$ & - \\
\hline $15 / 02 / 08$ & 23,1 & $3.889,6$ & - \\
\hline $18 / 02 / 08$ & 54,6 & $2.983,2$ & 1.000 \\
\hline $22 / 02 / 08$ & 45,5 & $1.831,1$ & - \\
\hline $25 / 02 / 08$ & 112,4 & $1.808,5$ & - \\
\hline $29 / 02 / 08$ & 99,3 & $1.188,2$ & - \\
\hline $10 / 04 / 08$ & 124,7 & $1.625,9$ & - \\
\hline $14 / 04 / 08$ & 67,9 & 754,6 & 140 \\
\hline $16 / 04 / 08$ & 37,1 & 768,7 & - \\
\hline $24 / 04 / 08$ & 57,7 & 680,6 & - \\
\hline $28 / 04 / 08$ & 57,8 & 768,2 & 10 \\
\hline $12 / 05 / 08$ & 55,2 & $1.170,7$ & - \\
\hline $15 / 05 / 08$ & 58,6 & 617,5 & - \\
\hline $26 / 05 / 08$ & 82,4 & $2.823,8$ & - \\
\hline $29 / 05 / 08$ & $1.681,6$ & 35,4 & 3 \\
\hline $02 / 06 / 08$ & 596,6 & 32,8 & 0 \\
\hline $12 / 06 / 08$ & 121,1 & $1.528,5$ & - \\
\hline $16 / 06 / 08$ & 78,8 & $2.648,6$ & 0 \\
\hline $18 / 06 / 08$ & 93,3 & $1.380,7$ & - \\
\hline $23 / 06 / 08$ & 42,7 & 979,9 & 40 \\
\hline $30 / 06 / 08$ & 30,5 & $2.344,2$ & 10 \\
\hline $02 / 07 / 08$ & 47,8 & $2.782,2$ & - \\
\hline 07/07/08 & 58,5 & $3.626,8$ & 0 \\
\hline $22 / 07 / 08$ & 29,8 & $5.255,5$ & 0 \\
\hline $24 / 07 / 08$ & 45,1 & $2.869,3$ & - \\
\hline $28 / 07 / 08$ & 75,8 & $4.739,7$ & 11 \\
\hline $31 / 07 / 08$ & 46,1 & $8.891,9$ & - \\
\hline $11 / 08 / 08$ & 31,9 & $4.262,0$ & 40 \\
\hline $14 / 08 / 08$ & 35,6 & $4.513,2$ & - \\
\hline $18 / 08 / 08$ & 21,4 & $3.322,7$ & 110 \\
\hline $19 / 08 / 08$ & 61,9 & $1.890,5$ & - \\
\hline $25 / 08 / 08$ & 61,9 & $1.644,8$ & - \\
\hline $28 / 08 / 08$ & 94,9 & $2.789,8$ & - \\
\hline $02 / 09 / 08$ & 66,3 & 945,3 & 0 \\
\hline $04 / 09 / 08$ & 71,5 & $1.364,6$ & - \\
\hline 08/09/08 & 79,5 & $1.241,1$ & 0 \\
\hline $11 / 09 / 08$ & 98,1 & $1.859,5$ & - \\
\hline $15 / 09 / 08$ & 91,8 & $2.262,4$ & 0 \\
\hline $18 / 09 / 08$ & 49,3 & $1.038,2$ & - \\
\hline $22 / 09 / 08$ & 74,2 & 975,6 & 60 \\
\hline $25 / 09 / 08$ & 121,0 & $1.149,3$ & - \\
\hline $29 / 09 / 08$ & 87,3 & 689,0 & 80 \\
\hline $02 / 10 / 08$ & 94,4 & $1.492,1$ & - \\
\hline $13 / 10 / 08$ & 204,9 & $9.144,9$ & 16 \\
\hline $23 / 10 / 08$ & 270,0 & $7.925,5$ & - \\
\hline $27 / 10 / 08$ & 50,5 & $6.825,8$ & - \\
\hline $03 / 11 / 08$ & 112,0 & $7.050,7$ & - \\
\hline
\end{tabular}




\begin{tabular}{|c|c|c|c|}
\hline \multirow{2}{*}{ Data } & \multicolumn{3}{|c|}{ Água Efluente ao Filtro 3 } \\
\cline { 2 - 4 } & $\begin{array}{c}\mathbf{C P} \geq \mathbf{2 , 0} \boldsymbol{\mu \mathbf { m }} \\
(\mathbf{n} \% / \mathbf{m L})\end{array}$ & $\begin{array}{c}\mathbf{1 , 2} \boldsymbol{\mu m} \leq \mathbf{C P}<\mathbf{2 , 0} \boldsymbol{\mu m} \\
(\mathbf{n} \% / \mathbf{m L})\end{array}$ & $\begin{array}{c}\mathbf{C B H} \\
(\mathbf{U F C} / \mathbf{m L})\end{array}$ \\
\hline $06 / 11 / 08$ & 80,6 & $3.052,4$ & - \\
\hline $10 / 11 / 08$ & 87,5 & $4.401,6$ & - \\
\hline $13 / 11 / 08$ & 68,8 & $3.087,6$ & - \\
\hline $08 / 12 / 08$ & - & - & 370 \\
\hline
\end{tabular}




\begin{tabular}{|c|c|c|c|}
\hline \multirow[b]{2}{*}{ Data } & \multicolumn{3}{|c|}{ Água Efluente ao Filtro 4} \\
\hline & $\begin{array}{c}\mathrm{CP} \geq 2,0 \mu \mathrm{m} \\
(\mathrm{n} \div / \mathrm{mL})\end{array}$ & $\begin{array}{c}1,2 \mu \mathrm{m} \leq \mathrm{CP}<2,0 \mu \mathrm{m} \\
(\mathrm{n} \div / \mathrm{mL})\end{array}$ & $\begin{array}{c}\mathrm{CBH} \\
\text { (UFC/mL) }\end{array}$ \\
\hline $10 / 07 / 07$ & 34,6 & $2.287,3$ & - \\
\hline $12 / 07 / 07$ & 30,3 & $1.189,4$ & - \\
\hline $16 / 07 / 07$ & 10,9 & 782,8 & - \\
\hline $18 / 07 / 07$ & 39,3 & 487,9 & - \\
\hline $20 / 07 / 07$ & 123,3 & $3.909,8$ & - \\
\hline $23 / 07 / 07$ & 26,0 & 786,0 & - \\
\hline $25 / 07 / 07$ & 141,3 & $1.588,1$ & - \\
\hline $27 / 07 / 07$ & 40,8 & $2.333,1$ & - \\
\hline $30 / 07 / 07$ & 223,0 & $4.212,2$ & - \\
\hline $01 / 08 / 07$ & 122,8 & $62.788,0$ & - \\
\hline $03 / 08 / 07$ & 547,4 & $7.917,2$ & - \\
\hline $06 / 08 / 07$ & 457,2 & $7.475,7$ & - \\
\hline $08 / 08 / 07$ & 479,7 & $7.557,2$ & - \\
\hline $10 / 08 / 07$ & 579,8 & $12.020,5$ & - \\
\hline $15 / 08 / 07$ & 873,0 & $8.533,6$ & - \\
\hline $17 / 08 / 07$ & 667,5 & $8.200,3$ & - \\
\hline $20 / 08 / 07$ & 634,5 & $7.287,3$ & - \\
\hline $24 / 08 / 07$ & 531,1 & $6.555,7$ & - \\
\hline $27 / 08 / 07$ & 389,2 & $4.559,9$ & - \\
\hline $31 / 08 / 07$ & 311,3 & $3.471,4$ & - \\
\hline $03 / 09 / 07$ & 156,3 & $3.350,0$ & - \\
\hline $10 / 09 / 07$ & 221,9 & $4.429,8$ & - \\
\hline $14 / 09 / 07$ & 343,1 & $4.339,2$ & - \\
\hline $19 / 09 / 07$ & 103,1 & $7.703,6$ & - \\
\hline $21 / 09 / 07$ & 86,5 & $3.544,7$ & - \\
\hline $24 / 09 / 07$ & 284,3 & $5.285,0$ & - \\
\hline $01 / 10 / 07$ & 132,1 & $2.716,4$ & - \\
\hline $05 / 10 / 07$ & 265,2 & $12.473,0$ & - \\
\hline $08 / 10 / 07$ & 220,8 & $4.137,9$ & - \\
\hline $15 / 10 / 07$ & 191,6 & $4.655,9$ & - \\
\hline 19/10/07 & 116,3 & $2.908,2$ & - \\
\hline $22 / 10 / 07$ & 172,7 & $4.249,6$ & - \\
\hline $26 / 10 / 07$ & 88,2 & $2.231,9$ & - \\
\hline $31 / 10 / 07$ & 50,4 & $2.535,1$ & - \\
\hline $05 / 11 / 07$ & 103,1 & $2.257,3$ & - \\
\hline 09/11/07 & 74,2 & 959,3 & - \\
\hline 12/11/07 & 115,2 & $3.419,0$ & - \\
\hline 19/11/07 & 91,0 & $1.932,6$ & - \\
\hline $23 / 11 / 07$ & 109,7 & $1.882,5$ & - \\
\hline $26 / 11 / 07$ & 323,6 & $2.469,2$ & - \\
\hline $30 / 11 / 07$ & 280,1 & $2.773,2$ & - \\
\hline $03 / 12 / 07$ & 273,0 & $2.319,3$ & - \\
\hline $07 / 12 / 07$ & 407,1 & $3.565,1$ & - \\
\hline 10/12/07 & 135,3 & $3.845,8$ & - \\
\hline $16 / 12 / 07$ & 234,5 & $7.759,7$ & - \\
\hline $21 / 12 / 07$ & 113,9 & $4.593,4$ & - \\
\hline $27 / 12 / 07$ & 110,2 & $4.225,7$ & - \\
\hline $04 / 01 / 08$ & 101,9 & $4.126,7$ & - \\
\hline $07 / 01 / 08$ & 58,6 & $3.376,7$ & - \\
\hline $11 / 01 / 08$ & 132,5 & $3.652,2$ & - \\
\hline $15 / 01 / 08$ & 132,5 & $5.980,6$ & - \\
\hline $18 / 01 / 08$ & 148,2 & $4.868,7$ & - \\
\hline
\end{tabular}




\begin{tabular}{|c|c|c|c|}
\hline \multirow[b]{2}{*}{ Data } & \multicolumn{3}{|c|}{ Água Efluente ao Filtro 4} \\
\hline & $\begin{array}{c}\mathrm{CP} \geq 2,0 \mu \mathrm{m} \\
(\mathrm{n} / \mathrm{mL})\end{array}$ & $\begin{array}{c}1,2 \mu \mathrm{m} \leq \mathrm{CP}<2,0 \mu \mathrm{m} \\
(\mathrm{n} \% / \mathrm{mL})\end{array}$ & $\begin{array}{c}\text { CBH } \\
\text { (UFC/mL) }\end{array}$ \\
\hline $28 / 01 / 08$ & 83,2 & $2.055,1$ & - \\
\hline $01 / 02 / 08$ & 20,6 & $7.474,2$ & - \\
\hline $08 / 02 / 08$ & 63,9 & $4.826,4$ & - \\
\hline $11 / 02 / 08$ & 74,8 & $4.881,9$ & - \\
\hline $15 / 02 / 08$ & 22,5 & $4.233,2$ & - \\
\hline $18 / 02 / 08$ & 43,1 & $3.351,5$ & 1.000 \\
\hline $22 / 02 / 08$ & 58,7 & $3.211,0$ & - \\
\hline $25 / 02 / 08$ & 72,5 & $1.022,2$ & - \\
\hline $29 / 02 / 08$ & 67,2 & 892,5 & - \\
\hline $10 / 04 / 08$ & 78,8 & $1.108,0$ & - \\
\hline $14 / 04 / 08$ & 47,2 & 867,4 & 20 \\
\hline $16 / 04 / 08$ & 63,2 & 826,2 & - \\
\hline $24 / 04 / 08$ & 78,9 & 506,2 & - \\
\hline $28 / 04 / 08$ & 37,1 & 387,7 & 20 \\
\hline $12 / 05 / 08$ & 483,2 & $1.508,7$ & - \\
\hline $15 / 05 / 08$ & 81,1 & $1.030,5$ & - \\
\hline $26 / 05 / 08$ & 73,3 & $2.638,3$ & - \\
\hline $29 / 05 / 08$ & $2.224,7$ & 66,0 & 1 \\
\hline $02 / 06 / 08$ & 898,6 & 86,6 & 60 \\
\hline $12 / 06 / 08$ & 216,7 & $2.315,4$ & - \\
\hline $16 / 06 / 08$ & 85,2 & $2.205,3$ & 20 \\
\hline $18 / 06 / 08$ & 81,5 & $1.654,9$ & - \\
\hline $23 / 06 / 08$ & 54,4 & $1.351,3$ & 40 \\
\hline $30 / 06 / 08$ & 55,4 & $2.858,2$ & 20 \\
\hline $02 / 07 / 08$ & 109,7 & $2.955,5$ & - \\
\hline $07 / 07 / 08$ & 88,9 & $3.517,9$ & 0 \\
\hline $22 / 07 / 08$ & 47,4 & $4.627,7$ & 0 \\
\hline $24 / 07 / 08$ & 162,0 & $3.389,3$ & - \\
\hline $28 / 07 / 08$ & 172,5 & $5.608,3$ & 68 \\
\hline $31 / 07 / 08$ & 26,4 & $6.526,6$ & - \\
\hline $11 / 08 / 08$ & 38,0 & $4.414,9$ & 30 \\
\hline $14 / 08 / 08$ & 46,5 & $5.332,4$ & - \\
\hline $18 / 08 / 08$ & 25,9 & $3.447,2$ & 40 \\
\hline $19 / 08 / 08$ & 63,7 & $2.652,6$ & - \\
\hline $25 / 08 / 08$ & 63,7 & $1.792,5$ & - \\
\hline $28 / 08 / 08$ & 56,9 & $1.618,8$ & - \\
\hline $02 / 09 / 08$ & 94,0 & $1.234,5$ & 0 \\
\hline $04 / 09 / 08$ & 77,0 & $1.776,2$ & - \\
\hline $08 / 09 / 08$ & 139,0 & $1.645,3$ & 0 \\
\hline $11 / 09 / 08$ & 143,3 & $2.266,6$ & - \\
\hline $15 / 09 / 08$ & 120,6 & $2.834,2$ & 40 \\
\hline $18 / 09 / 08$ & 65,3 & $1.223,7$ & - \\
\hline $22 / 09 / 08$ & 101,9 & $1.284,0$ & 10 \\
\hline $25 / 09 / 08$ & 140,9 & $1.505,5$ & \\
\hline $29 / 09 / 08$ & 108,8 & 935,5 & 10 \\
\hline $02 / 10 / 08$ & 83,0 & $2.651,0$ & - \\
\hline $13 / 10 / 08$ & 117,1 & $5.457,8$ & 15 \\
\hline $23 / 10 / 08$ & $1.477,7$ & $6.808,0$ & - \\
\hline $27 / 10 / 08$ & 186,4 & $6.927,8$ & - \\
\hline $03 / 11 / 08$ & 162,8 & $7.912,2$ & - \\
\hline
\end{tabular}




\begin{tabular}{|c|c|c|c|}
\hline \multirow[b]{2}{*}{ Data } & \multicolumn{3}{|c|}{ Água Efluente ao Filtro 4} \\
\hline & $\begin{array}{c}\mathrm{CP} \geq 2,0 \mu \mathrm{m} \\
(\mathrm{n} \div / \mathrm{mL})\end{array}$ & $\begin{array}{c}1,2 \mu \mathrm{m} \leq \mathrm{CP}<2,0 \mu \mathrm{m} \\
(\mathrm{n} \div / \mathrm{mL})\end{array}$ & $\begin{array}{c}\mathrm{CBH} \\
\text { (UFC/mL) }\end{array}$ \\
\hline 06/11/08 & 163,6 & $3.107,7$ & - \\
\hline $10 / 11 / 08$ & 262,8 & $4.444,9$ & - \\
\hline $13 / 11 / 08$ & 241,8 & $4.005,8$ & - \\
\hline $08 / 12 / 08$ & - & - & 2.000 \\
\hline
\end{tabular}




\section{APÊNDICE E - Valores de MIB e Geosmina}

\begin{tabular}{|c|c|c|c|c|c|c|}
\hline \multirow[b]{2}{*}{ Data } & \multicolumn{6}{|c|}{ MIB (ng/L) } \\
\hline & REAF & REAO & F1 & F2 & F3 & F4 \\
\hline $01 / 08 / 07$ & $<2,0$ & $<2,0$ & $<2,0$ & $<2,0$ & $<2,0$ & $<2,0$ \\
\hline $06 / 08 / 07$ & $<2,0$ & $<2,0$ & $<2,0$ & $<2,0$ & $<2,0$ & $<2,0$ \\
\hline $15 / 08 / 07$ & $<2,0$ & $<2,0$ & $<2,0$ & $<2,0$ & $<2,0$ & $<2,0$ \\
\hline $22 / 08 / 07$ & $<2,0$ & $<2,0$ & 3,6 & 2,5 & 3,0 & 2,8 \\
\hline $29 / 08 / 07$ & $<2,0$ & $<2,0$ & 8,7 & 2,3 & $<2,0$ & $<2,0$ \\
\hline $10 / 09 / 07$ & $<2,0$ & $<2,0$ & $<2,0$ & $<2,0$ & $<2,0$ & $<2,0$ \\
\hline $19 / 09 / 07$ & $<2,0$ & $<2,0$ & 6,8 & 11,0 & 4,1 & 6,5 \\
\hline $26 / 09 / 07$ & $<2,0$ & $<2,0$ & 6,7 & 27,0 & 8,9 & 35,0 \\
\hline $03 / 10 / 07$ & $<2,0$ & $<2,0$ & 4,1 & 6,9 & 10,0 & 3,4 \\
\hline $11 / 10 / 07$ & $<2,0$ & $<2,0$ & 11,0 & 4,6 & 3,6 & 8,5 \\
\hline $17 / 10 / 07$ & $<2,0$ & $<2,0$ & 7,4 & 5,1 & 13,0 & 12,0 \\
\hline $29 / 10 / 07$ & $<2,0$ & $<2,0$ & $<2,0$ & $<2,0$ & $<2,0$ & $<2,0$ \\
\hline $07 / 11 / 07$ & $<2,0$ & $<2,0$ & $<2,0$ & $<2,0$ & $<2,0$ & $<2,0$ \\
\hline $28 / 11 / 07$ & 3,2 & $<2,0$ & $<2,0$ & $<2,0$ & $<2,0$ & $<2,0$ \\
\hline $06 / 12 / 07$ & $<2,0$ & $<2,0$ & $<2,0$ & $<2,0$ & $<2,0$ & $<2,0$ \\
\hline $16 / 12 / 07$ & $<2,0$ & $<2,0$ & 9,7 & 9,9 & 8,0 & 7,1 \\
\hline $27 / 12 / 07$ & 2,5 & 2,1 & 16,0 & 9,8 & 3,6 & 17,0 \\
\hline $09 / 01 / 08$ & 43,0 & 44,0 & 28,0 & 30,0 & 25,0 & 62,0 \\
\hline $13 / 01 / 08$ & 55,0 & 47,0 & 16,0 & 38,0 & 26,0 & 42,0 \\
\hline $23 / 01 / 08$ & 26,0 & 46,0 & 3,2 & 9,8 & 9,5 & 11,0 \\
\hline $01 / 02 / 08$ & 12,0 & 8,7 & 8,9 & 10,0 & 11,0 & 2,0 \\
\hline $06 / 02 / 08$ & 6,2 & 6,1 & 3,4 & 10,0 & $<2,0$ & 5,1 \\
\hline $20 / 02 / 08$ & 3,0 & 3,3 & 4,4 & $<2,0$ & $<2,0$ & 2,0 \\
\hline $01 / 03 / 08$ & 2,0 & $<2,0$ & $<2,0$ & $<2,0$ & $<2,0$ & 4,1 \\
\hline $12 / 04 / 08$ & 5,8 & $<2,0$ & $<2,0$ & $<2,0$ & $<2,0$ & 2,1 \\
\hline $20 / 04 / 08$ & 7,0 & 3,7 & 2,9 & $<2,0$ & $<2,0$ & 6,0 \\
\hline $01 / 05 / 08$ & 14,0 & 12,0 & 7,6 & 6,4 & 13,0 & 12,0 \\
\hline $19 / 05 / 08$ & 36,0 & 12,0 & 3,8 & 7,9 & 15,0 & 25,0 \\
\hline $27 / 05 / 08$ & 265,0 & 146,0 & 39,0 & 99,0 & 86,0 & 183,0 \\
\hline $01 / 06 / 08$ & 375,0 & 75,0 & 33,0 & 60,0 & 144,0 & 293,0 \\
\hline $12 / 06 / 08$ & 6,4 & $<2,0$ & 4,6 & $<2,0$ & 38,0 & 15,0 \\
\hline $19 / 06 / 08$ & 3,4 & $<2,0$ & $<2,0$ & $<2,0$ & 17,0 & 2,8 \\
\hline $02 / 07 / 08$ & 2,6 & 2,4 & $<2,0$ & $<2,0$ & 4,2 & $<2,0$ \\
\hline $07 / 07 / 08$ & $<2,0$ & $<2,0$ & $<2,0$ & $<2,0$ & 2,9 & $<2,0$ \\
\hline $15 / 07 / 08$ & 4,2 & $<2,0$ & $<2,0$ & 3,0 & 7,8 & 2,6 \\
\hline $30 / 07 / 08$ & $\overline{3,4}$ & $<2,0$ & $<2,0$ & $<2,0$ & $<2,0$ & $<2,0$ \\
\hline $11 / 08 / 08$ & 5,9 & $<2,0$ & $<2,0$ & $<2,0$ & 4,4 & 4,2 \\
\hline $19 / 08 / 08$ & 5,1 & $<2,0$ & $<2,0$ & $<2,0$ & 5,7 & 7,4 \\
\hline 09/09/08 & 563,0 & 54,0 & 23,0 & 84,0 & 96,0 & 366,0 \\
\hline $14 / 09 / 08$ & 415,0 & 90,0 & 18,0 & 70,0 & 70,0 & 278,0 \\
\hline $17 / 09 / 08$ & 468,0 & 411,0 & 64,0 & 234,0 & 46,0 & 268,0 \\
\hline $19 / 09 / 08$ & 272,0 & 2,0 & 15,0 & 5,7 & 81,0 & 229,0 \\
\hline $25 / 09 / 08$ & 21,0 & 2,0 & 3,4 & $<2,0$ & 15,0 & 19,0 \\
\hline $16 / 10 / 08$ & 39,0 & 3,4 & $<2,0$ & 2,1 & 5,3 & 30,0 \\
\hline $25 / 10 / 08$ & 63,0 & 10,0 & 6,1 & 13,0 & 15,0 & 51,0 \\
\hline $04 / 11 / 08$ & 2,8 & $<2,0$ & $<2,0$ & $<2,0$ & 2,1 & 3,1 \\
\hline $17 / 11 / 08$ & $<2,0$ & $<2,0$ & $<2,0$ & $<2,0$ & $<2,0$ & 2,1 \\
\hline $29 / 11 / 08$ & 12,0 & 2,5 & $<2,0$ & $<2,0$ & $<2,0$ & 12,0 \\
\hline $07 / 12 / 08$ & 21,0 & 2,7 & $<2,0$ & $<2,0$ & $<2,0$ & 20,0 \\
\hline
\end{tabular}




\begin{tabular}{|c|c|c|c|c|c|c|}
\hline \multirow[b]{2}{*}{ Data } & \multicolumn{6}{|c|}{ Geosmina (ng/L) } \\
\hline & REAF & REAO & F1 & F2 & F3 & $\mathbf{F 4}$ \\
\hline $01 / 08 / 07$ & 2,2 & $<2,0$ & $<2,0$ & $<2,0$ & $<2,0$ & $<2,0$ \\
\hline $06 / 08 / 07$ & 3,9 & $<2,0$ & $<2,0$ & $<2,0$ & $<2,0$ & $<2,0$ \\
\hline 15/08/07 & 7,1 & 2,6 & $<2,0$ & $<2,0$ & $<2,0$ & $<2,0$ \\
\hline $22 / 08 / 07$ & 9,0 & 3,3 & $<2,0$ & $<2,0$ & $<2,0$ & 2,8 \\
\hline 29/08/07 & 3,4 & $<2,0$ & $<2,0$ & $<2,0$ & $<2,0$ & $<2,0$ \\
\hline 10/09/07 & $<2,0$ & $<2,0$ & $<2,0$ & $<2,0$ & $<2,0$ & $<2,0$ \\
\hline 19/09/07 & $<2,0$ & $<2,0$ & $<2,0$ & $<2,0$ & $<2,0$ & $<2,0$ \\
\hline 26/09/07 & $<2,0$ & $<2,0$ & $<2,0$ & $<2,0$ & $<2,0$ & $<2,0$ \\
\hline 03/10/07 & $<2,0$ & $<2,0$ & $<2,0$ & $<2,0$ & $<2,0$ & $<2,0$ \\
\hline 11/10/07 & 2,8 & $<2,0$ & $<2,0$ & $<2,0$ & $<2,0$ & $<2,0$ \\
\hline 17/10/07 & 2,7 & 2,3 & $<2,0$ & $<2,0$ & $<2,0$ & $<2,0$ \\
\hline 29/10/07 & $<2,0$ & $<2,0$ & $<2,0$ & $<2,0$ & $<2,0$ & $<2,0$ \\
\hline $07 / 11 / 07$ & 3,8 & 2,7 & $<2,0$ & $<2,0$ & $<2,0$ & $<2,0$ \\
\hline $28 / 11 / 07$ & 6,2 & 3,4 & $<2,0$ & 2,5 & $<2,0$ & 3,5 \\
\hline $06 / 12 / 07$ & 3,2 & 2,8 & $<2,0$ & $<2,0$ & $<2,0$ & $<2,0$ \\
\hline 16/12/07 & $<2,0$ & 2,8 & $<2,0$ & $<2,0$ & $<2,0$ & $<2,0$ \\
\hline $27 / 12 / 07$ & $<2,0$ & 2,5 & $<2,0$ & $<2,0$ & $<2,0$ & $<2,0$ \\
\hline 09/01/08 & 11,0 & 11,0 & $<2,0$ & $<2,0$ & $<2,0$ & 5,8 \\
\hline $13 / 01 / 08$ & 16,0 & 13,0 & 2,0 & 2,0 & 2,0 & 7,9 \\
\hline $23 / 01 / 08$ & 9,2 & 8,9 & $<2,0$ & $<2,0$ & $<2,0$ & 4,8 \\
\hline $01 / 02 / 08$ & $<2,0$ & $<2,0$ & $<2,0$ & $<2,0$ & $<2,0$ & $<2,0$ \\
\hline $06 / 02 / 08$ & $<2,0$ & $<2,0$ & $<2,0$ & $<2,0$ & $<2,0$ & $<2,0$ \\
\hline $20 / 02 / 08$ & 2,2 & $<2,0$ & $<2,0$ & $<2,0$ & $<2,0$ & $<2,0$ \\
\hline $01 / 03 / 08$ & 2,9 & $<2,0$ & $<2,0$ & $<2,0$ & $<2,0$ & $<2,0$ \\
\hline $12 / 04 / 08$ & 4,6 & $<2,0$ & $<2,0$ & $<2,0$ & $<2,0$ & 2,8 \\
\hline $20 / 04 / 08$ & 13,0 & 4,7 & $<2,0$ & $<2,0$ & $<2,0$ & 6,2 \\
\hline $01 / 05 / 08$ & 24,0 & 7,5 & $<2,0$ & $<2,0$ & $<2,0$ & 14,0 \\
\hline $19 / 05 / 08$ & $<2,0$ & $<2,0$ & $<2,0$ & $<2,0$ & $<2,0$ & $<2,0$ \\
\hline $27 / 05 / 08$ & $<2,0$ & $<2,0$ & $<2,0$ & $<2,0$ & $<2,0$ & $<2,0$ \\
\hline $01 / 06 / 08$ & $<2,0$ & $<2,0$ & $<2,0$ & $<2,0$ & $<2,0$ & $<2,0$ \\
\hline $12 / 06 / 08$ & $<2,0$ & $<2,0$ & $<2,0$ & $<2,0$ & $<2,0$ & $<2,0$ \\
\hline $19 / 06 / 08$ & $<2,0$ & $<2,0$ & $<2,0$ & $<2,0$ & $<2,0$ & $<2,0$ \\
\hline $02 / 07 / 08$ & 2,0 & 2,0 & $<2,0$ & $<2,0$ & $<2,0$ & 2,1 \\
\hline $07 / 07 / 08$ & 2,0 & 2,0 & $<2,0$ & $<2,0$ & $<2,0$ & $<2,0$ \\
\hline $15 / 07 / 08$ & $<2,0$ & $<2,0$ & $<2,0$ & $<2,0$ & $<2,0$ & $<2,0$ \\
\hline $30 / 07 / 08$ & 9,1 & 2,5 & $<2,0$ & $<2,0$ & $<2,0$ & 5,0 \\
\hline $11 / 08 / 08$ & 56,0 & $<2,0$ & $<2,0$ & $<2,0$ & $<2,0$ & 6,6 \\
\hline $19 / 08 / 08$ & 2,1 & $<2,0$ & $<2,0$ & $<2,0$ & $<2,0$ & $<2,0$ \\
\hline $09 / 09 / 08$ & $<2,0$ & $<2,0$ & $<2,0$ & $<2,0$ & $<2,0$ & $<2,0$ \\
\hline $14 / 09 / 08$ & 2,6 & $<2,0$ & $<2,0$ & $<2,0$ & $<2,0$ & $<2,0$ \\
\hline $17 / 09 / 08$ & $<2,0$ & $<2,0$ & $<2,0$ & $<2,0$ & $<2,0$ & $<2,0$ \\
\hline $19 / 09 / 08$ & $<2,0$ & $<2,0$ & $<2,0$ & $<2,0$ & $<2,0$ & $<2,0$ \\
\hline $25 / 09 / 08$ & 6,2 & $<2,0$ & $<2,0$ & $<2,0$ & $<2,0$ & $<2,0$ \\
\hline $16 / 10 / 08$ & 4,1 & $<2,0$ & $<2,0$ & $<2,0$ & $<2,0$ & $<2,0$ \\
\hline $25 / 10 / 08$ & $<2,0$ & $<2,0$ & $<2,0$ & $<2,0$ & $<2,0$ & $<2,0$ \\
\hline $04 / 11 / 08$ & 2,0 & $<2,0$ & $<2,0$ & $<2,0$ & $<2,0$ & $<2,0$ \\
\hline 17/11/08 & 4,3 & $<2,0$ & $<2,0$ & $<2,0$ & $<2,0$ & 2,2 \\
\hline $29 / 11 / 08$ & $<2,0$ & $<2,0$ & $<2,0$ & $<2,0$ & $<2,0$ & $<2,0$ \\
\hline $07 / 12 / 08$ & 2,1 & $<2,0$ & $<2,0$ & $<2,0$ & $<2,0$ & $<2,0$ \\
\hline
\end{tabular}




\section{APÊNDICE F - Valores de THM Instantâneos e na Rede de Distribuição}

\begin{tabular}{|c|c|c|c|c|c|c|}
\hline \multirow{2}{*}{ Data } & \multicolumn{7}{|c|}{ THM instantâneo $(\boldsymbol{\mu g} / \mathbf{L})$} \\
\cline { 2 - 7 } & REAF & REAO & F1 & F2 & F3 & F4 \\
\hline $01 / 08 / 07$ & 17,0 & 19,0 & $<0,5$ & 3,5 & $<0,5$ & 4,3 \\
\hline $06 / 08 / 07$ & 17,0 & 16,0 & 2,9 & $<0,5$ & $<0,5$ & 4,0 \\
\hline $15 / 08 / 07$ & 18,0 & 17,0 & 0,8 & 3,6 & 1,0 & 4,9 \\
\hline $22 / 08 / 07$ & 20,0 & 21,0 & 1,5 & 7,9 & 1,2 & 5,3 \\
\hline $29 / 08 / 07$ & 20,0 & 18,0 & 1,4 & 4,4 & 3,3 & 6,8 \\
\hline $10 / 09 / 07$ & 23,0 & 22,0 & 4,6 & 7,4 & 4,7 & 6,6 \\
\hline $19 / 09 / 07$ & 20,0 & 21,0 & 9,8 & 8,8 & 7,3 & 7,2 \\
\hline $26 / 09 / 07$ & 19,0 & 18,0 & 11,0 & 9,6 & 7,9 & 7,1 \\
\hline $03 / 10 / 07$ & 19,0 & 17,0 & 11,0 & 8,6 & 11,0 & 7,6 \\
\hline $11 / 10 / 07$ & 23,0 & 20,0 & 13,0 & 10,0 & 9,6 & 8,2 \\
\hline $17 / 10 / 07$ & 23,0 & 21,0 & 12,0 & 8,4 & 12,0 & 8,1 \\
\hline $29 / 10 / 07$ & 14,0 & 23,0 & 19,0 & 12,0 & 17,0 & 13,0 \\
\hline $07 / 11 / 07$ & 23,0 & 23,0 & 17,0 & 9,6 & 13,0 & 9,8 \\
\hline $28 / 11 / 07$ & 16,0 & 16,0 & 17,0 & 11,0 & 17,0 & 13,0 \\
\hline $06 / 12 / 07$ & 24,0 & 23,0 & 15,0 & 12,0 & 8,5 & 6,7 \\
\hline $16 / 12 / 07$ & 15,0 & 28,0 & 21,0 & 14,0 & 14,0 & 11,0 \\
\hline $27 / 12 / 07$ & 14,0 & 23,0 & 14,0 & 11,0 & 12,0 & 9,0 \\
\hline $09 / 01 / 08$ & 25,0 & 12,0 & 22,0 & 14,0 & 5,9 & 11,0 \\
\hline $13 / 01 / 08$ & 27,0 & 29,0 & 21,0 & 10,0 & 13,0 & 10,0 \\
\hline $23 / 01 / 08$ & 19,0 & 20,0 & 13,0 & 11,0 & 12,0 & 5,4 \\
\hline $01 / 02 / 08$ & 28,0 & 26,6 & 18,1 & 10,2 & 8,0 & 12,1 \\
\hline $06 / 02 / 08$ & 23,0 & 24,0 & 16,0 & 12,0 & 12,0 & 6,3 \\
\hline $20 / 02 / 08$ & 16,0 & 14,0 & 16,0 & 13,0 & 14,0 & 11,0 \\
\hline $01 / 03 / 08$ & 24,0 & 22,0 & 14,0 & 11,0 & 7,1 & 6,4 \\
\hline $12 / 04 / 08$ & 11,0 & 17,0 & 7,3 & 6,2 & 11,0 & 6,0 \\
\hline $20 / 04 / 08$ & 8,4 & 9,3 & 7,9 & 8,3 & 6,2 & 9,4 \\
\hline $01 / 05 / 08$ & 10,0 & 17,0 & 12,0 & 5,3 & 11,0 & 10,0 \\
\hline $19 / 05 / 08$ & 17,0 & 13,0 & 11,0 & 9,2 & 10,0 & 9,3 \\
\hline $27 / 05 / 08$ & 16,0 & 15,0 & 12,0 & 10,0 & 11,0 & 11,0 \\
\hline $19 / 06 / 08$ & 19,0 & 17,0 & 11,0 & 10,0 & 11,0 & 11,0 \\
\hline $07 / 07 / 08$ & 19,0 & 14,0 & 11,0 & 9,0 & 10,0 & 9,1 \\
\hline $30 / 07 / 08$ & 13,1 & 13,0 & 9,9 & 8,7 & 9,4 & 9,1 \\
\hline $09 / 09 / 08$ & 5,9 & 5,5 & 6,0 & 5,7 & 5,8 & 5,7 \\
\hline $19 / 09 / 08$ & 3,8 & 3,7 & 5,6 & 5,7 & 5,0 & 4,9 \\
\hline $16 / 10 / 08$ & 15,0 & 12,0 & 9,2 & 7,9 & 8,4 & 8,3 \\
\hline $25 / 10 / 08$ & 25,0 & 21,0 & 11,0 & 9,6 & 12,0 & 10,0 \\
\hline $17 / 11 / 08$ & 14,0 & 14,0 & 7,5 & 7,1 & 8,0 & 7,1 \\
\hline $29 / 11 / 08$ & 14,0 & 12,0 & 8,0 & 8,0 & 8,4 & 8,0 \\
\hline
\end{tabular}




\begin{tabular}{|c|c|c|c|c|c|c|}
\hline \multirow{2}{*}{ Data } & \multicolumn{7}{|c|}{ THM na rede de distribuição $(\boldsymbol{\mu g} / \mathbf{L})$} \\
\cline { 2 - 7 } & REAF & REAO & F1 & F2 & F3 & F4 \\
\hline $01 / 08 / 07$ & 68,0 & 58,0 & 5,1 & 27,0 & 4,4 & 32,0 \\
\hline $06 / 08 / 07$ & 51,0 & 57,0 & 25,0 & 4,8 & 4,3 & 29,0 \\
\hline $15 / 08 / 07$ & 76,0 & 62,0 & 10,0 & 33,0 & 7,2 & 48,0 \\
\hline $22 / 08 / 07$ & 55,0 & 54,0 & 22,0 & 30,0 & 5,9 & 31,0 \\
\hline $29 / 08 / 07$ & 56,0 & 56,0 & 7,1 & 24,0 & 9,3 & 27,0 \\
\hline $10 / 09 / 07$ & 42,0 & 72,0 & 23,0 & 42,0 & 16,0 & 33,0 \\
\hline $19 / 09 / 07$ & 65,0 & 68,0 & 25,0 & 41,0 & 20,0 & 39,0 \\
\hline $26 / 09 / 07$ & 58,0 & 55,0 & 21,0 & 31,0 & 22,0 & 34,0 \\
\hline $03 / 10 / 07$ & 54,0 & 5,9 & 23,0 & 34,0 & 20,0 & 34,0 \\
\hline $11 / 10 / 07$ & 70,0 & 76,0 & 35,0 & 41,0 & 30,0 & 41,0 \\
\hline $17 / 10 / 07$ & 66,0 & 72,0 & 29,0 & 38,0 & 30,0 & 46,0 \\
\hline $29 / 10 / 07$ & 57,0 & 96,0 & 47,0 & 35,0 & 37,0 & 60,0 \\
\hline $07 / 11 / 07$ & 87,0 & 63,0 & 41,0 & 29,0 & 36,0 & 51,0 \\
\hline $28 / 11 / 07$ & 87,0 & 63,0 & 41,0 & 29,0 & 36,0 & 51,0 \\
\hline $06 / 12 / 07$ & 49,0 & 44,0 & 37,0 & 42,0 & 33,0 & 50,0 \\
\hline $16 / 12 / 07$ & 39,0 & 55,0 & 39,0 & 52,0 & 32,0 & 48,0 \\
\hline $27 / 12 / 07$ & 30,0 & 64,0 & 36,0 & 46,0 & 40,0 & 49,0 \\
\hline $09 / 01 / 08$ & 88,0 & 89,0 & 42,0 & 49,0 & 37,0 & 47,0 \\
\hline $13 / 01 / 08$ & 94,0 & 97,0 & 47,0 & 56,0 & 39,0 & 74,0 \\
\hline $23 / 01 / 08$ & 58,0 & 60,0 & 24,0 & 19,0 & 17,0 & 21,0 \\
\hline $01 / 02 / 08$ & 88,6 & 79,9 & 31,0 & 52,3 & 28,9 & 28,0 \\
\hline $06 / 02 / 08$ & 77,0 & 43,0 & 23,0 & 45,0 & 36,0 & 47,0 \\
\hline $20 / 02 / 08$ & 73,0 & 82,0 & - & 41,0 & 47,0 & 50,0 \\
\hline $01 / 03 / 08$ & 48,0 & 38,0 & 42,0 & 46,0 & 40,0 & 49,0 \\
\hline $12 / 04 / 08$ & 31,0 & 91,0 & 24,0 & 24,0 & 21,0 & 26,0 \\
\hline $20 / 04 / 08$ & 36,0 & 35,0 & 37,0 & 41,0 & 32,0 & 26,0 \\
\hline $01 / 05 / 08$ & 34,0 & 33,0 & 24,0 & 44,0 & 22,0 & 20,0 \\
\hline $19 / 05 / 08$ & 64,0 & 62,0 & 37,0 & 37,0 & 34,0 & 44,0 \\
\hline $27 / 05 / 08$ & 65,0 & 66,0 & 38,0 & 39,0 & 37,0 & 44,0 \\
\hline $19 / 06 / 08$ & 66,0 & 72,0 & 40,0 & 42,0 & 39,0 & 43,0 \\
\hline $07 / 07 / 08$ & 53,0 & 54,0 & 34,0 & 36,0 & 34,0 & 38,0 \\
\hline $30 / 07 / 08$ & 57 & 57 & 31 & 36 & 32 & 40 \\
\hline $09 / 09 / 08$ & 38 & 31 & 21 & 21 & 19 & 23 \\
\hline $19 / 09 / 08$ & 28 & 28 & 26 & 18 & 17 & 20 \\
\hline $16 / 10 / 08$ & 62 & 64 & 35 & 35 & 28 & 35 \\
\hline $25 / 10 / 08$ & 69 & 74 & 36 & 40 & 42 & 49 \\
\hline $17 / 11 / 08$ & 46 & 45 & 27 & 34 & 24 & 24 \\
\hline $29 / 11 / 08$ & 53 & 54 & 26 & 29 & 26 & 34 \\
\hline
\end{tabular}


ANEXO A - Boletim Técnico do Filtrasorb 300 (CALGON) 


\section{FILTRASORB ${ }^{\circledR} 300 \& 400$}

\section{Granular Activated Carbons for Potable Water}

\section{Description}

FILTRASORB $^{\circledR} 300$ and FILTRASORB ${ }^{\circledR} 400$ are two high activity granular activated carbons developed by Calgon Carbon Corporation for the removal of taste and odor compounds and dissolved organic compounds from water treatment.

These activated carbons are made from selected grades of bituminous coal to produce a high activity, durable granular product capable of withstanding the abrasion associated with repeated backwashing, air scouring, and hydraulic transport. Activation is carefully controlled to produce an exceptionally high internal surface area with optimum pore size for effective adsorption of a broad range of high and low molecular weight organic contaminants. The product is also formulated to comply with all the applicable provisions of the AWWA Standard for Granular Activated Carbon, edition B604-96, the stringent extractable metals requirements of ANSI/NSF Standard 6I, and the Food Chemicals Codex.

\section{Applications}

FILTRASORB $^{\circledR} 300$ and 400 activated carbons can be used to treat surface and groundwater sources for the production of drinking water. These products can be used as a complete replacement for sand and anthracite media. FILTRASORB ${ }^{\circledR} 300$ and 400 activated carbons function as dual purpose media, providing both filtration and adsorption. FILTRASORB ${ }^{\circledR}$ has been used successfully in drinking water applications for over 40 years.

\section{Design Considerations}

As a replacement for existing filter media, conversion to FILTRASORB $^{\circledR} 300$ and 400 granular activated carbons impose no major changes to a plant's normal filtration operations. Calgon Carbon Corporation can also provide complete modular adsorption systems as an add-on treatment stage if required.

\section{Features}

- Bituminous-based raw material

- Coal is pulverized and reagglomerated with suitable binder

\section{Benefits}

- Provides higher hardness relative to other raw materials reducing the generation of fines and product losses during backwashing

- Generates the hardness and abrasion resistance required for thermal reactivation and minimizing generation of fines in operations requiring backwashing

- Pore structure provides a wider range of contaminant removal capabilities relative to other starting material

- High density, wets readily, and does not float, thus minimizing loss during backwash operations

- Creates optimal transport paths for faster adsorption

\begin{tabular}{lll} 
Specifications & F300 & F400 \\
\hline lodine Number, mg/g (min) & 900 & 1000 \\
\hline Moisture, weight \% (max \%) & 2 & 2 \\
\hline Abrasion Number $(\min )$ & 78 & 75 \\
\hline Effective Size, mm & $0.8-1.0$ & $0.55-0.75$ \\
\hline Uniformity Coefficient (max) & 2.1 & 1.9 \\
\hline Ash, weight \% (max) & 8 & 9 \\
\hline Apparent Density, g/cc (min) & 0.48 & 0.44 \\
US Sieve Series, weight \% & & \\
\hline Larger than No. $8(\max )$ & 15 & - \\
\hline Smaller than No. $30(\max )$ & 4 & - \\
Larger than No. I2 (max) & - & 5 \\
Smaller than No. 40 (max) & - & 4
\end{tabular}

\section{Carbon and Process Media}

Visit our website at www.calgoncarbon.com, or call 800-422-7266 to learn more about our complete range of products and services, and obtain local contact information. 

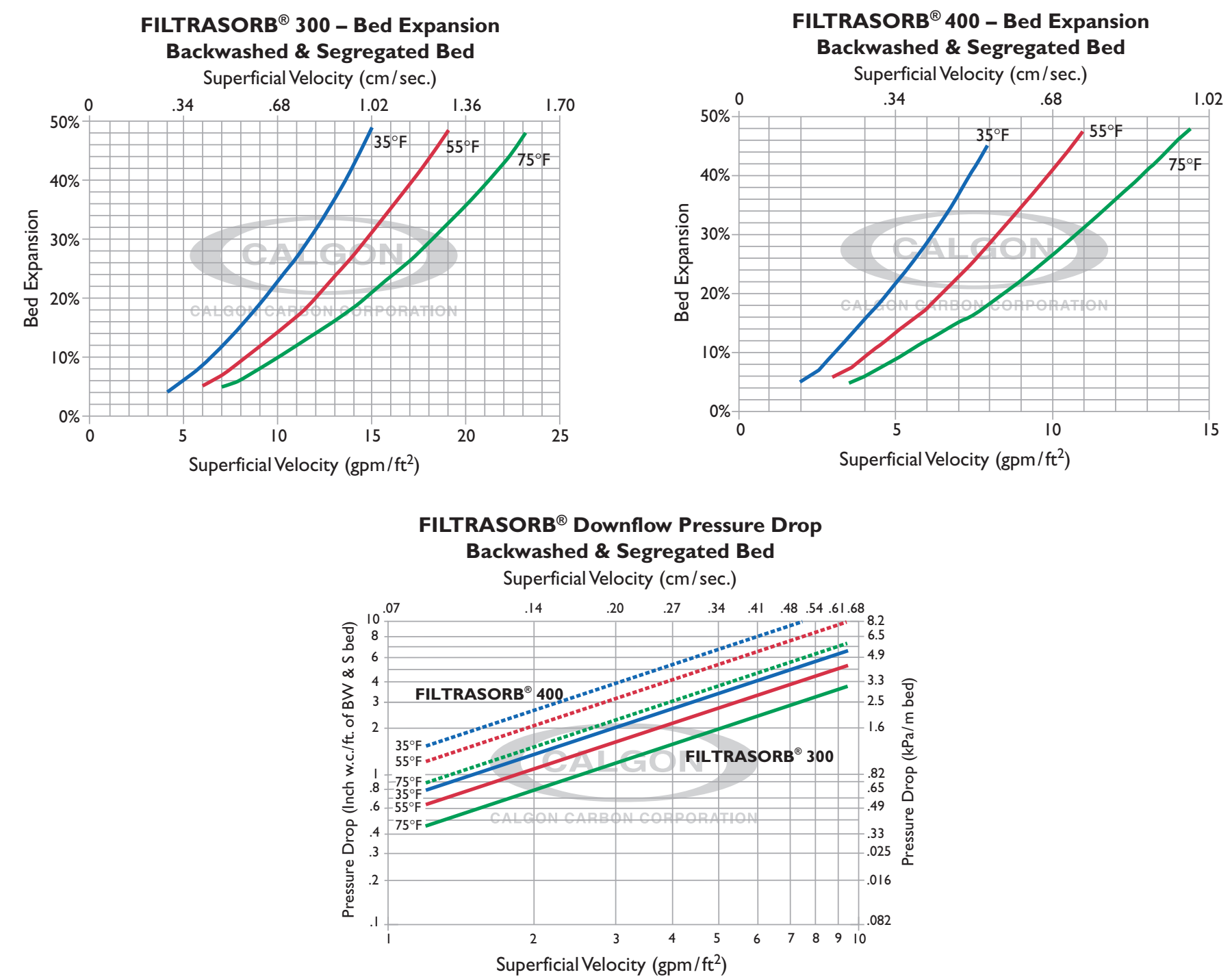

\section{Safety Message}

Wet activated carbon preferentially removes oxygen from air. In closed or partially closed containers and vessels, oxygen depletion may reach hazardous levels. If workers are to enter a

vessel containing carbon, appropriate sampling and work procedures for potentially low oxygen spaces should be followed, including all applicable federal and state requirements.

Visit our website at WwW.calgoncarbon.com

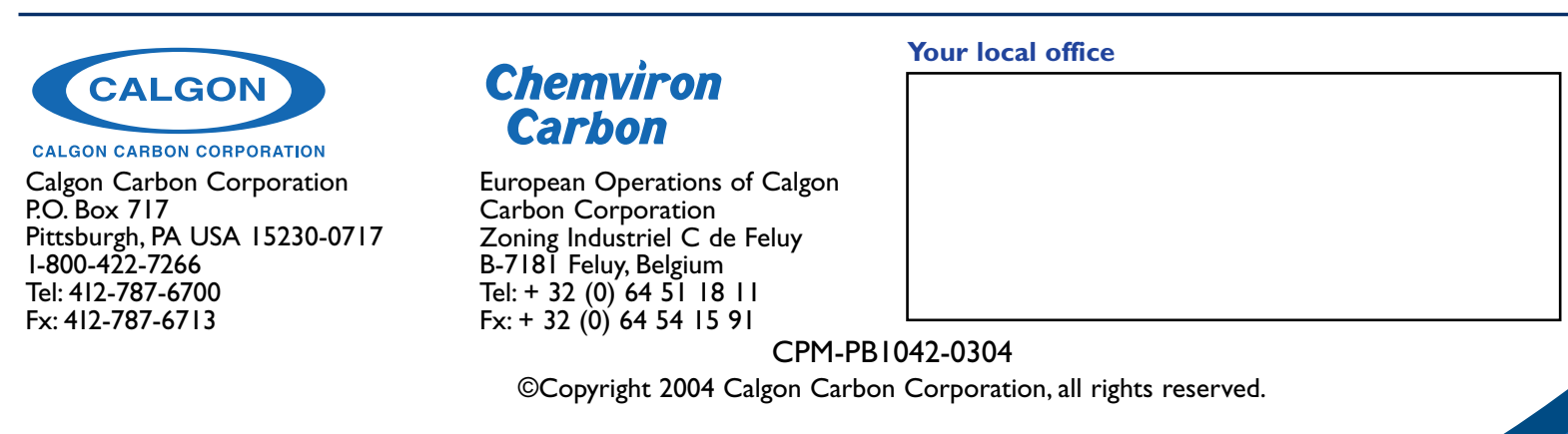


ANEXO B - Boletim Técnico do CAG 119 12X25 (CARBOMAFRA) 


\begin{tabular}{|l|l|l|l|}
\hline \multicolumn{4}{|c|}{ BOLETIM TÉCNICO } \\
CARVÃO ATIVADO 119 GRANULADO \\
\hline CARBOMAFRA \\
\hline Curitiba, 12/04/2007. & Boletim Número : 1032 & Revisão: 0 & Folha: $1 / 1$ \\
\hline
\end{tabular}

\section{CARBONO ATIVADO 119}

O Carbono 119 é um carvão ativado granulado de origem vegetal, de primeira calcinação, obtido pelo processo físico de ativação. Por ser produzido a partir de cascas de cocos, é dotado de elevada dureza e densidade, facilitando processos que necessitam de regenerações sucessivas.

É desenvolvido para trabalhar em leitos fixos e móveis, no tratamento e purificação de diversos fluídos. As distribuições de partículas fornecidas são selecionadas para proporcionar em elevadas taxas de adsorção e baixas resistências ao fluxo, para cada aplicação específica.

\section{APLICAÇÃO}

O Carbono 119 é utilizado no tratamento de água para remoção de compostos orgânicos, remoção de cloro, gosto e odor. Citamos por exemplo, tratamento de água em filtros domésticos, em uso industrial anterior às colunas de desmineralização, água potável e de processo . No tratamento de efluentes na fase final de polimento, para remoção de cor e traços de DQO.

Também é usado nas granulometrias maiores $(3,5 \times 8$ e $6 \times 12)$ para tratamento de gases em geral, recuperação de solventes, controle de poluição do ar, adsorção de álcool, nas aplicações que requerem alta eficiência e regenerações sucessivas.

\section{ESPECIFICAÇÕES}

$\mathrm{N}^{\circ}$. de lodo (mg I2/g C.A., AWWA B 600/78).......................min .850

Cinza (\%, ASTM D 2866/83) ………………………....... máx. 10

Umidade (\%, ASTM D 2867/70)..................................... máx. 10

Peso Específico Aparente (g/cm3, ASTM D 2854/70)......... 0,50 $\pm 0,05$

Dureza (\%, ASTM D 3802/79)........................................ min. 90

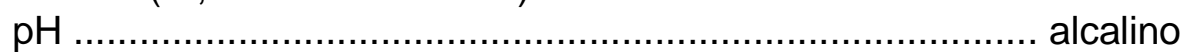

Carbono Fixo …........................................................... min. 80\%

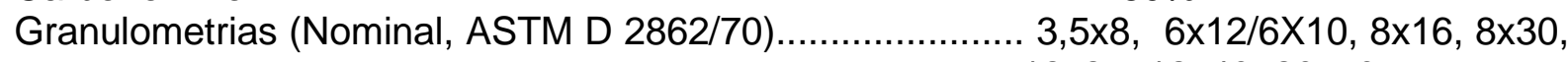
$12 \times 25,12 \times 40,20 \times 50$

\section{EMBALAGEM}

Sacos de ráfia revestidos internamente com polietileno. Peso Líquido: $30 \mathrm{~kg}$.

DOCUMENTO NÃO CONTROLADO 
INDÚSTRIA QUÍMICAS CARBOMAFRA S/A

EXPANSÃO DE LEITO DE CARVÃO ATIVADO GRANULADO

Curitiba, janeiro/2001

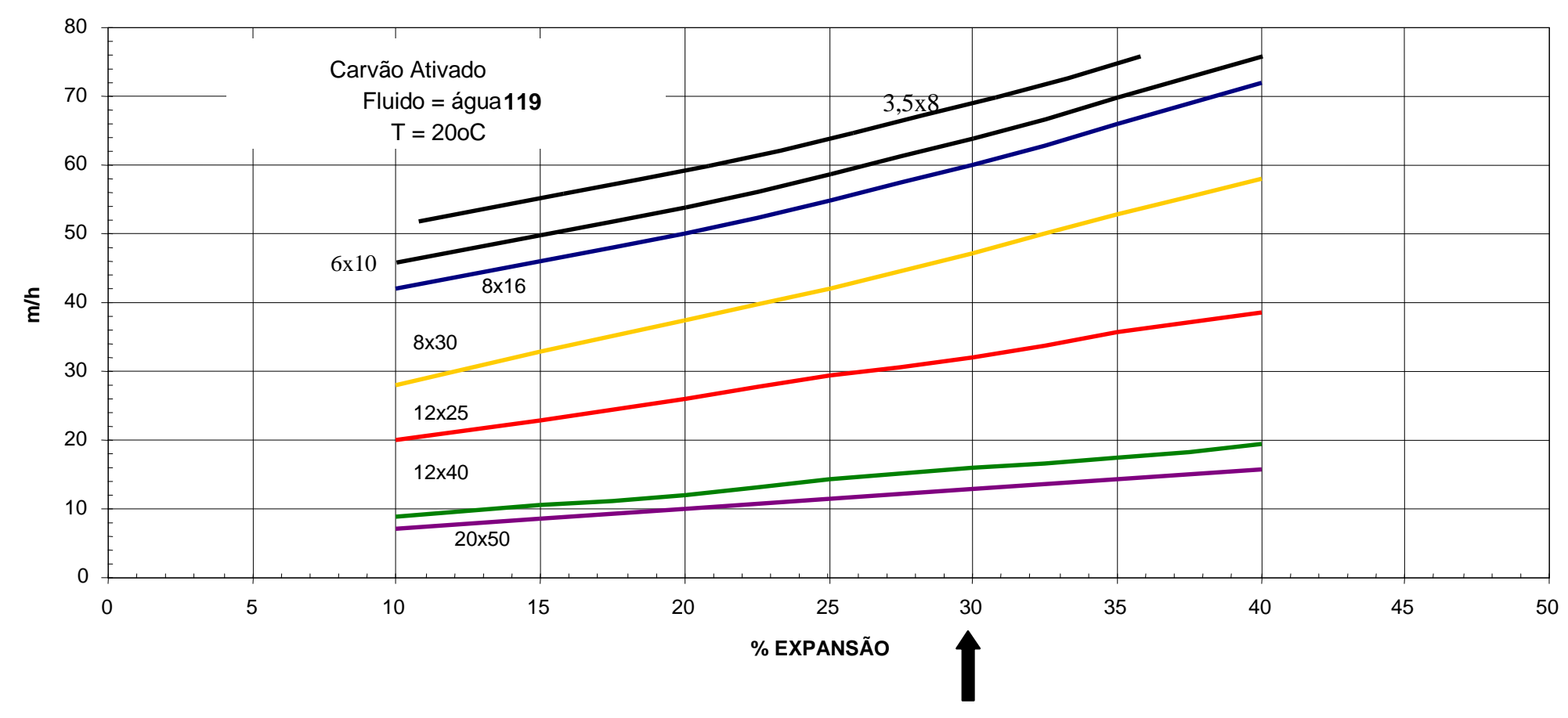

